\title{
UNDERGROUND STORAGE TANK MANAGEMENT PLAN
}

\author{
OAK RIDGE Y.12 PLANT \\ OAK RIDGE, TENNESSEE
}

Environmental Management Department

Health, Safety, Environment, and Accountability Organization

\section{Septernber 1994}

\section{Prepared by}

Science Applications International Corporation for the

Oak Ridge Y-12 Plant

Oak Ridge, Tennessee 37831

\section{Marlaged by}

Martin Marietta Energy Systems, Inc.

for the

U.S. Department of Energy

Under Contract No. DE-AC05-840R21400

\section{MANAGED BY}

MARTIN MARIETTA ENERGY SYSTEMS, INC.

FOR THE UNITED STATES 


\section{DISCLAIMER}

This report was prepared as an account of work sponsored by an agency of the United States Government. Neither the United States Government nor any agency thereof, nor any of their employees, makes any warranty, express or implied, or assumes any legal liability or responsibility for the accuracy, completeness, or usefulness of any information, apparatus, product, or process disclosed, or represents that its use would not infringe privately owned rights. Reference herein to any specific commercial product, process, or service by trade name, trademark, manufacturer, or otherwise, does not necessarily constitute or imply its endorsement, recommendation, or favoring by the United States Government or any agency thereof. The views and opinions of authors expressed herein do not necessarily state or reflect those of the United States Government or any agency thereof. 


\section{DISCLAIMER}

Portions of this document may be illegible in electronic image products. Images are produced from the best available original document. 


\title{
UNDERGROUND STORAGE TANK MANAGEMENT PLAN
}

\author{
OAK RIDGE Y-12 PLANT \\ OAK RIDGE, TENNESSEE
}

\begin{abstract}
Environmental Management Department
Health, Safety, Environment, and Accountability Organization
\end{abstract}

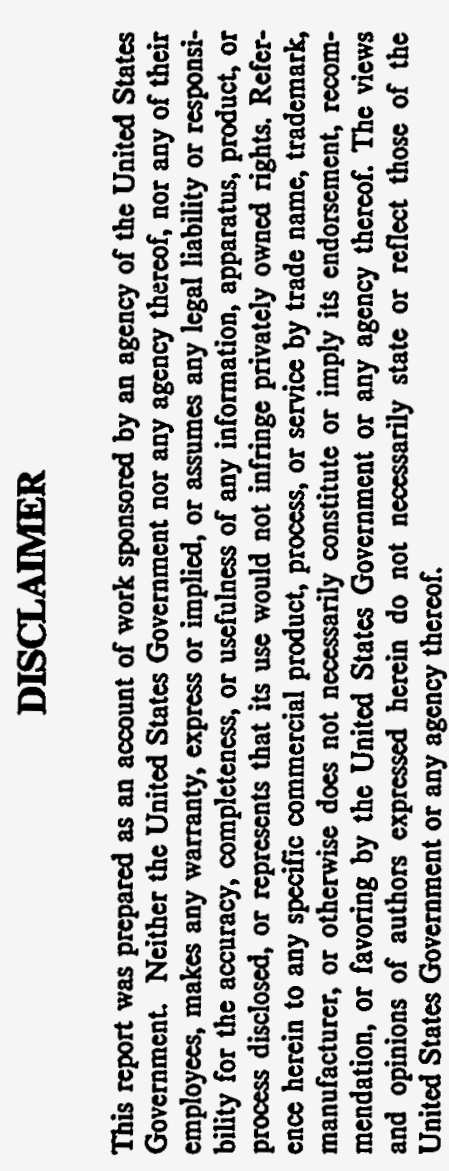

September 1994

Prepared by

Science Applications International Corporation for the Oak Ridge Y-12 Plant

Oak Ridge, Tennessee 37831

\author{
Managed by \\ Martin Marietta Energy Systems, Inc. \\ for the \\ U.S. Department of Energy \\ Under Contract No. DE-AC05-84OR21400
}


SCIENCE APPLICATIONS INTERNATIONAL CORPORATION

contributed to the preparation of this document and should not be considered an eligible contractor

for its review. 


\section{TABLE OF CONTENTS}

LIST OF FIGURES / TABLES.

LIST OF ACRONYMS.

EXECUTIVE SUMMARY

$\mathbf{v}$
$\mathbf{v}$
vii

1.0 REGULATORY REQUIREMENTS ..................................... $1-1$

1.1 Oak Ridge Reservation Federal Facility Agreement .......................... $1-1$

1.2 Department of Energy Orders ............................................. 1-1

1.3 Department of Energy UST Notification Requirements......................... 1-1

1.3.1 Requirements for Existing Tanks..................................... 1-1

1.3.2 Requirements for New Tanks................................... 1-2

1.3.3 Requirements for Release Reporting ............................ 1-2

1.4 Comprehensive Environmental Response, Compensation, and Liability Act .... 1-2

1.5 Resource Conservation and Recovery Act..................................... 1-2

1.6 Tennessee Department of Environment and Conservation Rule..................... 1-2

1.6.1 Program Scope and Minimum Requirements for Tanks .................. 1-3

1.6.2 UST Systems: Design, Construction, Installation, and Notification .... 1-4

1.6.3 General Operating Requirements .................................. $1-5$

1.6.4 Release Detection ............................................... $1-7$

1.6.5 Release Reporting, Investigation, and Confirmation...................... 1-11

1.6.6 Release Response and Corrective Action ............................... 1-11

1.6.7 Out-of-Service UST Systems and Closure .............................. 1-13

2.0 IMPLEMENTATION REQUIREMENTS........................................ 2-1

2.1 TDEC Reference Handbook...................................................... 2-1

2.2 Discovery of Free Product................................................ 2-1

2.3 Permanent UST System Closure................................................... 2-5

2.4 Analytical Requirements .................................................. 2-5

2.4.1 Analytical Methods ........................................... $2-5$

2.4.2 Data Reporting ............................................................... $2-7$

3.0 Y-12 PLANT UST PROGRAM INVENTORY .............................. $3-1$

4.0 Y-12 UST PROGRAM WASTE MANAGEMENT PRACTICES ............ 4-1

4.1 Investigation Derived Waste..................................................... 4-1

4.2 UST Upgrade Program Derived Waste ............................................... 4-1

4.3 Corrective Action Derived Waste ...................................................... $4-3$

4.4 Mixed Waste.................................................................... 4

APPENDICES

Appendix A Appendix B Appendix C Appendix D Appendix E Appendix $\mathrm{F}$ Appendix G Appendix $\mathrm{H}$

Applicable Portions of CERCLA

A-1

RCRA 40 CFR Part 280............................................. B-1

TDEC Chapter 1200-1-15 ............................................... C-1

Oak Ridge Y-12 Plant UST Operational Procedure ...................... D-1

TDEC UST System Report Forms................................. E-1

TDEC Environmental Assessment / Corrective Action Plan Guidelines F-1

TDEC UST Technical Guidance Documents............................. G-1

TDEC UST Closure Assessment Guidelines ....................... H-1 


\section{LIST OF FIGURES / TABLES}

Page

Figure Title

1 Decision flowchart for releases from petroleum UST systems.................... 2-2

$2 \quad$ UST waste management flowchart ....................................... $4-2$

Pocket $\quad$ Master UST site location map .............................................. 3-9

Individual UST site maps................................................... 3-11-3-57

Table Title

1 Summary of leak detection and corrosion protection requirements

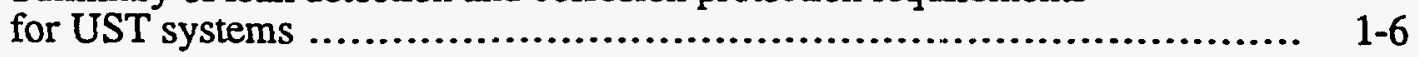

2 Implementation deadlines for UST performance requirements..................... $1-8$

3 Summary of leak detection choices for existing UST systems ................ 1-10

4 Summary of analytical requirements for samples collected from UST sites .... 2-6

$5 \quad$ Inventory of underground storage tanks at the $\mathrm{Y}-12$ Plant ................... 3-2

$6 \quad$ Summary of tank and piping information ................................. $3-6$

\section{LIST OF ACRONYMS}

BTEX

BTX

CERCLA

CFR

DOE

DRO

Energy Systems

EPA

FFA

GRO

IDW

NPDES

RCRA

SARA

TCLP

TDEC

TPH

TSCA

UST
Benzene, Toluene, Ethylbenzene, and Xylenes

Benzene, Toluene, and Xylene

Comprehensive Environmental Response, Compensation, and Liability Act Code of Federal Regulations

U.S. Department of Energy

Diesel Range Organics

Martin Marietta Energy Systems, Inc.

U.S. Environmental Protection Agency

Federal Facility Agreement

Gasoline Range Organics

investigation derived waste

National Pollutant Discharge Elimination Systern

Resource Conservation and Recovery Act

Superfund Amendments and Reauthorization Act

Toxicity Characteristic Leaching Procedure

Tennessee Department of Environment and Conservation

Total Petroleum Hydrocarbon

Toxic Substances Control Act

underground storage tank 
94-037MS/082694 


\section{EXECUTIVE SUMMARY}

The Underground Storage Tank (UST) Management Progrann at the Oak Ridge Y-12 Plant was established to locate UST systems in operation at the facility, to ensure that all operating UST systems are free of leaks, and to establish a program for the removal. of unnecessary UST systems and upgrade of UST systems that continue to be needed. The program implements an integrated approach to the management of UST systems, with each system. evaluated against the same requirements and regulations. A common approach is employed, in accordance with Tennessee Department of Environment and Conservation (TDEC) regulations and guidance, when corrective action is mandated. This Management Plan outlines the compliance issues that must be addressed by the UST Management Program, reviews the current UST inventory and compliance approach, and presents the status and planned activities associated with each UST system.

The UST Management Plan provides guidance for implementing TDEC regulations and guidelines for petroleum UST systems. The plan is divided into four major sections: (1) regulatory requirements, (2) implementation requirements, (3) Y-12 Plant UST Program inventory sites, and (4) UST waste management practices. These sections describe in detail the applicable regulatory drivers, the UST sites addressed under the Management Program, and the procedures and guidance used for compliance with applicable regulations. 


\subsection{REGULATORY REQUIREMENTS}

The Underground Storage Tank (UST) Management Program at the Oak Ridge Y-12 Plant was established with the mission of locating UST systems in operation at the plant site, ensuring that all operating UST systems are free of leaks, and establishing a program for the closure of unnecessary UST systems and upgrade of existing systems that are designated to remain in service. There are a number of state and Federal regulations and guidance procedures that influence or dictate decisions made during the management of UST systems at the Y-12 Plant. This section of the UST Management Plan provides a brief outline of the applicable regulations and procedures. In addition, all activities performed under the Y-12 Plant UST Management Program must adhere to Martin Marietta Energy Systems, Inc. (Energy Systems) policies, standards, and procedures. At a minimum, the Management Program must be in compliance with the applicable requirements outlined in this section of the Management Plan.

\subsection{Oak Ridge Reservation Federal Facility Agreement}

UST management programs are not specifically cited within the Oak Ridge Reservation Federal Facility Agreement (FFA). The FFA does mention radioactive waste UST systems located at the Oak Ridge National Laboratory. However, no radioactive waste UST systems are located at the Y-12 Plant; therefore, the related notation in the FFA is not applicable. The Y-12 UST Management Program is implemented in compliance with orders or regulations developed by the U.S. Department of Energy (DOE), U.S. Environmental Protection Agency (EPA), and the Tennessee Department of Environment and Conservation (TDEC). A summary of these orders or regulations is presented in subsequent subsections.

\subsection{Department of Energy Orders}

Although no DOE order specifically addresses UST systems, applicable orders to the Y-12 UST Management Program include DOE Order 5480.1B, Environmental Protection, Safety, and Health Program for DOE Operations, which prescribes the program and criteria for environmental protection, safety, and health for DOE operations; and DOE Order 5400.1, General Environmental Protection Program, which establishes requirements, authorities, and responsibilities for DOE operations that ensure compliance with applicable Federal, state, and local environmental protection laws and regulations.

\subsection{Department of Energy UST Notification Requirements}

Sections 1.3.1 through 1.3.3 summarize DOE notification requirements for UST systems that are to be implemented in addition to those requirements cited in the Code of Federal Regulations (CFR), Title 40 Part 280.

\subsubsection{Requirements for Existing Tanks}

DOE facilities should review current UST system inventories and notification forms issued on or before May of 1986 to ensure that all regulated systems have been reported to the proper agencies responsible for implementation of UST regulations.. In addition to notification forms for new regulated USTs, separate notification forms should be prepared and submitted concurrently for new unregulated USTs (i.e., those which are less than 110 gallons in size or are used for storage of heating oil) because DOE will treat these unregulated systems in the same manner as regulated systems. 


\subsubsection{Requirements for New Tanks}

DOE facilities should complete notification forms 45 days prior to bringing new UST systems into use to ensure compliance with the 30-day notification requirement of the implementing agency (TDEC). The notification shall include all required information and proper certifications, and shall be submitted on the appropriate TDEC notification form.

\subsubsection{Requirements for Release Reporting}

Suspected releases from UST systems must be reported to the Oak Ridge Operations Center immediately upon discovery. Suspected release situations include inconclusive tank tightness tests. Site checks shall be conducted to confirm the presence of a suspected release. DOE will be responsible for notifying the implementing agency (TDEC) of known or suspected release situations in accordance with the Environmental Protection Division's Environmental Incident Reporting Procedures.

\subsection{Comprehensive Environmental Response, Compensation, and Liability Act}

Comprehensive Environmental Response, Compensation, and Liability Act (CERCLA) regulations can be found within 40 CFR Part 300. Although CERCLA does not specifically address UST systems, it does include language that excludes petroleum products and crude oil from regulation under CERCLA. However, any CERCLA hazardous substance(s) released to the environment via leaking hazardous substance UST systems would be addressed under this regulation. Those portions of CERCLA concerning the exclusion of petroleum products as a regulated substance are presented in Appendix A of this document.

\subsection{Resource Conservation and Recovery Act}

Resource Conservation and Recovery Act (RCRA) regulations regarding UST systems can be found within $40 C F R$ Part 280. Of these three regulations, the primary one that addresses UST system operation, closure, and reporting requirements is 40 CFR Part 280 . A detailed summary of the three noted RCRA regulations, copies of the applicable sections of 40 CFR Parts 264 and 265, and a complete copy of 40 CFR Part 280 are all presented in Appendix B of this document.

The 40 CFR Part 280 was developed in response to the addition of Subtitle I to RCRA by Congress. Subtitle I required the EPA to develop regulations to protect human health and the environment from UST system releases. Under Section 9003, as amended by the Superfund Amendments and Reauthorization Act (SARA), the EPA and states under a cooperative agreement with EPA have the authority to clean up petroleum releases from UST systems, or to require system owners/operators to conduct such activities. Section 9004 permits the EPA to authorize states to implement their own UST programs in place of Federal programs provided that the state program requirements are "no less stringent" than that defined by EPA, and that the state programs provide for adequate enforcement.

\subsection{Tennessee Department of Environment and Conservation Rule}

Environmental compliance requirements related to petroleum UST systems located within the State of Tennessee are defined within the Rules of the TDEC, Division of Underground Storage Tanks, under Chapter 1200-1-15, Underground Storage Tank Program. Regulations contained within Chapter 1200-1-15 define the technical standards and corrective action requirements for owners/operators of petroleum UST systems and, therefore, apply to the Y-12 UST Management Program, which ensures compliance. A copy of the current Chapter 1200-1-15 revision is presented in Appendix $\mathrm{C}$ of this document. This chapter contains seven major subsections that address the following technical topics: 
- Program Scope and Minimum Requirements for Tanks (1200-1-15-.01)

- UST Systems: Design, Construction, Installation, and Notification (1200-1-15-.02)

- General Operating Requirements (1200-1-15-.03)

- $\quad$ Release Detection (1200-1-15-.04)

- Release Reporting, Investigation, and Confirmation (1200-1-15-.05)

- Release Response and Corrective Action for UST Systems Containing Petroleum (1200-1-15-.06)

- $\quad$ Out-of-Service UST Systems and Closure (1200-1-15-.07)

Chapter 1200-1-15 contains five appendices that address the issues of notification for underground storage tanks, statement for shipping tickets and invoices, groundwater and soil petroleum contamination cleanup levels, and removal of underground storage tanks. Chapter 1200-1-15 also contains four additional subsections that address the following financial topics:

- $\quad$ Financial Responsibility (1200-1-15-.08)

- Administrative Guidelines and Procedures for the Tennessee Petroleum Underground Storage Tank Fund (1200-1-15-.09)

- Fee Collection and Certification Issuance Regulations (1200-1-15-.10)

- Underground Storage Tank Program (1200-1-15-.11)

The following discussion summarizes the major points of the technical topic subsections of Chapter 1200-1-15. A discussion of the financial topic subsections is not included because the requirements in these subsections, with the exception of annual petroleum underground storage tank fees, do not apply to Federal facilities including the Y-12 Plant.

\subsubsection{Program Scope and Minimum Requirements for Tanks}

The requirements of Chapter 1200-1-15 apply to all owners/operators of an UST system as defined within Rule 1200-1-15-.01(3) except as otherwise provided by deferral. The requirements contained in Rules 1200-1-15-.02 through 1200-1-15-.05, and 1200-1-15-.07 through 1200-1-15.11 apply to owners/operators of all existing UST systems, excluding the following:

- $\quad$ wastewater treatment tank systems;

- $\quad$ any UST system containing radioactive material that is regulated under the Atomic -Energy Act of 1954 (42 USC 2011 and following);

- $\quad$ any UST system that is part of an emergency generator system at nuclear power generation facilities regulated by the Nuclear Regulatory Commission under 10 CFR 50 Appendix A;

- $\quad$ airport hydrant fuel distribution systems;

- $\quad$ UST systems with field-constructed tanks; 
- equipment or machinery that contain petroleum for operational purposes, such as hydraulic lift tanks and electrical equipment tanks;

- $\quad$ any UST system whose capacity is 110 gallons or less;

- any UST system that contains a de minimus concentration of petroleum; and

- any emergency spill of overflow containment UST system that is expeditiously emptied after use.

In addition, the requirements of Rule 1200-1-15-.04 do not apply to any existing UST system that stores fuel solely for use by emergency power generators. All new UST systems, including all of the deferred systems noted above with the exception of emergency power generator systems, must meet the minimum requirements for new installations. These requirements are that no new UST system may be installed for the purpose of storing petroleum unless (1) the system will prevent releases due to corrosion or structural failure for the operational life of the system; (2) the system is cathodically protected against corrosion, constructed of noncorrodible material, steel clad with a noncorrodible material, or designed in a manner to prevent the release or threatened release of petroleum; and (3) the system is constructed or lined with material that is compatible with the petroleum.

\subsubsection{UST Systems: Design, Construction, Installation, and Notification}

Each new UST system must be constructed of fiberglass-reinforced plastic; steel with cathodic protection; steel-fiberglass-reinforced-plastic composite; metal without additional corrosion protection provided that the subsurface environment is determined not to be corrosive enough to cause releases during operational lifetime and that owners/operators maintain records that demonstrate compliance with this requirement; or other TDEC-approved materials. In addition, spill and overfill equipment must be provided.

Each UST system must be installed according to the manufacturer's installation instructions. Tank and piping line tightness tests are to be performed to minimize the possibility of leakage during operation. A certification of installation must be issued following tank and line testing to demonstrate compliance with installation and notification requirements. One or more of the following certification methods may be employed to demonstrate compliance:

- the installer has been certified by the tank and piping manufacturer;

- the installation has been inspected and certified by a registered professional engineer;

- the installation has been inspected and approved by TDEC;

- all work listed in the manufacturer's installation checklists has been completed; or

- the owner/operator has complied with an equivalent performance standard.

Existing UST systems that are to remain in service must comply with new UST system performance standards, upgrading requirements for existing systems, or undergo closure. Existing steel tanks must be upgraded to meet one of the following requirements: interior lining, cathodic protection, or internal lining combined with cathodic protection. Existing metal piping must be outfitted with cathodic protection. Also, existing UST systems must be outfitted with spill and overfill prevention equipment. 
Notification requirements dictate that any owner who brings an UST system into service must submit a Chapter 1200-1-15 Appendix 1 form to the TDEC Division of Underground Storage Tanks 15 days prior to beginning of operation. Also, any owner/operator that replaces or upgrades an existing UST system must provide notification of such activity to TDEC using the Appendix 1 form within 30 days after completion of the replacement or upgrade. Any type of notification must be filed for each tank owned at a particular facility or location, either separately or collectively on one application. All owners/operators are required to certify compliance with the following requirements: tank and piping installation, cathodic protection, financial responsibility, and release detection.

\subsubsection{General Operating Requirements}

Spill and overfill control provisions require that the available volume of the tank to be filled must be greater than the proposed volume of petroleum to be added, and that the transfer operation is monitored constantly to prevent overfilling and spilling. Energy Systems has enacted procedures for filling UST systems at the Y-12 Plant that are presented in Appendix D of this document.

Corrosion protection and cathodic protection systems must be operated, maintained, and inspected in an effort to prevent the release of petroleum products. UST systems equipped with cathodic protection systems must be tested within 6 months of installation and at least every 3 years thereafter, and the protection system must be functioning as designed. In addition, impressed current cathodic protection systems must also be inspected every 60 days to ensure proper operation. For systems using cathodic protection, records of the protection operation must be maintained to demonstrate compliance, and must provide the results of the last two inspections for all protection systems and the last three inspections of impressed current protection systems. A summary of corrosion protection requirements for UST systems is presented in Table 1.

Owners/operators of UST systems must ensure that repairs will prevent releases due to structural failure or corrosion as long as the system is used to store petroleum. Repairs must meet the following requirements: repairs to systems must be conducted so as to effectively prevent releases for the operational life of the system; repairs to fiberglass-reinforced tanks must be made by the manufacturer's authorized representatives or in accordance with the manufacturer's specifications; metal pipe sections and fittings that have released product must be replaced; and repaired tanks and piping must be tightness tested within 30 days following completion of repairs. However, in place of tightness testing, one of the following methods may be used to document proper system repair: internal inspection, monthly monitoring for releases, or another test method approved by TDEC.

Owners/operators must submit the following information to TDEC:

- notification for all UST systems, including certification of installation for new UST systems;

- ' reports of all releases, including suspected releases, spills and overfills, and confirmed releases;

- corrective actions planned or implemented, including initial abatement measures, initial site characterization, free product removal, investigation of soil and groundwater cleanup, and corrective action plan; and 
Table 1. Summary of leak detection and corrosion protection requirements for UST systems

\begin{tabular}{|c|c|}
\hline 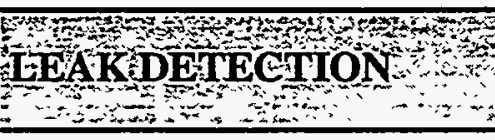 & 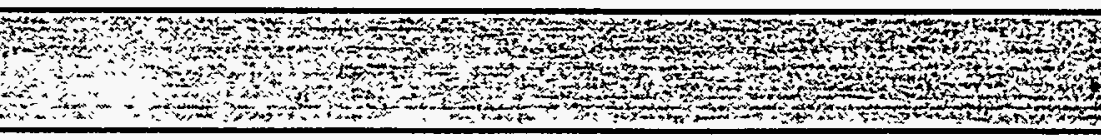 \\
\hline $\begin{array}{c}\text { 1NEW TANKS } \\
2 \text { choices }\end{array}$ & $\begin{array}{l}\text { - Monthly monitoring* } \\
\text { Monthly inventory control and tank tightness testing every } 5 \text { years } \\
\text { (You can only use this choice for } 10 \text { years after installation.) }\end{array}$ \\
\hline $\begin{array}{l}\text { 'EXISTING TANKS } \\
\begin{array}{l}3 \text { choices } \\
\text { (See Table 5) }\end{array} \\
\end{array}$ & $\begin{array}{l}\text { - Monthly monitoring* } \\
\text { - Monthly inventory control and annual tank tightness testing } \\
\text { (This choice can only be used until December 1998.) } \\
\text { Monthly inventory control and tank tightness testing every } 5 \text { years } \\
\text { (This choice can only be used for } 10 \text { years after adding corrosion protection and } \\
\text { spilloverfill prevention or until December 1998, whichever date is later.) }\end{array}$ \\
\hline $\begin{array}{l}\text { NEW \& EXISTING } \\
\text { PRESSURIZED PIPING } \\
\quad \text { Choice of one from each set }\end{array}$ & $\begin{array}{lll}\text { - } & \text { Automatic flow restrictor } & \text { - Annual line testing } \\
\text { - Automatic shutoff device } & \text {-and- } & \text { Monthly monitoring* } \\
\text { Continuous alarm system } & & \text { (except automatic tank gauging) }\end{array}$ \\
\hline $\begin{array}{l}\text { NEW \& EXISTING } \\
\text { SUCTION PIPING } \\
\quad 3 \text { choices }\end{array}$ & $\begin{array}{l}\text { Monthly monitoring* } \\
\text { (except automatic tank gauging) } \\
\text { - Line testing every } 3 \text { years } \\
\text { No requirements } \\
\text { (see note) }\end{array}$ \\
\hline OORROSIONTROTEG & $\begin{array}{l}\text { Nom } \\
\mathbf{N}\end{array}$ \\
\hline $\begin{array}{r}\text { NEW TANKS } \\
3 \text { choices } \\
\end{array}$ & $\begin{array}{l}\text { - } \quad \text { Coated and cathodically protected steel } \\
\text { - } \quad \text { Fiberglass } \\
\text { - Steel tank clad with fiberglass }\end{array}$ \\
\hline $\begin{array}{l}\text { EXISTING TANKS } \\
4 \text { choices }\end{array}$ & $\begin{array}{l}\text { - Same options as for new tanks } \\
\text { - Add cathodic protection system } \\
\text { - Interior lining } \\
\text { Interior lining and cathodic protection }\end{array}$ \\
\hline $\begin{array}{c}\text { NEW PIPING } \\
2 \text { choices } \\
\end{array}$ & $\begin{array}{l}\text { - Coated and cathodically protected steel } \\
\text { - Fiberglass }\end{array}$ \\
\hline $\begin{array}{l}\text { EXISTING PIPING } \\
2 \text { choices } \\
\end{array}$ & $\begin{array}{l}\text { - Same options as for new piping } \\
\text { - Cathodically protected steel }\end{array}$ \\
\hline SPILL/OVERFULIPRO & QTON \\
\hline ALL TANKS & $\begin{array}{l}\text { - Automatic shutoff devices -or- } \\
\text { - } \quad \text { Ball float valves } \\
\end{array}$ \\
\hline
\end{tabular}

*Monthly monitoring includes: Automatic tank gauging, groundwater monitoring, interstitial monitoring, vapor monitoring, and other approved inethods.

${ }^{1}$ Tanks of 550 gallons or less nominal capacity may use weekly, manual tank gauging as the sole method of release detection. Tanks of 551 to 2,000 gallons may use this method in place of manual inventory control. Tanks of greater than 2,000 gallons nominal capacity may not use this method to meet the requirements of this rule.

Note: No release detection is required for suction piping that is designed and constructed to meet the following standards:

1. The below-grade piping operates at less than atmospheric pressure;

2. The below-grade piping is sloped so that the contents of the pipe will drain back into the storage tank if the suction is released:

3. Only one check valve is included in each suction line;

4. The check valve is located directly below and as close as practical to the suction pump; and

5. A method is provided that allows compliance with parts 2,3 , and 4 , to be readily determined.

Source: EPA 1988. Musts for USTs, EPA/530/UST-88/008, September. 
notification prior to permanent closure or change in service.

Owners/operators are required to maintain the following infornation:

- analysis of site corrosion potential if corrosion protection equipment is not used;

- documentation of operation of corrosion protection equipment;

- documentation of UST system repairs;

- recent compliance with release detection requirements; and

- $\quad$ results of the site investigation conducted for permanent closure.

All of these records must be available at the site, or at a readily available alternative site for inspection by TDEC. Permanent closure records may be mailed to TDEC if they cannot be maintained at the site or at an alternative location.

\subsubsection{Release Detection}

Tank release detection shall be performed in such a manner as to detect a release from any portion of the UST system that routinely contains petroleum. Release detection equipment must be installed, calibrated, and maintained in accordance with manufacturer instructions including routine maintenance and service checks for operability, and must comply with the performance requirements for release detection methods.

TDEC must be notified when release detection indicates that a release may have occurred. Owners/operators must comply with release detection requirements within the specified timeframe, which is based on the year that the UST system was installed (Table 2). Any existing UST system that cannot comply with any of the eight approved methods for release detection must complete closure procedures by the release detection installation deadline.

Tanks must be monitored at least every 30 days for releases using automatic tank gauging, vapor monitoring, groundwater monitoring, interstitial monitoring, or other TDEC-approved method unless one of the following three conditions exist. First, UST systems that meet the performance standards for new or upgraded systems and monthly inventory control requirements may use tank tightness testing performed at least every 5 years as an interim release detection measure until December 22, 1998, or until 10 years after the tank was installed or upgraded, whichever is later. Second, UST systems that do not meet the performance standards for new or upgraded systems may use monthly inventory controls and annual tank tightness testing as an interim release detection measure until December 22, 1998 when the tank must be upgraded or permanently closed. Third, tanks that maintain a capacity of 550 gallons or less may use weekly tank gauging.

Piping underground that routinely contains petroleum must be monitored for releases in a manner that meets the following requirements. With regard to pressurized piping, the piping must be equipped with an automatic line leak detector and have an annual line tightness test or monthly monitoring conducted. With regard to suction piping, the piping must either have a line tightness test conducted at least every 3 years or use a monthly monitoring method. No release detection is required for suction piping if the following standards are met: the underground piping operates at less than atmospheric pressure; the piping is sloped so that the contents will drain back into the storage tank upon suction release; and only one check valve is included in the line and the valve is located directly below and as close as practical to the suction pump. 
Table 2. Implementation deadlines for UST performance requirements

\begin{tabular}{|c|c|c|c|}
\hline 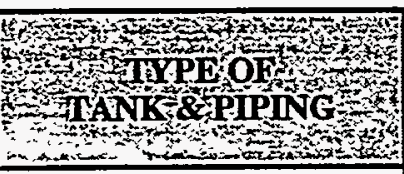 & 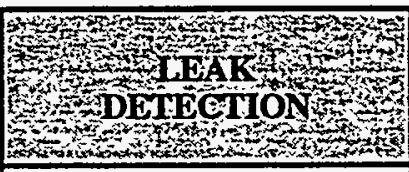 & 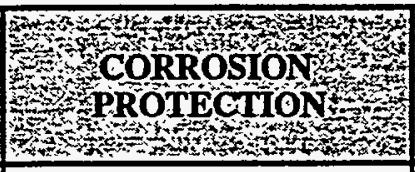 & 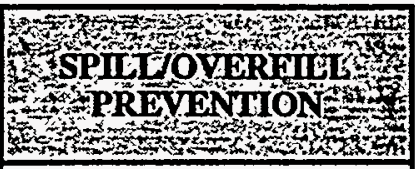 \\
\hline New tanks and piping* & At installation & At installation & At installation \\
\hline $\begin{array}{l}\text { Existing tanks** } \\
\text { Installed: } \\
\text { Before } 1965 \text { or unknown } \\
1965-1969 \\
1970-1974 \\
1975-1979 \\
\text { 1980-December } 1988\end{array}$ & $\begin{array}{l}\text { By no later than: } \\
\text { December } 1989 \\
\text { December } 1990 \\
\text { December } 1991 \\
\text { December } 1992 \\
\text { December } 1993\end{array}$ & \begin{tabular}{|l} 
December 1998 \\
December 1998 \\
December 1998 \\
December 1998 \\
December 1998
\end{tabular} & $\begin{array}{l}\text { December } 1998 \\
\text { December } 1998 \\
\text { December } 1998 \\
\text { December } 1998 \\
\text { December } 1998\end{array}$ \\
\hline $\begin{array}{l}\text { Existing piping** } \\
\text { Pressurized } \\
\text { Suction }\end{array}$ & $\begin{array}{l}\text { December } 1990 \\
\text { Same as existing tanks }\end{array}$ & $\begin{array}{l}\text { December } 1998 \\
\text { December } 1998\end{array}$ & $\begin{array}{l}\text { Does not apply } \\
\text { Does not apply }\end{array}$ \\
\hline $\begin{array}{l}\text { * New tanks and pipin } \\
\text { ** Existing tanks and pi }\end{array}$ & fore I & $\begin{array}{l}1988 \\
\text { nher } 1988\end{array}$ & \\
\hline
\end{tabular}

Source: EPA 1988. Musts for USTs, EPA/530/UST-88/008, September. 
Approved methods of release detection for tanks used to meet the requirements for petroleum UST systems are as follows:

- Monthly Inventory Control

- Manual Tank Gauging

- $\quad$ Tank Tightness Testing

- Automatic Tank Gauging

- Vapor Monitoring

- Groundwater Monitoring

- Interstitial Monitoring

- $\quad$ Other TDEC-approved Methods

Manual tank gauging may only be used as the sole method of release detection for tanks with capacities of 550 gallons or less. This method may be used in place of manual inventory control for tanks with capacities of between 551 and 2,000 gallons. Tanks with capacities greater than 2,000 gallons may not use manual tank gauging as a release detection method.

Approved methods of release detection for piping used to meet the requirements for petroleum UST systems are as follows:

- Automatic Line Leak Detectors

- $\quad$ Line Tightness Testing

- Vapor Monitoring

- Groundwater Monitoring

- $\quad$ Interstitial Monitoring

- $\quad$ Other TDEC-approved Methods

A summary of leak detection requirements for UST systems is presented in Tables 1 and 3.

Release detection records consisting of written performance claims must be maintained for 5 years from the detection system installation date. Sampling, testing, or monitoring data must be maintained for a 1-year period. Tank tightness test results must be retained until the next test is conducted. Written documentation regarding calibration, maintenance, and repair of on-site release detection equipment must be maintained for a 1-year period. Schedules of required calibration and maintenance, provided by the manufacturer, must be retained for 5 years from the date of the detection system installation. 
Table 3. Summary of leak detection choices for existing UST systems

If you don't use monthly monitoring at existing USTs, you must use a combination of periodic tank tightness tests and monthly inventory control. This combined method can only be used for a few years, as the chart below displays.

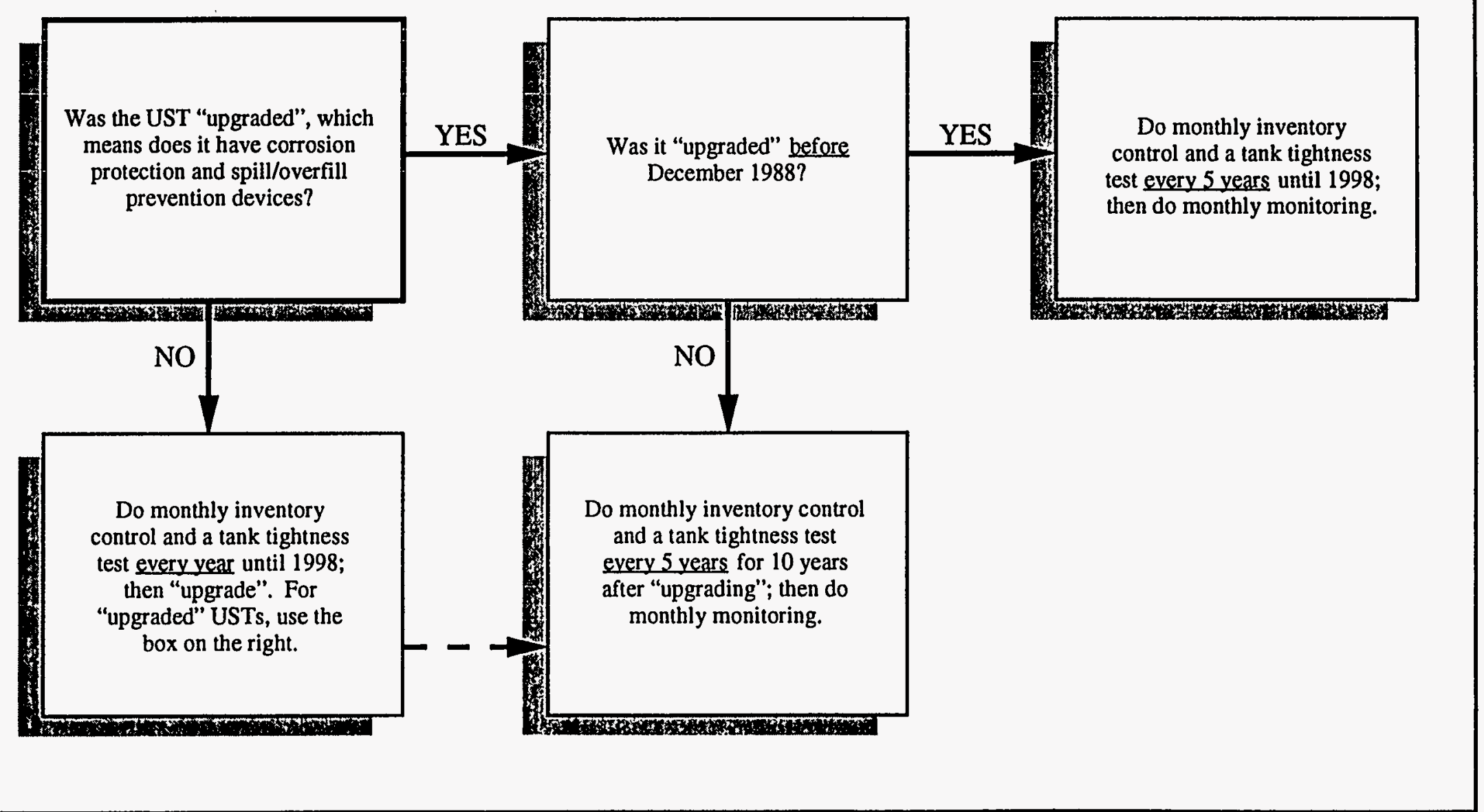

Source: EPA 1988. Musts for USTs, EPA/530/UST-88/008, September. 


\subsubsection{Release Reporting, Investigation, and Confirmation}

Owners/operators must report to TDEC, within 72 hours, any discovery of released petroleum products, unusual system operating conditions unless the system equipment is found to be defective (but not leaking) and is repaired or replaced immediately, or monitoring results that indicate that a release may have occurred unless (1) the monitoring device is found to be defective and is immediately repaired or replaced, and additional monitoring does not confirm the initial result, or (2) in the case of inventory control, a second month of data does not confirm the initial result.

Unless corrective action is initiated, owners/operators must immediately investigate and confirm all suspected releases of petroleum requiring reporting as described above within 7 days. A system test involving tank and line tightness testing must be conducted to determine whether a leak exists in the tank(s) or associated delivery piping. If a leak is determined to exist based on the results of tightness testing, the owner/operator must repair, replace, or upgrade the UST system, and must begin corrective action. If the results of tightness testing do not indicate that a leak exists, but environmental contamination is the basis for suspecting a release, the owner/operator must conduct a site check.

A site check must be performed to detect the presence of a suspected release where contamination is most likely to be present. The nature of the stored petroleum, type of leak suspected, type of backfill, and depth of groundwater are to be considered when selecting sample types, sample locations, and measurement methods. Corrective action is only required if the site check test results for the excavation zone or the UST site indicate that a release has occurred.

Owners/operators must immediately contain and clean up spills or overfills, and begin corrective action, if the spill or overfill results in a release to the environment of more than 25 gallons of petroleum, or causes a sheen on nearby surface water. Spills or overfills of petroleum that are less than 25 gallons must be immediately contained and undergo cleanup. The TDEC Division of Underground Storage Tanks must be informed within 72 hours of any releases exceeding 25 gallons, or immediately if cleanup of releases less than 25 gallons cannot be accomplished within 72 hours.

\subsubsection{Release Response and Corrective Action}

Upon confirmation of a release, the initial response action by owners/operators shall include reporting the release to the TDEC Division of Underground Storage Tanks within 72 hours, immediate action to prevent additional release, and mitigation of fire, explosion, and vapor hazards. After completion of the initial response actions, further response actions may include initial abatement measures and a site check, initial site characterization, free product removal, release investigation, and a corrective action plan. Each of these actions are described below.

\section{Initial Ahatement Measures / Site Check}

Unless otherwise directed, initial abatement measures and a site check must be implemented including (1) removal of petroleum from the UST system to prevent further release; (2) visual inspection of above-ground or exposed below-ground releases; (3) prevention of further petroleum migration into surrounding soil and groundwater; (4) monitoring and mitigation of hazards posed by vapors migrating from the excavation zone to subsurface structures; (5) mitigation of hazards posed by contaminated soils excavated as a result of release confirmation, site investigation, abatement, or corrective action activities; and (6) investigation to determine the presence of free product, and initiation of free product removal as soon as possible. A report summarizing initial 
abatement steps, including pertinent data, must be prepared and submitted to TDEC within 20 days after release confirmation.

Initial Site Characterization

Unless otherwise directed, owners/operators must assemble information about the site and the nature of the release, including information gained while confirming the release or completing initial abatement measures. This information must include the following: nature and estimated quantity of the release; data concerning surrounding populations, water quality, use and location of potentially affected wells, subsurface soil conditions, locations of subsurface sewers, climatological conditions, and land use; and results of the initial abatement measures and site check. An initial site characterization report must be prepared and submitted to TDEC within 45 days after release confirmation.

\section{Free Product Removal}

At sites where investigation indicates the presence of free product, owners/operators must remove free product to the maximum extent possible while continuing with other response actions. Free product removal must be conducted in such a manner that minimizes the spread of contamination into previously uncontaminated zones. Unless otherwise directed, a free product removal report must be prepared and submitted to TDEC within 45 days after release confirmation. This report must present the following information: name of responsible person(s); estimated quantity, type, and thickness of observed or measured free product; type of recovery system used; whether any discharge will take place on-site or off-site during the recovery operation, and the discharge location; type of discharge treatment and expected effluent quality; steps taken or planned to obtain necessary discharge permits; and disposition of recovered free product.

\section{$\underline{\text { Release Investigation }}$}

In order to determine the full extent and location of soil and groundwater contaminated by the release, owners/operators must conduct investigations or the release, the release site, and the surrounding area possibly affected by the release. This type of investigation is required if any of the following conditions exist: there is evidence that groundwater wells have been affected by the release, free product is discovered that requires recovery, there is evidence that contaminated soils may be in contact with groundwater, or the TDEC requests performance of an investigation. An investigation report must be prepared and submitted as soon as possible, or in accordance with a schedule established by the TDEC Division of Underground Storage Tanks.

\section{Corrective Action Plan}

At any point after reviewing information submitted in compliance with initial response, initial abatement measure / site check, or initial site characterization actions, the TDEC Division of Underground Storage Tanks may require the development and submission of a corrective action plan. If a plan is required, owners/operators must submit the plan according to a schedule and format established by TDEC. The corrective action plan will only be approved by TDEC after ensuring that its implementation will adequately protect human health, safety, and the environment. Upon approval of the plan, owners/operators must implement planned corrective actions including any modification required by TDEC. Monitoring, evaluation, and reporting of plan implementation results must be conducted in accordance with a schedule and format established by TDEC.

Owners/operators may, in the interest of minimizing environmental contamination and promoting more effective cleanup, begin remediation of soil and groundwater prior to corrective action plan approval. However, in doing so, the following conditions must be met: notify TDEC 
of intention to begin cleanup, comply with any conditions imposed by TDEC, and incorporate selfinitiated cleanup measures into the corrective action plan submitted to TDEC for approval.

The corrective action plan submitted to TDEC for approval must address or comply with the following requirements:

- Corrective action planning for groundwater contaminated by petroleum from UST systems that meet the contamination levels listed in Appendix 3 for drinking and non-drinking water supplies. The plan must determine if the contaminated groundwater met the definition of a drinking water supply before the contamination occurred, and propose site cleanup levels based on the category of groundwater.

- Corrective action planning for soils contaminated by petroleum from UST systems that meet the contamination levels listed in Appendix 4 for various soil permeability categories. The plan must propose site cleanup levels; based on the category of soil permeability, and the category of groundwater at the site. The permeability of the soil at the site must be reported in the corrective action. plan.

- For sites where the background level of petroleum, due to natural conditions, exceeds the levels for cleanup required for soil and/or groundwater as defined in Appendices 3 and 4 , the owner/operator will only be required to clean up to the naturally occurring background levels.

After an owner/operator has treated petroleum contamination for an extended period of time and the treatment system has reached asymptotic levels for contaminant removal, or the owner/operator believes that a particular site should not be subject to the cleanup requirements listed in Appendices 3 and 4, the TDEC Commissioner may be petitioned for a site-specific standard. However, in the case of an extended treatment period, a site-specific standard can only be requested after the level of contamination in soil and/or groundwater has remained relatively constant for at least four quarters.

\subsubsection{Out-of-Service UST Systems and Closure}

During temporarily closure of a UST system, owners/operators must continue operation and maintenance of corrosion protection and release detection systems. However, release detection is not required as long as the UST system is empty of petroleum product as defined per regulatory requirements. Compliance with reporting, investigation, confirmation, response, and corrective action requirements must be initiated if a release is suspected or confirmed during temporary closure.

When an UST system is temporarily closed for 3 months or longer, owners/operators must leave vent lines open and functioning; cap and secure all other lines, pumps, manways, and ancillary equipment; and must file an amended notification form. When an UST system is temporarily closed for more than 12 months, owners/operators must permanently close the system if it does not-meet either-performance standards for new -or upgraded UST systems, excluding the spill and overfill equipment requirements, unless a written extension of the 12-month temporary closure period is provided by the TDEC.

Permanent closure or change-in-service of UST systems require that owners/operators submit a site closure plan (application for permanent closure) to the TDEC Division of Underground Storage Tanks at least 30 days prior to initiation of activities, unless the action is in response to corrective action. Required assessment of the excavation zone must be performed after notifying TDEC but before completion of the permanent closure or change-in-service. 
To permanently close or change the service of a tank, the unit must be emptied and cleaned by removing all liquids and accumulated sludges. All tanks taken out of service permanently must also be either removed from the ground or filled with an inert solid material. Should an owner/operator elect to excavate and remove a tank from the site, all excavation, removal, storage, and disposal activities must be done in accordance with Appendix 5 requirements.

Before permanent closure or change-in-service is completed, owners/operators must measure for the presence of a release where contamination is most likely to be present at the UST site. In selecting sample types, sample locations, and measurement methods, owners/operators must consider the method of closure, the nature of the stored substance, the type of backfill, depth to groundwater, and other factors appropriate for identifying the presence of a release. The requirements for assessment of the UST site can be satisfied if one of the external release detection methods described in Section 1.6.4 of this document is operating at the time of closure, and indicates no release has occurred. In the event that free product, contaminated soils, or groundwater are found during assessment activities, owners/operators must begin corrective action.

Owners/operators must maintain records that are capable of demonstrating compliance with closure requirements. The results of the excavation zone assessment must be maintained for at least 3 years after completion of permanent closure or change-in-service by the party who performed the closure, by the current UST system owner/operator, or by mailing the records to TDEC if they cannot be maintained at the closed facility. 


\subsection{IMPLEMENTATION REQUIREMIENTS}

\subsection{TDEC Reference Handbook}

Environmental compliance requirements related to petroleum UST systems are defined within the Rules of the TDEC under Chapter 1200-1-15. However, implementation guidelines for compliance with the requirements contained within Chapter 1200-1-15 are defined in the second edition of the TDEC Division of Underground Storage Tanks Reference Handbook, which was issued in January of 1994.

The UST Reference Handbook defines various requirements regarding the reporting, response, confirmation, investigation, and corrective action for releases of petroleum from UST systems. It also defines the requirements for closure of petroleum UST systems. Figure 1 presents a decision flowchart that is based on the UST Reference H'andbook requirements. This flowchart illustrates the various decision pathways that should be followed after discovery of a release from a petroleum UST system.

Report forms to be utilized for documenting Initial Abatement Measures and Initial Site Characterization activities are presented in Appendix E of this document. Guidelines for the performance of Environmental Assessments and preparation of both Environmental Assessment Reports and Corrective Action Plans are presented in Appendix F. Technical Guidance Documents regarding monitoring of UST sites, procedures for obtaining a site-specific standard, performance of a general facility site check, and ranking of UST sites are presented in Appendix G.

The discussions presented in the following subsections provide information and requirements regarding UST topics that are not addressed within the Figure 1 decision flowchart.

\subsection{Discovery of Free Product}

In addition to the required actions and reporting presented in Figure 1, owners/operators must immediately begin removal of free petroleum product after discovery of a release in accordance with TDEC Technical Guidance Document - 004 (Appendix G). Situations that require removal of free product are: a measured thickness of free product greater than 0.10 inches in a well, the presence of a sheen on surface water, or the presence of a sheen on the ground surface or within a subsurface structure.

When free product removal is required, equipment capable of continuous free product removal must be installed within 48 hours after discovery, unless otherwise directed by TDEC. The removal system must be designed in such a manner to stop the migration of free product. Where surface water is impacted, petroleum absorbent material such as booms and pads must be installed and replaced whenever necessary. Within 45 days after release confirmation, a Free Product Removal Report must be submitted to TDEC. The form to be utilized for preparation of this report is presented in Appendix $\mathrm{E}$ of this document. 


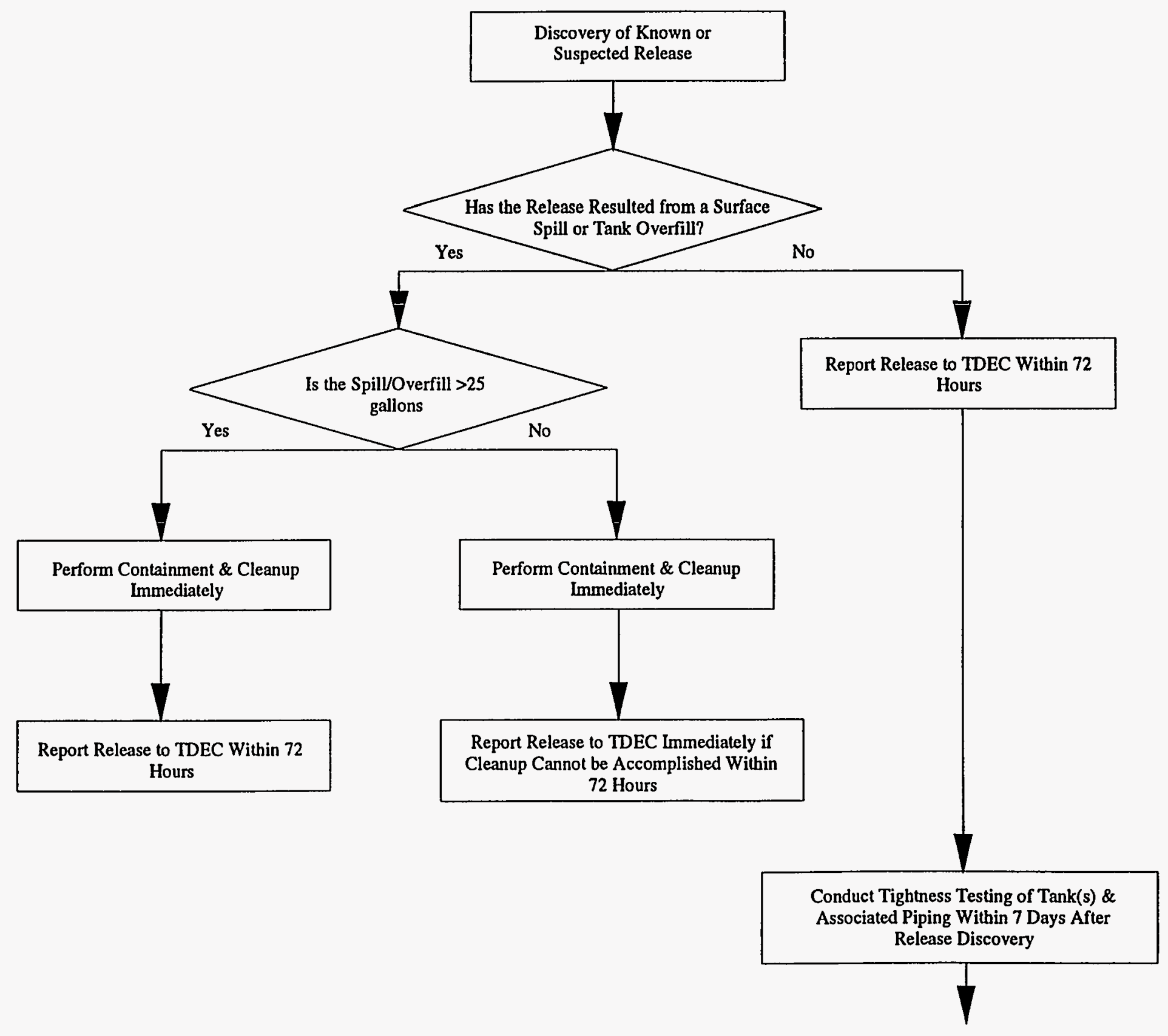




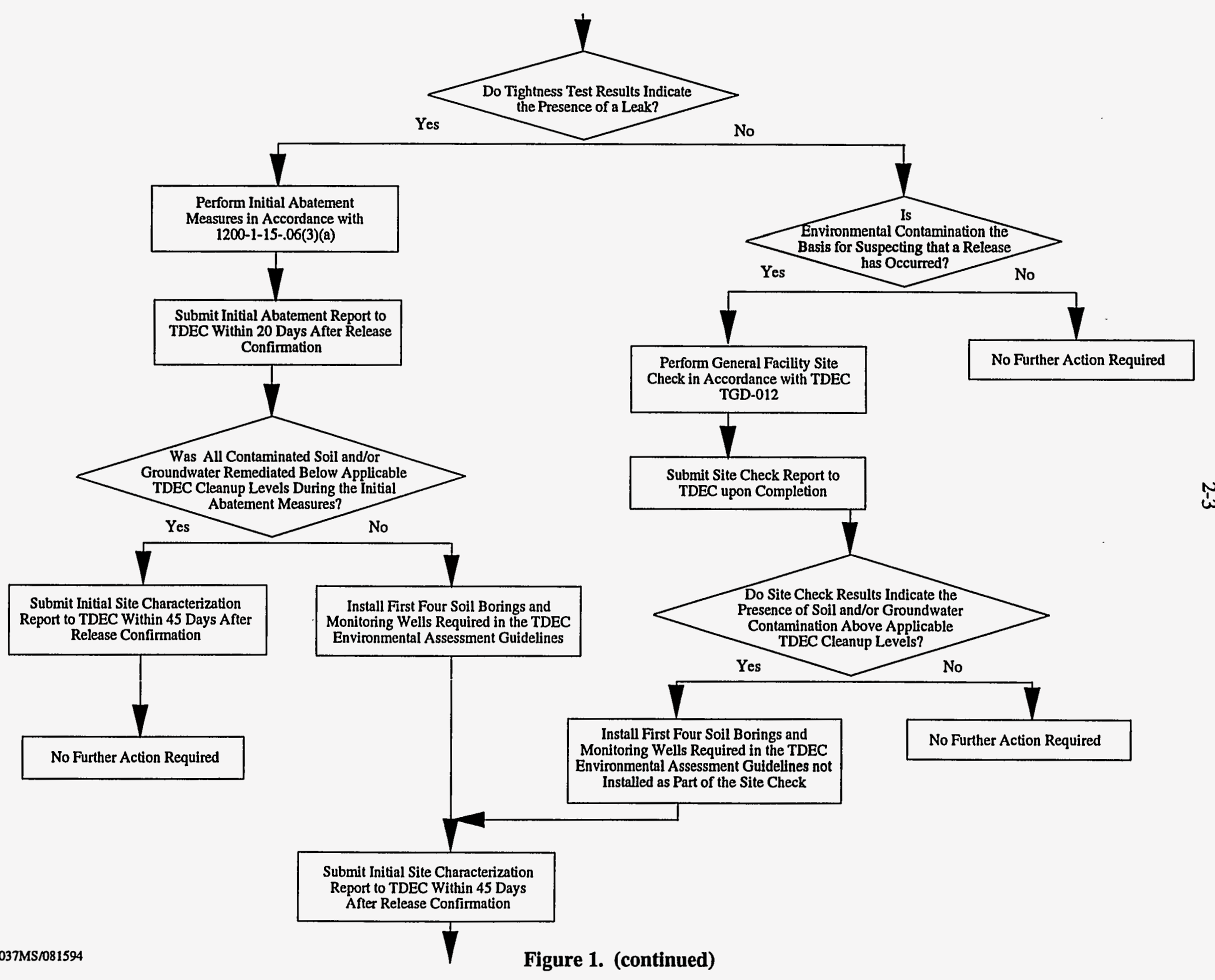




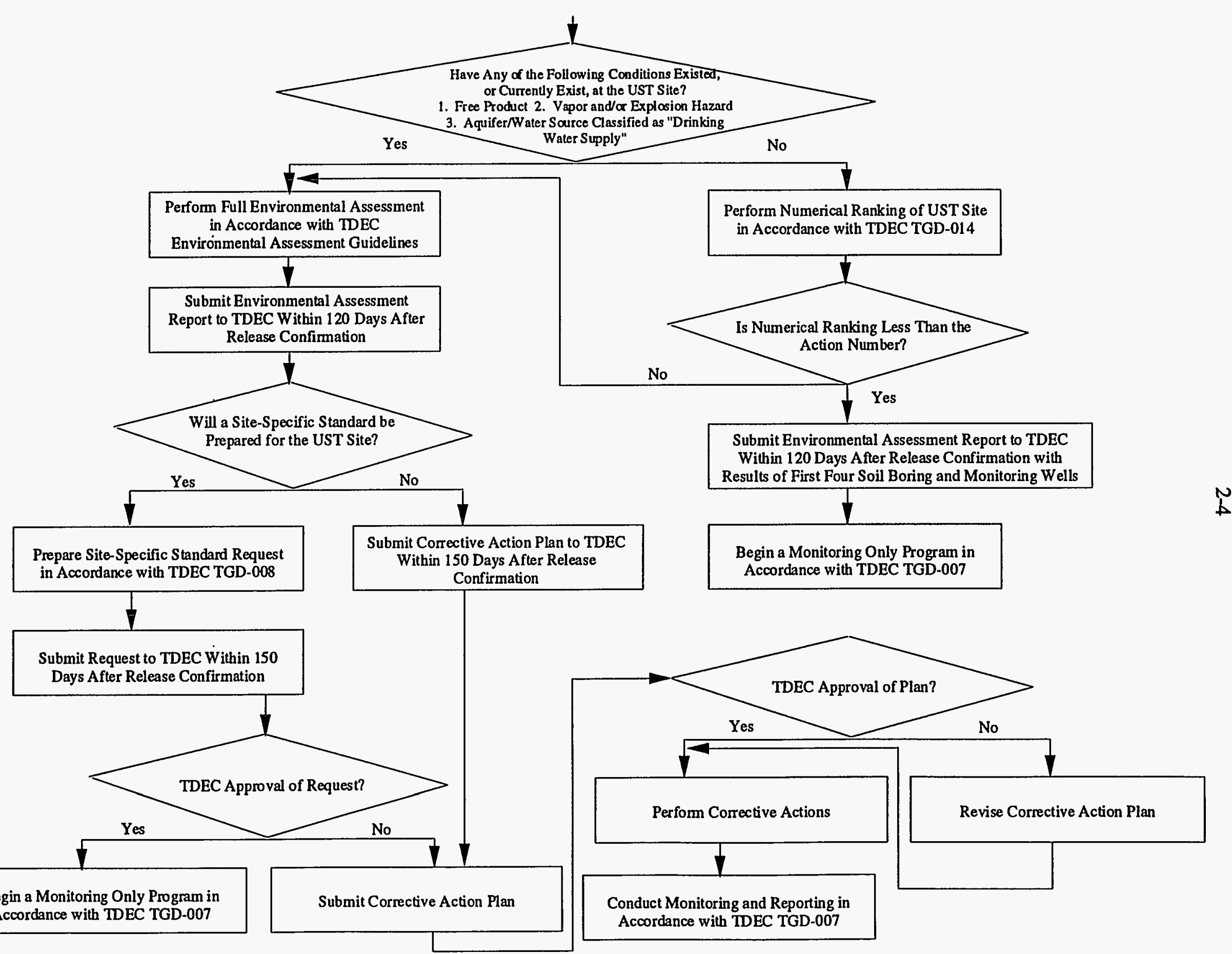




\subsection{Permanent UST System Closure}

Requirements for the permanent closure of UST systems are defined within Appendix 5 of Chapter 1200-1-15. Implementation guidance for closure activities is presented within the Closure Assessment Guidelines section of the UST Reference Handbook (Appendix H). In summary, an application for permanent system closure must be submitted to TDEC 30 days prior to the beginning of closure activities. Closure begins by removing all product and sludge from the UST system, and mitigating all vapors present within the system. Tanks are then excavated and removed from the tank bay, or are closed-in-place by filling the tanks with an inert material.

Soil samples are required to be collected after the UST system has been removed or closedin-place to ensure proper inspection of the tank bay area. In the case of UST removal, areas of obvious contamination must be overexcavated prior to sampling. Howvever, if more than 100 cubic yards of material is overexcavated (excluding tank bay backfill), the appropriate TDEC field office is to be contacted for further instructions. The number of soil samples to be collected, and the types of laboratory analyses to be conducted, will depend upon the type of product stored and the size(s) of the tanks.

In the event that free product is discovered during the UST system closure, TDEC must be notified within 72 hours. Upon receipt of the soil sample analysis results, a Permanent Closure Report must be submitted to TDEC within 45 days after the date of sample collection. In the event that the UST system closure soil sample results indicate the presence of contamination above the applicable TDEC closure action levels, then the appropriate actions in accordance with the Figure 1 decision flowchart must be implemented.

\subsection{Analytical Requirements}

\subsubsection{Analytical Methods}

Soil and groundwater samples collected during investigations of petroleum UST sites are required to be analyzed by approved laboratories following standard methods. A listing of laboratories approved by the TDEC is contained in Section 6 of the TDEC, Division of Underground Storage Tanks, Reference Handbook. Required analytical parameters, methods, and practical quantification limits are summarized in Table 4 and are described below.

Both soil and groundwater samples are required to be analyzed for Benzene, Toluene, and Xylene (BTX) and Total Petroleum Hydrocarbons (TPH). BTX analyses are to be performed following Test Methods for Evaluating Solid Waste (commonly known as SW-846). Purge and trap procedures following Method 5030 should be used for sample preparation. The actual constituent analysis must follow Method 8020 , using gas chromatography with a photoionization detector. However, in place of Methods 5030/8020, TDEC has approved the use of Method 8240 for BTX analysis. For soil, the level of Total BTX reported as the sum of Benzene, Toluene, Ortho-Xylene, Meta-Xylene, and Para-Xylene found in the sample, as well as the concentration of the individual results for Benzene, Toluene, and Total Xylene are reported.

Commonly, Ethylbenzene is quantified during the analysis of BTX constituents. Although not required by TDEC, Ethylbenzene results have been reported and included in the summation with Benzene, Toluene and Xylenes, resulting in a quantification of BTEX rather than BTX.

The required method(s) for TPH analyses is dependent upon the type of petroleum product released at a particular site. If gasoline or other low boiling point hydrocarbons $\left(70^{\circ}-180^{\circ} \mathrm{F}\right)$ were released, the Gasoline Range Organics (GRO) Method should be used. In the event that high boiling point hydrocarbon mixtures $\left(180^{\circ}-450^{\circ} \mathrm{F}\right)$ such as diesel fuel, kerosene, or fuel oil \#2 were released, the Diesel Range Organics (DRO) Method should be used. Releases of heavy 
Table 4. Summary of analytical requirements for samples collected from UST sites

\begin{tabular}{|l|l|l|}
\hline \multicolumn{1}{|c|}{ SUSPECTED CONTAMINANT } & \multicolumn{1}{|c|}{ ANALYTICAL METHOD $\cdots$} & \multicolumn{1}{|c|}{ QUANTIFICATIONLIMTT } \\
\hline \hline Benzene & SW-846 Method 5030/8020 & $0.002 \mathrm{ppm}$ (soil and groundwater) \\
\hline Toluene & SW-846 Method 5030/8020 & $0.002 \mathrm{ppm}$ (soil and groundwater) \\
\hline Xylenes & SW-846 Method 5030/8020 & $0.002 \mathrm{ppm}$ (soil and groundwater) \\
\hline $\begin{array}{l}\text { Benzene, Toluene, Xylene(s), and } \\
\text { Ethyl benzene }\end{array}$ & SW-846 Method 8240 & $0.005 \mathrm{ppm}$ (groundwater and soil) \\
\hline $\begin{array}{l}\text { Petroleum products with boiling } \\
\text { points between } 70^{\circ}-180^{\circ} \mathrm{F} \\
\text { (e.g., gasoline) }\end{array}$ & TPH-GRO & $\begin{array}{l}5 \mathrm{ppm} \text { (for soil) } \\
0.1 \mathrm{ppm} \text { (for groundwater) }\end{array}$ \\
\hline $\begin{array}{l}\text { Petroleum products with boiling } \\
\text { points between } 180^{\circ}-450^{\circ} \mathrm{F} \\
\text { (e.g., diesel, kerosene) }\end{array}$ & TPH-DRO & $\begin{array}{l}4 \mathrm{ppm} \text { (for soil) } \\
0.1 \mathrm{ppm} \text { (for groumdwater) }\end{array}$ \\
\hline $\begin{array}{l}\text { Petroleum products with boiling } \\
\text { points }>450^{\circ} \mathrm{F} \text { (e.g., used oil) }\end{array}$ & Method 503E or Method 418.1 & $\begin{array}{l}<100 \mathrm{ppm} \text { (soil } \\
1 \mathrm{ppm} \text { (groundwater) }\end{array}$ \\
\hline $\begin{array}{l}\text { A mixture of products with one } \\
\text { product having a boiling point } \\
\text { between } 70^{\circ}-180^{\circ} \mathrm{F} \text { and one having a } \\
\text { boiling point between } 180^{\circ}-450^{\circ} \mathrm{F} \\
\text { (e.g., gasoline and diesel) }\end{array}$ & TPH-GRO and TPH-DRO & \\
\hline Hydrocarbon type unknown & TPH-GRO and TPH-DRO & \\
\hline
\end{tabular}


hydrocarbon mixtures (boiling point $>450^{\circ}$ ) such as motor oil or used oil require the use of either Standard Methods of Analysis, Method 503 E, or Methods of Analysis of Water and Wastes, Method 418.1. In cases where the release of a combination of gasoline and diesel petroleum types is suspected or where the type of release is unknown, soil samples must be analyzed by both the GRO Method and the DRO Method and the results summed and reported as Total Petroleum Hydrocarbons.

\subsubsection{Data Reporting}

Requirements for the schematic and tabular presentation of analytical data within investigation reports are presented in the TDEC UST Reference Handbook. In addition to a tabular presentation of the data, original laboratory data sheets and copies of chain-of-custody forms are required to be submitted. The following information must be included on original laboratory data sheets:

- $\quad$ facility name;

- UST Facility ID number;

- sample location;

- $\quad$ sample depth from ground surface;

- date sampled;

- date submitted to the laboratory;

- date analyzed;

- analytical method; and

- detection limit. 


\subsection{Y-12 PLANT UST PROGRAM INVENTORY}

The UST systems located at the Y-12 Plant have been grouped into the following three categories:

- $\quad$ active/in-service petroleum UST systems ( 9 tanks / 7 sites);

- permanently closed petroleum UST systems (35 tanks / 25 sites); and

- hazardous substance UST systems (3 tanks / 3 sites).

The following section presents a summary of the tanks within the Y-12 Plant UST Program inventory (Table 5) and a summary of tanks and piping information for each unit within the inventory (Table 6). A master UST site location map (located within pocket) and individual UST site maps are also presented (following pocket map). All of the location and site maps are keyed to the UST Directory Numbers identified in Table 5. 
Table 5. Inventory of underground storage tanks at the Y-12 Plant

\begin{tabular}{|c|c|c|c|c|c|c|c|c|c|c|}
\hline $\begin{array}{l}\text { Directory } \\
\text { Location }\end{array}$ & Location & $\begin{array}{c}\text { Tank } \\
\text { identification } \\
\text { number }\end{array}$ & $\begin{array}{c}\text { Installation } \\
\text { date }\end{array}$ & $\begin{array}{c}\text { Out of } \\
\text { service date }\end{array}$ & $\begin{array}{l}\text { Capacity } \\
\text { (gallons) }\end{array}$ & Contents & Status & $\begin{array}{c}\text { Preliminary } \\
\text { investigations(s) }\end{array}$ & $\begin{array}{l}\text { Environmental } \\
\text { assessment () date to } \\
\text { regulatory agency }\end{array}$ & Corrective action \\
\hline \multicolumn{11}{|c|}{ Petroleum USTs } \\
\hline 1 & $9722-6$ & $2312-U$ & 1987 & In use & 550 & Diesel & $\begin{array}{l}\text { To be closed } \\
\text { by } 12 / 94\end{array}$ & NA & NA & NA \\
\hline 2 & $9722-5$ & $2313-U$ & 1987 & In use & 550 & Diesel & $\begin{array}{l}\text { To be closed } \\
\text { by } 12 / 94\end{array}$ & NA & NA & NA \\
\hline 3 & $9999-7$ & 2316-U & 1986 & In use & 550 & Diesel & $\begin{array}{l}\text { To be closed } \\
\text { by } 12 / 94\end{array}$ & NA & NA & NA \\
\hline 4 & 9999-5 & 2320-U & 1986 & In use & 550 & Diesel & $\begin{array}{l}\text { To be closed } \\
\text { by } 12 / 94\end{array}$ & NA & NA & NA \\
\hline 5 & $9722-4$ & 2333-U & 1988 & In use & 550 & Diesel & $\begin{array}{l}\text { To be closed } \\
\text { by } 12 / 94\end{array}$ & NA & NA & NA \\
\hline 6 & 9714 & $2334-U$ & 1987 & In use & 6,000 & Gasoline & $\begin{array}{l}\text { Full } \\
\text { compliance }\end{array}$ & Site check & NA & NA \\
\hline 7 & 9714 & $2335-U$ & 1987 & In use & 10,000 & Diesel & $\begin{array}{l}\text { Full } \\
\text { compliance }\end{array}$ & Site check & NA & NA \\
\hline 8 & $9754-3$ & 2396-U & 1993 & In use & 10,000 & Diesel & $\begin{array}{l}\text { Full } \\
\text { compliance }\end{array}$ & NA & NA & NA \\
\hline 9 & $9754-3$ & $2397-U$ & 1993 & In use & 20,000 & Gasoline & $\begin{array}{l}\text { Full } \\
\text { compliance }\end{array}$ & NA & NA & NA \\
\hline 10 & 9712 & $0084-U$ & 1958 & 1988 & 500 & Used oil & $\begin{array}{l}\text { Removed } \\
6 / 88\end{array}$ & CERCLA & TBD & TBD \\
\hline 11 & $9204-2$ & $0134-U$ & 1966 & 1982 & 117 & Gasoline & $\begin{array}{l}\text { Removed } \\
6 / 88\end{array}$ & ISCR, FPRR & SIR (3/92) & $\begin{array}{l}\text { EAR/CAP }(8 / 92), \text { CAP } \\
\text { approval }(5 / 93), \text { CR (4/94) }\end{array}$ \\
\hline 12 & $9754-2$ & 0439-U & 1978 & 1989 & 20,000 & Gasoline & $\begin{array}{l}\text { Removed } \\
9 / 89\end{array}$ & $\begin{array}{l}\text { IAR, ISCR, } \\
\text { FPRR }\end{array}$ & SIR/CAP (3/91) & $\begin{array}{l}\text { CAP (8/92), CAP approval } \\
(5 / 93) \text {, BMR (3/94), SSSR } \\
(4 / 94)\end{array}$ \\
\hline 13 & 9754-2 & $0440-U$ & 1978 & 1989 & 10,000 & Diesel & $\begin{array}{l}\text { Removed } \\
9 / 89\end{array}$ & $\begin{array}{l}\text { IAR, ISCR, } \\
\text { FPRR }\end{array}$ & SIR/CAP (3/91) & $\begin{array}{l}\text { CAP (8/92), CAP approval } \\
(5 / 93) \text {, BMR (3/94), SSSR } \\
(4 / 94)\end{array}$ \\
\hline 14 & 9754 & 2073-U & 1944 & 1979 & 1,000 & Gasoline & $\begin{array}{l}\text { Removed } \\
10 / 93\end{array}$ & SI & SIR/CAP (3/91) & $\begin{array}{l}\text { CAP (8/92), CAP approval } \\
(5 / 93), \text { BMR (3/94), SSSR } \\
(4 / 94)\end{array}$ \\
\hline
\end{tabular}


Table 5. (continued)

\begin{tabular}{|c|c|c|c|c|c|c|c|c|c|c|}
\hline $\begin{array}{l}\text { Directory } \\
\text { Location }\end{array}$ & Location & $\begin{array}{c}\text { Tank } \\
\text { identification } \\
\text { number }\end{array}$ & $\begin{array}{c}\text { Installation } \\
\text { date }\end{array}$ & $\begin{array}{c}\text { Out of } \\
\text { service date }\end{array}$ & $\begin{array}{l}\text { Capacity } \\
\text { (gallons) }\end{array}$ & Contents & Status & $\begin{array}{c}\text { Preliminary } \\
\text { investigations(s) }\end{array}$ & $\begin{array}{l}\text { Environmental } \\
\text { assessment () date to } \\
\text { regulatory agency }\end{array}$ & Corrective action \\
\hline 15 & 9754 & 2074-U & 1944 & 1979 & 1,000 & Gasoline & $\begin{array}{l}\text { Removed } \\
10 / 93\end{array}$ & SI & SIR/CAP (3/91) & $\begin{array}{l}\text { CAP (8/92), CAP approval } \\
(5 / 93), \text { BMR }(3 / 94), \text { SSSR } \\
(4 / 94)\end{array}$ \\
\hline 16 & 9754 & 2075-U & 1944 & 1979 & 1,000 & Diesel & $\begin{array}{l}\text { Removed } \\
10 / 93\end{array}$ & SI & SIR/CAP (3/91) & $\begin{array}{l}\text { CAP (8/92), CAP approval } \\
(5 / 93), \text { BMR }(3 / 94), \text { SSSR } \\
(4 / 94)\end{array}$ \\
\hline 17 & 9754-1 & $1219-U$ & 1964 & 1988 & 12,000 & Diesel & $\begin{array}{l}\text { Removed } \\
12 / 89\end{array}$ & EA & SIR $(3 / 91)$ & $\begin{array}{l}\text { CAP (5/92), SRS (2/94), } \\
\text { SRS approval (3/94), CMR } \\
(6 / 94, \text { SSSR }(8 / 94)\end{array}$ \\
\hline 18 & $9754-1$ & $1222-U$ & 1968 & 1988 & 12,000 & Gasoline & $\begin{array}{l}\text { Removed } \\
12 / 89\end{array}$ & EA & $\operatorname{SIR}(3 / 91)$ & $\begin{array}{l}\text { CAP (5/92), SRS (2/94), } \\
\text { SRS approval (3/94), CMR } \\
(6 / 94), \text { SSSR }(8 / 94)\end{array}$ \\
\hline 19 & $9720-15$ & 2068-U & 1968 & 1980 & 1,000 & Gasoline & $\begin{array}{l}\text { Removed } \\
2 / 90\end{array}$ & EA/FPRR & $\operatorname{SIR}(3 / 91)$ & $\begin{array}{l}\text { CAP (5/92), SRS (2/94), } \\
\text { SRS approval (3/94), CMR } \\
(6 / 94), \text { SSSR }(8 / 94)\end{array}$ \\
\hline 20 & 9754-1 & 2082-U & 1981 & 1988 & 1,000 & Gasoline & $\begin{array}{l}\text { Removed } \\
12 / 89\end{array}$ & EA & SIR (3/91) & $\begin{array}{l}\text { CAP (5/92), SRS (2/94), } \\
\text { SRS approval (3/94), CMR } \\
(6 / 94), \text { SSSR }(8 / 94)\end{array}$ \\
\hline 21 & PRW & $2310-U$ & 1975 & 1989 & 200 & Gasoline & $\begin{array}{l}\text { Removed } \\
11 / 89\end{array}$ & ISCR & SIR/CAP (7/91) & $\begin{array}{l}\text { EAR/CAP (3/93), CAP } \\
\text { approval }(12 / 93), \text { OE }(4 / 94, \\
5 / 94), \text { CR }(7 / 94)\end{array}$ \\
\hline 22 & $9201-1$ & 2331-II & 1973 & 1988 & 560 & Gasoline & $\begin{array}{l}\text { Remored } \\
12 / 88\end{array}$ & ISCR, PrnR & Sif (3igiz) & 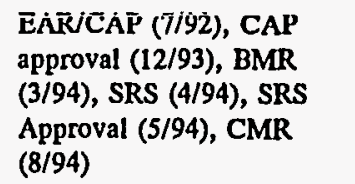 \\
\hline 23 & $9401-3$ & $0713-U$ & 1955 & 1988 & 10,500 & No. 2 fuel oil & $\begin{array}{l}\text { Removed } \\
11 / 88\end{array}$ & NI & NA & NA \\
\hline 24 & 9754 & $0836-U$ & 1944 & 1989 & 10,000 & Used oil & $\begin{array}{l}\text { Removed } \\
10 / 89\end{array}$ & RCRA & RCRA & RCRA \\
\hline 25 & $9204-3$ & $0928-U$ & 1966 & 1989 & 200 & Gasoline & $\begin{array}{l}\text { Removed } \\
5 / 89\end{array}$ & $\begin{array}{l}\text { RIR closure } \\
\text { approved (8/92) }\end{array}$ & NA & NA \\
\hline 28 & 9995 & 2078-U & 1965 & 1979 & 110 & Gasoline & $\begin{array}{l}\text { Inert filed } \\
1979\end{array}$ & CERCLA & TBD & TBD \\
\hline
\end{tabular}


Table 5. (continued)

\begin{tabular}{|c|c|c|c|c|c|c|c|c|c|c|}
\hline $\begin{array}{l}\text { Directory } \\
\text { Location }\end{array}$ & Location & $\begin{array}{c}\text { Tank } \\
\text { identification } \\
\text { number }\end{array}$ & $\begin{array}{c}\text { Installation } \\
\text { date }\end{array}$ & $\begin{array}{c}\text { Out of } \\
\text { service date }\end{array}$ & $\begin{array}{l}\text { Capacity } \\
\text { (gallons) } \\
\end{array}$ & Contents & Status & $\begin{array}{c}\text { Preliminary } \\
\text { investigations(s) }\end{array}$ & $\begin{array}{l}\text { Environmental } \\
\text { assessment () date to } \\
\text { regulatory agency }\end{array}$ & Corrective action \\
\hline 27 & 9995 & 2079-U & 1965 & 1979 & 55 & Gasoline & $\begin{array}{l}\text { Inert filed } \\
1979\end{array}$ & CERCLA & TBD & TBD \\
\hline 28 & 9996 & 2080-U & 1971 & 1987 & 560 & Gasoline & $\begin{array}{l}\text { Removed } \\
12 / 88\end{array}$ & $\mathbf{R I R}$ & NA & NA \\
\hline 29 & 9212 & 2081-U & 1958 & 1970 & 280 & Gasoline & $\begin{array}{l}\text { Removed } \\
4 / 91\end{array}$ & ISCR & NA & $\mathrm{OE} / \mathrm{CR}(12 / 91)$ \\
\hline 30 & $9201-5$ & 2099-U & 1971 & 1989 & 560 & Gasoline & $\begin{array}{l}\text { Removed } \\
7 / 89\end{array}$ & $\begin{array}{l}\text { IAR, RIR, } \\
\text { closure approved } \\
(3 / 90)\end{array}$ & NA & NA \\
\hline 31 & $9929-1$ & $2117-U$ & 1971 & 1983 & 550 & No. 2 fuel oil & $\begin{array}{l}\text { Removed } \\
10 / 88\end{array}$ & NI & NA & NA \\
\hline 32 & $9204-4$ & $2130-U$ & 1960 & 1992 & 550 & Gasoline & $\begin{array}{l}\text { Removed } \\
12 / 92\end{array}$ & $\mathbf{R I R}$ & NA & NA \\
\hline 33 & 9999 & 2293-U & 1954 & 1974 & 58 & Gasoline & $\begin{array}{l}\text { Removed } \\
1974\end{array}$ & NI & NA & NA \\
\hline 34 & 9999 & 2294-U & 1954 & 1974 & 58 & Gasoline & $\begin{array}{l}\text { Removed } \\
1974\end{array}$ & $\mathrm{NI}$ & NA & NA \\
\hline 35 & 9998 & $2305-U$ & 1956 & 1990 & 55 & Diesel & $\begin{array}{l}\text { Removed } \\
10 / 90\end{array}$ & $\mathbf{R I R}$ & NA & NA \\
\hline 36 & PRE & $2315-U$ & 1960 & 1988 & 64 & Gasoline & $\begin{array}{l}\text { Removed } \\
11 / 89\end{array}$ & ISCr & EAR/CAP (2/91) & OE/CAR (12/92) \\
\hline 37 & 9769 & $2330 . \mathrm{U}$ & 1949 & 1988 & 5,000 & No. 2 fuel oil & $\begin{array}{l}\text { Inert filed } \\
1988\end{array}$ & NI & NA & NA \\
\hline 38 & $\begin{array}{l}\text { Chest. } \\
\text { Ridge }\end{array}$ & $2336 \cdot U$ & 1981 & 1991 & 550 & Gasoline & $\begin{array}{l}\text { Removed } \\
5 / 91\end{array}$ & RIR & NA & NA \\
\hline 39 & $\begin{array}{l}\text { Buff. } \\
\text { Mtn. }\end{array}$ & $2337 \cdot U$ & 1972 & 1990 & 250 & Gasoline & $\begin{array}{l}\text { Removed } \\
3 / 90\end{array}$ & $\begin{array}{l}\text { IAR, ISCR SIR, } \\
\text { SIRI (1/92) }\end{array}$ & NA & NA \\
\hline 40 & $9720-13$ & $2338-U$ & 1970 & 1984 & 200 & Used oil & $\begin{array}{l}\text { Removed } \\
7 / 90\end{array}$ & $\mathbf{R I R}$ & TBD & TBD \\
\hline 41 & 9219 & $2395-U$ & 1964 & 1977 & 2,000 & No. 2 fuel oil & $\begin{array}{l}\text { Removed } \\
6 / 93\end{array}$ & TBD & TBD & TBD \\
\hline
\end{tabular}


Table 5. (continued)

\begin{tabular}{|c|c|c|c|c|c|c|c|c|c|c|}
\hline $\begin{array}{l}\text { Directory } \\
\text { Location }\end{array}$ & Location & $\begin{array}{c}\text { Tank } \\
\text { identification } \\
\text { number }\end{array}$ & $\begin{array}{c}\text { Installation } \\
\text { date }\end{array}$ & $\begin{array}{c}\text { Out of } \\
\text { service date }\end{array}$ & $\begin{array}{l}\text { Capacity } \\
\text { (gallons) }\end{array}$ & Contents & Status & $\begin{array}{c}\text { Preliminary } \\
\text { investigations(s) }\end{array}$ & $\begin{array}{l}\text { Environmental } \\
\text { assessment () date to } \\
\text { regulatory agency }\end{array}$ & Corrective action \\
\hline 42 & SYDD & 2063-U & 1959 & 1989 & 130 & Oil/solvent & $\begin{array}{l}\text { Removed } \\
7 / 89\end{array}$ & IAR, ISCR/FPRR & RCRA & RCRA \\
\hline 43 & SYDD & $2328-U$ & 1959 & 1989 & 475 & Oil/solvent & $\begin{array}{l}\text { Removed } \\
7 / 89\end{array}$ & IAR, ISCR/FPRR & RCRA & RCRA \\
\hline 44 & SYDD & 2329-U & 1959 & 1989 & 475 & Oil/solvent & $\begin{array}{l}\text { Removed } \\
7 / 89\end{array}$ & IAR, ISCR/FPRR & RCRA & RCRA \\
\hline \multicolumn{11}{|c|}{ Hazardous substance USTs } \\
\hline 45 & $9767-13$ & $2102-U$ & 1987 & 1992 & 7,500 & Methanol & $\begin{array}{l}\text { Removed } \\
1 / 93\end{array}$ & CR & NA & NA \\
\hline 46 & $9418-3$ & 2072-U & 1943 & 1960 & 45,000 & $\begin{array}{l}\text { Solid uranium } \\
\text { oxide }\end{array}$ & Exempt & CERCLA & CERCLA & CERCLA \\
\hline 47 & $9825-1$ & $2129-U$ & 1984 & In use & 240,000 & $\begin{array}{l}\text { Solid uranium } \\
\text { oxide }\end{array}$ & Exempt & NA & NA & NA \\
\hline
\end{tabular}

Notes

$\begin{array}{llll}\text { BMR } & =\text { baseline monitoring report } & \text { EAR } & =\text { Environmental Assessment Report } \\ \text { CAP } & =\text { corrective action plan } & \text { FPRR } & =\text { free product removal report } \\ \text { CAR } & =\text { corrective action report } & \text { IAR } & =\text { initial abatement report } \\ \text { CERCLA } & =\text { conducted under CERCLA } & \text { ISCR } & =\text { initial site characterization report } \\ \text { CMR } & =\text { Comprehensive Monitoring Report } & \text { NA } & =\text { Not applicable } \\ \text { CR } & =\text { closure report } & \text { NI } & =\text { Not investigated } \\ \mathbf{E} \dot{A} & =\text { environmentai assessment } & \text { UE } & =\text { overexcavation }\end{array}$

RCRA = conducted under RCRA, Subtitle C

RIR = Release Investigation Report

TBD $=$ to be determined

SIR = site investigation report

SRS = site ranking system

SSSR = site-specific standard request

SYDD $\quad$ Salvage Yard Drum Deheader 
Table 6. Summary of tank and piping information

\begin{tabular}{|c|c|c|c|c|c|c|c|c|c|c|c|c|}
\hline \multirow{3}{*}{$\begin{array}{c}\text { Directory } \\
\text { Number }\end{array}$} & \multirow[b]{3}{*}{ Location } & \multirow{3}{*}{$\begin{array}{c}\text { Tank } \\
\text { Number }\end{array}$} & \multicolumn{5}{|c|}{ TANK INFORMATION } & \multicolumn{4}{|c|}{ PIPING INFORMATION } & \multirow[b]{3}{*}{ Comments } \\
\hline & & & \multirow{2}{*}{$\begin{array}{c}\text { Construction } \\
\text { Material } \\
\end{array}$} & \multicolumn{4}{|c|}{ PROTECTION } & \multirow{2}{*}{$\begin{array}{c}\text { Construction } \\
\text { Material }\end{array}$} & \multirow[b]{2}{*}{ Typo } & \multicolumn{2}{|c|}{ PROTECTION } & \\
\hline & & & & Cathodic & Spill & Overfill & Release & & & Cathodic & Release & \\
\hline 1 & $9722-6$ & $2312-U$ & FGL (DW) & NA & $\mathbf{N}$ & $\mathbf{N}$ & $\mathbf{Y}$ & STEEL & $\mathbf{s}$ & $\mathbf{N}$ & $\mathbf{N}$ & Emergency generator tank \\
\hline 2 & $9722-5$ & 2313-U & FGL (DW) & NA & $\mathrm{N}$ & $\mathbf{N}$ & $\mathbf{Y}$ & STEEL & $s$ & $\mathbf{N}$ & $\mathbf{N}$ & Emergency generntor unk \\
\hline 3 & 9999-7 & $2316-U$ & FGL (sW) & NA & $\mathbf{N}$ & $\mathbf{N}$ & $\mathrm{N}$ & STEEL & $s$ & $\mathbf{N}$ & $\mathbf{N}$ & Emergency generator tank \\
\hline 4 & 9999-5 & $2320-U^{\prime}$ & FGL (SW) & NA & $\mathbf{N}$ & $\mathbf{N}$ & $\mathbf{N}$ & STEEL & $\mathbf{s}$ & $\mathbf{N}$ & $\mathbf{N}$ & Emergency generator tank \\
\hline 5 & $9722-4$ & $2333-U$ & FGL (DW) & NA & $\mathbf{N}$ & $\mathrm{N}$ & $\mathbf{Y}$ & STEEL & $\mathbf{s}$ & $\mathbf{N}$ & $\mathbf{N}$ & Emergency generator tank \\
\hline 6 & 9714 & 2334-U & FGL (SW) & NA & $\mathbf{Y}$ & $\mathbf{Y}$ & $\mathbf{Y}$ & FGL (SW) & $\mathbf{P}$ & NA & $x$ & Bulk fuel dispensing \\
\hline 7 & 9714 & 2335-U & FGL (SW) & NA & $\mathbf{Y}$ & $\mathbf{Y}$ & $\mathbf{Y}$ & FGL (SW) & $\mathbf{P}$ & NA & $\mathbf{Y}$ & Bulk fuel dispensing \\
\hline 8 & $9754-3$ & $2396-U$ & FGL (DW) & NA & $\mathbf{Y}$ & $\mathbf{x}$ & $\mathbf{Y}$ & FGL (DW) & $\mathbf{P}$ & NA & $\mathbf{Y}$ & Bulk fuel dispensing \\
\hline 9 & 9754-3 & 2397-U & FGL (DW) & NA & $\mathbf{Y}$ & $\mathbf{Y}$ & $\mathbf{Y}$ & FGL (DW) & $\mathbf{P}$ & NA & $\mathbf{Y}$ & Bulk fuel dispensing \\
\hline 10 & 9712 & 0084-U & STEEL & NA & $\mathbf{N}$ & $\mathbf{N}$ & $\mathbf{N}$ & STEEL & GF & $\mathbf{N}$ & $\mathbf{N}$ & Used oil collection \\
\hline 11 & $9204-2$ & 0134-Uं & STEEL & NA & $\mathbf{N}$ & $\mathbf{N}$ & $\mathbf{N}$ & STEEL & $\mathbf{s}$ & $\mathbf{N}$ & $\mathbf{N}$ & Emergency generator tank \\
\hline 12 & $9754-2$ & $0439-U$ & FGL (SW) & NA & $\mathbf{N}$ & $\mathbf{N}$ & $\mathbf{N}$ & FGL (SW) & $\mathbf{P}$ & NA & $\mathbf{N}$ & Bulk fuel dispensing \\
\hline 13 & $9754-2$ & $0440 \mathrm{U}$ & FGL (sW) & NA & $\mathbf{N}$ & $\mathbf{N}$ & $\mathbf{N}$ & FGL (SW) & $\mathbf{P}$ & NA & $\mathbf{N}$ & Bulk fuel dispensing \\
\hline 14 & 9754 & 2073-U & STEEL & NA & $N$ & $\mathbf{N}$ & $\mathbf{N}$ & STEEL & $\mathbf{s}$ & NA & $\mathbf{N}$ & Dispenser tank \\
\hline 15 & 9754 & $2074-U$ & STEEL & NA & $N$ & $\mathrm{~N}$ & $\mathbf{N}$ & STEEL & $\mathbf{s}$ & NA & $\mathbf{N}$ & Dispenser tank \\
\hline 16 & 9754 & 2075-U & STEEL & NA & $N$ & $\mathbf{N}$ & $\mathbf{N}$ & STEEL & $\mathbf{s}$ & $\cdot \mathbf{N}$ & $\mathbf{N}$ & Dispenser tank \\
\hline 17 & $9754-1$ & $1219-\mathrm{U}$ & STEEL & NA & $\mathbf{N}$ & $\mathrm{N}$ & $\mathbf{N}$ & GLVZD STL. & $\mathbf{s}$ & $\mathbf{N}$ & $\mathbf{N}$ & Bulk fuel dispensing \\
\hline 18 & 9754-1 & $1222-U$ & STEEL & NA & $\mathbf{N}$ & $\mathrm{N}$ & $\mathbf{N}$ & GLVZD STL. & $\mathbf{s}$ & $\mathbf{N}$ & $\mathbf{N}$ & Bulk fuel dispensing \\
\hline 19 & $9720-15$ & 2068-U & STEEL & $\mathrm{NA}$ & $\mathrm{N}$ & $\mathbf{N}$ & $\mathrm{N}$ & GLVZD STL. & $s$ & $\mathbf{N}$ & $\mathrm{N}$ & Dispenser tank \\
\hline 20 & $9754-1$ & $2082-U$ & STEEL & NA & $\mathrm{N}$ & $\mathbf{N}$ & $\mathbf{N}$ & GLVZD STL. & $s$ & $\mathbf{N}$ & $\mathbf{N}$ & Bulk fuel dispensing \\
\hline 21 & PRW & $2310-U$ & STEEL & NA & $\mathbf{N}$ & $\mathrm{N}$ & $\mathbf{N}$ & STEEL & $s$ & $\mathrm{~N}$ & $\mathrm{~N}$ & Emergency generator tank \\
\hline
\end{tabular}




\begin{tabular}{|c|c|c|c|c|c|c|c|c|c|c|c|c|}
\hline VyDd:duns ग1asouo & $\mathbf{N}$ & $\mathbf{N}$ & dD & VN & $\mathbf{N}$ & $\mathbf{N}$ & $\mathbf{N}$ & $N$ & בLI8ONOD & $\mathrm{n}-\varepsilon 902$ & aaxs & $\tau t$ \\
\hline 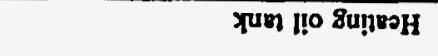 & $\mathbf{N}$ & $\mathbf{N}$ & $\mathbf{s}$ & \&GddOS & $\mathbf{N}$ & $\mathbf{N}$ & $\mathbf{N}$ & $\mathbf{N}$ & TagIS & n-S6民Z & 6126 & It \\
\hline 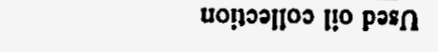 & $\mathbf{N}$ & $\mathbf{N}$ & Jפ & TgaIS 'IS & $\mathbf{N}$ & $\mathbf{N}$ & $\mathbf{N}$ & $\mathbf{N}$ & TGEIS 'IS & ח-8EEZ & $\mathfrak{E I - 0 Z \angle 6}$ & $0 t$ \\
\hline 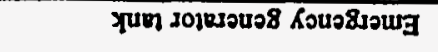 & $\mathbf{N}$ & $\mathbf{N}$ & $\mathrm{s}$ & TAGIS & $\mathbf{N}$ & $\mathbf{N}$ & $\mathbf{N}$ & $\mathbf{N}$ & TäIS & $\Pi-L \mathfrak{E E Z}$ & แ) แHก & $6 \varepsilon$ \\
\hline 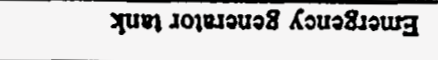 & $\mathbf{N}$ & $\mathbf{N}$ & $\mathbf{s}$ & 7gaIs & $\mathbf{N}$ & $N$ & N & $\mathbf{N}$ & 79ت1S & $\Omega \cdot 9 \mathbb{E E Z}$ & 8py 1s40 & $8 E$ \\
\hline 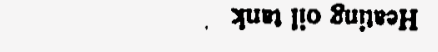 & N & $\mathbf{N}$ & $\mathbf{s}$ & 79Bls & N & $\mathbf{N}$ & N & $\mathbf{N}$ & 73aIs & n-OEEZ & 69166 & $L \varepsilon$ \\
\hline 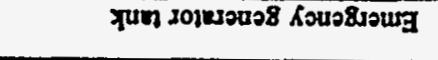 & $\mathbf{N}$ & $N$ & $\mathbf{s}$ & 8gddOO & $\mathbf{N}$ & $N$ & $\mathbf{N}$ & $\mathbf{N}$ & 7ag.IS & n-sIEZ & gdd & $9 \varepsilon$ \\
\hline 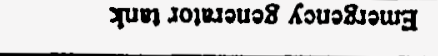 & $\mathbf{N}$ & N & $\mathbf{s}$ & yeddo0 & $\mathbf{N}$ & $\mathbf{N}$ & N & $\mathbf{N}$ & Tag.LS IS & $n-$ SOEZ & 8666 & $\varsigma \varepsilon$ \\
\hline 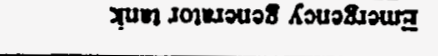 & I! & A & $\mathbf{s}$ & 'TIS 'GZATE & A & in & N & N & TES.5 & 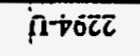 & 6666 & $\dot{\nabla} \bar{\varepsilon}$ \\
\hline 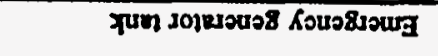 & $\mathbf{N}$ & N & s & IIS ' $\mathrm{ZZ \Lambda TD}$ & $\mathbf{N}$ & $\mathbf{N}$ & $\mathbf{N}$ & $N$ & 79aLs & $\mathbf{n}-\varepsilon 6 \tau \tau$ & 6666 & $\mathfrak{\varepsilon \varepsilon}$ \\
\hline Yun soruodeta & $\mathbf{N}$ & $\mathbf{N}$ & $\mathbf{s}$ & 'TLS ' GZATอ & $\mathbf{N}$ & $\mathbf{N}$ & $\mathbf{N}$ & $\mathbf{N}$ & Tagls & $n-0 \varepsilon I Z$ & $b+026$ & $\tau \varepsilon$ \\
\hline xum n!o 8uṇw: H & N & N & $\mathbf{s}$ & TgIIS & N & $\mathbf{N}$ & $\mathbf{N}$ & $\mathbf{N}$ & 7agls & $n-L I 12$ & I-6266 & $\mathfrak{I \varepsilon}$ \\
\hline yun dosuadr!d & $\mathbf{N}$ & $\mathbf{N}$ & $\mathbf{s}$ & 'TLS 'azATD & $\mathbf{N}$ & $N$ & $N$ & $\mathbf{N}$ & Tg9LS & $\Omega-6602$ & s-1026 & $O E$ \\
\hline Yun sorrade! & N & $\mathbf{N}$ & $\mathbf{s}$ & T33IS & N & N & $\mathbf{N}$ & N & Tag1S & $\Omega-180 \tau$ & 2126 & 62 \\
\hline Jun dosuods! & $\mathbf{N}$ & N & $\mathbf{s}$ & 'TLS $\cdot$ azATo & 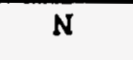 & N & N & $\mathbf{N}$ & Tagls & $\Omega-0802$ & 9666 & 82 \\
\hline 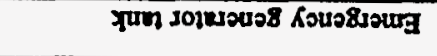 & $\mathbf{N}$ & $\mathbf{N}$ & $\mathbf{s}$ & 7ag.1S & $\mathbf{N}$ & $N$ & $\mathbf{N}$ & $\mathbf{N}$ & Tagls & $\Omega-6 L 0 \tau$ & S666 & $\angle \tau$ \\
\hline 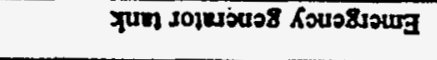 & $\mathbf{N}$ & $\mathbf{N}$ & s & Tag1s & $\mathbf{N}$ & $\mathbf{N}$ & $\mathbf{N}$ & $\mathbf{N}$ & TagIS & $n-8 L 0 Z$ & $\$ 666$ & $9 \tau$ \\
\hline 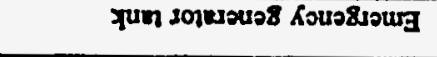 & $\boldsymbol{N}$ & $N$ & s & TIS IS & $\mathbf{N}$ & $\mathbf{N}$ & N & N & TgGIS IS & $n-8260$ & $\varepsilon+0 z 6$ & $\boldsymbol{s \tau}$ \\
\hline 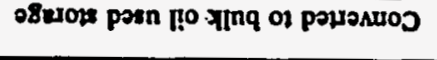 & N & $N$ & בס & 'TIS aZATO & N & $\mathbf{N}$ & N & VN & Tagis & $\mathrm{n}^{-9}-9 \varepsilon 80$ & tSL6 & $b 2$ \\
\hline 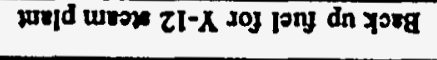 & $\mathbf{N}$ & $\mathbf{N}$ & $\mathbf{s}$ & 7agls & $\mathbf{N}$ & $\mathbf{N}$ & $\mathbf{N}$ & VN & TEMIS & $\underline{n-\varepsilon I L 0}$ & E-10t6 & $\varepsilon$ \\
\hline 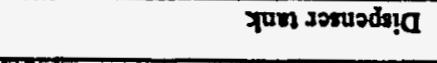 & $\mathbf{N}$ & $\mathbf{N}$ & $\mathbf{s}$ & 7agls & $\mathbf{N}$ & $\mathbf{N}$ & N & VN & TäLS & 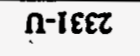 & $10-1026$ & $\tau 2$ \\
\hline \multirow[t]{3}{*}{ squatumos } & อSEP|PY & $\begin{array}{r}\text { गุpoपpв } \\
.\end{array}$ & \multirow[t]{2}{*}{$\operatorname{dd} K_{I}$} & \multirow[t]{2}{*}{ 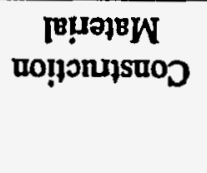 } & $\begin{array}{c}\text { әรвәрәу } \\
\ldots\end{array}$ & 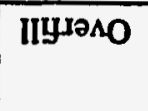 & IIIds & ग!р0чाв & \multirow[t]{2}{*}{ 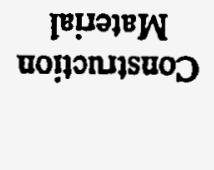 } & \multirow[t]{3}{*}{ 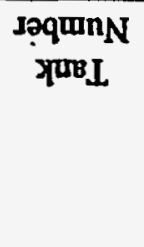 } & \multirow[t]{3}{*}{ นоп̣BSOI } & \multirow[t]{3}{*}{$\begin{array}{l}\text { sequnn } \\
\text { Srojoes! }\end{array}$} \\
\hline & NOLĹ & GIOXd & & & & NOLIDE & IOYd & & & & & \\
\hline & \multicolumn{4}{|c|}{ NOLLVWXOHNI DNIdId } & \multicolumn{5}{|c|}{ NOISVWYOANI YNVI } & & & \\
\hline
\end{tabular}

(pənụpuos) 9 ә әqе 
Table 6. (continued)

\begin{tabular}{|c|c|c|c|c|c|c|c|c|c|c|c|c|}
\hline \multirow{3}{*}{$\begin{array}{l}\text { Directory } \\
\text { Number }\end{array}$} & \multirow[b]{3}{*}{ Location } & \multirow{3}{*}{$\begin{array}{c}\text { Tank } \\
\text { Number }\end{array}$} & \multicolumn{5}{|c|}{ TANK INFORMATION } & \multicolumn{4}{|c|}{ PIPING INFORMATION } & \multirow[b]{3}{*}{ Comments } \\
\hline & & & \multirow{2}{*}{$\begin{array}{l}\text { Construction } \\
\text { Material }\end{array}$} & \multicolumn{4}{|c|}{ PROTECTION } & \multirow{2}{*}{$\begin{array}{l}\text { Construction } \\
\text { Material }\end{array}$} & \multirow[b]{2}{*}{ Typo } & \multicolumn{2}{|c|}{ PROTECTION } & \\
\hline & & & & Cathodic & Spill & Overfill & Release & & & Cathodic & Release & \\
\hline 43 & SXDD & 2328-Uं & CONCRETE & $\mathbf{N}$ & $\mathbf{N}$ & $\mathbf{N}$ & $\mathbf{N}$ & NA & GF & $\mathbf{N}$ & $\mathbf{N}$ & Concrete sump;RCRA \\
\hline 44 & SYDD & 2329-U & CONCRETE & $\mathrm{N}$ & $\mathrm{N}$ & $\mathbf{N}$ & $N$ & NA & GF & $\mathbf{N}$ & $\mathbf{N}$ & Concrete sump;RCRA \\
\hline 45 & $9767-13$ & $2102-U$ & STEEL & $\mathbf{Y}$ & $N$ & $\mathbf{N}$ & N & STEEL & $s$ & $\mathbf{N}$ & $\mathbf{N}$ & $\begin{array}{l}\text { No underground piping;Tank was } \\
\text { located within concrete vault }\end{array}$ \\
\hline 46 & 9418-3 & $2072-U$ & CONCRETE & $\mathbf{N}$ & $\mathbf{N}$ & $\mathbf{N}$ & $\mathbf{N}$ & NA & NA & $\mathbf{N}$ & $\mathrm{N}$ & Concrete vault;CERCLA \\
\hline 47 & $9825-1$ & $2129-U$ & CONCRETE & $\mathbf{N}$ & $\mathbf{N}$ & $\mathbf{N}$ & $\mathbf{N}$ & NA & NA & $\mathbf{N}$ & $\mathbf{N}$ & Concrete vault;CERCLA \\
\hline
\end{tabular}

$\begin{array}{lllll}\text { DW-double walled } & \text { GF=gravity feed } & \text { N=no } & \text { P=pressurized } & \text { S=xuction } \\ \text { FGL=fibergalss } & \text { GLVZD.ST.=galvanized steel } & \text { N/A=not applicable } & \text { ST. STEEL= stainless steel } & \text { SW-single walled }\end{array}$




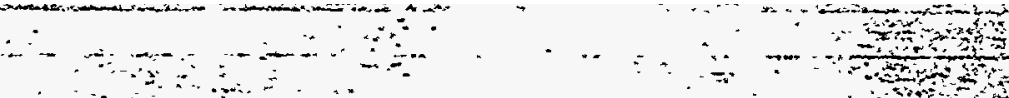

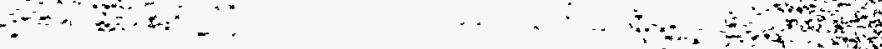

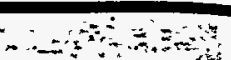

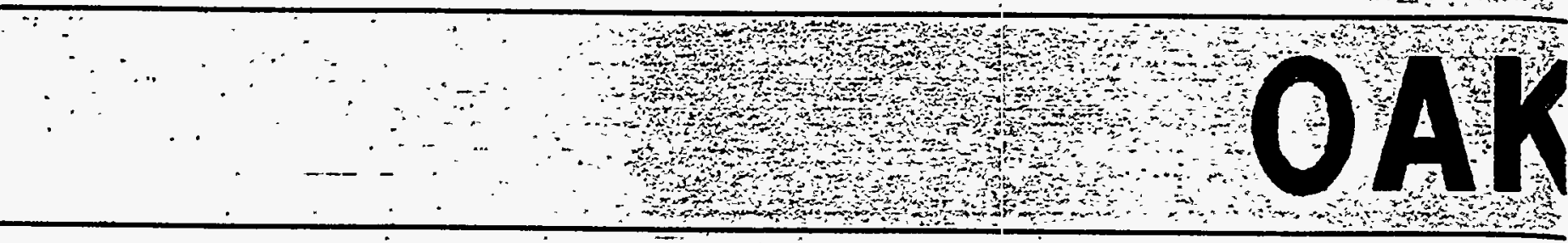

\section{G}

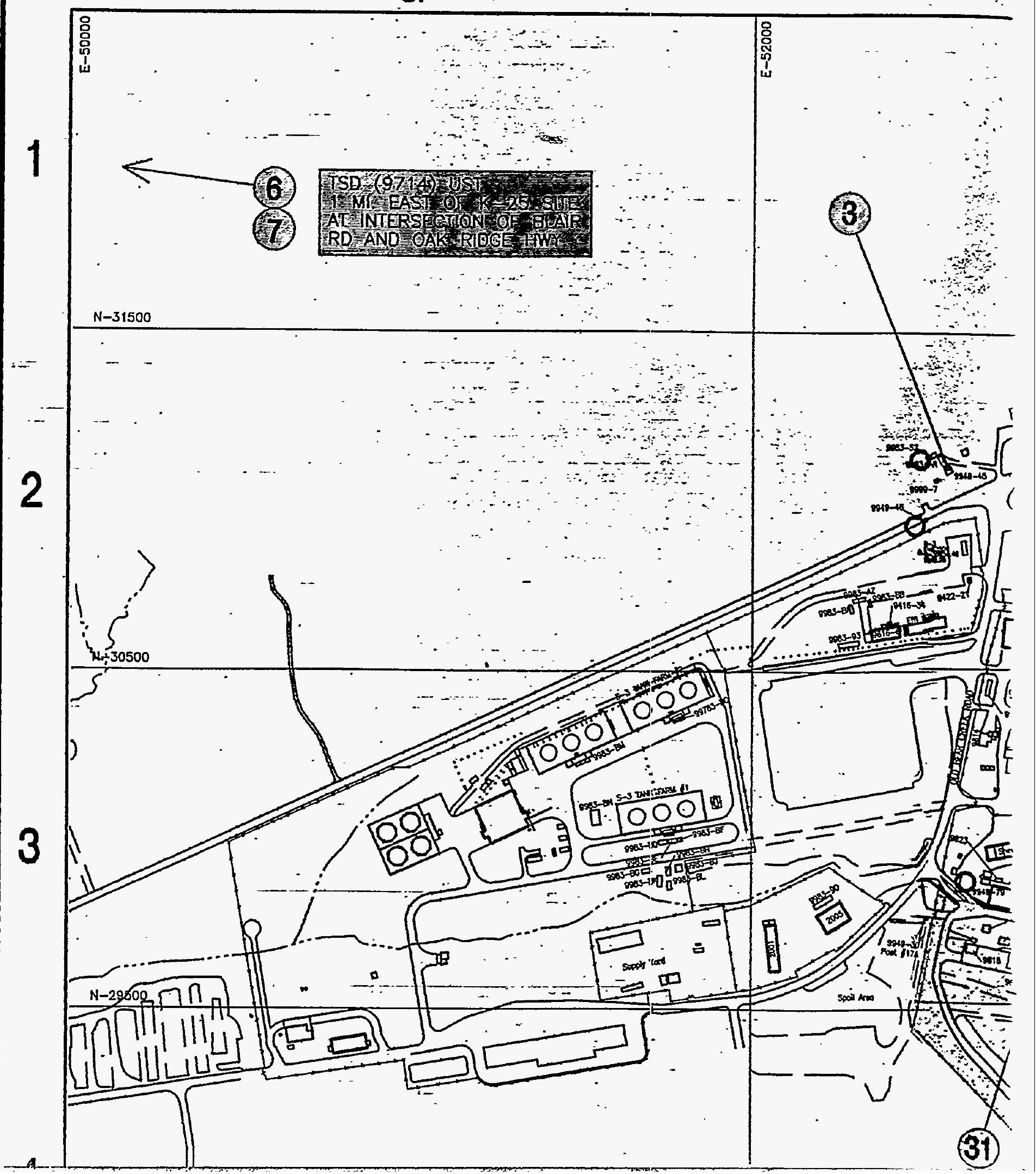


(t)

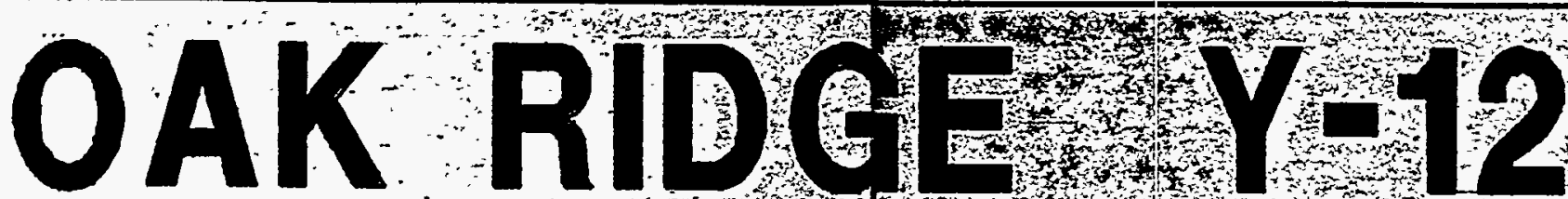 \\ D.}

\section{$\mathrm{F}$}

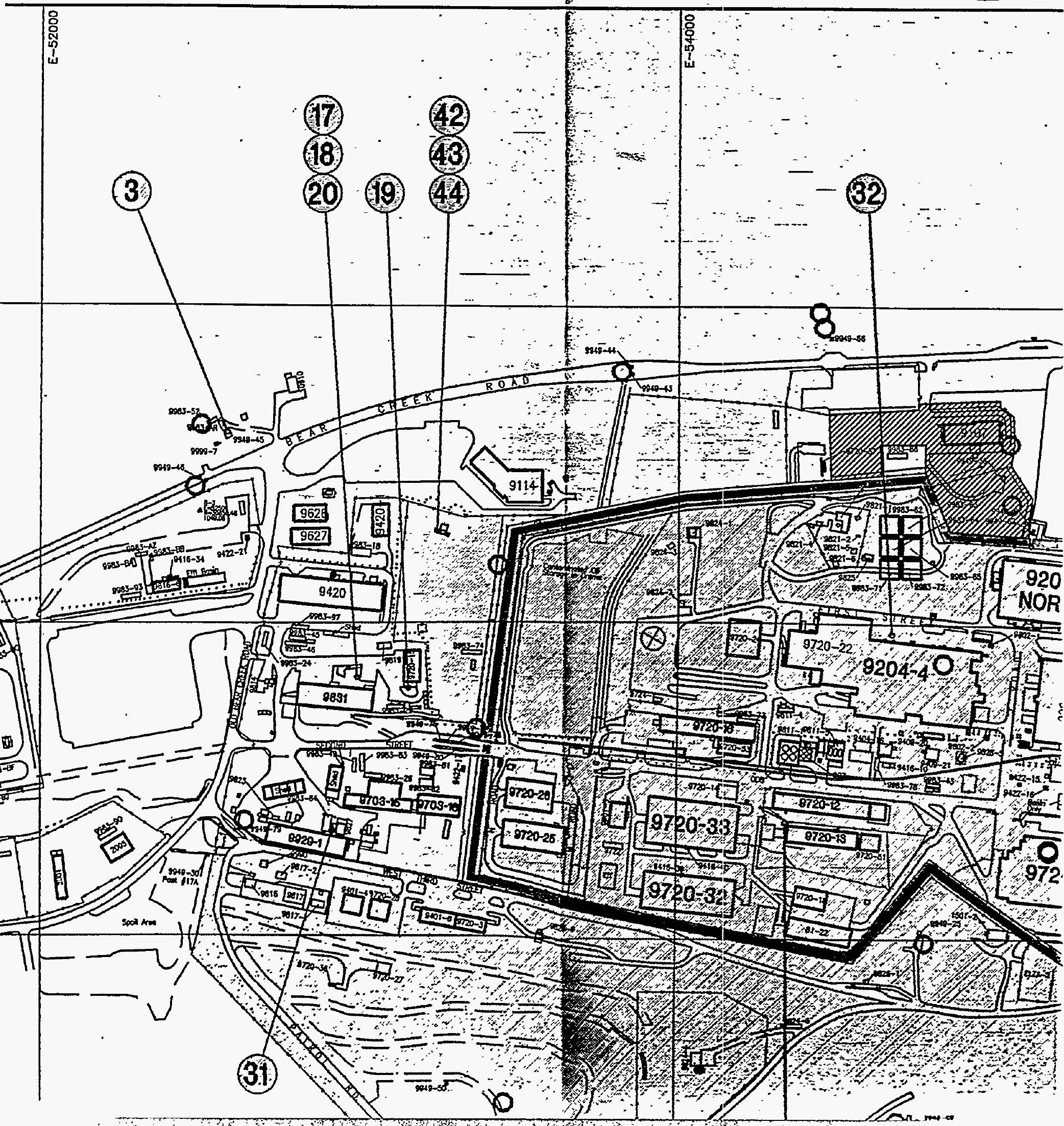




\section{PLANT}

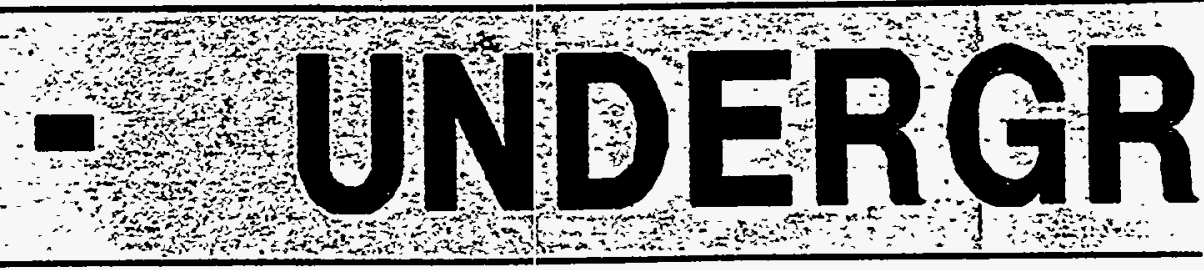

B

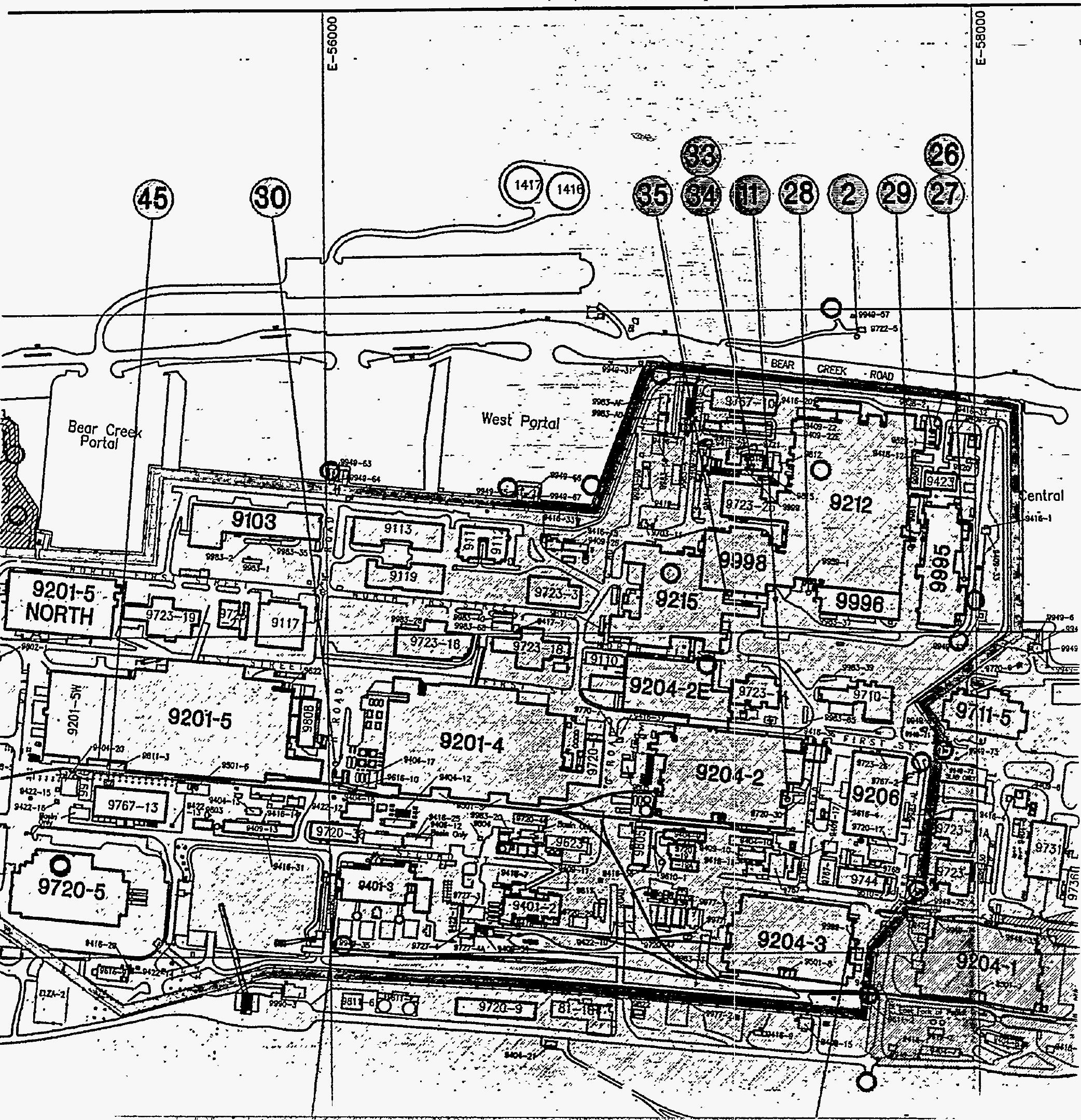


$\because \quad \therefore-109=$
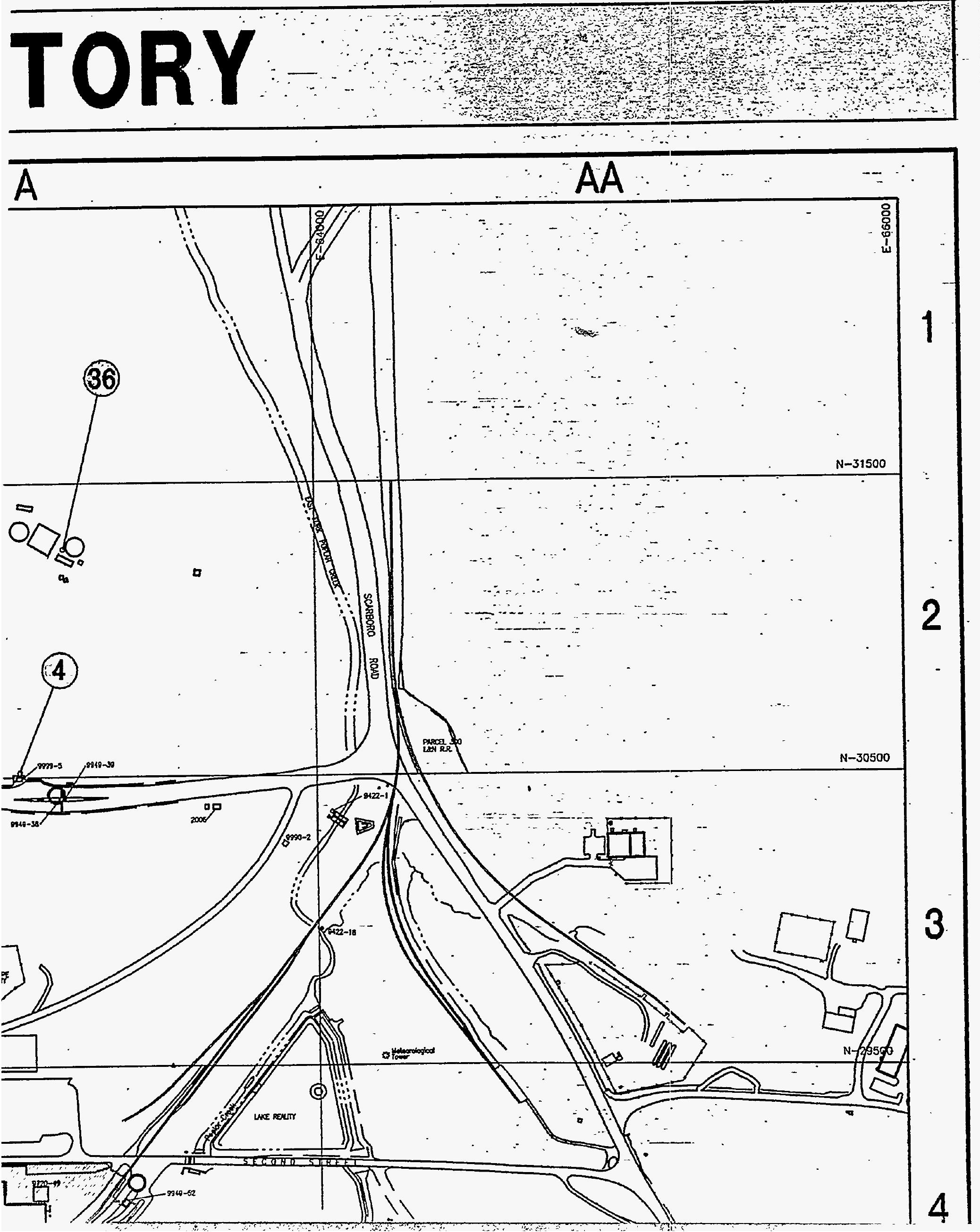



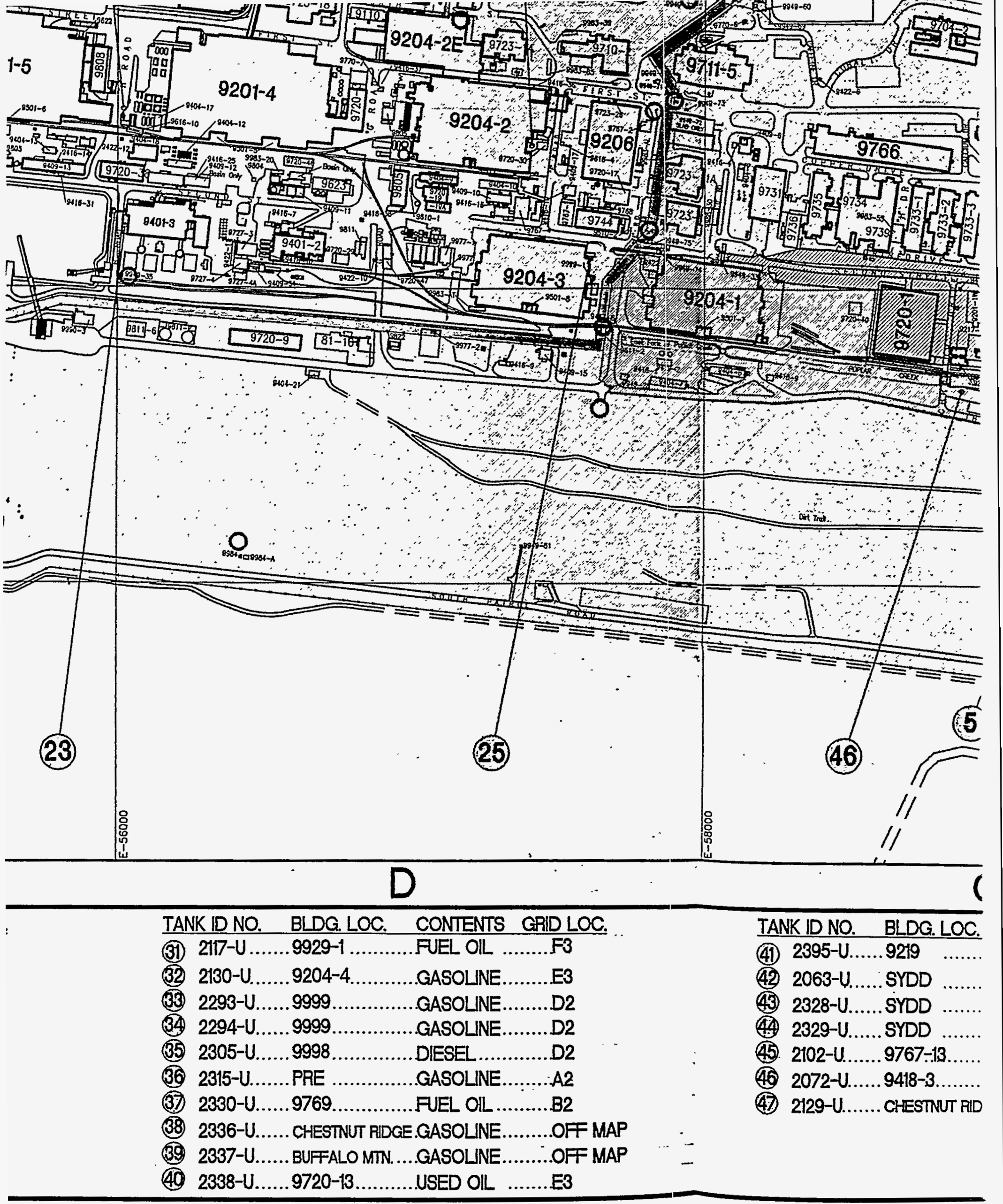


3-11

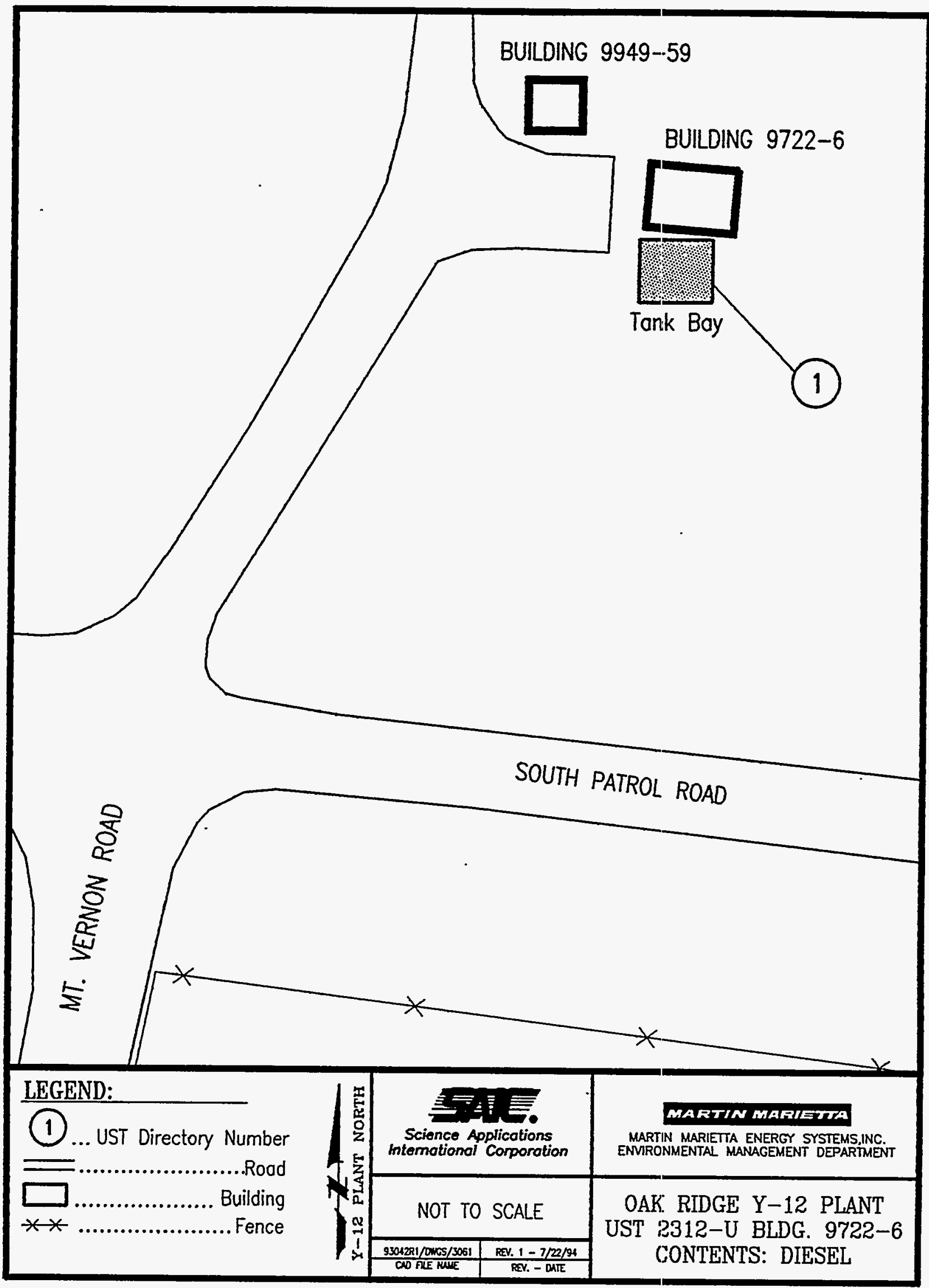




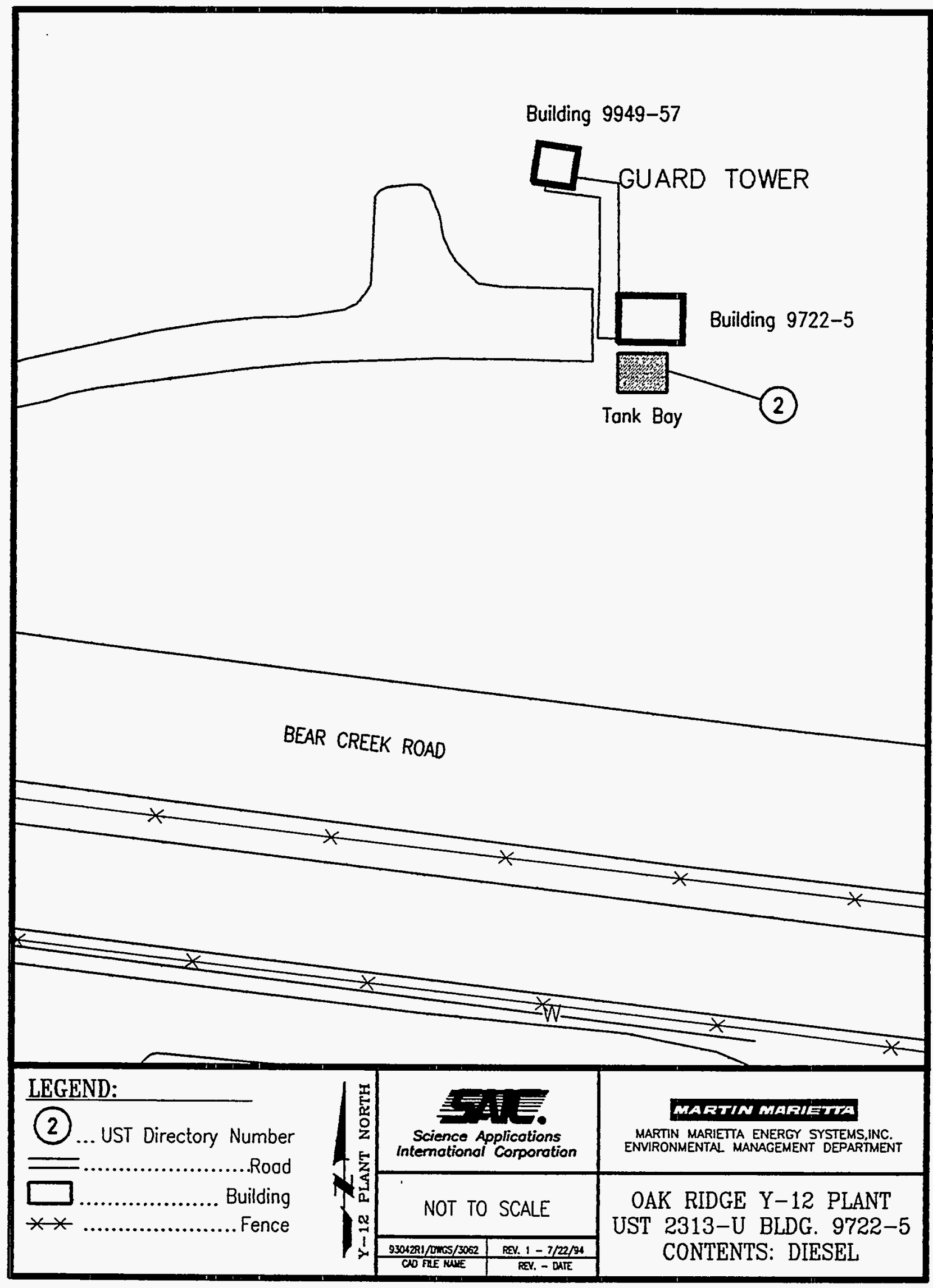




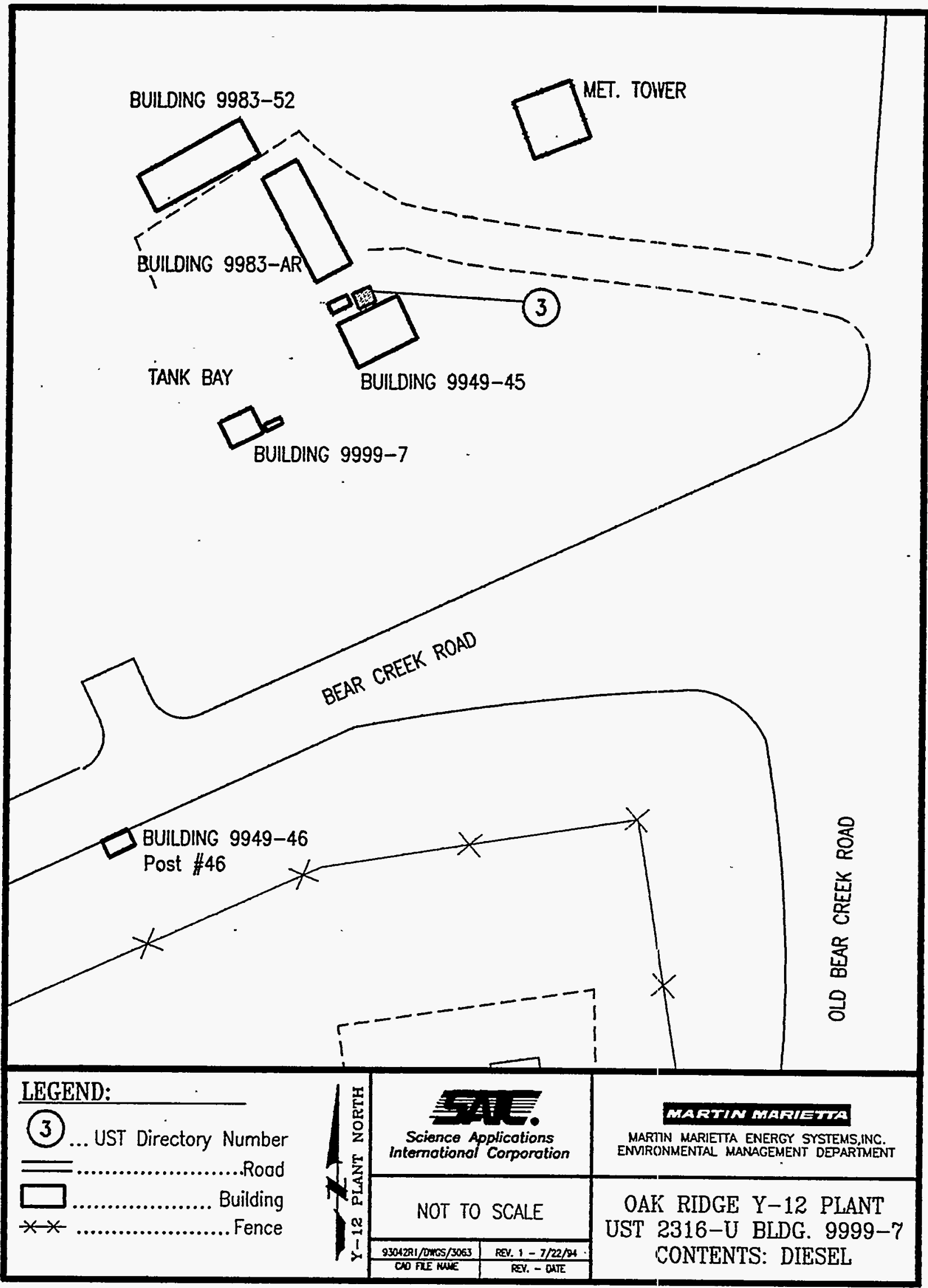


Grass Cover

4
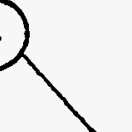

Tank Bay

BUILDING 9999-5

BEAR CREEK ROAD

Aspholt

Guard

Stations-

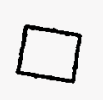

$\square$

East

Entrance

Grass Cover

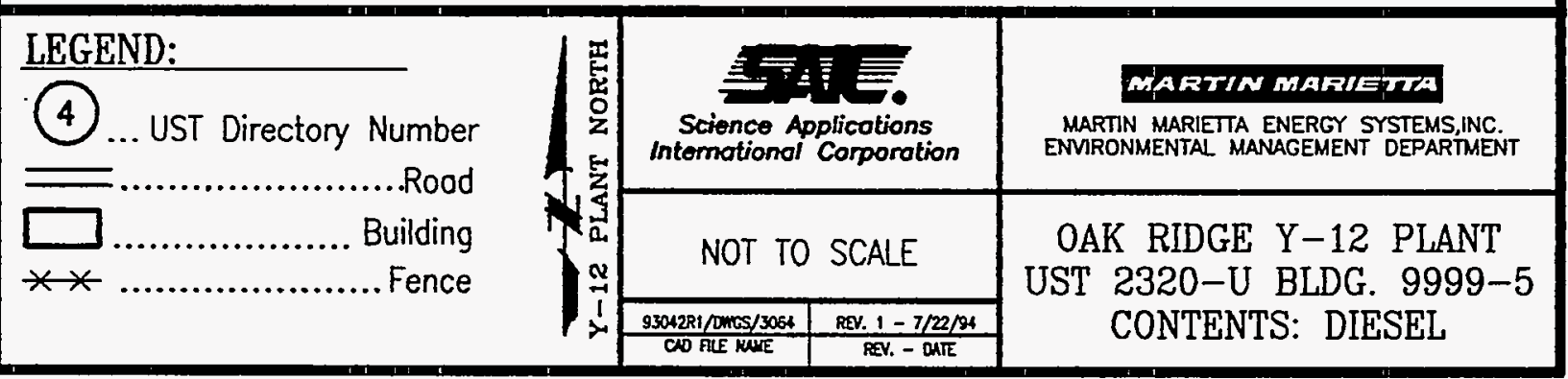


3-15

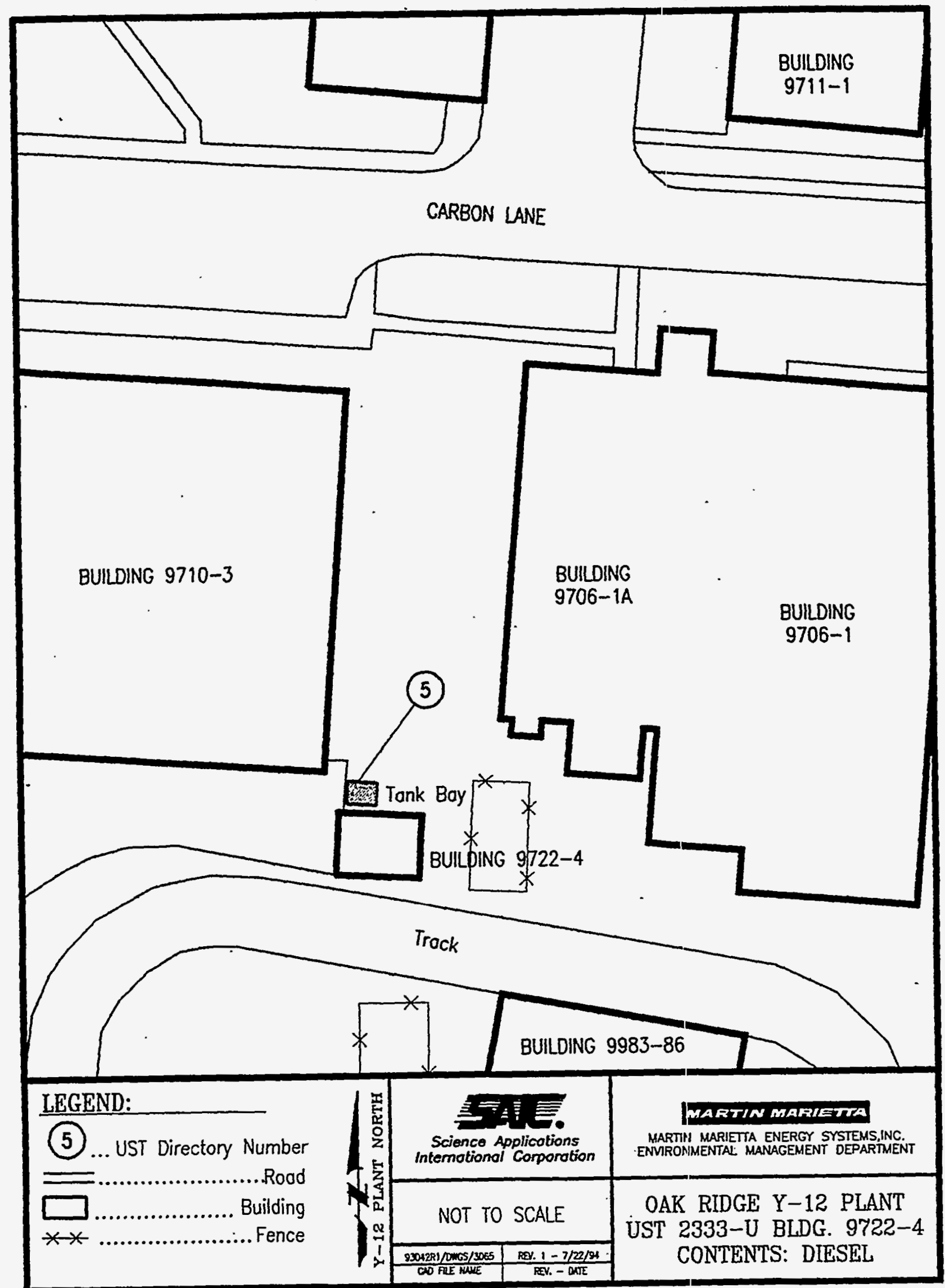




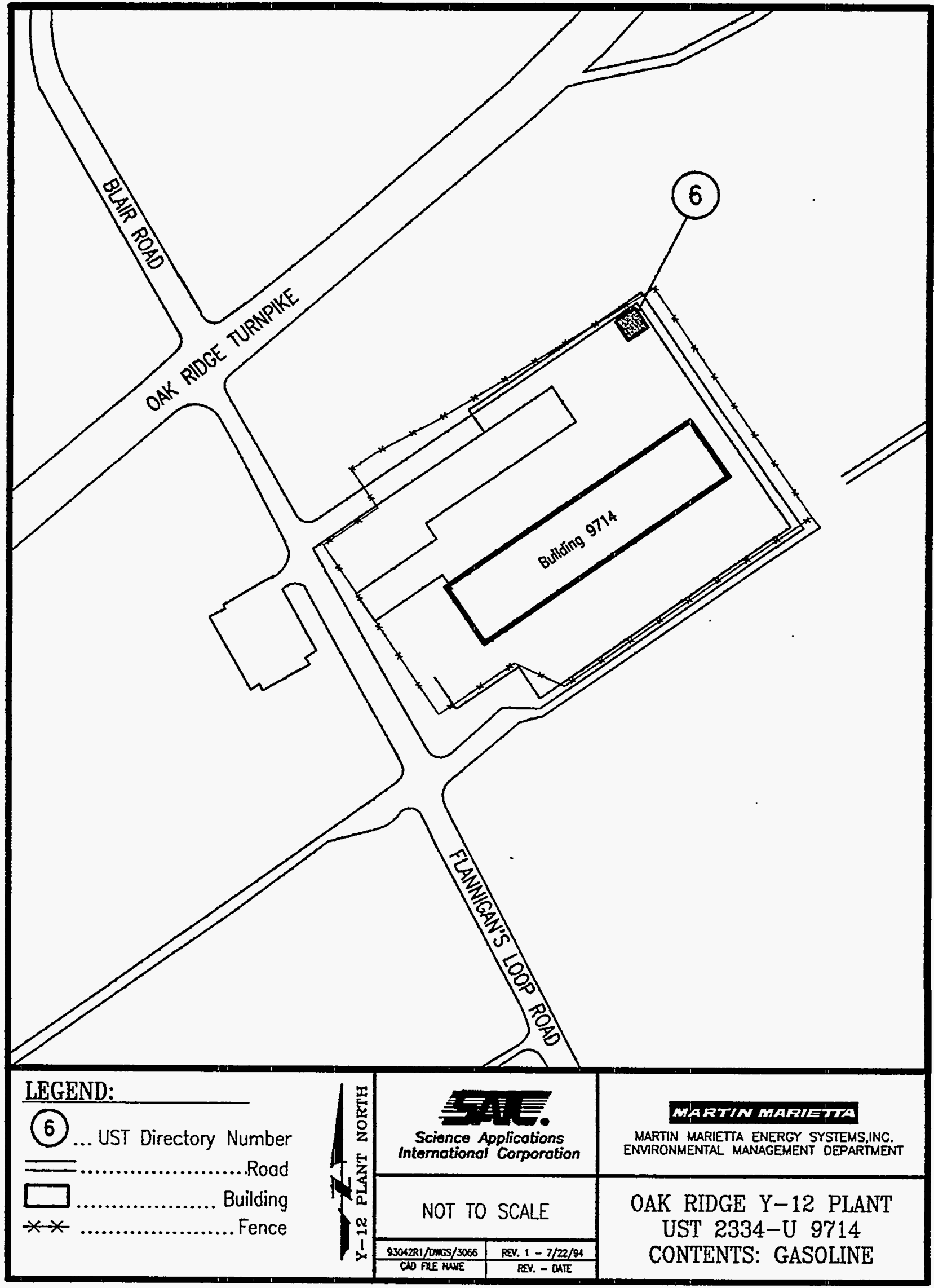




\section{3-17}

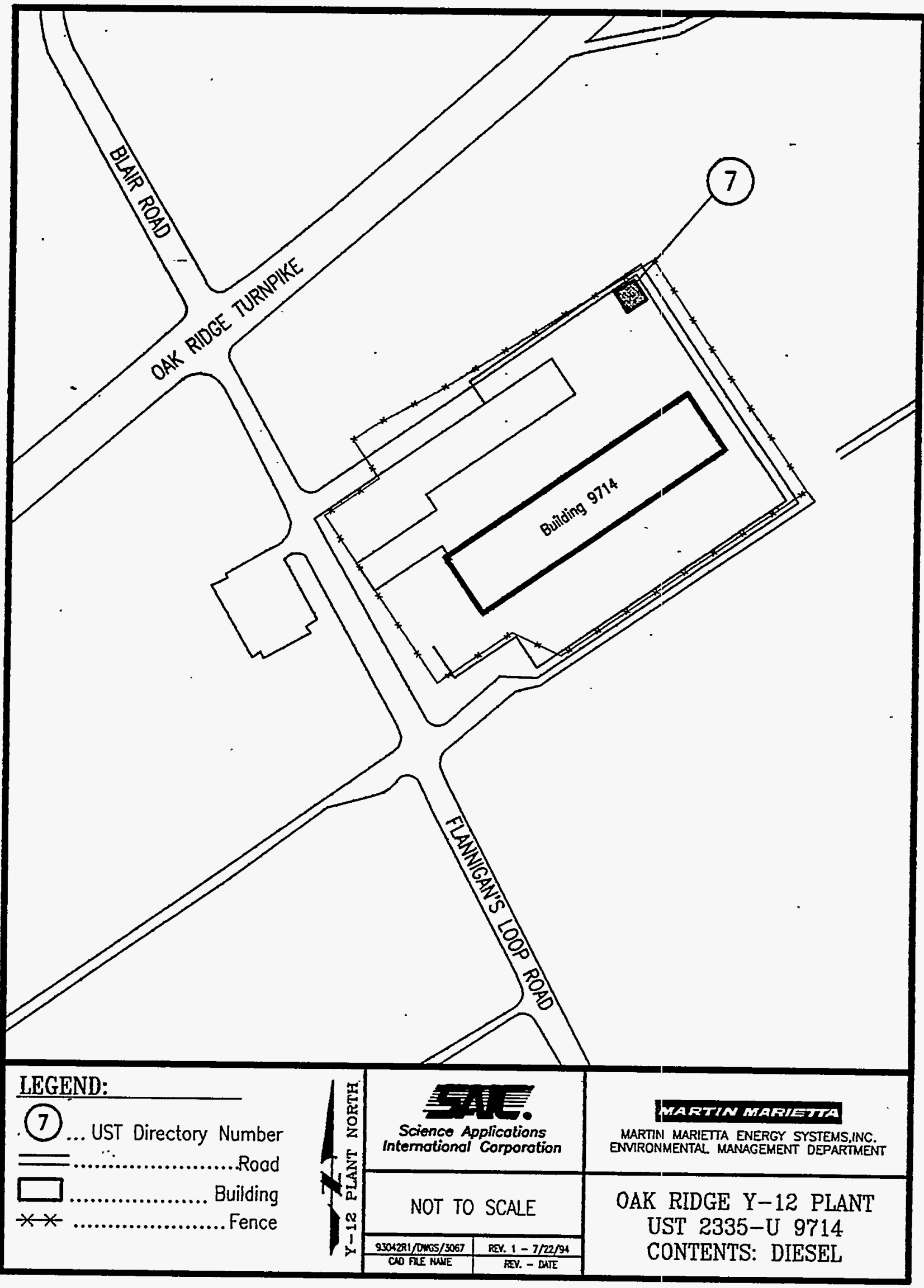




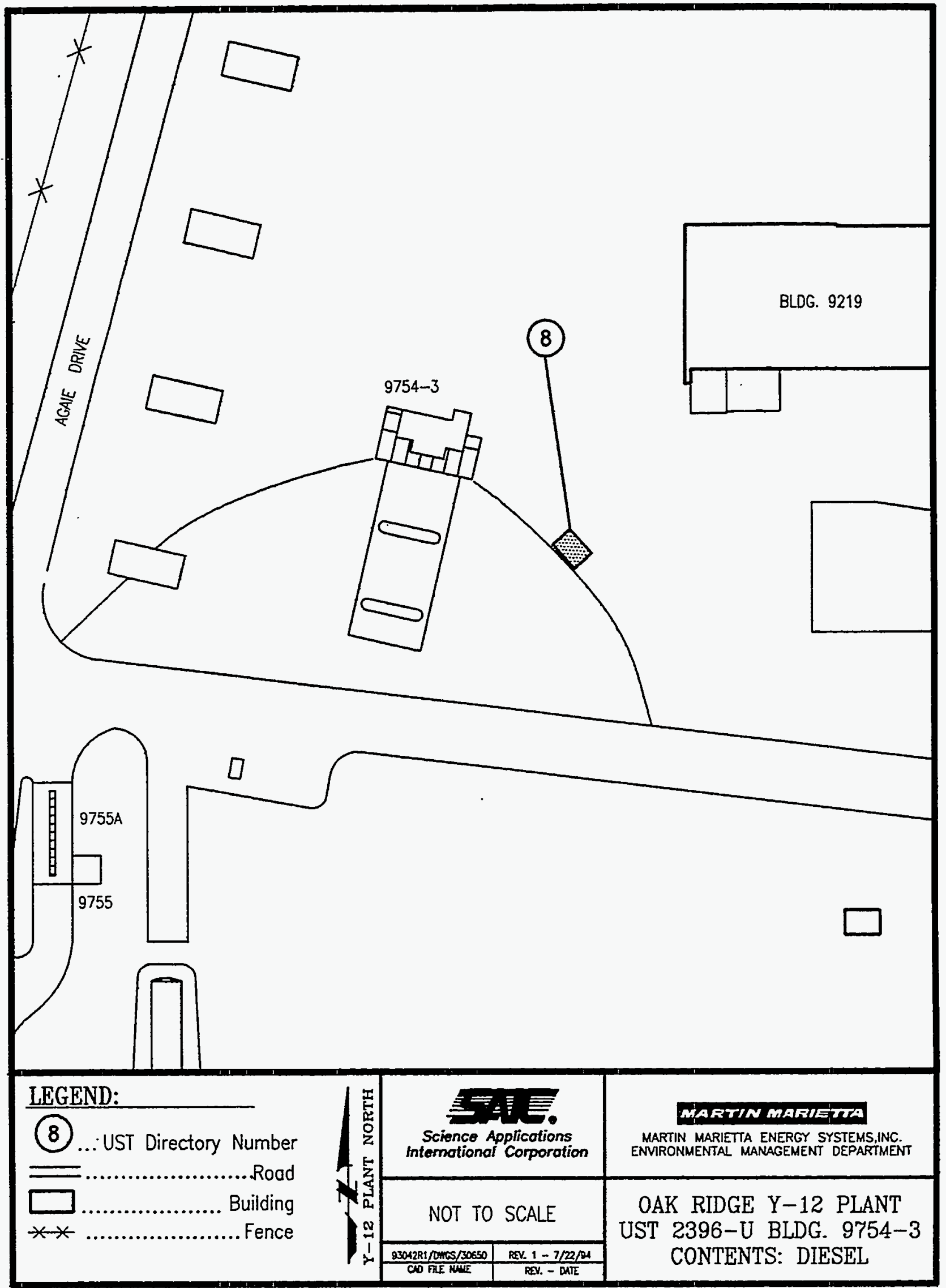




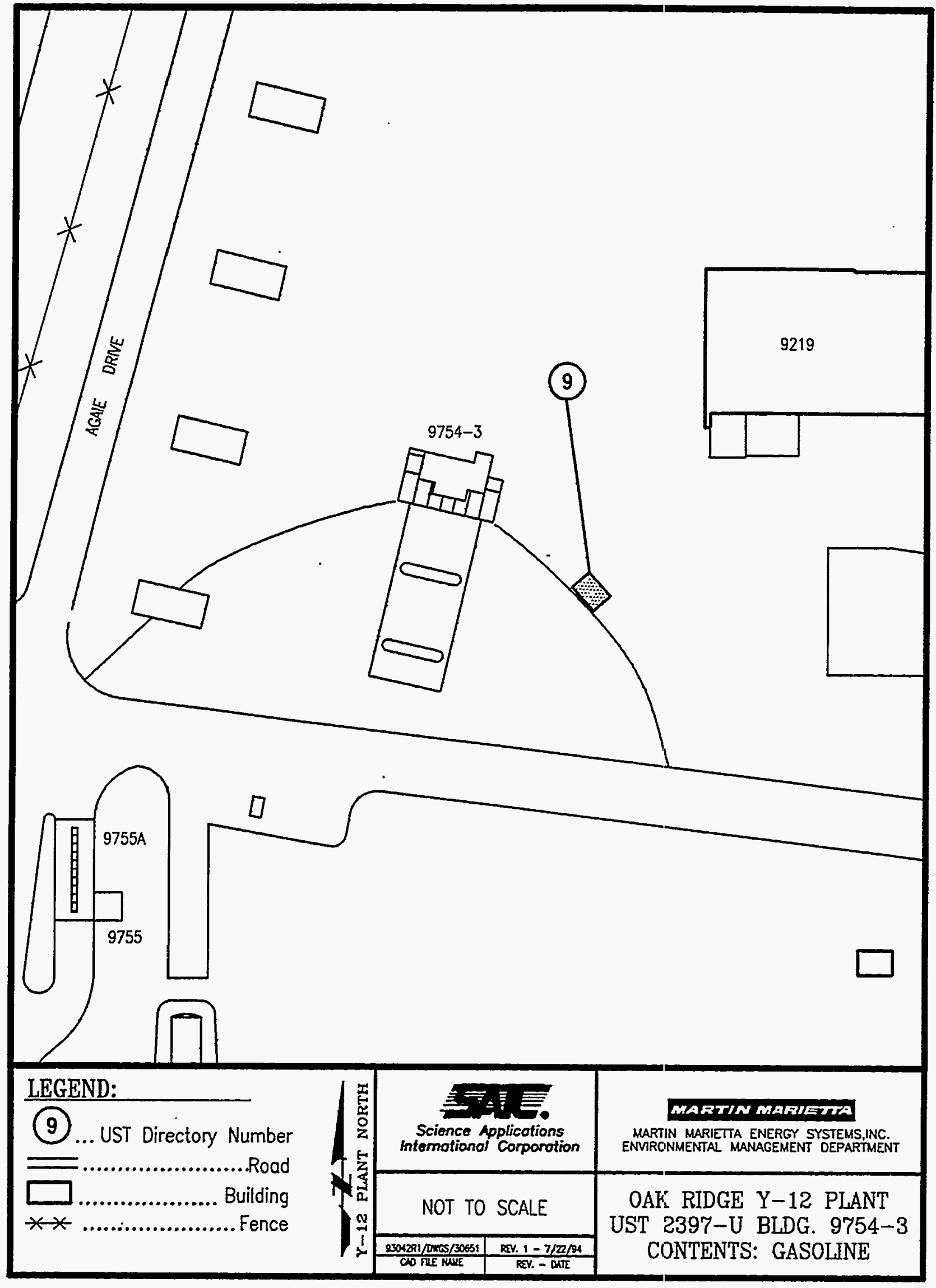




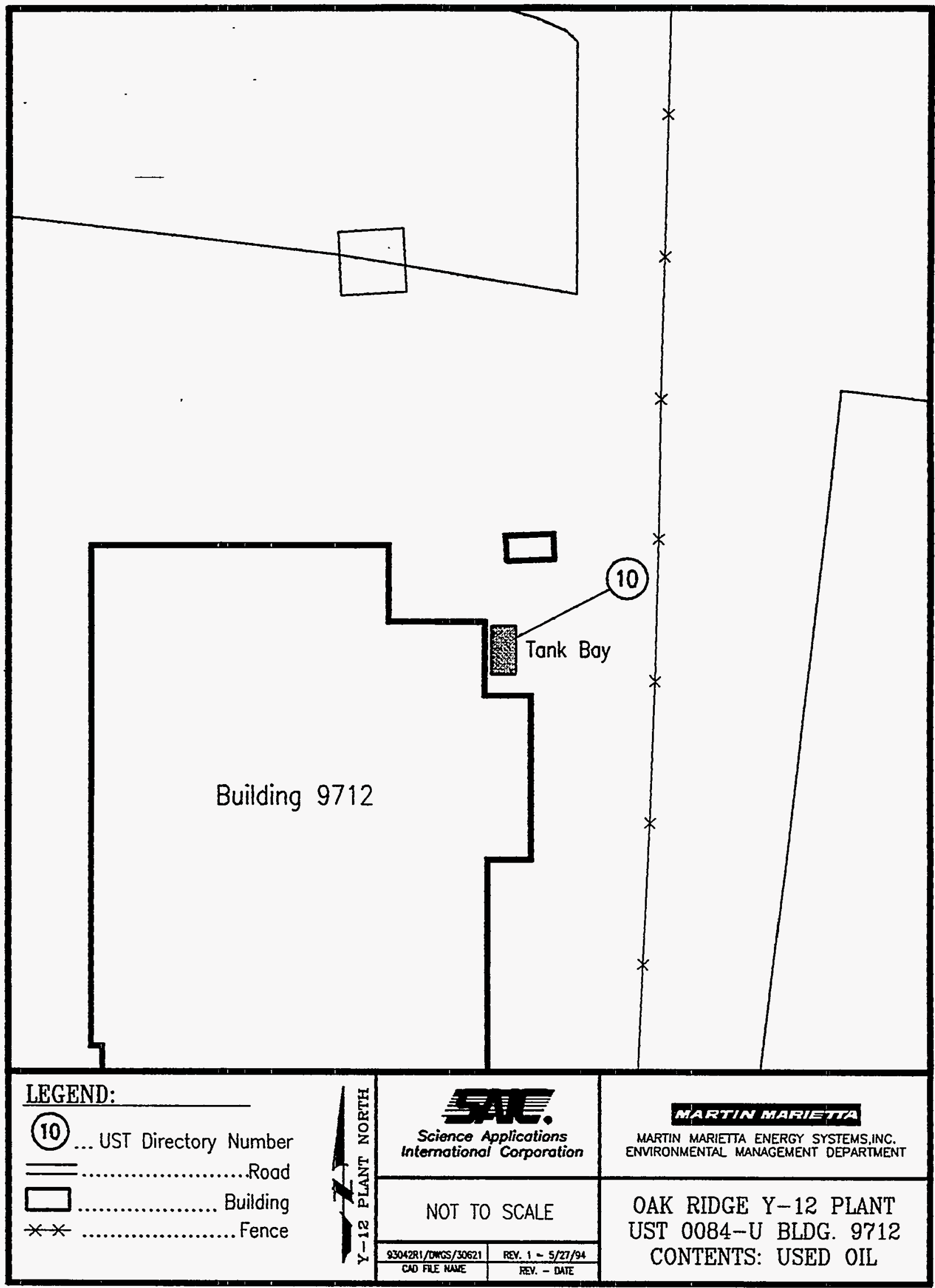


3-21

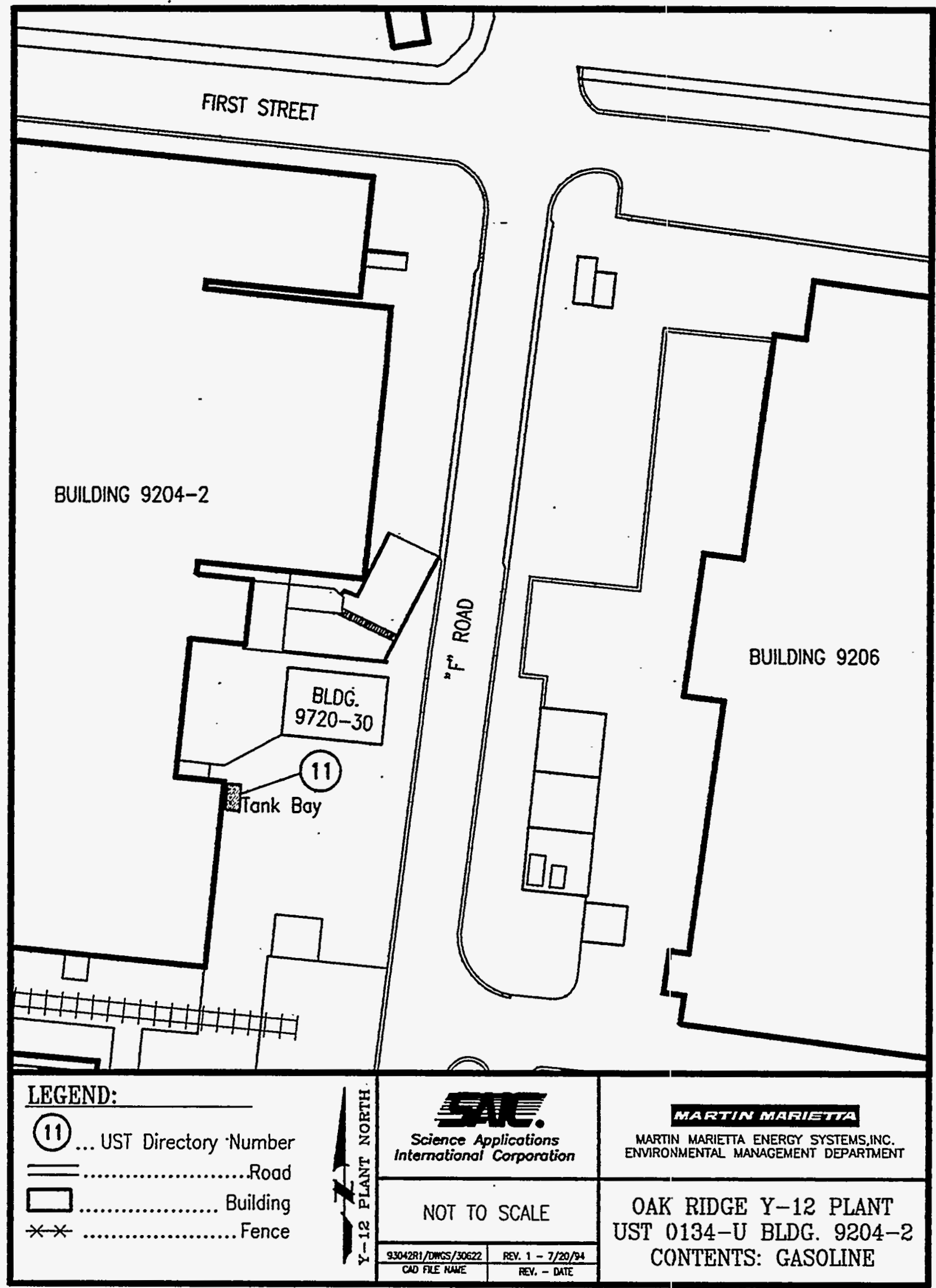




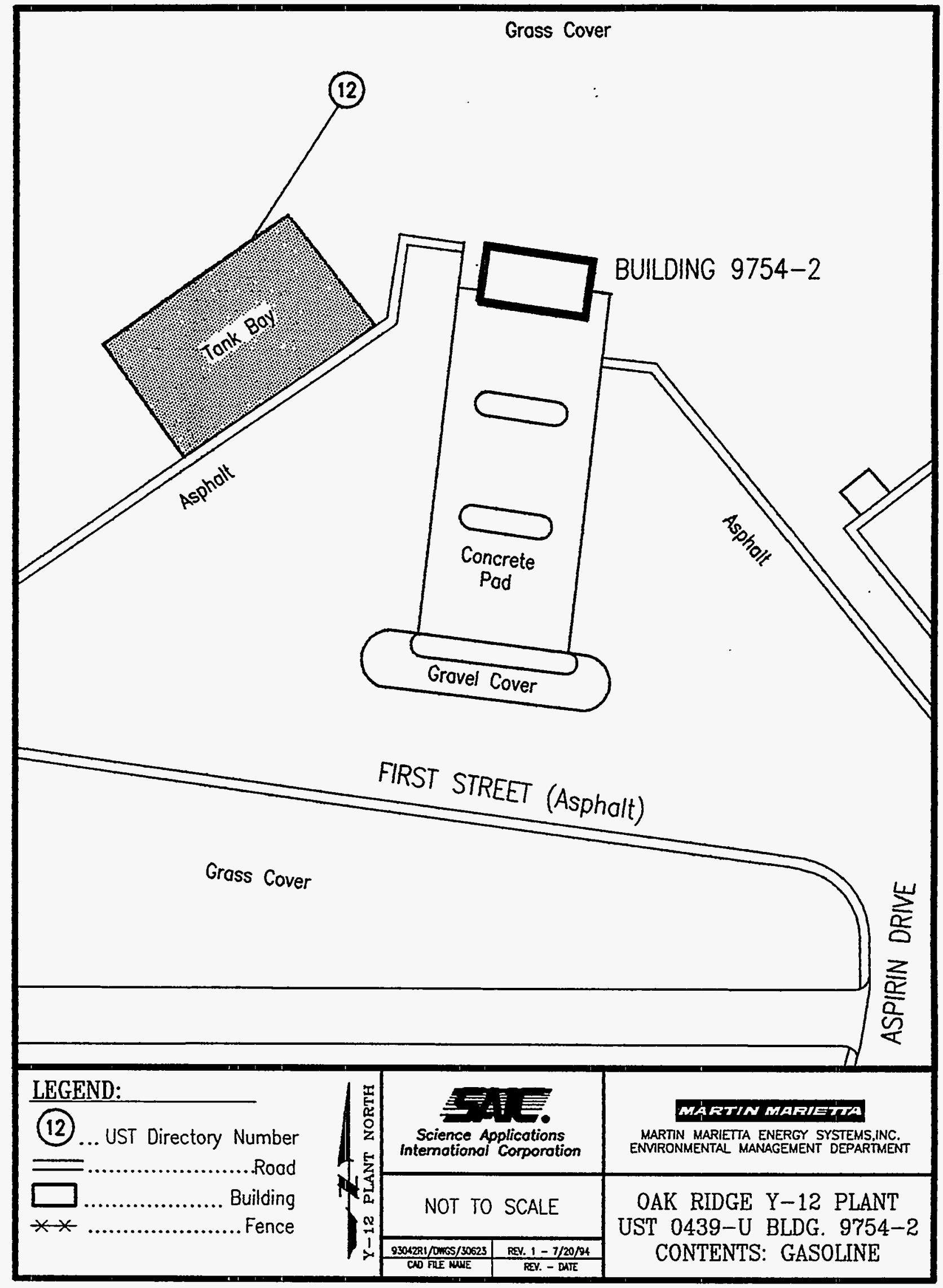




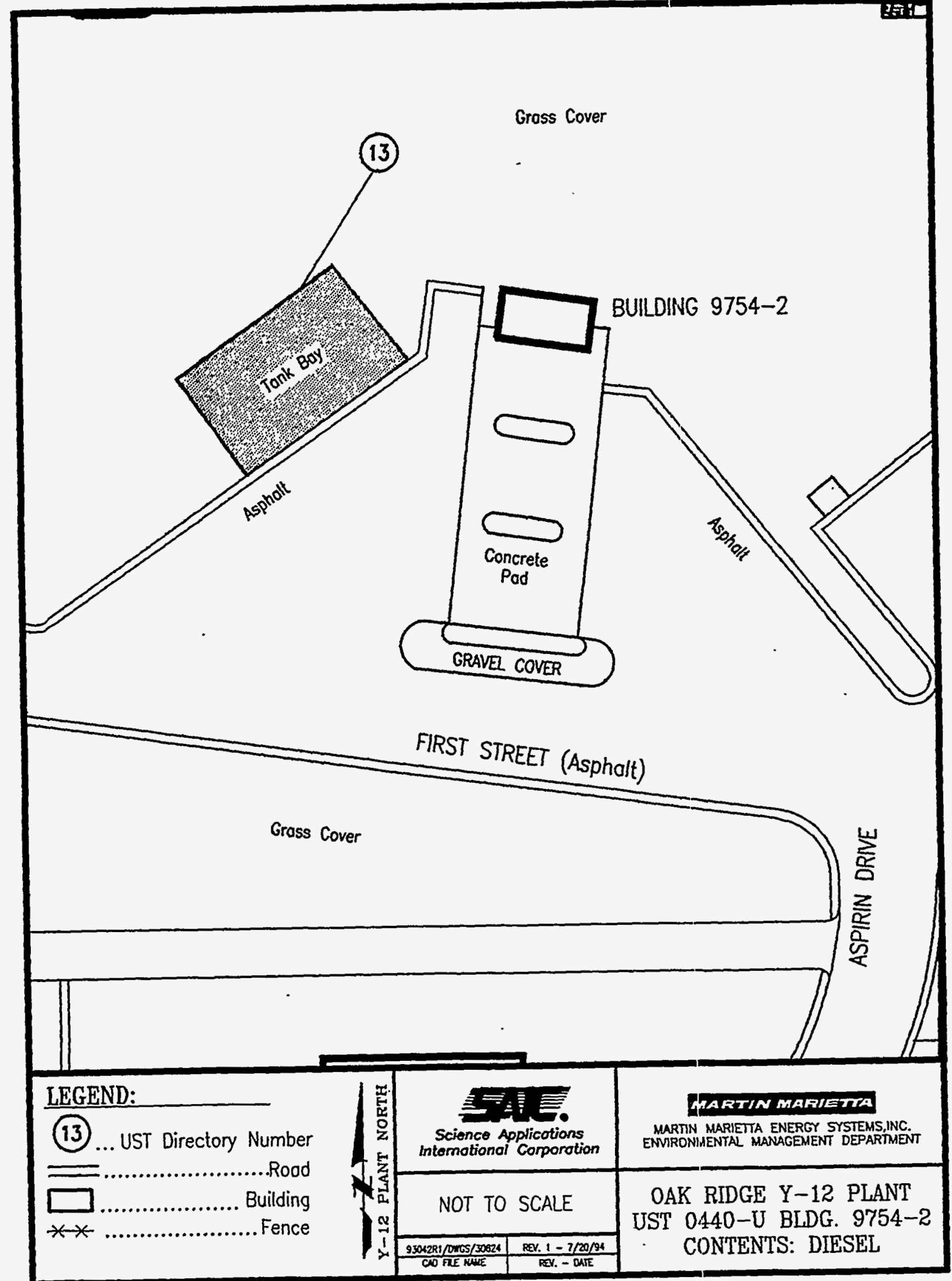




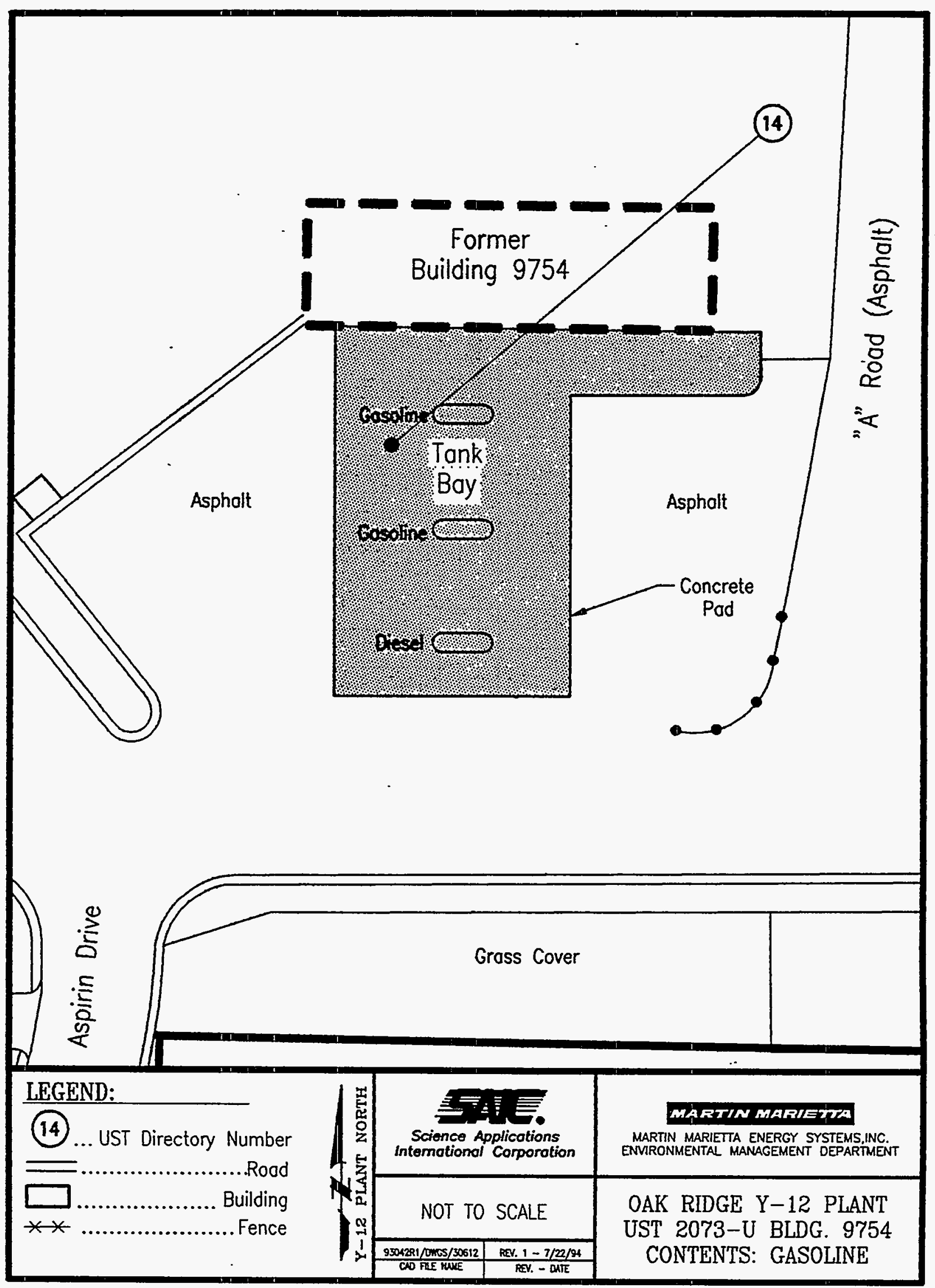




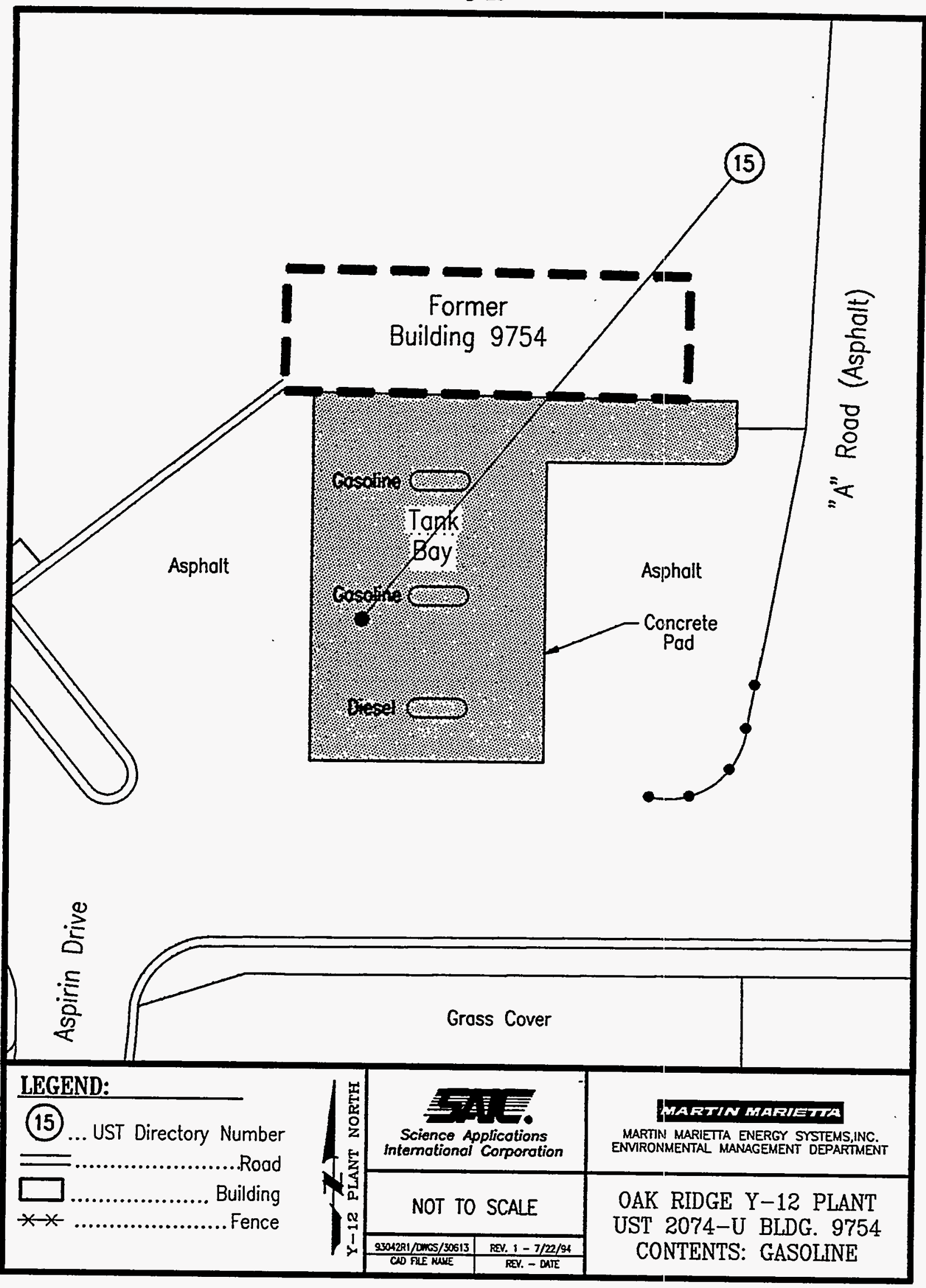




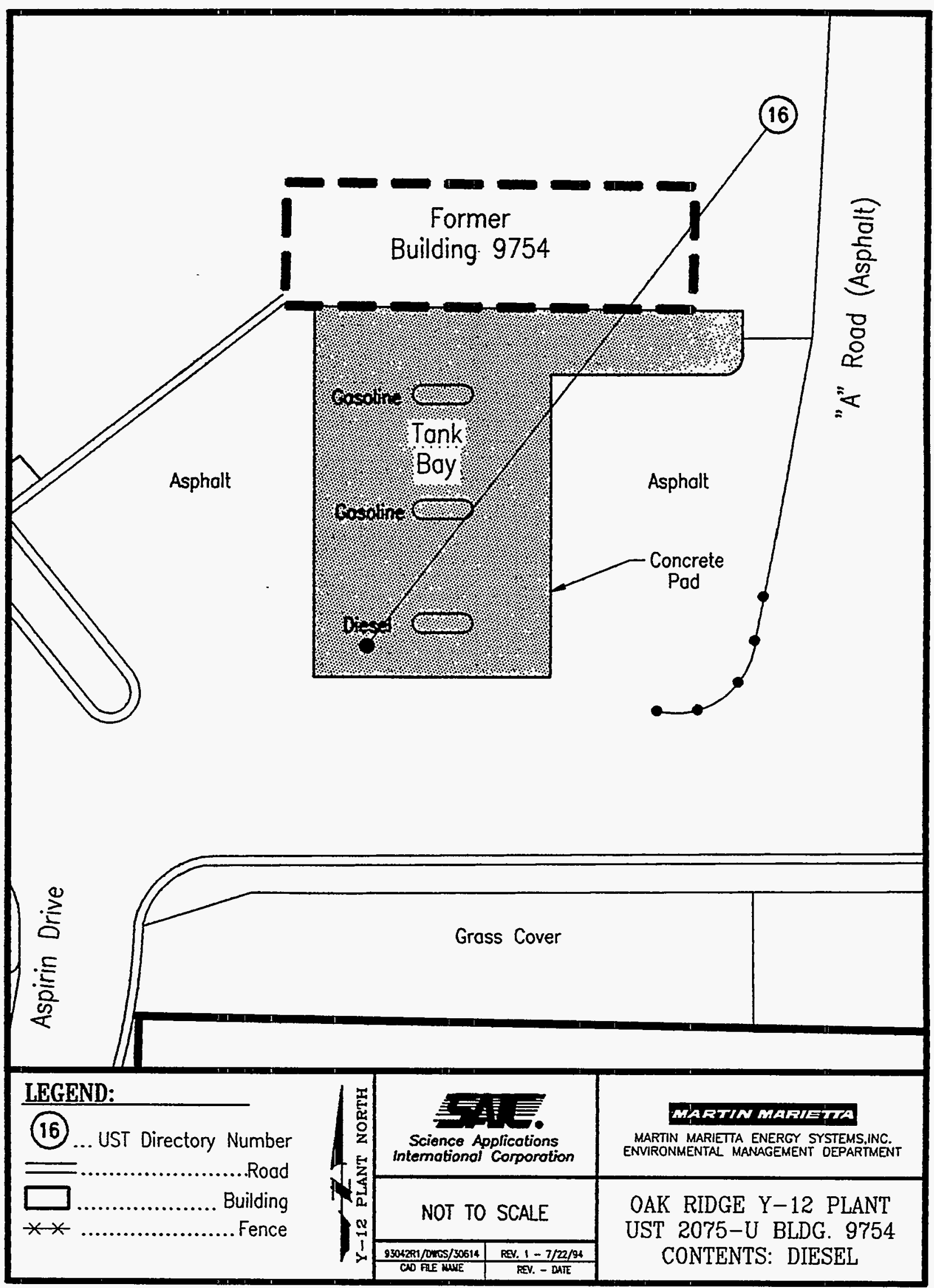




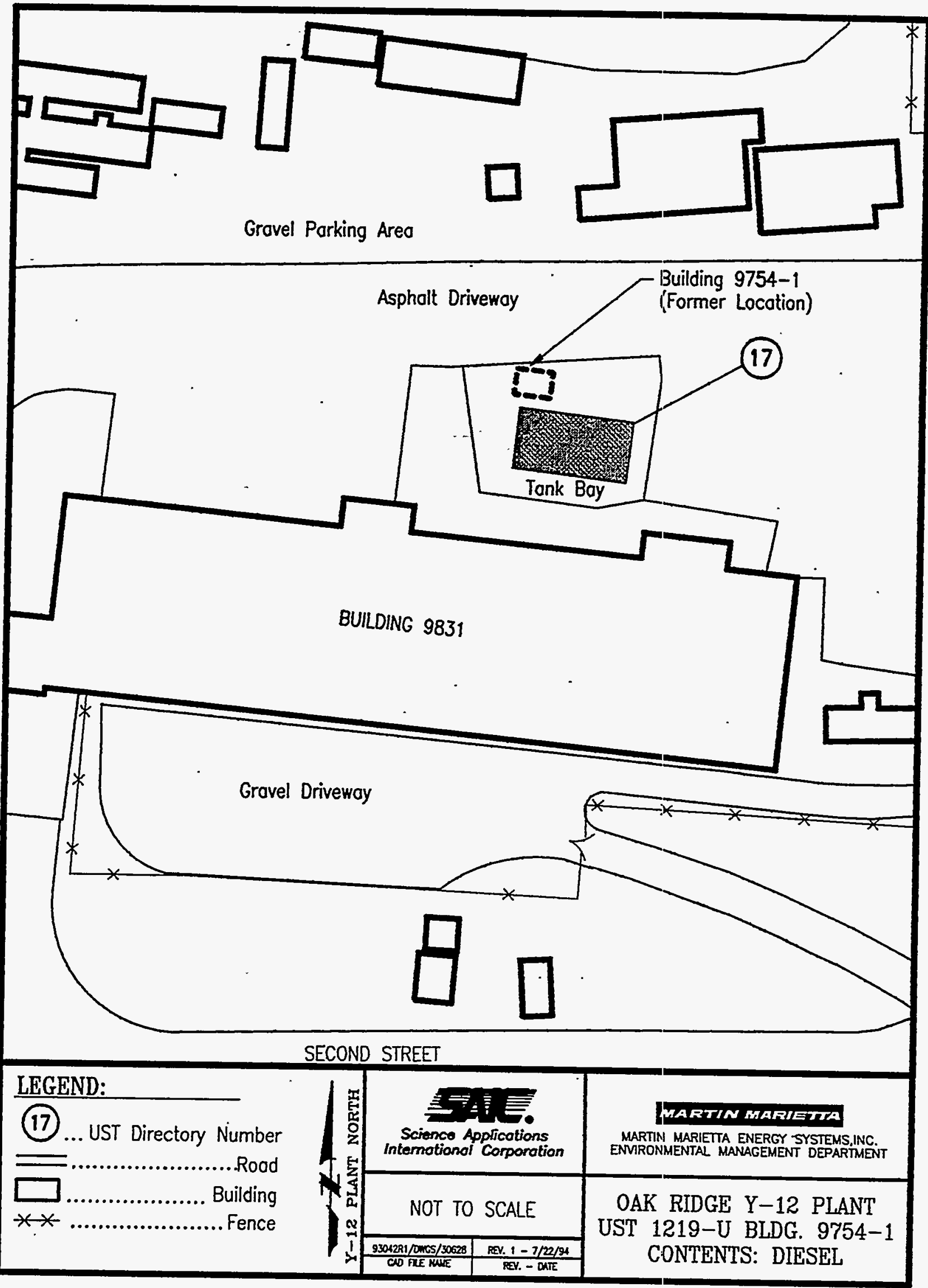




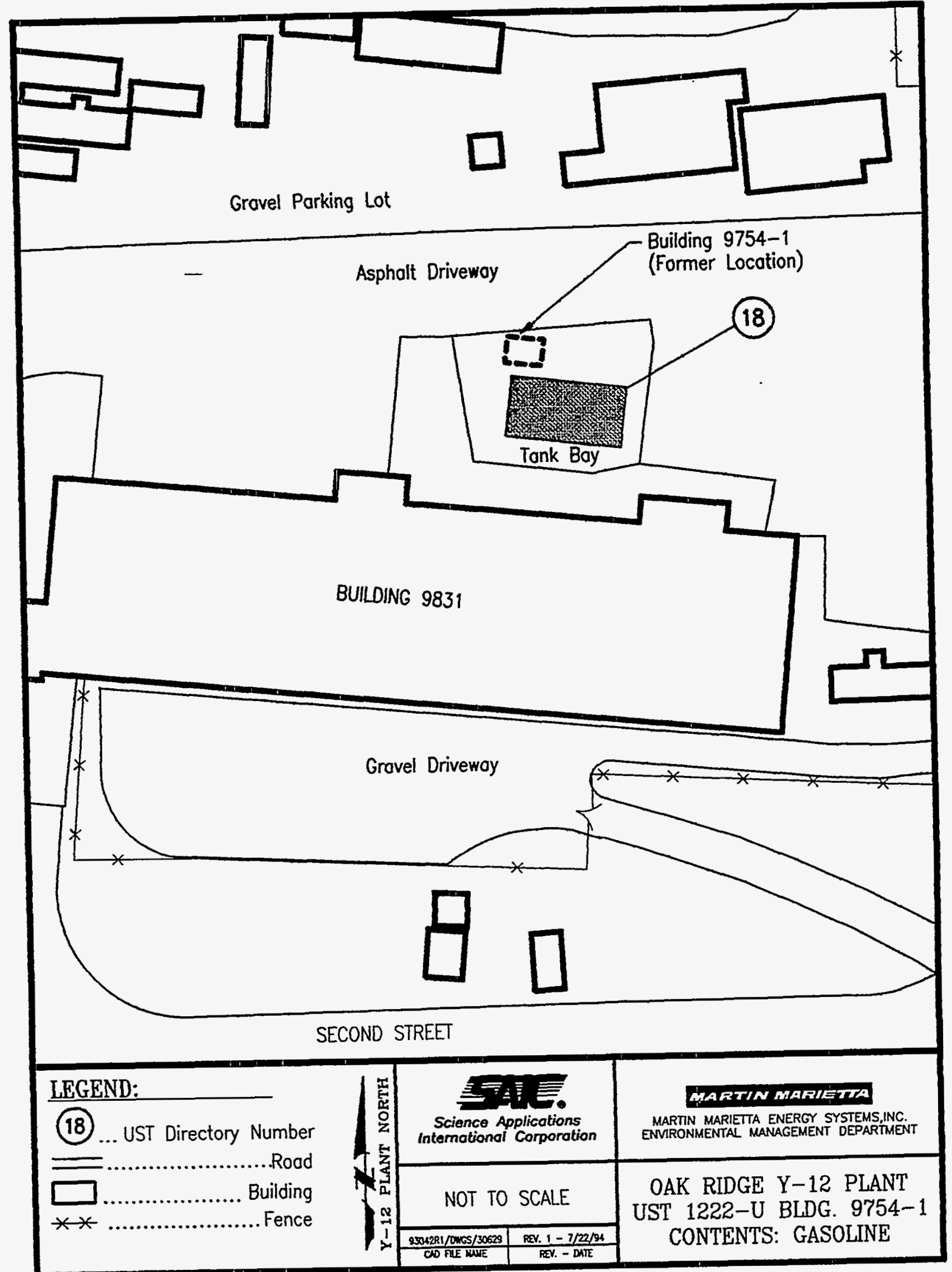




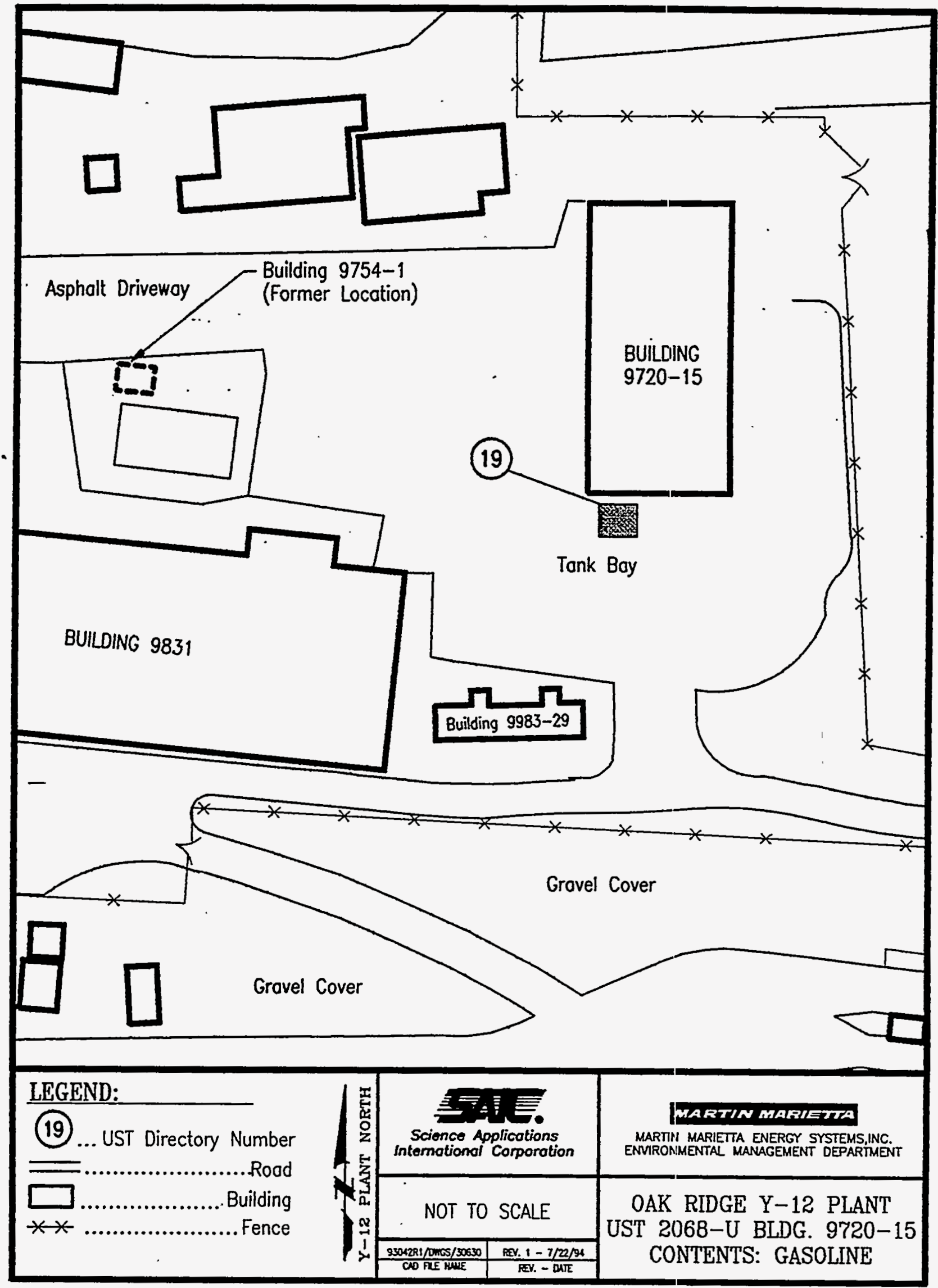




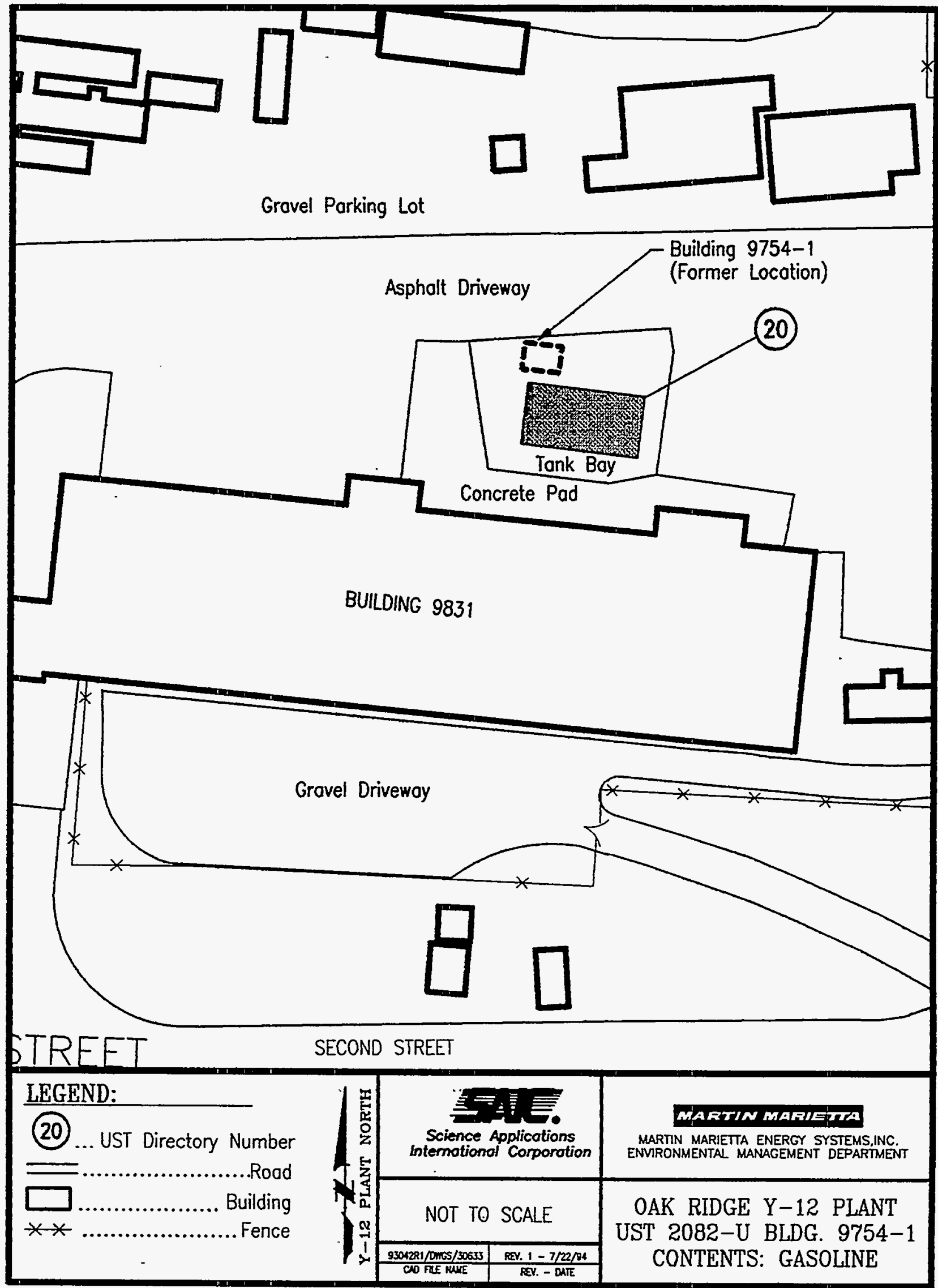




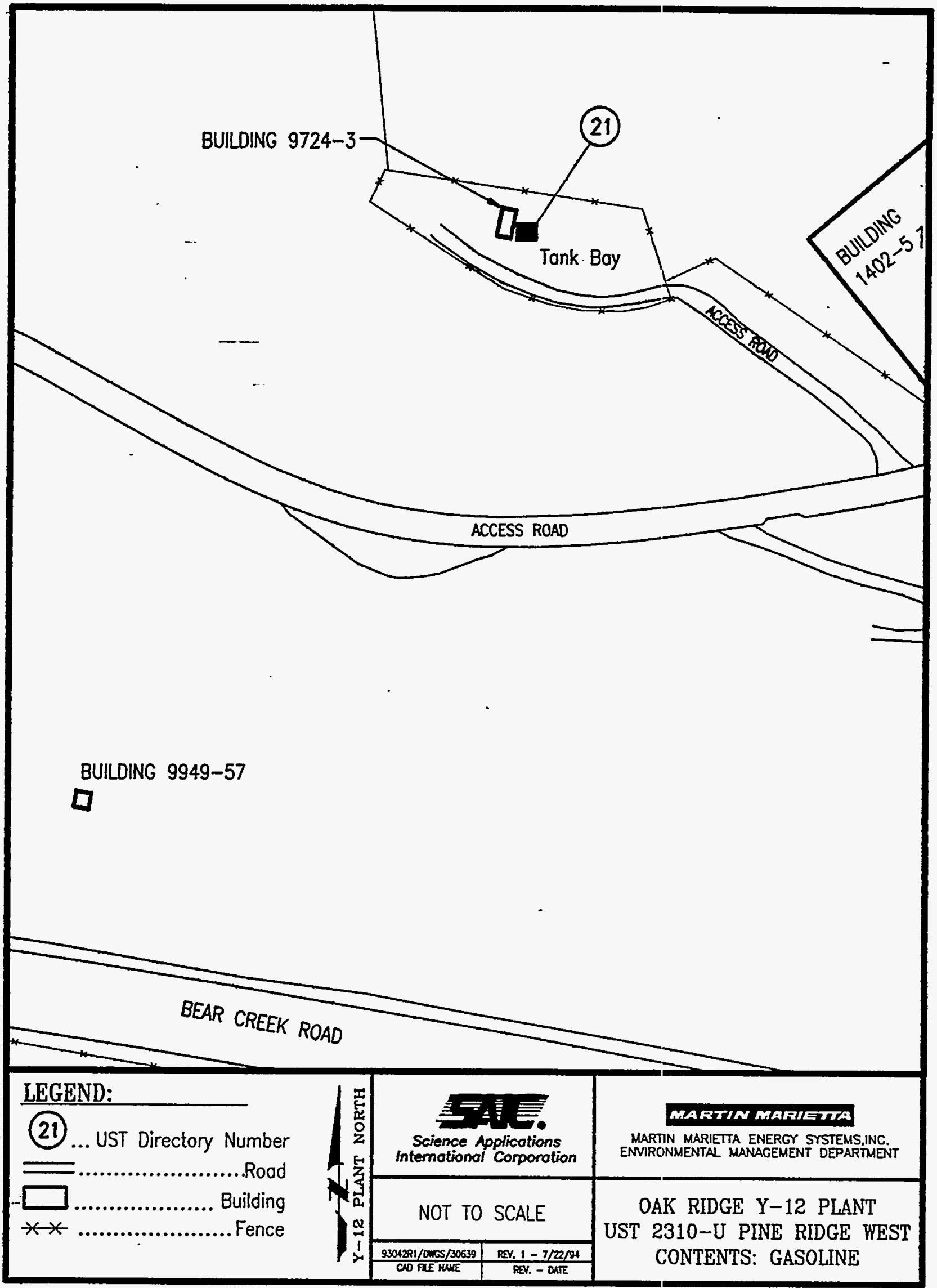




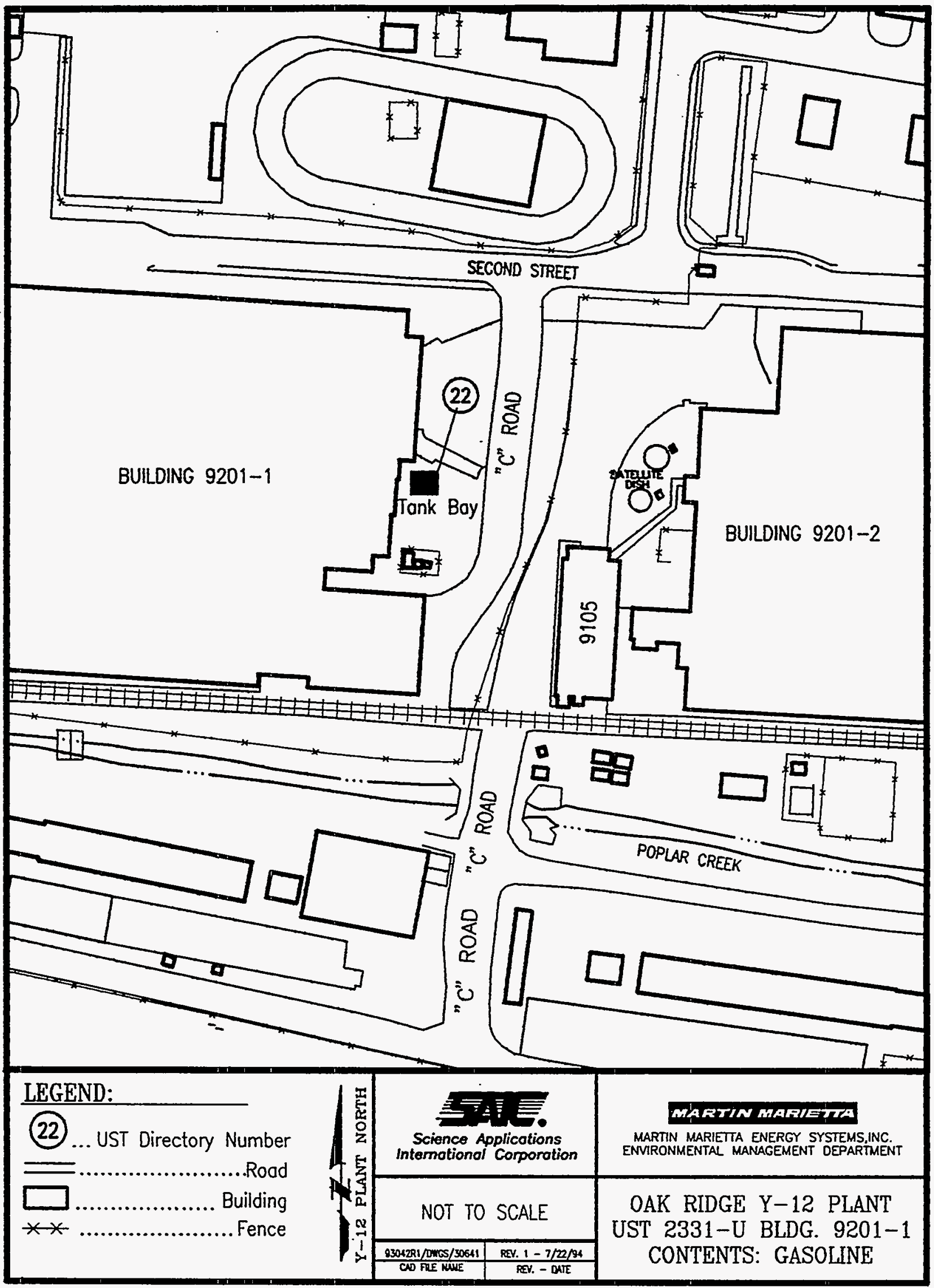




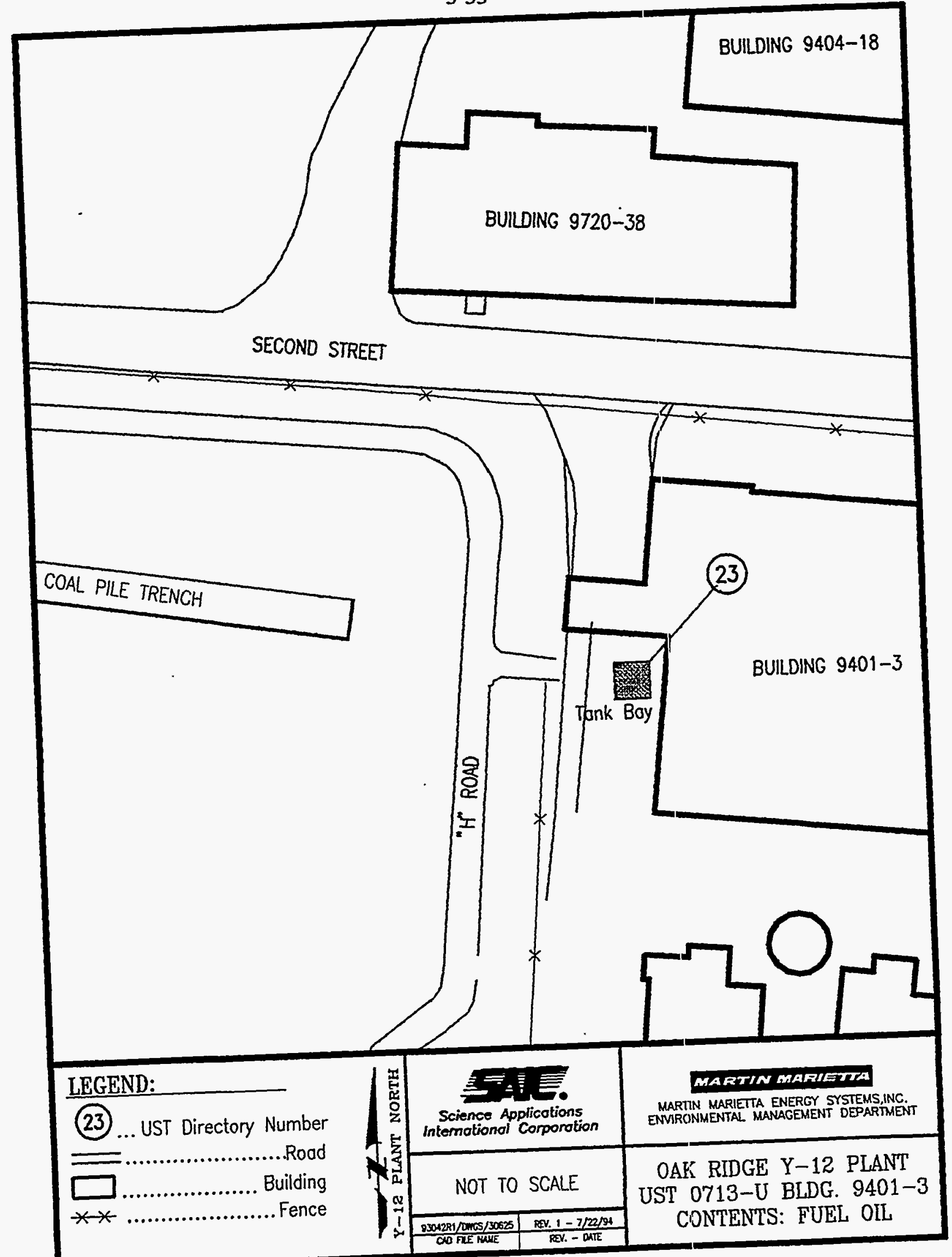




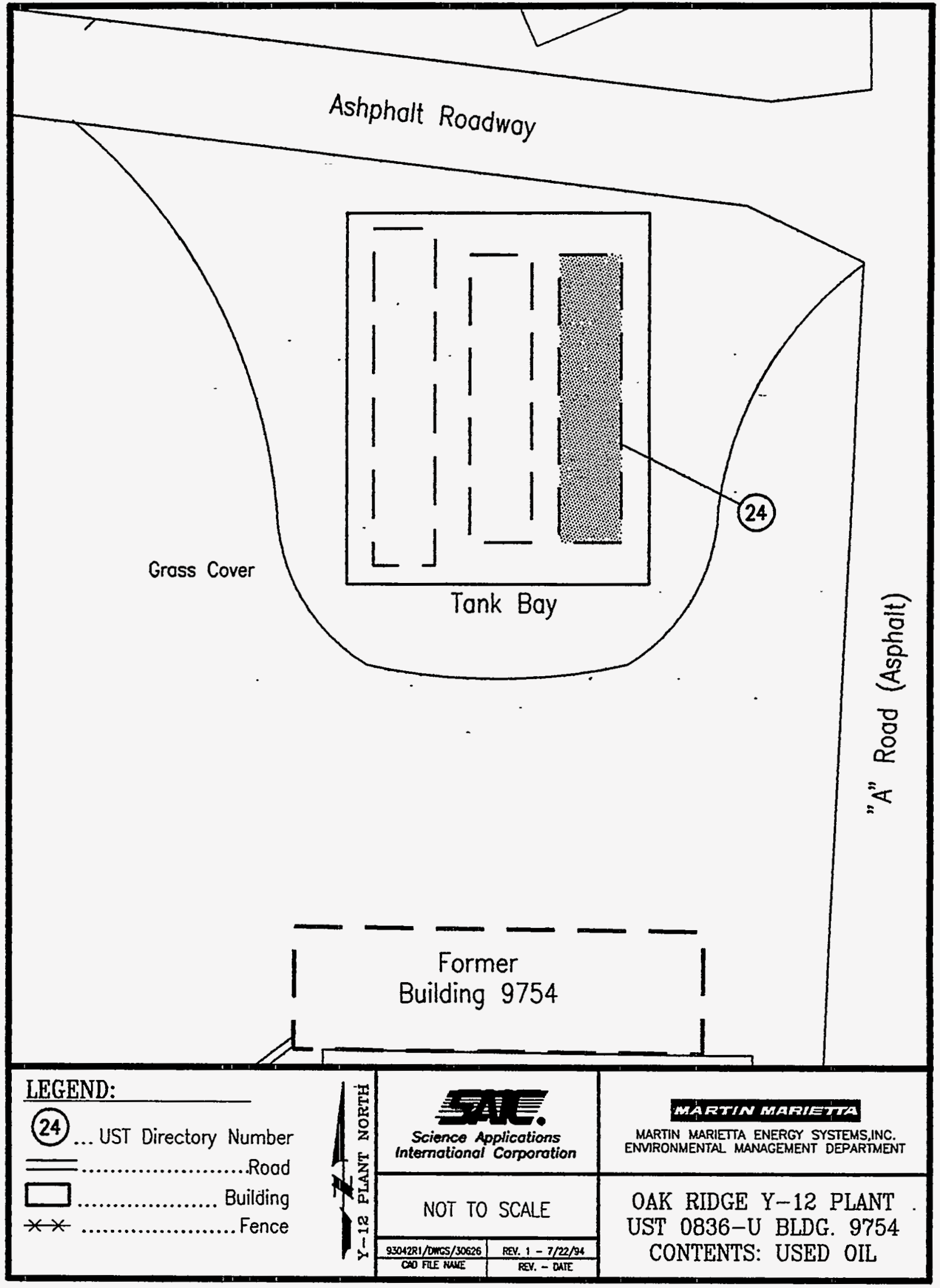


3-35

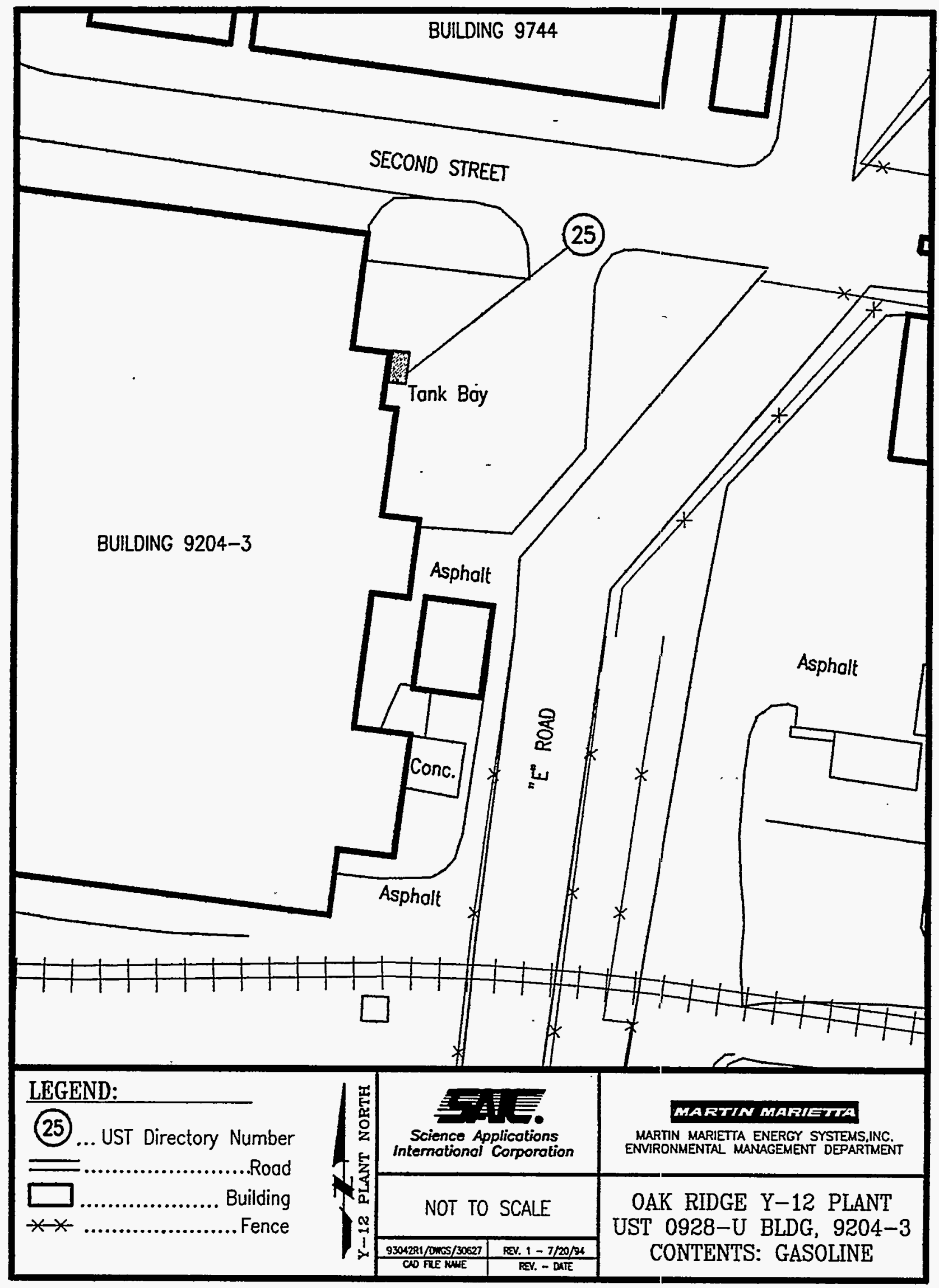




\section{3-36}

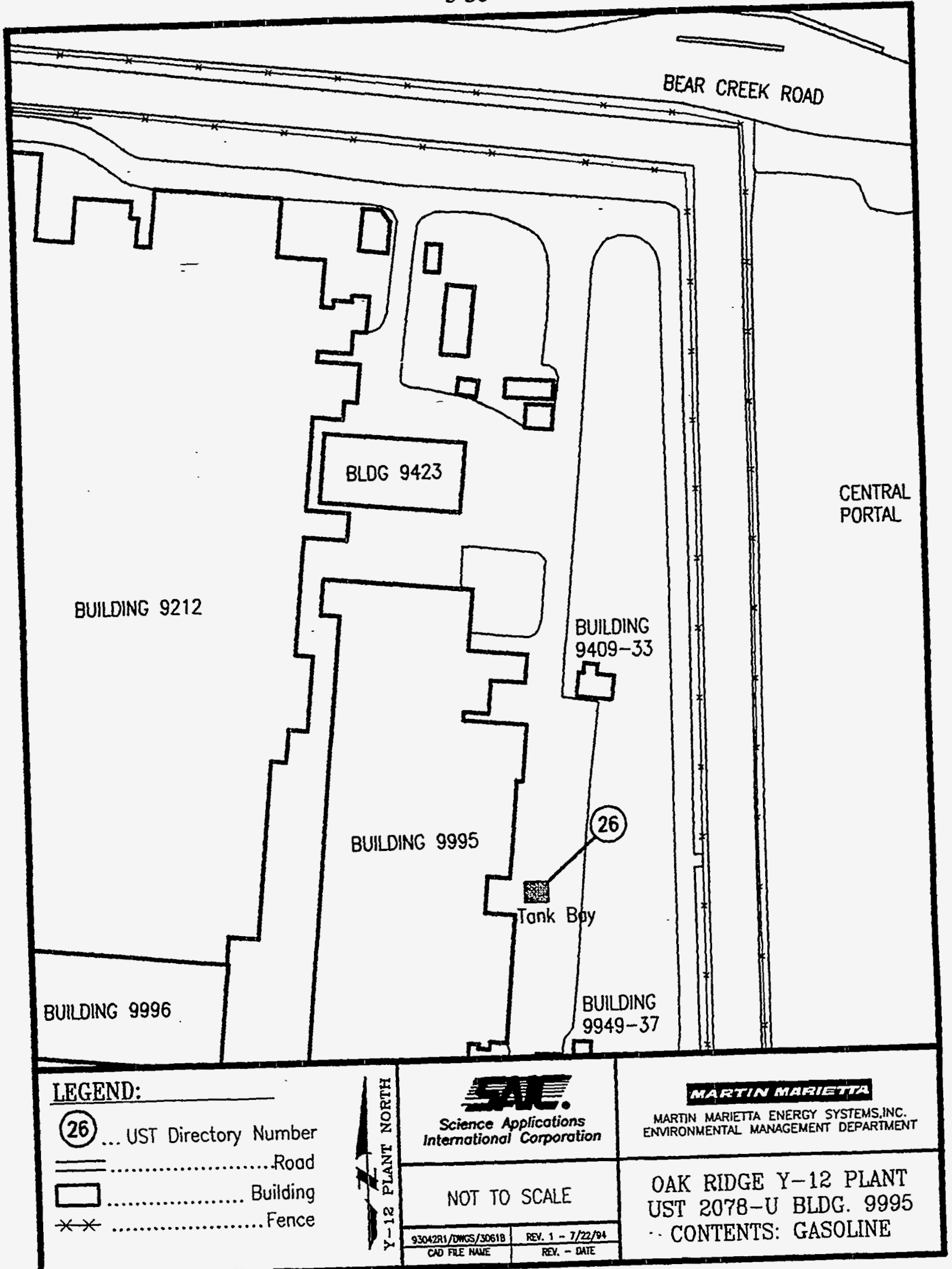




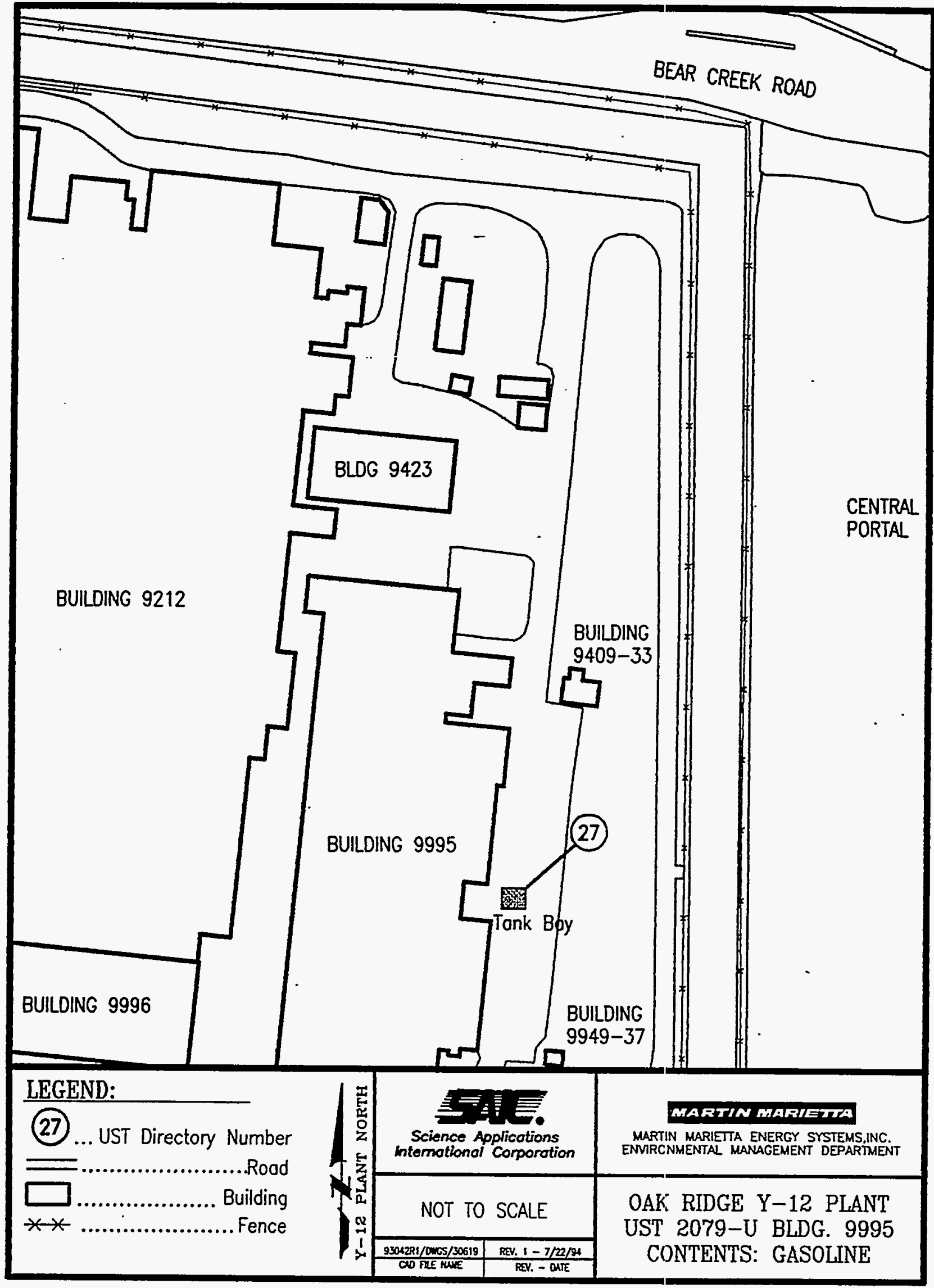




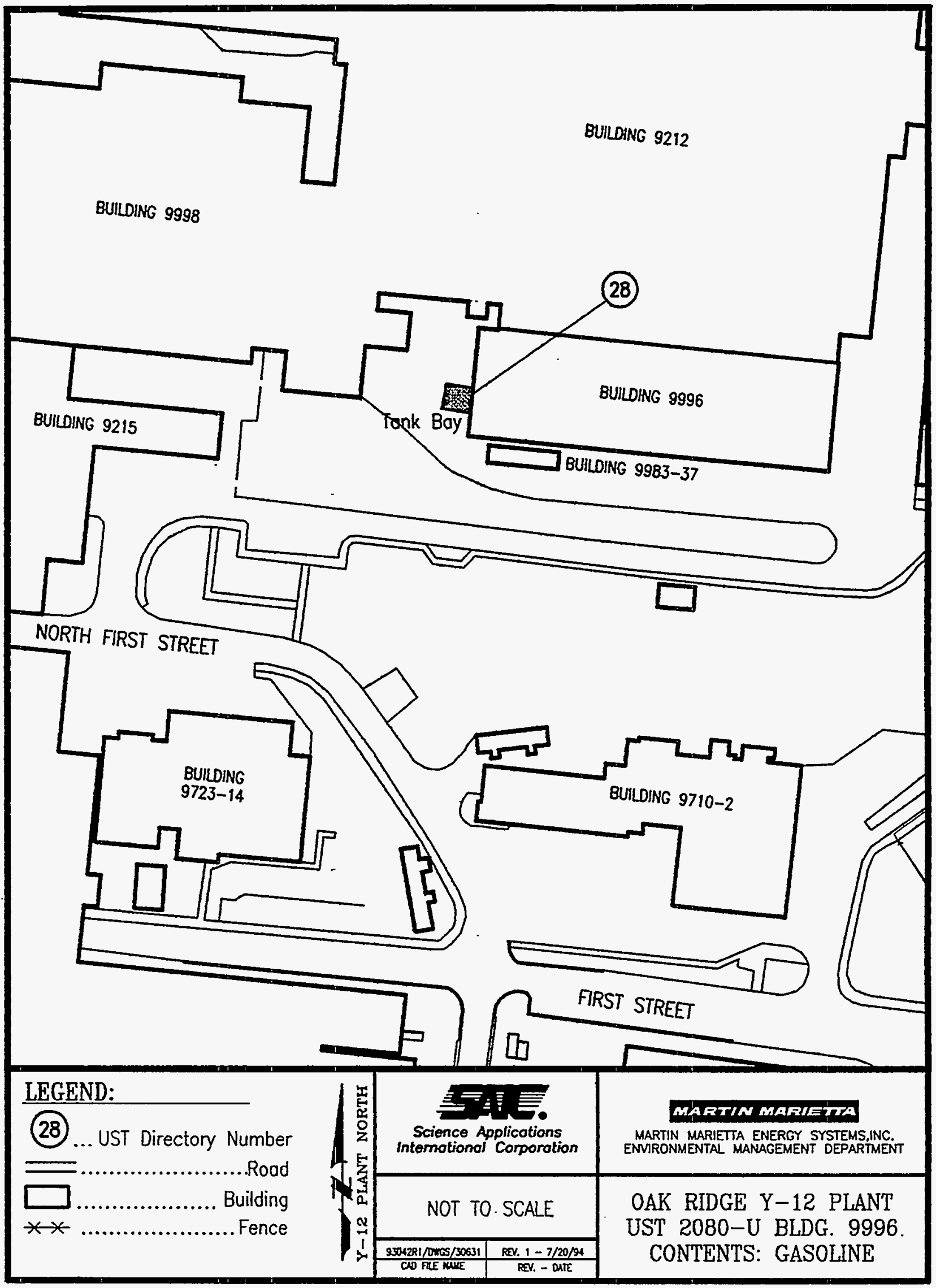




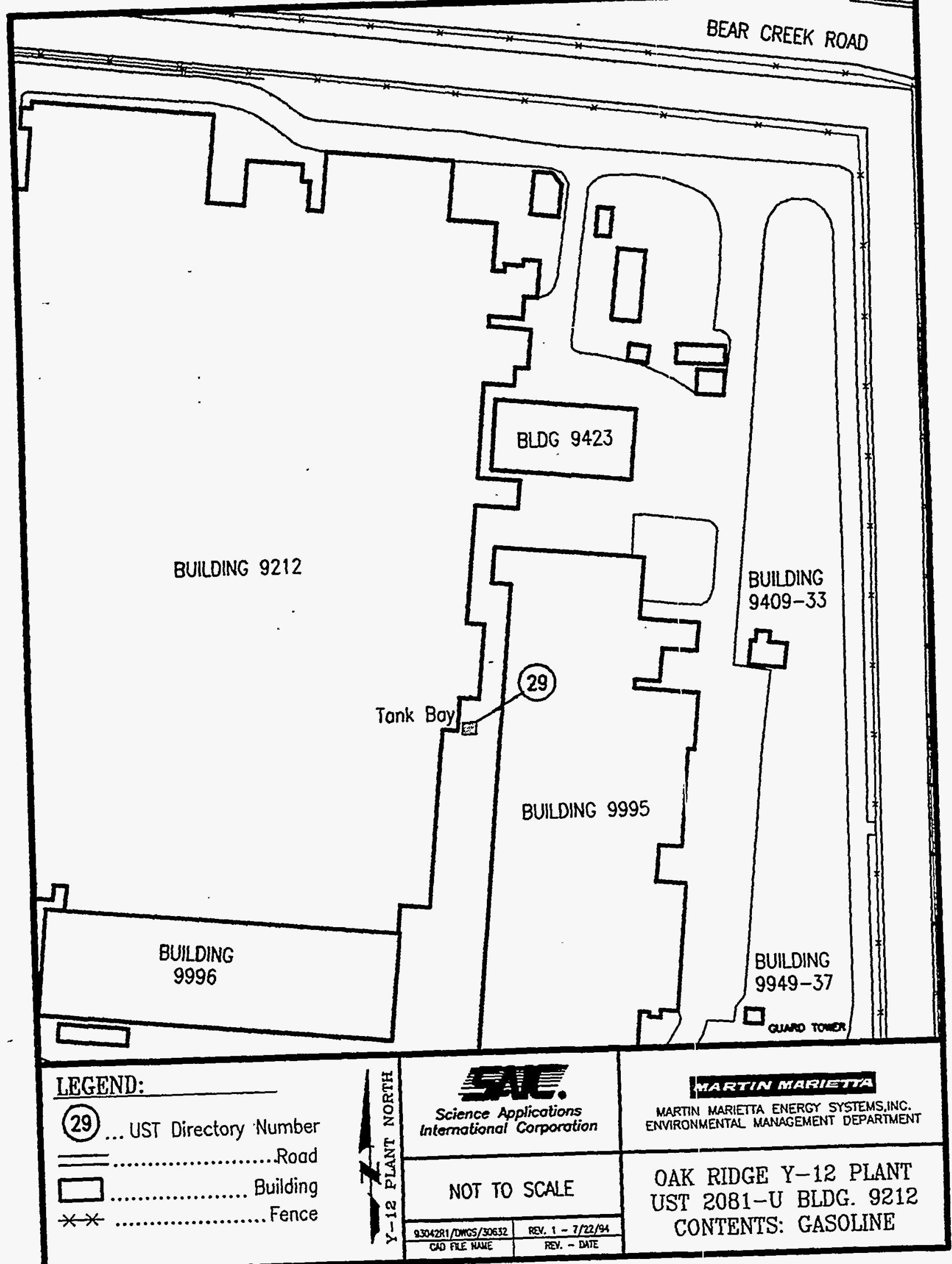




\section{3-40}

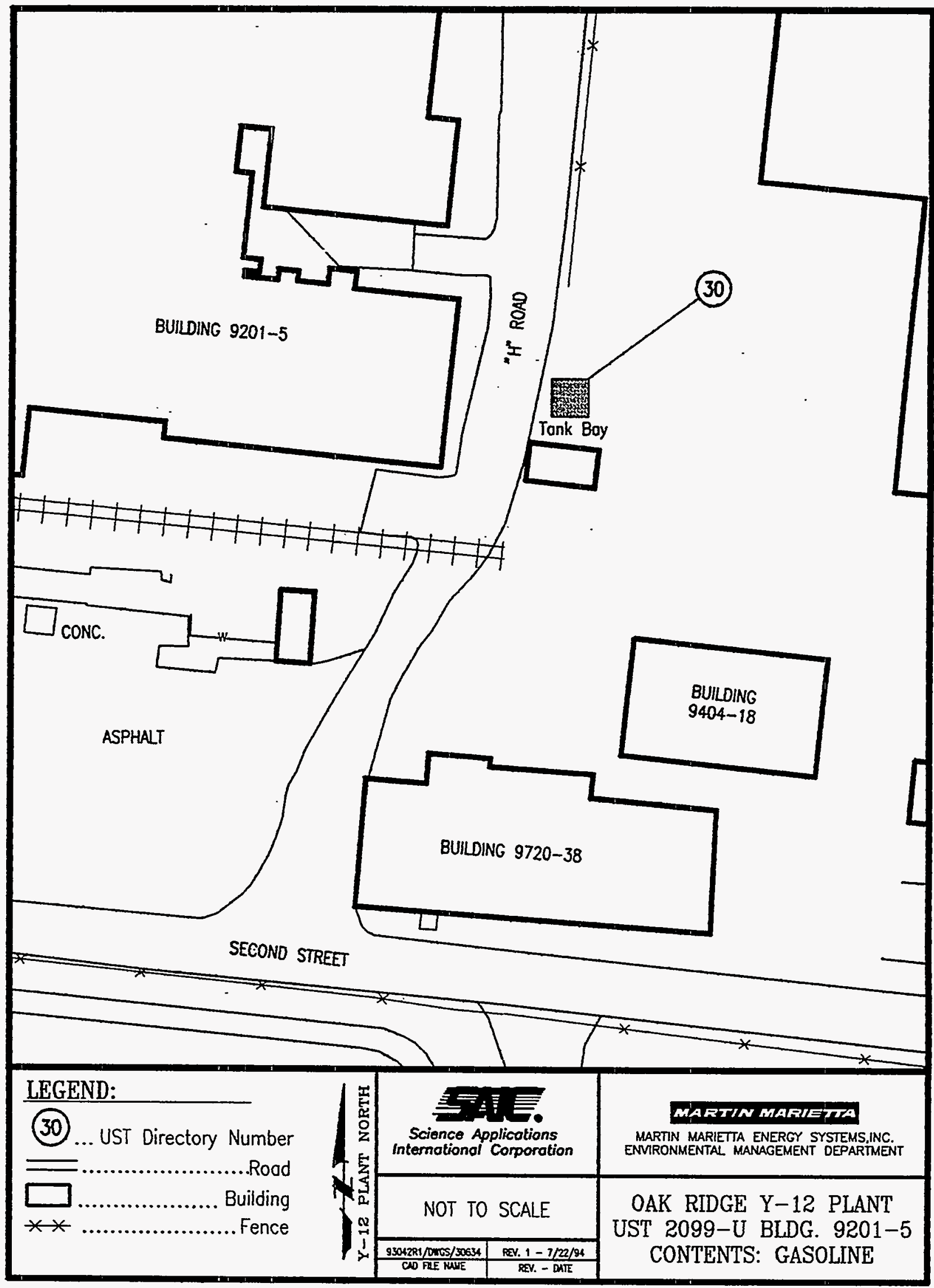




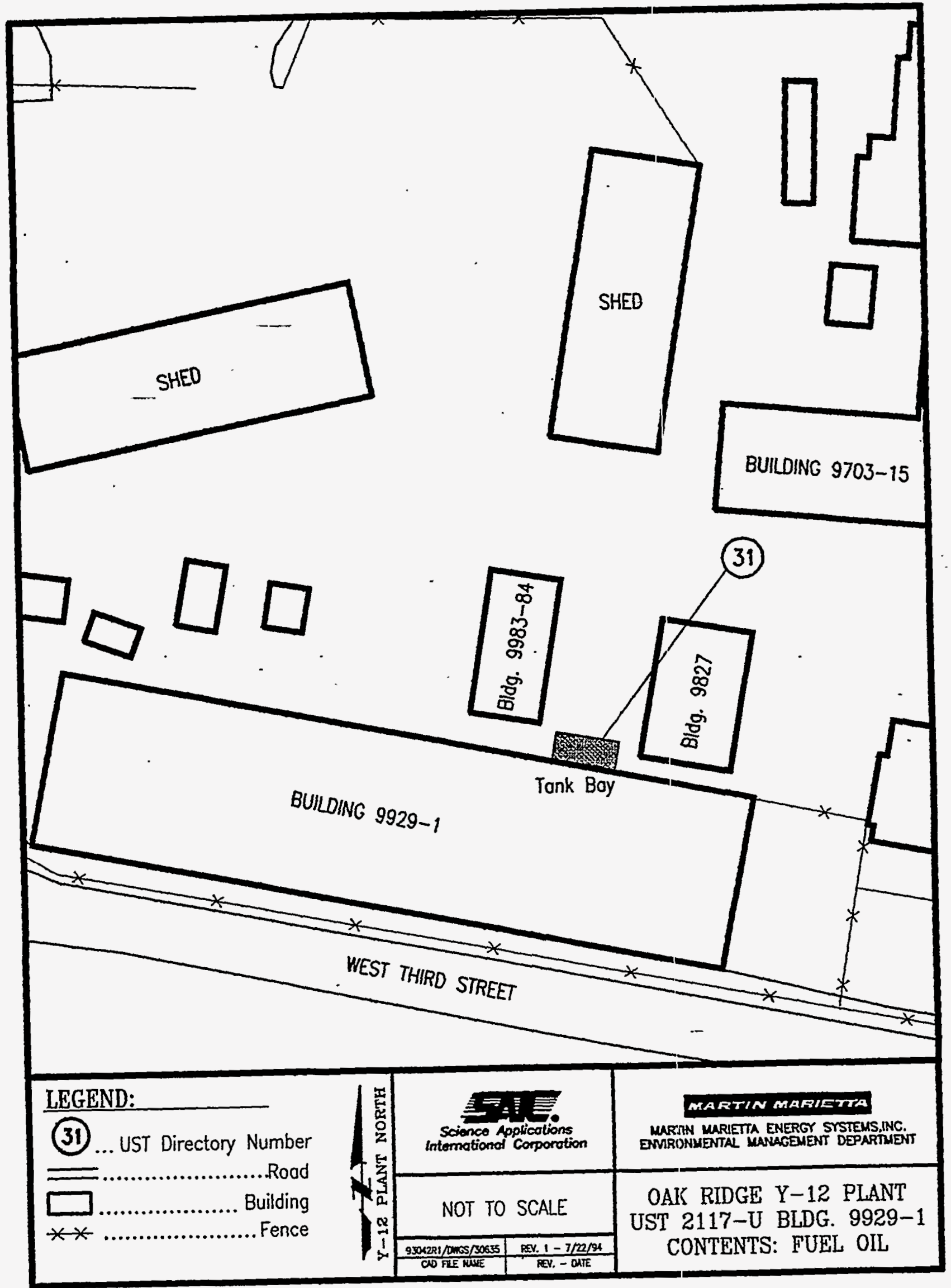




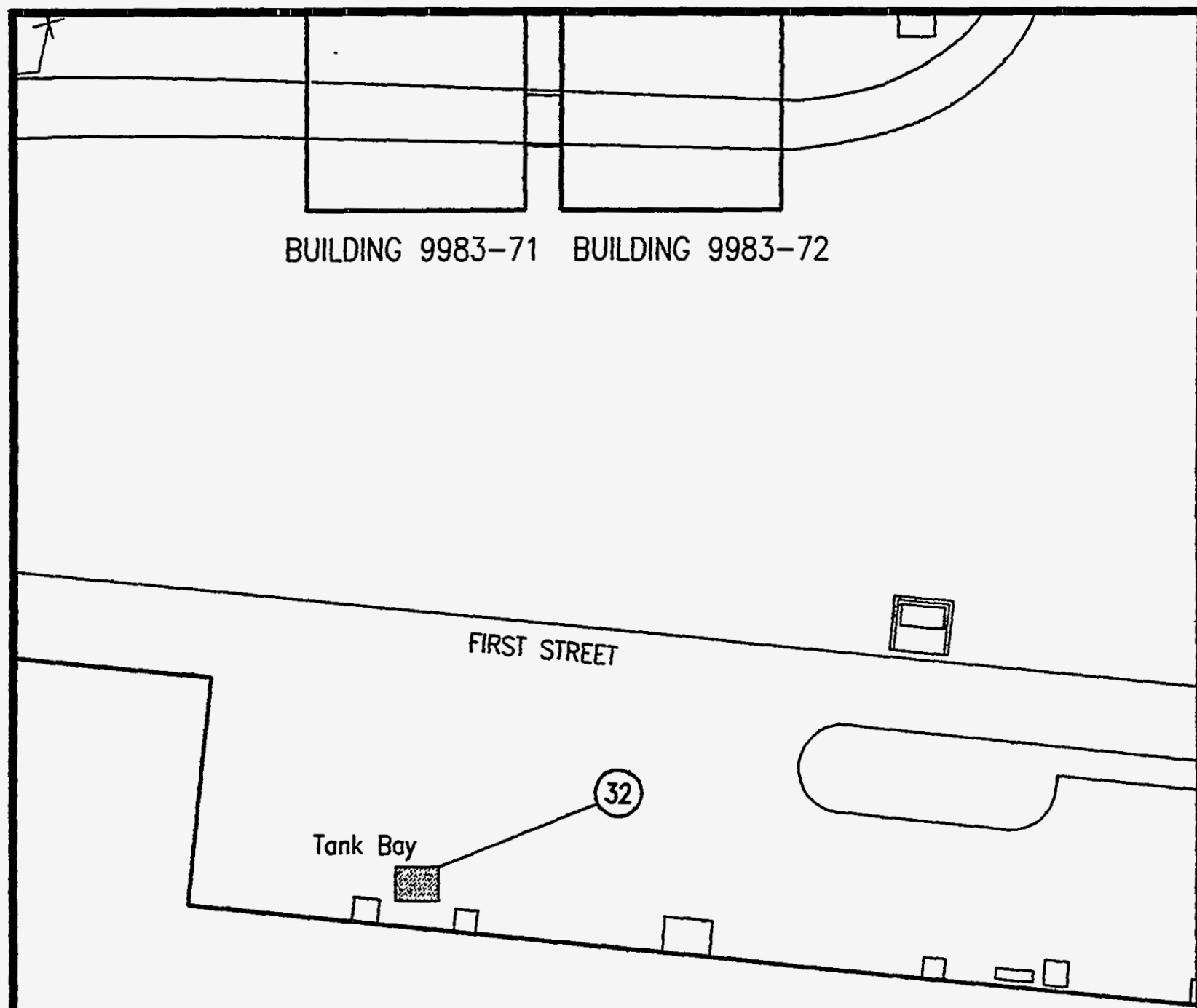

BUILDING 9204-4

LEGEND:

(32) ... UST Directory Number

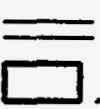
...Rood

$* *$

Building Fence

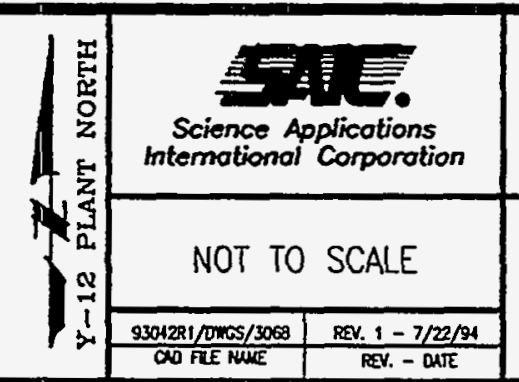

MARTIN MARIE iTA

MARTIN MARIETTA ENERGY SYSTEMS.INC. ENVIRONMENTAL MANAGEMENT DEPARTMENT

OAK RIDGE Y-12 PLANT UST 2130-U BLDG. 9204-4 CONTENTS: GASOLINE 


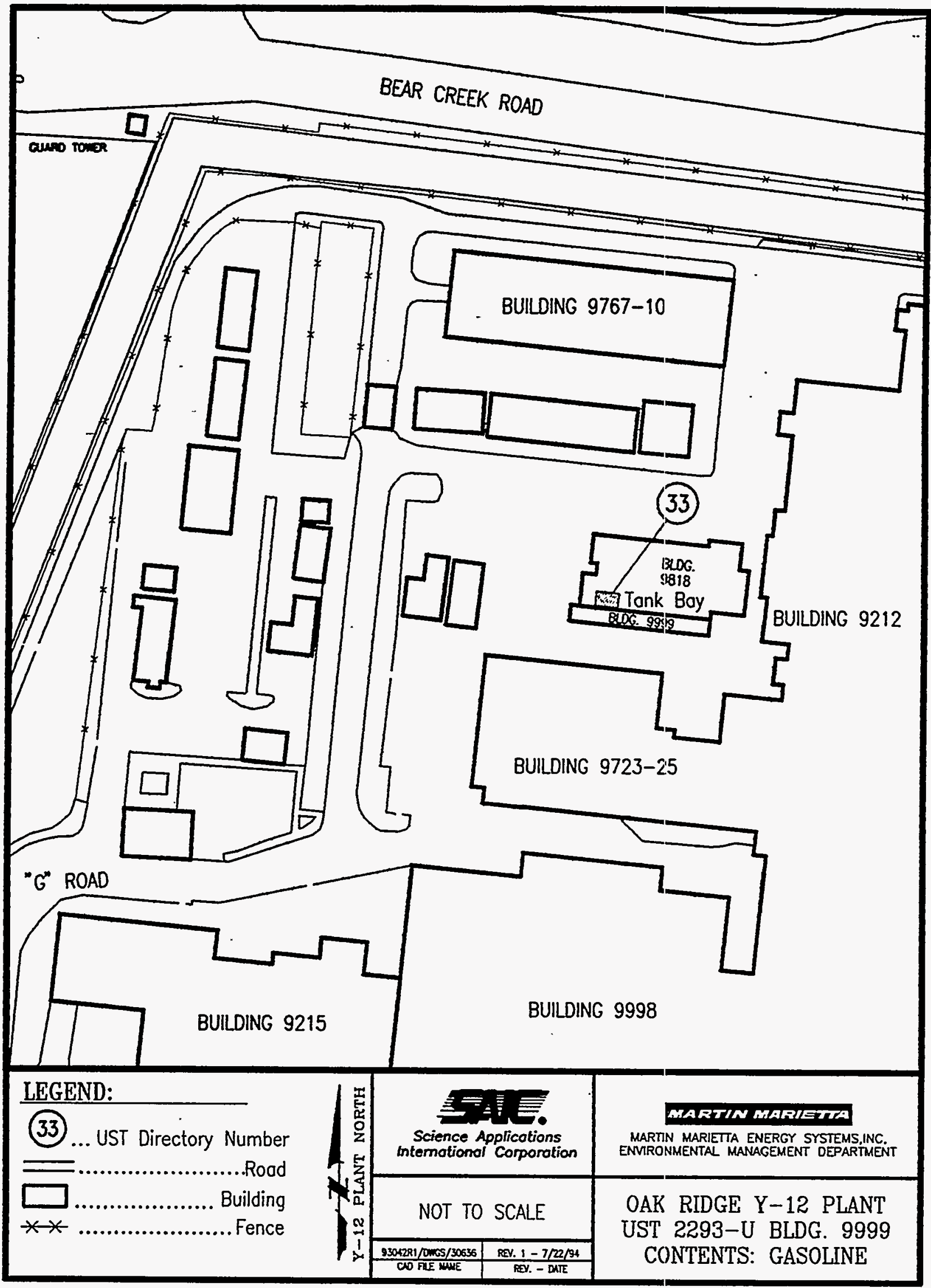




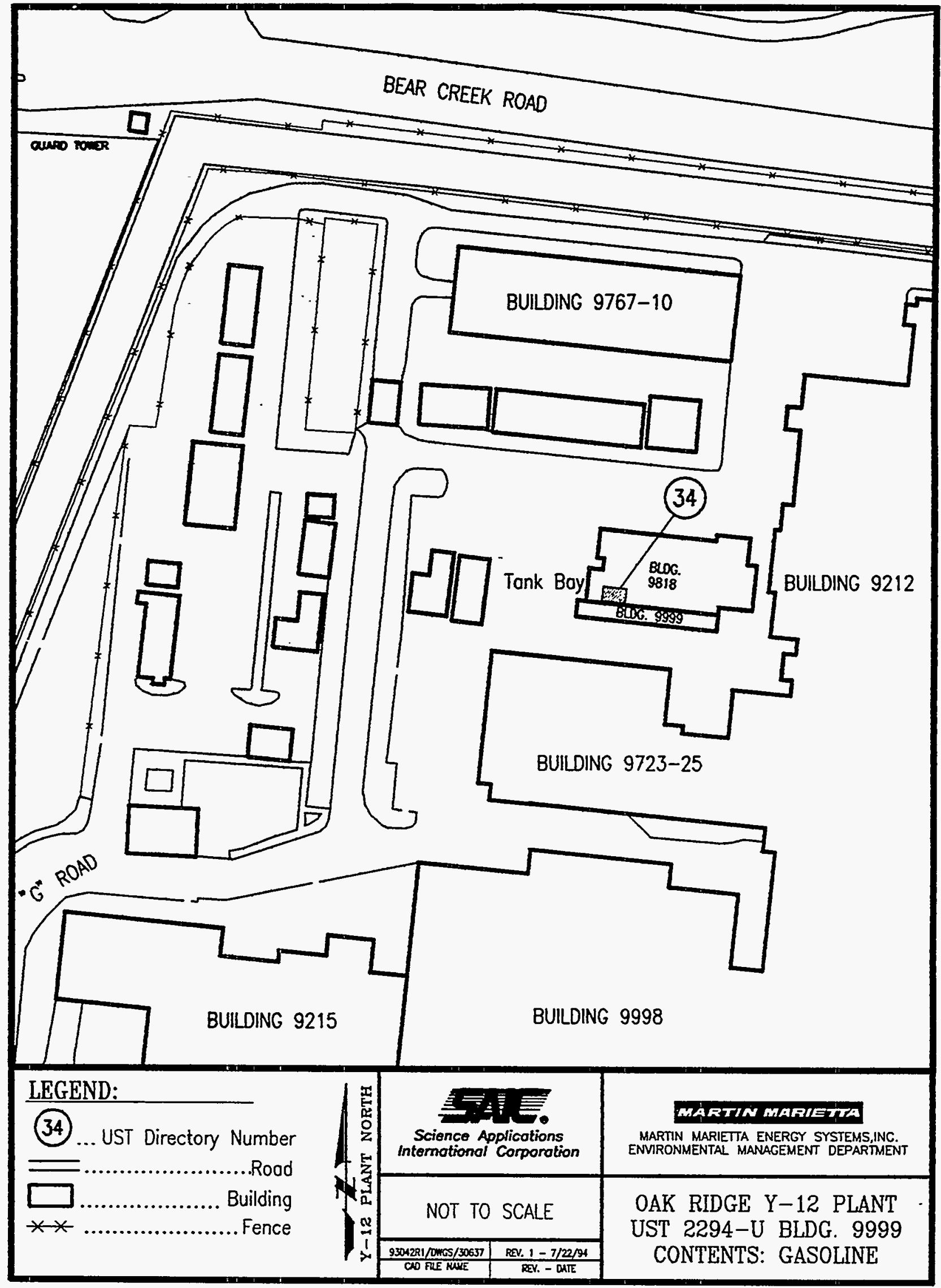




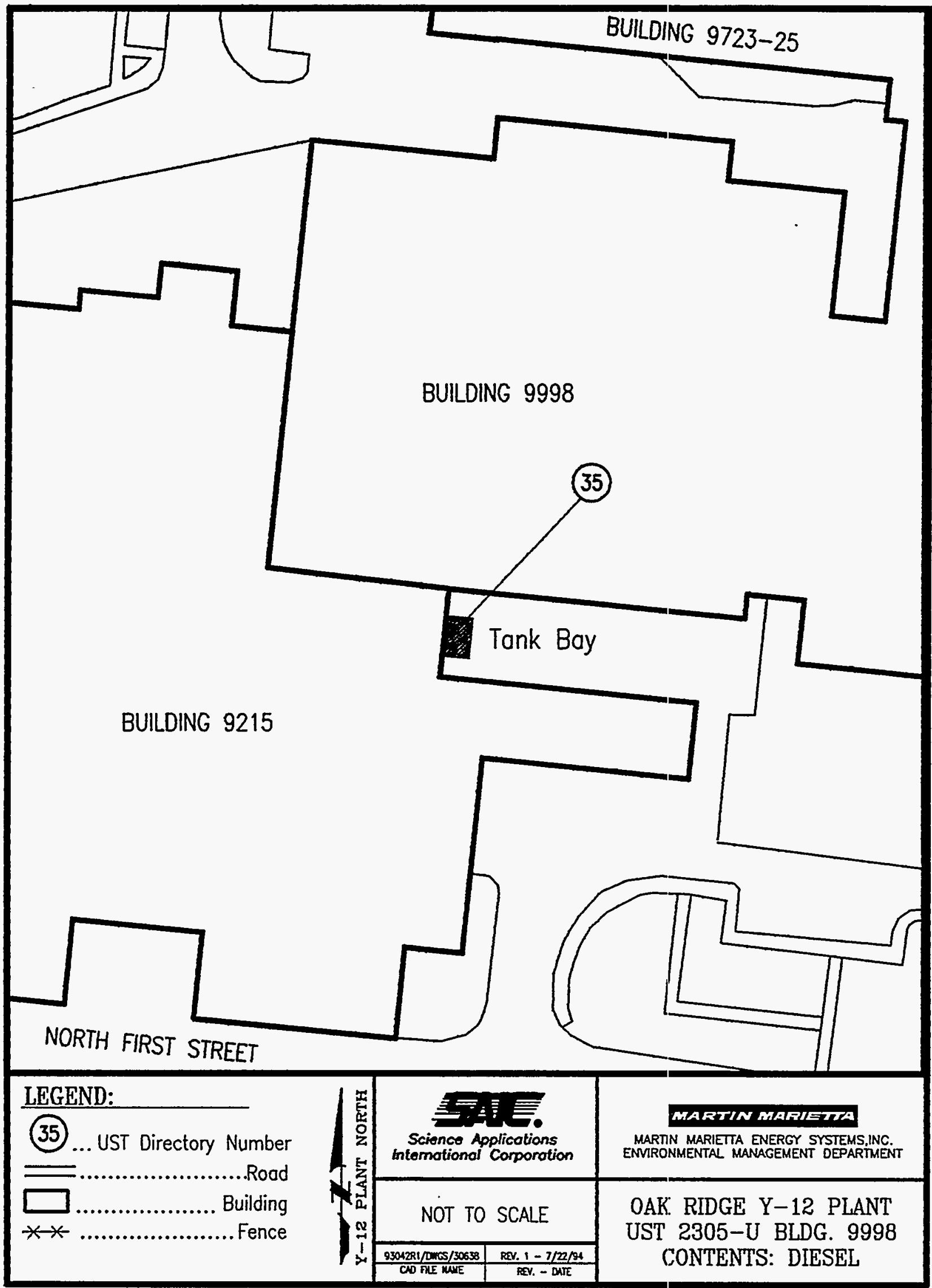




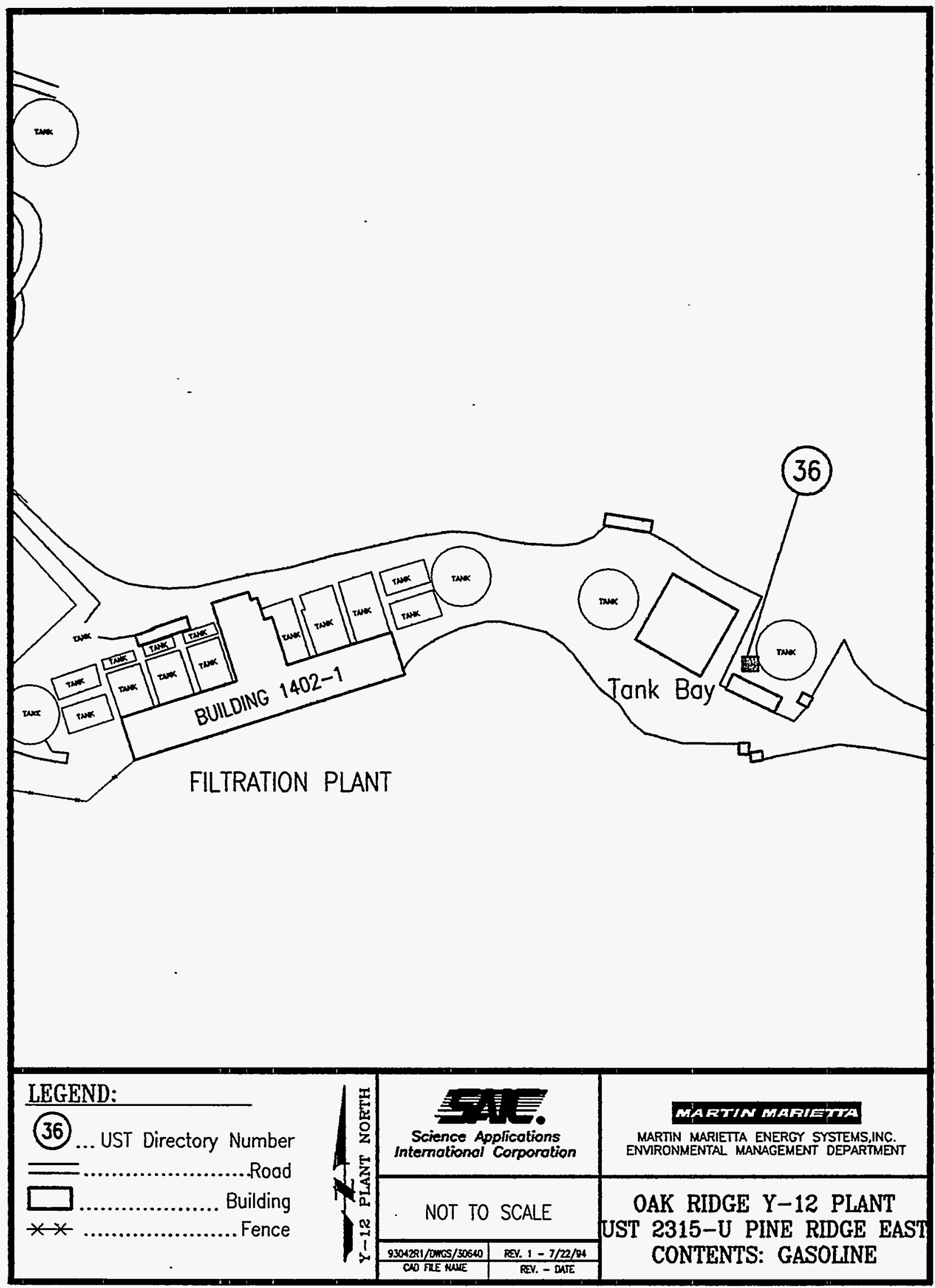




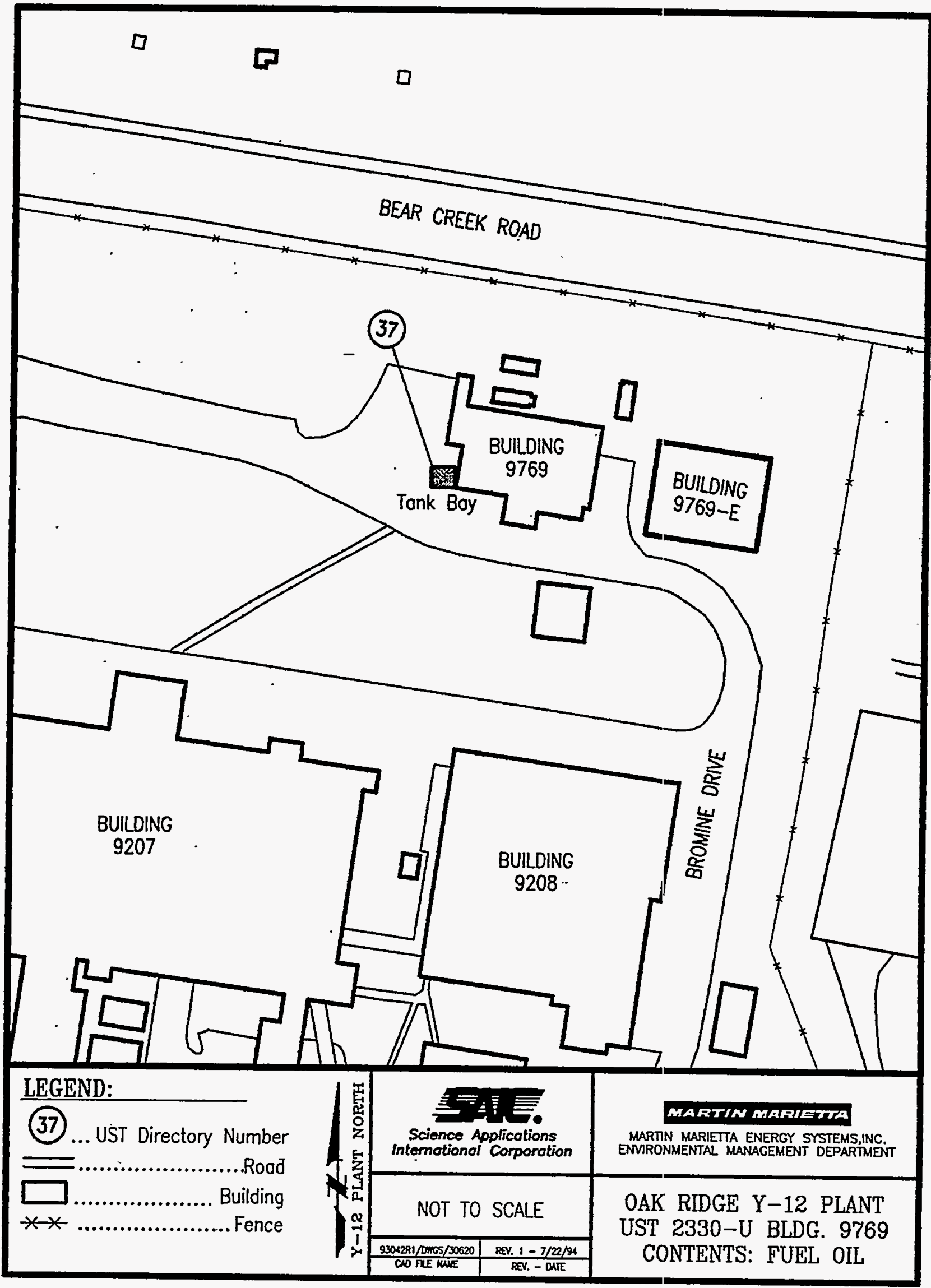




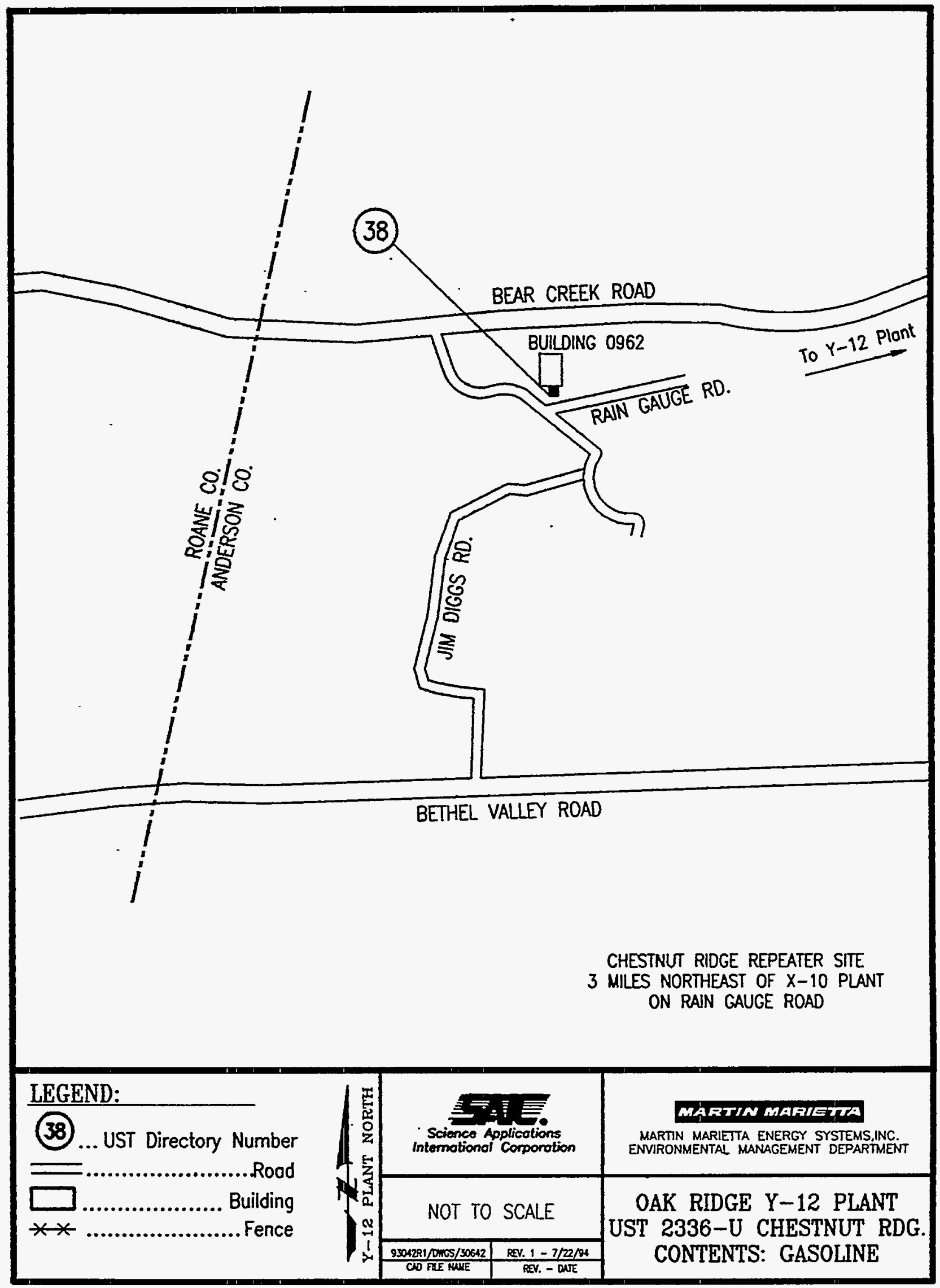




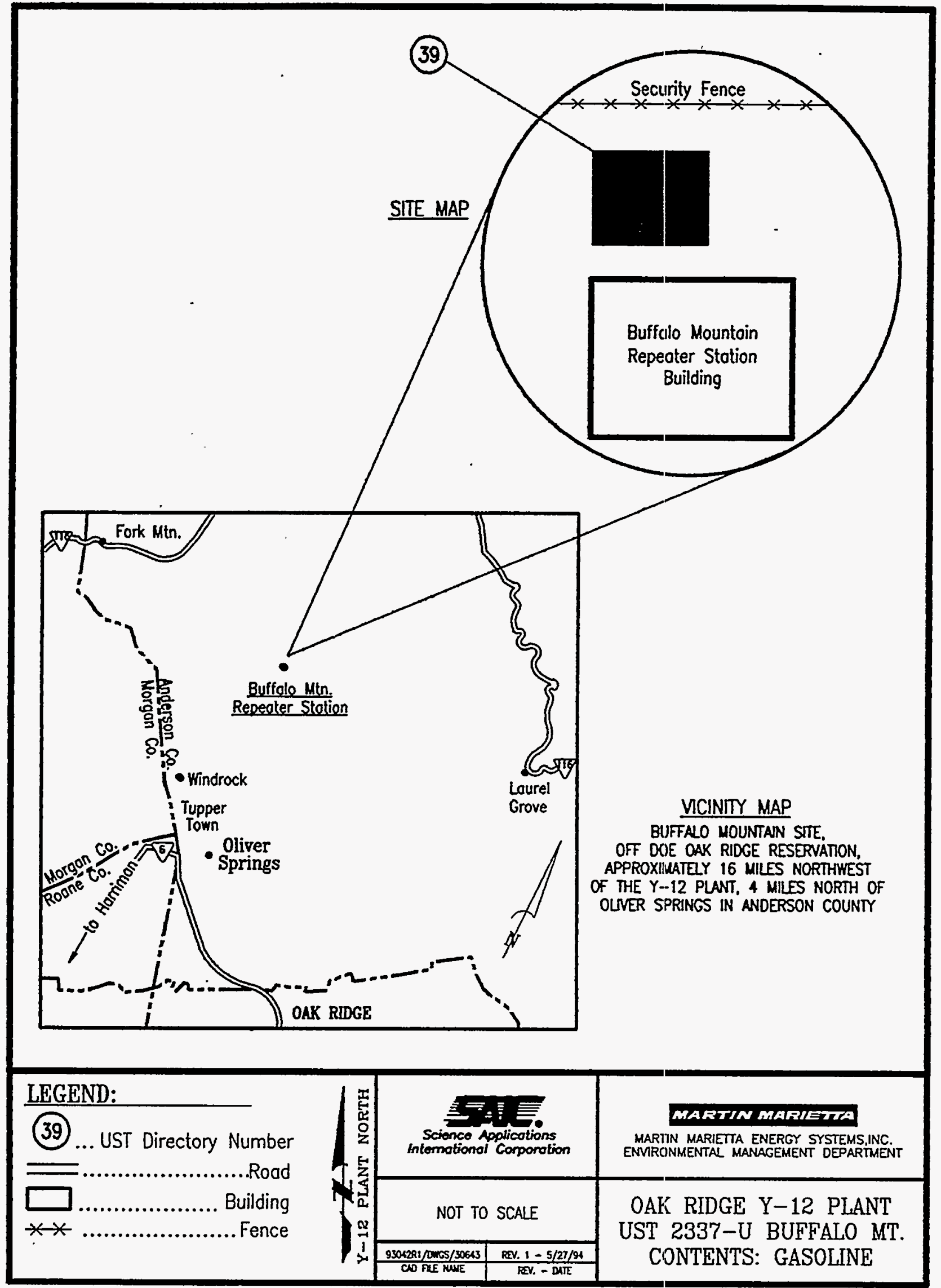




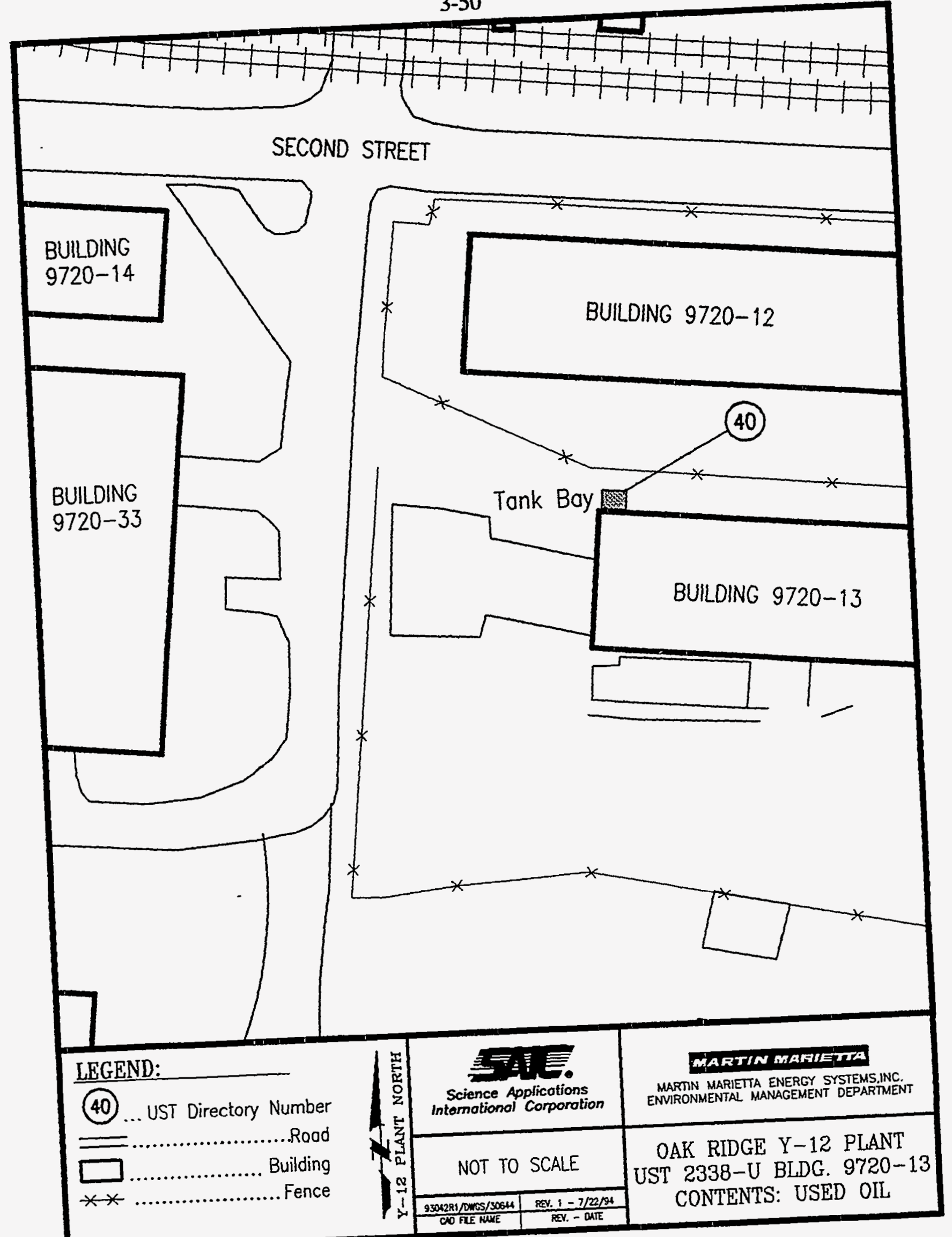




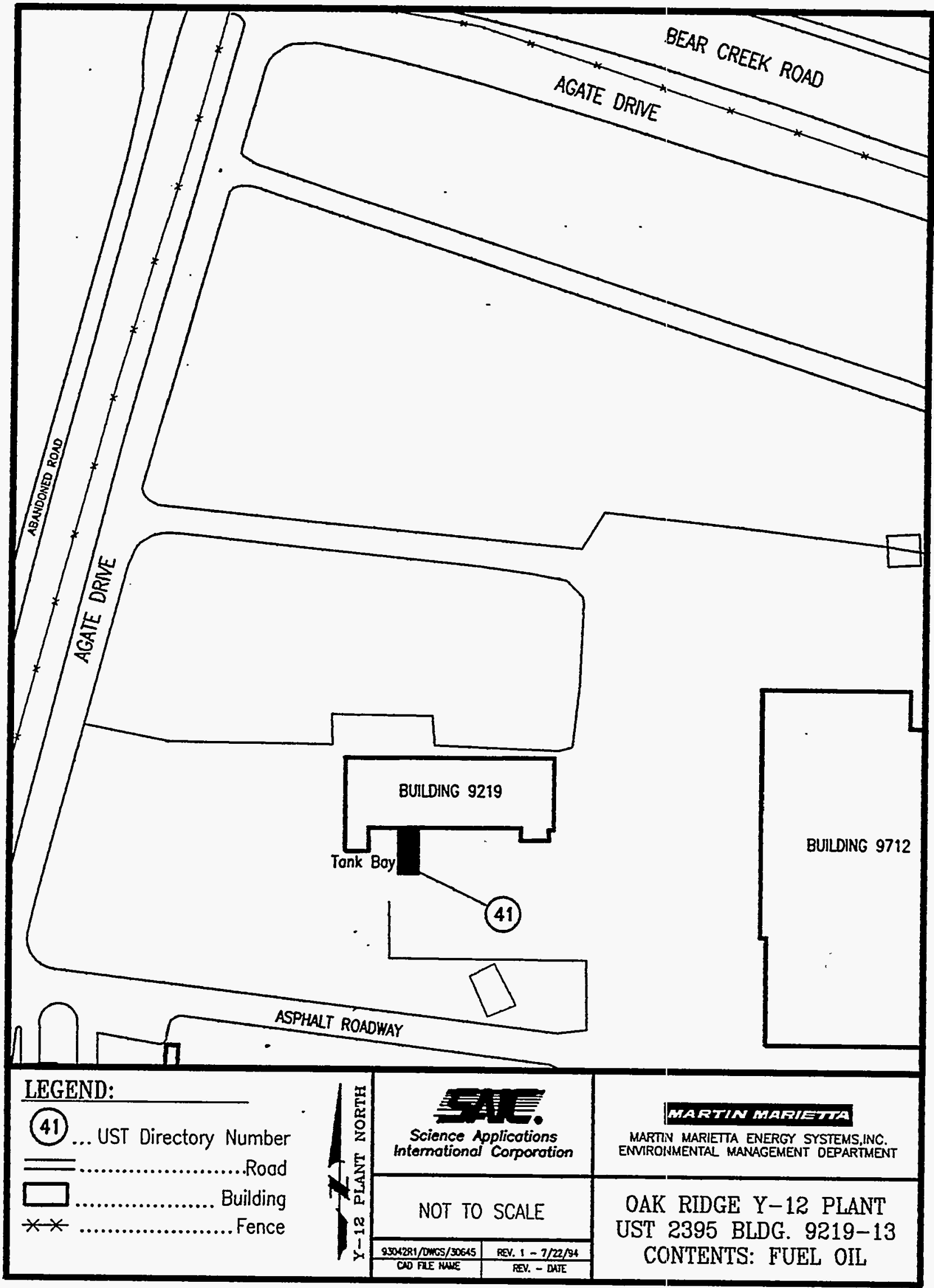




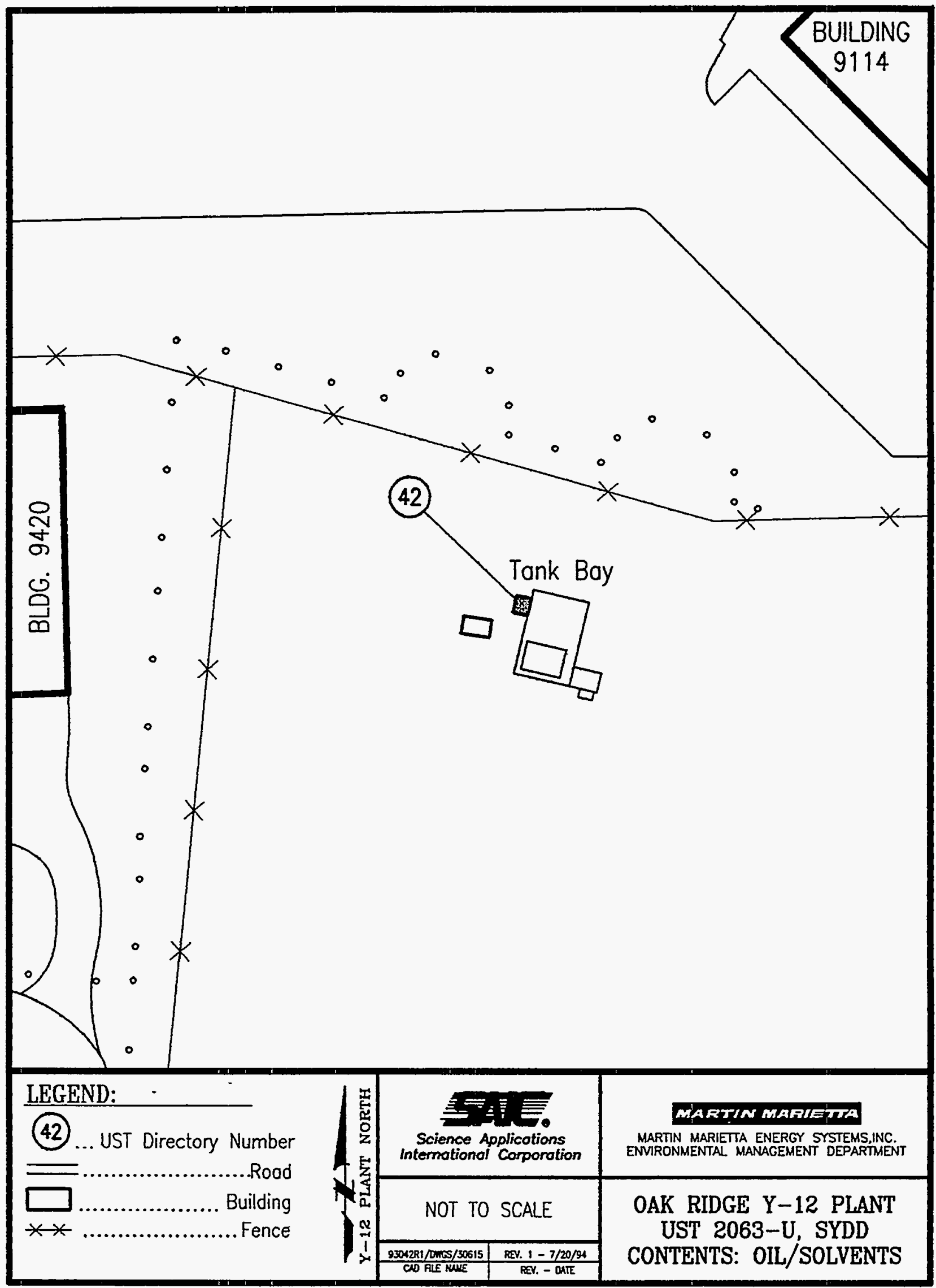




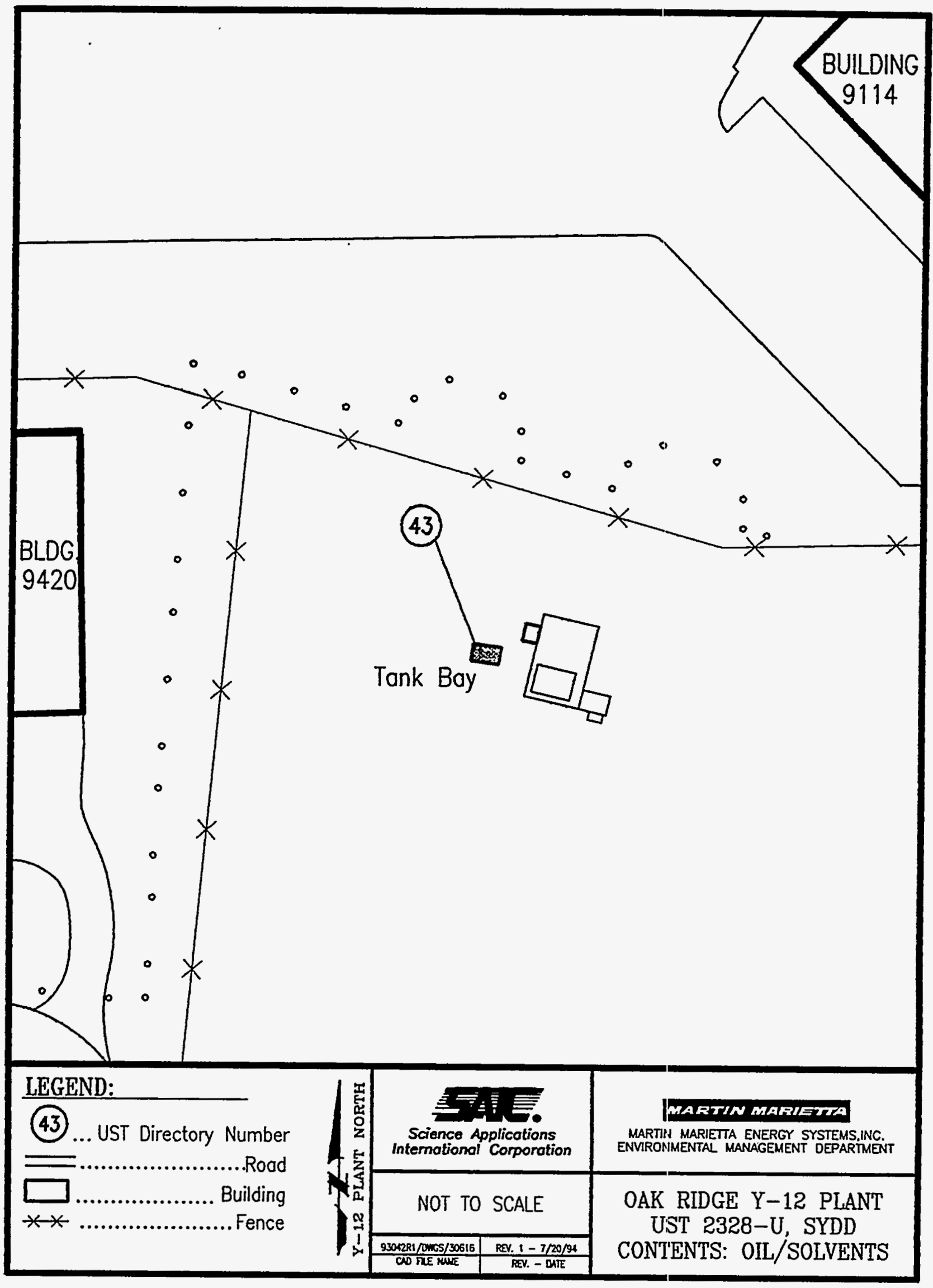




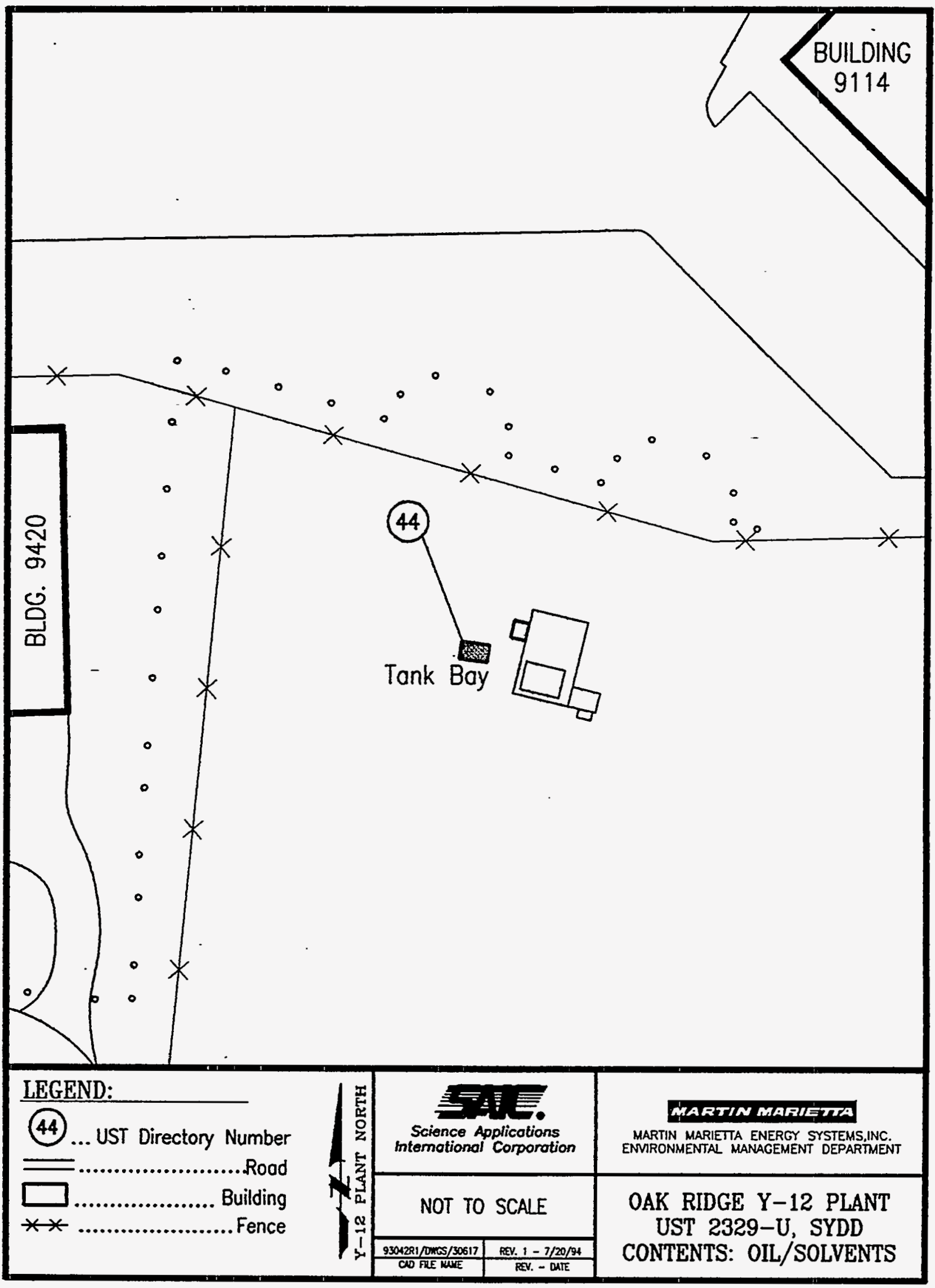




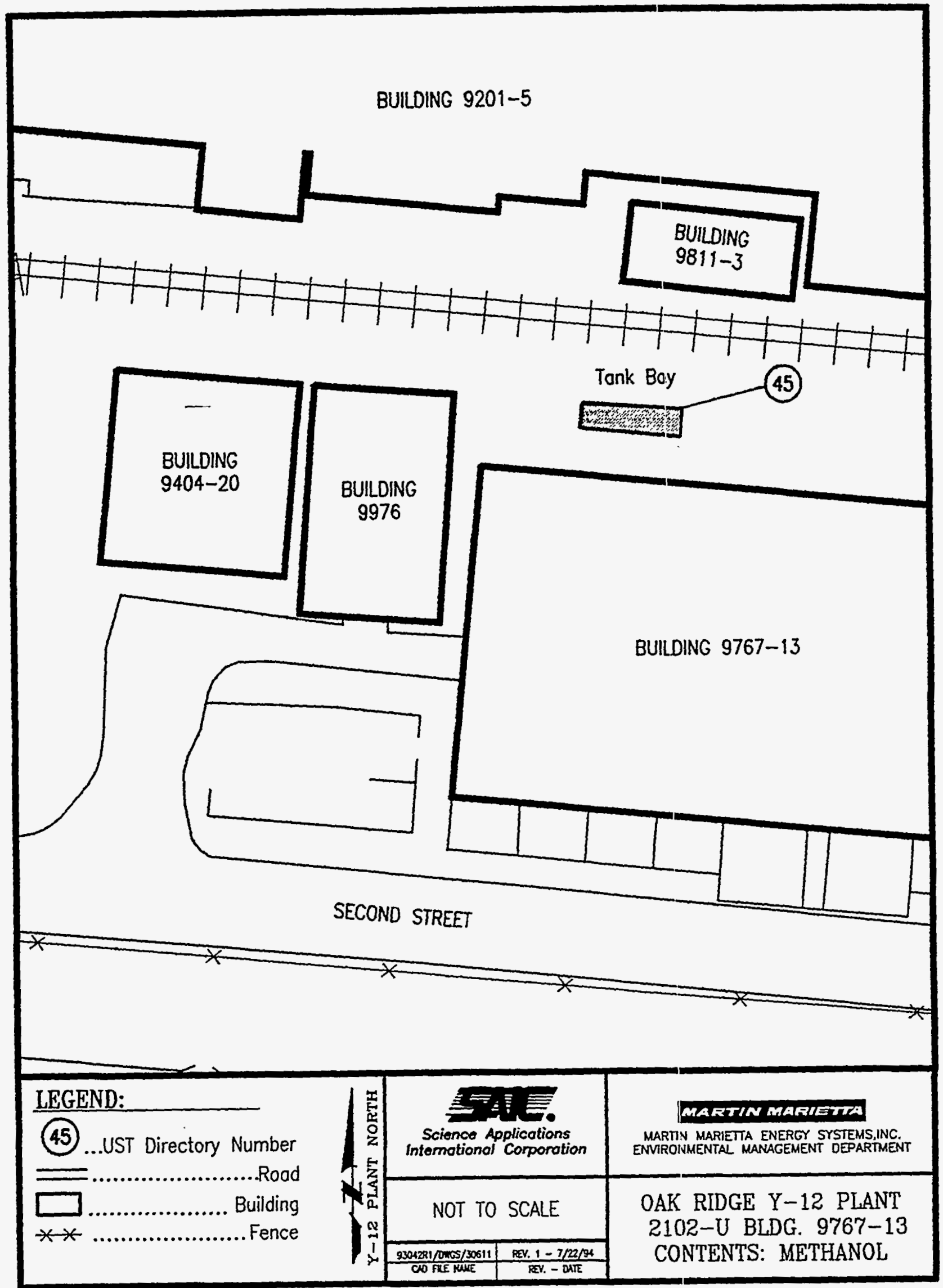




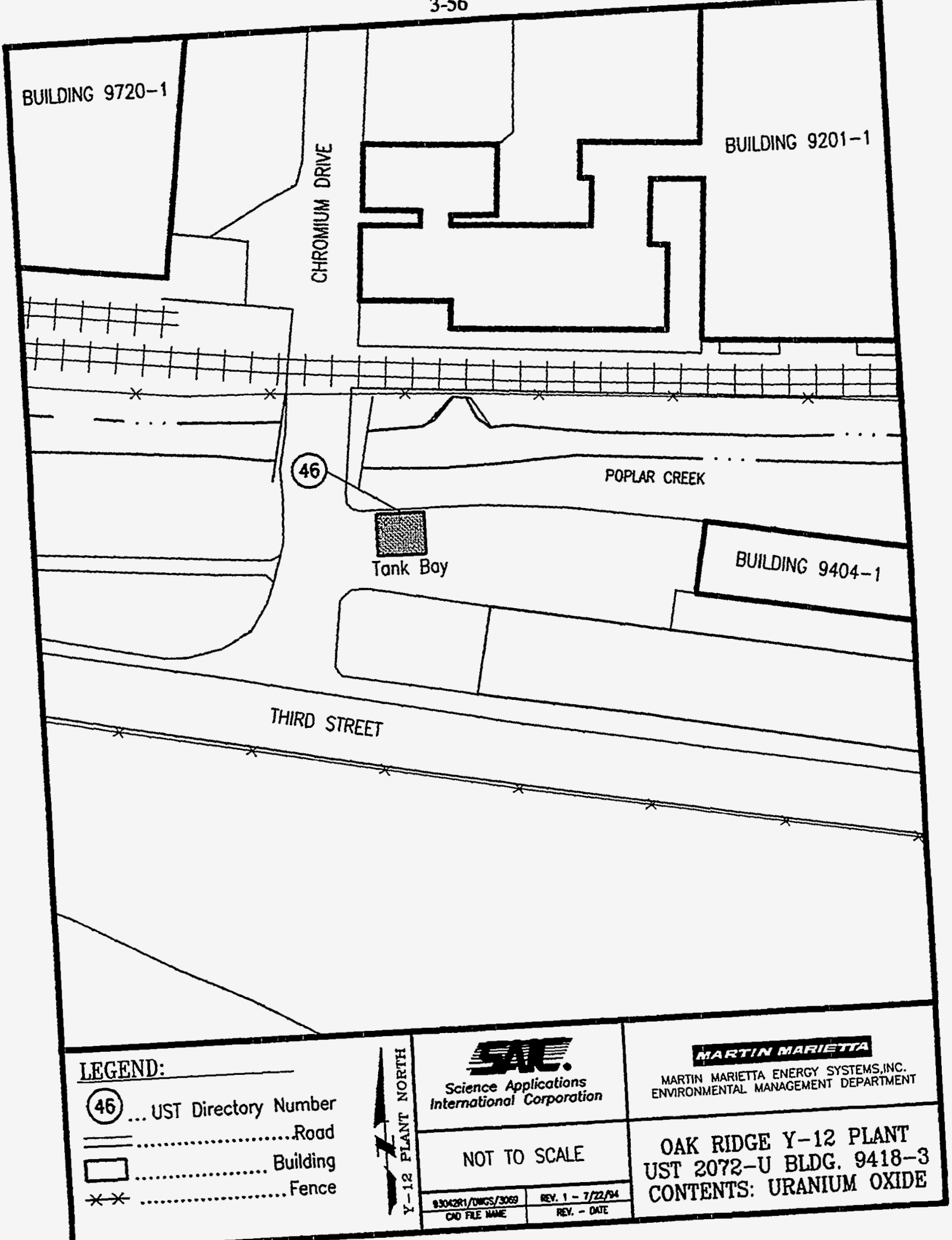




\section{3-57}

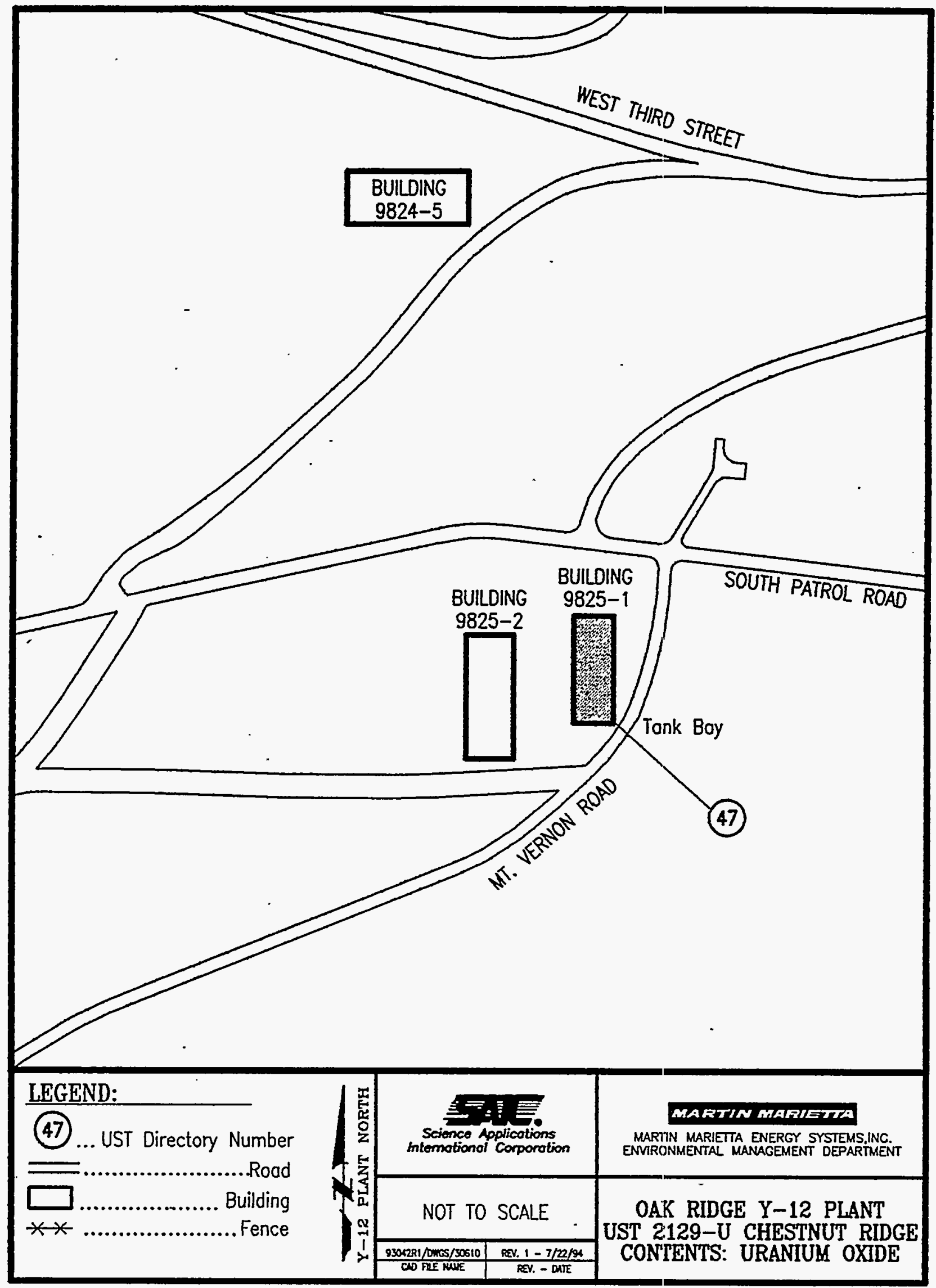




\subsection{Y-12 UST PROGRAM WASTE MANAGEMENT PRACTICES}

The Y-12 UST Management Program generates an intermittent waste stream that is derived from three potential sources. The first potential source is from investigation derived waste (IDW) from ongoing UST site assessment activities. The second source: of potentially contaminated environmental media is the Y-12 UST upgrade program that produces waste during tank removal and related construction activities. Finally, corrective action options proposed for remediation of contaminated soil and groundwater at UST sites will generate significant waste streams if implemented. A summary of the wastes managed from the three potential sources noted above is presented in Figure 2.

Waste management practices for the Y-12 UST Management Program will be performed in accordance with applicable EPA and TDEC regulations, DOE Orders, and Energy Systems policies and procedures.

\subsection{Investigation Derived Waste}

Investigation activities associated with the Y-12 UST Management Program generate small. volumes of IDW (primarily soil media) on an intermittent basis. Typical activities that will produce IDW include General Facility Site Checks, Initial Site Characterizations, Environmental Assessments, and site monitoring. These activities may generate decontamination fluids, well development and purge water, debris (e.g., concrete), soil drill cuttings, solvents and oils, personnel protective equipment and other related waste, asbestos insulation, and miscellaneous solid and/or liquid wastes (e.g., residual analytical sample).

All IDW generated in the field is drummed or covered with plastic sheeting pending analytical characterization. Types of analytical characterization information that are typically available for IDW include field screening results, laboratory analytical results for associated environmental samples, and the results of Toxicity Characteristic Leaching Procedure (TCLP) analyses for wastes to undergo disposal by landfilling. Based on the results of characterization, clean waste soil will be transferred to a Y-12 Plant landfill or used as land application. Contaminated waste soil will be appropriately containerized, labeled, and placed within an appropriate and approved storage area [e.g., Toxic Substances Control Act (TSCA) or RCRA storage area] pending final treatment and/or disposal. All IDW liquid. waste will be transferred to a Y-12 Plant groundwater treatment facility or a liquid storage facility.

Management of laboratory waste derived from Y-12 Plant UST sites is performed in accordance with approved laboratory waste management plans and laboratory best management practices. The analytical residues associated with current UST activities are relatively small in volume and do not warrant separate handling.

\subsection{UST Upgrade Program Derived Waste}

The Y-12 Plant UST upgrade program consists of the ongoing activities to improve or decommission existing UST systems to meet TDEC requirements and Energy Systems best management practice.standards. In general, these activities consist of tank removal and closure assessment sampling. Wastes generated during these activities include excavated soil, surface materials, tank units and associated piping, and closure assessment sampling and analytical wastes.

Excavated soil and surface materials are stockpiled at or near the UST sites, and are covered with plastic sheeting pending analytical characterization. Characterization is accomplished in the same manner as was previously noted for IDW. Tanks and piping are purged and screened for explosive vapors prior to removal. This equipment is screened a second time before being 


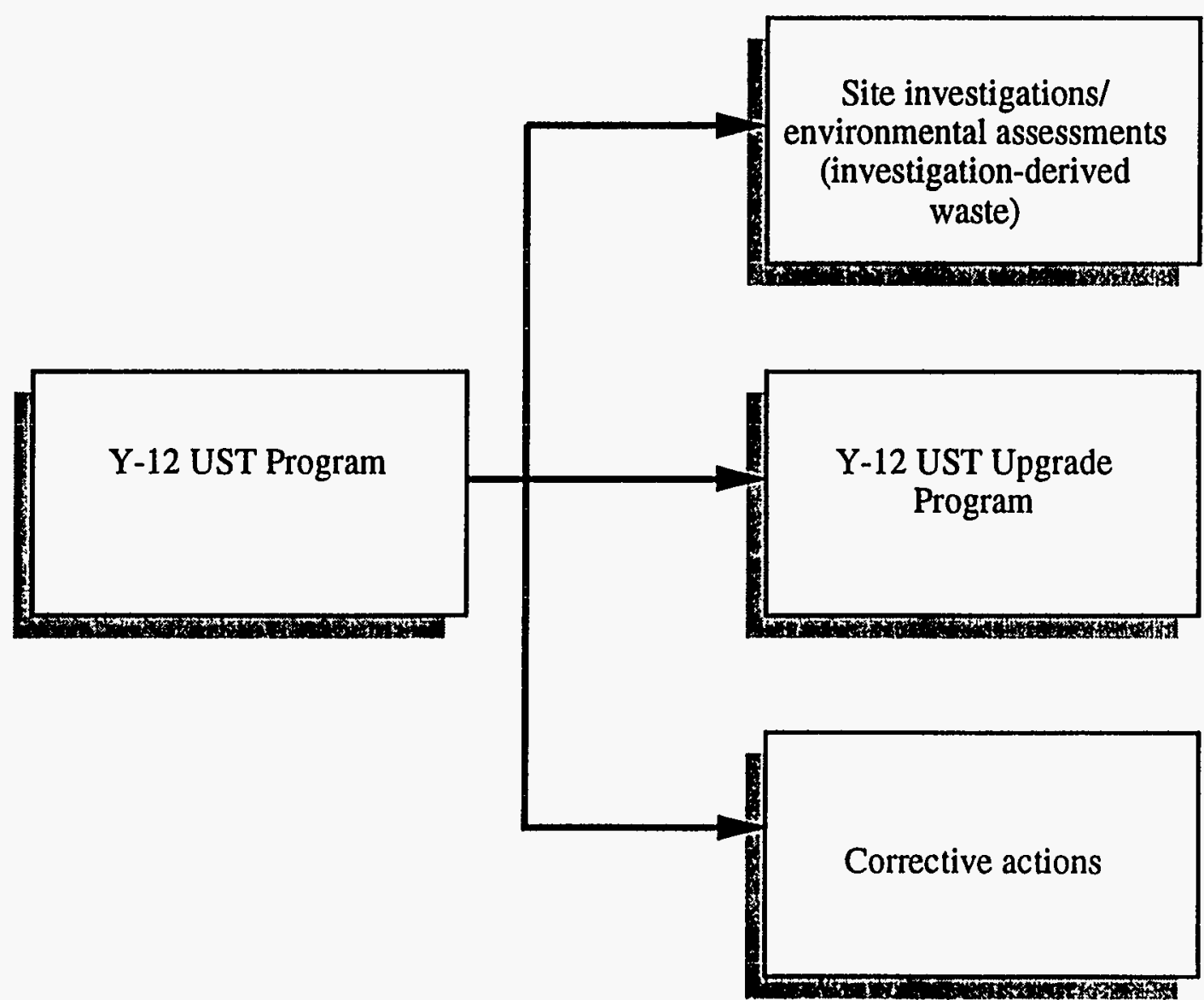

DRILL CUTTINGS

MONITOR WELL PURGE WATER

MONITOR WELL DEVELOPMENT WATER

PERSONAL PROTECTION EQUIPMENT

DECONTAMINATION FLUIDS

SAMPLE ANALYTICAL RESIDUE

EXCAVATED SOII

COVER MATERIALS

TANKS

PIPING

FITTINGS

ASSOCIATED SAMPLING/ANALYTICAL WASTE

SOIL EXCAVATION

MONITORING WELL INSTALLATION

SAMPLING/ANALYSIS

SECONDARY TREATMENT WASTE STREAM(S)

PERSONAL PROTECTION EQUIPMENT

Figure 2. UST waste management flowchart 
transferred to the Y-12 Plant scrap yard. Applicable tank identification and labeling requirements are adhered to, and all shipping and disposal records are maintained by the Y-12 UST Management Program. If the tanks are found to be in good condition, they may be re-used by Energy Systems or sold. Tanks and piping found to be in poor condition are wrapped in plastic upon removal and transferred to the Y-12 Plant scrap yard where they are crushed, cut apart, and either sold as scrap or recycled. Sampling and analytical wastes are managed in the same manner as was previously noted for IDW.

\subsection{Corrective Action Derived Waste}

Each of the Y-12 Plant UST sites that has soil and/or groundwater contamination above applicable TDEC levels may undergo corrective action if numerical site ranking results exceed the site action number, or if a site-specific standard is not approved by TD)EC. The corrective action(s) chosen for remediation will be developed and approved by TDEC on a site-specific basis. Typical remedial activities will generate a number of potential waste streams. These wastes would be derived from the following: soil excavation activities, recovery and monitoring well installation and development, sampling and analysis activities, treatment of contarninated media, confirmatory sampling and analysis, and personnel protective equipment used during remedial activities.

Most of the waste types noted above will be handled and disposed of in the same manner as was previously noted for IDW and upgrade program derived waste. Secondary waste streams generated during remediation may include contaminated leachate, runoff, or ash that will be appropriately containerized, labeled, and placed within an appropriate and approved storage area (e.g., TSCA or RCRA storage area) pending final treatment and/or disposal. Clean soil will be landfilled or used for direct land application at the Y-12 Plant, and clean water will be released through a National Pollutant Discharge Elimination System (NPDES) permitted outfall.

\subsection{Mixed Waste}

Any environmental media from a Y-12 Plant UST site that are contaminated by radiological material will be segregated during investigation, upgrade, and remedial activities. DOE and Energy Systems policies and procedures for handling radiologically contaminated materials will be adhered to, and all such waste will be segregated, characterized, stored, and disposed of in accordance with this guidance. UST regulatory authorities will be notified of the occurrence of radiologically contamination when discovered at Y-12 Plant UST sites. 


\section{DISTRIBUTION}

Health, Safety, Environment, and Accountability Organization

U.S. Department of Energy

- ...D.E. Bohrman (2)

L.L. Cunningham/E.M. Ingram $-\ldots$

E:M:-Atkins - -

R.J. Spence/W.G. McMillian

S.R. Lankford

Environmental Compliance Organization

A.K. Lee/DOE-OSTI (2)

S.H. Welch

Y-12 Central Files 


\begin{abstract}
APPENDIX A
APPLICABLE PORTIONS OF THE COMPREHENSIVE ENVIRONMENTAL RESPONSE, COMPENSATION, . AND LIABILITY ACT
\end{abstract}




\section{COMPREHENSIVE ENVIRONMENTAL RESPONSE, COMPENSATION, AND LABILTY ACT}

(SUPERFUND)

\section{as amended}

An Act to provide for liability, compensation, cleanup, and emergency response for hazardous substances released into the environment and the cleanup of inactive iazardous waste disposal sites.

Be it enacted by the Senate and House of Representatives of the United States of America in Congress Assembled

\section{SHORT TITLE AND TABLE OF CONTENTS}

This Act may be cited as the "Comprehensive Environmental Response, Compensation, and Liability Act of $1980^{n}$.

\section{TITLE I - HAZARDOUS SUBSTANCES RELEASES, LLABILITY, COMPENSATION}

Sec. 101. Definitions

Sec. 102. Reportable Quantities and Additional Designation

Sec. 103. Notices, Penalties

Sec. 104. Response Authorities

Sec. 105. National Contingency Plan

Sec. 106. Abatement Action

Sec. 107. Liability

Sec. 108. Financial Responsibility

Sec. 109. Civil Penalities and Awards

Sec. 110. Employee Protection

Sec. 111. Uses of Fund

Sec.112. Claims Procedure

Sec. 113. Litigation, Jurisdiction and Venue

Sec. 114. Relationship to Other Law

Sec. 115. . Authority to Delegate, Issue Regulations

Sec. 116. Schedules

Sec. 117. Public Participation

Sec. 118. High Priority for Drinking Water Supplies

Sec. 119. Response Action Contractors

Sec. 120. Federal Facilities

Sec. 121. Cleanup Standards

Sec. 122 Settlement

Sec. 123. Reimbursement to Local Governments

Sec. 124. Methane Recovery

Sec. 125. Section 3001(b)(3)(a)(i) Waste

Sec. 126. Indian Tribes

\footnotetext{
1 Public Law 96-510, as amended by PL 97-216, July 18, 1982; J.L 97-272, September 30, 1982; PL 98-45, July 12, 1983; PL 99-160, November 25, 1985; PL $99-499$ (Superfund Amendments and Reauthorization Act), October 17, 1986; PL 100-202, December 2;, 1987; and PL 100-707, November 23, 1988; PL 101-221. December 12, 1989; PL 101-239, December 19, 1989; PL 101-380, August 18, 1990; PL 101-508, November 5, 1990; PL 101-584, November 15, 1.990.
} 
subsurface strata, or ambient air within the United States or under the jurisdiction of the United States.

(9) The term "facility" means (A) any building, structure, installation, equipment, pipe or pipeline (including any pipe into a sewer or publicly owned treatment works), well, pit, pond, lagoon, impoundment, ditch, landfill, storage container, motor vebicle, rolling stock, or aircraf, or (B) any site or area where a hazardous substance has been deposited, stored, disposed of, or placed, or otherwise come to be located; but does not include any consumer product in consumer use or any vessel.

(10) The term "federally permitted release" means (A) discharges in compliance with a permit under section 402 of the Federal Water Pollution Control Act, (B) discharges resulting from circumstances identified and reviewed and made part of the public record with respect to a permit issued or modified under section $\mathbf{4 0 2}$ of the Federal Water Pollution Control Act and subject to a condition of such permit, (C) continuous or anticipated intermittent discharges from a point source, identified in a permit or permit application under section $\mathbf{4 0 2}$ of the Federal Water Pollution Control Act, which are caused by events occurring within the scope of relevant operating or treatment systems, (D) discharges in compliance with a legally enforceable permit under section 404 of the Federal Water Pollution Control Act, (E) releases in compliance with a legally enforceable final permit issued pursuant to section 3005(a) through (d) of the Solid Waste Disposal Act [42 U.S.C. 6925(a)-(d)] from a hazardous waste treatment, storage, or disposal facility when such permit specifically identifies the hazardous substances and makes such substances subject to a standard of practice, control procedure or bioassay limitation or condition, or other control on the hazardous substances in such releases, (F) any release in compliance with a legally enforceable permit issued under section 102 or section 103 of the Marine Protection, Research, and Sanctuaries Act of 1972 , (G) any injection of fluids authorized under Federal underground injection control programs or State programs submitted for Federal approval (and not disapproved by the Administrator of the Environmental Protection Agency) pursuant to part $C$ of the Safe Drinking Water Act [42 U.S.C. $300 \mathrm{~h}$ et seq.], $(\mathrm{H})$ any emission into the air subject to a permit or control regulation under section 111 [42 U.S.C. 7411], section 112 [42 U.S.C. 7412], title I part C [42 U.S.C. 7470 et seq.], title I part $D$ [42 U.S.C. 7501 et seq.], or State implementation plans submitted in accordance with section 110 of the Clean Air Act [42 U.S.C. 7410] (and not disapproved by the Administrator of the Environmental Protection Agency), including any schedule or waiver granted, promulgated, or approved under these sections, (I) any injection of fluids or other materials authorized under applicable State law (i) for the purpose of stimulating or treating wells for the production of crude oil, natural gas, or water, (ii) for the purpose of secondary, tertiary, or other enbanced recovery of crude oil or natural gas, or (iii) which are brought to the surface in conjunction with the production of crude oil or natural gas and which are reinjected, $(J)$ the introduction of any pollutant into a publicly owned treatment works when such pollutant is specified in and in compliance with applicable pretreatment standards of section 307 (b) or (c) of the Clean Water Ad and enforceable requirements in a pretreatment program submitted by a State or municipality for Federal approval under section $\mathbf{4 0 2}$ of such $A c t$, and $(K)$ any release of source, special nuclear, or byproduct material, as those terms are defined in the Atomic Energy Act of 1954 [42 U.S.C. 2011 et seq.], in compliance with a legally enforceable license, permit, regulation, or order issued pursuant to the Atomic Energy Act of 1954. (11) The term "Fund" or "Trust Fund" means the Hazardous Substance Response Fund cstablished by section 221 of this Act or, in the case of a hazardous waste disposal facility for which liability has been transferred under section 107(k) of this Act, the Post-closure Liability Fund established by section 232 of this Act.

(12) The term "ground water" means water in a saturated zone or stratum beneath the surface of land or water.

(13) The term "guarantor" means any person, other than the owner or operator, who provides evidence of financial responsibility for an owner or operator under this Act.

(14) The term "hazardous substance" means (A) any substance designated pursuant to section 311(b)(2)(A) of the Federal Water Pollution Control Act, (B) any element, compound, mixture, solution, or substance designated pursuant to section 102 of this Act, (C) any hazardous waste having the characteristies identified under or listed pursuant to section 3001 of the Solid Waste Disposal Act [42 U.S.C. 6921] (but not including any waste the regulation of which under the Solid Waste 
Disposal Act [42 U.S.C. 6901 et seq.] has been suspended by Act of Congress), (D) any toxic pollutant listed under section 307(a) of the Federal Water Pollution Control Act, (E) any bazardous air pollutant listed under section 112 of the Clean Air Act [42 U.S.C. 7412], and (F) any imminently hazardous chemical substance or mixture with respect to which the Administratcor has taken action pursuant to section 7 of the Toxic Substances Control Act. The term does not ixciude petroleum, including crude oil or any fraction thereof which is not otherwise specifically listed or designated as a hazardous substance under subparagraphs (A) through (F) of this paragraph, and the term does not include natural gas, natural gas liquids, liquefied natural gas, or synthetic gas usable for fuel (or mixtures of natural gas and such synthetic gas).

(15) The term "navigable waters" or "navigable waters of the United States" mizans the waters of the United States, including the territorial seas.

(16) The term "natural resources" means land, fish, wildlife, biota, air, water, ground water, drinking water supplies, and other such resources belonging to, managed by, held in trust by, appertaining to, or otherwise controlled by the United States (including the resources of the fishery conservation zone established by the Fishery Conservation and Management Act of 1976 [16 U.S.C. 1801 et seq.]), any State, local government, or any foreign government, any Indian tribe, or, if such resources are subject to a trust restriction or alienation, any member of an Indian tribe.

(17) The term "offshore facility" means any facility of any kind located in, on, or under, any of the navigable waters of the United States, and any facility of any kind which is subject to the jurisdiction of the United States and is located in, on, or under any other waters, other than a vessel or a public vessel.

(18) The term "onshore facility" means any facility (including, but not limited to, motor vehicles and rolling stock) of any kind located in, on, or under, any land or nonnavigable waters within the United States.

(19) The term "otherwise subject to the jurisdiction of the United States" means subject to the jurisdiction of the United States by virtue of United States citizenship, United States vessel documentation or numbering, or as provided by international agreement to which the United States is a party.

(20)(A) The term "owner or operator" means (i) in the case of a vessel, any person owning, operating, or chartering by demise, such vessel, (ii) in the case of an onshore facility or an offshore facility, any person owning or operating such facility, and (iii) in the case of any abandoned facility, title or control of which was conveyed due to bankruptcy, foreclosure, tax delinquency, abandonment, or similar means to a unit of State or local government, any person who owned, operated, or otherwise controlled activities at such facility immediately beforehand. Such term does not include a person, who, without participating in the management of a vessel or facility, holds indicia of ownership primarily to protect his security interest in the vessel or facility.

(B) In the case of a hazardous substance which bas been accepted for transportation by a common or contract carrier and except as provided in section 107(a)(3) or (4) of this Act, (i) the term "owner or operator" shall mean such common carrier or other bona fide for hire carrier acting as an independent contractor during such transportation, (ii) the shipper of such hazardous substance shall not be considered to have caused or contributed to any release during such transportation which resulted solely from circumstances or conditions beyond his control. (C) In the case of a hazardous substance which bas been delivered by a conmon or contract carrier to a disposal or treatment facility and except as provided in section 107(a)(3) or (4) of this Act, (i) the term "owner or operator" shall not include such common or contract carrier, and (ii) such common or contract carrier shall not be considered to have causied or contributed to any release at such disposal or treatment facility resulting from circumstances or conditions beyond its control.

(D) The term "owner or operator" does not include a unit of State or local government which acquired ownership or control involuntarily through bankruptcy, tax delinquency, abandonment, or other circumstances in which the government involuntarily acquiresi title by virtue of its function as sovereign. The exclusion provided under this paragraph shall not apply to any State or local government which has caused or contributed to the release or threatened release of a hazardous substance from the facility, and such a State or local government shall be subject 
to the transportation movemeat. and at the ordinary ope:ating conveaieace of a common or contract carrier, and any such stoppage sinall be consicered as a continuiry of moveanent and not as the storage of a bazardous substance.

(27) The terms "United States" and "State" include the several States of the United States, the District of Columbia, the Commonwealth of Puerto Rico, Guam, American Samoa, the United States Virgin Islands, the Commonwealth of the Northern Marianas, and any other territory or possession over which the United States has jurisdiction.

(28) The term "vessel" means every description of watercraft or other artificial contrivance used, or capable of being used, as a means of transportation on water.

(29) The terms "disposal", "hazardous waste", and "treatment" shall bave the meaning provided in section 1004 of the Solid Waste Disposal Act [42 U:S.C. 6903].

(30) The terms "territorial sea" and "contiguous zone" shall have the meaning provided in section 502 of the Federal Water Pollution Control Act.

(31) The term "national contingency plan" means the national contingescy plan published under section 311(c) of the Federal Water Pollution Control Act or revised pursuant to section 105 of this Act.

(32) The terms "liable" or "liability" under this title shall be construed to be the standard of liability which obtains under section 311 of the Federal Water Pollution Control Act.

(33) The term "pollutant or contaminant" shall include, but not be limited to, any element, substance, compound, or mixture, including cisease-causing agents, which after release into the environment and upon exposure, ingestion, intalation, or assimilation into any organism, either directly from the environment or indirectly by ingestion through food chains, will or may reasonably be anticipated to cause death, disease, behavioral abnormalities, cancer, genetic mutation, physiological malfunctions (including malfunctions in reproduction) or physical deformations, in such organisms or their offspring, except that the term "pollutant or contaminant" shall not include petroleum, including crude oil or any fraction thereof which is not otherwise specifically listed or designated as a hazardous substance under subparagraphs (A) through (F) of paragraph (14) and shall not include narural gas, liquefied natural gas, or synthetic gas of pipeline quality (or mixtures of natural gas and such syothetic gas).

(34) The term "alternative water supplies" includes, but is not limited to, drinking water and household water supplies.

(35)(A) The term "contractual relationship", for the purpose of section $107(\mathrm{~b})(3)$ includes, but is not limited to, land contracts, deeds or otber instruments transferring title or possession, unless the real property on which the facility concerned is located was acquired by the defendant after the disposal or placement of the hazardous substance on, in, or at the facility, and one or more of the circumstances described in clause (i), (ii), or (iii) is also established by the defendant by a preponderance of the evidence:

(i) At the time the defendant acquired the facility the defendant did not know and had no reason to know that any hazardous substance which is the subject of the release or threatened release was disposed of on, in, or at the facility.

(ii) The defendant is a government entity which acquirec the facility by escheat, or through any other involuntary transfer or acquisition, or through the exercise of eminent domain authority by purchase or condemnation.

(iii) The defendant acquired the facility by inheritance or bequest.

In addition to establishing the foregoing, the defendant must establish that be has satisfied the requirements of section $I=7(b)(3)(a)$ and (b).

(B) To establish that the defendant had no reason to know, as provided in clause (i) of subparagraph (A) of this paragraph, the defendant must have undertaken, at the time of acquisition, all appropriate inquiry into the previous ownership and uses of the property consistent with good commercial or customary practice in an effort to minimize liability. For purposes of the preceding sentence the court shall take into account any specialized knowledge or experience on the part of the defendant, the relationship of the purchase price to the value of the property if uncontaminated, commonly knopu or reasonably ascertainable information about the property, the obviousness of the presence or likely presence of contamination at the property, and the ability to detect such contamination by appropriate inspection. 
Attorney General of the United States and to the Administrator of the Eavironneatal Pactection Agency.

\section{RELATIONSHIP TO OTHER LAW}

[H2 U.S.C. 9614]

Sec. 114. (a) Nothing in this Act shall be construed or interpreted as preempting any State from imposing any additional liability or requirements with respect to the release of hazardous substances within such State.

(b) Any person who receives compensation for removal costs or damages or claims pursuant to this Act shall be preciuded from recovering compensation for the same: removal costs or damages or claims pursuant to any other State or Federal law. Any person who receives compensation for removal costs or damages or claims pursuant to any other Federal or State liw stall be precluded from receiving compensation for the same removal costs or damages or claims as provided in this Act.

(c) Recycled oil -

(1) Service station dealers, etc. - No person (including the United States or any State) may recover, under the authority of subsection (a)(3) or (a)(4) of section 107, from a service station dealer for any response costs or damages resulting from a release or threatened release of recycled oil, or use the authority of section 106 against a service station dealer other than a person described in subsection (a)(1) or (a)(2) of section 107 , if such recycled oil -

(A) is not mixed with any other hazardous substance, anit

(B) is stored, treated, transported, or otherwise managed in compliance with regulations or standards promulgated pursuant to section 3014 of the Solid Waste Disposal Aat and other applicable authorities.

Nothing in this paragraph shall affect or modify in any way the obligation or liability of any person under any other provision of State or Federal law, including common law, for damages injury, or loss resulting from a release or threatened release of any hizardous substance or for removal or remedial action or the costs of removal or remedial action.

(2) Presumprion. - Solely for the purposes of this subsection, a service station dealer may presume that a small quantity of used oil is not mixed with other bazardous substances if it -

(A) has been removed from the engine of a light duty motor vehicle or household appliances by the owner of such vehicle or appliances, and

(B) is presented, by such owner, to the dealer for collection, accumulation, and delivery to an oil recycling facility.

(3) Definition. - For purposes of this subsection, the terms "used oil" and "recycled oil" have the same meanings as set forth in section 1004(36) and 1994(37) of the Solid Waste Disposal Act and regulations promulgated pursuant to that Aa

(4) Effective date. - The effective date of paragraphs (1) and (2) of this subsection shall be the effective date of regulations or standards promulgated under section 3014 of the Solid Waste

Disposal Act that include, among other provisions, a requirement to conduct corrective action to respond to any releases of recycled oil under subtitle $C$ or subtitle I of such Act.

(d) Except as provided in this title, no owner or operator of a vessel or facility who establishes and maintains evidence of financial responsibility in accordance with this title shall be required under any State or local law, rule, or regulation to establish or maintain any other evidence of financial responsibility in connection with liability for the release of a bazardous substance from such vessel or facility. Evidence of compliance with the Enancial responsibility requirements of this title shall be accepted by a State in lieu of any other requirement of Enancial responsibility imposed by such State in connection with liability for the release of a hazardous substarice from such vessel or facility.

\section{AUTHORTY TO DELEGATE ISSUE REGIULATIONS}

[42 U.S.C9415]

Sec 115. The President is authorized to delegate and assign any duties or powers imposed upon or assigned to him and to promulgate any regulations necessary to carry out the provisions of this title. 
recipient to accomolisi a public purpose in which substantial EPA involvement is anticipated during the performance of the project.

"Discharge" as defined by section 311(a)(2) of the CWA, includes, but is not limited to, any spilling leaking pumping. pouring, emitting, emptying, or dumping of oil, but excludes discharges in compliance with a permit under section 402 of the CWA, discharges resulting from circumstances identified and reviewed and made a part of the public record with respect to a permit issued or modified under section 402 of the CWA, and subject to a condition in such permit, or continuous or anticipated intermittent discharges from a point source, identified in a permit or permit application under section 402 of the CWA, that are caused by events occurring within the scope of relevant operating or treatment systems. For purposes of the NCP, discharge also means threat of discharge.

"Dispersants" means those chemical agents that emulsify, disperse, or solubilize oil into the water column or promote the surface spreading of oil slicks to facilitate dispersal of the oil into the water column.

"Drinking water supply" as defined by section 101(7) of CERCLA, means any raw or finished water source that is or may be used by a public water system (as defined in the Safe Drinking Water Aa) or as drinking water by one or more individuals.

"Environment" as defined by section 101(8) of CERCLA, means the navigable waters, the waters of the contiguous zone, and the ocean waters of which the narural. resources are under the exclusive management authority of the United States under the Magnuson Fishery Conservation and Management Act; and any otber surface water, ground water, drinking water supply, land surface or subsurface strata, or ambient air within the United States or under the jurisdiction of the United States.

"Facility" as defined by section 101(9) of CERCLA, means any building, structure, installation, equipment, pipe or pipeline (including any pipe into a sewer or publicly owned treatment works), well, pit, pond, lagoon, impoundment, ditch, landfill, storage container, motor vehicle, rolling stock, or aircraft, or any site or area, where a bazardous substance has been deposited, stored, disposed of, or placed, or otherwise come to be located; but does not include any consumer produet in consumer use or any vessel.

"Feasibility study" (FS) means a study undertaken by the lead agency to develop and evaluate options for remedial action. The FS emphasizes data analysis and is generally performed concurrently and in an interactive fashion with the remedial investigation $(R I)$, using data gathered during the RI. The RI data are used to define the objectives of the response action, to develop remedial action alternatives, and to undertake an initial screening and detailed analysis of the alternatives. The term also refers to a report that describes the results of the study.

"First federal official" means the first federal representative of a participating agency of the National Response Team to arrive at the scene of a discharge or a release. This official coordinates activities under the NCP and may initiate, in consultation with the OSC, any necessary actions until the arrival of the predesignated OSC. A state with primary jurisdiction over a site covered by a cooperative agreement will act in the stead of the first federal official for any incident at the site.

"Fund or Trust Fund" means the Hazardous Substance Superfund established by section 9507 of the Internal Revenue Code of 1986.

"Ground mater" as defined by section 101(12) of CERCLA, means water in a saturated zone or stratum beneath the surface of land or water.

"Hazard Ranking System" (HRS) means the method used by EPA to evaluate the relative potential of hazardous substance releases to cause bealth or safety problems, or ecological or environmental damage.

"Hazardous substance" as defined by section 101(14) of CERCLA, means: Any substance designated pursuant to section $311(b)(2)(A)$ of the CWA; any element, compound, micture, solution, or substance designated pursuant to section 102 of CERCLA; any hazardous waste having the characteristios identified under or listed pursuant to section 3001 of the Solid Waste Disposal Act (but not including any waste the regulation of which under the Solid Waste Disposal Act has been suspended by Act of Congress); any toxic pollutant listed under section 307(a) of the CWA; any hazardous air pollutant listed under section 112 of the Clean Air Act; and any 
imminently bazardous chemical substance or mixture with respect to which the EPA Administrator has taken action pursuant to section 7 of the Toxic Substances Control Act. The term does not include petroleum, including crude oil or any fraction thereof which is not otherwise specifically listed or designated as a hazardous substance in the first sentence of this paragraph, and the term does not include natural gas, natural gas liquids, liquefied natural gas, or syathetic gas usable for fuel (or mixtures of natural gas and such synthetic gas).

"Indian tribe" as defined by section 101(36) of CERCLA, means any Indian tribe, band, nation, or other organized group or community, including any Alaska Native village but not including any Alaska Native regional or village corporation, which is recognized as eligible for the special programs and services provided by the United States to Indians because of their status as Indians.

"Inland waters," for the purposes of classifying the size of discharges, means those waters of the United States in the inland zone, waters of the Great Lakes, and specified ports and harbors on inland rivers.

"Inland zone" means the environment inland of the coastal zone excluding the Great Lakes and specified ports and harbors on inland rivers. The term inland zone delineates an area of federal responsibility for response action. Precise boundaries are determined by EPAVUSCG agreements and identified in federal regional contingency plans.

"Lead agency" means the agency that provides the OSC/RPM to plan and implement response action under the NCP. EPA, the USCG, another federal agency, ot a state (or political subdivision of a state) operating pursuant to a contract or cooperative agreement executed pursuant to section 104(d)(1) of CERCLA, or designated pursuant to a Superfund Memorandum of Agreement (SMOA) entered into pursuant to subpart $F$ of the NCP or other agreements may be the lead agency for a response action. In the case of a release of a hazardous substance, pollutant, or contaminant, where the release is on, or the sole source of the release is from, any facility or vessel under the jurisdiction, custody, or control of Department of Defense (DOD) or Department of Energy (DOE), then DOD or DOE will be the lead agency. Where the release is on, or the sole source of the release is from, any lacility or vessel under the jurisdiction, custody, or control of a federal agency other than EPA, the USCG, DOD, or DOE, then that agency will be the lead agency for remedial actions and removal actions other than emergencies. The federal agency maintains its lead agency responsibilities whether the remedy is selected by the federal agency for non-NPL sites or by EPA and the federal agency or by EPA alone under CERCLA section 120. The lead agency will consult with the support ajency, if one exists, throughout the response process.

"Management ol: migration" means actions that are taken to minimize and mitigate the migration of bazardous substances or pollutiants or contaminants and the effects of such migration. Measures may include, but are not limited to, management of a plume of contamination, restoration of a drinhing water aquifer, or surface water restoration.

"Miscellaneous oil spill control agent" is any product, other than a dispersant, sinking agent, surface collecting agent, biological additive, or burning agent, that can be used to enhance oil spill cleanup, removal, treatment, or mitigation.

"National Priorities List" (NPL) means the list, compiled by EPA pursuant to CERCLA section 105, of uncontrolled hazardous substance releases in the United States that are priorities for long-term remedial evaluation and response.

"Natural resources" means land, fish, wildlife, biota, air, nater, ground water, drinking water supplies, and other such resources belonging $\mathrm{ta}^{\mathrm{a}}$ managed by, beld in trust by, appertaining to, or otherwise controlled by the United States (including the resources of the exclusive economic zone defined by the Magnuson Fishery Conservation and Management Act of 1976), any state or local government, any foreign government, any Indian tribe, or, if such resources are subject to a trust restriction on alienation, any member of an Indian tribe.

"Navigable waters," as defined by 40 CFR 110.1, means the waters of the United States, including the territorial seas. The term includes:

(a) All waters that are currently used, were used in the past, or may be susceptible to use in interstate or foreign commerce, including all waters that are subject to the ebb and flow of the tide; 
(b) Interstate waters, including interstate wetlands;

(c) All other waters such as intrastate lakes, rivers, streams (including intermittent streams), mudflats, sandfiats, and wetlands, the use, degradation, or destruction of which would affect or could affect interstate or foreign commerce including any such waters:

(1) That are or could be used by interstate or foreign travelers for recreational or other purposes;

(2) From which fish or shellifish are or could be taken and sold in interstate or foreign commerce;

(3) That are used or could be used for industrial purposes by industries in interstate commerce;

(d) All impoundments of waters otherwise defined as navigable waters under this section;

(c) Tributaries of waters identified in paragraphs (a) through (d) of this definition, including adjacent wetlands; and

(f) Wetlands adjacent to waters identified in paragraphs (a) through (c) of this definition: Provided, that waste treatment systems (other than cooling ponds meeting the criteria of this paragraph) are not waters of the United States.

"Offshore facility" as defined by section 101(17) of CERCLA and section 311(a)(11) of the CWA, means any facility of any kind located in, on, or under any of the navigable waters of the United States and any facility of any kind which is subject to the jurisdiction of the United States and is located in, on, or under any other waters, other than a vessel or a public vessel.

"Oil" as defined by section 311(a)(1) of the CWA, means oil of any kind or in any form, including, but not limited to, petroleum, fuel oil, sludge, oil refuse, and oil mixed with wastes other than dredged spoil

"Oil pollution fund" means the fund established by section 311(k) of the CWA.

"On-scene coordinator" (OSC) means the federal official predesignated by EPA or the USCG to coordinate and direct federal responses under subpart $D$, or the official designated by the lead agency to coordinate and direct removal actions under subpart $E$ of the NCP.

"Onshore facility" as defined by section 101(18) of CERCLA, means any facility (including, but not limited to, motor vehicles and rolling stock) of any kind located in, on. or under any land or non-navigable waters within the United States; and, as defined by section 311(a)(10) of the CWA, means any facility (including, but not limited to, motor vehicles and rolling stock) of any kind located in, on, or under any land within the United States other than submerged land.

"On-site" means the areal extent of contamination and all suitable areas in very close proximity to the contamination necessary for implementation of the response action.

"Operable unit" means a discrete action that comprises an incremental step toward comprehensively addressing site problems. This discrete portion of a remedial response manages migration, or eliminates or mitigates a release, threat of a release, or pathway of exposure. The cleanup of a site can be divided into a number of operable units, depending on the complexity of the problems associated with the site. Operable units may address geographical portions of a site, specific site problems, or initial phases of an action, or may consist of any set of actions performed over time or any actions that are concurrent but located in different parts of a site.

"Operation and maintenance" (O\&M) means measures required to maintain the effectiveness of response actions.

"Person" as defined by section 101(21) of CERCLA, means an individual, firm, corporation, association, partnership, consortium, joint venture, commercial entity, United States government, state, municipality, commission, political subdivision of a state, or any interstate body.

"Pollutant or contaminant" as defined by section 101(33) of CERCLA, shall include, but not be limited to, any element, substance, compound, or mixture, including disease-causing agents, which after release into the environment and upon exposure, ingestion, inhalation, or assimilation into any organism, either directly from the environment or indirectly by ingestion through food chains, will or may reasonably be anticipated to cause death, disease, behavioral abnormalities, cancer, genetic mutation, physiological malfunctions (including malfunctions in reproduction) or physical deformations, in such organisms or their offspring. The term does not include petroleum, including crude oil or any fraction thereof which is not otherwise specifically listed or designated as a bazardous substance under section 
101(14) (A) through (F) of CERCLA, nor does it include natural gas, liquified natural gas, or synthetic gas of pipeline quality (or mixtures of natural gas and such synthetic gas). For purposes of the NCP, the term pollutant or contaminant means any pollutant or contaminant that may present an imminent and substantial danger to public health or welfare.

"Post-removal site control" means those activities that are necessary to sustain the integrity of a Fund-financed removal action following its conclusion. Post-removal site control may be a removal or remedial action under CERCLA. The term includes, without being limited to, activities such as relighting gas flares, replacing filters, and collecting leachate.

"Preliminary assessment" (PA) means review of existing information and an off-site -reconnaissance, if appropriate, to determine if a release may require additional investigation or action. A PA may include an on-site reconnaissance, if appropriate.

"Public participation," see the definition for commuaity relations.

"Public vessel" as defined by section $311(a)(4)$ of the CWA, means a vessel owned or bareboat-chartered and operated by the United States, or by a state or political subdivision thereof, or by a foreign nation, except when such vessel is engaged in commerce.

"Quality assurance project plan" (QAPP) is a written document, associated with all remedial site sampling activities, which presents in specific terms the organization (where applicable), objectives, functional activities, and specific quality assurance (QA) and quality control (QC) activities designed to achieve the data quality objectives of a specific project(s) or continuing operation(s). The QAPP is prepared for each specific project or continuing operation (or group of similar projects or continuing operations). The QAPP will be prepared by the responsible program office, regional office, laboratory, contractor, recipient of an assistance agreement, or other organizaticn. For as enforcement action, potentially re $\omega_{j}$ onsible parties may prepare a QAPP subject to lead agency approval.

"Release" as defined by section 101(22) of CERCLA, means any spilling, leaking, pumping, pouring, emitting, emptying, discharging, injecting, escaping, leaching, dumping, or disposing into the environment (including the abandonment or discarding of barrels, containers, and other closed receptacles containing any bazardous substance or pollutant or contaminant), but excludes: Any release which results in exposure to persons solely within a workplace, with respect to a claim which such persons may assert against the employer of such persons; emissions from the engine exhaust of a motor vehicle, rolling stock, aircraft, vessel, or pipeline pumping station engine; release of source, byproduct, or special auciear material from a nuclear incident, as those terms are defined in the Atomit: Energy Act of 1954, if such release is subject to requirements with respect to financial protection established by the INuclear Regulatory Commission under section 170 of such Act, or, for the purposes of section 104 of CERCLA or any other response action, any release of source, byproduct, or special nuclear material fron any processing site designated under siection 102(a)(1) or 302(a) of the Uranium Mill Tailings Radiation Control A.ct of 1978; and the normal application of fertilizer. For purposes of the NCF', release also means threat of release.

"Relevant and appropriate requirements" means those cleanup stazndards, standards of controh, and other substantive requirements, criteria, or limitations promulgated under federal environmental or state environmental or facility siting laws that, while not "applicable" to a hazardous substance, pollutint, contaminant, remedial action, location, or other circumstance at a CE:RCLA site, address problems or situations sufficiently similar to those encountered at the CERCLA site that their use is well suited to the particular site. Only those state standards that are identified in a timely manner and are more stringent than federal requirements may be relevant and appropriate.

"Remedial design" (RD) means the technical analysis and procedures which follow the selection of remedy for a site and result in a detailed set of plans and specifications for implementation of the remedial action.

"Remedial investigation" (RI) is a process undertaken by the lead agency to determine the nature and extent of the problem presented by the release. The RI emphasizes data collection and site characterization, and is generally performed concuirently and in an 
designated by the EPA Administrator, Governor, SERC, or LEPC, as appropriate.

\section{$\$ 300220$ Related Titie III issues.}

Other related Title III requirements are found in 40 CFR part 355.

\section{Subpart D-Operaticasi Response Piases for OUl Removal}

\section{$\$ 300300$ Phase I-Discovery or notification.}

(a) A discharge of oil may be discovered through:

(1) A report submitted by the person in charge of a vessel or facility, in accordance with statutory requirements;

(2) Deliberate search by patrols;

(3) Random or incidental observation by goverament agencies or the public; or

(4) Other sources.

(b) Any person in charge of a vessel or a facility shall, as soon as he or she has knowledge of any discharge from such ressel or facility in violation of section 311(b)(3) of the Clean Water Act, immediately iotify the NRC. If direct reporting to the NRC is not practicable, reports may be made to the USCG or EPA predesigmated OSC for the geographic area where the discharge occurs. The EPA predesignated OSC may also be contacted through the regional 24-bour emergency response telephone number. All such reports shall be promptly relayed to the NRC. If it is not possible to notify the NRC or predesignated OSC immediately, reports may be made immediately to the nearest Coast Guard unit. In any event such person in charge of the vessel or facility shall notify the NRC as soon as possible.

(c) Any other person shall, as appropriate, notify the NRC of a discharge of oil

(d) Upon receipt of a notilication of discharge, the NRC shall promptly notify the OSC. The OSC shall proceed with the following phases as outlined in the RCP and OSC contingency plan.

\section{$\$ 300.305$ Phase II -Preliminary assessment and initiation of action.}

(a) The OSC is responsible for promptly initiating a preliminary assessmexi

(b) The preliminary assessmeat shall be conducted using available information, supplemented where necessary and possiole by an on-scene inspection. Tae OSC siall undertake actions to:

(1) Evaluate the magoitude and severiny of the discharge or threat to public health or welfare or the environment;

(2) Assess the feasibility of removal;

(3) To the exsent practicable, identify potentially responsible parties; and

(4) Ensure that authority exists for undertaking additional response actions.

(c) The OSC, in consultation with legal authorities when appropriate, shall make a reasonable effort to have the discharger voluntarily and promptly perform removal actions. The OSC shall ensure adequate surveillance over whatever actions are initiated. If effective actions are not being taken to eliminate the threat, or if removal is not being properly done, the OSC shall, to the extent practicable under the circumstances, so advise the responsible party: If the responsible party does not take proper removal actions, or is unknown, or is otherwise unavailabie, the OSC shall, pursuant to section 311(c)(1) of the CWA determine whether authority for a federal response exists, and, if so, take appropriate response actions. Where practicable, continuing efforts should be made to encourage response by responsible parties.

(d) If natural resources are or may be injured by the discharge, the OSC shall ensure that state and federal trustees of affected natural resources are promptly notified in order that the trustees may initiate appropriate actions, including those identified in subpart $G$. The OSC shall seek to coordinate assessments, evaluations, investigations, and planning with state and federal trustees.

\section{$\$ 300.310$ Phase III - Containment, countermeasures, cleanup, and disposal.}

(a) Defensive actions shall begin as soon as possible to prevent, minimize, or mitigate threat(s) to public bealth or welfare or the environment Actions may include but are not limited to: Analyzing water samples to determine the source and spread of the oil; controlling the source of discharge; measuring and sampling; source and spread control or salvage operations; placement of physical barriers to deter the spread of the oil and to protect natural resources; control of the water discharged from upstream impoundment; and the use of chemicals and other materials in accordance with subpart 
$J$ of this part to restrain the spread of the oil and mitigate its effects.

(b) As appropriate, actions shall be taken to recover the oil or mitigate its effects. Of the numerous chemical or physical methods that may be used, the chosen methods shall be the most consistent with protecting public bealth and welfare and the eavironment. Sinking agents shall not be used.

(c) Oil and contaminated materials recovered in cleanup operations shall be disposed of in accordance with the RCP and OSC contingency plan and any applicable laws, regulations, or requirements.

\section{$\$ 300315$ Phase IV-Documentation and cost recovery.}

(a) Documentation shall be collected and maintained to support all actions taken under the CWA and to form the basis for cost recovery. Whenever practicable, documentation shall be sufficient to prove the source and circumstances of the incident, the responsible party or parties, and impact and potential impacts to public health and welfare and the environment. When appropriate, documentation shall also be collected for scientific understanding of the environment and for the research and development of improved response methods and technology. Damages to private citizens, including loss of earnings, are not addressed by the NCP. Evidentiary and cost documentation procedures are specified in the USCG Marine Safety Manual (Commandant Instruction M16000.11) and further provisions are contained in 33 CFR part 153.

(b) OSCs shall submit OSC reports to the RRT as required by $\$ 300.165$.

(c) OSCs shall ensure the necessary collection and safeguarding of information, samples, and reports. Samples and information shall be gathered expeditiousiy during the response to ensure an accurate record of the impacts incurred. Documentation materials shall be made available to the trustees of affected natural resources. The OSC shall make available to trustees of the affected natural resources information and documentation that can assist the trustees in the determination of actual or potential natural resource injuries.

(d) Information and reports obtained by the EPA or USCG OSC shall be transmitted to the approoriatt: offices respousiole for follow-up actions.

\section{$\$ 300.320$ General pattern of response.}

(a) When the OSC receives a report of a discharge, actions normally should be taken in the following selyuence:

(1) When the reported discharge is an actual or potenlial major discharge, immediately notify the RRT, including the affected state, if appropriate, and the NRC.

(2) Investigate the report to determine pertinent information such as the threat posed to public hiealth or welfare or the environment, the type and quantity of polluting material, and the source of the discharge.

(3) Officially classify the size of the discharge and delermine the course of action to be followed.

(4) Determine vihether a discharger or other person is properly carrying out removal. Removal is being done properly when:

(i) The cleanup is fully sufficient to minimize or mitigate threat(s) to public heaith and weifare and the environment. Removal efforts are improper to the exrent that federal efforts are necessary to minimize further or mitigate those threats; and

(ii) The removal efforts are in accordance with applicable regulations, including the NCP.

(5) Determine whether a state or political subdivision thereof has the capability to carry olut response actions and whether a contract or cooperative agreement has been established with the appropriate fund administrator for this purpose.

(6) Notify the trusitees of affected natural resources in accordance with the applicable RCP.

(b) The prelininary inquiry will probably show that the sinuation falls into one of four categories. These categories and the appropriate response to each are outlined below:

(1) If the investigation shows that no discharge occurred, or it shows a minor discharge with no removal action required, the case may be elosed for response purposes.

(2) If the investigation shows a minor discharge with the responsible party taking proper removal action, contact shall be established with the party. The removal action shall, whenever possible, be 
monitored to ensure continued proper action.

(3) If the investigation shows a minor discharge with improper removal action being taken, the following measures shall be taken:

(i) An immediate effort shall, as appropriate, be made to stop further pollution and remove past and ongoing contamination.

(ii) The responsible party shall be advised of what action will be considered appropriate.

(iii) If the responsible party does not properiy respond, the party shall be notified of potential liability for federal response performed under the CWA. This liability includes all costs of removal and may inciude the costs of assessing and restoring. rehabilitating, replacing, or acquiring the equivalent of damaged natural resources, and other actual or necessary costs of a federal response.

(iv) The OSC shall notify appropriate state and local officials, keep the RRT advised, and initiate Pbase III operations, as described in $\$ 300.310$, as conditions warranl.

(v) Information shall be collected for possible recovery of response costs in accordance with $\$ 300.315$.

(4) When the investigation shows that an acrual or potential medium or major oil discharge exists, the OSC shall follow the same general procedures as for a minor discharge. If appropriate, the OSC shall recommend activation of the RRT.

\section{$\$ 300330$ Whldufe conservation.}

The Department of the Interior, Department of Commerce, and state representatives to the RRT shall arrange for the coordination of professional and volunteer groups permitted and trained to participate in wildilife dispersal, collection, cleaning, rehabilitation, and recovery activities, consistent with 16 U.S.C. 703-712 and applicable state lans. The RCP and OSC contingency plans shall, to the extent practicable, identify organizations or institutions that are permitted to participate in such activities and operate such facilities. Wildlife conservation activities will normally be included in Pbase III response actions, described in $\$ 300,310$.

\section{$\$ 300.335$ Funding}

(a) If the person responsible for the discharge does not act promptly or take proper removal actions, or if the person responsible for the discharge is unknown, federal discharge removal actions may begin under section 311(c)(1) of the CWA. The discharger, if known, is liable for costs of federal removal in accordance with section 311(f) of the CWA and other federal laws.

(b) Actions undertaken by the participating agencies in response to pollution shall be carried out under existing programs and authorities when available. Federal agencies will make resources available, expend funds, or participate in response to oil discharges under their existing authority. Authority to expend resources will be in accordance with agencies' basic statutes and, if required, through interagency agreements. Where the OSC requests assistance from a federal agency, that agency may be reimbursed in accordance with the provisions of 33 CFR 153.407. Specific interagency reimbursement agreements may be signed when necessary to ensure that the federal resources will be available for a timely response to a discharge of oil The ultimate decisions as to the appropriateness of expending funds rest with the agency that is held accountable for such expenditures.

(c) The OSC shall exercise sufficient control over removal operations to be able to certify that reimbursement from the following funds is appropriate:

(1) The oil pollution fund, administered by the Commandant, USCG, that has been established pursuant to section 311(k) of the CWA or any other spill response fund established by Congress. Regulations governing the administration and use of the section $311(k)$ fund are contained in 33 CFR part 153.

(2) The fund authorized by the Deepwater Port Act is administered by the Commandant, USCG. Governing regulations are contained in 33 CFR part 137.

(3) The fund authorized by the Outer Continental Shelf Lands Act, as amended, is administered by the Commandant, USCG. Governing regulations are contained in 33 CFR parts 135 and 136.

(4) The fund authorized by the Trans-Alaska Pipeline Authorization Act is administered by a Board of Trustees under the purview of the Secretary of the Interior. Governing regulations are contained in 43 CFR part 29. 
(d) Response actions other than removal, such as scientific investigations not in support of removal actions or law enforcement, shall be provided by the agency with legal responsibility for those specific actions.

(e) The funding of a response to a discharge from a federally operated or supervised facility or vessel is the responsibility of the operating or supervising agency.

(f) The following agencies have funds available for certain discharge removal actions:

(1) EPA may provide funds to begin timely discharge removal actions when the OSC is an EPA representative.

(2) The USCG pollution control efforts are funded under "operating expenses." These funds are used in accordance with agency directives.

(3) The Department of Defense has two specific sources of funds that may be applicable to an oil discharge under appropriate circumstances. This does not consider military resources that might be made available under specific conditions.

(i) Funds required for removal of a sunken vessel or similar obstruction of navigation are available to the Corps of Engineers through Civil Works Appropriations, Operations and Maintenance, General.

(ii) The U.S. Navy may conduct salvage operations contingent on defense operational commitments, when funded by the requesting agency. Such funding may be requested on a direct cite basis.

(4) Pursuant to section 311 (c)(2)(H) of the CWA, the state or states affected by a discharge of oil may act where necessary to remove such discharge and may, pursuant to 33 CFR part 153, be reimbursed from the oil pollution fund for the reasonable costs incurred in such a removal.

(i) Removal by a state is necessary within the meaning of section $311(\mathrm{c})(2)(\mathrm{H})$ of the CWA when the OSC determines that the owner or operator of the vessel, onshore facility, or offshore facility from which the discharge oceurs does not effect removal properly, or is unknown, and that:

(A) State action is required to minimize or mitigate significant threat(s) to the public health or welfare or the environment that federal action cannot minimize or mitigate; or

(B) Removal or partial removal can be done by the state at a cost that is less than or not signiricantly greater than the cost that would be incurred by the federal agescies.

(ii) State removal actions must be in compliance with the N(PP in order to qualify for reimbursement.

(iii) State removal actions are considered to be F'base III actions, described in $\$ 300.310$, under the same definitions applicable to federal agencies.

(iv) Actions taken by local governments in support of federal discharge removal operations are considered to be actions of the state for purposes of this section. The $R C P$ and OSC contingency plan shall show what funds and resources are available from participating agencies under various conditions and cost arrangements. Interagency agreemenlis may be necessary to specify when reimbursement is required.

\section{Subpart E-Hazardous Substance Response}

\section{$\$ 300.400$ General.}

(a) This subpart establishes methods and criteria for determining the appropriate extent of response authorized by CERCLA:

(1) When there is a release of a bazardous substance into the environment; or

(2) When there is a release into the environment of any pollutant or contaminant that may present an imminent and substantial danger to the public health or welfare.

(b) Limitations on response. Uniess the lead agency determines that a release constitutes a public health or environmental emergency and no other person with the authority and capability to respond will do so in a timely manner, a removal or remedial action under section 1014 of CERCLA shall not be undertaken in risponse to a release:

(1) Of a maturally occurring substance in its unaitered form, or alitered solely through naturally occurring processes or phenomena, from a location where it is naturally found;

(2) From products that are part of the structure of, and result: in exposure within, residential buildings or business or community structures; or

(3) Into public or private drinking water supplies due to detericiration of the system through ordinary use.

(c) Fund-financed action. In determining the need for and in planning or undertaking Fund-financed action, the lead agency shall, to the extent practieable: 


\section{APPENDIX B}

RESOURCE CONSERVATION AND RECOVERY ACT

40 CFR PART 280 


\section{PART 280-UNDERGROUND STORAGE TANKS}

Subpart A-Program Scope and Interim Prohibition

Sec.

280.10 Applicability.

280.11 - Interin prohibition for deferred UST syrtems.

280.12 Defonitions.

\section{Subpart B-UST Systems: Design, \\ Construction, Installation and} Notification

280.20 Performance standards for new UST syrtems.

280.21 Upgrding of existing UST systems. 280.22 Notificution requirements.

\section{Subpart C-General Operating} Requirements

280.30 Spill and overfill control.

280.31 Operation and maintenance of corrosion prolection.

280.32 Compatibility.

280.33 Repairs allowed

280.34 Reporting end recordkeeping.

\section{Subpart D-Release Detection}

280.40 anorel requiremente for a!! UST systems.

280.41 Requirements for petroleum UST systems.

280.42 Requirements for hazardous substence UST systems.

280.43 Methods of relese detoction for inks.

280.44 Method of relesse detection for piring

280.45 Relesse detection recordkeeping.

Subpart E-Release Reporting, Investigation, and Confirmation 280.50 Reporting of surpected releases. impacts.

280.52 Relesse investigation and confirmation steps.

280.53 Reporting and cleanup of spilts and overfills.

Subpart F-Release Response and

Corrective Action for UST Systems

Containing Petroleum or Hazardous Substances

280.60 General.

280.61 Initial response.

280.62 Initial sbatement measures und site check.

280.63 Initial site characterization.

280.64 Free product removal.

280.65 Investigations for soil and ground-wader cleanup.

280.66 Corrective action plan.

280.67 Public participation.

\section{Subpart G-Out-of-Service UST} Systems and Closure

280.70 Temporary closure.

280.71 Permanent clooure and changes-in-service.

280.72 Assessing the site at closure or change-in-service.

280.73 Applicability to previously closed UST rystems.

280.74 Closure reconds.

\section{Subpart H-Financial} Responsibility

280.90 Applicability

280.91 Compliance dates.

280.92 Definition of terms.

280.93 Amoum end scope of required financial responsibility.

280.94 Allowable mechanisms and combinations of mechanisms.

280.95 Financial test of self-insurance.

280.96 Guarantec.

280.97 Insurance and risk relention group covernge.

280.98 Surety bond.
280.99 Letter of credit

280.100 Use of state-required mechanism.

280.101 State fund or other state assurance.

280.102 Trust find

280.103 Standby trust fund.

280.104 Local government bond rating test.

280.105 Local government financial test.

280.106 Local government guarantec.

280.107 Local government fund

280.108 Subatitution of financial assurance mechanisms by owner or operator.

280.109 Cancellation or nonrenewal by a provider of financial bys a provider

280.110 Reporting by owner or operator.

280.111 Recordkecping.

280.112 Drawing on financial assurance mechanisms.

280.113 Release from the requirements.

280.114 Bankruptcy or other incapacity of owner or operator or

provider of financial assurance.

280.115 Replenishment of guarentees, letters of credit, or surety bonds.

280.116 Suspension of enforcement [Reserved]

Appendix I-Notification for Underground Storage Tanks (Form)

Appendix U-List of Agencies Designated to Receive Notifications

Appendix in-Státement ior Shipping Tickets and Invoices

Authority: 42 U.S.C. 6912, 6991, 6991(a), 6991(b), 6991(c), 6991(d), 6991(c), 6991(1), 6991(h), 6993(g).

Source: 53 FR 37194, Sept. 23, 1988, unless otherwise noted.

[Amondod at 56 FR 38344, Aug. 13, 1991: 56 FR 66373. Doc. 23. 1991; 58 FR 9050. Feb. 18. 1993; 59 FR 9607. Fb. 28, 1994]
Subpart A-Program Scope and Interim Prohibition

280.10 Applicability.

(a) The requirements of this part apply to all owners and operators of an UST system as defined in 280.12 except as otherwise provided in paragrapis (b), (c), and (d) of this section. Any UST system listed in paragraph (c) of this section must meet the requirements of 280.11 .

(b) The following UST systems are excluded from the requirements of this part:

(1) Any UST system holding hazardous wastes listed or idemtified under Subtitle $C$ of the Solid Waste Disposal Act, or a mixture of such hazardous waste and other regulated ubstances.

(2) Any wastewater treatment tank system that is part of a wastewater treatment facility regulated under section 402 or 307 (b) of the Clean Water Act.

(3) Equipment or mochinery that contains regulated substances for operational purposes such as hydraulic lif tanks and electrical equipment tanks.

(4) Any UST system whose capacity is 110 gallons or less.

(5) Any UST system that contains a de minimis concentration of regulated substances.

(6) Any emergency spill or overflow comlainment UST system that is expeditiously emptied after use.

(c) Deferrals. Subparts B, C, D, E, and O do not apply to any of the following types of UST systems:

(1) Wastewater treatment tank systems;

(2) Any UST systems comtaining radioactive material that are regulated under the Atomic Energy Act of 1954 (42 U.S.C. 2011 and following);

(3) Any UST system that is part of an emergency generalor system at nuclear power generation facilities regulated by the Nuclear Regulatory Commission under 10 CFR Part 30. Appendix A:

(4) Airport hydrant fuel distribution

(5) UST systems with field-constructed tanks. 
(d) Deferrals. Subpart D does not epply to any UST instem that stores fuel solely for use by emergency power generators.

[S3 FR 37194, Scpt. 23, 1988]

\subsection{Interim prohibition for deferred UST systems.}

(a) No person may install an UST system listed in 280.10 (c) for the purpose of storing regulated subetences unless the UST system

(whecher of single or double-wall construction):

(1) Will prevent releases due to corrosion or structural faiture for the operational life of the

ST systam:

(2) Is cathodically prokected against meterial, stoel cled with a noncorrodible meterial, or designed in a manner to prevent the relesse or threatened release of any stored subtence; and

(3) Is constructed $\propto$ lined with material that is compatible with the stored substance.

(b) Notwrithstanding paragraph (a) of this ecction, en UST isstem without corrosion protection mxy be installed at $a$ site that is determined by a corrosion expert not to be exrosive enough to cause it to have a relesse tue to corrosion during its operating life. Orners and operators must maintain records the demonstrate compliance with the requirements of this paragraph for the remsining life of the tank

Note: The Nationel Aseociztion of Carrosion Enginears Sunderd RP-02-85, Cortur of Extemal Corrosion on Mietullic Buried Partielly Buried or Submerged Liquid Storage Sy teons, may be used es guidence for comply ins with peregraph (b) of this soction.

[S3 FR 37194, Sept 23, 1988]

\subsection{Definitions.}

Aboveground relesse means eny relesse to the surface of the land or to surface water. This incturder, but is noc limited ta, relestes from the htore ground portion of an UST zystem and atoveground releases essociated with overfills and transfer operations es the regulated sutotence moves to of from en UST system. Ancillery equipment mears any devices inctuding tut nol limited to, such devices as piping fittinga, flenges, valves, and purnpo used to distribute, meter, or control the flow of regulated substances to and from an UST. Belowground release means any release to the subsurface of the land and to ground water. This includes, but is not limited to, releases from the belowground portions of an underground storage tank system and belowground releases associated with overfills and transfer operations as the regulated substance moves to or from an underground storage tank.

Beneath the surface of tho ground means beneath the ground surface or otherwise covered with earthen materials.

Cathodic protection is a technique to prevent corrosion of a metal surface by making that surface the cathode of an electrochemical cell. For example, a tank system cen be cathodically protected through the application cathodically protected through the application of either galvanic anodes or impressed current.
Cathodic protection tester means a person Cathodic protection tester means a person who can demonstrato an understanding of the principles and messurements of all common types of cathodic protoction systems es applied to buried or submerged metal piping end tenk have oducation and experienco in soil resistivity, stray current, structure-to-soil potential, and componemt electrical isolation measurememts of buried metal piping and tank systems.

CERCLA means the Comprehensive Environmental Response, Compensation, and Liability Act of 1980, 25 amended. Compatible means the ability of two or more substances to maintain their respective physical and chemical properties upon contect with one mother for the design life of the tank system under conditions likely to bo encoumtered in the UST.

Connected piping means all underground piping including valves, elbows, joints, flanges, and flexible comectors attached to a tank system through which regulated substances
flow. For the purpose of determining how much piping is comected to any individual UST system, the piping that joins two UST aystem should be allocated equally between them.

Consunptive use with respect to heating oil means consumed on the premises.

Corrosion expert means a person who, by resson of thorough knowledge of the physical sciences and the principles of engineering and mathematics acouired by a professional oducation and related practical experience, is qualified to engage in the practice of corrosion control on buried or submerged metal piping systems and metal tanks. Such a person must be accredited or certified as being qualified by the National Association of Corrouion Engineers or be a registered professional engineer who has certification or licensing that includes education and experience in corrosion control of buried or submerged metal piping systems and metal anks.

Dielectric material means a material that does not conduct direct electrical current Dielectric coatings are used to electrically isolate UST systems from the surrounding soils. Dielectric bushings wre used to electrically isolate portions of the UST system (e.g., tank from piping).

Electrical equipment means underground equipment that contains dielectric fluid that is necessary for the operation of equipment such transformers and buried electrical cable.

Excavation zone means the volume

comaining tho tank system and backfill material bounded by tho ground surface, walls, and floor of the pit and trenches into which the UST system is placed at the time of installation.

Existing tank system means a lank system used to contain an eccumulation of regulated substances or for which installation has co:-menced on or before December 22, 1988. Installation is considered to have commenced if:

(a) The owner or operator has oblained all foderal, state, and local approvals or permits necessary to begin physical construction of the site or installation of the tank system; and if

(b)(1) Either a contintous on-site physical construction or installation program has begur

(2) The owner or operator has entered into contractual obligations - which cannot be cancelled or modified without substantial loss-for physical construction at the site or installation of the tank aystem to be completed within a reasonable time.

Farm tank is a tank locared on a tract of land devoled to the production of crops or raising animals, including fish, and associated residences and improvements. A farm tank must be located on the farm property. Form includes fish hatcheries, rangeland and nurseries with growing operations.

Flow-through process tank is a tank that forms an integral part of a production process through which there is a steady, variable, recurring, or intermittent flow of materials during the operation of the process.

Flow-through process tanks do not include tanks used for the storage of materials prior to their introduction into the production process or for the storage of finished products or by-products from the production process. Free product refers to a regulated substance that is present as a non-aqueous phase liquid (e.g., liquid not dissolved in water.)

Gathering lines mears any pipeline. equipment, facility, or building usod in the transportation of oil or gas during oil or gas production or gathering operations.

Hazardous substance UST system means an underground storage tank system that contains a hazardous substance defined in section 101(14) of the Comprehemive Environmental Response, Compensation and Liability Act of 1980 (but not including any substance regulated as a hazardous waste under subtitle C) or any mixture of such substances and petroleum, and which is not a petroleum UST system

Heating oil means petroleum that is No. 1 , No. 2, No. 4-light, No. 4 - heavy, No. 5-light, No. 5 -heavy, and No. 6 technical grades of fuel oil; other residual fucl oils (including Navy Special Fuel Oil and Bunker C); and other fuels when used as substitutes for one of these fuel oils. Heating oil is typically used in the operation of heating equipment, boilers, or fumaces.

Hydraulic lift tank means a tank holding hydraulic fluid for a closed-loop mechanical system that uses compressed air or hydraulic
fluid to operate lifs, elevators, and other simila fluid to
devices. evices.

Implementing agency means EPA, or, in the case of a state with a program approved under section 9004 (or purauant to a memorandum of sgreement with EPA), the designated state or local agency responsible for carrying out an approved UST program.

Liquid trap means sumps, well cellars, and other traps used in association with oil and $g$ as production, gathering, and extraction operations 
(including ges production plants), for the purpose of collecting oil, water, and oher liquids. These liquid treps may temporacily collect liquids for subsequenl disposition or reinjection into 2 production or pipeline stream, or mxy colfect and separate liquids from $2 \mathrm{~g} 2 \mathrm{~s}$ or may
streasm.

Maintenence means the normial oparational upkeep to prevent an underground storage tank ystem from relessing product.

Motor fuel means petroleurn or a petroletrm-based rubstance that is motor gasoline, svistion gasoline, No. 1 or No. 2 diesel fuel, or any grade of gaschol, and is typically ured in the cperation of a motot engine.

New tunk syrtem means a tank syrtem that will be used to contain en eccumulation of regulated substances and for which installation has commenced after December 22, 1988. (Sœ also Existing Tank System.)

Nonconmercial purposes with respect to mator fuel meers not for resale.

On the premises where slored with respect to teeting oil meens UST zystems located on

the same preperty where the stored heating oil tis

Operational tife refers to the period begiming when installation of the lenk system has commenoed until the time the tark system is property closed under Subpart O.

Operator means any person in control of, or having responsibility for, the daily operation of the UST system.

Overfill relense is a release that occurs when a tenk in filled beyond its capecity. resulting in a discherge of the regulated rutertence to the environment.

Ouner means:

(a) In the case of an UST syztem in use on November 8, 1984, or brought into use after the dre, my person who owns on UST system used fer rtorige, use, or dispensing of regulated suterances; and

(b) In the case of any UST system in uso wefore Novernber \& 1984, but no lenger in use m that date, eny person who owned such UST immediately before the discontinuation of its use.

Persen meens en individusl, trust, firm. joint steck company, Federnl egency, compration stade, munvicipality, commission political subdivision of a state, or any interstate body. Person siso includes a consortinem a joint venture, a commercial entity, and the United Stales Oovernment.

Petroleurm UST system means an

underground storage tank system that contains petroleum or a mixture of petroleurn with de minimis quantities of other regulated ubrtances. Such systems include those contrining motor fuels, jet fuels, distillate fuel oils, residual fucl oils, lubricants, petroleum olvents, and used oils.

Pipe or Piping means a hollow cylinder of tubular conduit that is constructed of non-ererthen materials.

Pipeline facilities (including gathering lines) are new and existing pipe rights-of-way and any associsted equipment, facilities, or

ings.

Regulated substance means:

(a) Any substance defined in rection 101(14) of the Comprehensive Environ-mental Response, Compensation and Liability Act (CERCLA) of 1980 (but not including eny substance regulated as a hazandous wasto under subtitle $C_{\text {) }}$ and

(b) Petroleum, including crude oil or eny frection thereof that is liquid at stand ard conditions of temperature and pressure 60 degress Fahrenheit and 14.7 pounds per square inch absolute).

The term regulated substance includes but is not limited to petroleum and petroleumbased substances comprised of a complex blend of hydrocerbons derived from crude oil though

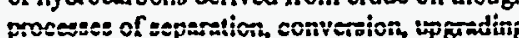
and finishing, such as motor fuels, jet fuels. distillate fuel oils, residual fucl oils, lubricents, petroleum solvents, and used oile.

Release means any spilling, leaking. mittine, discharging escaping, leaching or emitting, discharging, escaping, leaching or surface water or subsurface soils.

Release delection means determining whether a release of a regulated substance has occurred from the UST system into tho environment or into the interstitial spece between the UST system and its secondary berier or secondary conteinment sround it Repair means to restore a tank or UST yxtem component that has caused a release of product from the UST system.
Residemtial tank is a tank locatod on propeity used primarily for dwelling purposes. SARA means the Superfund Amendments and Reauthorization Act of 1986

Septic tank is a water-tight covered receptacle designed to receive or process, through liquid separation or biological digestion, the sewage discharged from a building sewer. The effluent from such receptacio is distributed for disposal through the soil and settled solids and scum from the tank are pumped out periodically and hauled to a treatment facility.

Storm-water or wastewater collection system means piping, pumps, conduits, and any other equipment nocessary to collect and transport the flow of aurface water nun-off resulting from precipitation, or domestic, commencial, or industrial wastewaler to and from retention areas or any areas where treatment is designatod to occur. The collection of storm water and wastewater does not include treatment except where incidental to conveyance.

Surface impoundment is a natural topographic depression, mar-made excavation, or diked urea formed primarily of excavathen or diked area foreston prinarily of earthen materials (although it may be lined with man-rl.

Tank is a stationary device designed to contain an accumulation of regulated substances and constructed of non-carthen materials (c.g., concrete, stecl, plastic) that provide structural support.

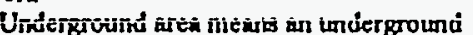
room, nuch as a besement, celler, shafl or vaulh providing enoubh apace for physical inepection providing enough space for physical inspection of the exicrior of tre

Underground release means any belowground release.

Underground storage tank or UST means any one or combination of tanks (including underground pipes consected thereto) that is used to contain an accumulation of regulated substances, and the volume of which (including the volume of underground pipes connected thereto) is 10 percent or more beneath the surface of the ground. This term does not include any: (a) Ferm or residential tank of 1,100 gallons or less cepscity used for storing motor fuel for noncommercial purposes;

(b) Tank used for storing heating oil for consumptive use on the premises where stored;

(c) Septic tank:

(d) Pipeline facility (including gothering lines) regulated under:

(I) The Natural Gas Pipeline Safety Act of 1968 (49 U.S.C. App. 1671, ef seq.), or

(2) The Hazandous Liquid Pipeline Safety Act of 1979 (49 U.S.C. App. 2001, et seq.), or

(3) Which is an intrastate pipeline facility regulated under state laws comparable to the provisions of the law referred to in paragraph (d)(1) $o r(d)(2)$ of this definition:

(e) Surface impoundment, pit, pond, or lagoon;

(f) Storm-water or wastewater collection system;

(g) Flow-through process tank

(h) Liquid trap or associated gathering lines directly related to oil or gas production and gathering operations; or

(i) Storage tank situated in an underground area (such as a basement, cellar, mine- working. drift, shaft, or tunnel) if the storage tank is situated upon or above the surface of the floor The term underground storage tank or UST does not include any pipes connectod to any tank which is described in paragraphs (a) through (i) of this definition.

Upgrade means the addition or retrofit of some systems such as cathodic prolection, lining, or spill and overfill controls to improve ine abiiity of on underground storage tank system to prevent the release of product.

UST system or Tank syatem means an underground storage tank, connected underground piping, underground ancillary equipment, and contaimnent system, if any. Wastewater treatment tank means a tank that is designed to receive and treat an influent wastewater through physical, chemical, or biological methods.

[53 FR 37194, Sept. 23, 1988] 


\section{Subpart B-UST Systems: Design, Construction, Installation and Notification}

280.20 Performance standards for net UST systems.

In order to prevedt releases due to structural frilure, corrocion, or spills and overfills for as long as the UST system is used to store regulatod substences, all ownen and operators of new UST syrtems must meet the following requirements.

(a) Tonts. Eech tenk must be properly designed and construxted and any portion undeground that rouxinely contains praduct unust be protected from corrosion, in sccordance with $x$ code of prectice developed by 2 netionally recognized association or independent lexting laboratory es specified
below:

(1) The tank is constructed of fibengless-reinforeed plastic; or

Note The following indurty codes may be used to comply with paragraph (a)(1) of this section: Underwrites Laboratories Stunderd 1316, Stendard for Gless Fibar-Reinforead Plestic Underground Storage Tanks for Petroleum Products: Underwriter Reinfored Plartic Underromd Tants for Pard for Peinored Phastic Undefround Tanks for Paroleum Products; or American Socty of Tertins and Miterial Clase-Fiber Reinfored Polyester Uaderground Peroleum Storege Tante.

(2) The tank is constructed of steel and cathodically protected in the following manner

(i) The tank is costed with a suitsble dielectric material;

(ii) Field-installed cathodic protection systams are designed by 2 corrosion expert;

(iii) Impressed current systems are designed to allow determinzion of current operating rutus es required in 280.31 (c); and

(iv) Cathodic protection systems are operaled and mainceined in mecordance with 2s0.31 or socording to guidelines established by the inf lementing asency; or

Nite The following codes end rtanderds muy te used to omply with perasniph (e.X(2) of this section:

(A) Steel Tenk Institute Specification for STI-P3 System of External Corrosion

Protection of Underground Steel Storage Tanks;
(B) Underwriters Laboratories Standand 1746. Comosion Protection Systems for Underground Storage Tanks;

(C) Underwriters Labonatories of Canade CAN4-S603-M85, Standard for Stoel Underground Tanks for Flammable and Combustible Liquids, and CAN4-O03.1-M85. Standard for Oalvanic Corrosion Protection. Systems for Underground Tanks for Flammable and Combustible Liquids, and

CAN4-S631-M 34, Lsolating Bushings for Steel

Underground Tanks Protected with Caatings

and Oalvanic Systems; or

(D) National Association of Corrosion Engineers Standard RP-02-85, Control of

External Corrosion on Metallic Buriod, Pertially

Buried, or Submerged Liquid Storage Systems,

and Underwriters Labora- tories Standard 58 ,

Standard for Steel Underground Tanks for

Standard for Steel Underground Tanks

(3) The tank is constructed of a stecl-

fiberglass-reinforced-plastic composito; or

Note: The following industry codes may be usod to comply with paregraph (*)(3) of this section: Underwritars Laboratories Standard 1746, Conrosion Prototion Systems for Underground Storige Tunkes of the Association for Composito Tanks ACT-100 Specification for the Fabrication of FRP Cled Underground Storage Tariks.

(4) The tank is constructod of metal without additional corrosion protection measures provided that:

(i) The tank is installed at a site that is determined by a corrosion expert not to be corrosive enough to cause it to have a release tue to corrosion during its operating life; and

(ii) Owners and operators maintnin records that demonstrale compliance with the requirements of paragraphs (a)(4)(i) for the remaining life of the tank; or

(5) The tank construction and corrosion protection are determined by the implementing agency to be designed to prevent the release or threatened release of any stored regulated substance in a manner that is no less prodective of humans health end the environment then paragraphs (a) (1) through (4) of this section.

(b) Piping. The piping that routinely contrins regulated substances and is in contact with the ground must be properly dexigned. constructed, and protected from corrosion in accordance with 2 code of practice developed by a nationally recognized sssociation or independent testing laboratory as specified below:

(1) The piping is constructed of fiberglass-reinforced plastic; or

Note: The following codes and standards may be used to comply with paragraph (bX1) of this soction

(A) Underwriters Laboratories Subject 971, UL Listed Non-Metal Pipe;

(B) Underwriters Laboratories Standard 367, Pipe Connectors for Flammable and Comburtible and LP Oas:

(C) Underwriters Laboratories of Canads Guide ULC-107, Glass Fiber Reinforeed

Plastic Pipe and Fittings for Flammable Liquids; end

(D) Underwriters Laboratories of Canada Standard CAN 4-S633-M81, Flexible Underground Hose Comnectors.

(2) The piping is constructed of steel and cathodically protected in the following manner.

(i) The piping is coated with a suitable dielectric malerial;

(ii) Field-installed cathodic protection systems are designed by a corrosion expert;

(iii) Impressed current systems are designed to allow determination of curremt operating status as required in 280.31 (c), and

(iv) Cathodic protoction systems are operated and maintained in accordance with 280.31 or guidelines established by the implementing agency; or

Note: The following codes and standards may be usod to Note: The following codes and standards may
comply with paragraph (b) (2) of this soction:

(A) National Fire Protection Association Standard 30, Flammable and Combustible Liquids Code;

(B) American Petroleum Institute Publication 1615, Installation of Underground Petroleum Storage Systems;

(C) American Petroleum Institute

Publication 1632, Cathodic Protection of

Underground Petroleum Storage Tanks and Piping Systems; and

(D) National Association of Corrosion Engineers Stendard RP-01-69, Control of External Corrosion on Submerged Metallic Piping Systems.

(3) The piping is constructod of metal without additional corrosion protection measures provided that: (i) The piping is installed at a site that is determined by a corrosion expert to not be corrosive enough to cause it to have a release due to corrosion during its operating life; and

(ii) Owners and operators maintain reconds that demonstrate compliance with the

requirements of paragraph (b)(3)(i) of this section for the remaining life of the piping; or Note: National Fire Protoction Associstion Standard 30 Flammsble and Combutible Liquids Code; and Natione Association of Corrosion Engineers Standard RP-01-69. Control of Extemel Corrosion on Submerged Metallic Piping Systems, may be used to comply with paragraph (3) of this roction

(4) The piping construction and corrosion protection are determined by the imple- menting agency to be designed to prevemt the release or threatened release of any stored regulated substance in a manner that is no less protective of human health and the environment than the requirements in paragraphs (b) (1) through (3) of this section.

(c) Spill and overfll prevention equipment.

(1) Except as provided in paragraph (c)X2) of this section, to prevent spilling and overfilling associated with product transfer to the UST system, owners and operators must use the following spill and overfill prevention equipment:

(i) Spill prevention equipment that will prevent release of product to the environment when the transfer hose is detached from the fill pipe (for example, a spill catchmemt basin); and

(ii) Overfill prevemtion equipment that will:

(A) Automatically shut off flow into the tank when the tank is no more than 95 percem full; or

(B) Alert the transfer operator when the tank is no more than 90 percent full by restricting the now into the tank or triggering a high-level alarm; or

(C) Restrict flow 30 minutes prior to overfilling, alert the operator with a high level alarm one mimute before overfilling, or autornatically shut off flow into the tank so that none of the fitings located on top of the tank are exposed to product due to overfilling

(2) Owners and operators are not required to use the spill and overfill prevention equipment specified in paragraph (c)(1) of this section if: (i) Alternative equipment is used that is determinod by the implementing agency to be 
no less protective of human heath and the envisonment then the equipment specified in presereph (cX(I) (i) or (ii) of this section; or

(ii) The UST system is filled by transfers of no more than 25 gallons at one time.

(d) Inssallation All tsnks and piping must be property installed in accordance with a code of practice developed by a nationally

recognized association or independert terting

laboratory and in acoordance with the

mesof exturer's instructions.

Note Trenk rod piping system installation precticas and prosedure dectibed in the following codes ming be used graph (d) of this

(i) Americm Petroleurn Institure Puhlication 1615. Installation of Underground Petroleum Storige Syrtem; or

(ii) Petroleurn Equiprnent Institule

Publication RP100, Recommended Practices for installation of Underground Liquid Storage Syrtems; or

(iii) American National Standands Institute Stondand BJ1.3, Petroleuton Refinery Piping. and Americen National Stendands Institute and American National Stendards

Transportation Piping Systern.

(c) Certification of installation. All owners and operators must ensure thes one or more of the following methods of certification, testing. or inspection is used to demonstrate compliance with paragraph (d) of this section by providing 2 certification of compliance on the UST necification form in sccondance with 280.22

(1) The installer hes been certifiod by the conk end piping menufacturen; or

(2) The installer has been certified or licensed by the implementing agency; or

(3) The installation has been inspected and certified by a registered professional engineer with education and experience in UST yystem installation; or

(4) The installation hes beea inspected and afproved by the implementing agency; or

(5) All work listed in the manufacturer's installation chacklists hes been completed; or (6) The ouner and cyerator have complied with enother methed for ensuring compliance with parzegreph (d) of this section that is dermined by the imglementing agency to be no less proxective of bumen health and the envirenment.
[53 FR 37194, Sept 23, 1988, a amended at $56 \mathrm{FR}$ 38344, Aug. 13. 1991]

\subsection{Upgrading of existing UST systems.}

(a) Alternatives allowed. Not later than December 22, 1998, all existing UST systems must comply with one of the following requirements:

(1) New UST system performance standards under 280.20;

(2) The upgrading requirements in paragraphs (b) through (d) of this section; or

(3) Closure requirements under Subpart $O$ of this part including spplicablo requirement for corrective action under Subpart F.

(b) Tank upgrading reguirements. Stoel tanks must be up graded to meet one of the following requirements in accordance with a code of practice developed by a nationally recognized association or independent testing aboralory

(1) Interior Uning. A tank may be upgraded by internal lining if:

(i) The lining is installed in accordance with the requirements of 280.33, and

(ii) Within 10 years after lining, and every 5 years thereafter, the lined tank is internally inspected and found to be structurally sound with the lining still performing in accordance with original design specifications.

(2) Cathodic protection. A tank may be upgraded by cathodic protection if the cathodic protection system meets the requirements of $280.20(\mathrm{a})(2)$ (ii), (iii), and (iv) and the integrity

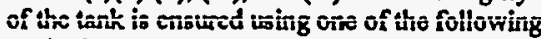
methods:

(i) The tank is intemally inspected and assessed to ensure that the lenk is structurally sound and free of corrosion holes prior to installing the cathodic protection system; or

(ii) The tank has been installed for less than 10 years and is monitored monthly for releases in sccordance with 280.43 (d) through (h); or

(iii) The tank has been installed for less than 10 years and is sasessed for corrosion holes by conducting two (2) tightness tests that meet the requirements of $280.43(\mathrm{c})$. The first tightness test must be conducted prior to installing the test must be conducted prior to installing tightress test must be conducted betwoen three
(3) and six (6) months following the first ecration of the cathodic proloction system; or (iv) The tank is assessed for corrosion holes by a method that is determined by the implementing agency to prevent releases in a manner that is no less protective of human health and the environment than paragraphs (b)(2) (i) through (iii) of this section.

(3) Intermal lining combined with cathodic protection. A tank may be upgraded by both

(i) The lining is installed in accondance with the requirements of 280.33; and

(ii) The cathodic prolection system meets

the requirements of 280.20 (a)(2) (ii), (iii), and (iv).

Nole: The following codes and standards may be used to comply with this soction:

(A) American Petroleum Institute Publication 1631, Recommended Practice for the Interior Lining of Existing Steel Underground Storage Tanks;

(B) National Leak Prevention Association Standard 631, Spill Prevention, Minimum 10

Year Life Extension of Existing Steel

Underground Tarks by Lining Without the Addition of Cathadic Protection;

(C) National Association of Corrosion Engineers Standard RP-02-85, Control of Extemal Corrosion on Metallic Buried, Partially Buried, or Submerged Liquid Storage Systems:

(D) American Petroleum Institute

Publication 1632, Cathodic Protection of

Underground Petroleum Storage Tanks and piping Systeme.

(c) Piping upgrading requirements. Metal piping that routinely contains regulated

substances and is in comtact with the ground must be cathodically protected in accordance with $a$ code of practice developed by a nationally recognized essociation or independent testing laboratory and must meet the requirements of 280.20 (b)(2) (ii), (iii), and (iv).

Note: The coda and standerds listed in the note following $280.20(b)(2)$ may be used to comply with this
requirement.

(d) Spill and overfill prevention equipment. To prevent spilling and overfilling associated with product transfer to the UST system, all existing UST systems must comply with new UST system spill and overfill prevention equipment requirements specified in 280.20(c).

[S3 FR 37194, SepL 23, 1988]

280.22 Notification requirements.

(a) Any owner who brings an underground storage tank system into use after May 8,1986 . must within 30 days of bringing such tank into use, submit, in the form prescribed in Appendix I of this part, a notice of existence of such tank system to the state or local agency or department designated in Appendix II of this part to receive such notice.

Note: Owmers and operators of UST systems that were in the ground on or anter Moy 8, 1986, unless taken out of operation on or before January 1,1974 , were required to notify the designitiod state or losal agency in excordance with the Hazardous and Solid Waste Amendments of 1984, Pub. L. 98.616, on a form published by EPA on Novernber 8. 1985 (50 FR 46002) unleas notice wess given pursuent to soction 103(c) of CERCLA. Owners and operators who have not complied with the notification requirements may use portions I through VI of the (b) In states where state law, regulations, or procedures require ownens to use forms that differ from those set forth in Appendix I of this part to fulfill the requirements of this section, the state forms may be submitted in lieu of the forms set forth in Appendix I of this part. If 2 state requires that its form be used in licu of the form presemted in this regulation, such form must meet the requirements of section 9002 .

(c) Owners required to submit notices under paragraph (a) of this section must provide notices to the appropriale agencies or departments identified in Appendix II of this part for each tank they own. Owners may provide notice for several tanks using one notification form, but owners who own tanks located at more than one place of operation must file a separate notification form for each separate place of operation.

(d) Notices required to be submittod under paragraph (a) of this section must provide all of the information in sections I through VI of the prescribed form (or appropriate state form) for each tank for which notice must be given. Notices for tanks installed aner December 22 1988 must also provide all of the information in 
section VII of the prescribed form (or apropriate rtste form) for each tank for which notice murt be given.

(e) All owpers and operalors of new UST nytems must certify in the notification form compliance with the following requirements:

(1) Inotallation of tanks and piping under 280.20 (e)

(2) Cethodic procection of stoel tanks and piping under 280.20 (a) and (b):

(3) Finencial responsibility under Subpart $H$ of this part and

(4) Release detection under 280.41 and 280.42 .

(f) All owners and operators of new UST systems murt ensure that the installer certifics in the notification form that the methods used to install the tunks and piping complies with the requirements in 280.20(d).

(8) Beginning October 24, 1988, eny person who selis a tank interded to be used as an underground storage tank must notify the purcheser of such tank of the owner's perification obligations under paragraph (s) of this section. The form provided in Appendix III of this part may be uned to comply with this requirement

[53 FR 37194, Sepe 23, 1988]

\section{Subpart C-General Operating Requirements}

\subsection{Spill and overfill control.}

(a) Orners and operalora must ensure that relesses due is spilling or overfilling do not occur. The owner and operator must ensure that the volume avilable in the tenk is greater than the volume of proctuat to be transferred to the lenk before the transfer is made trenser operation is monitored constantly to prevent overfilling and opilling.

Note: The transfer procedures described in National Fire Pretection Association Pullication 385 nagy be used to comply with peregraph (2) of this sectisn. Further guidexe on peill and overtil prertention sppess in American Petroleum instlle Publication 1621.

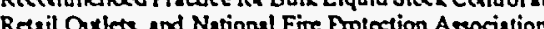
Seenderd 30 Find (b) The owner and operator must report investigate, and clean up any spills and overills in sccordance with 280.53 .

[S3 FR 37194, Sepe 23, 1988]

\subsection{Operation and maintenance of corrosion protection.}

All owners and operators of steel UST systems with corrosion protection must comply with the following requirements to ensure that releases due to corrosion are prevented for as long as the UST system is used to store regulated substances:

(a) All corrosion protection systems must be operated and maintained to comtinuously provide corrosion protection to the metal components of that portion of the tank and piping that routinely contain regulated

aubstances and are in contact with the ground.

(b) All UST systems equipped with cathodic protection systems must be inspected for proper operation by a qualified cathodic prolection tester in accordance with the following requirements:

(1) Freguency. All cathodic protection systems must be tested within 6 months of or according to another reasonable time freme cotablished by the inclementing agency; and

(2) Inspection criferla. The criteris that ore used to determine that cathodic protection is adequate $s$ required by this section must be in accordance with a code of practice developed by a nationally recognized association.

Note: National Association of Cortosion Engineers Stunderd RP-02.85. Control of Extarnal Corrosion on Metallic Buriod, Partilly Buriod, or Submarged Liquid Storage Systems, may be used to comply with paragriph (b)(2) of this section.

(c) UST systems with impressed current cthodic protection systems must also be inspected every 60 days to ensure the equipment is nurning properly.

(d) For UST systems using cathodic mrotection, reconds of the operation of the cathodic protection must be maintsined (in accondance with 280.34) to demonstrale compliance with the performance stendands in this section.

These records must provide the following:
(1) The reautls of the last three inspections rauired in paragraph (c) of this soction, and

(2) The results of teeting from the last two inspections required in paragraph (b) of this soction.

[S3 FR 37194, Seph. 23, 1988]

280.32 Compatibility.

Owners and operators must use an UST system made of or lined with materials that are compatible with the substance stored in the UST system.

Note: Owners and operators storing alcohol blends may we the following oodes to comply with the roquirements of this soction:

(a) American Petroleum Institute Publication 1626, Storing and Handling Ethanol and Gasoline-Ethanol Blends a Distribution Terminals and Service Stations; and (b) American Petroleum Institute

Publication 1627. Storage and Handling of Gasoline-Methanol/ Cosolvent Blends at Distribution Terminals and Service Stations. [53 FR 37194, Sept. 23, 1988]

\subsection{Repairs allowed.}

Owners and operators of UST systems must ensure that repairs will prevent releases due to structural failure or corrosion es long as the UST system is used to store regulated substances. The repairs must meet the following requirements:

(a) Reprirs to UST systems must be properly conducted in accordance with a code of practice doveloped by a nationally recognized association or an independent testing laboratory.

Note: The following codes and standards may be used to comply with paragraph (e) of this rection: National Fire Protoction Association Standerd 30. Flammable and Combustible Liquids Code; American Petroleum Institute Publication 2200. Repairing Crude Oil, Americe Petroum Recommended Prectice for the Interior Lining of Existing Steel Undergend Storege Tunter and Nation Leak Prevention Associution Stendard 631. Spill Prevention Minimum 10 Year L ife Extension Steel Underground Tanks by Lining Without the Addition of Cathodic Protoction (b) Repairs to fiberglass-reinforced plestic tanks may be made by the manufacturer's authorized represemtatives or in accordance with a code of practice developed by a nationally recognized association or an independert lesting laboralory.

(c) Metal pipe sections and fittings that have released product as a result of corrosion or other damage must be replaced. Fiberglass pipes and fittings may be repaired in accordance with the manufacturer's apecifications.

(d) Repaired tanks and piping must be tightness tested in accondance with 280.43 (c) and $280.44(\mathrm{~b})$ within 30 days following the date of the completion of the repair except as provided in peragraphs (d) (1) through (3), of this section:

(1) The repaired tank is internally inspected in accordance with a code of practice developed by a nationally recognized association or an independent testing laboratory, or

(2) The repaired portion of the UST system is monitored momthly for releases in acoordance with a method specified in 280.43 (d) through (h); or

(3) Another test method is used that is determined by the implementing agency to be no less protoctive of human health and the environment than those listed above.

(c) Within 6 months following the repair of any cathodically protected UST system, the cathodic protection system must be tested in accordance with 280.31 (b) and (c) to ensure that it is operating properly.

(f) UST system owners and operators must maintain reconds of each repair for the remaining operaling life of the UST system that demonstrate compliance with the requirements of this section.

[S3 FR 37194, Sept. 23, 1988]

\subsection{Reporting and} recordkeeping

Owners and operators of UST systems must cooperate fully with inspections, monitoring and teating conducted by the implememting agency, as well as requests for documert subrnission, lesting, and monitoring by the owner or operator pursuamt to section 9005 of Subtitle I of the Resource Conservation and Recovery Act, as amended. 
(a) Reporting. Owners end operators must subnit the following information to the implementing agency:

(1) Notification for all UST systems (280.22) which includes certification of installation for newr UST yystems [280.20(e)]

(2) Reports of all relesses including ruspected releses (280.50), spills and overfills (280.53), and confirmed relesses (280.61);

(3) Corrective actions planned or taken

inctuding initial abatement measures (280.62) initial site characterization (280.63), free

product removal (Sec. 280.64), investigation of soil and ground-water clemup (280.65), and carrective action plen (280.66); and

(4) A notification before permanent closure or chenge-in-service (280.71)

(b) Recondkeeping. Owners and operators must meintain the following information:

(1) A corrosion expert's analysis of sito corrosion potential if corrosion protoction equipment is nol used [280.20(a) (4);

$280.20(b)(3)]$.

(2) Documentation of operation of corrosion procetion equipment (280.31)

(B) Documentation of UST system repairs [280.33(f)]:

(4) Reoent compliance with relesse detection requirements $(280.45)$; and

(5) Results of the site invertigation conducted at permanent closure (280.74).

(c) A railablitity and Malmtenance of

Records. Owners and operators must keep the reconds requined either:

(1) At the UST site and immediately available for inspection by the implementing egency; or

(2) Al a readily available allemative site and be provided for inspection to the implementing agency upon request.

(3) In the case of permanent closure reconds required under 280.74, ormers and operators are also provided with the additional alternative of mailing closure reconds to the implementing sency if they cannot be kept at the site or an aftemative site as indicated above.

Note: The recordkeeping and reporting requirements in this section have been approved by the Office of Conaganent and budgct and

[53 FR 37194, Sept. 23, 1988]

\section{Subpart D Release Detoction}

280.40 General requirements for all UST systems.

(a) Ownera and operators of new and existing UST systems must provido a method, or combination of methods, of release detection that:

1) Can detect a relesse from any portion of the tank and the connected underground piping thel routinely contains product;

(2) Is installed, calibrated, operated, and maintained in accordance with the manufacturer's instructions, including routine maintenance and service checke for operability or running condition; and

(3) Meets the performanee requirements in $\$ 280.43$ or 280.44 , with any performance cleims and their described in writing by the equipment manufacturer or installer. In addition, methods used after the date shown in the following table corresponding with the specified method except for methods permanently installed prior to that

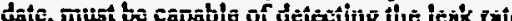
or quantity specified for that method in the corresponding section of the rule (also shown in corresponding section of the rule (also shown the table) wilh a probability detection (Pd) of 0.95 and a probability of false alarm (Pfa) of 0.05 .

\begin{tabular}{|c|c|c|}
\hline Method & Section & $\begin{array}{l}\text { Dato after which Pd/Pfa must be } \\
\text { demonstrated }\end{array}$ \\
\hline $\begin{array}{l}\text { Manual Tank Gauging } \\
\text { Tank Tightress Testing } \\
\text { Automatic Tank Gauging } \\
\text { Alutomatic Line Leak Detectors } \\
\text { Line Tightness Texting }\end{array}$ & $\begin{array}{l}280.43(\mathrm{~b}) \\
280.43(\mathrm{c}) \\
280.43(\mathrm{~d}) \\
280.44(\mathrm{a}) \\
280.44(\mathrm{~b})\end{array}$ & $\begin{array}{l}\text { December 22, } 1990 . \\
\text { December 22, } 1980 . \\
\text { December 22, } 1990 . \\
\text { Seplember 22, } 1991 . \\
\text { December 22, } 1980 .\end{array}$ \\
\hline
\end{tabular}

(b) When a release detection method operated in accordance with the performance standards in 280.43 and 280.44 indicates release may havo occurred, owners and operators must notify the implementing agency in eccordanos with Subpart $E$.

SCHEDULE FOR PHASE-IN OF RELEASE DETECTION

\begin{tabular}{|c|c|c|c|c|c|}
\hline \multirow[t]{2}{*}{ Year system was installed } & \multicolumn{5}{|c|}{$\begin{array}{c}\text { Year when release detection is required (by December } 22 \text { of the year } \\
\text { indicaled) }\end{array}$} \\
\hline & 1989 & 1990 & 1921 & 1992 & 1993 \\
\hline $\begin{array}{l}\text { Beforo } 1965 \text { or dato unknown } \\
1965-69 \\
1970-74 \\
1975-79 \\
1980-88\end{array}$ & $\mathbf{R D}$ & 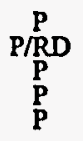 & RD & $R D$ & $R D$ \\
\hline \multicolumn{6}{|c|}{ New tanks (afler December 22) immediately upon installation. } \\
\hline
\end{tabular}

$P=$ Must begin release detoction for all pressurized piping 24 defined 280,4l(b)(1)
$R D=$ Must begin release detoction for tanks end suction piping in accordance with 280.41 (a)

(d) Any existing UST system that cannot apply a method of release detection that complies with the requirements of this subpar must complete the closure procedures in Subpart $O$ by the date on which releaso detoction is required for that UST system under paragraph (c) of this section.

53 FR 37194, Sept. 23, 1988, as amended at SS FR 7753, April 27. 1990; 55 FR 23738, Jume 12, 1990: 56 R 26, Jan. 2, 1991]

\subsection{Requirements for} petroleum UST systems.

Owners and operators of petroleum UST syatems must provide release detection for tanks and piping as follows: (c) Owners and operators of all UST systems must comply with the release detection requirements of this subpart by December 22 of the year listed in the following table: (a) Tanks. Tanks must be monitored at least every 30 days for releases using one of the methods listed in 280.43 (d) through (h) except that:

(1) UST systems that meet the performance standands in 280.20 or 280.21 , and the monthly invemtory comtrol requirements in $280.43(a)$ or (b), may use tank tightness lesting [conducted in accordance with 280.43 (c)] al least every 5 years until Docember 22, 1998, or until 10 years afler the tank is installed or upgraded under 280.21(b), whichever is later,

(2) UST systems that do not meet the performance stendands in 280.20 or 280.21 may use mombly inventory controls [conducted in accordance with 280.43(a) or (b)] and annuel lank tightness testing (conducted in accondance 
with 280.43(c)] until December 22, 1998 when the tenk must be upgraded under 280.21 or permanemtly closed under 280.71 ; and

(3) Tanks with capucity of 550 gallons or less may use weekly tank gauging (conducted in acoordance with $280.43(\mathrm{~b})]$.

(b) Piping. Underground piping that routinely contains regulated substances must be monitored for releases in a manner that meets one of the following requirements:

(1) Pressurized piping. Underground piping thas conveys regulated substances under pressure must:

(i) Be equipped with an automatic line leak detector conducted in sccordance with $280.44(2)$, and

(ii) Have an anual line tightness test conducted in accordence with $280.44($ b) or have monthly monitoring conducted in accordence with 280.44 (c).

(2) Suction fiping. Underground piping that conveys regulated substances under suction must either have a line tightness test conducted it least every 3 yem and in aceordence with 280.44 (b) or we a monthly monitoring method conduct in accondance with 280.4 (c). No release detection is required for suction piping that is designed and constructed to meet the followring standards:

(i) The below-grade piping operates at less than atmospheric pressure;

(ii) The below-grade piping is sloped so that the corrents of the pipe will drain back into the storage tank if the suction is relexsed;

(iii) Only one check valve is included in ench suction line:

(iv) The check value is located directly below and as close as practical to the suction fump; and

(v) A method is provided that allows compliance with paragraphs (b)(2) (ii)-(iv) of this section to be readily determined.

[53 FR 37194, Seph 23, 1988]

\subsection{Requirements for} hazsidous substance UST systems.

Owners and operitors of taszerdous suletance UST systoms must provide relesse detection that meets the following requirements: (a) Release detection at existing UST systems must meet the requirememts for petroleum UST systems in 280.41. By December 22, 1998, all existing hazardous subrtance UST systems must meet the release delection requirements for new systems in paragraph (b) of this section.

(b) Release detection at new hazardous substance UST systems must meet the following requirements:

(1) Secondary containment systems must be designed, constructed, and installed to:

(i) Contain regulated substances released from the tank system until they are detected and removed:

(ii) Prevent the release of regulated substances to the environment al any time during the operational life of the UST system

(iii) Be checked for evidence of a release at lesst every 30 days.

Note: The provisions of 40 CFR 263.193, Contuinment and Datection of Relesses, may be usod to comply with theos requirements

(2) Double-walled tanks must be designed, constructed, and installed to:

(i) Comtain a release from any portion of the inner tank within the outer wall; and

(ii) Detect the failure of the imer wall.

(3) External liners (including vaults) must be designed, constructed, and installed to:

(i) Comtain 100 percent of the capacity of

the largest tank within its boundary,

(ii) Prevent the interference of precipitation or ground-water intrusion with the ability to contain or detect a release of regulated substances; and

(iii) Surround the tenk completely (i.c., it is capable of preventing laleral as well es vertical migration of regulated substances).

(4) Underground piping must be equipped with secondary contsinment that satisfies the requirements of paragraph (b)(1) of this section (e.g., trench liners, jacketing of double-walled pipe). In addition, underground piping that conveys regulated substances under pressure must be equipped with an automatic line leak detector in accordance with $280.44(\mathrm{a})$.

(5) Other methods of release detection may be used if owners and operators:

(i) Demonstrate to the implementing agency that an allemale method can detect a release of the stored aubelance as effectively as any of the methods allowed in 280.43 (b) through (h) can detect a release of petroleurm;

(ii) Provide information to the implementing agency on effective corrective sction techrologies, heatth risks, and chemical and physical properties of the stored substance, and the characteristics of the UST site; and

(iii) Obtain approval from the implementing agency to use the afternate release detection method before the installation and operation of the new UST system.

[53 FR 37194, Sept. 23, 1988]

\subsection{Methods of release detection for tanks.}

Each method of release detection for tanks used to meet the requirements of 280.41 must

be conducted in accordance with the following

(a) Inventory control. Product inventory control (or another test of equivalem

performance) must be conducted monthly to detect a release of at least 1.0 pereent of flow-through plus 130 gallons on a monthly basis in the following manner

(1) Inventory volume messurements for regulated substance inputs, withdrawals, and the emount still remaining in the tank are recorded each operating day,

(2) The equipment used is capable of measuring the level of product over the full range of the tank's height to the nearest one-eighth of an inch;

(3) The regulated subetance inpurts are reconciled with delivery receipts by measurement of the tank inventory volume before and after delivery;

(4) Deliveries are made through a drop tube that extends to within one foot of the tank bottom:

(5) Product dispensing is metered and recorded within the local standards for meter calibration or an acruracy of 6 cubic inches for every 5 gallons of product withdrawn; and

(6) The measurement of any water level in the bottom of the tank is made to the nearest onc-eighth of an inch at least once a month. Note: Pratices describod in the Americen Petroleum Institure Publication 1621 . Recommended Practice for
Bulk Liquid Slock Control at Retsil Outlets, msy be used, where applicable. as guidence in meeting the roquirements of this paragraph.

(b) Manual tank gauging. Manual tank gauging must meet the following requirements:

(1) Tank liquid level measurements are taken at the beginning and ending of a period of at least 36 hours during which no liquid is added to or semoved from the tank:

(2) Level measurements are based on an average of two consecutive stick resdings a both the beginning and ending of the period

(3) The equipmemt used is capable of measuring the level of product over the full range of the tank's height to the nearest one-eighth of an inch;

(4) A leak is suspected and subject to the requirements of Subpart $E$ if the variation between beginning and ending measurements exceeds the weekly or momthly standards in the following table:

\begin{tabular}{|c|c|c|}
\hline $\begin{array}{l}\text { Nominal tank } \\
\text { capacity }\end{array}$ & $\begin{array}{l}\text { Weekly } \\
\text { standard } \\
\text { (one test) }\end{array}$ & $\begin{array}{l}\text { Momthly } \\
\text { standard } \\
\text { (average of } \\
\text { four tests) }\end{array}$ \\
\hline $\begin{array}{l}530 \text { gallons or } \\
\text { less. } \\
551-1,000 \\
\text { gallons. } \\
1,001-2,000 \\
\text { gallons }\end{array}$ & $\begin{array}{l}10 \text { gallons. } \\
13 \text { gallons. } \\
26 \text { gallons. }\end{array}$ & 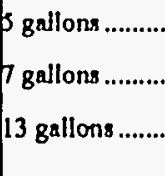 \\
\hline
\end{tabular}

(5) Only tanks of 550 gallons or less nominal capacity may use this as the sole method of release detection. Tanks of 551 to 2,000 gallons may use the method in place of manual invemtory control in $280.43(\mathrm{a})$. Tanks of greater than 2,000 gallons nominal capscity may not use this method to meet the requirements of this subpart.

(c) Tank tightness testing. Tank tightness testing (or another test of equivalemt

performance) must be capable of detecting a 0.1 gallon per hour leak rate from any portion of the tank that routinely contains product while accourting for the effects of thermal expansion or contraction of the product, vapor pockets. ank deformation, evaporation or condensation, and the location of the water table. 
(d) Auromatic tonk gauging. Equipment for unomutic tenk gauging that teste for the loss of product and conducts inventory control must meet the following requirements:

(1) The sutomatic product level monitor tert can delect 10.2 gallon per bour leak rate from amy portion of the tank that routinely contsins product; and

(2) Inventory control (or mother lext of equivalem performance) is conducted in ccordance with the requirements of $280.43(\mathrm{a})$.

(c) I'apor monicoring. Teating or monitoring for vapors within the soil gas of the excavation zone must meet the following requirements:

(1) The materials used as backfill are sufficiently porous (c.8., gravel, wand, crushed reck) to readily allow diffusion of vapors from reteses into the excevation area;

(2) The stored regulated subrtence, or a tracer compound placed in the tente system, is sufficiemtly volatile (c.g. gesoline) to result in a saper level that is detectable by the monitoring devices localed in the excavation zone in the event of a release from the lenk.

(3) The messurement of vepors by the menitering device is not rendered inoperntive by the ground water, rainfall, or soil moisture or cither known interferences so that a releare could so undetected for more then 30 days,

(4) The level of background contamination in the excavation zone will not interfere with the method used to detect releases from the tank;

(5) The vapor monitors are designod and operaled to detect any significment incresse in concentration above background of the regulased substance stored in the tank system, a compenent or components of that substance, of a tracer compound placed in the tank system:

(6) In the UST excavition zone, the site is

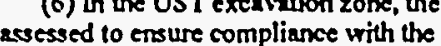
requirements in paragraphs (c) (1) through (4) requirements in paragraphs (c) (1) through (4)
of this section and to establish the number and of this section and to establish the number and releases within the excavation zone from any portion of the tark that routinely contuins product: and

7) Mlonitorins welts are clearty marked and secured to avoid unauhorized access and tempering.

(n) Ground water monitoring. Testing or menitering fer liquids on the ground water must meet the following requirements:
(1) The regulated substance stored is mmiscible in water and has a specific gravity of less than one;

(2) Ground water is never more than 20 feet from the ground surface and the hydraulic conductivity of the soil(s) between the UST system and the monitoring wells or devices is not less than $0.01 \mathrm{~cm} / \mathrm{sec}$ (e.8., the soil should consist of gravels, coarse to medium sands, coarse sitts or other permeable materials)

(3) The slotted portion of the monitoring well casing must be designed to prevent migration of natural soils or filter pack into the well and to allow entry of regulated substance on the water table into the well under both high and low ground-water conditions;

(4) Monitoring wells shall be sealed from

the ground surface to the top of the filter pack;

(5) Monitoring weils or devices intercept the excavation zone or are as close to it as is echnically fessible;

(6) The comtinuous monitoring devices or manual methods used can detect the presence of at least one-eighth of en inch of free product on top of the ground water in the monitoring wells;

(7) Within and immediately below the UST system excavation zone, the site is assessed to ensure compliance with the requirements in paragraphs (I) (1) through (5) of this section and to cstablish the mumber and positioning of monitoring wells or devices that will detect releases from eny portion of the tank that routinely contrins product; and

(8) Monitoring wells are clearly marked and secured to avoid unauthorized access and

mering.

(8) Interstiffal monlforing. Interstitial monitoring between the UST system and a secondary barrier immediately around or beneath it may be used, but only if the system is designed constructed and installed to detect a leak from any portion of the tank that routinely contains product and also meets one of the ollowing requirements:

(1) For double-walled UST systems, the sampling or testing method can detect a release through the inner wall in any portion of the tank that routinely comains product;

Nole: The provisions outl ined in the Stocl Tenk Institule' Stend ard for Duel Wall Underground Slocege Tants be used es guidance for aspocts of the design $m$ construction of undaground steel double-walled tanks.
(2) For UST systems with a socondary barrier within the excavation zone, the sampling or testing method used can detect a release between the UST system and the secondary barrier.

(i) The socondary barrier around or beneath the UST aystem consists of artificially constructed material that is sufficiently thick and impermeable (at least $10^{-6} \mathrm{~cm} / \mathrm{sec}$ for the and impermeable (at least $10^{-6} \mathrm{~cm} / \mathrm{sec}$ for the regulated substance stored) to direct a release;

(ii) The barrier is compatible with the regulated substence stored so that a release from the UST system will not cause a deterioration of the berrier allowing a release to pass through undetected:

(iii) For cathodically protected tanks, the econdary berrier must be installed so that it does not interfere with the proper operation of the cathodic protection system

(iv) The ground water, soil moisture, or rainfall will not render the testing or sampling method used inoperative so that a release could 80 undetected for more then 30 days;

(v) The sito is asseased to ensure that the secondary barrier is always above the ground the berier in a 25-year flood plain, tricos inder auch conditions;

(vi) Monitoring wells are clearly marked and secured to avoid unauthorized sccess and tampering.

(3) For tanks with an internally fitted liner an automated device can detect a release between the inner wall of the tank and the liner, end the liner is compontible with the athotanso tored.

(h) Other methods. Any other type of relense detection method, or combination of methods, can be used if:

(1) It can detect 20.2 gallon per hour leak rate or a release of 150 gallons within a month with a probability of detection of 0.95 and a probability of false alarm of 0.05 ; or

(2) The implementing agency may approve nother method if the owner and operator can demonstrate that the method can detect a release is effectively as any of the methods allowed in paragraphs (c) through (b) of this section. In comparing methods, the implemerting agency shall consider the size of release that the method can detect and the frequency and reliability with which it can be detected. If the method is approved, the owner and operator must comply with any conditions imposed by the implementing agency on its use to ensure the protection of human health and the environment.

[53 FR 37194, SepL 23, 1988]

\subsection{Methods of release} detection for piping

Esch method of release detection for piping used to meet the requirements of 280.41 must be conducted in accondance with the following:

(a) Automatic line leak detectors. Methods which alert the operator to the presence of a leak by restricting or shutting off the flow of reguiated substances through piping or triggering an audible or visual alarm may be used only if they detect leaks of 3 gallons per hour at 10 pounds per square inch line pressure
within 1 hour. An annual test of the operation of the leak detector must be conducted in accordance with the manufacturer's requirements.

(b) Line tightness lesting. A periodic test of piping may be conducted only if it can detect a 0.1 gallon per hour leak rate at one and one-half times the operating pressure.

(c) Applicable tank methods. Any of the methods in 280.43 (c) through (h) may be used if they are designed to detect a release from any portion of the underground piping that routinely contains regulated substances.

[53 FR 37194, Sept. 23, 1988]

\subsection{Release detection recordkceping.}

All UST system owners and operators must maimlain reconds in accordance with 280.34 demonstrating compliance with all applicable requirements of this Subpart. These records must include the following:

(a) All written performance cláims pertaining to any release detection system used, and the manner in which these claims have been justified or tested by the equipment manufacturer or installer, must be maintained for 3 years, or for another reasonable period of time determined by the implementing agency, from the date of installation: 
(b) The results of any sampling, testing or monitoring must be maintained for at least 1 year, or for another reasonable period of time determined by the implememing agency, except thas the resurts of tank tightness testing conducted in accordance with 280.43 (c) must be retained until the next teat is conducted; and

(c) H'ritten documentation of all calibration meirtensnce, and repair of release detection equipment permanently located on-site must be maintained for a leart one year after the servicing work is completed, or for another ressonable time period deremined by the implementing agency. Any achedules of required celitration and maintenance provided
requenting agency. Any achedules of required calitration and maintenance
hy the release detection equipment

mamufacture must be retained for 5 years from the date of installation.

[53 FR 37194, Sept 23. 1988]

Subpart E-Release Reporting, Investigation, and Confirmation

\subsection{Reporting of suspected} releases.

Ouners and cperxlors of UST aystems must report to the implementing agency within 24 hours, or another ressonable time period specified by the implementing agency, and follow the procedures in 280.52 for any of the following conditions:

(a) The discovery by owners and operators or chers of relessed regulated substences at the UST site or in the surrounding area (such as the presence of free product or vepors in soils, basemente, sewer and utility lines, and nearby surface water).

(b) Umususl operating conditions observed by owners end operators (such ss the erratic hehsvior of product dispensing equipment, the sudden loss of product from the UST system, or an unexplained presence of waler in the tank), unless system equipment is found to be defertive bu nol leaking, and is imrnediately repaired or replaced; and

(c) Mimitoring results from a relesse detertion methed required under 280.41 and 280.42 that indicate a relesse may have cecurred unless:
(1) The monitoring device is found to be defective, and is immediately repaired, recalibrated or replaced, and additional monitoring does not confirm the initial result; or

(2) In the case of inventory control, a second month of dats does not confirm the initial result.

[53 FR 37194, Seph. 23, 1988]

\subsection{Investigation due to off-site impacts.}

When required by the implementing agency, owners and operators of UST systems must follow the procedures in 280.52 to determine if the UST system is the source of off-site regulated substances (such as the presence of free product or vapors in soils, basements, sewer and utility lines, and nearby surface and drinking waters) that has been observed by the implementing a gency or brought to its attention by another party.

[53 FR 37194, Sept, 23, 1988]

\subsection{Release investigation and} confirmation steps.

Unless corrective setion is initiated in accordance with Subpart $F$, owners and operators must immediately investigate and confirm all suspected releases of regulated substances requiring reporting under 280.50 within 7 days, or another reasonable time period specified by the implementing agency, using either the following oteps or another proceture approved by the implementing agency:

(a) System test. Owners and operators must conduct tests [according to the requirements for tightiness lesting in 280.43 (c) and 280.44(b)] thal determine whether a leak exists in the portion of the tank that routinely contains product, or the attached delivery piping, or both.

(1) Owners and operators must repair, replace or upgrade the UST system, and begin corrective action in accordance with Subpart F if the lest results for the system, tank, or delivery piping indicate that a leak exists.

(2) Further investigation is not required if the test results for the system, tank, and delivery piping do not indicate that a leak exists and if environmental comtamination is not the basis for suspocting a release.

(3) Owners and operators must conduct a site check as described in paragraph (b) of this soction if the test results for the system, tank, and delivery piping do not indicate that a leak exists but environmental contamination is the basis for guapecting a release.

(b) Site check Owners and operators must measure for the presence of a release where comtamination is most likely to be present at the UST sile. In selecting sample types, sample locations, and measurement methods, owners and operators must consider the nature of the stored substance, the type of initial alarm or cause for auspicion, the typo of backfill, the depth of ground water, and other factors appropriate for identifying the presence and sounce of the release.

(1) If the test results for the excavation zone or the UST site indicate that a release has occurred, owners and operators must begin corrective action in accordance with Subpart $F$

(2) If the test results for the excavation zone or the UST sito do not indicate that a release hes occurred, further investigation is not required. [S3 FR 37194, Sept. 23, 1988]

\subsection{Reporting and cleanup of} spills and overfills.

(a) Owners and operators of UST systems must contain and immediately clean up a spill or overfill and report to the implementing agency within 24 hours, or another reasonable time period specified by the implementing agency, and begin corrective action in accondance with Subpart $F$ in the following cases:

(1) Spill or overfill of petroleum that results in a release to the environment that exceeds 25 gallons or another reasonable amount specified by the implementing agency, or that causes a sheen on nearby surface water, and

(2) Spill or overfill of a hazandous substance that results in a release to the environment that equals or exceeds its reportable quantity under CERCLA (40 CFR Part 302).

(b) Owners and operators of UST systems must contain and immediately clean up a spill or overfill of petroleum that is less than 25
gallons or another reasonable amount specified by the implementing agency, and a spill or overfill of a hozardous substance that is less than the reportable quantity. If cleanup canno be accomplished within 24 hours, or another reasonable time period established by the implementing agency, owners and operators must immediately notify the implememting agency.

Nole: Pursuant to 302.6 and 355.40 , a release of hazardous substance oqual to or in excess of its reportable quantity must also be reportod immodialely (rather than within 24 hours) to the National Reaponse Conter under sections 102 and 103 of the Comprehensive Environmental Response, Compensation, and Liebility Act of 1980 and to appropriate state and local authoritie under Title III of the Superfund Amendments and Reauthorization Act of 1986 .

[S3 FR 37194, SepL 23, 1988]

Subpart F-Release Response and Corrective Action for UST Systems Containing Petrolcum or

Hazardous Substances

280.60 General.

Owners and operalors of petroleum or hazardous substance UST systems must, in response to a confirmed release from the UST system, comply with the requirements of this subpart except for USTs excluded under $280.10(\mathrm{~b})$ and UST systems subject to RCRA Subtitle $\mathrm{C}$ corrective action requirements under section 3004 (u) of the Resource Conservation and Recovery Act, as amended.

[53 FR 37194. Sept. 23, 1988]

\subsection{Initial response.}

Upon confirmation of a release in accondance with $\mathbf{2 8 0 . 5 2}$ or after a release from the UST system is identified in any other manner, owners and operators must perform the following initial response actions within 24 hours of a release or within another reasonable period of time determined by the implementing agency:

(a) Report the release to the implemerting agency (e.g., by telephone or electronic mail);

(b) Take immediate action to prevent any further release of the regulated substance into the environment; and 
(c) Identify and mitigale fire, explosion, and vaper hazards.

[53 FR 37194, Sept 23, 1988]

\subsection{Initial abatement measures and site check.}

(a) Unless directod to do otherwise by the inplementing agency, owners and operators must perform the following abatement measures:

(1) Remove as much of the regulated substance from the UST ajutem as is neceasary

10 prevent further relesse to the environment:

(2) Visually inspect my aboveground releseses or expoed belowground releases and prevent further migration of the released substence into surrounding soiks and ground water.

(3) Continue to monitor ind mitigate any additional fire and safety hezands posed by vepers or free product that heve migrated from the UST excavation zone and entered into subsurface structures (such as sewers or basements):

(4) Remedy houads posed by contuminated soils that are excenated or exposed as a result of release confirmation, site investigation, abutement, or corrective action activities. If these remedies inctude treatment or disposal of these remedies inchude treatment or disposal of
soils, the owner and operator must comply with applicable State and local requirememts;

(5) Measure for the presence of a release utiere comlamination is most likely to be present at the UST site, unless the presence and sotre of the relese heve ben confirmed in accordance with the site check required by accordace with the site check required by $280.52(b)$ or the closure site assessmem of $2 \$ 0.72(\mathrm{a})$. In selecting semple types, sample
incations, and messurement methuds, the ouner and operator must consider the nature of the stored substance, the type of backfill, depth to ground water and other factors as appropriate for identifying the presence and source of the relese; and

(6) Investigate to determine the porsible mesence of free product, and begin free product removel 2 soon as practicable and in cocondence with 280.64 .

(b) Within 20 days after relesse coffirmstion or within another reasonable period of time determined by the implementing agency, owners and operators must submit a report to the implementing a gency summarizing the in itial abalement steps taken under paragraph ( $\mathbf{a}$ ) of this section and any resulting information or date.

[53 FR 37194, Sept 23, 1988]

280.63 Initial site characterization.

(a) Unless directed to do otherwise by the implementing agency, owners and operators must assemble information about the site and the nature of the release, including information gainod while confirming the release or completing the initial abatement measures in 280.60 and 280.61 .

This information must include, but is not necessarily limited to the following:

(1) Data on the nature and estimated quantity of release:

(2) Data from available sources and/or sitc investigations concerning the following factors: surrounding populations, water quality, use and approximate locations of wells potentially affectod by the release, subsurface soil conditions, locations of subsurface scwers, climntological conditions, and land use;

(3) Results of the site chock required under 280.62(a)(5); and

(4) Results of the free product investigations required under $280.62(a)(6)$, to be used by owners and operators to determine whether free protuct must be reoovered under 280.64 .

(b) Within 45 days of release confirmation or mother ressonable period of time determined by the implementing agency, owners and operators must submit the information collccted in compliance with paragraph (a) of this section to the implementing agency in a manner that demonstrates its applicability end technical adequacy, or in a format and acconding to the adequacy, or in a format and acconding to the
schedule required by the implementing agency. [33 FR 37194, Seph 23, 1988]

\subsection{Free product removal.}

At sites where investigations under 280.62 (a) (6) indicate the presence of free profuct, owners and operators must remove free product to the maximum extent practicable as determined by the imple- menting agency while comtinuing as necessary, any actions initiated under 280.61 through 280.63, or preparing for actions required under 280.65 through 280.66. In meeting the requirements of this section, owners and operators must: (a) Conduct free product removal in manner that minimizes the spread of comtamination into previously uncontami- nated zones by using recovery and disposal tochniques appropriate to the hydrogeologic conditions at the site, and that properly treats, discharges or disposes of recovery byproducts in compliance with applicable local, State, and Federal regulations;

(b) Use abatement of free product migration as a minimum objective for the design of the

froo product removal system;

(c) Handle any flammable products in a safe and competent manner to prevent fires or explosions; and

(d) Unless directed to do otherwise by the implementing agency, prepare and submit to the implementing agency, within 45 days anter confirming a release, a free product removal report that provides at least the following information:

(1) The name of the person(s) responsible for implementing the free product removal measures:

(2) The estimaded quantity, type, and thickness of froc product observed or measured in wells, boreholes, and excavations;

(3) The type of free product recovery ystem used;

(4) Whether any discharge will take place on-site or off-site during the recovery operation and where this discharge wiil be located;

(5) The type of treatment applied to, and the effluent quality expected from, any discharge

(6) Tho steps that have been or are being taken to obtain necessary permits for any discharge; and

(7) The disposition of the recovered free product.

[53 FR 37194. Sept. 23, 1988]

280.65 Investigations for soil and ground-water cleanup.

(a) In order to determine the full extert and location of soils comtaminated by the release and the presence and concentrations of dissolved product comtamination in the ground water, owners and operators must conduct investigations of the release, the release site, and the surrounding area possibly affected by the release if any of the following conditions exist:

(1) There is evidence thas ground-water wells have been affected by the release (e.8., found during release confurmation or previous corrective action measures);

(2) Free product is found to need recovery in compliance with 280.64;

(3) There is evidence that contaminatod soils may be in contact with ground water (e.g. as found during conduct of the initial reaponse 280.60 through 280.64); and

(4) The implementing agency requests an investigation, based on the potential effects of contaminated soil or ground water on nearby surface water and ground-water resources.

(b) Owners and operators must submit the information collected under paragraph (a) of this section as soon as practicable or in

accordance with a schedule established by the implementing agency.

[33 FR 37194, Seph. 23, 1988]

280.66 Corrective action plan.

(a) At any poimt after reviewing the information submitted in compliance with 280.61 through 280.63 , the implementing agency may require owners and operators to submit additional information or to develop and submit a corrective action plan for responding

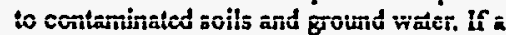
plan is required, owners and operators must submit the plan according to a schedule and format establiahed by the implememting agency. Alternatively, owners and operators may, anter fulfilling the requirements of 280.61 through 280.63 , choose to submit a corrective action plan for responding to contaminated soil and ground water. In either case, owners and operators are responsible for submitting a plan that provides for sdequate protection of humen health and the environmem as determined by the implementing agency, and must modify their plan as necessary to meet this standard.

(b) The implementing agency will approve that implementation of the plan will adequately 
protect humen health, safety, and the eavironment In making this determination, the implementing agency should consider the following factors es sppropriate:

(1) The phyrical and chemical characleristics of the regulatod substance, including its toxicity, persistence, and potential for migration:

(2) The hydrogeologic characteristics of the facility and the surrounding area:

(3) The proximity, quality, ind current and future uses of nearby surface water and ground rater,

(4) The potential effects of residual contsmination on nearby surface water and ground water.

(5) An exposure sosersment; and

(6) Any information assembled in complime with this subpat.

(c) Upon approval of the corrective action plan or as directed by the implememing agency. outers and operators must imple- mert the plar, inchuding modifications to the plan made by the implementing agency. They must monilor, evaluate, and report the results of implementing the plan in sccordance with schectule end in a format establishod by the implememting agency.

(d) Owners and operators may, in the interest of minimizing enviromental contamination and promoting more effective cleanup, begin cleanup of soil and ground water before the corrective action plen is epproved provided that they:

(1) Notify the implementing agency of their intention to begin clesmup;

(2) Comply with eny conditions imposed by the implementing agency, including hatting cleanup or mitigating adverse consequences from cleasup activities: and

(3) Incorporac these self-initisted cleanup messures in the cerrective action plan that is submitted to the implementing agency for epproval.

[S3 FR 37194. Sefh. 23, 1988]

280.67 Public participation.

(a) For each confirmed relesse that requires 2 comertive sction plen, the implementing esency must provide notice to the public by means designed to reach those members of the public directly affected by the release and the planned corrective action. This notice may nclude, but is not limited to, public notice in local newspapers, block advertisements, public service announce- ments, publication in a stato register, letters to individunal households, or personal contsets by field staff.

(b) The implememting agency must ensure that site release information and decision concerning the corrective action plan are mad available to the public for inspection upon request.

(c) Before approving a corrective action plan, the implementing agency may hold 2 public meeting to consider comments on the proposed corroctivo action plan if there is sufficient public interest, or for any other reason

(d) The implementing agency must give public notice that complies with paragraph (a) of this section if implementation of an approved corrective action plan does not achieve the extablished cleanup levels in the plan and termination of that plan is under consideration by the implementing agency.

[53 FR 37194, Sept 23, 1988]

\section{Subpart G-Out-of-Service UST} Systems and Closure

\subsection{Temporary closure.}

(a) When an UST system is temporarily closed, owners and operators must comtinue operation and maintenance of corrosion protection in accordance with 280.31 , and any release detection in accondance with Subpart $D$. Subparts $E$ and $F$ must be complied with if a release is suspected or confirmed. However, relesse detection is not required es long ss the UST system is empty. The UST system is empty when all materials have been removed using commonly employed practices so that no more than 2.3 centimeters (one inch) of residue, or 0.3 percent by weight of the total capacity of the UST system, remain in the system.

(b) When an UST system is temporarily closed for 3 month or more, owners and operators must also comply with the following requirements:

(1) Leave vent lines open and functioning:
(2) Cap and secure all other lines, pumps, manways, and ancillary equipment

(c) When an UST system is temporarily closed for more than 12 months, owners and operator must permanently close the UST operalo must permanently close the UST system if it does not meet either performance standards in 280.20 for new UsT systems or the upgrading requirements in 280.21 , except that the spill and overfill equipment requirements do not have to be met. Owners and operators must permanently close the substandard UST syotems at the end of this 12-month period in accordance with 280.71-280.74, unless the implementing agency provides an extension of the 12 -month temporary closure period. Owners and operators must complete site assessmert in accordance with 280.72 before such an extension can be applied for.

[53 FR 37194, Seph. 23, 1988]

\subsection{Permanent closure and} changes-iñ-service.

(a) At least 30 days before beginning either permanent closure or a change-in-service under paragraphs (b) and (c) of this section, or within mother ressomable time period delermined by the implemente the implems the must notify the inplementing agency of intent to permanently close or make the chango-in- rervice, untess such action is in response to corrective action. The required assessment of the excavation zone under 280.72 must be performed after notifying the implementing agency but before completion of the permanent closure or a change-in-service.

(b) To permanently close a tank, owners and operators must empty and clean it by removing ill liquids and accumulated sludges. All tanks laken out of service permanently must also be either removed from the ground or filled with on inert solid material.

(c) Continued use of an UST system to store a non-regulated substance is considered a change-in-service. Before a change-in-service, owners and operators must empry and clean the owners and operators must empty and clean the sludge and conduct a site assessment in sludge and conduct a site as

Note: The following cleming and closure prooodure may be used to comply with this soction:
(A) American Petroleum Institute Recommended Practice 1604, Removal and Disposal of Used Underground Petroleum Storage Tanks;

(B) American Petroleum Institute Publication 2015, Cleaning Petroleum Storage Tanks:

(C) American Petroleum Institute Recommended Practice 1631, Imterior Lining of Underground Slorage Tanks, may be used as guidance for compliance with this section; and

(D) The National Institute for Occupational Safety and Health Criteria for a Recommended Standard - * Working in Confined Space may be used as guidance for conducting safe closure procedures at some hazardous substance tanks. [53 FR 37194, Sept 23, 1988]

\subsection{Assessing the site at closure} or change-in-service.

(a) Before permanemt clonure or a change-in-service is completed, owners and operators must measure for the presence of a release where contamination is most likely to be present at the UST site. In selecting sample types, acmple locations and messurement types, sample locations, and measurement methods, owners and operators must consider the method of closure, the nature of the stored substance, the type of backnth, the depth to ground water, and other factors appropriate for identifying the presence of a release. The requirements of this section are satisfied if one of the external release detection methods allowed in $280.43(\mathrm{e})$ and ( $($ ) is operating in accordance with the requirements in 280.43 at the time of closure, and indicates no release has occurred.

(b) If contaminated soils, contaminated ground waler, or free product as a liquid or vapor is discovered under paragraph (a) of this section, or by any other manner, owners and operators must begin corrective action in accordance with Subpart $F$.

[S3 FR 37194, Sepl 23, 1988]

\subsection{Applicability to previously} closed UST systems.

When directed by the implementing agency. the owner and operaitor of an UST system permanently closed before December 22, 1988 
must asess the excavation zone and close the UST rystem in scoordence with this Subpart if relesses from the UST may, in the judgment of the implementing asency pose a curent or polemisal threat to human beath and the exvirontent.

[S3 FR 37194, Scpe 23, 1988]

\subsection{Closure records.}

Oxners and operstors must meintain records in accord ance with 280.34 that are crpabte of demonstrating compliance with closure requirements under this Subpart. The results of the excavation zone assessment required in 280.72 must be maintained for 20 kest 3 yesrs efter completion of permanent chosure or change-in-service in one of the following ways:

(a) By the owners and operators who took the UST system out of service:

(b) By the current ormers and operators of the UST system site; or

(c) By mailing these reconts to the implementing agency if they cannol be maintained at the closed facility.

[Soure: 53 FR 43370, Ot 26, 1988, unless otherwise noted ]

\section{Subpart H-Financial Responsibility}

\subsection{Applicability.}

(a) This subpart applies to ourners and operators of all petroleum undereround storage tank (UST) systems except as oherwise provided in this section.

(b) Owners and operators of petroleum UST systems are subject to these require- ments if they are in operation on or afler the date for carpliance established in 280.91 .

(c) State and Federal government emtitics whose debts and liabilities are the debts and

1 Revised, 59 FR 9607. February 28, 1994

3 Added, 59 FR 9607 , Fetwuery 28,1994 liabilities of a state or the United States are exempt from the requirements of this subpart.

(d) The requirements of this subpart do not ppoly to owners and operators of any UST system described in 280.10 (b) or (c)

(c) If the owner and operator of a petroleum underground storage tank are separate persons, only one person is required to demonstrate financial responsibility; however, both partics are liable in event of nonompliance.

Regardless of which party complica, the date set for compliance at a particular facility is

determined by the characteristics of the owner

as set forth in 280.91 .

\section{[33 FR 43370, Oct 26, 1988}

\subsection{Compliance dates.}

Owners of petroleum underground storage tanks are required to comply with the requirements of this subpart by the following

(a) All petroleum marketing firms owning 1,000 or more USTs and all other UST owners that report a tangible net worth of $\$ 20$ million or more to the U.S. Securities and Exchange Commission (SEC), Dun and Bradstreet, the Energy Information Administration of the Rural Electrification Administration; January 24,1989 , except that compliance with $280.94(\mathrm{~b})$ is required by: July $24,1989$.

(b) All petroleum marketing firms owning 00-999 USTr; October 26, 1989.

(c) All petroleum marketing firms owning 1991.

(d) All petroleum UST owners nol described in paragraphs $(\mathrm{A}),(\mathrm{b})$, or (c) of this section, excluding local government entities: December 31, 1993.

(c) All local government emtities (including Indian tribes) not included in paragraph $(\Omega$ of this section; Februery 18, 1994.
2) (f) Indian tribes that own USTs on Indian lands which meet the applicable technical requirements of this part; December 31, 1998.

[53 FR, 43370, Oct. 26, 1988, as amendad at 54 FR 5452

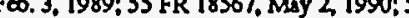
Oct. 31, 1990; 56 FR 66373, Doc. 23, 1991; 59 FR 9607 Fb. 28, 1994]

\subsection{Definition of terms.}

When used in this subpart, the following terms shall have the meanings given below:

"Accidental release" means any sudden or nonsudden release of petroleum from an underground storage tank that results in a need for corroctive action and/or compensa- tion for bodily injury or property damage neither expected nor intended by the tank owner or operator.

"Bodily injury" shall have the meaning given to this term by applicable state law; however, this term shall not include thooe liabilities which, consistent with stendard insurance industry practices, are excluded from coverage in liability insurance policies for bodily injury.

"Chief Financial Offices," in the case of local government owners and operators, mesns the individual with the overall authority and responsibility for the collection, disbursement, and use of funds by the local government

"Controlling interest" means direct ownership of at least 50 percent of the voting stock of another entity.

"Director of the Implementing Agency" mesess the EPA Regional Administrator, or, in the case of a state with a program approved under section 9004, the Director of the designated state or local agency responsible for carrying out an approved UST program.

"Financial reporting year" means the latest consecutive twelve-month period for which any of the following reports used to support financial test is prepared:

(1) a $10-K$ report submitted to the SEC
(2) an annual report of tangible net worth submitted to Dun and Bradstrect; or

(3) annual reports submitted to the EnerBy Information Administration or the Rural

Electrification Administration. "Financis reporting year" may thus comprise a fiscal or a calendar year period

"Legal defense cost" is any expense that an owner or operator or provider of financial assurance incurs in defending against claims or actions brought,

(1) By EPA or a state to require corrective action or to recover the costs of corrective

(2) By or on behalf of a thind party for bodily injury or property damage caused by an accidental release; or

(3) By any person to enforce the terms of a inancial assurance mechanism.

"Local governmem" shall have the meaning given this term by applicable state law and includes Indian tribes. The term is generally intended to include:

(l) Counties, municipalities, townships, separately chartered and operated special districts (including local government public transit systems and redevelopment authorities), and independent school districts authorized as governmental bodies by state charter or constitution; and

(2) Special districts and independent school distriets established by coumties, municipalities, townships, and other general purpose governments to provide essential services.

"Occurrence" means an accident, including continuous or repeated exposure to conditions, which results in a release from an underground storage tank.

Note: This definition is intended to assist in the understanding of these regulations and is not intendod either to lunit the meaning of occurrence in $a$ way tha conflids with standard insurance usage or to prevent the use of other standard insurance terms in place of occurrence. 
"Onter or operator," when the owner or operator are separate parties, refers to the pasty that is obtaining or has obtained financial sourances.

"Petroleum marketing facilities" include al facilities as which petroleurm is produced or refined and all facilities from which petroleum is sold or transferred to other petroleum merketers or to the public.

"Petroleurm marketing firms" are all firms ouning petroleum marketing facilities. Firms owning other types of facilities with USTB as well as petroleurn marketing facilities are considered to be petroleum marketing firms.

"Property darmage" shall have the meaning given this term by applicable state law. This term shall $n \alpha$ include those liabilities which, corsistert with standard insurance industry prectices, exe excluded from coverage in liability insurance policies for property damage. However, such exclusions for property damage shall not include corrective action essociated with releases from tanks which are covered by the policy.

"Provider of financill essurance" means an entity that provides financial assurance to an owrer or eperator of an underground storage tank through me of the mechanisms listed in 280.95-280.103, including a guarantor, insurer, risk retention group, surety, issuer of a letter of credith issuer of a statc-required mechanism, or a state.

"Substsntial business relationship" means the extent of a business relationship necessary under applicable state law to make a guarantec contrect issued incident to thet relationship valid and enforcestile. A guarumtec contract is issued incident to that relationahip if it arises from and depends on existing economic transections between the guarantor and the ormet or operator.

"Substantial governmental relationship" mears the extert of a governmental relationship mexns the extert of a governmental relacionship neveserny under applicable stare law to make relationship valid and enforceable. A guarantee relationship valid and enforceable. A guarantee centract is issued "incidem to that relationship in the event of an UIST relexse such $\mathrm{x}$ cererminous toundaries, overlapping constituenciex, common ground-water aquifer, or cther relationship other then monelasy compensation that provides a motivation for the guarantor to provide a guarantec.

"Tangible net worth" means the tangible assets that remain after deducting liabilities; such assets do not include intangibles such as goodwill and rights to patents or royalties. For purposes of this definition, assets means all existing and all probable future economic benefits obtained or controlled by a particular entity as a reault of pest transactions.

"Terminstion" under $\$ 280.97$ (b)(1) and § $280.97(\mathrm{~b})(2)$ means only those changes that could result in a gap in coverage 29 when the insured has not obxained substitute coverage or hus obseinad substitute coverage with a differem retranctive dale than the retrosctive date of the original policy.

[S3 FR 43370, Oct. 26, 1988, es amended at 54 FR 47081,

Nov. 9, 1989; 58 FR 9050, Feb. 18, 1993]

\subsection{Amount and scope of required financial responsibility.}

(a) Owners or operators of petroleum underground storage tanks must demonstrate financial responsibility for taking corrective action and for compensating third partics for bodily injury and property damage caused by accidental releases arising from the operation of petroleum underground storage tanks in at least the following per-occurrence amounts:

(1) For owners or operators of petroleum underground storage tanks that are located at petroleum marketing facilities, or that handle an average of more then 10,000 gallons of petroleum per month based on annual throughput for the previous calendar year, SI million.

(2) For all other owners or operators of petroleum underground storage lanks; $\$ 500,000$.

(b) Owners or operators of petroleum underground storage tanks must demonstrate financial responsibility for taking corrective action and for cormpensating thind parties for bodily injury and property dinnage caused by accidental releases arising from the operation of petroleum underground storago tnnks in at least the following annual aggregate amounts:
(1) For owners or operators of 1 to 100 petroleum underground storage tanks, $S 1$ million; and

(2) For owners or operators of 101 or more petroleum underground storage tanks, \$2 million.

(c) For the purposes of paragraphs (b) and (f) of this section, only, a petroleum underground storage tank means a single comtainment unit and does not mean combinations of single containment units.

(d) Except as provided in paragraph (c) of this section, if the owner or operator uses separate mechanisms or separate combinations of mechanisms to demonstrato financial responsibility for:

1) Taking corrective action:

(2) Compensating third parties for bodily injury and property damage caused by sudden accidental relcases; or

(3) Compenseting third parties for bodily injury and property damage causod by injury and property damage caused by nonsudden accidemal relesses, the amount of assurance provided by each mechanism or combination of mechanisms must be in the full this section.

(c) If an owner or operator uses separate mechanisms or separate combinations of

mechanisms to demonstrate financial responsibility for different petroleum underground storage tanks, the annual aggregate required shall be based on the number of tanks covered by each such separate mechanism or covered by each such separate

(f) Owners or operators shall review the amount of aggregate assurance provided whenever additional petroleum underground storage tanks are acquired or installed. If the number of petroleum underground storage tank for which assurance must be provided exceeds 100 , the owner or operator shall demonstrate financial responsibility in the amount of at least $\$ 2$ million of annual aggregate assurance by the anniversary of the date on which the mechanism demonstrating financial responsibjility become effective. If assurance is being demonstrated by a combination of mechanisms, the owner or a combination of mechanisms, the ow shall demonstrate financiel responsibility in the amoumt of at least $\$ 2$ million of annual aggregate assurance by the first-occurring effective date armiversary of any one of the mechanisms combined (other than a financial test or guarantec) to provide assurance. (g) The amounts of assurance required under this section exclude legal defense costs.

(h) The required per-occurrence and annual ageregate coverage amounts do not in any way limit the liability of the owner or operator.

[S3 FR 43370. Oct. 26, 1988]

280.94 Allowable mechanisms and combinations of mechanisms.

(a) Subject to the limilations of paragraptis (b) and (c) of this section,

(1) An owner or operator, including a local government owner or operalor, may use any one or combination of the mechanisms listed in Secs. 280.95 through 280.103 to demonstrate financial responsibility under this subpart for one or more underground storage tanks, and

(2) A local government owner or operator may use any one or combination of the mechanisms listed in $\$ \$ 280.104$ through 280.107 to demonstrate financial responsibility under this subpart for one or more underground storage tanks.

(b) An owner or operator may use a guarantee under Sec. 280.96 or surety bond under Sec. 280.98 to establish financial responsibility only if the Attomey(s) General of the state(s) in which the underground storage tanks are located has (have) submittod a written statement to the implementing agency that a guarantee or surety bond executed as described in this section is a legally valid and enforceable obligation in that state.

(c) An owner or operator may use self-insurance in combination with a guaranto only if, for the purpose of meeting the requirements of the financial test under this rule, the financial statements of the owner or operator are not consolidated with the financial statements of the guaramtor.

[53 FR 43370, OCt. 26. 1988, as amended at 58 FR 9051 . Feb. 18, 1993]

\subsection{Financial test of} self-insurance.

(a) An owner or operator, and/or guarantor, may salisfy the requirememts of 280.93 by 
pacing a freancial test as specified in this section. To pess the finencial test of self-insurence, the orner or operator, md/or gutrartion must meet the criteria of paragreph (b) or (c) of this section based on year-end finstivil statements for the latest completed fiscal year.

(b) $(1)$ The onter or operator, and/or guerantor, must have a tangible net worth of at leert ten times:

(i) The total of the applicable aggregate amoum required by 280.93 , based on the number of underground storage tanks for which a finmeisl test is used to demonstrate financial responsibility to EPA under this section or to a stete implementing asency under a state stagram atroved by EPA under 40 CFR Part 281:

(ii) The sum of the corrective setion cost etimster, the curremt closure and post-closure cere cost estimates, and amount of liability coverage for which a financial test is used to demonstrate financial responsibility to EPA under 40 CFR 264.101, 264.143, 264.145, $265.143,165.145,264.147$, and 265.147 or to 2 stute implementing agency under a state program arthorized by EPA under 40 CFR Part 271: and

(iii) The sum of current plugging and abendorment cost estimates for which a finmeial tert is used to demonstrate financial rexponsibility to EPA under 40 CFR 144.63 or to a state implementing agency under a state program authorized by EPA under 40 CFR Part 145.

(2) The ouner or operater, and/or gues=ner must have a tengible net worth of at least S10 million.

(3) The ouner or operator, and/or gunnant or must have a letter signed by the chief financial officer worded as specified in paragraph (d) of this section.

(4) The owner or operator, and/or guarantor, must either:

(i) File financial statements amusally with the U.S. Securitie and Exchange Commission the Energy Information Administration, or the Rurl Electrification Administration; or

(ii) Report anmually the firm's tengible net worth to Duen and Bradstreet, and Dun and Brot must have essigned the firm finencial strength rating of $4 \mathrm{~A}$ or $3 \mathrm{~A}$
(5) The firm's year-end financial statements, if independently audited, cannot include an sdverse auditor's opinion, a disclainer of opinion, or a going concem qualification

(c)(1) The owner or operator, and/or guarantor must meet the financial test requirements of 40 CFR 264.147(f)(1) substituting the appropriate amounts specified in Sec. 280.93 (b)(1) and (b)(2) for the amount of liability coverage each time specified in that section.

(2) The fiscal year-end financial stalements of the owner or operator, and/or guarantor, must to exernined by en independent certified public rocountant and be accompanied by the

(3) The firm's year-end financial statements cannot include an adverse auditor's opinion, a disclaime of opinion, or a going concern qualification.

(4) The owner or operator, and/or guarantor, must have a letter signed by the chief financial officer, worded as specified in paragraph (d) of this section.

(5) If the financial statements of the owner or operator, end/or guarantor, are not submitted entually to the U.S. Sccurities and Exchange Commission, the Energy Information Administration or the Rural Electrification Adrninistration, the owner or operator, and/or guarantor, must obtrin a special report by an independent certified public accountent stating that:

(i) He has compared the data that the letter form the chief financial officer specifics as

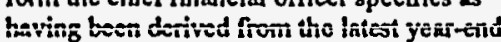
financial stalements of the owner or operator. and/or guarantor, with the amounts in such financial statements; and

(ii) In connection with that comparison, no matters came to his attention which caused him to believe that the apecified data should be adjusted.

(d) To demonstrate that it meets the financial test under paragraph (b) or (c) of this section, the chief financial officer of the owner or operator, or guerantor, must sign, within 120 days of the close of eact financial reporting year, as defined by the twelve- momth period for year, as defined by the twelve- momth period for
which financial statements used to support the which financial statements used to support exsctly as follows, except that the instructions in brackets are to be replaced by the relevant information and the brackets deleted:

\section{Letter from Chief Financial Officer}

I am the chicf financial officer of [insert: name and address of the owner or operator, or gumantor]. This letter is in support of the use of guarantor]. This letter is in support of the use [insert: the financial test of self-insurance, and/or guarantec] to demonstrate financial action and/or compensating third parties for bodily injury and property damage] caused by [insert: sudden accidental releases and/or nonsudden accidental releases] in the amount of af lenat [insert: dollar amount] per occurrence a lingert: dollar amount] annual aggrente arising from operating (an) underground storage tank(s).

Underground storage tanks at the following facilities are essured by this financial test or a financial test under an authorized State program by this [insert: owner or operator, and/or guarantor]: [List for each facility: the name and address of the facility where tanks assured by this financial test are located, and whether tanks are assured by this financial test or a financial test under 5 Ste program approved under 40 CFR Part 281. If separate mechanisms or combinations of mechanisms are being used to assure any of the tanks at this facility, list each assure any of the tanks at this facility, list each tank assured by this financial test or a financial test under a State program authorizod under 40 CFR Part 281 by the tank idemtification number to 40 CFP 280.22 or the correponding Stats requirements.]

A [insert: financial test, and/or guanantec] is also used by this [insert: owner or operator, or guarantor] to demonstrate evidence of financial responsibility in the following amounts under other EPA regulations or stare programs authorized by EPA under 40 CFR Parts 271 and 145:

$$
\text { EPA Regulations }
$$

Closure (264.143 and 265.143)........ \$ Post-Closure Care (264.145 and 265.145) ...................................... \$ Liability Coverage (264.147 and 5 Corrective Action [264.101(b)].......... 5 Plugging and Abandonmemt (144.63) s Closure

Post-Closure Care

Liability Coverage.

Cove............................... Plugging and Abandonment Total.

This [insert: owner or operator, or guarantor] has not receivod an adverse opinion, a disclaimer of opinion, or a going concem qualification from an independert auditor on his financial statements for the latest completed fiscal ycar.

[Fill in the information for Altemative $I$ if the criteria of paragraph (b) of 280.95 are being used to demonstrate compliance with the financial test requirements. Fill in the information for Alternative II if the criteria of paragraph (c) of 280.95 are being used to cemonsiraic compiiance with the rinanciai test requirements.] 
Alternative I

1. Amoura of enmial UST aggregrte coverage being assured by a financial test, 2. Amount of comective action, closure and post-ciosure care costs, liability covernga and plugging and abandonment costs covered by anancial teot, and'or guarantec...

3. Sum of lines 1 and 2 ....

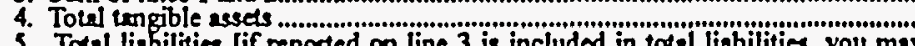

. Total liabilities [if reported on line 3 is included in total liabilities, you may deduct that mount from this line and add that amount to line 6] ..................... 6. Tengible net worth [subtract line 5 from line 4]

7. Is line 6 a least 510 million?

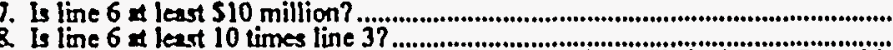

9. Have financial statements for the latest fiscal year been filod with the Securities

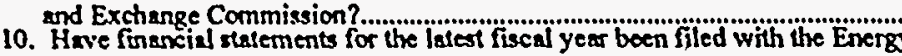
Information Adninistration?

11. Have fmanciv statements for the latest fiscal year been fild with the Rural

12. Hect finencial idformation been provided to Din and Bridstreet, and has Din and Bradstreel provided a fin ancial streng th enting of 4A or 5 A? [Answer "Yes" only if both criteria have been met.]

Alternativo II

1. Amount of annual UST aggregate coverage boing assured by 2 test, and/or

2 Amount of corrective action, closure and post-ciosure caro costs, tiability coverage and plugging and abandonment costs covered by a financial teot, and/or puaramtec.

3. Sum of lines 1 and 2 ....

4. Total tangible assets..... liabilities, you may deduct that amound from this line and add that amount to

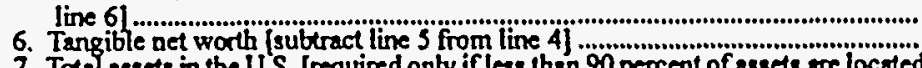
percent of asoets ure located in the U.S.]

8. Is line 6 leart $\$ 10$ million?.

io. Are at least 90 percent of sesets locatod in the U.S.? [if "No" compleic line 11. 11. line 7 a leart 6 times line 3 ?

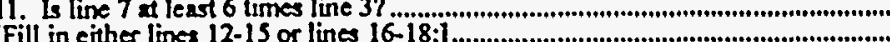

13. Current Rssets .

13. Nerert lisbilities.ition [subtract line i3 from line i2].

15. Is line 14 a leart 6 times line 3 ?

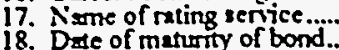

s

$s$

$\mathbf{s}$
$\mathbf{s}$
$\mathbf{s}$

s

Yes No

- -

$-$

-

$-$

$-$

s.

$\mathbf{s}$

\$

s

s

$s$

$s$

Yes No

- $=$

- -

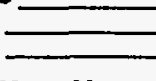

Yes No

- $=$

$= \pm$

19. Have financial statements for the latest fiscal year been filed with the SEC, the Energy Information Administration, or the Rural Electrification Administration?

IIf No, please attach a report from an independent certified public accountant certifying that there are no material differences between the data as reported in lines 4-18 above and the financial statements for the latest fiscal year.]

[For both Altemative I and Afternative II complete the certification with this statement.]

I hereby certify that the wording of this letter is identical to the wording specified in $\mathbf{4 0}$ CFR Part 280.95(d) as such regulations were constituted on the date shown immediately below.

[Signature]

[Name]

[Title]

Date]

(c) If an owner or operator using the test to provide financial assurance finds that he or she no longer meets the requirements of the financial test based on the year-end financial statements, the owner or operator must obtain altemative coverage within 150 days of the end of the year for which financial statements have been prepared.

(f) The Director of the implementing agency may require reports of financial condition at any time from the owner or operator, and/or

guarantor. If the Director finds, on the basis of such reports or other information, that the owner or operator, and/or guarantor, no longer meets the financial test requirements of 280.95 (b) or (c) and (d), the owner or operator must obtain altemate coverage within 30 days after notification of such $\mathrm{a}$ finding.

(g) If the owner or operator fails to obtain alternate assurance within 150 days of finding that he or she no longer meets the requirements of the financial lest based on the year-end financial statements, or within 30 days of notification by the Director of the implementing agency that he or she no longer meets the requirements of the financial test, the owner or operator must notify the Director of such failure within 10 days.
[53 FR 43370, Oct 26, 1988]

\subsection{Guarantee.}

(a) An owner or operator may satisfy the requirements of 280.93 by obtaining a guarantec that conforms to the requirements of this section. The guarantor must be:

(1) A firm that (i) possesses a controlling interest in the owner or operator, (ii) possesses a controlling imterest in a firm described under paragraph (a)(1)(i) of this section; or, (iii) is controlled through stock ownership by a common parent firm that possesses a controlling interest in the owner or operator, or,

(2) A firm engaged in a substantial business relationship with the owner or operator and issuing the guarantee as an act incident to that business relationship.

(b) Within 120 days of the close of each financial reporting year the guarantor mus ienionstrate that it meets the financial test criteria of 280.95 based on year-end financial statements for the latest completed financial reporting year by completing the letter from the chief financial officer described in 280.95 (d) and must deliver the letter to the owner or operator. If the guarantor fails to meet the requirements of the financial test at the end of any financial reporting year, within 120 days of the end of that financial reporting year the guarantor shall send by certified mail, before cancellation or nonrencwal of the guarantee, notice to the owner or operator. If the Director of the implementing agency notifies the guarantor that he no longer meets the requirements of the financial test of 280.95 (b) or (c) and (d), the guarantor must notify the owner or operator within 10 days of receiving such notification from the Director. In both cases, the guarantoe will terminate no less than 120 days afler the date the owner or operator receives the notification, as evidenced by the return receiph. The owner or operator must obtain aftemative coverage as apecified in 280.110 (c).

(c) The guarantee must be worded as follows, except that instructions in brackets are 
to be replaced with the relevant information and the brackets deleted:

\section{Guarantee}

Guarantee made this [date] by [name of guranteeing entity], a business entity organized under the laws of the state of [name of state]. herein refered to ss guarantor, to [the state implementing agency) and to any and all third farties, and obligees, on behalf of [owner or operator] of [business eddress].

Recitals.

(1) Guerser or meets or exceeds the financial lest criteria of 40 CFR 280.95 (b) or (c) and (d) end ecrees to comply with the requirements for guterutors es specified in 40 CFR 280.96 (b)

(2) [Orwiser or operator] owts or operates the following underground storage tank(s) covered by this guarantee: [List the number of tenbs at each facility and the name(s) and address(es) of the facility(ies) where the tanks are focated If more than one instrument is used to essure different tanka al any one facility, for exch tank covered by this instrument, list the tank identificetion mumber provided in the noxification sutomitted pursuant to 40 CFR 280.22 or the corres- ponding state requirement, and the name and address of the facility.] This guarartee satisfies 40 CFR Part 280. Subpart requirements for assuring funding for [insert: requirements for assuring funding for [insert: third parties for bodily injury and property third parties for bodily injury and property damage caused by cither sudden accidental releses or nonsudden accidental releases or accidental relesses; if coverage is different for coverese splicable to esch tank or location erising from coerating the stove-identified underesound storage tank( $(x)$ in the amount of [insert dolles amount] per occurtence and [insert dollar mount] amual aggregate.

(3) [Insert appropriate phrase: On betualf of our suthidingy (if gunorantor is corporate paren of the owtet or cperator): On trefinalf of our effiliate (if guasentor is a related firm of the ownet cr (operafor); or Incident to our business reletionship with (if guaranlor is providing the guaraxtee es en incidem to a substantiad buriness relationship with ouner or operator)] [owner or cperator]. guarantor guarantees to [implementing agency] and to any and all third parties thet:

In the event that [owner or operator] fails to provide alternative coverage within 60 days after receipt of a notice of cancellation of this guarantece and the [Director of the implementing agency] has determinad or suspects that a release has occurred at an underground storago release has occurred at an underground storago upon instructions from the [Director], shall fund 2 standby trust fund in accordance with the provisions of $40 \mathrm{CFR} 280.108$, in an amount not to excoed the covernge limits specified above. In the event that the [Director] determines that [owner or operalor] has failed to perform corrective action for relesses arising out of the operation of the above-identified tank(s) in eccordance with 40 CFR Part 280, Subpart F, the guarantor upon written instructions from the [Director] shall find a standby trust in eccordance with the provisions of $40 \mathrm{CFR}$ 280.108, in an amount not to exceed tho coverage limits specifiod above.

If [owner or operalor] fails to satisfy a judgment or award based on a determination of liability for bodily injury or property damage to thind parties caused by [ sudden and/or hind partes caused sccidental neleses aring from the nonsudden] sccicder releases anising from the operaion of the above-identified tank(s), or fails to pay an amount agroed to in settlement
2 claim erising from or alleged to arise from such injury or damage, the guaramtor, upon written instructions from the [Director], shall fund $a$ standby trust in accordance with the provisions of 40 CFR 280.108 to eatisfy such jud grment(a), awned(s), or settlement ereement( $s$ ) up to the limits of coverage specified above.

(1) Guarantor agrees that if, at the end of any fiscal year before cancellation of this guarmitec, the guarantor frils to meet the financial test crileriz of 40 CFR 280.95 (b) or (c) and (d), guarmtor shall send within 120 dnye of such failure, by centified mail, notice to [owner or operator]. The guarantee will terminate 120 days from the date of receipt of the nolice by [owner or operator], es evidenoed by the return receiph.

(3) Ouerantor agrees to notify [owner or operator] by certified mail of a voluntary or involumary proceeding under Title 11 (Bankruptcy), U.S. Code naming guarantor as debtor, within 10 days after commence- ment of the proceeding.

(ด) Guarantor agrees to remain bound under this gusantee notwithstanding any modification or alteration of any obligation of [owner or operator] pursuant to 40 CFR Part 280.

(7) Guarantor agrees to remain bound under (7) Guarantor agrees to remain bound under this guarantec for 80 long as [owner or operald
must comply with the applicable fin ancial responsibility requirements of 40 CFR Part 280 Subpart $H$ for the above-identified tank(B), except that guarantor may cancel this guarantec by sending notice by certified mail to lowner or operator], such cancellation to become effective no carlier than 120 days after receipt of iuch notice by [owner or operator], as evidenced by the return receipt

(8) The guarantor's obligation does not apply to any of the following:

(a) Any obligation of [insert owner or operator] under a workers' compensation, disability benefrts, or unemployment compensation law or other similar law;

(b) Bodily injury to an employee of [insert owner or operalor] arising from, and in the course of, employment by [insert owner or operator];

(c) Bodily injury or property damage arising from the ownership, maintenance, use, or entrustment to others of any aircraft, motor vehicle, or watercraft;

(d) Property damage to any property owned rented, loaded to, in the care, custody, or contro of, or occupied by [insert owner or operator] that is not the direct result of a release from a petroleum indengresnd stersese turter;

(c) Bodily damage or property damage for which [insert owner or operat or] is obligated to pay damages by reason of the assumplion of
liability in a contract or agreememt other than a contract or agreement entered into to meet the requirements of 40 CFR 280.93 .

(9) Guarantor expressly waives notice of acceptance of this guarantee by (the implementing agency], by any or all third parties, or by [owner or operalor].

Ihereby certify that the wording of this gutaranlec is idemical to the wording specified in 40 CFR 280.96(c) as such regulations were constituted on the effective date shown immediately below. Effective date:
[Name of guarantor]

[Authorized signature for guaramtor]

[Name of person signing]

[Title of person signing]

Signature of witness or nolary:

(d) An owner or operator who uses a guaramee to satisfy the requirements of Sec. 280.93 must establish a standby trust fund when the guarantec is obtained. Under the terms of the guarantec, all amounis paid by the guarantor under the guarantee will be deposited directly into the standby trust fund in accordance with instructions from the Director of the implementing agency under 280.108 . This standby trust fund must meet the requirements specified in 280.103 .

[53 FR 43370, Oct. 26, 1988]

280.97 Insurance and risk retention group coverage.

(a) An owner or operator may satisfy the requirements of 290.93 by obtaining liability insurance that conforms to the requirements of this section from a qualified insurer or risk retemtion group. Such insurance may be in the form of a separate insurance policy or an endorsement to an existing insurance policy.

(b) Each insurance policy must be amended by an endorsement worded as specified in paragraph (b)(1) of this section, or evidenced by a certificate of insurance worded as specified in paragraph (b)(2) of this soction, except that inetnutione in breskets must be seplaced with the relevam information and the brackets deleted:

(1) Endorsement

Name: [name of each covered location]

Address: [address of each covered location]

Policy Number

Period of Coverage: [current policy period]

Name of [Insuret or Risk Retemtion Oroup]: 
Address of [Insuret or Risk Retention Oroup]:

Name of Insured:

\section{Address of Insured:}

Endorsement:

1. This endorsement certifies that the policy to atich the endorsement is attached provides lisbility insusence covering the following undenground storage tenks:

(Lint the number of tanks at each facility and the name(s) and address(es) of the facility(ies) instrument is ued to assure different tanks at eny one facility, for each tank covered by this instrument, list the tenk identification number provided in the notification submitted pursuara to 40 CFR 280.22, or the corresponding state require ment and the name and address of the facility.]

for linsert: taking corrective sction and/or compensating third partice for bodily injury and property damage caused by either sudden property damage ceused by either sudden accidental relesses or nonsudden sccidental relezes or accidental relesses; if coverage is the type of covernge applicable to each tank or location] ariaing from operating the underground norage tank(s) identified above.

The limits of liability we linsert the dollar moumt of the exch occurrence and annus! escregate limits of the Insuret's or Oroup's lisbility, if the amount of coverage is different for difierent types of coverage or for different underground storage lenks or locations, indicate the emount of coverage for each type of coverage and/or for each undenground slorage tenk or location]. exclusive of legal defense carts. This coverage is provided under [policy numiter]. The effective date of said policy is [dase].

3. The insurance affonded with respect to such mecurrences is subject to all of the tarms and emditions of the policy. provided. however, that any provisions inconsistent with subections (a) through (c) of this Paragreph 2 are hereby amended to conform with

subsections (a) through (e):

2. Bankruptcy or insolvency of the insured shall not relieve the [Insurer or Oroup] of its obligations under the policy to which this

b. The [Insuret or Oroup] is liable for the payment of amounts within any deductible applicable to the policy to the provider of corrective action or a damaged third-party, with - right of reimbursement by the insured for any such payment made by the [Insurer or Group] This provision does not apply with respect to that amount of any deductible for which coverage is demonstraled under another mechanism or combination of mechanisma as machanism or combination of mechanist $c$. Whenever requerted by [a Director of an implementing agency], the [Insurer or Group] agrees to furnish to [the Director] a signed duplicate original of the policy and all endorsements.

d. Cancellation or any other termination of the insurance by the [Insurer or Group] will be effective only upon written notice and only after the expiration of 60 days after copy of such written notice is received by the insured.

written notice is received by the insured.
[Insert for claims-made policies:

[Insert for claims-made policies: c. The insurance covers claims for any
occurrence that commencod during the term of the policy that is discoverod and reported to the [ Insurer or Group] within six months of the effective date of the cancellation or termination of the policy.]

\section{I hereby certify that the wording of this} instrument is identical to the wording in $40 \mathrm{CFR}$ 280.97(b) (1) and that the [ Insurer or Oroup] is [licensed to transact the business of insurance or eligible to provide insurance as an excess or surplus lines insuret in one or more states].

[Signature of authorized representative of Insurer or Risk Retertion Group

Name of person signing

[Ti!". of person signingl, Authorized

Representative of [name of Insurer or Risk Representative of

[Address of Representative]

(2) Certificate of Insurance

Name: [name of each covered location]
Address: [address of each coverod location]

Policy Number:

Endorsement (if applicable)

Period of Coverage: [current policy period]

Name of [Insurer or Risk Retention Group]:

Address of [Insurer or Risk Retention Oroup]:

Name of Insured:

Address of Insured:

Certification:

1. [Name of Insurer or Risk Retemtion Group], [the Insurer or Group], as identified abovo, hereby certifies that it has issued liability insurance covering the following underground storage tank(a):

(List the number of tanks at each facility and the name(s) and address(es) of the facility(ies) where the tanks are localed. If more than ono instrument is used to assure different tank at any ono facility, for each tank covered by this instrument, list the tank identification number provided in the notification submitted pursuant to 40 CFR 280.22 , or the corresponding state requiremem, and the name and address of the facility.] for [insert: taking corrective action and/or compensating third parties for bodily injury and property damage caused by either sudden ccidental releases or nonsudden accidental releases or accidental releases; if coverage is different for different tanks or locations, indicato the type of coverage applicable to each tank or location] arising from operating the underground storage tank(s) identified above.

The limits of liability are [insert the dollar smount of the exch occurrence and annual aggregate limits of the Insurer's or Group's liability; if the amount of coverage is differem for differemt types of coverage or for different underground storage tanks or locations, indicate the amount of coverage for each type of coverage and/or for each underground storage lank or location], exclusive of legal defense costs. This coverage is provided under [policy number]. The effective date of said policy is [date].

2. The [Insurer or Oroup] further certifies the following with respect to the insurance described in Paragraph 1 :

2. Bankruptcy or insolvency of the insured shall not relieve the [Insurer or Oroup] of its obligations under the policy to which this certificate applies.

b. The [Insurer or Group] is liable for the payment of amounts within any deductible applicable to the policy to the provider of corrective action or a damaged third-party, with a right of reimbursement by the insured for any such payment made by the [Insurer or Group] This provision does not apply with respect to that amount of any deductible for which coverage is demonstraled under another mechanism or combination of mochanisms as specified in 40 CFR 280.95-280.102.

c. Whenever requested by [a Director of an implementing agency], the [Insuret or Oroup] agrees to fumish to [the Director] a signed duplicate original of the policy and all endorsememts.

d. Cancellation or any other termination of the insurance by the [Insurer or Oroup] will be effective only upon written notice and only after the expiration of 60 days after a copy of auch written notice is received by the insured

[Insert for claims-made policies:

e. The insurance covers claims for any occurrence that commenced during the term of the policy that is discovered and reported to the [ Insurer or Oroup] within six months of the effective date of the cancellation or other termination of the policy.]

I hereby certify that the wording of thi instrument is identical to the wording in $40 \mathrm{CFR}$ $280.97(b)(2)$ and that the [Insurer or Group] is [ licensed to transact the business of insurance, or eligible to provide insurance as an excess or surplus lines insurer, in one or more states].

[Signature of authorized representative of Insurer] [Type name]

Title]. Authorized Represemtative of [name of Insurer or Risk Retention Group

Address of Represemtative] 
(c) Esch insurance policy must be issued by on insure or 2 risk retertion grourp that, it a minimum, is licensed to transact the business of inorare or elipite to provide in excess or suplus lines insurer in one or more excess or

[S3 FR 43370, Oct 26, 1988, \& amended at S4 FR 47081. Nov. 9.1959]

\subsection{Surety bond.}

(a) An orner or operator may satisfy the requirements of 280.93 by obtaining a surety bond thet conforms to the requirements of this section. The surety compreny issuing the bond murt be ammg thoee listed as roceptable sureties on federal bonds in the latest Circular 370 of the U.S. Depertmert of the Tressury.

(b) The surety bond must be worded 2 follows, except that instructions in brackets must be replaced with the relevent information and the trackets deleted

\section{Performance Bond}

Date bond executed

Period of colerage:

Priscipal: [legal name and business address of outmer or operator]

Type of organization: [insert individual, joint venture, partnership, or corporation]

State of incorporation (if appliceble):

Surety(ies): [name(s) and businees address(es)]

Scope of Coverage: [List the mumber of tanks at each facility and the mame(s) and address(es) of the facility(ies) witere the tanks are localed. If mere than one instrument is used to assure more than one instrument is used to assure covered by this instrument, list the tank covered by this instrument, list the sank sutrritted pursuant to 40 CFR 280.22 or the sutrritted pursuant to 40 CFR 280.22 or the correspondens state requiretivent and the name and address of the facility. Lint the coverage guaranteed by the bond: taking corrective action and/or compensaling third parties for bodily injury and property damage caused by either sudden accidental relesses or nonsudden accidental releases or accidental relesses arising from operating the underground storage tank]. Penal sums of bond:

Per occurrence 5

Annual ageregate $\$$

Know All Persons by These Presents, that we, the Principal and Surety(iex) hereto are firmly bound to [the implementing agency], in the above penal sums for the payment of which we bind ourselves, our heirs, executors, administrators, successors, and assigns jointly and severally, providod that, where tho and severally, providod thent, where tho Surety(ies) are corporations acting as
co-sureties, we, the Sureties, bind ourselves in co-sureties, we, the Sureties, bind ourselves in
such sums jointly and severally only for the purpose of allowing a joint action or actions agninst any or all of us, and for all other purposes each Surety binds itself, jointly and severally with the Principal, for the payment of such sums only as is set forth opposite the name of such Surety, but if no limit of liability is indicated, the limit of liability shall be the full amount of the penel sums.

Whereas said Mrincipal is required under Subtitle I of the Resource Conservation and Recovery Act (RCRA), as amended, to provide financial assurance for [insert: taking corrective action and/or compense- ting third parties for bodily injury and property damage caused by either sudden accidemtal releases or nonsudden accidental releases or accidental releases; if

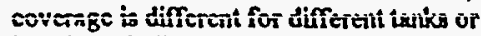
locations, indicale the typo of coverago applicable to cach tank or location] arising from operating the underground storage tanks identified above, and

Whereas said Principal shall establish a standby trust fund as is required when a surety bond is used to provide such financial assurance; Now, therefore, the conditions of the obligation are such that if the Principal shall Faithrully [take corrective action, in accordance with 40 CFR Part 280 . Subpart $F$ and the Director of the stato implementing agency's instructions for, and/or compensate injured instructions for, end/or compensate injured
thind parties for bodily injury and property damage caused by either sudden or nonsudden or sudden and nonsudden] accidemal releases arising from operating the tank(s) identified sbove, or if the Principal shall provide alternate financial assurance, as specified in 40 CFR Part 280 , Subpart $\mathrm{H}$, within 120 days after the date the notice of cancellation is received by the Principal from the Surety(ies), then this Principal from the Surety(ies), then this to remain in full force and effect.

Such obligation does nol apply to any of the following:

(a) Any obligation of [insert owner or operator] under $\&$ workers' compensation, disability benefits, or unemployment compensation law or other similar law,

(b) Bodily injury to an employee of [insert owner or operator] arising from, and in the course of, employment by [insert owner or operator];

(c) Bodily injury or property damage arising from the ownership, maintenance, use, or cntrustment to others of any aircran, motor vehicle, or watereraf:

(d) Property damage to any property owned rented, loaned to, in the care, custody, or control of, or occupied by [insert owner or operator] that is not the direct result of a release from a petroleum undenground storage tank;

(c) Bodily injury or property damage for which [insert owner or operator] is obligatod to pay damages by reason of the assumption of liability in a contract or agreement other than a contract or agreement entered into to meet the requirements of 40 CFR 280.93.

The Surety(ies) shall become liable on this bond obligation only when the Principal has failex to furfiti the conditions described xiove.

Upon notification by [the Director of the implementing agency] that the Principal has failed to [ take corrective action, in acoondano with 40 CFR Part 280, Subpart F and the Director's instructions, and/or compensate injured third parties] as guaranteed by this bond, the Surety(ics) shall either perform [corrective action in accordanco with 40 CFR Part 280 and tho Director's instructions, and/or third-party liability compens ationl or place funds in an mount up to tho annual ageregete peni aum into the openthy truat fund as dinected by ince 40 CFR 280.108 .

Upon nification by (the Director] that the Upon notification by [the Director] the
Principal has failed to provide altemate financial assurance within 60 days anter the date the notice of cancellation is received by the Principal from the Surety(ies) and that [the Director] has determined or suspects that a release has oocurred, the Surety(ies) shall place funds in an amount not exceeding the annual ageregate penal sum into the standby trust fund as directed by [the Diroctor] under $40 \mathrm{CFR}$ 280.108.

The Surety(ies) hereby waive(s) notification of amendments to applicable laws, staturtes, rules, and regulations and agrees that no such amendment shall in any way alleviate its (their) obligation on this bond:

The liability of the Surety(ies) shall no be discharged by any paymem or succession of paymerts hereunder, unless and until such payment or payments shall amount in the annual aggregate to the penal sum shown on the face of the bond, but in no evert shall the obligation of the Surety(ies) hereunder exceed The Surety(ies) may cancel the bond by ending notice of cancellation by certified mail to the Principal, provided, however, that cancellation shall not occur during the 120 days beginning on the date of receipt of the notice of cancellation by the Principal, as evidenced by the return receipt.

The Principal may terminate this bond by sending written notice to the Surety(ies).

In Witness Thereof, the Principal and Surety(ies) have executed this Bond and have affixed the ir seals on the date set forth above.

The persons whose signatures appear below hereby certify that they are authorized to exocute this surety bond on behalf of the Principal and Surety(ies) and that the wording of this surety bond is idemtical to the wording specified in 40 CFR 280.98 (b) as such regulations were constituted on the date this bond was executed.

Principal

[Signature(s)]

[Namen $(n)$ ]

[Title(s)]

[Corporate seal]

Corporate Surety(les)

[Name and addreas]

[Liability limit: $\$$ 
[Sigleture(s)]

[Names(s) and titio(s)]

[Corporate seal]

[For every co-surety, provide signature(s), corporate seal, and other information in the seme mannet as for Surety above.]

Bond preminum: $S$

(c) Under the terms of the bond, the strety will become liable on the bond obligation when the ouner or operator frils to perform as guarumeed by the bond In all caser, the surety's lisbility is limited to the per-occurrence and annusel eqgregate penal sums.

(d) The owner or operitor who uses a surety tond to entisfy the requirements of 280.93 must extablish a standby trust fund when the surety bond is scquired Under the terms of the bond, all amounts paid by the surety undea the bond will be deposited directly into the standby trust fund in accordance with instructions from the Director under 280.108 This standby trust fund must meet the requirements specified in 280.103.

[33 FR 43370, Oct 26, 1988]

\subsection{Letter of credit.}

(a) An owner or operator may satisfy the requirements of 280.93 by obtaining an irrevocable standby letter of credit that

conforms to the requirements of this section.

The issuing institution must be an entity that has the authority to issue letters of credit in each state where used and whose letter-of-credit operations are regulaled and exemined by a federal or state agency.

(b) The letter of credit must be worded as followx, except that instructions in brackets are to te replaced with the relevent information and the trackets deleted.

\section{Irrevocable Standby Letter of} Credit

Niame and address of issuing institution] [Name and address of Director(s) of state impiementing egency(ies)]

Dear Sir or MIadum: We hereby establish cur Irrevacentle Stendby Letier of Credit No. ar in sccount of [owner or operalor name) of [address] up to the aggregate armount of [in words] U.S. dollars (S[insert dollar amoumt]) available upon presentation [insert, if more than one Director of a state implementing agency is beneficiary, by any one of you] of

(1) your sight draft, bearing reference to this letter of credit, No. $\longrightarrow$ and

(2) your signed statement reading as follows: I certify that the amount of the draft is payable pursuant to regulations issued under authority of Subtitle I of the Resource Conservation and Recovery Act of 1976, as amended.

This letter of credit may be drawn on to cover linsert: laking corrective action andlor compensating third partics for bodily injury and property damage caused by either sudden accidental releases or nonsudden accidental releases or accidertal releases] arising from operaling the underground storage $\operatorname{tank}(B)$ identified below in the amount of [in wortls] wonds] S[insert dollar anount] arnual aggregste. [List the number of tanks at each facility and the name(s) and address(es) of the facility(ies) where the tanks are located. If more facility(ies) where the tanks are located. If more
than one instrument is used to nssure different than one instrument is used to nssure differemt by this instrument, list the tank identification by this instrument, list the tank identification
number provided in the notification submitted number provided in the notification
pursuant to $40 \mathrm{CFR} 280.22$, or the pursuant to 40 CFR 280.22 , or the and address of the facility.]

The letter of credit may not be drawn on to cover any of the following:

(2) Any obligation of finsert owner or operator] under a workers' compensation, disability benefits, or unemploymem

(b) Bodily injury to an employee of [insert owner or operator] arising from, and in the course of, employment by [insert owner or operator];

(c) Bodily injury or property damage arising from the ownership, maintenance, use, or entrustment to others of any aircran, motor vehicle, or watercrant.

(d) Property damage to mny property owned, remted, lanned to, in the care, custody, or cont of, or occupied by [insert owner or operator]
that is not the direct result of a release from a petroleum underground storage tank; (c) Bodily injury or property damage for which [insert owner or operator] is obligated to pay damages by reason of the assumption of liability in a contract or agreement other than a contract or agreement entered into to meet the requirements of 40 CFR 280.93 .

This letter of credit is effective as of [date] and shall expire on [date], but such expiration date shall be automatically extended for a period of [at least the length of the original term] on [expiration dats? and on each successive expiration date, unless, at least 120 days before the current expiration date, we notify [owner or operator] by certified mail that notify [owner or operator] by certified mail we have decided not to extend this letter of credit beyond the curremt expiration date. In the event that [owner or operator] is so notified, any unused portion of the credit shall be available upon presentation of your sight draft for 120 days after the date of receipt by [owner or operator], as shown on the signed return reccipt.

Whenever this letter of credit is drawn on under and in compliance with the terms of this credit, we shall duly honor such draft upon presentation to us, and we shall deposit the amount of the draft directly into the standby trust fund of [owner or operator] in sccordance with your instructions.

We certify that the wording of this letter of credit is identical to the wording specified in 40 CFR 280.99(b) as such regulations wero constitured on the date shown immediately below.

[Signature(s) and title(s) of official(s) of issuing

institution]

This credit is subject to [insert the most recent odition of the Uniform Customs and Practioe for Documentary Credits, published by the International Chamber of Commerce, or the Uniform Commercial Code].

(c) An owner or operator who uses a letter of credit to satisfy the requirements of 280.93 must also cotablish a standby trust fund when the letter of credit is acquired. Under the terms of the letter of credit, all amounts paid pursuant to a draft by the Director of the implementing agency will be deposited by the issuing institution directly into the standby trust fund in institution directly into the standby trust fund in ander 280.108. This standby trust fund must meet the requirements specified in 280.103 . (d) The letter of credit must be irrevocable with a term specified by the issuing institution. The letter of credit must provide that credit be automatically renewed for the same lerm as the original term, unless, at least 120 danys before the current expiration date, the issuing institution notifies the owner or operator by certified mail of its decision no to renew the letter of crodit. Under the terms of the letter of credit, the 120 days will begin on the date when the owner or operator receives the notice, as evidenced by the retum receipt.

[S3 FR 43370, OA. 26, 1988]

\subsection{Use of state-required} mechanism.

(a) For underground storage tanks localed in a state that does not have an approved program. and where the state requires owners or operators of underground storage tanks to demonstrale financial responsibility for taking corrective setion and/or for compensating third parties for bodily injury and property damage. an owner or operator may use a state-required finincial mechenism to mect the requiremems financial mechanism to mect the require
of 280.93 if the Regional Administrator determines that the state mechanism is at least equivalent to the financial mechanisms specified in this subpart.

(b) Tho Regional Administrator will evaluate the equivalency of a state-required mechanism principally in terms of: certainty of the availability of funds for taking corrective action and/or for compensating third parties; the amount of funds that will be made available; and the types of costs covered. The Region Administrator may also consider other factors as is necessary.

(c) The state, an owner or operator, or any other interested party may submit to the Regional Administrator a written petition requesting that one or more of the state-required mechanisms be considered acceptable for meeting the requirements of 280.93 . The submission must include copies of the appropriate state statutory and regulatory requirements and must show the amount of funds for corrective action and/or for compensating third parties assured by uhe mechanism(s). The Regional Administrator may require the petitioner to submit additional 
information ss is deemed necessery to make this determinetion.

(d) Any petition under this section may be submitted on behalf of all of the state's

underground storage tank owmers end operator.

(c) The Regional Administrator will notify the petitioner of his determination reganding the mechanism's acceptability in lieu of finsncial mechanisms specified in this subpart. Pending this determination, the owners end operators using such mochmisms will be deemed to be in compliance with the requirements of 280.93 for underground storage tunka loceted in the state for the amounts and types of costs covered by such mecturenissns.

[53 FR 43370 , Ott 26, 1988, as amended at 53 FR 51274. Dec. 21, 1988]

\subsection{State fund or other state} assurance.

(a) An owner or operator may satisfy the requirements of 280.93 for underground storage tariks locted in a state, where EPA is

administering the requirements of this subpart, which assures that monies will be available frem a state fund or state sesurance program to cover coots up to the limits specified in 280.93 or oherwise assures that such costs will be paid if the Regional Administrator determines that the rate's sasurance is at leart equivalent to the frnancisl mechanisms specified in this subpart.

(b) The Regional Administrat or will evaluse the equivalency of a state fund or other state essurance principally in terms of: Certainty of the aveilability of funds for taking corrective action and/or for compensating third parties; the amourx of funds thas will be made available; and the types of costs covered. The Regional Administrator may also consider other fectors $2 s$ is necessery.

(c) The state must rubmit to the Regional Administrator a description of the state fund or other state eesurance to be supplied as financial essurance, along with $a$ list of the classes of underground storage tenks to which the funds may be applied. The Regional Administralor may require the stre to sutwrit additional information $2 s$ is deemed necessary to make 2 decrmination regerding the meeperability of the stute fund or other stale ecsurance. Fending the determinstion by the Regional Administrator the owner or operator of a coverod class of USTs will be deemed to be in compliance with the requirements of 280.93 for the amounts and types of costs covered by the state fund or other (d) assurance.

(d) The Regional Administrator will notify the state of his determination reganding the ecceptability of the state's fund or other assurance in lieu of financial mechanisms specified in this subpart. Within 60 days after the Regional Adninistrator notifies a stato that a state fund or other state sssuranco is sceptable, the stato must provide to each owner or operator for which it is assurning financial responsibility a letter or certificalo describing the nature of the state's assumption of responsibility. The letter or certificate from the state must include, or have atheched to in the stlo mint inclised the following information. the facility's name and addions and the emount of funds for corrective is assured by the state. The owner or operator is sssured by the state. The owner or operator must maintain this letter or certificate on file as with $280.107(\mathrm{~b} \times(5)$

[53 FR 43370, Oct, 26, 1988]

\subsection{Trust fund.}

(a) An owner or operator may satisfy the requirements of 280.93 by establishing a trust fund that conforms to the requiremems of this section. The trustee must be an entity that has the authority to act es a trustec and whose trust operations are regulated and examined by a federal agency or men agency of the state in which the fund is established.

(b) The wording of the trust agreement must be identical to the wording specified in

$280.103(\mathrm{~b})(1)$, and must be sccompanied by 2 formal certification of acknowledgement as specified in $280.103(b)(2)$

(c) The trust fund, when established, must be funded for the full required amount of coverage, or funded for part of the required amount of coverage and used in combination with other mechanism(s) that provide the remsining required coverage.

(d) If the value of the trust fund is greater than the required amount of coverage, the owner or operator may submit a written request to the Director of the implementing agency for release of the excess.

(c) If other financial sesurance as specified in this subpart is substituted for all or part of the trust fund, the owner or operator may submit a written request to the Director of the

implementing agency for release of the excess.

(f) Within 60 days afler receiving a request from the owner or operator for release of funds as specified in paragraph (d) or (c) of this section, the Director of the implementing agency will instruct the trustee to release to the owner ox operator such finds as the Director specifies in writing.

[33 FR 13370, Oct 26, 1988]

\subsection{Standby trust fund.}

(a) An owner or operator using any one of the mechanisms authorized by $280.96,280.98$ or 280.99 must establish a standby trust fund when the mechanism is acquired. The trustec of the standby trust fund must be an entity that has the standby trust fund must be an entity that has the authority to act as a trustec and whose trust operations are regulated and examined by a Federal agency or an agency of
which the fund is cstablishod.

(b)(1) The atandby trust agreememt, or trust agreement, must be worded as follows, except that instructions in brackets are to be replaced with the relevant information and the brackéts deleted:

\section{Trust Agreement}

Trust sgreement, the Agreement, entered into as of [date] by and between [name of the owner or operalor], a [name of state] [insert corporation, partrership, sssociation, or proprietorship], the Grantor, and [name of corporate trustec], [insert incorporated in the tate of - or a national bank], the Trustec.

Whereas, the United States Environmental Prolection Agency, EPA, an agency of the United States Governmem, has established certain regulations spplicable to the Orantor, requiring that an owner or operator of an requiring that an owner or operator of an
underground storage tank shall provide underground storage tank shall provide needed for corrective action and third-party compensation for bodily injury and property damage caused by sudden and nonsudden accidemal releases arising from the operation of the underground storage tank. The attached Schedule $A$ lists the number of tanks at each facility and the name(s) and address(es) of the facility(ies) where the tanks are located that are covered by the standby trust agreement

[Whereas, the Grantor has elected to establish [insert cither a guarantce, surety bond, or letter of credit] to provide all or part of such financial assurance for the underground storage tanks identified herein and is required to establish a standby trust fund able to accept payments from the instrument (This paragraph is only applicable to the standby trust agreement.)];

Whereas, the Grantor, acting through its duly authorized officers, has selected the Trustec to be the trustee under this agreement, and the Trustoe is willing to set as trustee;

Now, therefore, the Orantor and the Trustce agree as follows:

\section{Section 1. Definitions}

As used in this Agreement:

(a) The term Orantor means the owner or operator who emters into this Agreement and any successors or assigns of the Grantor.

(b) The term Trustee means the Trustce who enters into this Agreement and any successor Trustec.

Section 2. Identification of the Financial Assurance Mechanism.

This Agreement pertains to the [identify the financial essurance mechanism, either a guaranice, surety bond, or letter of credit, from which the stand by trust find is established to receive payments (This paragraph is only applicable to the standby trust agreement.)].

Section 3. Establishment of Fund.

The Orantor and the Trustec hereby establish a trust fund, the Fund, for the benefrt of [implemerting agency]. The Orantor and the Trustec intend that no third party have access to the Fund except as herein provided. (The Fund is cotablished initially as a standby to receive payments and shall not consist of any property.] Payments made by the provider of financint aserurance puraune to the Director of the implementing agency's] instruction are transferred to the Trustee and are referred to as 
the Fund together with all earnings and profits thereon, less any payments or distributions made by the Trustoe pursuant to this Agreement. The Fund shall be held by the Trustee, IN TRUST, as hereinafler provided. The Trustoe ahall not be responsible nor shall it underiake any responsibility for the amount or adequacy of, nor eny duty to collect from the Gramtor as provider of financial assurance, any Famor as provider of financial essurance, any payments nocessery to discharge any
the Orantor extabliahed by (the state implementing agency].

Section 4. Porment for [Corrective Action and 'or Third Party Liability Claims"].

The Trustec shall make payments from the Fund es lthe Director of the implememtin egency] shall direct, in writing, to provide for the payment of the coots of [insert: taking corrective action and/or compensating thisd perties for bodily injury and property damage crused ty" either sudden sccidental releases or nensudden accidental relesses or sccidental releses] arising from operating the tanks covered by the financial assurance mechanism identified in this Agreement.

The Fund may nol be drawn upon to cover any of the following:

(a) Any obligution of [insert owner or operator] under a workers' compensation, disability benefits, or unemployment compensation law or other similas law,

(b) Bodily injury to an employee of [insert onner or operator] arising from, and in the course of employment by linsert owner or crenter]:

(c) Bodity injury or propenty damnge arising from the ownership. mrintenance, use, or entrusument to whers of any sirctaft, motor thicle or watercraft

(d) Property damige to any property owned, rerted, lowned to, in the care, custody, or control of. or ceccpied by [insert owner or operafor] thas is not the direct resuh of a relesse from proteum undenground storage tenk.

(e) Bodily injury or property damage for which [insert oumer or operater] is obligated to pay domages by resen of the sesumption of lisbility in a contrat or a greemenl nther than a centract or agreement entered into to mest the minact or agreemem enlered ist
The Trustee shall reimburse the Grantor, or other persons as specified by [the Director] from the Fund for corrective action

expenditures and/or thint-party liability claims in such amounts as [the Director] shall direct in writing. In addition, the Trusto shall refund to the Orantor such amounts as [the Director] specifies in writing. Upon refund, such funds specifies in writing. Upon refund, such funds defined herein.

Section 5. Payments Comprising the Fund

Payments made to the Trustee for the Fund shall consist of cash and securities acceptable to the Trustee.

Section 6. Trustee Management.

The Trustee shall invest and reinvest the principal and income of the Fund and keep the Fund invested as a single fund, without distinetion between principal and income, in 2000 dance with general investment policies and guidelines which the Oramtor may communicate in writing to the Trustee from time to time, subject, however, to the provisions of this Section. In investing, reinvesting. exchanging selling and managing the Fund, the Trustee shall discharge his dutics with respect to the trust find solely in the interest of the beneficiaries and with the care, skill. prudence, and diligence under the circumstances then prevailing which persons of prudence, scting in a like capacity and familiar with such matters, would use in the conduct of an enterprise of a like character and with like aims; except that:

(i) Securities or other obligations of the Gramtor, or any other owner or operator of the tanks, or eny of their affiliates as defined in the Investment Company Act of 1940, as amended is U.S.C. $80 \mathrm{a}-2$ (a), thall not be acquired or 15 U.S.C. $80 \mathrm{~m}-2(\mathrm{a})$, shall not be acquired or
held, unless they ere securities or other obligations of the federal or a state government; (ii) The Trustee is authorized to invest the Fund in time or demand deposits of the Trustee to the extent insured by en agency of the federal or state government; and

(iii) The Trunlec is suthorized to hold cash sweiting investment or distribution uninvested for a reasonable time and without linbility for the payment of interest thereon.
Section 7. Commingling and Invesiment The Trustee is expressly authorized in its discretion:

(a) To transfer from time to time any or all of the assets of the Fund to any common, commingled, or collective trust fund created by the Trustee in which the Fund is eligible to participate, subject to all of the provisions thereof, to be commingled with the assets of other trusts participating therein; and

(b) To purchase shares in any investment company registered under the Investment Company Act of 1940, 15 U.S.C. $80 \mathrm{a}-1$ et seq. including one which may be created, managed, undenwritten, or to which investment advice is rendered or the shares of which are sold by the Trustee. The Trustee may vote such shares in its discretion.

Section 8. Express Powers of Trustee

Without in any way limiting the powers and discretions conferred upon the Trustee by the other provisions of this Agreement or by law, the Trustee is expressly authorized and empowered:

(a) To sell, exchange, convey, transfer, or otherwise dispose of any property held by it, by public or private sale. No person dealing with the Trustee shall be bound to see to the mplication of tho purchase money or to inquire into the validity or expediency of any such sale or other disposition:

(b) To make, execule, acknowledge, and deliver any and all documents of transfer and conveyance and any and all other instruments that may be necessary or appropriale to carry out the powers herein granted

(c) To register any securities held in the Fund in its own name or in the name of a nominee and to hold any security in bearer form or in book entry, or to combine certificates representing such securities with certificates of the same issue held by the Trustee in other the same issue held by the Trustce in other fiduciary capacities, or to deposit or arrange for the deposit of such securities in a qualified central depository even though, when so held in bulk in the name of the nominee of such depository with other securities deposited there in by mother person, or to deposit or arrange for the deposit of any securities issued by the Unitod States Government, or any agency or instrumentality there of, with : Federal Reserve bank, but the books and records of the Trustee shall at all times show that all such securities are part of the Fund;

(d) To deposit any cash in the Fund in

interest-bearing accounts maintained or saving certificates issued by the Trustee, in its separnte corporate capacity, or in any other banking institution affiliated with the Trestec, to the extent insured by an agency of the federal or state government; and

(e) To compromise or otherwise adjust all claims in favor of or against the Fund.

Section 9. Taxes and Expense.

All taxes of any kind that may be assessed or levied against or in respect of the Fund and all brokerage commissions incurred by the Fund shall be paid from the Fund. All other expenses incurred by the Trustec in connection with the administration of this Trust, including fees for legal services rendered to the Trustoc, the compensation of the Trustee to the extent not paid directly by the Grantor, and all other proper charges and disbursements of the Trustec shall be paid from the Fund.

Section 10. Advice of Counsel

The Trustee may from time to time consult with counsel, who may be counsel to the Orantor, with respect to any questions arising as to the construction of this Agreemert or any action to be taken hereunder. The Trustec shal be fully protected, to the extent permitted by law, in acting upon the advice of counsel.

Section 11. Trustee Compensation

The Trustee shall be entitled to reasonable compensation for its services as a greed upon in writing from time to time with the Orantor.

Section 12. Successor Trustee

The Trustec may resign or the Gramtor may replace the Tinatec, but such resignation or replacement shall not be effective until the Orantor has appointed a succensor trustee and this success or sccepts the appointment. The successor triatee shall have the same powers and duties as those conferred upon the Truatec hereunder. Upon the successor trustec's acceptance of the appointment, the Trustec shall 
sosign, trensfor, md pay over to the successor truster the funds and properties then constituring the Fund. If for any reason the Grantor cumot or does not act in the event of the resignation of the Truster, the Trustee may sply to a court of competent jurisdiction for the appointment of a successor trustee or for instructions. The suceasor trustee shall specify the date on which it assumes sdministration of the date on which it assumes sdministration of present Trustoc by certified meil 10 days before such change becomes effective. Any expenses incurred by the Trustee 25 a result of amy of the acts cootemplated by this Section shall be paid ss provided in Section 9.

Section 13. Instructions to the Trustee.

All onders, requeste, ind instructions by the Oraxt or to the Trustee shall be in writing. sigoed by such perrons as are designaled in the attsached Schectule B or such other designees as the Orantor may designete by amendmerx to Schedule B. The Thuste ahall be fully prolected in ecting without inquiry in accondence with the Orentor 's onders, requestes, and instruction. Al ordere, requeste, and instructions by (the Director of the implementing 2 gency] to the Trustee atall be in writing, signed by (the Director]. and the Thustee shall act and ishall be fully prolected in acting in accordance with such orders, requests, and instructions. The Trustee shall have the right to essume, in the absence of written notice to the contrary, that no event constituting a chenge or 2 terminstion of the arthority of any person to act on behalf of the Orantor or [the director] hereunder hes occurred. The Trustee shall have no duty to act in the absence of such onders, requests, and instructions from the Orentor and/or [the

Director), except as provided for herein.

Section 14. Amendment of Agreement

This Agreement may be amended by an instrument in writing executed by the Orantor and the Trustee, or by the Trustec and [ the Directer of the implementing agency] if the Orestor cesess to exist.

Secrion 15. Imenocability and Termination Subjoct to the right of the partics to amend this Aereement es provided in Section 14, this Trust shall be irrevocable and shall comtinue until terminated at the written direction of the Gramtor and the Trustec, or by the Trustee and [the Director of the implementing agency], if the Grantor ceases to exist. Upon termination of the Trush all remaining trut property lese final thest administration expenses, shall bo delliv to the Grantor.

Section 16. Immunity and Indemnification

The Thustec shall not incur personal liability of any nature in connection with any act or omission, made in good frith, in the edministration of this Trust, or in carrying out any directions by the Grantor or [the Director of the implementing agency] issued in accondence with this Agrecenent. The Trustee shall bo indemified and saved hemless by tho Orantor from the the Trustee may be subjected by reason of any act or conduct in its official capacity, including all expenses ressonably incurred in its defense in the event the Orantor fails to provido such defenre.

Section 17. Choice of Law

This Agreement shall be administered, construed, and enforoed according to tho laws of the state of [insert name of state], or the Comptroller of the Currency in the case of National Association banks.

\section{Section 18. Interpretation}

As used in this Agreement, words in the singular include the plural and words in the plural include the singular. The descriptive headings for each section of this Agreement shall not affect the interpretation or the legal efficacy of this Agreement.

In Witness where of the parties have caused this Agreement to be executed by their respective officers duly authorized and their corporate seals (if applicable) to be hereunto affixed and attested as of the date first above written. The parties below certify that the wording of this Agreement is identical to the wonding specified in 40 CFR 280.103(b)(1) as such regulations were constituted on the date written above.

[Signature of Grantor]

[Name of the Orantor]

[Title]
Attest:
[Signature of Trustee]

Name of the Trustee]

[Title]

Seal]

Name of the Witness]

[Title]

(2) The standby trust agreement, or trist accompanied by a formal certification of acknowledgement similar to the following. Stato requirements may differ on the proper content of this acknowledgment.

Stalo of

County of

On this [dade], before me personaliy came [owner or operator] to me known, who, being by me duly swom, did depose and say that the/he resides at [address], that she/he is [title] of [corporation], the corporation described in of [corporation], the corporation described in and which executed the above instrument; that the/ho knows the seal of said corporation; that the seal affixed to such instrument is such corporate seal; that it was so affixed by order of that the he signed her/his name thereto by like order.

[Signature of Notary Public]

[Name of Notary Public]

(c) The Director of the implementing agency will instruct the trustee to refund the balance of the standby trust fund to the provider of financial assurance if the Director determines that no additional corrective action costs or thind-party liability claims will occur as a result

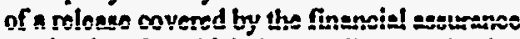
mechanism for which the standby trust fund wes ertablished.

(d) An owner or operator may establish one trust fund as the depository mectianism for all funds assured in compliance with this rule.

[S3 FR 43370, Oct 26, 1988, as amended at S3 FR 51274, Doc. 21, 1988]

\subsection{Local government bond rating test.}

(a) A general purpose local government owner or operator end/or local governmen serving as a guaramtor may satisfy the requirements of $\S 280.93$ by having a currently outstanding issue or issues of general obligation bonds of $\$ 1$ million or more, excluding refunded obligations, with a Moody's rating of Ass, As, A, or Bas, or a Standard \& Poor's rating of AAA, AA, A or BBB. Where a locel governent has multiple outstending issues, or goverm where a local government's bonds are rated by lowest rating must be used to determine eligibility. Bonds that are backed by credi enhancement other than municipal bond insurance may not be considered in deternining the amount of applicable bonds outstanding.

(b) A local government owner or opertitor or local government serving as a guaramor that is not a general-purpose local government and does not have the legal authority to issuce general obligation bonds may satisfy the requirements of $\S 280.93$ by having a curremtly outstanding issue or issues of revenue bonds of S1 million or more, excluding refunded issues and by also having a Mooty's rating of Aas, $A$ $A$, or Baa, or a Standard \& Poor's rating of $A A A, A A, A$, or $B B B$ as the lowest rating for any rated revenue bond issued by the local government. Where bonds are rated by both Moody's and Standard \& Poor's, the lower rating for each bond must be used to determine cligibility. Bonds that are backod by credit enancent may not be considered in determining the amount of applicable bonds outstanding

(c) The local government owner or operator and/or guarantor must maintain a copy of its bond rating published within the lart 12 monthes by Moody's or Standard \& Poor's.

(d) To demoñuate that it miceis ture local government bond rating test, the chief financia officer of a general purpose local government owner or operator and/or guarantor must sign a letter worded exactly as follows, except that the instructions in brackets are to be replaced by the relevant information and the brackets deleted:

\section{Letter from Chief Financial Onicer}

I am the chicf financial officer of [insert: name and address of local govermment owner or operator, or guarantorl. This letter is in support of the use of the bond rating teat to demonstrate financial responsibility for linsert: "Lnking corrective action" and/or "compensating third parties for bodily injury and property damage"] 
crused by [insert: "sudden socidental relesses" end'or "nonsudden accidental releases"] in the amount of at lesst [insert: doller amourn] per occurreace and [insert: dollar emourx] ennual aggregate arising from operating (an)

underground storage tank(s).

Underground storage tanks at the following facilitics are sesured by this bond rating test: [List for each facility: the name and address of the faxility utrere tanks are assured by the bond rating lest].

\begin{tabular}{|c|c|c|c|c|}
\hline Iesue date & Maturity date & Outstanding smount & Bond rating & Rating agency \\
\hline & & & & $\begin{array}{c}\text { [Moody's or } \\
\text { Standard \& Poor's] }\end{array}$ \\
\hline
\end{tabular}

The tokal outrtending obligation of [insert emount]. excluding refunded bond issues, exeents the minimum umount of SI million. All outrtanding Beneral obligation bonds issued by this goverrment that have been rated by Moody's or Standend \& Poor's are rated as at lesst investment grade (Moody's Bes or Standand \& Poor's BBB) based on the mort recent ratings published within the last 12 months. Neither rating service hes provided notification within the last 12 months of doungrading of bond ratings below investment gade or of withdrawal of bond rating other than for repsymerx of outstanding bond issues. I hereby certify that the wording of this letter is identical to the wording specified in 40 CFR P 280.104 (d) as such regulations were constituted on the date shown immediately below.

[Date]

[Signature]

[Name]

[Trume]

(c) To demorstrate that it meets the local sorement bond rating lest, the chicf financial officer of kesl government ohner or operator and'or guaremtor cher then a general purpose coiemrnent must sign a keter worded exactly as follows, exceps that the instructions in brackets are to be replaced by the relevart information and the brackets deleted:
The details of the issue date, maturity, outstanding amount, bond rating, and bond rating agency of all outstanding bond issues that are being used by [name of local government owner or operator, or guarantor] to demonstrate financial responsibility are as follows: [complete table] Standard \& Poor'

I am the chief financial officer of finsert: operator, or guarentor]. This letter is in support of the use of the bond rating lest to demonstrate financial responsibility for linsert: "taking financial responsibility for [insert: "taking corrective action" and/or "compensating thind
parties for bodily injury and property damage" caused by [insert : "sudden accidental releases" and/or "nonsudden accidental relesses"] in the amount of at least [insert: dollar amount] per occurrence and [insert: dollar amount] annual asgregate arising from operating (an) aggregate arising from operaing (an) govermment is not organized to provide general government is nol organized to provide general
governmemal services and does not have the governmemal services and does not have the
legal authority under state law or constitutional provisions to issue general obligation debt.

Underground storage tanks at the following facilities are assured by this bond rating test: [List for esch facility: the name and address of the facility where tanks ere assured by the bond rating tert].

The details of the issue date, maturity, outstanding amount, bond rating, and bond rating agency of all outstanding revenue bond issuxes that are being used by [namo of local government owner or operator, or guarantor] to demonstrate financial responsibility are as follows: [complete table]

\section{Letter from Chief Financial Officer} name and address of local government owner or

\begin{tabular}{|c|c|c|c|c|}
\hline Lssue date & Maturity date & Outstanding amount & Bond rating & Rating agency \\
\hline & & & & $\begin{array}{c}\text { [Moody's or } \\
\text { Standard \& Poor's }\end{array}$ \\
\hline
\end{tabular}

The total outstanding obligation of [insert amount], excluding refunded bond issues, exceeds the minimum amount of S1 million. Al outstending revenue bonds issued by this government that have been rated by Moody's or Standard \& Poor's are rated as at least investment grade (Moody's Bas or Standard \& Poor's BBB) based on the most recent natings published within the last 12 monthe revemue bonds listed are not backed by third-party crodit enhancement or are insured by a municipal bond insurance company. Neither rating service has provided notification withi the last 12 months of downgrading of bond ratings below investment grade or of withdrawal of bond rating other than for repayment of outstanding bond issues.

I hereby certify that the wording of this letter is identical to the wording specified in 40 CFR Part 280.104(e) ws such regulations were constituted on the dato shown immediately below.

[Date]

[Name]

Title]

(f) The Director of the implementing agency may require reports of financial condition at any timo from the local govemment owner or operator, and/or local government guarantor. If the Director finds, on the basis of such reports or other information, that the local government owner or operator, and/or guarantor, no longer meets the local government bond rating test requirements of $\$ 280.104$, the local government owner or operator must obtain alternative coverage within 30 days after notification of such a finding.

(8) If a local government owner or operator using the bond rating test to provide financial assurance finds that it no longer meets the bond rating test sequirements, the local government owner or operator must obtain alternative coverage within 150 days of the change in status.
[58 FR 9053, Feb. 18, 1993]

280.105 Local government financial test.

(a) A local government owner or operator may satisfy the requirements of $\$ 280.93$ by passing the financial test apocified in this soction. To be eligiblo to use the financial test, the local government owner or operator must have the ability and authority to assess and levy taxes or to freely establish fees and charges. To pass the local government financial test, the owner or operator must meet the criterin of paragraphs (b) (2) and (b)(3) of this section based on year-end financial statements for the atest completed fiscal year.

(b)(1) The local government owner or operalor must have the following information available, as shown in the year-end financial statements for the latest completed fiscal year:

(i) Total revenues: Consists of the sum of general fund operating and non-operating revenues including net local taxes, licenses and permits, fines and forfeitures, revenues from use of money and property, charges for services, investment carnings, sales (property, publications, etc.), intergovernmental revenues (reatricted and unrestricted), and total revenues from all other governmental funds including enterprise, debt service, capital projocts, and special revenues, but excluding revenues to funds held in a trust or agency capacity. For purposes of this test, the calculation of total revenues shall exclude all transfers between funds under the direct control of the local governmemt using the financial test (interfund transfers), liquidation of investmems, and suance of debt.

(ii) Total expenditures: Consists of the sum of general fund operaling and non-oper ating expenditures including public safety, public utilities, transportation, public works, environmental protection, cuhtural and 
recreationsal, commuruity development, revenue sharing employee benefits and compersation. office management, plaming and zoning. cespital projects, interest paymezts on debh payments for retirement of debt principal, and tolal expenditures from all other governmental funds including enterprise, debt service, capital funds including enterprise, debt service, capital projects, and special revepues. For purposes of this lest, the calculation of total expenditures shall exchude all transfers between funds under the direct control of the local governm

(iii) Local revenues: Consists of tod revenues (as defined in paragreph $(b)(1)(i)$ of this section) minus the sum of all trensfers from other govermmentel entities, including all monies received from Federal, rtate, or local monies received from

(iv) Deb retvice: Consists of the sum of all interest and principal payments on all long-term credit obligations and all interest-bearing short-term crodit obligations. Inchudes interest and principal payments on general obligation bonds, revenue bonds, noder, mortgapes, judgments, end interest beering werents.

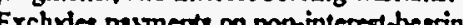
short-term obligetions, imerfind obligations shert-tem obligations, imterfend obligations, emouns owed in a trum or agency capacity, 2 governments

(v) Total funds: Consists of the sum of cash and investment recurrities from all funds, including general, enterprise, debt service, capital projects, and special revenue funds, but excluding employee retirement funds, at the end of the !onol governmex's Inenciel reportins vear. Includes Foderal socurities, Federal gency securities, stute and local govermment securities, and other securities such as bonds. nodes and mortgages. For purposes of this test noles and mortgeges. For purposes of this test the calculation of total finds shall exclude agency funds, private trust finds, accounts non-security assets.

(vi) Population consists of the number of mprie in the ares served by the locel government.

(2) The focel government's year-end frnancial ststements, if independemty audited, cence include $m$ adverse auditor's opinion or 2 disclaimer of cpirion. The locel govemment carrmed have outstending issues of general
Obligation or revenue bonds that are rated as less than invertment grade.

(3) The local government owner or operator must have a letter signed by the chief financial officer wonded as specified in paragraph $(c)$ of this section.

(c) To demonstrate that it meets the financial test under paragraph (b) of this section, the chief financial officer of the local government owner or operator, must sign, within 120 days of the close of each financial reporting year, as defined by the twelve-month period for which finencial statements used to support tho finamial teat are prepered a letter worded exactly as follows, except that the . instructions in brackets are to be replaced by the instructions in brackets are to be replaced by the
relevart information and the brackets deleled:

\section{Letter From Chief Financial Officer}

I am the chief financial officer of [insert: name and address of the owner or operator]. This letter is in support of the use of the local government financial test to demonstrate financial responsibility for [insert: "taking corrective action" and/or "compensating third parties for bodily injury and property damage"] caused by linsert: "sudden sccidental releases" and/or "nonsudden accidental relesses"] in the amount of at least [ineert: dollar amount] per amrount of at least [insert. dollar amoum] per ageregate arising from operating [an] underground storage tank [s].

Underground storage tanks at the following facilities are assured by this financial test [List for ench facility: the nume and addrese of the facility where tanks assured by this financial test are localed. If separate mechanisms or combinations of mechanisme are being used to cossure any of the tanks at this facility, list tank assured by this financial test by the tank identification number provided in the
notification submitted pursuant to $40 \mathrm{CFR}$ Part 280.22 or the corresponding state requirements. This owner or operator has not roceived an adverse opinion, or a disclaimer of opinion from an independent auditor on its financial statements for the latest completed fiscal year. Any outstanding issues of general obligation or revenue bonds, if rated, have a Moody's rating of Ase, An A or Bas or a Stand and and Poor's rating of $A A A, A A, A$, or $B B B$; if rated by both firms, the bonds have a Moody's rating of Ass, As, A, or Bas and a Standard and Poor's rating of AAA, AA, A, or BBB.

\section{Worksheet for Municipal Financlal Test}

\section{Part I: Basic Information}

\section{Total Revenuses}

2. Revenues (dollars)

Value of revenues excludes liquidation of investmemts and issuance of debt. Value includes all general fund operating and non-operating revenues, as well as all revenues from all other governmental funds including enterprise, debt service, capital projects, and special revenues, but excluding revenues to funds held in 2 trust or agency capacity.

b. Subtract interfund transfers

(dollars)

$$
\text { c. Total Revenues (dollars) }
$$

2. Total Expenditures

2. Expenditures (dollara)

Value consists of the sum of general fund operating and non-operating expenditures including interest payments on debt, payments for retirement of debt principal, and total expenditures from all other governmental funds including enterprise, debt service, capital

projects, and special revenues.

b. Subtract interfund transfers (dollars)

$$
\text { c. Totai Expenditures (doilars) }
$$

3. Local Revenues

a. Total Revenues (from 1c) (dollars)

b. Subtract total intergovernmental transfers (dollars)

c. Local Revenues (dollars)

4. Debt Service

a Imerest and fiscal charges (dollars)

b. Add debt retirement (dollars)

c. Total Debt Service (dollars)

5. Total Funds (Doliars)

$$
\text { (Sum of amounts heid es cash and }
$$

investmemt securities from all funds, excluding

omounts held for employee retirement funds,

agency funds, and trust funds)

Population (Persons)

Part II: Application of Test
7. Total Revenues to Population . Total Revenues (from lc) b. Population (from 6 ) c. Divide $7 \mathrm{a}$ by $7 \mathrm{~b}$ Divide by 5,212 f. Multiply by 4.095

8. Total Expenses to Population a. Total Expenses (from 2c) b. Population (from 6) c. Divide $8 \mathrm{a}$ by $8 \mathrm{~b}$

d. Subtract 524

c. Divide by 5,401 f. Muttiply by 4.095

9. Local Revenues to Total Revenue a. Local Revenues (from 3c)

b. Total Revenues (from lc)

c. Divide $9 \mathrm{a}$ by $9 \mathrm{~b}$

d. Subtract 695 f. Multiply by 2.840

10. Debt Service to Population a. Debt Service (from 4d)

b. Population (from 6)

c. Divide 10a by $10 \mathrm{~b}$

d. Subtract 51

Divide by $1, \overline{038}$

C. Multiply by $-1.8 \overline{66}$

11. Debt Service to Total Revenues

Debt Service (from 4d)

b. Total Revenues (from Ic)

c. Divide lla by $11 \mathrm{~b}$

d. Subtract 068

c. Divide by .259

C. Multiply by $-3 . \overline{533}$

12. Total Revenues to Total Expenses

a. Total Revenues (from Ic)

b. Total Expenses (from 2c)

c. Divide 12a by 12

Subtract 910

. Divide by .899

f. Muttiply by $3.4 \overline{58}$

13. Funds Balance to Todal Revenues

. Total Funds (from 5)

b. Total Revenues (from 1c)

c. Divide $13 \mathrm{a}$ by $13 \mathrm{~b}$

d. Subtract .891

c. Divide by $9.1 \overline{56}$

f. Multiply by 3.270

14. Funds Balanee to Totsl Expenses

a. Total Funds (from 5 )

b. Total Expenses (from 2c) 
c. Divide 14 by 146

d. Subtract 866

e. Divide by 6.409

f. Multiply by 3.270

15. Totsl Funds to Population

2. Total Funds (from 5)

b. Population (from 6 )

c. Divide $15 \mathrm{a}$ by $15 \mathrm{~b}$

d. Sustract 270

e. Divide by $4.5 \overline{48}$

f. Mulipily by 1.856

16. Add $7 f+8 f+9 f+10 f+11 f+12 f+13 f+14 f$ $+15 f+4.937$

I hereby ortify that the financial index shown on line 16 of the workaheet is greater than zero and thel the wonding of this letter is identical to the woording specified in 40 CFR $P$ or 280.105 (c) es ruch regulations were constituted on the date shown inmedintely below.

[Date]

[Signature]

Name

[Title]

(d) If a local government oumer or operato using the teat to provide financial assurance finds that it no longer meets the requirememts of the financial test based on the year-end financial ststements, the owner or operator must obxain efternative coverage within 150 days of the end of the year for which financial statements have been prepered.

(e) The Director of the implementing agency may require reports of financial condition an any time from the local government owner or operator. If the Director finds, on the basis of such reports or other information, that the local govemment ownet or operator no fonger meets the financial test requirements of $\S$ 280.105 (b) and (c) the ouner or opertor obtain stemse coverage within 30 days after nodification of such a finding.

(D) If the local governmem owner or cperator fails to obtain attemate sksurance within 150 doys of finding that it no longer mects the requirements of the financial test hased on the jear-end financial statements or within 30 days of notification by the Director of the inflementing agency that it no longer meets the requirements of the financial test, the oumer or cpertitor must notify the Director of such failure within 10 days.
[58 FR 9054, Feb. 18, 1993]

\subsection{Local government guarantee.}

(a) A local government owner or operator may satisfy the requirements of $\S 280.93$ by obtaining a guarartec that conforms to the requirements of this section. The guarantor must be either the state in which the local government owner or operator is located or a local government having a "substantial governmental relationship" with the owner and operator and issuing the gunarartec as an act incident to that relationship. $\Lambda$ local government acting the guarentor must:

(1) demonstrate that it meets the bond rating test requirement of $\$ 280.104$ and deliver copy of the chief financial officer's letter 2 contained in $\$ 280.104$ (c) to the local

government owner.or operator, or

(2) demonstrate that it meets the workshoet test requirements of $\$ 280.105$ and deliver 2 copy of the chief financial officer's letter as contuined in $\$ 280.105$ (c) to the local sovernment owner or operator, or

(3) demonstrate that it meets the locel government find requirements of $\$ 280.107$ (a) $\$ 280.107(b)$, or $\$ 280.107$ (c) and deliver copy of the chief financial officer's letter as contained in $\S 280.107$ to the local government owner or operator.

(b) If the local government gursantor is unable to demonstrate financial assurance under any of $\S 280.104,280.103,280.107(\mathrm{a})$, $280.107(\mathrm{~b})$, or 280.107 (c), at the end of the $280.107(\mathrm{~b})$, or $280.107(\mathrm{c})$, at the end of the
financial reporting year, the guaramtor shall send financial reporting year, the guaramtor she non-renewal of the guarantec, notice to the owner or operator. The guarantee will terminate no less than 120 days after the date the owner or operator receives the notification, as evidenced by the retum receipt. The ownet or operator must obtain alternative coverage as specified in $\S 280.114(c)$.

(c) The guarantec agreement must bo worded as specified in paragraph (d) or (c) of this section, depending on which of the following altemative guarantee arrangements is selected:

(1) If, in the default or incapscity of the owner or operalor, the guarantor guaramiees to fund a standby trust as directed by the Director of the implementing agency, the guarantec shall be worded as specifiod in paragraph (d) of this section.

(2) If, in the default or incapacity of the owner or operator, the guaramtor guarantees to make payments as directed by the Director of the implementing agency for taking corrective action or compensating thind parties for bodily injury and property damage, the guarantec shall be worded as specified in paragraph (c) of this section.

(d) If the guarantor is a state, the local government guarantee with standby trust must be worded exactly as follows, except that instructions in brackets are to be replaced with relevant information and the brackets deleted:

Local Covernment Guarantee With Standby Trust Made by a State Guarantee made this [date] by [name of state], herein referred to as guarantor, to [the state implementing agency] and to any and all third parties, and obliges, on behalf of [local government owner or operator] Recitals

1) Guarantor is a state.

(2) [Local government owner or operator] owns or operates the following underground storage tank(s) covered by this guarantee:

(List the number of tanks at each facility and the name(s) and address(es) of the facility(ies) where the tanks are located. If more than one instrument is used to assure different tanks at any one facility, for each tank covered by this instrument, list the tank identification number provided in the notification submitted pursuant to 40 CFR Part 280 or the corresponding state requirement, and the name and address of the facility.] This guarantee satisfies 40 CFR Part 280, Subpart H

requirements for assuring funding for [insert: requirememts for assuring funding for [insert:
"taking corrective action" and/or "compensating third parties for bodily injury and property damage caused by" either "sudden accidenta releases" or "nonsudden accidental releases" or "accidental relesses"; if coverage is differemt for different tanks or locations, indicate the type of coverage applicable to each tank or location] srising from operating the above-identified underground storage tank(s) in the amoum of [insert dollar amount] per occurrence and [insert dollar amoumt] annual aggregate.
(3) Ouarantor guarantecs to limplementing agency] and to any and all third partics that:

In the event that local government owner or operator] fails to provide allemative coverage within 60 days after receipt of a notice of cancellation of this guarantec and the [Director of the implementing agency] has determined or suspects that a release has occurred at an underground storage tank covered by this guarantec, the guarantor, upon instructions from the [Director] shall fund a standby trust fund in accordance with the provisions of 40 CFR part 280.112 , in an amount not to exceed the coverage limits specified above.

In the event that the [Director] determines that [local government owner or operafor] has failed to perform corrective action for releases arising out of the operation of the

above-identified tank(s) in accordance with 40 CFR part 280, subpart F, the guaramtor upon written inetructions from the [Director] shall fund a standby trust fund in accordance with the provisions of 40 CFR part 280.112, in an amount not to exceed the coverage limits specified above.

If [owner or operator] fails to satisfy a judgment or award based on a determination of liability for bodily injury or property damage to third partics caused by ["sudden" and/or "nonsudden"] accidental reicases arising from the operation of the above-identifiad tank(s), or fails to pay an amount agreed to in setllement of a claim arising from or alleged to arise from such injury or damage, the guaramtor, upon written instructions from the [Director], shall fund a standby trust in accordance with the provisions of 40 CFR part 280.112 to sedisfy such judgment(s), award(s), or settlememt agreement(s) up to the limits of coverage specified above.

(4) Gurrantor agrees to notify lowner or operalor] by certified mail of a volumtary or involuntary proceeding under Title 11 (Bankruptcy), U.S. Code naming guaramtor as debtor, within 10 days after commencement of the proceeding.

(5) Guarantor agrees to remain bound under this guarantec notwithstanding any modification or alleration of any obligation of [owner or operator] pursuant to 40 CFR part 280.

(6) Guarantor agrees to remain bound under this guaramtee for so long as flocal government 
onter or cperator] must comply with the 4pplicable finsncial responsibility requirements of 40 CFR pert 280, Subpeart $H$ for the above identified tank(s), except that guarantor may cancel this guerentee by sending notice by certified mail to [owner or operator], such cancellation to become effective no eartier than 120 days efter receipt of such notice by [owner or cpertior], as evidenced by the return receipt.

(7) The guarantor's obligation does not 4ply to any of the following:

(2) Any obligation of (local government ownet or cperator] under a workers' compensation, dissbility benefits, or unemptoyment compersation law or ather similar lats

(b) Bodity injury to en employee of [insert: fecal govermmert owner or operalor] erisin B from, and in the coune of, employment by [insert: local governmemt owner or operalor];

(c) Bodily ingury or property damage arising from the ownership, maintenance, use, or entrurtment to others of my sircreft, motor vehicle or waterctuft;

(d) Property damege to eny property owned rented, loaded to, in the care, custody, or control of, or cocupied by (insert: local government ouner or operator] that is not the direct result of a relesse from a petroleum underground storage tanki

(c) Bodily damage or property damage for which [insert owner or operator] is obligated to pay damages by reason of the assumption of lisbility in a contract or agreement other than contract or a coecment entered into to meet the centrad or atem of 40 CFP pert 280.93.

(8) Guarentor expressly waives notice of eccepence of this guarantee by [the inflementing agency], by any ox all third parties, or by llocal government ouner or operator].

Thereby certify that the wording of this guarantee is identical to the wording specified were constutured on the

Efrective date:

Neme of gueruntor]

[Authorized signature for guasantor]

Neme of person signing]

Titie of person signing]

Signature of witness or notary:
If the guarantor is a local government, the local govemunent guarantee with standby trust must be worded exactly as follows, except that instructions in brackets are to be replaced with relevant information and the brackets deleted:

Local Oovernment Guarantee With Standby Trust Made by a Local Government

Ouarantee made this [date] by [namo of guaranlecing entity], a local government organized under the laws of [name of state], herein referred to as guarantor, to [the state implementing agency] and to any and all third parties, and obliges, on behalf of (local govemment owner or operator)

$$
\text { Recitals }
$$

(1) Cuarantor meets or exceeds [select one: the local government bond rating lest requirements of 40 CFR Part 280.104, the local government fintancial test requirements of 40 CFR Part 280.105, or the local government fund under 40 CFR Part 280.107(a), 280.107(b), or 280.107(c)].

(2) [Locel government owner or operator] owns or operates the following underground itorage tank(s) covered by this guarantoe:

(List the number of tanks at each facility and the name(s) and address(es) of the facility(ies) where the tanks are located. If more than one instrument is used to assure different tanks at any one facility, for each tank covered by this instrument, list the tank identification mumber provided in the notification submitted pursuant to 40 CFR Part 280 or the

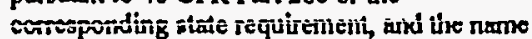
and address of the facility.] This guarantec satisfics 40 CFR Part 280, Subpart H requirememts for 2ssuring funding for linsert: requirements for 2ssuring funding for [insert: third parties for bodily injury and property damage cuused by" either "suddern accidemel releases" or "nonsudden accidental releases" or "accidental releases"; if covernge is different for different tanks or locations, indicale the type of coverage applicable to each tank or location! arising from operating the above-identified underground storage tank(s) in the amoumt of [insert dollar emouml] per occurrence and [insert: dollar amount] annual aggregate.

(3) Incident to our substamial govermmental relationship with llocal govermment owner or operator], guarantor guarantees to

[implementing agency] and to any and all third parties that:

In the event that [local government owner or operator] fails to provide altemative coverage within 60 days after receipt of a notice of

canceliation of this guarantoe and the [Director of the implementing a gency] has determined or suspects that a release has occurred at an underground storage tank covered by this guarantec, the guarantor, upon instructions from tho [Director] shall find 2 standby trest fund in scordance with the provisions of 40 CFR Part 280.112, in an amount not to exceed the 280.112, in an amount not to excecd
coverage limits specified above.

In the event that the [Director] determines that [local government owner or operator] has failed to perform corrective action for releases arising out of the operation of the

above-identified tank(s) in sccondance with 40 CFR Part 280, Subpart F, the guarantor upon written instructions from the [Director] shall fund a standby trust fund in accordance with the provisions of 40 CFR Part 280.112, in an amount not to exceed the coverage limits apecifiod above.

If [owner or operator] fails to satisfy a jud gment or award based on a determination of liability for bodily injury or property damage to thind parties caused by ["sudden" and/or "nonsudden"] accidental releases arising from the operation of the above-identified tank(s), or fails to pay an amount agreed to in settlement of a claim arising from or alleged to arise from such injury or damage, the guarantor, upon written instructions from the [Director], shall writuen instructions from the [Director], shall provisions of 40 CFR Part 280.112 to satisfy provisions of 40 CFR Part 280.112 to satisfy
such judgment(s), award(s), or settlement agreemem(s) up to the limits of coverage specified above.

(4) Guarantor agrees that, if at the end of any fiscal year before cancellation of this guarantec, tho guaramtor fails to meet or exceed the requirements of the financial responsibility mechanism specified in paragraph (1). guarantor shall send within 120 days of such failure, by certified mail, notice to [local government owner or operator], es evidenced the retum receipt.

(3) Guarantor agre is to notify lowner or operafor] by certified mail of a voluntery or involuntary proceeding under Title 11

(Bankruptey), U.S. Code naming guarantor as debhor, within 10 days afler commencement of the proceeding.

(6) Ouarantor agrees to remain bound under this guarantee notwithstanding any modification or alteration of any obligation of [owner $\alpha$ operator] pursuant to 40 CFR Part 280.

7) Guarantor agrees to remain bound under this guarantee for 80 long as (local governmemt owner or operator] must comply with the applicable financial responsibility requirements of 40 CFR Part 280. Subpart $H$ for the above identified tank(s), except that guarantor may cancel this guarantee by sending notice by certified mail to [owner or operator], such cancellation to become effective no carlier than 120 days after receipt of such notice by [owner or operator], as evidenced by the return receipt.

(8) The guarantor's obligation does not apply to any of the following:

(a) Any obligation of [local government owner or operator] under a workers' owner or operator] under a workers' unemploymem compensation law or other similar law:

(b) Bodily injury to an employee of [insert: local government owner or operator] arisin from, and in the course of, employment by [insert: local government owner or operat or]:

(c) Bodily injury or property damage arising from the ownership, maintenance, use, or entrustment to others of any nircraf, molor vehicle, or watercraft:

(d) Property damage to any property owned rented, loaned to, in the care, custody, or comtrol of, or occupied by [insert: local government owner or operalor] that is not the direct result of a release from a petroleum underground stor age tank

(c) Bodily damage or property damage for which [insert: owner or operator] is obligated to pay damages by reason of the assumption of liability in a contract or a greement other than 2 contract or agrecmemt entered into to met the requirements of 40 CFR Part 280.93

(9) Ouarantor expressly waives notice of acceptance of this guaramee by (the

implememting agency], by any or all third parties, or by [local government owner or operator]. 
Thereby cerify that the wording of this gussertee is identical to the wording specified in 40 CFR Part 280.106(d) es such regulations were constituted on the effective date shown immediately below.

Effective date:

[iame of guarantor]

[Authorized signature for guarantor]

[Name of person signing]

Tritle of person signing]

Signature of witness or notary:

(e) If the guarentor is a stete, the locel government guarantee withouk standby trust must te weried exactly as follows, except that instructions in brackets are to be replaced with relevent informstion and the brackets deleted:

Local Government Guarantee Without Standby Trust Made by a State

Guarantec made this [date] by [name of state], herein referred to as guarantor, to [the stste implementing asency] and to any and all third partices and obliges, on behalf of [local sovernment owiner or operator]. Recitals

(1) Guaramtor is a state.

(2) [Local government owner or operator] owts or operates the following underground storege tank ( 1 ) covered by this guarantee: [List the mumber of tanks at each facility and the name(s) and address(es) of the facility(ies) where the tenks are located. If more than one instrumemt is used to sssure different tanks at instrumem is used to sssure different tanks at any one fecility, for each tank covered by this instrumem, list the tank identification number to 40 CFR Part 280 or the corresponding state requirement and the name and address of the facility.] This guerantee satisfies 40 CFR Part 2M. Sutfert Hi requirements for essuring funding for timett: rating corrective action funding for fine

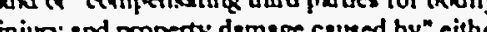
injory and property damse caured by" either accidemal relesses" or "accidental relesses"; if accidental relesses" or "accidemtal releases"
coverage is different for different tanks or locations, indicate the type of coverage applicable to each tank or location] arising from operating the above-identified underground storage tank(s) in the amount of [insert: dolla storage tank(s) in the amount of [insert: dollar amount] annual aggregale.

(3) Guaramtor guarantees to [implementing agency] and to any and all third parties and obliges that:

In the event that [local govermment owner or operator] fails to provide alternative coverage within 60 days after receipt of a notice of cancellation of this guarantee and the [Director of the implementing agency] has determined or suspects that a release has occurred at an underground storage tank covered by this guaranice, the guarantor, upon written instructions from the [Director] shall make funds available to pay for corrective actions and compensate third parties for bodily injury and property damage in an amount not to exceed the coverage limits specified above.

In the event that the [Director] determines that [local government owner or operator] has railed to perform corrective action for releases arising out of the operation of the

above-identified tank(s) in accondance with 40 CFR Part 280, Subpart F, the guarantor upon written instructions from the [Director] shall make finds available to pay for corrective action in an amount not to exceed the coverage limits specified above.

If [owner or operator] fails to satisfy a judgment or awand based on a determination of liability for bodily injury or property damage to third parties caused by ["sudden" and/or "nonsudden"] accidental releases arising from the operation of the above-identified tank(s), or fails to pay an emount agreed to in settlement of a claim arising from or alleged to arise from such injury or damage, the guaramtor, upon such injury or damage, the guaramior, upon written instructions from the [Director], shall parties for bodily injury and property damage in an amount not to exceed the coverage limits specified above.

(4) Ounsuntor agrees to notify lowner or operator] by certified mail of a voluntary or involuntary proceeding under Title 11

(Brnkruplcy), U.S. Code naming guarantor as deblor, within 10 days afler commencement of the proceeding.
(5) Guarantor agrecs to remain bound under this guarumee notwithstanding mny modification or alteration of any obligation of [owner or operator] pursuani to $40 \mathrm{CFR}$ Part 280.

(6) Guarantor agrees to remain bound under this guaramee for so long as [local governmem owner or operator] must comply with the applicable financial responsibility requirements of 40 CFR Part 280, Subpart $H$ for the above identified tank(s) except that guarantor may cancel this guerantec by sending notice by cancel this guaramtec by sending notice by certified mail to [owner or operator], such 120 days after receipt of such notice by [owner or operator], as evidenced by the return receipt. If notified of a probable release, the guarantor agrees to remain bound to the terms of this guarantec for all charges arising from the release, up to the coverage limits specified above, notwithstanding the cancellation of the guarantee with respect to future releases.

(7) The guarantor's obligation does not apply to any of the following:

(a) Any obligation of [local government owner or operntor] under a workers' compensation disability benefits, or unemployment compensation law or other similar law;

(b) Bodily injury to an employee of [insert local government owner or operator] arising from, and in the course of, employment by [insert: local government owner or operator];

(c) Bodily injury or property damage arising from the ownership, maintenance, use, or entrustment to others of any aircraft, motor vehicle, or watercraft;

(d) Property damage to any property owned rented, loaded to, in the care, custody, or control of, or occupied by [insert: local government owner or operator] that is not the direct result of 2 release from a petroleum underground storage tank:

(c) Bodily damage or property damage for which [insert: owner or operator] is obligated to pay damages by reason of the assumption of linbility in a contract or agreement other than a contract or agreement emtered into to meet the requirements of 40 CFR Part 280.93.

(8) Ouarantor expressly waives notice of acceptance of this guarantee by the implementing agency], by any or all third parties, or by [local government owner or operator].

I hereby certify that the wording of this guarantee is identical to the wording specified in 40 CFR Part 280.106(e) as such regulations were constituted on the effective date shown immediately below.

Effective date:

[Name of guarantor]

[Authorized signature for guarantor]

[Name of person signing]

[Title of person signing]

Signature of witness or notary:

If the guarantor is a local govermment, the local governmemt guarantee without standby trust must be worded exactly as follows, except that instructions in brackets are to be replaced with relevant information and the brackets deleted:

Local Government Guarantee

Without Standby Trust Made by a Local Government

Guarantee made this [date] by [name of guaranteeing emity], a local government organized under the laws of [name of state], herein referred to as guarantor, to [the state implementing agency] and to any and all thire parties, and obliges, on behalf of [local government owner or operator].

$$
\text { Recitals }
$$

(1) Guarantor meets or exceeds [select one: the local government bond rating test requirements of 40 CFR part 280.104, the local government financial test requirememts of 40 part CFR 280.105, the local government fund under 40 CFR part 280.107 (a), 280.107(b), or $280.107(\mathrm{c})$.

(2) [Local government owner or operator] owns or operates the following underground storage tank(s) covered by this guarantce:

[List the number of tanks at each facility and the name(s) and address(es) of the facility(ies) where the tanks are located. If more than one instrumemt is used to assure different tanks at any one facility, for each tank covered by this instrumemt list the tank identification number provided in the notification submitted pursuant to 40 CFR Part 280 or the 
corresponding state requinement, and the name and address of the facility.] This gumantee entisfies 40 CFR pert 280, subpart H requirements for assuring funding for [insert: "tuking corrective action" and/or "compensating third parties for bodity injury and property damage caused by" either "sudden sccidemtal relesses" or "nonsudden accidental releases" or "mocidentel relesses"; if coverage is different for different tanios or locations, indicate the type of coverege anplicable to each tenk or location] srising from operating the above-identifiod undereround storage tenk(s) in the emount of [insert: dollar emount] per occurrence and [insert: doller mount] ennual egeregate.

(3) Incident to our substantial governmental relationship with [local government owner or eperator]. guerantor guerantecz to [imptementing agency] and to any and all thind parties and obliges that:

In the event that llocal govemument owner or eperator] fails to provide enemative covernge prerator] fails to provide allemative coverna cenceliation of this guanantec and the [Director cancellation of this guarantec and the [Director
of the implementing agency] has determined or surpects that a release has oocurred at an underground storage tenk covered by this gueramtec, the guasantor, upon writicn instnuctions from the [Director] shall make funds svailable to pay for corrective ections and compensate third parties for bodily injury and property damage in an amount not to exceed the coverege limits specified above.

In the event that the [Director] determines that [local government opner or opernior] has failed to perform corrective action for teleases arising out of the operation of the

atove-identified tank(s) in accordance with 40 CFR pert 280. Subpart F, the guarantor upon make finds avilable to pay for corrective ections in an amourd not to exceed the coverage limits specified above.

If [owner or operalor] fails to satisfy a judgment or atiend hased on a deterinination of lishility for bedily injury or property damage to thind pertices caused by ["sudden" and/or "nonsubten"] accidental relesses arising from the crearation of the above-idemified tank(s), or frils to pay an emount egreed to in settlement of a clsim sising from or alleged to arise from such injury or damage, the guarantor, upon written instructions from the [Director], shal make funds available to compensate thind parties for bodily injury and property damage in an amount not to exceed the coverage limits specified above.

(4) Guarantor agrees that if at the end of any fiscal year before cancellation of this guarantec, the guarantor fails to meet or exceed the requirements of the financial responsibility mochanism specified in paragraph (1) guarantor shall send within 120 days of such failure, by certified mail, notice to llocal government owner or operator], as cvidenced by the return receiph.

(3) Guaramtor a grees to notify [owner or operator] by certified mail of 2 voluntary or involuntary proceeding under Titlo 11 (Bankruptcy), U.S. Code naming guarentor as debtor, within 10 days after commencement of the proceeding.

(6) Guerantor agrees to remain bound under this guarantec notwithstanding any modification or alteration of any obligation of [owner or operator] pursuent to 40 CFR part 280.

(7) Guarantor agrees to remain bound under this guarantoe for so long as [local government owner or operator] must comply with the applicable financial responsibility requirements
of 40 CFR Part 280, Subpart H for the above identified tank(s), except that guaramtor may cencel this guarantec by sending notice by certified mail to [owner or operator], such cancellation to become effective no earlier than 120 days anter receipt of sucti notice by fowner or operator], w evidenced by the retum receipt. If notified of a probable relesse, the guarantor agrees to remain bound to the terms of this guarantec for all charges arising from the release, up to the coverage limits specified above, notwithstanding the cancellation of the guarantec with respect to future releases.

(8) The guarantor's obligation does not apply to any of the following:

(a) Any obligation of [local government owner or operator] under $a$ workers" compensation disability benefits, or unemployment compensation law or other imilas law:

(b) Bodily injury to an employee of [insert: local government owner or operator] arising [insert: local government owner cr operalor] (c) Bodily injury or property damage arising from the ownership, maintenance, use, or entrustment to others of any aircraft, motor vehicle, or watercraft;

(d) Property damage to any property owned, rented, loaded to, in the care, custody, or control of, or occupied by [insert: local government owner or operator] that is not the direct result of $a$ release from a petroleum underground storage tank;

(c) Bodily damage or property damage for which [insert: owner or operator] is obligated to pay damages by reason of the assumption of liability in a contract or agreement other than contract or agreement entered into to meet the requirements of 40 CFR Part 280.93.

(9) Guarantor expressly waives notice of acceptance of this guarantoe by [the implementing agency], by any or all third parties, or by [local government owner or operator].

I hereby certify that the wording of this guarantoo is identical to the wording specifiod in 40 CFR Part 280.106(e) as such regulation were constituted on the effective date shown immediately below.

Effective date:

(Name of guarantor]

[Authorized signature for guaramtor]

[Name of person signing]

[Title of person signing]

Signature of witness or notary:

[58 FR 9054, Feb. 18, 1993]

\subsection{Local government fund.}

A local government owner or operalor may satisfy the requirements of $\$ \mathbf{2 8 0 . 9 3}$ by establishing a dedicated fund account that conforms to the requirements of this section. Except as specified in paragraph (b), a dedicated fund may not bo commingled with other funds or otherwise used in normal operations. A dedicated find will be considered eligible if it meets one of the following requirements:

(a) The fund is dedicaled by state constitutional provision, or local government statute, charter, ordinance, or order to pay for taking corrective action and for compensating third parties for bodily injury and property damage caused by accidental releases arising from the operation of petroleum underground storage tanks and is funded for the full amount of coverage required under $\$ 280.93$, or funded for part of the required amount of coverage and used in combination with other mochanism(s) that provide the remaining coverage; or

(b) The fund is dedicated by state constitutional provision, or local government statute, charter, ordinance, or order as a contingency fund for general emergencies, including taking corrective sction and compensating third partics for bodily injury and property damage caused by accidental releases arising from the operation of petroleum underground storage tanks, and is funded for five times the full amount of coverage required under $\$ 280.93$, or funded for part of the required amount of coverage and used in combination with other mechanism(s) that provide the remaining coverage. If the fund is funded for less than five times the amount of coverage required under $\$ 280.93$. the amount of financial responsibility demonstrated by the fund may not exceed one-fith the amount in the fund; or

(c) The fund is dedicuted by state constitutional provision, or local governmemt statute, charter, ordinance or order to pay for taking corrective action and for compensating third parties for bodily injury and property damage caused by accidemtal releases arising from the operation of petroleum underground storage tanks. A payment is made to the fund once every year for seven years until the find is fully-funded. This seven year period is hereafler sefered to as the "payy-in-periods." Thi aninuint formula:

$$
\frac{T F-C F}{Y}
$$

Where TF is the total required finsncial assurance for the owner or operator, CF is the curremt amount in the fund, and $Y$ is the number of years remaining in the pay-in-period, and;

(1) The local government owner or operalor has available bonding authority, approved through voter referendum (if such approval is . necessary prior to the issuance of bonds), for en amoumt equal to the difference between the 
required amount of coverage and the emount beld in the dedicated fund. This bonding wuthority shall be available for taking corrective action and for compensating third parties for bodity injury end property damage caused by scoidertal relesses arising from the operation of petroleum underground slorage tanks, or (2) The local government owner or operator has a letter signed by the appropriale state attorney general stating that the use of the bonding authority will not increase the local govomment's debt bejond the legal debt ceilings ertablished by the relevent state laws. The keter most also stade that prior voter aprovial is not necessary before use of the onding euthority.

(d) To demonstrate that it meets the requirements of the local government fund, the ctrief financial officer of the local government orter or operator and/or guarantor must sion letter worded exectly as follows, except thet the instructions in brackets are to be replace

relevert information and the brackets deleted:

\section{Letter from Chief Financial Officer}

I $\mathrm{mm}$ the chief financial officer of [insert: name and address of local governunent owner or opesator, or guerantor]. This letter is in support of the use of the local government fund mechanism to demonstrate financial responsibility for [insert: "taking corrective action" and/or "compensating third perties for bodily injury and property damagen ] caused by [insert: "sudden accidental relesses" and/or [insert: "sudden accidental reiesses" and/or of as leart [insert: dollar amoumt] per occurrence and [insert: doller amount] amnual aggregate arising from operating (an) underground storage $\operatorname{tank}(s)$

Underground storage tanks at the following facilities are assured by this local government fund mechenism: [List for each facility: the name and address of the facility where lanks we ascured ty the local government fund]

Inscrit: The locel government fund is funded for the full amount of coverage required under $\$ 280.93$, or funded for part of the required emeurnt of covers ge and used in combination with aher mechanism(s) that provide the remaining coverage." or "The local government fund is funded for ten times the full amount of coverage required under $\$ 280.93$, or funded for part of the required amount of coverage and used in combination with other mechanisms(s) that provide the remaining coverage," or "A payment is made to the fund once every year for seven years until the fund is fully-funded and [name of local government owner or operator] has available bonding authority, approved through voter referendum, of $m$ emount equal to the difference between the required amount of coverage and the the required in the decaled fund" or payment is made to the fund once every year for payment is made to the fund once every year for seven years until the fund is fully-funded and
have attached a letter signed by the State Attorney General stating that (1) the use of the bonding authority will not increase the local govemment's debt beyond the legal debr ceilings established by the relevant state laws and (2) that prior voler approval is not

necessmy before use of the bonding authority"].

The details of the local government fund are as follows:

Amount in Fund (market value of fund at clowe of last fiscal year):

IIf fund balance is incrementally funded as specified in $\$ 280.107$ (c), insert:

Amoum added to fund in the most recently completed fiscal year:

Number of years remaining in the pay-in period: __

A copy of the state constitutional provision. or local government stature, charter, ordinance or order dedicating the fund is attached.

1 hereby certify that the wording of this letter is identical to the wording specified in 40 CFR 280.107(d) as such regulations were constituted on the date shown immediately below.

$$
\begin{aligned}
& \text { [Date] } \\
& \text { [Signsture] } \\
& \text { [Name] } \\
& \text { [Titule] }
\end{aligned}
$$

[58 FR 9054, FD. 18, 1993]

280.108 Substitution of financial assurance mechanisms by owner or operator.

(a) An owner or operator may substitute any alternate funancial assurance mechanisms as specified in this subpart, provided that at all times he maintains an effective financial assurance mechanism or combination of mechanisms that setisfies the requirements of 280.93.

(b) After obtaining afternate financial assurance as specified in this subpart, an owner or operator may cancel a frnancial assurance mechanism by providing notice to the provider of financial assurance.

[53 FR 43370, Oct 26, 1988, os amendod at 58 FR 9053 Feb. 18, 1993]

\subsection{Cancellation or} nonrenewal by 2 provider of financial assurance.

(a) Except as otherwise provided, a provider of financial assurance may cancel or fail to renew an assurance mechanism by sending notice of termination by certified mail to the owner or operator.

(1) Termination of a local government guarantec, a guarantec, a surety bond, or a letter of credit may not occur until 120 days after the dnte on which the owner or operator roceives the notice of termination, as evidenced by the return receipt.

(2) Termination of insurance or risk retention coverage, except for non- payment or misrepresentation by the insured, or state-funded assurance may not occur until 60 days after the date on which the owner or operator receives the nolice of terminialion, as evidenced by the return receipt. Termination for non-payment of premium or misrepresentation by the insured may not occur until a minimum of 10 days after the date on which the owner or operator receives the nolice of termination, 28 operator receives the nolice of
evidenced by the retum receipt.

(b) If a provider of financial reaponsibility cancels or fails to renew for reasons other than incapacity of the provider $2 s$ specified in $\$$ 280.114, the owner or operator must obtain alternate coverage as apecified in this section within 60 days after receipl of the notice of termination. If the owner or operator fails to obtain altemate coverage within 60 days affer receipt of the notice of termination, the owner or operator must notify the Director of the implementing agency of such failure and submit:

(1) The name and address of the provider of financial assurance;

(2) The effective date of termination; and

(3) The cvidence of the financial assistance mechanism subject to the termination maintained in accordance with $\$ 280.107$ (b).

[53 FR 43370, Oct. 26, 1988, as amended at S4 FR 47082. Nov. 9, 1989; S8 FR 9054, Feb. 18, 1993]

\subsection{Reporting by owner or} operator.

(a) An owner or operator must submit the appropriate forms listed in $\$ 280.111$ (b) documenting curremt evidence of fin ancial responsibility to the Director of the implememting agency:

(1) Within 30 days after the owner or operator identifies a release from an underground storage tank required to be reported under $\$ 280.53$ or $\$ 280.61$;

(2) If the owner or operator fails to obtain atternate coverage as required by this subpert within 30 days after the owner or operator receives notice of

(i) Commencement of a voluntary or involuntary proceeding under Title 11 (Bankruptcy), U.S. Code, naming a provider of inancial assurance as a deblor,

(ii) Suspension or revocation of the authority of a provider of financial assurance to issue a financial assurance mechanism.

(iii) Failure of a guarantor to meet the requirements of the financial test,

(iv) Other incapacity of a provider of financial assurance; or

(3) As required by $\S 280.95(\mathrm{~B})$ and $\S$ 280.109(b).

(b) An owner or operator must certify compliance with the financial responsibility requirements of this part as spocified in the new tank notification form when notifying the appropriate state or local agency of the installation of a new underground storage tank under $\$ 280.22$.

(c) The Director of the Implementing Agency may require an ownet or operator to submit evidence of financial assurance as described in $\$ 280.111$ (b) or other information 
retersant to compliance with this subpart at any

time.

(The information requirements in this soction have boen 4proved by the Onfice of Minagement and Budiget and origeod OMB coutrol number 2050-0056).

[53 FR 43370. Oa 26. 1988, 24 amended al 58 FR 9056 , Feb. 18, 1993]

\subsection{Recordkeeping}

(a) Owners or operators must maindein evidence of all finsuxial assurance mechernisms uned to demonstrate fonencial responsibility under this subpart for an underground storige tenk until relesed from the requirements of this suhyert under \$208.113. An owner or operator must meintein such evidence at the und erground storege tenk site or the owner's or operator's plsce of work Reconds maintsined off-site must plsoe of work Records maintsined offesilable upon request of the implementing agency.

b) An oxner or operalor must maintain the following types of evidence of financial responsibility:

(1) An opmer or operator wing an essurance mechanism specified in $\$ \mathbf{2 8 0 . 9 5}$ through 280.100 or $\$ 280.102$ or $\$ \$ 280.104$ through 280.107 must maintain a copy of the instrument rooded es specified.

(2) An owner or operalor using a financial lest or guerentee, or a local govermment

financial test or a local government guarantec upported by the local government firancial test must maintin a copy of the chief financial officer's letter besed on year-end financial statements for the most rocent completed financial reporting year. Such evidence must be on fite no liter than 120 days after the close of the fin minciel reporing yeer. (3) An orner or operalor using a guarardec,
surety bond or letter of credit must maintain a surety bond, or letter of credit must maintain a copy of the signed standby trust fund agreement

(4) A local govermment owner or operator using a local government guaramtec under \$ 280.106 (d) must maintuin a copy of the signed standity trust fund egreement and copies of any emendrnents to the sereernent.

(5) A kacal government owner or operato using the focal government bond rating test under $\$ 280.104$ must maintain 2 copy of its bond rating published within the last twelve months by Moody's or Standard \& Poor's.

(G) A local government owner or operator using the local government guaramee under 280.106, where the guarantor's demonstration of financial responsibility relies on the bond rating test under $\$ 280.104$ must maintain a copy of the guarantor's bond rating published within the last twelve months by Moody's or Standard \& Poor's.

(7) An owner or operator using an insurance policy or risk retention group coverage must maintain a copy of the signed insurance policy or risk retention group coverage policy, with the endorsement or certificate of insurance and my amendments to the egreenemts.

(8) An owner or operator covered by a state find or other state essurance must maintain on file a copy of any evidence of coverage supplied by or required by the state under $\$$ 280.101(d).

(9) An owner or operator using a local government fund under $\$ 280.107$ must maintain the following documents:

(i) A copy of the state constitutional provision or local government atatute, charter, (ii) Yee, or order dedicating the fund, and (ii) Year-end financial statemients for the most recent completed financial reporting year showing the amount in the fund. If the fund is established under $\$ 280.107$ (a) (3) using incremental funding backed by bonding suthority, the financial statements must show the previous year's balance, the amount of finding during the year, and the closing balance in the fund.

(iiij) if tine fund is established under $\S$ $280.107(a)(3)$ using incremental funding backed by bondin $B$ authority, the owner or operator must also maintain documentation of the required bonding authority, including either the resulis of a voler referendum (under $\$$ 280.107(a)(3)(i)), or attestation by the State Attorney General as specified under \$ 280.107(a)(3)(ii)

(10) A local governement owner or operator using the local government guarantec supported by the local government fund must maintain a copy of the guarantor's year-end financial statements for the most recent completed financial reporting year showing the amount of the fund. (11)(i) An owner or operator using an ssurance mechanism specified in $\$ \S 280.95$ through 280.107 must maintain an updated copy of a certification of financial responsibility worded as follows, except that instructions in brackets are to be replaced with the relevant information and the brackets deleted: Certification of Financial Responsibility

[Owner or operator] hereby certifies that it is in compliance with the requirements of subpart $\mathrm{H}$ of $40 \mathrm{CFR}$ part 280 . The financis sssurance mochenism(s) used to demonstrate financial responsibility under subpart $H$ of 40 financial responsibility under subpart $\mathrm{H}$ of 40 CFR part 280 is (are) as follows: IFor each mechaniam, list the type of mechanism, name of issuer, mechanism number (if epplicnble), smourt of coverage, effective period of coverage and whether the mechanism covers "taking corrective action" and/or "compensating third parties for bodily injury and property damage caused by" either "sudden accidental releases" or "nonsudden accidental relesses" or "accidental releases."]

[Signature of owner or operator]

[Name of owner or operator]

[Title]

[Date]

[Signature of witness or notary]

[Name of witness or notary]

[Date]

(ii) The owner or operator must update this certification whenever the fin ancial assurance mechanism(s) used to demonstrate financial responsibility change(s).

(The information requirements in this section have been approved by the Ofice of Manegement and Budget an essignod OMB control number 2050-0056.)

(S3 FR 43370, Oct. 26, 1988, as amendod at S8 FR 9059. FCb. 18, 1993]

\subsection{Drawing on financial} assurance mechanisms.

(a) Except ss specified in paragraph (d) of this section, the Director of the implementing egency shall require the guaramtor, surety, or institution issuing a letter of credit to plece the arto to the limit of finds provided by the financial (1)(i) The owner or operator fails to (1)(i) The owner or operator fails to
cetsblish altemate financial assurance within 60 days afler receiving notice of cancellation of the guarantee, surety bond, letter of credit, $o r, a s$ applicable, other financial assurance mechanism; and

(ii) The Director determines or suspocts that a release from an underground storage tank covered by the mechanism has occurred and so notifies the owner or operator or the owner or operator has notified the Director pursuam to subparts $E$ or $F$ of a release from an underground storage tank oovered by the mechanism; or

(2) The conditions of paragraph (b)(1) or (b)(2) (i) or (ii) of this section are satisfiod.

(b) The Director of the implememting agency may draw on a standhy trust fund when (I) The Director makes a linal

determination that a release has occurred and immediate or long-term corrective action for the release is needed, and the owner or operator. after appropriate notice and opportunity to comply, has not conducted corrective action as required under 40 CFR part 280, subpart F; or

(2) The Director has received either:

(i) Certification from the owner or operator and the third-party liability claimam(s) and from attorneys representing the owner or operator and the third-party liability claimant(s) that a third-party liability claim should be paid. The certification must be worded as follows, except that instructions in brackets are to be replaced with the relevant information and the brackets deleted:

Certification of Valid Claim

The undersigned, as principals and as legal representatives of [insert: owner or operator] and (insert: name and addreas of third-party claimant], hereby certify that the claim of bodily injury [and/or] property dnmage caused by an accidental release arising from operating [owner's or operator's] underground storage tank should be paid in the amount of SL [Signalures]

Owner or Operator

Atlomey for Owner or Operator

(Notary)

[Signatures]

Claimam(s)

Attomey(s) for Claimant(s)

(Notary) 
or (ii) A valid final court onder establishing a judgrixent against the owner or operutor for bodity injury or property damage caused by an cocideriel release from an underground storage mecidental relesse from an underground storage subpart and the Director determines that the owder or operator has not satisfied the judgment.

(c) If the Director of the implementing sency determines that the amount of corrective action costs and third-party liability claims eligible for payment under paragraph (b) of this section mxy exceed the balance of the standby trust find and the obligation of the provider of

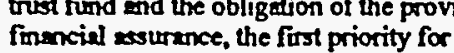
payment shall be corrective action coot necesesry to protect hurmen health and the emiroment. The Director shall pay third-perty listility cleims in the order in which the Director receives certificalions under parzgraph (b) $(2)(i)$ of this rection, and valid court onder under peregraph (b)(2)(ii) of this section.

(d) A govermentel entity acting as guarantor under $\$ 280.106$ (c), the local govenment guaramtec without standby trust,

govemment guaramtee without standby trust, under the circumstances described in $\$ \mathbf{2 8 0 . 1 1 2}$ (a) (b), and (c).

[S3 FR 43370, Oct 26, 1988; as amended at 58 FR 9051, Feb. 18. 1993]

\subsection{Release from the requirements.}

An owner or operator is no longer required to maintuin financial responsibility under this subpart for an underground storage tank after the tank has been properly closed or, if corrective action is required, after corrective action hes been conpicted and the lank has been properly clowed is required by 40 CFR Part 280, Subpart O.

[53 FR 43370, OCt 26, 1988, w rmended at S4 FR 47082, Nov. 9. 1989; 58 FR 9051 . Feb. 18, 1993]

280.114 Bankruptcy or other incapacity of owner or operator or provider of financial assurance.

(a) Within 10 days after commencement of 2 volumesy or involuntary proceeding under
Title 11 (Bankruptcy), U.S. Code, naming an owner or operator as debtor, the owner or operator must notify the Director of the implementing agency by certified mail of such commencement and submit the appropriate forms listed in $\$ 280.111$ (b) documenting currem financial responsibility.

(b) Within 10 days after commencement of a voluntary or involuntary proceoding under Title 11 (Bankrupley), U.S. Code, naming \& guarantor providing financial assurance ss debtor, such guarantor must notify the owner or operutor by certified mail of such commencement so required under tho terms of the guarantec specified in $\$ 280.96$.

(c) Within 10 days afler commencement of a voluntary or involuntary proceoding under Title 11 (Bankouplcy), U.S. Code, naming a local government owner or operator as debtor. the local government owner or operator must notify the Director of the implementing agency by certified mail of such commencement and submit the appropriate forms listed in \$280.111(b) documenting current financial 9280.111 (b) docusibility.

(d) Within 10 days after commencememt of voluntary or involuntary proceeding under Title 11 (Bankruptcy), U.S. Code, naming guarantor providing a local government financial assurance as debtor, such guarantor must notify the local government owner or operator by certified mail of such commencement ss required under the terms of the guarantec specified in $\$ \mathbf{2 8 0 . 1 0 6}$

(c) An owner or operator who obtains finsncial assurance by a mechanism other than the financial test of self-insurance will be deemed to bo without the required financial assurance in the event of a bankruptcy or incapacity of its provider of financial assurance, or 2 suspension or revocation of the authority of the provider of financial assurance to issue a guarantee, insurance policy, risk retention group coverage policy, surety bond, letter of credit, or state-required mechanism. The owner or operator must obtrin attemato financial essurance as specified in this subpart within 30 days enter receiving notice of such an event. If the owner or operator does nol obtain alternate coverage within 30 days after such notification, he must notify the Director of the implementing agency.
(D) Within 30 days after receipt of notification that a state find or other state assurance has become incapable of paying for assured corrective action or third-party compensation costs, the owner or operator must obtain afternate financial essurance.

[53 FR 43370, Oct. 26, 1988, as amended at 58 FR 905 ]. Feb. 18, 1993]

\subsection{Replenishment of guarantees, letters of credit, or surety bonds.}

(a) If at any time after a standby trust is funded upon the instruction of the Diroctor of the implementing agency with funds drawn from a guarantee, local government guaramtee with standby trust, letter of credit, or surety bond, and the amount in the standby trust is reduced below the full amount of coverage required, the owner or operator shall by the anniversary date of the financial mechanism from which the finds were drawn:

(1) Replenish the value of financial assurance to equal the full smount of coverage required, or
(2) Acquire another financial assurance mechanism for the amount by which funds in the standby trust have been reduced.

(b) For purposes of this section, the full amount of coverage required is the amount of coverage to be provided by $\$ \mathbf{2 8 0 . 9 3}$ of this subpart. If a combination of mechanisms was used to provide the assurance funds which were drawn upon, replenishment shall occur by the earliest anniversary date among the mechanisms.

[53 FR 43370, Oct. 26, 1988, es amended at 58 FR 90S1, Feb. 18, 1993]

\subsection{Suspension of} enforcement. [Reserved]

\section{Appendix I-Notification for} Underground Storage Tanks (Form) 


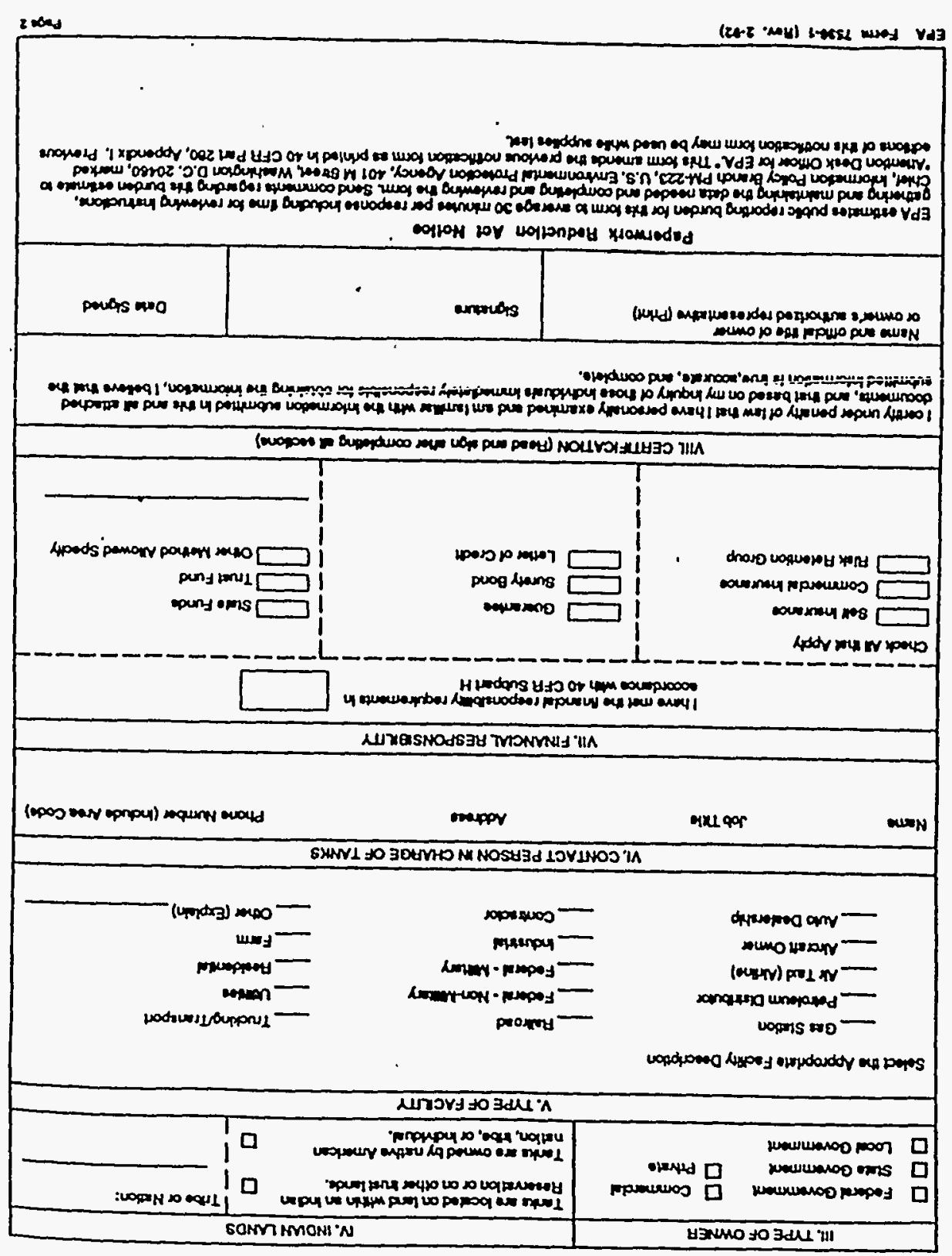

| x!puadd '08Z Jed

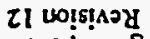

$\$ 66 I^{\prime \prime I ~} 25 \pi 8 \mathrm{nV}$

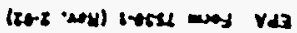

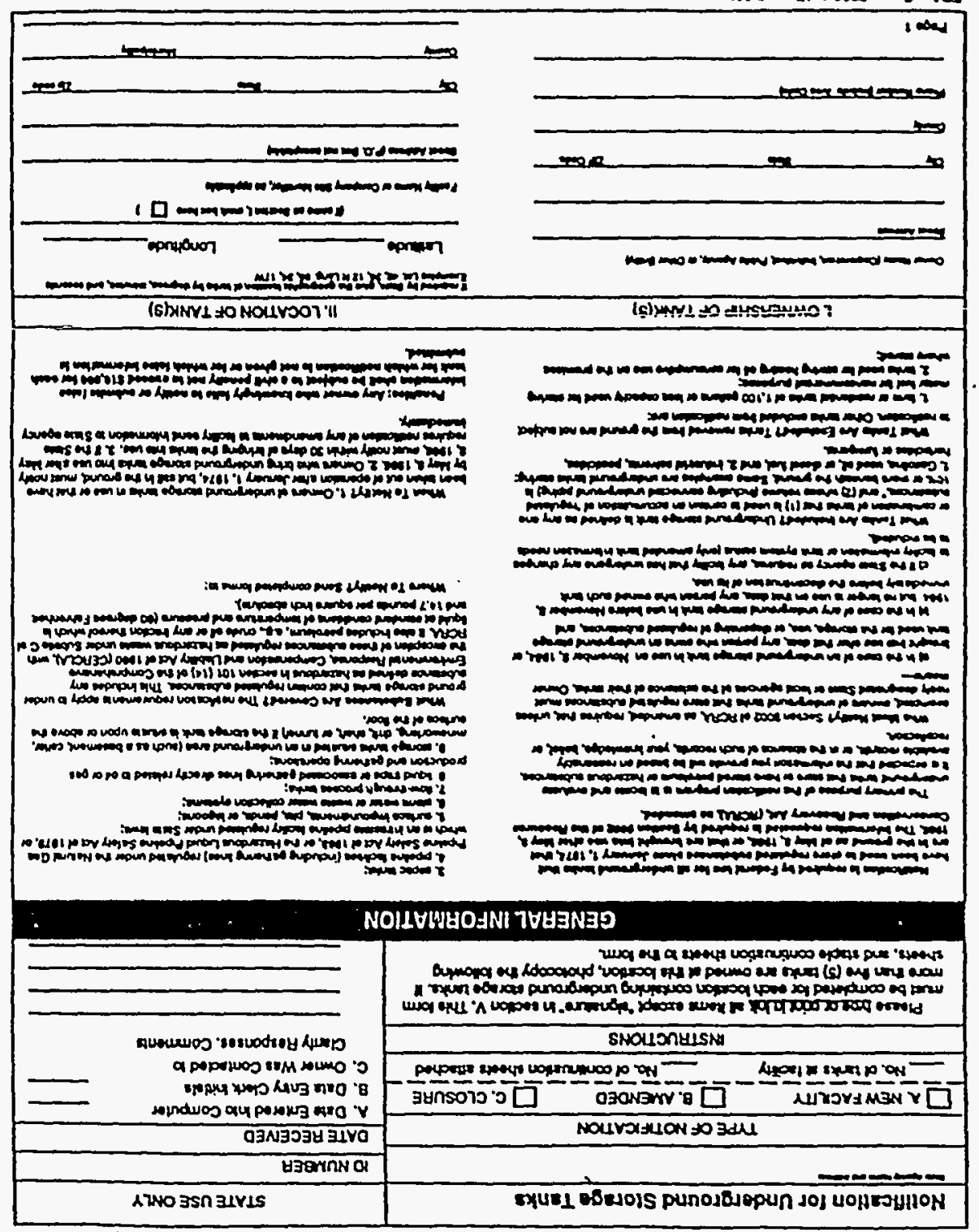

К็นจถิ 

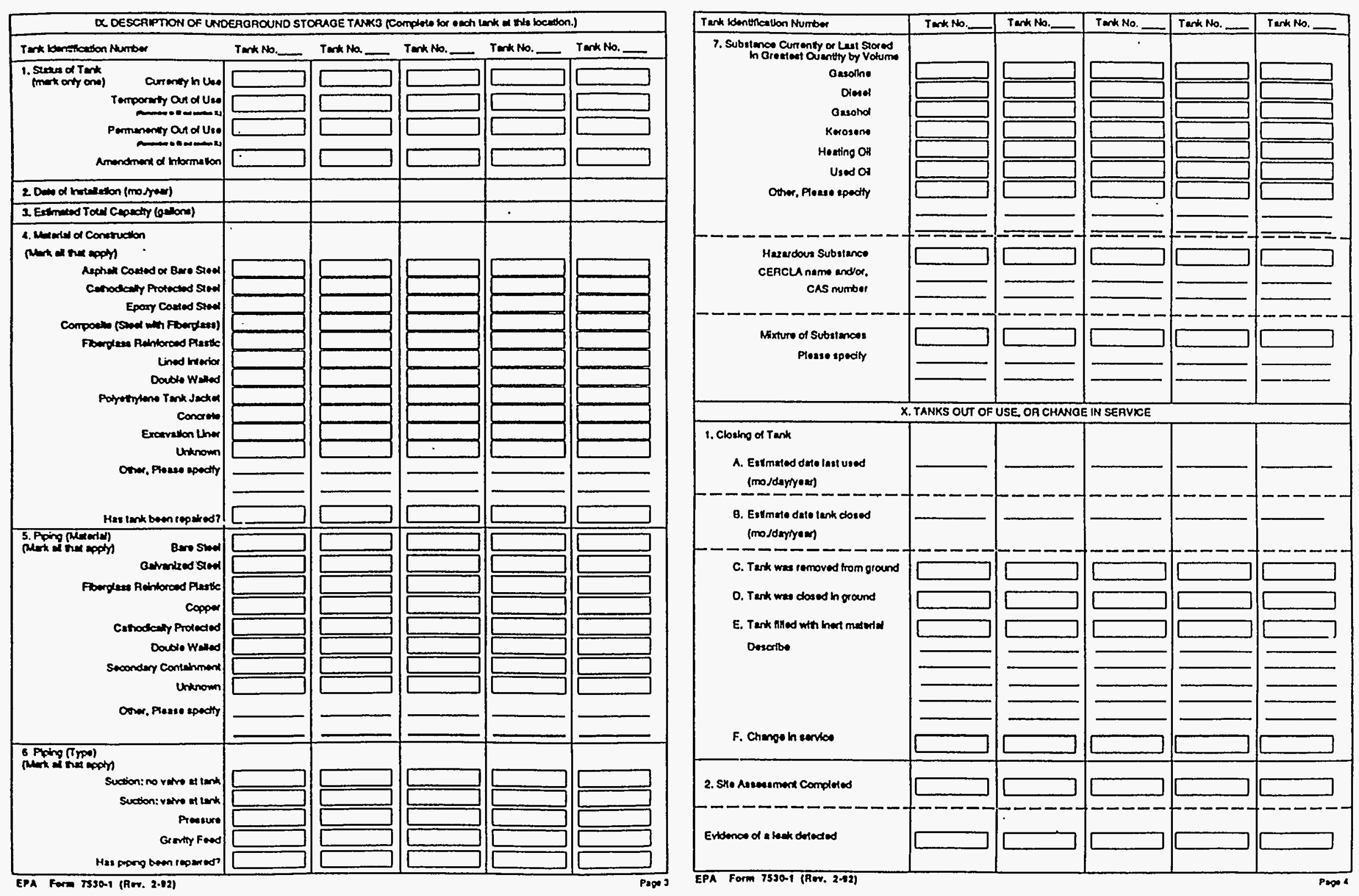
XT CERTFLATION OF COMPL WWCE (CCWPLETE FOR NLL NEW NNO UPGRUDED TANKS AT THIS LOCATLON

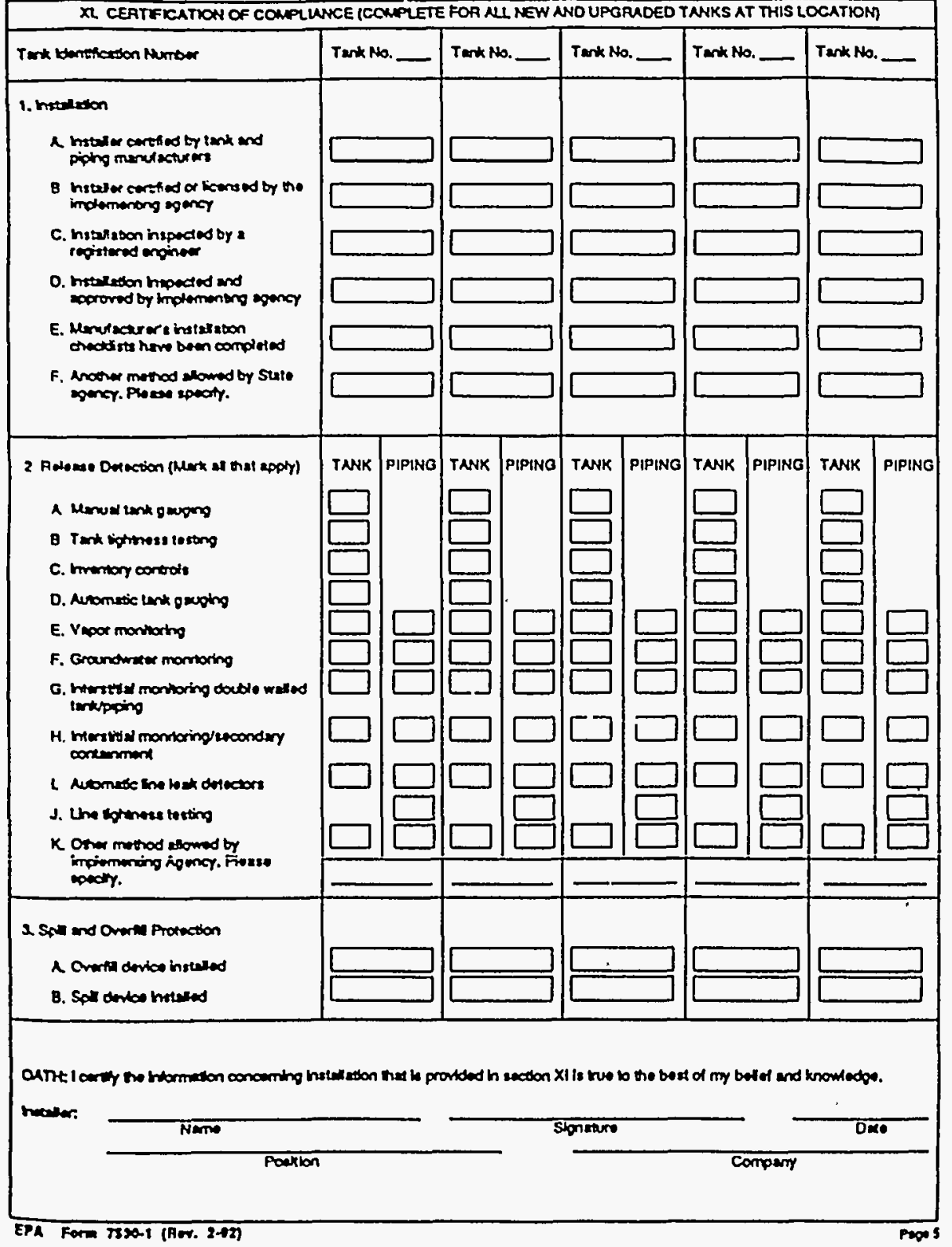

Appendix II-List of Agencies Designated To Receive Notifications

Alabama (EPA Form), Alabams Department of Environmental Management, Ground Water Section/Water Division, 1751 Congressman W.L. Dickinson Drive, Montgomery, Alabama 36130, 205/271-7823

Alaska (EPA Form), Department of Environmental Conservation, Box 0 . Juneau, Alaska 99811-1800,970/465-2653

American Samos (EPA Form), Executive Secretary, Environmental Quality Commission, Office of the Governor, American Samoan Government, Pago Pago, American Samoa 96799; Attention: UST Notification

Arizona (EPA Form), Attention: UST Coordinator, Arizona Department of Environmental Quality, Environ- mental Health Services, 2005 N. Central, Phoenix, Arizona 85004

Arkansas (EPA Form), Arkanses Department of Pollution Control and Ecology, P.O. Box 9583, Little Rock, Arkansas 72219.

California (Stale Form), Executive Director, State Waler Resources Control Board, P.O. Box 100. Sacramento, California 95801 , 916/445.1533

Colorado (EPA Form), Section Chief, Colorado Department of Health, Waste Management Division, Underground Tank Program, 4210 East 11th Avemue, Denver, Colorado 80220 , 303/320-8333

Connecticut (State Form), Hazardous Materials Management Unit, Department of Environmental Protection, State OMrico Building, 163 Capitol Avenuc, Hartford, Connecticut 06106

Delaware (State Form), Division of Air and Waste Management, Depart- ment of Natural Resources and Environmental Control, P.O. Box 1401, 89 Kings Highway, Dover, Delaware 19903, 302/726-5409

District of Columbia (EPA Form), Attention: UST Notification Form, Department of Consumer and Regulatory Affairs, Pealicides and liazardous Waste Management Branch, Room 114, 5010
Overlook Avenue SW., Washington, DC 20032

Florida (State Form), Florida Department of Environmental Regulation, Solid Waste Section, Twin Towers Office Building, 2600 Blair Stone Road, Tallahassec, Florida 32399, 90-4/487-4398

Georgia (EPA Form), Georgia Departmemt of Natural Resources, Environmental Prolection Division, Underground Storage Tank Program, 3420 Norman Berry Drive 7th Floor, Hapeville, Georgia 30354, 70-4/656-7404

Guam (State Form), Administrator, Ouam Environmental Protection Agency, P.O. Box 2999. Agana, Ouam 96910, Overseas Operator (Commercial call 646-8863)

Hawaii (EPA Form), Administrator, Hazardous Waste Program, 645 Haleknuwila Strech Honolulu, Hawaii $96813,808 / 548-2270$

Idaho (EPA Form), Underground Storage Tank Coordinator, Water Quality Bureau. Division of Environmental Quality, Idaho Department of Health and Welfare, $450 \mathrm{~W}$. State Strcet, Boise, Idaho 83720 208/334-4251

Illinois (EPA Form), Underground Storage Tank Coordinator, Division of Fire Prevemtion Office of State Fire Marshal, 3150 Executive Park Drive, Springfield, Illinois 62703-4599

Indiana (EPA Form), Underground Storage Tank Program, Office of Environmental Response, Indiana Department of Environmental Management, 103 South Meridian Street, Indianapolis, Indiana 46225

lowa (State Form), UST Coordinator, Iowa Department of Natural Resources, Henry A Wallace Building, 900 East Orand, Des Moines, lowa 50219, 512/281-8135

Kansas (EPA Form), Kansas Department of Health and Environment, Forbes Field Building 740, Topeka, Kansas 66620 . 913/296-1594

Kentucky (State Form), Department of Environmental Protection Hazard. ous Waste Branch, Fort Boone Plaza, Building 12, 18 Reilly Road, Frankfort, Kemlucky $40601,501 / 564-6716$

Louisiana (State Form), Secretary, Louisiana Department of Environmental Quality, P.O. 
Box 44066, Baton Rouge, Louisiana 70804, $501 / 342-1265$

Maine (State Form), Attention: Underground Tenks Program, Bureau of Oil and Hazardous Misterial Control, Department of Environmental Protection, State House-Station 17, Augusta, Maine 04333

Marjland (EPA Form). Science and Health Advisory Group, Office of Environmentsl Programs, 20! West Preston Strect, Programs, 201 West Prest

Messachusetts (EPA Form), UST Registry, Department of Public Safety, 1010 Commonireslth Avenue. Boston, M(excectrusetts 02215, 617/366-4500

Mirthigen (EFA Form). Mlichigan Depertmemt of Strte Police, Fire Marshal Division, Oeneral Office Building. 7150 Hartis Drive, Lensing. Michigan 48913

Mimesota (Sule Form). Undenground Storage Tank Progran, Division of Solid and Harandous Wastes, Minnesota Pollution Control Agency, 520 West Lafayette Rosd, Control Agency, 520 West

Missiesippi (State Form), Department of Natural Resources, Bureau of Pollution Control, Undenground Stonge Tank Section, P.O. Box 10385, Jackson, Mississippi 39209. $601,961.5171$

Missouri (EPA Form), UST Coordinator, Missouri Department of Natural Resourees, P.O. Box 176. Jefferson Cily, Missouri P.O. Box 176, Jefic
$65102314751-7428$

Montana (EPA Form), Solid and Hazardous Warte Bureau, Department of Heafth and Environmental Science, Cogswell Bldg. Room B-201, Helena, Montena 59620

Netraske (EPA Form). Nebraske State Fire Mershal. P.O. Box 94677. Lincoln. Netraske 68509-4677, 402/471-9465

Nevada (EPA Form), Attention: UST Coordinator, Division of Environmental Protection. Department of Conservation and Natural Resources, Capitol Complex 201 S. Fall Street. Carson City, Nerada 89710 . $800992-0900$, Ext $4670,702 / 885-4670$

New Hempehire (EPA Form). NH Dept of Enviremental Services. Water Susply and P.O. Box 95. Concond New Hempshire 03301, Attertion: UST Registration
New Jersey (State Form) Underground Storage Tank Coordinator, Department of Tank Coordinator, Department of
Environmental Prolection, Division of Environmental Prolection, Division of
Water Resources (CN-029), Trentor. New Water Resources (CN-029),
Jersey 08625, 609/292-0424

New Mexico (EPA Form), New Mexico Environmental Improvement Division, Groundwater/Hazerdous Waste Bureau, P.O. Box 968, Santa Fe, New Mexico 37504 S05/827-2933

New York (EPA Form), Bulk Storage Section, Division of Water, Department of Environmental Conservation, so Wolf Roxd, Room 326, Albany, New York 12233-0001, 518/457-4351

North Carolina (EPA Form), Division of Environmental Management, Ground-Water Operations Branch, Department of Natural Resources and Community Development, P.O. Box 27687, Raleigh, North Carolina 27611, Ralcigh,

North Dakota (State Form), Division of Hazardous Management and Special Studies, North Dakota Department of Health, Box 3520, Bismarck, North Dakota 58502-5520

Northern Mariens Islands (EPA Form), Chief, Division of Environmental Quality, P.O. Box 1304, Commonwealth of Northem Mariana Islands, Saipan, CM 96950, Cable Address: Oov. NMI Saipan, Overseas Operator: 6984

Otio (State Form), State Fire Marshal's Office, Department of Commerce, 8895 E. Main Street, Reynoldsburg, Ohio 43068, State Hotline: 800/282-1927 Oxlahoma (EPA Form), Underground Storago Tank Program, OkJahoma Corporation Comm. Jim Thorpe Building, Oklahoma City. Oklahoma 73105

Oregon (State Form), Underground Storage Tank Program, Hazardous and Solid Waste Division, Department of Environmental Quality, 811 S.W. Sixth Avenue, Portland, Oregon 98204, 503/229-5788

Pennsylvania (EPA Form), PA Department of Environmental Resources, Bureau of Water Ounlity Manngemem, Ground Water Unit, Th Floor Fulton Building, P.O. Box 2063, Harrisburg, Pernsylvania 17120
Puerto Rico (EPA Form), Director, Water Quality Control Area, Environ- mental Quality Boand, Common- wealth of Puerto Rico Santurce, Puerto Rico, 809/725-0717

Rhode Island (EPA Form), UST Registration, Department of Environmental Management 83 Park Stroet, Providence, Rhode Island 02903, 401/277-2234

South Carolina (State Form), Ground-Water Protection Division. South Carolins Department of Health and Environmental Control, 2600 Bull Street, Columbia, South Carolins 29201, 803/758-5213

South Dakoth (EPA Form), Office of Wate Quality, Department of Water and Natura Resources, Joe Foss Building, Pierre, South Dakola 57501

Ternessec (EPA Form), Tennessee Department of Health and Environment, Division of Superfund Underground Storage Tank
Section, 150 Ninth Avenue, North, Nashville, Tennessec 37219-5404, Nashville,

Texas (EPA Form), Underground Storage Tank Program, Texas Water Commission, P.O. Box 13087, Austin, Texas 7871

Utah (EPA Form), Division of Environments Heath, P.O. Box 45500, Salt Lake City, Utah 84145-0500

Vermont (State Form), Underground Storage Tank Program, Vermont AEC/Waste Management Division, State Office Management Division, State Office Building, Montp
802/828-3395

Virginia (EPA Form), Virginia Water Control Board, P.O. Box 11143, Rictumond, Virginia 23230-1143, 804/257.6685

Virgin Islands (EPA Form), 205(J) Coordinator, Division of Netural Resources Management, $14 \mathrm{~F}$ Building 111, Watergut Homes, Christianstead, St. Croix, Virgin Islands 00820

Washington (State Form), Underground Storage Tank Notification, Solid and Hazardous Waste Program, Depurtment of Ecology, M/S PV-11, Olympia, Washington 98504-8711, 206/459-6316

West Virginia (EPA Form), Attention: UST Notification Solid and Hazardous Waste, Oround Weter Branch, West Virginis Department of Natural Resources, 1201
Oreenbriar Strect, Charleston, West Virginia 25311

Wisconsin (Stale Form), Bureau of Petroleum Inspection, P.O. Box 7969, Madison, Wisconsin 33707, 608/266-7603

Wyoming (EPA Form), Water Quality Division, Department of Environmental Quality, Herschler Building, 4th Floor West, 122 West 2sth Street, Cheyenne, Wyoming 82002, 307/777-7781.

\section{Appendix III-Statement for} Shipping Tickets and Invoices

Note: A Foderal lew (the Resource Conservation and Recovery Act (RCRA), as amended (Pub. L. 98.616)] requires ounters of certain underground storege tanks to notify designated State or local agencies by May 8, 1986, of the existence of their tanks. Notifications for tanks brought into use anter May 8, 1986, must be made within 2ive Consull EpAs regulations, issuad on November by this lew. 
$\bullet$

APPENDIX C

TENNESSEE DEPARTMENT OF ENVIRONMENT AND CONSERVATION UNDERGROUND STORAGE TANK REGULATIONS

CHAPTER 1200-1-15 



\title{
RULES \\ OF \\ THE DEPARTMENT OF HEALTH AND ENVIRONMENT \\ DTVISION OF UNDERGROUND STORAGI: TANKS
}

\author{
CEAPTER 1200-1-15 \\ UNDERGROUND STORAGE TANX PRCIGRAM
}

TABLE OF CONTENTS

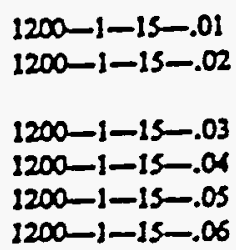
UST Systems: Design, Construction, lostallation and Notifieation

Geserd Operatiog Requirements

Release Detection

Release Reporins, Investigation, and Confirmacion Rejesse Response and Corrective Action for UST Systems Contuining Petroleum

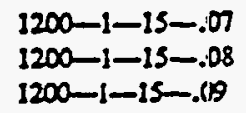

$1200-1-15-.07$ $1200-1-15-.08$ $1200-1-15-.19$

Out-of-Service UST Systems and Closure Finsaciel Responsibility Adminirrative Guidelines and Procodures for the Tennesee Pesoletron Uadeground Storage Tank Fund

1200-1-15-.10 Fee Collecion and Cerrifiente Issuance Regulations

1200-1-15-.11 Uaderground Storage Trok Progrem

\section{0-1-15-.01 PROGRAM SCOPE AND MINDMUM REQUIREMENIS FOR IANKS.}

(1) Applicability.

(a) The requirements of this chapter apply to all owners and operators of an UST system as defined in rule 1200-1-15-.01(3) except as otherwise provided in subparagraph (b) and (c) of rule $1200-1-15-.01(1)$.

Any new UST systems listed in subparagraph (b) of role 1200-1-15-.01(1) must meet the requirements of rule $1200-1-15-.01(2)$.

(b) Deferrais. Rules $1200-1-15-.02$ through $1200-1-1: 5-.05$ and $1200-1-15-.07$ through $1200-1-15-.11$ do not apply to any of the following types of UST systems:

1. Wastewater treatment tank systems;

2. Any UST systems containing radioactive material that: are regulated under the Atomic Energy Act of 1954 (42 USC 2011 and following):

3. Any UST system that is part of an emergency generator system at nuelear power generation facilities regulated by the Nuclear Regulatory Commission under 10 CFR 50 Appendix A;

4. Aiport hydrant fuel distribution systems; and

5. UST systems with field-constructed tanks.

6. Equipment or machinery that contains petroleum for operational purposes such as hydraulic lift tanks and electrical equipment tanks.

7. Any UST system whose capacity is 110 gallons or less.

8. Any UST system that contains a de minimis concentration of petroleum.

9. Any emergency spill or overflow containment UST system that is expeditiously emptied after use.

(c) Defertals. Rule 1200-1-15-.04 does not apply to any UST system that stores fuel solely for use by emergency power geserators.

(2) Mininum Requirements for Tanks.

(a) No person may install an UST system for the purpose of storing petroleum unless the UST system (whether of single or double-wall construetion): 
(Fule 1200-1-15-.01, continued)

1. Will prevent releases due to corrosion or struetural failure for the operational life of the UST system;

2. Is cathodically protected against corrosion, constructed of noneorrodible material, steel clad with a noncomodible material, or designed in a manner to prevent the release or threatened release of any petroleum; and

3. Is constructed or lined with material that is compatible with the petroleum.

(b) Notwithstanding subparagraph (a) of this paragraph, an UST system without corrosion protection may be installed at a site that is determined by a corrosion expert not to be corrosive enough to cause it to have a release due to corrosion during its operating life. Owners and operators must maintain records that demonstrate compliance with the requirements of this subparagraph for the remaining life of the tank.

[Note: The National Association of Corrosion Engineers Standard RP-02-85 (Mareh 19:15) Control of Exzernal Corrosion on Metallic Buried, Parially Buried, or Submerged Liquid Storage iystems, may be referred to for additional information.]

(3) Definitions.

(a) "Aboveground release" means any release to the surface of the land or to surface water. This includes, but is not limited to, seleases from the above-ground portion of an UST system and abo "eground releases associated with overfills and transfer operations as the petroleum moves 20 or from: an UST system.

(b) "Aneillary equipment" means any devices including, but not limited to, such devices as pi jing, fittings, flanges, valves, and pumps used to distribute, meier, or control the flow of petroleu $n$ to and from an UST.

(c) "Asymptotic level" means a graphical representation of the level of contaminant remaining in soil and/or ground water, where the $y$-axis of the graph indicates contaminant level and the $x$-axis $r$ :presents length of treatment. Samples of the soll and/or ground water shall be taken quarterly. After the slope of the graph approximates the slope of the $x$-axis, using the data from four consecutive fuarers, an asymptotic level of treatment would bave been reached; provided that the contaminant treatment system has been properly designed and operated.

(d) "Bedrock" means any rock, solid and continuous, which is exposed at the surface of the earth or overiain by uncorssolidated material.

(e) "Belowground release" means any release to the subsurface of the land or to ground wa ter. This includes, but is not limited to, releases from the belowground portions of an undergroun. 1 storage tank system and belowground releases associated with overnills and transfer operations as the fetroleum moves to or from an underground storage tank.

(I) "Beneath the surface of the ground" means beneath the ground surface or otherwise covered with earthen materials.

(g) "Cathodic protection" is a technique to prevent corrosion of a metal surface by making that surface the cathode of an eleetrochemical cell. For example, a tank system can be cathodically protected through the application of either galvanic anodes or impiessed curren. 
(Rule 1200-1-15-.01, continued)

(b) "Cathodic protection tester" means a person who can demonstsate an understanding of the pripciples and measurements of all common types of eathodit: protection systems as applied to buried or submerged metal piping and tank systems. Al a minimwn, such persons must have education and experience in soil resisrivity, stray cursent, strueture-10-soil potential, and component electrical isolacion measurements of buried metal piping and tank systems.

(i) "CERCLA" means the Comprehensive Environmental Response, Compensation, and Liability Aet of 1980 , as amended.

(j) "Compatible" means the ability of two or more substances to maintain their respective physical and chemieal properties upon contact with one another for the design life of the tank system under conditions likely to be encountered in the UST.

(x) "Conneced piping" means all underground piping including valves, elbows, joints, flanges, and llexible connectors attached to a tank system through which petroleasn flows. For the purpose of determining how much piping is conneeted to any individual UST systen, the piping that joins two UST systems shouid be allocated equally between them.

(l) "Consumption" with respect to heating oil means consuraed on the premises where stored.

(m) "Corrosion experr" means a person who; by reason of thorough knowledge of the physical sciences and the principles of engineering and mathematies acquirel by a professional edueation and related practical experience, is qualinied to engage in the practice of. corrosion control on buried or submerged metal piping systems and metal tanks. Such a person must submit documentation for review by the Division that they have acereditation or cerrification as a corrosion specialist or senior corrosion rechnologist by the National Association of Corrosion Engineers or have education and a minimum of 4 years responsible charge work experience in the corsosion field. If it is determined by the Division that a person has sufficient experience and education to be qualified to take responsible charge in corrosion control of buried or submerged metal piping systems and metal tanis, then that person shall be classified by the Division as a Corrosion Expers for the purposes of this rule.

(n) . "Dielectric material" means a material that does not conduce direct electrical current. Dielectric coatings are used to electrically isolate UST systems from the surolunding soils. Dielectric bushings are used to electrically isolate porions of the UST system (e.g., tank from piping).

(o) "Division" means the Division designated by the Commissioner of the Deparment of Health and Environment as the ageney to implement the Underground Storage Tank Progran in Tennessee.

(p) "Drinking water supply" means any aquifer or water source whose chemical charaeteristics meet the primary and secondary drinking water standards as definted under rule $1200-5-1$ and provides a yield of at least one-half gallon per minute. This shall also inciude any water supply used for drinking by the citizens of the state.

(q) "Electrical equipment" means underground equipment that contains dielectric fluid that is necessary for the operauion of equipment such as transformers and buried electrical cable.

(r) "Excavation zone" means the volume containing the tank system and backfill material bounded by the ground surface, walls, and floor of the pit and trenches into which the UST system is placed at the time of installation.

(s) " "Existing tank system" means a tank system used to contain an accumulation of perroleum or for which installation had comrenced on or before December 212,1988 . Installation is considered to have commenced if: 
(Rule 1200-1-15-.01, continued)

1. the orner or operator has obtained all federal, state; and local approvals or permits necessary so begin physical construction of the site or installation of the tank system; and if,

2. (i) ejther a continuous on-site physieal construction or installation program has begun; or,

(ii) the owner or operator has entered into contractual obligations (which cannot be cancelled or modified without substantial loss) for physical construction at the site or installation of the tank system to be completed within a reasonable time.

(t) "Farm tank" is a tank loeated on a tract of land devoted to the production of crops or raising animals, including fish, and associated residences and improvements. A farm tank must be located on the farm property. "Farm" ineludes fish hatcheries, rangeland and nurseries with growing operations.

(u) "Flow-through process tank" means a tank whose principle use is not for storage but is primarily used in the manufacture of a product or in a treatment process. Flow-through process tanks form an integral part of a production process through which there is a steady, variable, recurring, or intermittent flow of materials during the operation of the process. Flow-through process tanks do not include tanks used for the storage of materials prior to their introduction into the production process or for the storage of finished produets or by-produets from the produerion process.

(v) "Free product" refers to petroleum that is present as a nonaqueous phase liquid (e.8., liquid not dissolved in water.)

(w) "Gathering lines" means any pipeline, equipment, facility, or building used in the transportation of oil or gas during oil or gas producrion or gathering operations.

(x) "Ground water" means water below the land surface in a zone of saturation.

(v) "Heating oil" means petroleum that is No. 1, No. 2, No. 4-light, No. 4-heavy, No. 5-light, No. 5-beavy, and No. 6 technieal grades of fuel oil; other residual fuel oils (inciuding Navy Special Fuel Oil and Bunker C); and other fuels when used as substitutes for one of these fuel oils. Heating oil is typically used in the operation of beating equipment, boilers, or furnaces.

(2) "Hydraulic lift tank" means a tank holding hydraulic fluid for a closed-loop mechanical system that uses compressed air or hydraulic fluid to operate lifts, elevators, and other similar devices.

(a2) "Liquid trap" means sumps, well cellars, and other traps used in association with oil and gas production, gathering, and extraction operations (including gas produetion plants), for the purpose of collecting oil, water, and other liquids. These liquid traps may temporarily colleet liquids for subsequent disposition or reinjection into a production or pipeline stream, or may collect and separate liquids from a gas stream.

(bb) "Maintenance" means the normal operational upkeep to prevent an underground storage tank system from releasing petroleum.

(ic) "Motor fuel" means petroleum or a petroleum-based substance that is motor gasoline, aviation gasoline, No. 1 or No. 2 diesel fuel, or any grade of gasobol, and is typieally used in the operation of a motor engine.

(dd) "New tank system" means a tank system that will be used to contain an accumulation of petroleum and for which installation has commenced after December 22, 1988. (See aiso "Esisting Tank Syrrem").

(ee) "Noncommercial purposes" with respect to motor fuel means not for resaie. 
(Rule 1200-1-15-.01, continued)

(fi) "On the premises where stored" with respect to heating; oil means UST systems located on the same property where the stored heating oil is used.

(gg) "Operational life" refers to the period beginning when installation of the tank systern bas commenced until the time the tank system is properly closel under rule $1200-1-15-.07$.

(hh) "Operator" means any person in control of, or having responsibility for, the daily operation of the UST system.

(ii) "Overfill release" is a release that occurs when a tank is filled beyond its capacity, resulting in a discharge of the petroleum to the environment.

(ij) "Owner" means: (a) in the case of an UST system in ust: on November 8, 1984, or brought into use after that date, any person who owns an UST systemt used for storage, use, or dispensing of petroleum; and (b) in the case of any UST sy'stem in use before Novernber 8, 1984, but no longer in use on that date, any person who owned such UST immediately before the discontinuation of its use.

(kk) "Person" means any and all persons, ineluding individuals, firms, partnerships, associations, public or private institutions, state and federal agencies, municipalities or polivieal subdivisions, or officers thereof, departments, agencies or instrumentalities, or public or private corporations or officers thereof, organized or existing under the laws of this state or any other state or country.

(11) . "Petroleum" means crude oil or any fraction thereof that is liquid at standard temperature and pressure (60 degrees Fahrenheit and 14.7 pounds per square inch absolute).

(mm) "Petroleum UST system" means an underground storage tank system that contains petroleum or a mixture of persoleum with de minimis quantivies of other hazardous substances. Such systems include those containing motor fuels, jet fuels, distillate fuel oils, residual fuel oils, lubricants, petroleum solvents, and used oils.

(nn) "Pipe" or "Piping" means a bollow cylinder or tubular conduit that is constructed of non-earithen materiais.

(oo) "Pipeline facilities (including gathe:ing lines)" are new and existing pipe rights-of-kay and any associated equipmeni, facilities, or buildings.

(pp) "Release" means any spilling, overnlling, leaking, emiting, discharging, escaping, leaching or disposing of a petroleum substance from an UST including, its associated piping, into ground water. surface water, or subsurface soils.

(q9) "Release detection" means deteminiag whether a release of petroleum has occurred from the UST system into the environment or into the interstivial space between the UST system and its secondary barrier or secondary containment around it.

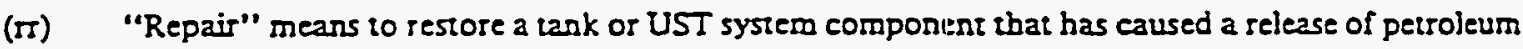
from the UST systers.

(ss) "Residential tank" is a tank located on property used prinarily for dwelling purposes.

(ti) "SARA" means the Superfund Amendments and Reauthorization Aet of 1986. 


\section{C-8}

ROUND STORAGE TANK PROGRAM

CHAPTER $1200-1-15$

$2.00-1-15-.01$, continued)

(uu) "Septic tank" is a watertight covered receptacie designed to receive or process, through liquid separation or biological digestion, the seriage discharged from a building sewer. The efflvent from such receptacle is distributed for disposal through the soil and setiled solids and scum from the tank are pumped out periodically and hauled to a treatment facility.

(w) "Storm-water or wastewater collection system" means piping, pumps, conduits, and any other equipment necessary to collect and transport the flow of surface water run-off resulting from precipitation, or domestic, commercial, or industrial wastewater to and from retention areas or any areas where treatment is designated to occur. The collection of storm water and wastewater does not include treatment except where incidental to conveyance.

(ww) "Surface impoundment" is a natural topographic depression, man-made excavation , or diked area formed primarily of earthen materials (although it may be lined with man-made materials) that is not an injection well.

(xa) "Tank" is a stationary device designed to contain an accumulation of petroleum and constructed of non-earhen materials (e.g., wood, conerete, steel, fibergless) that provide structural suppor.

(yy) "Underground area" means an underground room, such as a basement, cellar, shaft or vault, providing enough space for physical inspection of the exterior of the tank situated on or above the surface of the floor.

(zz) "Underground release" means any belowground release.

(aas) "Underground storage tank" or "UST" means any one or combination of tanks (including underground pipes connected thereto) that is used to contain an accumulation of petroleum, and the volume of which (including the volume of underground pipes conneeted thereto) is 10 percent or more beneath the surface of the ground. This term does not include any:

1. Farm or residential tank of 1,100 gallons or less capacity used for storing motor fuel for noncommercial purposes;

2. Tank used for storing hea:ing oil for consumpion on the premises where stored;

3. Septic tank;

4. Pipeline facility (including gathering lines) regulated under:

(i) The Natural Gas Pipeline Safety Act of 1968 (49 U.S.C. App. 1671. et seq.), or

(ii) The Hazardous Liquic Pipeline Safety As of 1979 (49 U.S.C. App. 2001, et seq.), or

(iii) Which is an intrastate pipeline facility regulated under state laws compa:zble to the provisions of the law refered to in paragraph (d) 1 . or (d) 2. of this definition;

5. Surface impoundment, pit, pond, or lagoon:

6. Storm-water or wastewater collection system;

7. Flow-through process tank; 
(Rule 1200-1-15-.01, continued)

8. Liquid trap or associated gathering lines directly related to oil or gas producrion and gathering operations; or

9. Storage tank situated in an underground area (such as: a basement, cellar, mineworking, drift, shaft, or tunnel) if the storage tank is situated upon or above the surface of the floor.

The term "underground storage tank" or "UST" doss not include any pipes connected to any tank which is described in parts 1. through 9. of thil subparagraph.

(bbb) "Upgrade" means the addition or retrofit of some systems such as cachodic protection, lining. or spill and overfill controls to improve the abiitty of an underground storage tank system to prevent the release of petroleum.

(coc) "UST system" or "Tank system" means an undergrournd storage tank, connected underground piping, underground ancillary equipment, and containntent system, if any.

(ddd) "Wastewater treatment tank" means a tank that is designed to receive and treat an influent wastewater through physical, chemical, or biological methods.

Authority: T.C.A. $8568-53-101$ et. seq., 68-53-107, 68-53-113 and 4-5-201 et. seq. Administrative History: Original rule filed March 1, 1990; effective April 15, 1990. Amendment filet July 3, 1991; effective August 17, 1991

1200-1-15-.02 UST SYSTEMS: DESIGN, CONSTRUCTION, INSTATIATION AND NOTIFICATION.

(1) Performance standards for new UST systems.

In order to prevent releases due to struetural failure, comosion, or spills and overfills for as long as the UST system is used to store petroleum, all owners and/or operators of new UST systems must meet the following requirements.

(a) Tanks. Each tank must be properly designed and construeted, and any porion underground that routinely contains petroleum must be protected from esrrosion as specified below:

1. The tank is constructed of fiberglass-reinforced plasis:

NNote: The following publications provide information on this subject: Underwriters Laboratories Standard 1316 (First Edivion, Revised 1987), Stantard for Glass-Fiber-Reinforced Plostic Underground Storoge Tonks for Petroleum Products: Underwriter's Laboratories of Canada CAN4S615-M 83 (First Edition, February 1983), Siandard for Reinforced Plestic Underground Tonks for Petroleum Produetr, or Ameriean Society of Testing and Materials Standard D4021-86 (1986 Edition), Standard Specification for Gless-Fiber-Reinforced Polyester Underground Petroleum Storage Tonks.]

2. The tank is consructed of steel and eathodically protected in the following manner:

(i) The tank is coated with a suitable dielectric material:

(ii) Field-installed cathodic protection systems are designed by a cortosion exper;

(iii) Impressed current systems are designed to allow determination of current operating status as required in rule $1200-1-15-.03(2)(c)$; andi 
(Ruie $1200-1-15-.02$, continued)

. (iv) Cathodic protection systerns are operated and maintained in accordance with rule $1200-1-15-.03(2)$ or a method determined by the Division to provide equivalent protection against corrosion.

Note: The following publications provide information on this subject: Steel Tank Institute May 1987 Edition) Specification for STI-P3 System of External Corrosion Protection of Underground Steel Storage Tanks; Undenwriters Laboratories Standard 1746, First Edition, Proposed November 1987), Corrosion Protection Systems for Underground Storage Tanks; Underwriters Laboratories of Canada CAN4 S603-M85, (1985 Edition), Standard for Steel Underground Tanks for Flammable and Combustible Liquids, and CAN4-603.1-M85, (1985 Edition), Standard for Galvanic Corrosion Protection Systems for Underground Tanks for Flammable and Combustible Liquids, and CAN4S631-M84, (1984 Edition), Isolating Bushings for Sieel Underground Tanks Protected with Coatings and Galvanic Systems; or National Association of Corrosion Engineers Standard RP-02-85 (March 1985), Control of External Corrosion on Metallic Buried, Partially Buried, or Submerged Liquid Storage Systems, and Underwriters Laboratories Standard 58 (Eighth Edition, 1986), Standard for Steel Underground Tanks for Flammable and Com. bustible Liquids.]

3. The tank is constructed of a steel-fiberglass-reinforced-plastic composite:

Note: The following publications provide information on this subject: Undenwriters Laboratories Standard 1746 (First Edition, Proposed November 1987), Corrosion Protection Systems for Underground Storage Tanks, or the Association for Composite Tanks ACT-100 (March 1988 Revision), Specification for the Fabrication of FRP Clad Underground Storage Tanks.]

4. The tank is consrueted of metal without additional comosion protection measures provided that:

(i) The tank is installed at a site that is determined by a corrosion exper net to be corrosive enough to cause it to have a release due to corrosion during its operational life; ard

(ii) Owners and/or operators maintain records that demonstrate compliance with the requirements of subpar (a)4.(i) of this paragjaph for the remaining life of the tank: or

5. The tank construetion and corrosion protection are determined by the Division to be designed to prevent the release or threatened release of any stored petroleum in a manne: that is no less protective of human bealth and the environment than pars (a)1. through 4. of th:s paragraph.

(b) Piping. The piping that routinely contains petroleum and is in contact with the zround must be properly designed, constructed, and protected from corrosion as specified below:

1. The piping is constructed of fiberglass-reinforeed plastic; or

Note: The following publications provide information on this subjes: Undeswriters Laboratories Subject 971, UL Listed Non-Metal Pipe; Underwriters Laboratories Standard 567 (Sixih Edition. 1989). Pipe Connectors for Flammable and Combustible and LP Ger. Underwriters Laboiatories of Canada Guide ULC-107C (1984 Edivion), Gless Fiber Reinforced Plersic Pipe and Fintings for Flommable Liquids, and Underwriters Laboratories of Canada Standard CAN4-S633-M84 (First Edition, June 1984), Fexible Underground Hose Connectors for Flammable and Combustion Liquids.]

2. The piping is constructed of steel and catbodically protected in the following manner:

(i) The piping is coated uith a suitable dielectric material; 
(Rule 1200-1-15-.02, continued)

(ii) Field-installed cathodic protection systems are designed by a corrosion expert;

(iii) Impressed current systems are designed to allow cleterminarion of current operating status as required in rule $1200-1-15-.03(2)(c)$; and

(iv) Cathodic protection systems are operated and maintained in accordance with rule $1200-1-15-.03(2)$ or in a manner determined by the Division to provide equivalent protection against corrosion.

[Note: The following publications provide information on this subject: National Fire Protection Association Standard 30 (1987 Edition), Flamrnable and Combustible Liquids Code; American Petroleum Institute Publication 1615 (Fourth Edition, November 1987), Installation of Underground Petroleum Storoge Systems, Ameriesn Petroleum Institute Publication 1632 (First Edition, 1983), Cathodic Protection of Underground Petroleum Storoge Tanks and Piping Systems, and National Association of Corrosion Engineers Standard RP-01-69 (1983 Revision), Control of External Corrosion on Submerged Metallic Piping Systems.]

3. The piping is constructed of metal without additional corrosion protection measures provided thar:

(i) The piping is installed at a site that is determined by a corrosion expert to not be corrosive enough to cause it to have a release due to corrosion during its operational life; and

(ii) Owners and/or operators maintain records that demonstrate compliance with the requirements of subpart (b)3.(1) of rule $1200-1-15-.02(1)$ for the semaining life of the piping; or

(Note: National Fire Protection Association Standard 30 (1987 Edition), Flammable and Combustible Liquids Code, and National Association of Corrosion Engineers Standard RP-01-69 (9883 Revision), Control of External Corrosion on Submerged Metallic Piping Systems, provide information on this subject.

4. The piping construction and corrosion protection are determined by the Division to be designed to prevent the release or threatened release of any stored petroleum in a mazner that is no less protestive of human health and the envisonment than the requirements in parts (b) 1. through 3. of rule $1200-1-15-.02(1)$.

(c) Spill and overfill prevention equipmeat.

1. Except as provided in part (c)2. of rule $1200-1-15-.02(1)$, to prevent spilling and over filling associated with petroleum transfer to the UST system, owners and/or operators must use the following spill and overfill prevention equipment:

(i) Spill prevention equipment that will prevent release of pe:roleum to the environment when the transfer hose is detached from the fill pipe (for example, a spill catchment basin); and

(ii) Overn!ll prevention equipment that will:

(I) Automatically shut off flow into the tank when the tank is no more than 95 percent full: or

(II) Alert the transfer operator when the tank is no more than 90 percent full by restricting the flow into the tank or triggering a high-level alarm.

(III) Restrict flow 30 minutes prior to overfilling, alert the operator with a high level alarm one minute before overfilling, or automatizally shut off flow into the tanks 50 that none of the fittings located on top of the tanj: ase exposed to product due to overilling. 
(Rule 1200-1-15-.02, continued)

2. Owners and/or operators are not required to use the spill and overfill prevention equipment specifsed in part (c)1. of rule $1200-1-15-.02(1)$ if:

(i) Alternative equipment is used that is determined by the Division to be no less protective of human health and the environment than the equipment specified in subpart (c)1.(j) or (ii) of rule 1200-1-15-.02(1); or

(ii) The UST system is filled by transfers of no more than 25 gallons at one time.

(d) Installation.

1. All tanks and piping must be installed in accordance with the manufacturer's installation instruetions; and

2. After instaliation has been completed and before the. system is placed into operation, a tank ightness test as specified in rule 1200-1-15-.04(3)(c) and a line tightness test as specified in rule 1200-1-15-.04(4)(b) must be conducted. The tank tightness test and line tightness test must indicate the tank system will not leak prior to placing the tank system into operation.

[Note: Tank and piping system installation practices and procedures described in the following publications provide information on this subject: American Petroleum Institute Publication 1615 (Fourth Edition, November 1987), Installation of Underground Petroleum Storage System; Petroleum Equipment Institute Publication RP100 (1987 Edition), Recommended Proctices for Installation of Underground Liquid Storage Systems, or American National Standards Institute Standard B31.3 (1987), Petroleum Refinery Piping, and American National Standards Institute Standard B31.4 (1989), Liguid Petroleum Transportation Piping System.]

(e) Cerification of installation. All oumers and/or operators must ensure that one or more of the following methods of cerrification, testing, or inspection is used to demonstrate complianee with subparagraph (d) of rule 1200-1-15-.02(1) by providing a certification of compliance on the UST notification form in accordance with rule $1200-1-15-.02(3)$.

1. The instalier has been cerified by the tank and piping manufacturers; or

2. The installation has been inspected and cerified by a registered professional engineer with education and experience in UST system installation; or

3. The installation has been inspected and approved by the Division; or

4. All work listed in the manufactures's installation checklists has been completed; or

5. The owner and operator have complied with another method for ensuring compliance with paragraph (d) of rule $1200-1-15-.02(1)$ that is determined by the Division to be no less protective of human health and the environment.

(2) Upgrading of existing UST systems.

(a) Altematives allowed. Not later than December 22, 1998, all existing UST systems must comply with one of the following requirements:

1. New UST system performance standards under rule 1200-1-15-.02(1);

2. The upgrading requirements in subparagraphs (b) through (d) of this paragraph; or 
(Rule 1200-1-15-.02, continued)

3. Closure requirements under rule $1200-1-15-.07$, including applieable requirements for corrective action under rule $1200-1-15-.05$.

(b) Tank upgrading requirements. Steel tanks must be upgraded to meet one of the following requirements;

1. Interior lining. A tank may be upgraded by internal lining if:

(i) The lining is installed in accordance with the requirements of rule $1200-1-15-.03(4)$ and at least the following procedures and practices:

(I) The storage tank lining material must be compatible with the product to be stored;

(II) The tank shell must be structurally sound prior to lining;

(III) Lining manufacturers directions are followed during installation of lining; and

(IV) After the tank is lined and before the tank is returned to service, the tank must be tank tightness tested according to rule 1200-1-15-.04(3)(c); and

(ii) Within 10 years after lining, and every 5 years thereafter, the lined tank is internally inspected and found to be structurally sound with the lining still performing in accordance with original design specifications.

2. Cathodic protection. A tank may be upgraded by cathodic protection if the cathodic protection system meets the requirements of rule $1200-1-15--.02$ (i)(a)2.(ii), (iii), and (iv) and the integrity of the tank is ensured using one of the folloring methods:

(i) The tank is internally inspected and assessed to ensure that the tank is structurally sound and free of corrosion holes prior to installing the cathodic protecrion system; or

(ii) The tank has bas been installed for less than 10 years and is monitored monthly for releases in accordance with rule $1200-1-15-.04(3)$ (d) through (t); or

(iii) The tank has been installed for less than 10 yeirs and is assessed for corrosion holes by conducting two (2) tightness ters that meet the requirements of rule $1200-1-15-.04(3)$ (c). The first ightness test must be conducted prior to installing the cathodic protection system. The second tightness test must be conducted between three (3) and six (ด) months following the first operation of the cathodic protection system; or

(iv) The tank is assessed for corrosion holes by a method that is determined by the Division to prevent releases in a manner that is no less protective of human health and the environment than subpars (b)2.(I) through (iii) of this paragraph.

3. Internal lining combined with eathodic protection. A tank may be upgraded by both internal lining and cathodic protection if:

(i) The lining is installed in accordance with the requirements of rule $1200-1-15-.03(4)$ and rale $1200-1-15-.02(2)(b) 1 .(i)$, and

(ii) The cathodic protection system mets the requirements of rule $1200-1-15-.02(1)$ (a)2.(ii), (iii), and (iv). 
(Rule $1200-1-15-.02$, continued)

NNote: The following publications provide information on this subject: American Petroleum Institute Publication 1631 (Second Edition, December 1987), Recommended Practice for the Interior Lining of Existing Steel Underground Storage Tanks, National Leak Prevention Association Standard 631 (Second Edition, September 1988), Spill Prevention, Minimum 10 Year Life Extersion of Existing Steel Underground Tanks by Lining Without the Addition of Cathodic Protection; National Association of Corrosion Engincers Standard RP-02-85 (March 1985), Control of External Corrosion on Metallic Buried, Portiolly Buried, or Submerged Liquid Storage Systems, and American Petroleum Institute Publica. tion 1632 (First Edition, 1983), Cathodic Protection of Underground Petroleum Storoge Tanks and Piping Systems.]

(c) Piping upgrading requirements. Metal piping that routinely contains petroleum and is in contact with the ground must be cathodically protected and meet the requirements of rule $1200-1-15-.02(1)$ (b)2.(ii), (iii), and (iv).

Note: The publications listed in the note following rule $1200-1-15-.02(1)(b) 2$. provide information on this subject.]

(d) Spill and overfill prevention equipment. To prevent spilling and overfilling associated with petroleum transfer to the UST system, all existing UST systems must comply with new UST system spill and overfill prevention equipment requirements specified in rule $1200-1-15-.02(1)(c)$.

(3) Notification requirements.

(a) Any owner who brings an underground storage tank systers into use after July 1, 1989, must 15 days in advance of bringing such tank into use, submit, in the form prescribed in Appendix 1 of this rule, a notice of existence of such tank system to the Division. Any owner or operator wishing to replace or upgrade an existing and properly registered UST system may do so as needed, provided that within 30 days after completion of said replacement or upgrading, he shall notify the Division of the changes made on the form preseribed in Appendix 1, indicating that it is an amendment to the existing system.

Note: Owners and/or operators of UST systems that wete in the ground on or after May 8, 1986. unless taken out of operation on or before January 1, 1974, were required to notify the designated state or local agency in accordance with the Hazardous and Solid Waste Amendments of 1984, Public Law 98-616, on a form published by EPA on November 8, 1985. (50 FR 46602) uniess notice was given pursuant to section 103(c) of CERCLA. Owners and/or operators who have not complied with the notificarion requirements may use portions I through VI of the notification form contained in Appendix 1 of this role.]

(b) Owners and/or operators shall use the form in Appendix I of this rile to sepor petroleum underground storage tanks.

(c) Owners required to submit notices under subparagraph (a) of this paragraph must provide notices to the Division for each tank they own. Owners may provide notice for several tanks using one notification form, but owners who own tanks located at more than one place of operation must file a separate norification form for each separate place of operation.

(d) Notices required to be submitted under subparagraph (a) of rule $1200-1-15-.02$ (3) must provide all of the information in Secrions I through VI of the prescribed form for each tank for which notice must be given. Notices for tanks installed after December 22, 1988, must also provide all of the information in Section VII of the prescribed form for each tank for which notice must be given. 
(Rule $1200-1-15-.02$, continued)

(e) All owners and operators of new UST systems must cerify in the notification form compliance with the following requirements:

1. Installation of tanks and piping under rule $1200-1-15-.02(1)(e)$;

2. Cathodic protection of steel tanks and piping under rule $1200-1-15-.02(1)(a)$ and (b);

3. Financial responsibility under rule $1200-1-15-.08$; and

4. Release detection under sule $1200-1-15-.04(2)$.

(I) All owners and operators of new UST systems must ensure that the installe: centifies in the notification form that the methods used to install the tanks and piping complies with the requirements in rule $1200-1-15-.02(1)(d)$.

(g) Beginning October 26, 1988, any person who sells a tank intended to be used as an underground storage tank must notify the purchaser of such tank of the owner's notification obligations under subparagraph (a) of rule 1200-1-15-.02(3). The form provided in Appendix 2 may be used to comply with this requirement.

(h) Any change in the status of the tanks at a petroleum UST facility must be repored within thiny (30) days of said change. This includes but is not limited to chinges of ownership, upgrading or replacement of tanks, and changes in service. Such repors shall be made using an amended notification form. In the case of a sale of tanks, the seller must submit the amended notification form and must also inform the buyer of the notification requirement.

Authority: T.C.A. \$§68-53-101 et seq., 68-53-107, 68-53-113 and 4-5-201 et seq. Administrative History: Original rule filed March 1. 1990; effective April 15, 1990. Amendment filud July 3. 1991; effective August 17, 1991.

1200-1-15-.03 GENERAI OPERATING REQUIREMENTS.

(1) Spill and overfill control.

(a) Ouners and/or operators must ensure that releases due so spillir.z c: overfilitis do set vecur. The owner and/or operator must ensure that the volume jvailitile in the tant is greater than the volume of petroleum to be transferred to the tank before the transfer is made and thac the transfer operation is monitored constantly to prevent overfilling and spilling.

(Note: The following publications provide information on this subjen: National Fire Protection Association Pubiication 385 (1985 Edition). Tonk Vehicies for Flom-m.sse =rd Combustible Liquids; American Petroleum Institute Publication 1621 (Third Edition. 1977). Recommended Practice for Euik Liquid Stock Control at Retail Outlers, and National Fir: Protestion .4ssociatson Standard 30 (1987 Edition), Flammable and Combustible Liquids Code.]

(b) The owner and/or operator must repor, investigare, ano clean up any spills and overfills in accord. ance with rule $1200-1-15-.05(4)$.

(2) Operation and maintenance of corrosion protection.

All ouners and/or operators of steel UST systems with corrosicin protection must comply with the following requirements to ensure that rejeases due to corrosion are prevented for as long as ihe UST system is used to store petroleum:

- (a) All corrosion protection systems must be operated and maintained to continuously provide corrosion protection to the metal components of that portion of the tank and pipir.s that routineis contains petroleum and is in contact with the ground.

(b) All UST systems equipped with cathodic protection systems must be inspeesed for prope: operaticn by a qualiñed cathodic protection tester in accordance with the following requirements: 
(Rule 1200-1-15-.03, continued)

1. Frequency. All cathodic protection systems must be tested wishin 6 months of installation and at least every 3 years thereafter;

2. The cathodic protection system must be functioning as designed and is effectively preventing corrosion; and

3. The owner and/or operator shall maintain records that demonstrate compliance with this paragraph.

(Note: National Association of Corrosion Engineers Standard RP-02-85 (March 1985 Edit:on), Control of External Corrosion on Metallic Buried, Partially Buried, or Submerged Liquid Storage Systems, provides information on this subject.]

(c) UST systems with impressed eurrent eathodic protection systems must also be inspected every 60 day's to ensure the equipment is running properly.

(d) For UST systems using cathodic protection, records of the operation of the cathodic protection must be maintained (in accordance with rule 1200-1-15-.03(5)) to demonstrate compliance with the performance standards in rule 1200-1-15-.03(2). These records must provide the following:

1. The results of the jast three inspections required in subparagraph (c) of rule $1200-1-15-.03$ (2); and

2. The results of testing from the last two inspections required in subparagraph (b) of rule $1200-1-15-.03(2)$.

(3) Compatability.

Owners and/or operators must use an UST system made of or lined with materials that are compatibla with the petroleum stored in the UST system.

(Niote: The following publications provide information on storing alcohol blends: American Petroleum Institure Publication 1626 (First Edition, April 1985), Storing and Fandling Ethonol and Gasoline-Ethanoi Blends at Distribution Terminals and Service Stations, and American Petroleum Institute Publication 1627 (First Edition, August 1986), Storage and Hondling of Gasoline-Methanol/Co-solvent Blend's at Distribution Terminels and Service Stations.]

(4) Repairs allow'ed.

Owrness and/or operato:s of UST systens must ensure that repairs will prevent releases due to structural failure or corrosion as long as the UST system is used to store petroleum. The repairs niust meet the follow. ing requirements:

(a) Repairs to UST systems must be condueted so as to effectively prevent releases for the operational life of the tank system.

INore: The following publications provide information on this subject: National Fire Protection Association Standard 30 (1987 Edition), Flammable and Combustible Liquids Code; Americas Petroleum Institute Publication 2200 (Second Edition, 1983), Repairing Crude Oil, Liquified Petroleum Gos, and Prociuct Pipelines. American Petroleum Institute Publication 1631 (Second Edition. December 1987). Recommended Practice for the Interior Lining of Existing Steel Undergrousd Storage Tanks: and National Leak Prevention Association Standard 631 (Second Edition, September 1988). Spill Prevention, Minimum 10 Year Life Extersion of Existing Steel Underground Tanks by Lining Wistiour the Adidition of Cathodic Protection.] 
(Rule 1200-1-15-.03, continued)

(b) Repairs to fiberglass-reinforced plastic tanks shall be made by the manufacturer's authorized representatives or in accordance with the manufacturer's specifieations.

(c) Metal pipe sections and fittings that have released product as a result of corrosion or other damage must be replaced. Fiberglass pipes and fittings may be repaired in accordance with the manufacturer's specifications.

(d) Repaired tanks and piping must be tightness tested in accordance with rule 1200-1-15-.04(3)(c) and rule $1200-1-15-.04(4)(\mathrm{b})$ within 30 days following the date of the completion of the repaiexcept as provided in pars (d)1. through 3 . of rule 1200--1-15-.03(4):

1. The repaired tank is internally inspected; or

2. The repaired portion of the UST system is monitored monthly for releases in accordance with a method speciried in rule $1200-1-15-.04(3)$ (d) through $(\mathrm{h})$; or

3. Another test method is used that is determined by the Ilivision to be no less protective of human health and the environment than those listed above.

(e) Within 6 months following the repair of any cathodically protected UST system, the cathodic protection system must be tested in accordance with rule $1200-1-15-.03(2)(b)$ and (c) to ensure that it is operating properly.

(f) UST system owners and/or operators must maintain records of each repair for the remaining operating life of the UST system that demonstrate compliance with the requirements of rule $1200-1-15-.03$ (4).

(5) Reporing and recordkeeping.

Owners and/or operators of UST systems must cooperate fully with inspections, monitoring and testing conducted by the Division, as well as requests for document submission, testing, and monitoring by the owner or operator pursuant to the Tennessee Petroleum Underground Storage Tank Act T.C.A. $\$ 68-53-107$.

(a) Reporing. Owners and/or operators must submi: the following information to the Division:

1. Notification for all UST systems (rule $1200-1-15-.02(3)$, which includes certification of installation for new UST systems (rules $1200-1-15-.02(1)(\mathrm{e})$ );

2. Repors of all releases including suspected releases (rule 1200-1-15-.05(1)), spills and ove:fills (rule $1200-1-15-.05(4)$ ), and confimed releases (rule 1200-1-15-.05(2));

3. Corrective actions planned or taken including initial abatement measures (rui: $1200-1-15-.06(3)$ ), initial site characterization (rule 1200-1-15-.06(4)), free product removal (rule 1200-1-15-.06(5)), investigation of soil and ground-water cleanup (:uis 1200-1-15-.06(6)), and corrective aetion plan (rule 1200-1-15- .06(7)); and

4. A notifieation before $p=r m a n e n t$ closure or change-int-service (rule $1200-1-15-.07(2))$.

(b) Recordkeeping. Owners and/or operators must maintain the following information:

1. A corrosion exper's analysis of site corrosion potential if corrosion protection equipmer: is not used (ruie 1200-1-15-.02(1)(a)4; rule 1200-1-15-.02(1)(b)3); 
(Rule 1200-1-15-.03, continued)

2. Documentation of operation of corrosion protection equipment (rule 1200-1-15-.03(2));

3. Documentation of UST system repairs (rule $1200-1-15-.03(4)(f)$ );

4. Recent compliance with release detection requirements (rule 1200-1-15-.04(5)); and

5. Results of the site investigation conducted at permanent closure (rule $1200-1-15-.07(5)$ ).

(c) Availability and Maintenance of Records. Owners and/or operators must keep the records required either:

1. At the UST site and immediately avaijable for inspection by the Division; or

2. At a readily available alremative site and be provided for inspection to the Division upon requiest.

3. In the case of permanent closure records required under rule 1200-1-15-.07(5), owmers and/or operators are also provided with the additional alternative of mailing closure records to the Division if they cannot be kept at the site or an alternative site as indicated above.

Authority: T.C.A. $\$ \$ 68-53-101$ et seq. and 4-5- 201 et seq. Administrative History: Original rule filed March 1. 1990; effective April 15, 1990.

\section{0-1-15-.04 RELEASE DETECTION.}

(1) General requirements for release detection.

(a) Owners and/or operators of new and existing UST systems must provide a method, or combination of methods, of release detection that:

1. Can detect a release from any porion of the tank and the connected underground piping that routinely contains petroleum;

2. Is installed, calibrated, operated, and s.aintasned in acco:dance with the manufacturer's instructions, inciuding routine maintenance and sernce checks fo: operability or running condivion: and

3. Meets the performance requirements in rule $1200-1-15-.04(3)$ or rule $1200-1-15-.04(4)$, with any perfomance claums and ther manner of determunation described in uriting by the equipment manufacturer or installer. In addition. methods used after December 22, 1990 except for methods permanently installed pnor to that date, must be capable of detecting the leak rate or quantity specified for that method in rule $1200-1-15-.04(3)(b)$, (c), and (d) or rule $1200-1-15-.04(4)(a)$ and $(b)$ with a probability of detection of 0.95 and a probability of false alarm of 0.05 .

(b) When a release detection method operated in accordance with the performance standards in rule $1200-1-15-.04(3)$ and rule $1200-1-15-.04(4)$ indicates a release may have occurred, oumers and operators must notify the Division in accordance with rule $1200-1-15-.05$.

(c) Owners and/or operators of all UST systems must comply with the release detection requirements of sule $1200-1-15-.04$ by December 22 of the year listed in the following table: 
(Rule 1200-1-15-.04, continued) Year System was installed
Year when release detection is required (by December 22 of the year indicated) $\begin{array}{llll}1989 & 1990 & 1991 & .1992\end{array}$ 1993

\section{Before 1965 or} Date Unknown 1965-1969 1970-1974 1975-1979 1980-1988

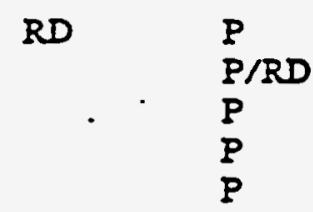

$R D$

\section{RD}

New tanks (after December 22, 1988) immediateiy upos instaliation

P - Must begin release detection for all pressurized piping in accordance with rule $1200-1-15-.04(2)(b) 1$.

RD - Must begin reiease detection for tanks and suction piping in accordance with rule $1200-1-15-.04(2)(a)$ and rule $1200-1-15-.04(2)(b) 2$.

.

(d) Any existing UST system that cannot apply a method of release detection that complies with the requirements of rule 1200-1-15-.04 must complete the closure procedures in rule 1200-1-15-.07 by the date on which release detection is required for that UST system under subparagraph (c) of rule $1200-1-15-.04(1)$.

(2) Requirements for petroleum UST systems.

Owners and operators of petroleum UST systems must provide release detection for tanks and piping as follows:

(a) Tanks. Tanks must be monitored at least every 30 days for releases using one of the methods listed in rule $1200-1-15-.04(3)(d)-(n)$ except that:

1. UST systems that meet the performance standards in rule $1200-1-15-.02(1)$ or rule $1200-1-15-.02(2)$, and the monthly inventory control requirements in rule $1200-1-15-.04(3)$ (a) or (b), may use tank tightness testing (conducted in accordance with rule 1200-1-15-.04(3)(c)) at least every 5 years urtil December 22, 1998 or unil 10 years afrer the tank is installed or upgraded under role $1200-1-15-.02(2)(0)$, whichever is later;

2. USI systems that do not meet the performance standards in rule $1200-1-15-.02(1)$ or rule $1200-1-15-.02$ (2) may use monehly inventory con"rols (condueted in accordance with rule $1200-1-15-.04(3)(2)$ or (b)) and annual tank tightn:ss testing (conducted in accordance with rule 1200-1-15-.0\$(3)(c)) until December 22, 1998 when the tank must be upgraded under rule $1200-1-15-.02(2)$ or permanendy closed under rule $1200-1-15-.07(2)$; and

3. Tanks with capacity of 550 gallons or less may use weekly tank gauging (conducted in accordance with sule $1200-1-15-.04(3)(0))$.

(b) Piping. Underground piping that routinely contains petroltum must be monitored for releases in a manner that meets one of the following requirements:

1. Pressurized piping. Underground piping that conveys petroleum under pressure must: 
(Rule 1200-1-15-.04, continued)

(i) Be equipped with an automatic line leak detector conducted in accordance with rule $1200-1-15-.04(4)(2) ;$ and

(ii) Have an annual line tightness test conducted in accordance with rule $1200-1-15-.04(4)$ (b) or have monthly monitoring conducted in accordance with rule $1200-1-15-.04(4)(c)$.

2. Suction piping. Underground piping that conveys petroleum under suction must either bave a line tightness test conducted at least every 3 years and in accordance with rule $1200-1-15-.04(4)(b)$, or use a monthly monitoring method conducted in accordance with rule 1200-1-15-.04(4)(c). No release detection is required for suction piping that is designed and construeted to meet the following standards:

(i) The below-grade piping operates at less than atmospheric pressure;

(ii) The below-grade piping is sloped so that the contents of the pipe will drain back into the storage tank if the suction is released;

(iii) Only one check valve is included in each suction line;

(iv) The check valve is located directly below and as close as practical to the suction pump; and

(v) A method is provided that allows compliance with subparts (b)2(ii)-(iv) of rule $1200-1-15-.04(2)$ to be readily determined.

(3) Methods of release detection for tanks.

Each method of rejease detection for tanks used to meet the requirements of nule 1200-1-15-.04(2) must be conducted in accordance with the following:

(a) Inventory control. Produet inventory control (or another test of equivalent performance) must be conducted monthly to detect a release of at least 1.0 percent of flow-through plus 130 gallons on a monthly basis in the following manner:

1. Inventory volume measurements for petroleum inputs, withdrawals, and the amount still semaining in the tank are recorded each operating day;

2. The equipment used is capable of measuring the level of petroleum over the full range of the tank's height to the nearest one-eighth of an inch;

3. The petroleum inputs are reconciled with delivery receipts by measurement of the tank inventory volume before and after delivery;

4. Deliveries are made through a drop tube that extends to within one foot of the tank bottom:

5. Petroleum dispensing is metered and recorded within the losal standards for meter calibration or an accuracy of 6 cubic inches for every 5 gallons of petroleum withdrawn; and

6. The measurement of any water level in the bottom of the tank is made to the nearest one-eighth of an inch at least once a month.

[Note: American Petroleum Institute Publication 1621 (Fourhb Edition, 1987), Recommended Practice for Bulk Liquid Stock Control at Resail Outlets, provides information on this subject.) 
(Rule 1200-1-15-.04, continued)

(b) Manual tank gauging. Manual tank gauging must meet the following requirements:

1. Tank liquid level measurements are taken at the beginning and ending of a period of at least 36 hours during which no liquid is added to or removed from the tank;

2. Level measurements are based on an average of two consecutive stick readings at both the beginning and ending of the period;

3. The equipment used is capable of measuring the level of petroleum over the full range of the tank's height to the nearest one-eighth of an inch;

4. A leak is suspected and subjeet to the requirements of rule $1200-1-15-.05$ if the variation between beginning and ending measurements exceeds the weekly or monthly standards in the following tabie:

$\begin{array}{lll}\begin{array}{l}\text { Nominal } \\ \text { Tank Capacity }\end{array} & \begin{array}{l}\text { Weekly Standard } \\ \text { (one test) }\end{array} & \begin{array}{l}\text { Monthly Standard } \\ \text { (Average of } 4 \text { Tests) }\end{array} \\ \begin{array}{l}550 \text { gallons } \\ \text { or less } \\ 551-1000\end{array} & 10 \text { gallons } & 5 \text { gallons } \\ \begin{array}{l}\text { gallons } \\ 1001-2000\end{array} & 13 \text { gallons } & 7 \text { gallons } \\ \text { gallons } & 26 \text { gallons } & 13 \text { gallons }\end{array}$

5. Oniy tanks of 550 gallons or less nominal capacity may use this as the sole method of release detection. Tanks of 551 to 2,000 gallons may use the Inethod in place of manual inventory control in rule 1200-1-15-.04(3)(a). Tanks of greater than 2,000 gallons nominal capacity may not use this method to meet the requirements of this rule.

(c) Tank tightness testing. Tank tightness testing (or another test of equivalent performance) must be capable of detecting a 0.1 gallon per hour leak rate from any porion of the tank that routinely contains petroleum while accounting for the effects of thermal expansion or contraction of the petroleun, vapor pockets, tank deformation, evaporation or condensation, and the location of the water table.

(d) Automatic tank gauging. Equipment for automatic tank gatuging that tests for the loss of petroleum and conducts inventory control must meet the following requirements:

1. The automatic produet level monitor test can detect a 0.2 gallon per bour leak rate from any porion of the tank that routinely contains petrolewn; and

2. Inventory control (or another test of equivalent performance) is conducted in accordance with the requirements of rule $1200-1-15-.04(3)(\mathrm{a})$.

(e) Vapor monitoring. Testing or monitoring for vapors within the soil gas of the excavation zone must meet the following requirements:

1. The materiais used as backfill are sufficiently porous (e.g., gravel, sand, crushed rock) to readily allow diffusion of vapors from releases into the ixcavation area;

2. The stored petroleum, or a tracer compound placed in the tank system, is sufficiently volatile (e.g., gasoline) to result in a vapor level that is dettetable by the monitoring devices located in the excavation zone in the event of a release from the tank; 
(Rule 1200-1-15-.04, continued)

3. The measurement of vapors by the monitoring device is not rendered inoperative by the ground water, rainfall, or soil moisture or other known interferences so that a release could go undetected for more than 30 days;

4. The leve! of background contamination in the excavation zone will not interfere with the method used to detect releases from the tank;

5. The vapor monitors are designed and operated to detect any signifieant increase in concentration above background of the petroleum stored in the tank system, a component or components of that substance, or a tracer compound placed in the tank system;

6. In the UST excavation zone, the site is assessed to ensure compliance with the requirements in parts (e)1. 4 . of rule $1200-1-15-.04(3)$ and to establish the number and positioning of monitoring wells tha: will detect releases within the excavation zone from any portion of the tank that soutinely contains petroleum; and

7. Monitoring weils are clearly marked and secured to avoid unauthorized access and tampering.

(f) Groundwater monitoring. Testing or monitoring for liquids on the ground water must meet the following requirements:

1. Ground water monitoring shall not be allowed in areas where the tank excavation zone has encountered bedrock.

2. The petroleum stored is immiscible in water and has a specific gravity of less than one;

3. Ground water is never more than 20 feet from the ground surface and the hydraulic conductivity of the soil(s) between the UST system and the monitoring wells or devices is not less than $0.01 \mathrm{~cm} / \mathrm{sec}$ (e.g., the soil should consist of gravels, coarse to medium sands, coarse silts or other permeable materials);

4. The slotted porion of the monitoring well casing must be designed to prevent migration of natural soils or filter pack into the well and to allow entry of petroleum on the water table into the well under both high and low ground water conditions:

5. Monitoring wells shall be sealed from the ground surface to the top of the filter pach:

6. Monitoring wells or devices intercept the excavation zone or are as close to it as is iechnieally ieasible;

7. The continuous monitoring devices or manual methods used can detect the presence of at leasi one-eighth of an inch of free product on top of the ground water in the montonns wells;

8. Within and immediately below the UST system excavation zone, the site is assessed to ensure compliance with the :equirements in pars (I)1.-5. of rule 1200-1-15-.04(3) and to establish the number and positioning of monitoring wells or devices that rill detect releases from any portion of the tank that routinely contains petroleur; and

9. Monitoring wells are elearly marked and secured to avoid unauthorized ascess and tampering.

(g) Interstitial monitoring. Interstitia: monitoring between the UST system and a secondary barrier immediately around or beneath it may be used, but only if the system is designed, constructed and installed to deteet a leak from any porion of the tank that routinely contains petroleum and also meets one of the following requirements: 
(Rule 1200-1-15-.04, continued)

1. For double-walled UST systems, the sampling or testing method can detect a release through the inner wall in any porion of the tank that routinely contains petroleum;

[Note: Steel Tank Institute's (April, 1989 Edition) Standard for Dual Wall Underground Storage Tanks provides information on this subject.]

2. For UST systems with a secondary barrier within the excavation zone, the sampling or testing method used can detect a release between the UST system and the secondary barrier;

(i) The secondary barrier around or beneath the UST' system consists of arificially constructed material that is sufficiently thick and impermeable (at least $10.6 \mathrm{~cm} / \mathrm{sec}$ for the petroleum stored) to direct a release to the monitoring point and permit its detection;

(ii) The barrier is compatible with the petroleum stored so that a release from the UST system will not cause a deterioration of the barrier allowing a release to pass through undetected;

(iii) For cathodically protected tanks, the seeondary barrier must be installed so that it does not interfere with the proper operation of the cathodic protection system;

(iv) The ground water, soil moisture, or rainfall will not render the testing or sampling method used inoperative so that a release could go undereeted for more than 30 days;

(v) The site is assessed to ensure that the secondary barrier is always above the ground water and not in a 25-year flood plain, unless the barries and monitoring designs are for use under such conditions; and,

(vi) Monitoring wells are clearly marked and secured to avoid unauthorized access and tampering.

3. For tanks with an internally fitted liner, an automated device can detect a release between the inner wall of the tank and the liner, and the liner is compatible with the substance stored.

(h) Other methods. Any other type of release detection method, or combination of methods, can be used if:

1. It can detec: a 0.2 gallon per hour leak rate or a release of 150 gallons within a month with a probability of detection of 0.95 and a probability of false alarm of 0.05 ; or

2. The Division may approve another method if the owner and operator ean demonstrate that the method can detect a release as effective as any of the rnethods allowed in subparagraphs (c)-(h) of rule $1200-1-15-.04(3)$. In comparing methods, the Division shall consider the size of release that the method can detect and the frequeney and reliability with which it can be detected. If the method is approved, the owner and operator must comply with any conditions imposed by the Division on its use to ensure the protection of human health and the environment.

(4) Methods of release detection for piping.

Each method of release detection for piping used to meet the requirements of rule $1200-1-15-.04(2)$ must be conducted in accordance with the following: 
(Rule 1200-1-15-.04, continued)

(a) Automatic line leak detectors. Methods which aler the operator to the preserce of a leak by restricting or shutring off the flow of petroleum through piping or triggering an audible or visual alarm may be used only if they detect leaks of 3 gallons per hour at 10 pounds per square inch line pressure writhin 1 hour. An annual test of the operation of the leak detector. must be conducted in accordance with the manufacturer's requirements.

(b) Line tightness testing. A periodic test of piping may be condueted only if it can detect a 0.1 gallon per bour leak rate at one and one-half times the operating pressure.

(c) Applieable tank methods. Any of the methods in rule.1200-1-15-.04(3)(e) through (h) may be used if they are designed to detect a release from any portion of the underground piping that rourinely contains petroleum.

(5) Release detection recordkeeping.

All UST system owners and/or operators must maintain records in accordance with rule 1200-1-15-.03(5) demonstrating compliance with all applicable requirements of rule 1200-1-15-.04. These records must include the following:

(a) All written performance claims pertaining to any release detection system used, and the manner in which these claims have been justified or tested by the equipment manufacturer or installer, must be maintained for 5 years from the date of installation;

(b) The results of any sampling, testing, or monitoring must be maintained for at least 1 year except that the results of tank tightness testing conducted in accordance with rule $1200-1-15-.04(3)(c)$ must be retained until the next test is conducted; and

(c) Written documentation of all calibration, maintenance, and repair of release derection equipment permanently located on-site must be maintained for at least one yeas after the servicing work is complesed. Any schedules of required alibration and maintenance provided by the release detection equipment manufacturer must be retained for 5 years from the date of installation.

Authority: T.C.A. $\$ \S 68-53-101$ et seq. and 4-5-201 et seq. Administrative History: Original rule filed March 1. 1990; effective April 15. 1990.

1200-1-15-.05 RELEASE REPORTING, INVESTIGATION AND CONFIRMATION.

(1) Reporing of suspected releases.

Owners and/or operators of UST systems must report to the Division within 72 hours and follow the procedures in rule $1200-1-15-.05(3)$ for any of the following conditions:

(a) The discovery by owners and/or operators or others of released petroleum at the UST site or in the surrounding area (such as the presence of free product or vapors in soils, basements, sewer and utility lines, and nearby surface water).

(b) Unusual operating conditions observed by owners and/or operators (such as the erratic behavior of petroleum dispensing equipment, the sudden loss of petroleum from the UST system, or an unexplained presence of water in the tank), unless system equipment is found to be defective but not leaking, and is immediately repaired or replaced; and.

(c) Monitoring results from a release detection method required under rule $1200-1-15-.04$ (2) that indicate a release may have oceurred unless: 
(Rule 1200-1-15-.05, continued)

1. The monitoring device is found to be defecrive, and is immediately repaired, recalibrated or replaced, and additional monitoring does not confirm the initial result: o:

2. In the case of inventory control, a second month of data does not confirs the initial result.

(2) Investigation due to off-site impacts.

When required by the Division, owners and/or operators of UST' systems must follow the procedures in rule 1200-1-15-.05(3) to determine if the UST system is the sturee of off-site impacts. These impacts include the discovery of petroleum (such as the presence of free product or vapors in soils, basements, sewer.and utility lines, and searby surface and drinking waters) that has been observed by the Division or brought to its attention by another pary.

(3) Release investigation and confirmation steps.

Unless corrective action is initiated in accordance with rule 1200-1-15-.06, owners and/or operators must immediately ïvestigate and confim all suspected releases of petroleum sequiring reporting under rule 1200-1-15-.05(1) within 7 days using the following steps:

(a) System test. Owners and/or operators must conduct tests (according to the requirements for tightness testing in rule 1200-1-15-.04(3)(c) and rule 1200-1-15--.04(4)(b)) that determine whether a leak exists in that porion of the tank that routinely contaiss petroleum, or the attached delivery piping, or both.

1. Owners and/or operators must repair, replace or upgrade the UST system, and begin corrective action in accordance with rule $1200-1-15-.06$ if the test results for the system, tank, or delivery piping indicate that a leak exists.

2. Further investigation is not required if the test results for the system, tank, and delivery piping do not indicate that a leak exists and if environmental contamination is not the basis for suspecting a release.

3. Orners and/o: operators must conduct a site check as described in paragraph (b) of this section if the test results for tie system, tank, and delivery piping do not indicate that a leak exists but environmental conizeination is the basis for suspecting a release.

(b) Site check. Owners and/o: operators must measure for the presence of a release where contamination is mosi likely to be present at the US, site. In selecting sample types, sample loca:ions, and measurement methods, oumers and/or operators must consider the nature of the stored petroleum, the type of initial alarm or cause fo: suspision, the tspe of backfill, the depth of ground wate:, and other factors appropriate for identifying the presence and source of the release.

1. If the test results for the excavation zone or the UST site indicate that a release has occurred, owners and/or operators must begin corrective action in accordance with rule 1200-1-15-.06;

2. If the test results for the excavarion zone or the UST site do not incicate that a release has occurtec, furher investigation is not reguired.

(4) Reporing and cleanup of spills and overfills. 
(Ruie 1200-1-15-.05, continued)

(a) Owners and/or operators of UST systems must contain and immediately clean up a spill or overfill and report to the Division within 72 hours and begin corrective aetion if a spill or overfill of petsoleum results in a release to the environment that exceeds 25 gallons or that causes a sheen on nearby surface water; or

(b) Owners and operators of UST systems must contain and immediately clean up a spill or overfill of petroleum that is less than 25 gallons. If cleanup cannot be accomplished within 72 hours owners and/or operators must immediately.notify the Division.

Authority: T.C.A. \$68-53-101 et seq. and 4-5-201 et seq. Administrative Fistory: Original rule filed March 1, 1990; effective April 15, 1990.

1200-1-15-.06 RELEASE RESPONSE AND CORRECTTVE ACTION FOR UST SYSTEMS CONTAINING PEIROLEUM.

(1) General.

Owners and/or operators of petroleum UST systems must, in response to a confirmed release from the UST system, comply with the requirements of rale $1200-1-15-.06$.

(2) Initial response.

Upon confirmation of a release in accordance with rule 1200-1-15-.05(3) or after a release from the - UST system is identified in any other manner, owners and/or operators must perform the following initial response ations:

(a) Report the release to the Division within 72 hours (e.g., by telephone or electronic mail);

(b) Take immediate action to prevent any furcher release of the petroleum into the environment; and

(c) Take immediate action to identify and mitigate fire, explosion, and vapor hazards.

(3) Initial abatement measures and site check.

(a) Uniess directed to do otherwise by the Division, owners and/or operators must perform the following abatement measures:

1. Remove as much of the perroleum from the UST system as is necessary to prevent further release to the environment;

2. Visually inspeet any aboveground releases or exposed belowground releases and prevent furcher migration of the petroleum into surrounding soils and ground water;

3. Continue to monitor and mitigate any additional fire and safety hazards posed by vapors or free product that have migrated from the UST excavation zone and entered into subsurface struetures (such as sewers or basements);

4. Remedy hazards posed by contaminated soils that are excavated or exposed as a jesult of release confirmation, site investigation, abatement, or corrective action activities. If these remedies include treatment or disposal of soils, the owner and/or operator must comply with applicable state and local requirements; 
(Ruje 1200-1-15-.06, continued)

5. Measure for the presence of a release where contamination is most likely to be present at the UST site, uniess the presence and source of the release bave been confirmed in accordance with the site check required by rule $1200-1-15-.05(3)(b)$ or the closure site assessment of rule $1200-1-15-.07(3)(a)$. In selecting sample types, samipie locations, and measurement methods, the owner and operator must consider the nature of the stored petroleum, the tspe of backrill, depth to ground water and other factors as appropriate for identifying the presence and source of the release; and

6. Investigate to determine the possible presence of fres product, and begin free product removal as s000 as practicable and in accordance with ruie 1200-1-15-.06(5).

(b) Within 20 days after release confirmation owners and/or operators must submit a report to the Division summarizing the initial abatement steps taken under subparagraph (a) of rule 1200-1-15-.06(3) and any resulting information or data.

(4) Initial site characterization.

(a) Unless directed to do otherwise by the Division, owners and/or operators must assemble information about the site and the nature of the release, including infornation gained while confirming the release or completing the initial abatement measures in rule 1200-1-15-.06(1) and rule 1200-1-15-.06(2). This information must include, but is not necessarily limited to the following:

1. Data on the nature and estimated quantity of release;

2. Data from available sources and or site investigations concerning the following factors: surrounding populations, water quality, use and appromiate locations of wells potentially affected by the release, subsurface soil conditions, locations of subsurface sewers, climatological conditions, and land use;

3. Results of the sire check required under rule $1200-1-15-.06(3)(2) 5$; and

4. Results of the free product investigations required under sule $1200-1-15-.06(3)(2) 6$, to be used by owners and/or operators to determine whethe: free produc: must be secovered under rule $1200-1-15-.06(5)$.

(b) Within 45 days of release confirmation owners and/o: operators must submut the information coilected in compliance with subparagraph (a) of rule 1200-1-15-.06(4) to the Division in a manne: that demonstrates its applicability and techneal adequacy, or in a format and ascording to the schedule required by the Division.

(5) Free produet removal.

At sites where investigations under rule $1200-1-15-.06$ (3)(a) 6 indicate the p:esence of fres product, owners and/or operators must semove free product to the maximum eatent practicable as determined by the Division while continuing, as necessarj; anj actions initiated unjer rule $1200-1-15-.06(2)$ through rule $1200-1-15-.06(4)$, or preparing for acrions required under rule 1200-1-15-.05(6) through rule $1200-1-15-.06(7)$. In meeting the requirements of this paragraph, owners and/or operators must: 
(Rule 1200-1-15-.06, continued)

(a) Conduce free product removal in a manner that minimizes the spread of contamination into previous. ly uncontaminated zones by using recovery and disposal techniques appropriate to the hydrogeologic conditions at the site, and that properly treats, discharges or disposes of recovery byproducts in compliance with applicable local, state and federal regulations;

(b) Use abatement of free product migration as a minimum objective for the design of the free product sernoval system;

(c) Handle any flammable produets in a safe and competent manner to prevent fires or explosions; and

(d) Unless directed to do otherwise by the Division, prepare and submit to the Division, within 45 days afier confirming a reiease, a free product removal report that provides at least the following information:

1. The name of the person(s) responsible for implementing the free product removal measures;

2. The estimated quantity, type, and thickness of free product observed or measured in wells, borcholes, and excavations;

3. The type of free product recovery system used;

4. Whether any discharge will take place on-site or off-site during the recovery operation and where this discharge will be loeated;

5. The type of treatment applied to, and the effluent quality expected from, any diseharge;

6. The steps that have been or are being taken to obtain necessary permits for any diseharge, and

7. The disposition of the recovered free product

(Q) Investigations for soil and ground water cleanup.

(a) In order to determine the full oxent and location of soils contaminated by the release and the presence and concentrations of dissolved product contamination in the ground water, owners and/or operators must conduct investigations of the release, the release sits and the sursounding area possibly affected by the release if any of the following conditions exist:

1. There is evidence that ground water wells have been affected by the release (eg., as found during release confirmation or previous correcrive action measures);

2. Free product is found to need recovery in compliance with rule $1200-1-15-.06(5)$;

3. There is evidence that contaminated soils may be in contact with ground water (eg., as found during conduct of the initial response measures or investigations required under rule $1200-1-15-.06(1)$ through rule 1200-1-15-.06(5); and

4. The Division requess an investigation, based on the potential effects of contaminated soil or ground water on nearby surface water and ground water resources.

(b) Owners and/or operators must submit the information collected under subparagraph (a) of this paragraph as soon as practicable or in accordance with a schedule established by the Division. 
(Rule 1200-1-15-.05, continued)

(7) Corrective action plan.

(a) At any point after reviewing the information submitted in compliance with rule $1200-1-15-.06(2)$ through rule 1200-1-15-.06(4), the Division may require owners and/or operators to submit additional information or to develop and submit a corrective action plan for responding to contaminated soils and ground water. If a plan is required, owners and/or operators must submit the plan according to a schedule and format erablished by the Division. Altenlatively, owners and/or operators may, after fulfilling the requirements of rule 1200-i-15-.05(2) through rule 1200-1-15-.05(4), choose to submit a corrective action plan for responding to contaminated soil and ground wate:. In either case, owners and/or operators are responsible for submitring a plan that provides for adequate prozection of human health and the environment as determined by the Division, and must modify their plan as necessary to meet this standard.

(b) The Division will approve the corrective action plan only after ensuring that implementation of the plan will adequately protect human health, safety, and the environment. In making this determination, the Division should consider the following factors is appropriate:

1. The physical and chemical characteristies of the peiroleum, inciuding its toxicity, persistence, and potential for migration;

2. The hydrogeologic characteristics of the facility and the surrounding area;

3. The proximity, quality, and current and future uses if gearby surface water and ground water,

4. The potential effects of residual contamination on aearby surface water and ground water;

5. An exposure assessment; and

6. Any information assembled in compliance with rall: $1200-1-15-.06$.

(c) Upon approval of the corrective action plan or as directed by the Division, owners and/or operators must impiement the plan, including modifications to the plan made by the Division. They mus monitor, evaluate, and report the results of implementing the plan in accordence with a schedule and in a format established by the Division.

(d) Owners andi/or operators may, in the interest of minimizing environmen:al contanination and promoting more effective cleanup, begin cleanup of soil and ground water before the corsective action plan is approved provided that they:

1. Notify the Division of their intention to begin cleasup;

2. Comply with any conditions imposed by the Division, including halting cleanup or mitigating adverse consequences from cleanup activities; and

3. Incorporate these self-initiated cieanup measures in the corrective action plan that is submitted to the Division for approval.

(e) 1. Ground water contaminated by petroleum from UST systems must be addressed in the corrective action plan and meet the levels as listed in Appendix 3 for drinking water supplies and nondrinling water supplies. The corrective action plan nust determine if the contaminated ground water met the definition of a "drinking water supply" before the contamination occurred and propose site cleanup levels based on the category of ground wzter. 
$-1-15-.05$, continued)

2 Soil contaminated by petroleum from UST systems must be addressed in the corrective action plar. The level of soil cleanup shall follow Appendix 4. Soil cleanup levels shall vary depending upon the permeability of the soil and whether the ground water below the site is a "drinking pater supply" or "non-drinking water supply". The permeability of the soil at the site and the type ground vater below the site must be reported in the corrective action plan.

3. For sites where the background level of petroleum, due to natural conditions, exceeds the levels of cleanup required for soil and/or ground water in Appendices 3 and 4, then the owner and/or operator shall only be required to cleanup to the naturally occurring background levels.

4. After an owner and/or operator has treated petroleum contamination at a site for an extended period of time and the treatment system for soil and/or ground water has reached asymptotic levels for contaminant removal, then the owner and/or operator may request a site specific standard from the Commissioner. The site specific standard request must document the type of treatment used at the site, the length of trearment, and that the level of coniaminant in the soil and/or ground water has remained relatively constant for at least four (4) quarters. The site specifie standard request must also contain the parameters in paragraph 5 below. If the Commissioner does not aet on the request within 90 days of receipt, it shall be deemed to be denied. The owner and/or operator may appeal any denial of a site specific standard request to the Board. The Commissioner shall submit an annual report to the Board documenting the site specific standards grented during the calendar year.

5. If the owner and/or operator believes that a particular site should not be subject to the cleanup requirements in Appendices 3 and 4, the owner and/or operator may petition the Commissioner for a site specific standard. The owner and/or operator must, at 2 minimum, include the following in the site specific standard request:

(i) The physical and chemical characteristies of petroleum; including its toxicity, persistence, and potential for migration:

(ii) The hydrogeologic characteristies of the petroleum site and the surrounding land;

(iii) The proximity, quality, and current and future uses of ground water,

(iv) An exposure assessment; and

(v) The proximity; quality, and current and future uses of surface waters.

Should the Commissioner deny the properly completed site specific standard request or fail to act within ninety $(90)$ ealendar days of receipt, the owner and/or operator may petition the Board for the site specific standard. The site specifje standard request must include all items listed above, at a minimum.

6. If the owner and/os operator has been granted a site specific standard based on a request described in part S. of this subparagraph and it is later determined that the information supplied in the request was not accurate or there has been a change in the information supplied in subpars 5.(i) through $(v)$, then the Commissioner may revoke the site specifie standard. The revocation of a site specific standard may be appealed to the Board. 
(Rule 1200-1-15-.06, continued)

(8) Public parricipation.

(a) For each confirmed release that requires a corrective action plan, the Division must provide nouce to the public by means designed to reach those members of the public directly affected by the release and the planned corrective action. This notice may include, but is not limited to, public notice in loeal newspapers, block adverisements, public service announcements, publication in a state register, letters to individual households, or personal contacts by field staff.

(b) The Division must ensure that site release information and decisions concersing the corrective action plan are rnade available to the public for inspection upos request.

(c) Before approving a corrective action plan, the Division maty hold a public meeting to consider comments on the proposed corrective action plan if there is sufficient public interest, or for any other reason.

(d) The Division must give pubic notice that complies with subparagraph (a) of nule $1200-1-15-.06(8)$ if implementation of an approved corrective action plan does not achieve the established cleanup levels. in the plan and termination of that plan is under consideration by the Division.

Authority: T.C.A. \$§68-53-101 et seq. and 4-5-201 et seq. Administrative History: Original rule filed March 1, 1990; effective April 15, 1990.

\section{0-1-15-.07 OUT-OF-SERYICE UST SYSTEMS AND CLOSURE}

(1) Temporary closure.

(a) When an UST system is temporarily closed, owners and/or operators must continue operation and maintenance of corrosion protection in accordance with rule $1200-1-15-.03(2)$, and any release detertion in accordance with role 1200-1-15-.04. Rule 1200-1.-15-.05 and rule 1200-1-15-.06 must be complied with if a release is suspected or confurmed. Hiowever, release detection is not required as long as the UST system is empty. The UST system is emfity when all materiais have been removed using commonly employed practices so that no more than 2.5 centimeters (one inch) of residue or 0.3 percent by weight of the total capacity of the UST system, remain in the system.

(b) When an UST system is temporarily closed for 3 months or more, owners and/or operators must also comply with the following requirements:

1. Leave vent lines open and functioning; and

2. Cap and secure all other lines, pumps, manways, ancl ancillary equipment.

3. File amended notification form shouing the tank system as Temporarily Out of Use

(c) When an UST system is temporarily closed for more than 12 months, owners and/or operators must permanently close the UST system if it does not meet either performance standards in rule $1200-1-15-.02$ (1) for new UST systems or the upgrading requirements in rule 1200-1-15-.02(2), exeept that the spill and overfill equipment requirements do not have to be met. Ouners and/or operators must permanently close the substandard UST systems at the end of this 12-month period in accordance with rule 1200-1-15-.07(2) through rule 1200-1-15-.07(5), uniess the Division provides a written extension of the 12-month temporary closure period. Owners and/or operators must complete a site assessment in aceordance with rule $1200-1-15-.07(3)$ before such an extension can be applied for. 
(Rule 1200-1-15-.07, continued)

(2) Permanent closure and changes-in-service

(a) At least 30 days before beginning either permanent closure or a change-in-service under paragraphs (b) and (c) of rule 1200-1-15-.07(2) owners and/or operators must submit a site closure plan to the Division to permanently close or make the change-in-service unless such action is in response to corrective action. The required assessment of the excavation zone under rule 1200-1-15-.07(3) must be performed after notifying the Division but before completion of the permanent closure or a change-in-service

(b) To permanently close a tank, owners and/or operators must empty and clean it by removing all liquids and accumulated siudges. All tanks taken out of service permanently must also be either removed from the ground or filled with an inert solid material such as a cement compound, sand, gravel, etc The iner solid material must have a specific gravity greater than 1.0 .

(c) Continued use of an UST system to store a non-regulated substance is considered a change-in-service Before a change-in-service, owners and/or operators must empty and clean the tank by removing all liquid and accumulated sludge and conduct $a$ site assessment in accordance with rule $1200-1-15-.07(3)$.

(d) Should an owner and/or operator elect to exeavate and remove a tank from the site, such excavation and removal must be done in accordance with Appendix 5.

(e) Once a tank has been excavated, it may be stored on-site or transported off-site for storage or disposal. Excavated tanks which have not been cut into sections for disposal shall be considered in storage and shall at all times, while in storage be maintained in a vapor-free state and stored in accordance with Appendix 5.

(f) Tanks may not be stored at a UST facility unless they are maintained in a vapor-free state, stored in accordance with Appendix $S$, and one of the following conditions are met:

1. (i) Tanks have been cleaned by removal of all liquids and aceumulated sludges; and

(ii) Tanks have been purged of vapors so that any explosive leveis do not oxceed 20 percent of the lower flammable limit for the regulated substance; and

(iii) Tanks have an opening or openings installed which comprise a minimum of 10 percent of the total tank surface area. Such openings will not be considered openings if they are in contact or contiguous with the ground or surface on which the tank may be resting; or

2. 1.(i) and (ii) above have been complied with and there are no remaining UST5 either in use or in a temporarily elosed condition at the facility, or

3. Tankes which are removed from a UST facility and are intended for reuse at the same or another facility as USTs may be stored at a UST facility if the owner and/o: operator meets the conditions described in 1.(i) and (ii), and eirber removes the tank off-site from a UST facility or puts it back into service within 30 days of excavation.

(8) Tanks must be stored in a manner which does not pose safety hazards. Tanks must be stored in a position with the iank's center of gravity closest to the ground. Tanks may not be stacked. Tanks must be secured so that they will not roll or slide across a level or sloping ground surface 
(Rule 1200-1-15-07, continued)

(h) Trasporation and disposal of tanks xill be subjeet 20 all applieable Federal, Sute and loeal law's and regulations conceraing the safe transporation and proper disposal of such materials.

Note: The followins publieations provide information on this subject: American Petroleum Institute Recommended Przetice 1604 (Second Edition. December 1987), Removal and Disposal of Used Underground Petroleum Storoge Tonis, Ameriean Petroleum Institute Publieation 2015 (Third Edition, September 1985), Cleaning Petrolesm Storage Tanks, Aseriean Petroleum Institute Recommended Practice 1631 (Second Edition, Deeember 1987), Interior .Lining of Underground Storage Janks. The National Institute for Oecuparional Safery and Health Crittria Documens 80-106 (1980 Edition), Criterie for a Recommended Standard . . . Working in Confined Space may be used as guidance for conouc-

. ting safe closure procedures at some petroleum tanks.]

(3) Assessing the site at closure or change-in-service

(a) Before permanent closure or 2 change-in-service is completed, owners and/or operators must measure for the presence of a release where contamination is most likely 20 be fresent at the UST site In selecting sample types, sample locations, and measurement merbods, owners and/or operators mus consider the method of closure, the nature of the stored stbsrages, the type of baelerill, the depth to ground water, and other factors appropriase for identifying the presence of a release The requirements of this paragraph are satisfied if one of the exernal relesse deteesion methods allowed in rule $1200-1-15-.04(3)(e)$ and $(f)$ is operating in accurdanee with the requirements in rule $1200-1-15-.04(3)$ at the time of closure, and indieates so release has oceurred.

(b) If contaminated soils, contaminated ground water, or fre: produet as a liquid or vapor is discovered under subparagraph (a) of this paragraph, or by any other manner, ouners and/or operators must begin corrective aetion in aceordance with rule 1200-1-15-.06.

(4) Applicability to previousiy elosed Uist systems.

When direted by the Division, the ou'ner and/or cperator of an UST systers permasently elosed before December 22, 1988 must assess the exeavation zOne and elost: the UST system in aceordance with role 1200-1-15-.07 if releases from the UST ma), in the judgment of the Division, pose a current or potential threat to human health and the envuronmess.

(5) Closure records.

Owners and/or operators must maintain resords in 2eco:cianse with rule 1200-1-15-.03(5) that are eapab!e of demonstreting compliance with closure requirements under rule 1200-1-15-.07. The results of the exeavation zone assessment required in rule 1200-1-15-.07(3) raust be maintained for at least 3 jears afte: complesion of permanent elosure o: change-in-servise ts. one of the following ways:

(a) By the ouners and/or operato:s who took the L'SI syst:s out of service;

(b) By the current owners and/or operators of the UST system site; or

(c) By maiting these records to the Division if they cannot be maintained at the closed facility:

Authority: T.C.A. \$\$68-53-101 et seq. and 4-5-201 et seq. Administrative History: Original rale filed March 1. 1990; effective April 15, 1990. 
Appeadix 1

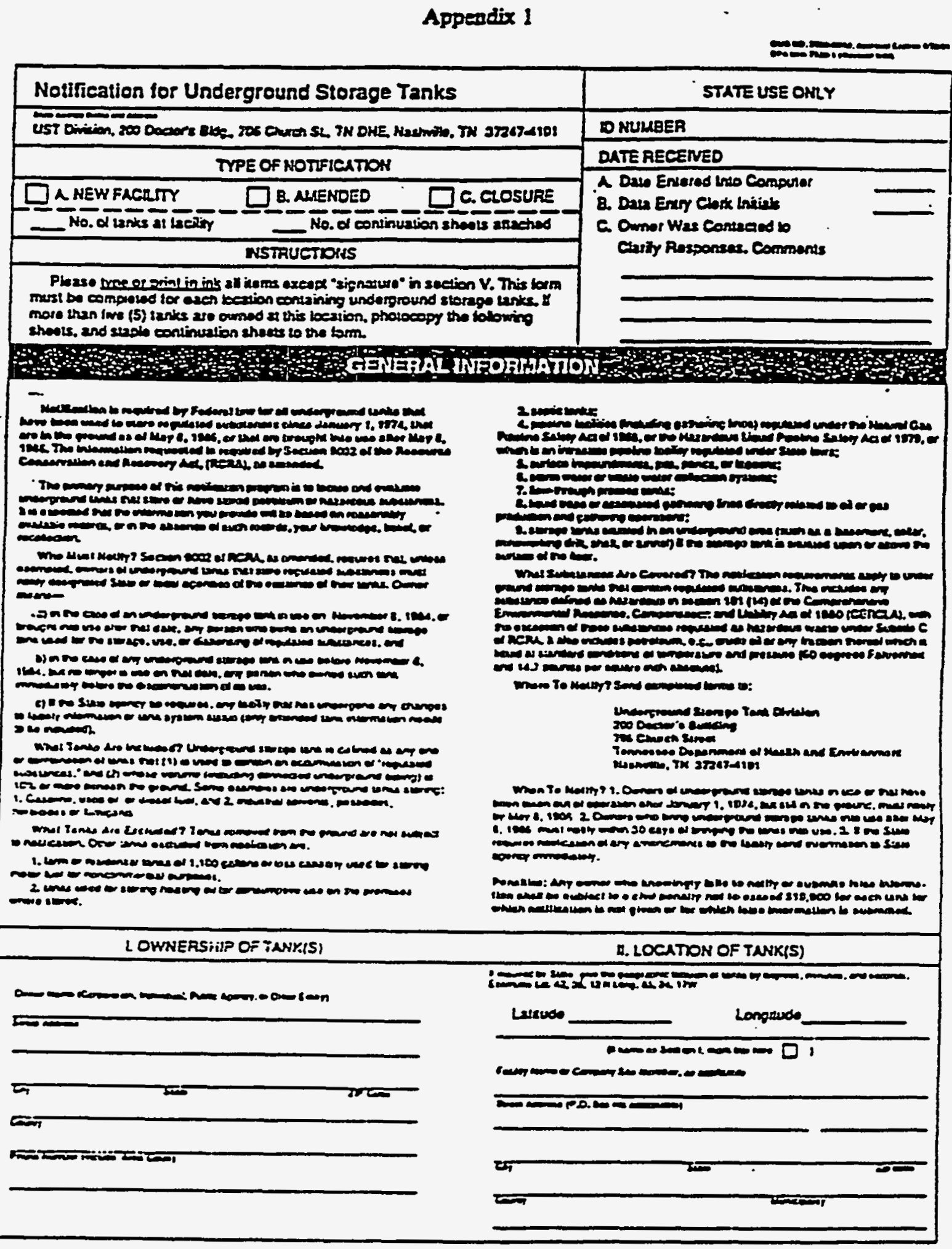

rh-3197 (kev. 2-91) 
(Appendix 1, continued)

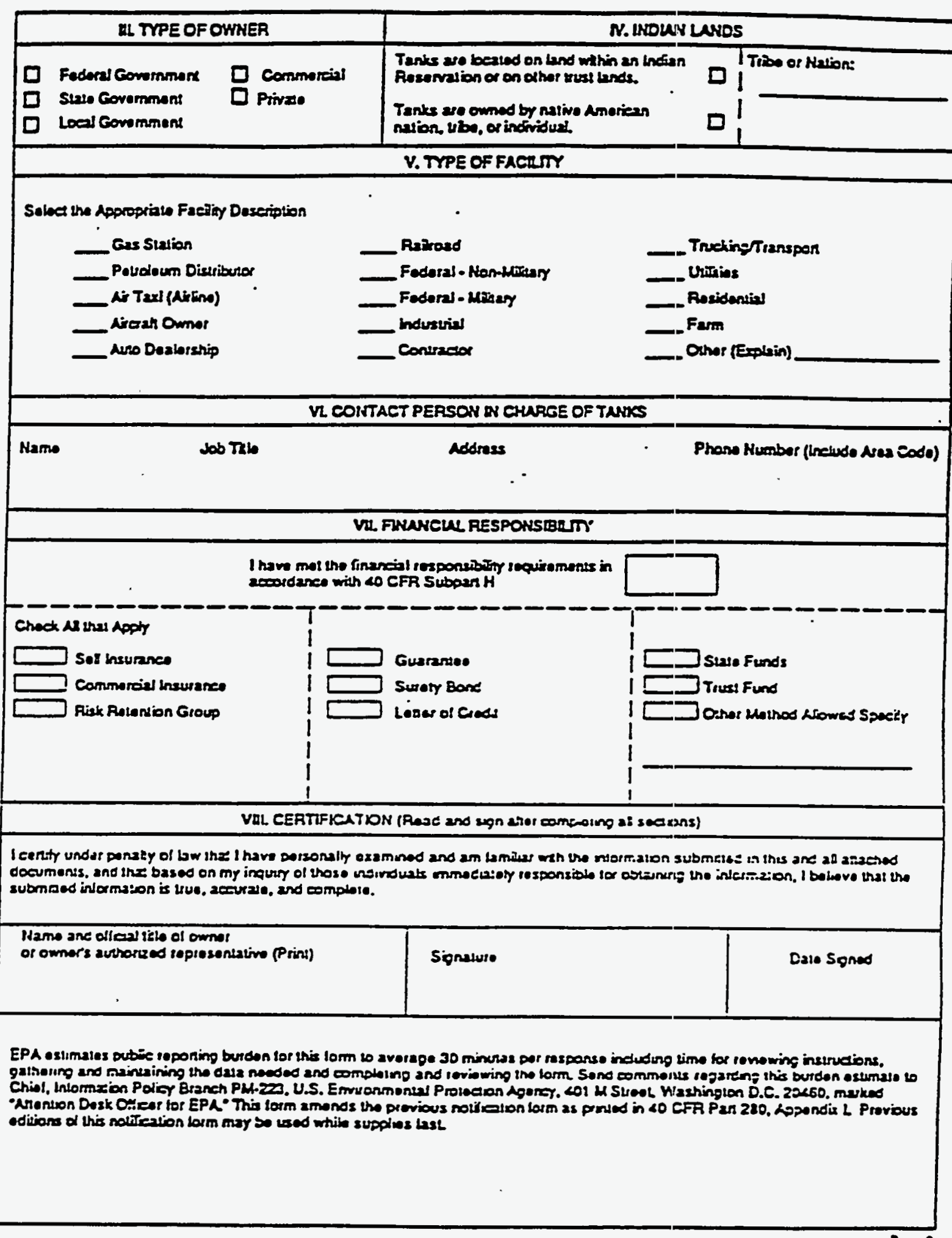


(Appendix 1, continued)

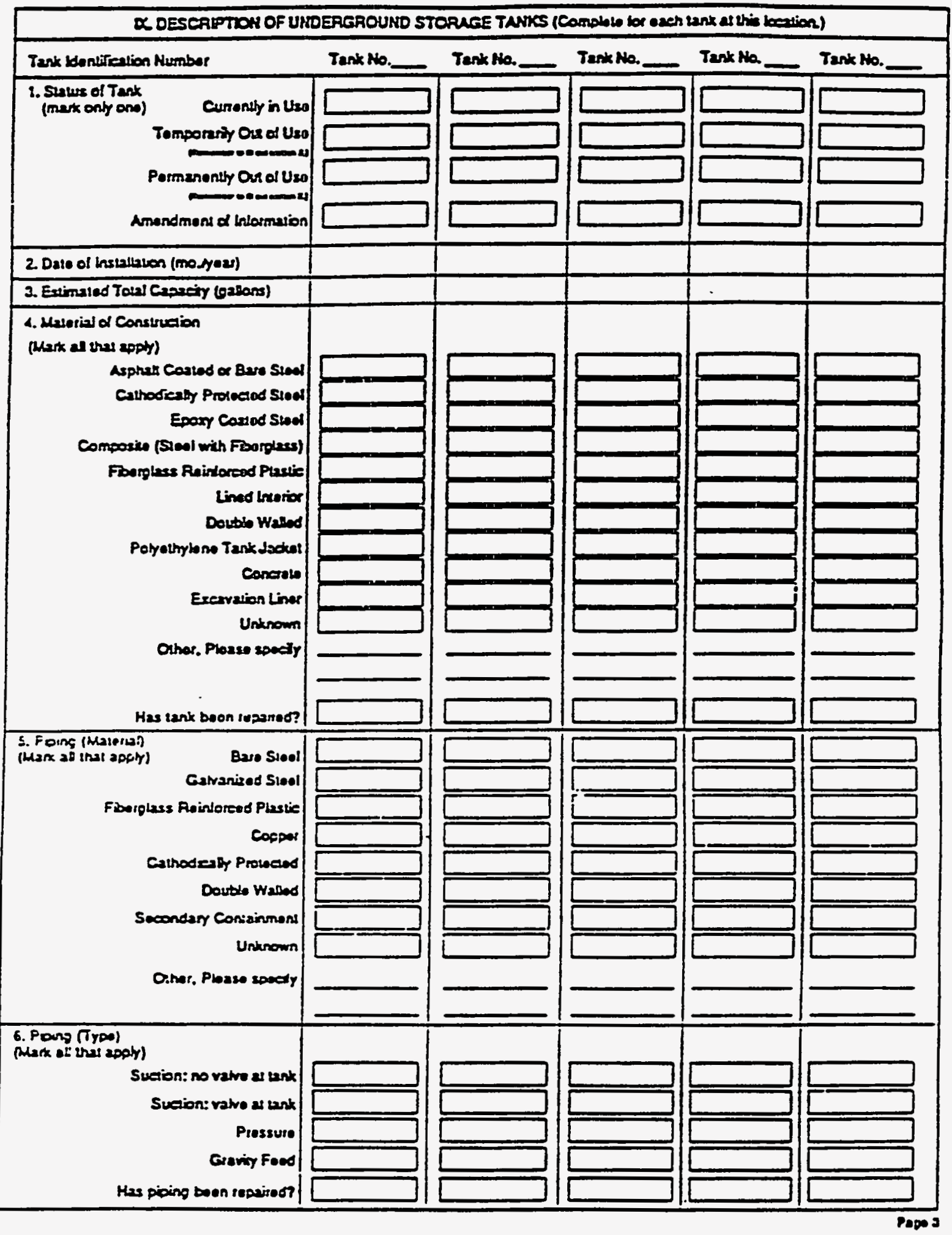


(Appendix 1, continued)

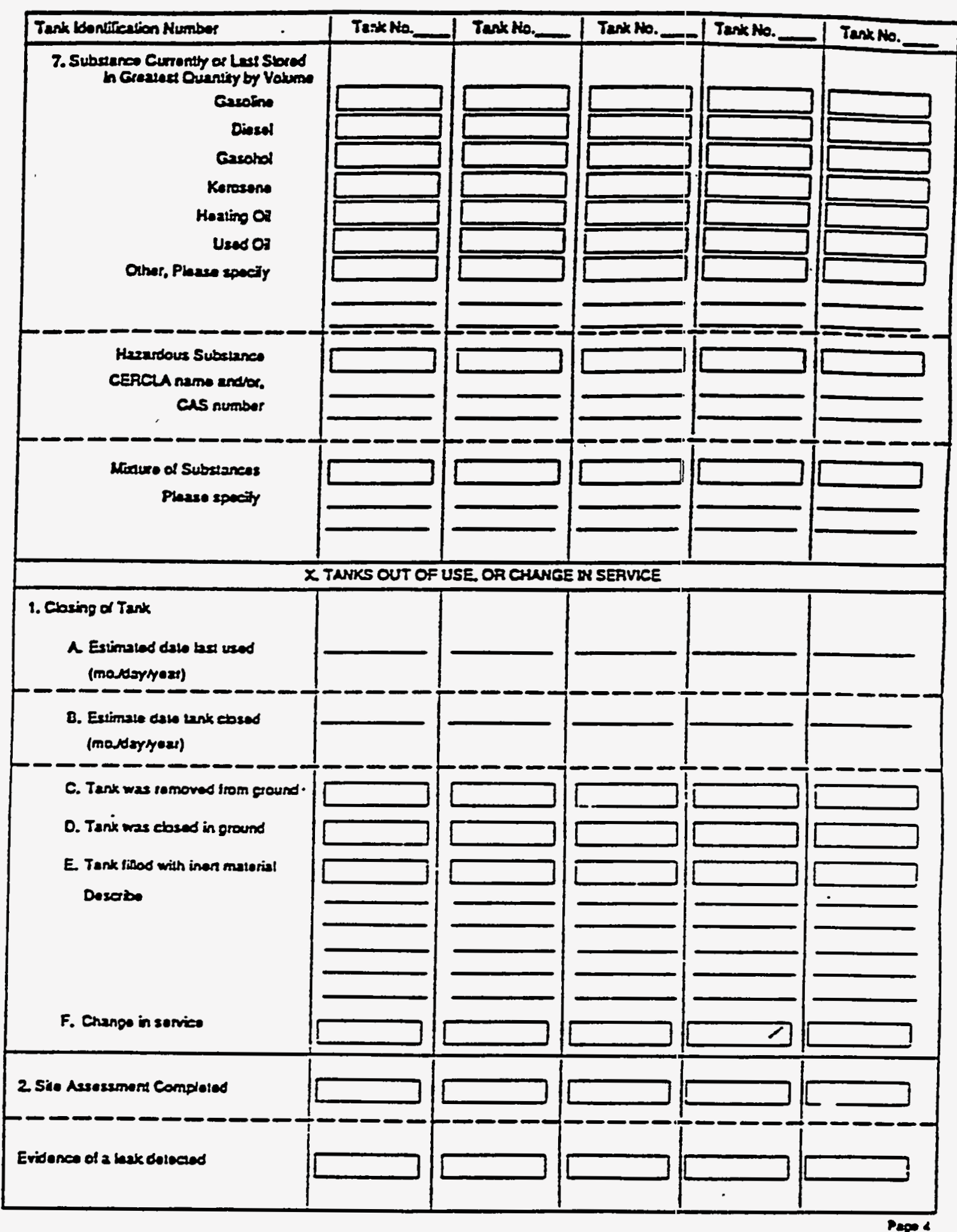


(Appendix 1, continued)

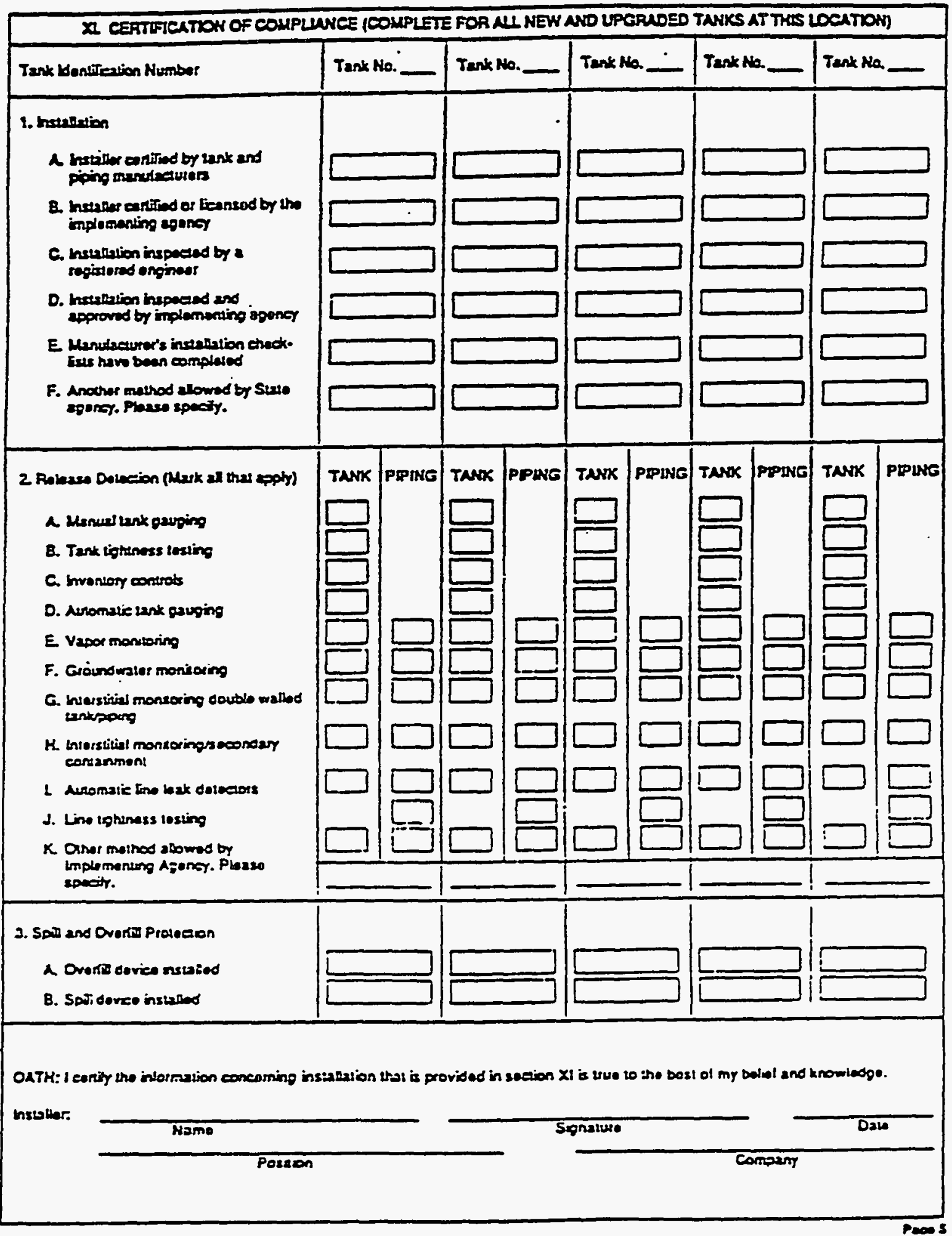


Appendix 2 - Statement for Sbipping Tickets and Invoices

Note - A Federal law (the Resource Conservation and Recovery Act (RCRA), is amended (Pub. L. 98-610) requires owners of cernain underground storage tanks to notify designated State or local agencies by May 8 , 1986, of the existence of their tanks. The Tennessee Petroleurn Underground Storage Tank Aet (T.CA. \$68-53-10l et seg.) also contains notification requirements. Notifications for tanks brought into use after July 1, 1989 must be made 15 days in advance of installation. Consult EPA's regulations, issued on November 8, 1986 (40 CFR Part 280) and state law (T.CA. \$68-33-111] et seq.) and state regulations (Chapter $1200-1-15)$ to determine if you are affected by these laws and regulations.

Appendix 3

PETROLEUM CONTAMINATION CLEANIJP LEVEIS

GROUND WATER CLEANUP LEVEL

DRINKING WATER .

NON-DRINKTNG WATER
BENZENE LEVEL

0.005 PPM

0.070 PPM
TOTAL PETROLEUM HYDROCARBON IEVEL

0.100 PPM

1.0 PPM

Appendix 4

PETROLEUM CONTAMINATION CLEANUP LEVELS

\begin{tabular}{|c|c|c|c|}
\hline SOIL PERMEABILITY & $-10-4 \mathrm{CM} / \mathrm{SEC}$ & $10-4$ TO 10 -6 CM/SEC & $-10-6 \mathrm{CM} / \mathrm{SEC}$ \\
\hline SOIL CLEANUP LEVEL & & B.TX LEVEL PPM & \\
\hline DRINKING WATER & 10 & 50 & 100 \\
\hline NON-DRINKING WATER & so & 250 & 500 \\
\hline
\end{tabular}

OR

TOTAL PETROLEUM HYDROCARBON CLEANUP LEVELS

\begin{tabular}{|c|c|c|c|}
\hline SOIL PERMEABILITY & $-10-4 \mathrm{CM} / \mathrm{SEC}$ & $10-4$ TO $10-6 \mathrm{CM} / \mathrm{SEC}$ & $-10-6 \mathrm{CM} / \mathrm{SEC}$ \\
\hline SOIL CLEANUP LEVEL & & T.P.H. PPM LEVEL & \\
\hline DRINKING WATER & 100 & 250 & 500 \\
\hline NON-DRINKING WATER & 250 & 500 & 1000 \\
\hline
\end{tabular}




\section{APPENDIX 5}

\section{REMOVAI OF UNDERGROUND TANTS}

\section{(1) Preparation}

(a) Drain produet piping into the tank, being careful to avoid any spillage Cap or remove product piping.

(b) Remove liquids ard residues from the tank by using explosion-proof or air-driven pumps. Pump motors and suction hoses must be bonded to the tank or otherwise grounded io prevent electrostatic ignition hazards. It may be necessary to use a hand pump to remove the last few inches of liquid from the bottom of the tank.

NOTE: (The Federal Resoure Conservation and Recovery Act (RCRA) 42 U.S.C. Section 6901 et seq., and the Tennessee Hazardous Waste Management Act (HWMA) Par 1 T.CAA. 868-46-101 et seq. place restrictions on disposal of cerain residues that may be present in some underground storage tanks. Residues from tanks that have held leaded gasoline should be treated with extreme caution. Lead compounds and other residues in the tank may be classified as hazardous wastes).

(c) Excavate to the top of tank.

(d) Remove the III pipe, gauge pipe vapor recovery truek connection, submersible pumps, and other tank fixtures. Remove the drop tube, except when it is planned to vapor-free the tank by using an eductor. Cap or remove all non-produet lines, such as vapor recovery lines, except the vent line The vent line must remzin connected unil the tank is purged. Temporarily plug all other tank openings so that all vapors will exit through the vent line during the vapor-freeing process.

(2) Purging

(a) Remove flammable vapors by one of the methods deseribed in B.2 through 5., or as required by loeal codes. These methods provide a means for temporary vapor-freeing of the tank atmosphere. However, it is imporant to recognize that the tank may continue to be a source of nammable vapors even after following the vapor-freeing p:ocedures described in 2 through $S$. For this reason, caution must always be exercised when handling or working around tanks that have stored flammable or combustible liquids. Before initiating work in the tank area or on the tank, a combustible gas indieator must be used to assess vapor concentrations in the tank and work area. All work must be done in accordance with Section C. "Testing"

(b) Ven: all vapors from the tank at a minimum height of 12 feet above grade and 3 feet above any adjacent roof lines until the tank is purged of flammable vapors. The work area must be free from sources of ignition.

(c) Flammable and combustible vapors may be purged with an inert gas such as carbon dioxide $\left(\mathrm{CO}_{2}\right)$ or nitrogen $\left(\mathrm{N}_{2}\right)$. This method is not to be utilized if the tank is to be entered for any reason, as the tank aumosphere will be oxygen deficient. The iner gas is to be introduced through a single tank opening at a point near the bottom of the tank at the end of the tank opposite the vent. When iner gases are used, they must be introduced under low pressure to avoid the generation of static elecricity. When using $\mathrm{CO}_{2}$ or $\mathrm{N}_{2}$. pressures in the tank must not exceed 5 pounds per square inch gauge.

CAUTION: The process of introducing compressed gases into the tank may create a potential ignition bazard as the result of the development of static electrical charges. The discharging device must therefore be grounded. Explosions have resulted from the discharging of $\mathrm{CO}_{2}$ fire exinguishers into tanks containing a flammable vapor-air mixture $\mathrm{CO}_{2}$ exinguishers must not be used for inerting flammable aumospheres. 
(Appendix S, continued)

(d) If the method described in 3 is not practical, the vapors in the tank may be displaced by adding solid carbon dicxide (dry jce) to the tank in the amount of at least 1.5 pounds per 100 gallons of tank apacity. The dry ice should be crushed and distributed evenly over the greatest possible area in the tank to promote rapid evaporation. As the dry ice vaporizes, flammable vapors will flow out of the tank and may surround the area. Therefore, where practical, plug all tank openings except the vent after. introducing the solid $\mathrm{CO}_{2}$ and continue to observe all normal safety precaurions regarding flammable or combustible vapors. Make sure that all of the dry ice has evaporated before proceeding.

(c) Flammable vapors may be exhausted from the tank by one of two methods of tank ventilation listed belok:

1. Ventilation using an eductor-type air mover usually driven by compressed air. The eductor-type air mover must be properjy bonded to prevent the genetation and discharge of static electricity. When using this method, the fill (drop) tube must remain in place to ensure ventilation at the bottom of the tank. Tanks equipped with fill (drop) rubes that are not removable should be purged by this method. An eductor extension shall be used to discharge vapors a minimum of 12 feet above grade.and at least 3 feet above any adjacent roof line.

2. Ventilation with a diffused air blower. When using.this purging method, it is imperative that the air-diffusing pipe is properly bonded to prevent the discharge of a spark. Fill (drop) tubes must be removed to allow proper diffusion of the air in the tank. Air supply should be from a compressor that has been checked to ensure a clean ail: supply and is free from volatile vapors. Air pressure in the tank must not exceed 5 pounds per square inch gauge

(3) Testing

(a) The tank atmosphere and the excavation area are to be regulariy tested for flammable or combustible vapor concentrations until the tank is removed from both the excavation and the site Such tests are to be made with a combustible gas indicator which is properly calibrated according to the manufacturer's instructions and which is thoroughly checked and maintained in accordance with the manufacturer's instructions. Persons responsible for testing must be completely familiar with the use of the instrument and the interpretation of the instrument's readings.

(b) The tank vapor space is to be tested by placing the combustible gas indicator probe into the fill opening with the drop tube removed. Readings should be taken at the bottom, middle, and upper porions of the tank, and the instrument should be cleared after each reading. If the tank is equipped with a non-remorable fill tube, readings are to be taken through another opening. Liquid produet must not enter the probe Readings of 20 percent or less of the lower flammable limit must be obtained before the tank is considered safe for removal from the ground.

(c) Tanks purged with an iner gas must be sampled with an o:sygen indicator and the axygen content must be considered while interpreting combustible gas indicator results.

(4) Removal

(a) After the tank has been freed of vapors and before it is recooved from the excavation, plug or cap all accessible holes. One plug must have a 1/8-inch vent hole to prevent the tank from being subjected to excessive differential pressure caused by temperature changes. The tank must always be positioned with this vent plug on top of the tank during subsequent tuansport and storage 
(Appendix 5, continued)

(b) Excavate around the tank to uncover it for removal. Remove the tank from the cxcavation and place it on a level surface Use wood blocks to prevent movement of the tank after removal and prior to loading on a truck for transportation. Use serewed (boiler) plugs to plug any corrosion holes in the rank shell.

(c) Precautions must be taken to assure any vapors left in the tank do not reach a combustibie level. If this situation oceurs, the rank must be pirged according to Section $B$.

(d) Before the rank is removed from the site, the tank atmosphere must be checked with a combusible gas indicator to ensure that it does not exceed 20 percent of the lower flammable limit.

(e) The tank must be secured on a truck for transportation to the storage or disposal site with the $1 / 8$-inch vent hole located at the uppermost point on the tank. Tanks must be transported in accordance with all applicable local, state, and federal laws and regulations.

(I) Tanks must be labeled after removal from the ground but prior 20 removal from the site Regardless of the condition of the tank, the label must contain a warning agzinst certain types of reuse The former contents and present vapor state of each tank, incluaing vapor-freeing treatment and data must also be indieated. The label must be similar to the following in legible letters at least 2 inches high:

\section{IANK HAS CONTADNED LEADED GASOLINE*}

\section{NOT VAPOR FREE}

\section{NOT SUITABLE FOR STORAGE OF FOOD OR LIQUIDS \\ . INTENDED FOR HUMAN OR ANIMAL CONSUMPTION}

\section{DATE OF REMOVAL: MONTH/DAY/YEAR}

- Or ctber flammable/combustible liquid. Use the applicable designation, for example DIESEI.

Tanks that have held leaded motor fuels (or whose service history is unknown) must also be clearly labeled with the following information.

\section{TANK HAS CONTAINED LEADED GASOIINE \\ IEAD VAPORS MAY BE RELEASED IF HEAT \\ IS APPLIED TO THIE TANK SHELL}

\section{STORAGE OF USED IANKS}

Storage Procedures

(a) Tanks must be vapor-freed before being placed in storage Tanks must also be free of all liquids and residues. All tank openings must be tightly plugged or capped, with one plug having a 1/8-inch vent hole to prevent the tank from being subjected to excessive differential pressure caused by temperature changes. Tanks must be stored with the vented plug at the highest point on the tank. All tanks must be labeled.

(b) Used tanks must be stored in secure areas where the general public will not have access. 
1200-1-15-.08 FINANCLAL RESPONSIBITTY.

(1) Applicability

(a) This rule applies to owners and operators of all petroleuna underground storage tank (UST) systems exept as otherwise provided in this paragraph.

(b) Owners and operators of petroieum UST systems are subjest to these requirements if they are in operation on or after the date for compliance established in rilie $1200-1-15-.08(2)$.

(c) State and federal government entities whose debts and liabilities are the debts and liabilities of a state or the United States are deemed to meet financial responsibility requirements without having to meet requirements of this rule.

(d) The requirements of this rule do not apply to opners and operators of any UST system deseribed in rale $1200-1-15-.01(1)(b)$.

(e) If the owner and operator of a petroleum underground storage tank are separate persons, only one person is required to demonstrate financial responsibility; however, both parties are liable in event of noncompliance Regardless of which party complies, the ditte set for compliance at a particular facility is determined by the characteristies of the owner as set forth in rule $1200-1-15-.08(2)$.

\section{(2) Compliance Dates}

Orners of petroleum underground storage tanks are required 10 comply with the requirements of this rule by the following dates:

(a) All petroleum marketing firms owning 1,000 or more US.B and all other UST owners that repor a tangible net worth of 520 million or more 10 the U.S. Securities and Exchange Commission (SEC), Dun and Bradstret, the Energy Information Administration, or the Rural Electrifieation Administration; January 24, 1989.

(b) All petroleum marketing fums owning 100-999 USTs; October 26, 1989.

(c) All petroleum marketing firms owning 13.99 USTs at more than one facility; April 26, 1991.

(d) All petroleum UST owners not described in subparagraphs (a), (b), or (c) of this paragraph, including all local government entities; October 26, 1991.

(3) Definition of Terms.

When used in this rule the following terms shall have the meinings given below:

(a) "Accidental release" means any sudden or nonsudden releast: of petroleum from an underground storage tank that results in a need for correcrive aetion and/or compensation for bodily injury or propeny damage neither expected nor intended by the tank ounter or operator.

(b) "Board" means Tennessee Pesoleum Underground Storige Tank Boand established under T.CA. \$68-53-101 et seq.

(c) "Bodily injury" shall have the meaning given to this terra by applicable Tennesset law. 
(Rule $1200-1-15-.08$, continued)

(d) "Commissioner" means Commissioner of Health and Environment, his authorized represeatatives, or in the event of his absence or a vacancy in the Commissioner's Ofrsee, the Deputy Commissioner.

(e) "Controlling interest" means direct ownership of at leart 50 percent of the voting stock of another entity.

(f) "Department" means the Deparment of Fealth and Environment.

(8) "Financial reporing year" means the latert consecutive twelve-month period for which any of the follow. ing reports used to support a financial tert is prepared: (1) a 10-K report submitted to the SEC; (2) an annual report of tangible net worth submitted to Dun and Bradstret; or (3) annual reports submitted to the Energy Information Administration or the Rural Electrification Administration. "Financial reporing year" may thus comprise a fiscal or a calendar year period.

(k) "Fund" meane petroleum underground storage tank fund established under T.C.A. §68-53-10I et seg., uniess the context clearly indicares otherwise

(i) "Legal defense cost" is any expense that an owner or operator or provider of financial assurance incurs in defending against claims or secions brought (1) by EPA or the Commissioner to require corrective aetion or to recover the costs of corrective action; (2) by or on behalf of a third party for bodily injury or property damage caused by an accidental release; or (3) by any person to enforce the terms of a financial assurance mechanism.

(j) "Occurrence" means the discovery of environmental contamination at a specific time and date, due to the release of petroleum froducts from petroleum underground storage taoks.

(x) "Owner or operator," when the owner or operator are separate paries, refers ts the party that is obtaining or has obtained financial assurances.

(1) "Petroleum marketing facilities" include all facilities at which petroleum is produced or refined and all facilities from which petroleum is sold or transferred to other petroleum markerers or so the public

(m) "Petroieum marketing firms" are all firms owning petroleum marketing facilities. Firms ouning other types of facilities with USTS as well as petroleum marketing facilities are considered to be petroleum marketing firms.

(a) "Property damage" shall have the meaning given tbis term by applicable Tennessee law:. Exclusions for property damage shall no: include corrertive action associated with releases from tanks which are covered by the policy.

(o) "Provider of financial assurance" means an entity that provides financial assurance to an owner or operator of an underground storage tank through one of the mechanisms listed in rule $1200-1-15-.08(6)$ through rule $1200-1-15-.08(13)$, including a guarantor, insurer, risk retestion group, surety, issuer of a letter of credit, o: the state of Tennessee.

(p) "Substantial business relationship" means the corent of 2 business :jationship necessary under applicable Tennessee law to make a giveantee contret issued incident to that relationship valid and en. forceable A guarantee contract is issued "incident to that relationship" if it arises from and depends on existing economic transactions between the guarantor and the owner or operator.

(q) "Tar Zble net worts" means the tangible assets that remain after deducring liabilities; such assets do not isclude intengibies such as good wiil and rights to patents or royalties. For purposes of this defrnitios, "assets" means all existing and all probable furure economic benefits obrained or coatrolled by a pazicular entity as a result of past transactions.

(r) "Termination" under 1200-1-15-.08(8)1. and 1200-1-15-.08(8)2. meens only those cbanges that could result in a gap in coverage as where the insured nas not obteined substitute coverege or has obtained subsitute coverage with a different reuroactive date than the retroarive date of the original policy. 
(Ruic 1200-1-15-.08, continued)

(4) Amount and Scope of Required Financial Responsibility.

(a) Owners or operators of petroleum underground storage tanks: meust demonstrate financial responsibility for taking corrective action and for compensating third parties for bodily injury and property damage caused by accidental releases arising from the operation of petroleum underground storage tanks in -at least the following per-occurrence amounts:

1. For owners or operators of petroleum underground storage taniks that are loeated at petroleum marketing facitities, or that handle an average of more than 10,000 gallons of petroleum per month based on annual throughput for the previous calendir year; SI million.

2 For all other owners or operators of petroleum underground storage tanks; 5500,000 .

3. For owzers or operators who have paid all annual fees ind have met all obligations to participate in the fund, the fund shall be responsible for the following:

(i) For owners or operators of 1 to 12 petroleum underground storage tanks, corrective action costs above ten thousand dollars $(\$ 10,000)$ in an amount not to exceed one million dollars $(\$ 1,000,000)$ per site per oceurrence and court arards involving third party liability claims above ten thousand dollars $(\$ 10,000)$ in an amtount not to exced one million dollars $(\$ 1,000,000)$.

(ii) For owners or operators of 13 to 999 petroleum underground storage tanks, corrective action above twenty thousand dollars $(520,000)$ in an amount not to exeed one million $(51,000,000)$ per site per oceurance, and court avrards involving third party liability claims above an amount not less than twenty five thoutand dollars $(525,000)$ nor mose than fifty thousand dollars, and not to exced one million dollars $(51,000,000)$. The amount between twenty five thousand dollars $(\$ 25,000)$ and fifty thousand dollars $(\$ 50,000)$ pill be set annually by the Board. Effective May 1, 1990 the imount is thirty seven thousand five hundred dollars $(\$ 37,500)$ for third party claims.

(iii) For orners or operators of 1,000 or more petroleum underground storage tanks, corrective aetion costs above fifty thousand dollars $(550,00)$ in an amount not to ereed one million dollars $(\$ 1,000,000)$ per site per oceureace, and court awards involving third party liability claims above an amoust not less than one hundred fifty thousand dollars $(\$ 150,000)$ nor more than three hundred thousand dollars $(\$ 300,000)$, and not to exceed one million dollars $(51,000,000)$. The anount between one hundred fifty thousand dollars $(5150,000)$ and three hundred thousand dollars $(5300,000)$ will be set ennually by the Board. Effective May 1 , 1990 the amount is two bundred twenty-five thousand dollars $(5225,000)$ for third party ciaims.

This part is subject to rule 1200-1-15-.08(20)(1), and rule 1200-1-15-.09. The owners or operators eligible for fund benefit must have a per occurrence finangial assurance of either twenty thousand dollars $(\$ 20,000)$ for 1 so 12 petroleum underground storage tanks, fifty seven thousand five hundred dollars $(\$ 57,500)$ for 13 to 999 petroleum underground storage tantes or two hundred seventy five thourand dollars $(5275,000)$ for 1,000 or more petroleum underground storage tanks. In the event the fund has insufficient resourees 10 meet corrective action and/or third party compenssation costs, the responsibility for paying for corrective action and/or third party compensation costs sball be the responsibility of the ourner, operator, or otiner responsible party.

(b) Orners or operators of petroleum underground storage tanki; must demonstrate financial responsibility for taking corrective action and for compensating thind parties for bodily injury and property damage caused by accidental releases arising from the operation of petroleum underground storage tanks in at least the following annual aggregate amounts:

1. To assure that ourners or operators ean meet financial requirements for entry to the fund for both corsective acrion and third pary liabiity, okneis or operators eligible for the fund must bave annual aggregate amounts at least as large as the amount in the Annual Agsregate Amount column of Table I which corresponds to the numbe: of tanks ourned. 


\section{C-46}

UNDERGROUND STORAGE IANK PROGRAM

(Rule 1200-1-15-.08, continued)

Table 1

Number of Tanks Owned vs. Financial Responsibility Requirements

\begin{tabular}{|c|c|c|c|c|}
\hline $\begin{array}{c}\text { Number of } \\
\text { Tanks } \\
\text { Owned } \\
1-12 \\
13-999 \\
1000+\end{array}$ & $\begin{array}{l}\text { Corrective } \\
\text { Action Per } \\
\text { Occurrence } \\
\text { Amount } \\
\\
\$ 10,000 \\
\$ 20,000 \\
\$ 50,000\end{array}$ & $\begin{array}{l}\text { Third Party } \\
\text { Compensation } \\
\text { Per } \\
\text { Occurrence } \\
\text { Amount } \\
\\
\$ 10,000 \\
\$ 37,500 \\
\$ 225,000\end{array}$ & $\begin{array}{l}\text { Total Per } \\
\text { Aggregate } \\
\text { Amount } \\
\mathbf{S 2 0 , 0 0 0} \\
\mathbf{5 5 7 , 5 0 0} \\
\mathbf{S 2 7 5 , 0 0 0}\end{array}$ & $\begin{array}{c}\text { Agnual } \\
\text { Aggregate } \\
\text { Amount } \\
\\
\$ 20,000 \\
\$ 77,500 \\
\$ 375,000\end{array}$ \\
\hline
\end{tabular}

- The Annual Aggregate Amount for orners of 13 to 999 tanks is determined by multiplying the Corrective Aetion Per Oceurence Amount by 2 , then adding the Third Party Compensation Per Oecurence Amounat. The Annual A8gregate Amount for owners of 1,000 or more tanks is determined by multiplying the Corrective Action Per Oecurrence Amount by 3, then adding the Third Party Compensation Per Occurence Amount. 
(Rule 1200-1-15-.08, continued)

(c) For the purposes of subparagraphs (b) and (() only, "a petrileum underground storage tank" means a. single containment unit and does not mean combinations of single containment units.

(d) Exeept as provided in subparagraph (e), if the oumer or operator uses separate mecharisms or separate combinations of mechanisms to demonstrate financial responsibility for:

1. taking corsective action; or

2. compensating third parties for bodily injury and property camage caused by accidental releases;

the amount of assurance provided by each mechanism or conbination of mechanisms must be in the full amount specified in subparagraphs (a) and (b) of this ylaragraph.

(e) If an ormer or operator uses separate mechanisms or separare combinations of mechanisms to demonstrate financial responsibility for different petroleum underground storage tanks, the annual aggregate required shall be based on the number of tanies correred by each such separate mechanism or combination of mechanisms.

(f) Owners or operators shall review the amount of aggregate assurance provided whenever additional petroleum underground storage tanks are acquired or installed. If the number of petroleum underground storage tanks for which assurance must be provided exeeds 12, the owner or operator shall demonstrate financial responsibility in the amount defined in subparagraph (b) by the anniversary of the date on which the mechanism demonstrating financial responsibility became effective If assurance is being demonstrated by a combination of mechanisms, the owner cis operator shall demonstrate financial responsibility in the amount defined in subparagraph (b) by the first-oceurring effective date anniversary of any one of the mechanisms combined (other than a financial test or guarantec) to provide assurance

(g) The amounts of assurance required under this paragraph exclude legal defense costs.

(h) The required per-occurrence and annual aggregate coverage amounts do not in any way limit the liability of the owner or operator.

(5) Allowable Mecharisms and Combinations of Mechanisms

(a) Subject to the limitations of subparagraph (b) of this paragraph, an owner or operator may use any one or combination of the mechanisms listed in rule 1200-1-15-.08(6) through rule 1200-1-15-.08(13) to demonstrate financial responsibility under this nale for one or more underground storage tanks. 
(Rule 1200-1-15-.08, continued)

(b) An ownes or operator may use self-insurance in combination with a gusantee only if, for the purpose of meeting the requirements of the financial test under this rule, the financial statements of the owner or operator are not consolidated with the financial statements of the guarantor.

(6) Financial Test of Self-Insurance

(a) An owner or operator, and/or guarantor, may satisfy the requirements of rule $1200-1-15-.08(4)$ by passing a financial test as specified in this paragraph. To pass the financial test of self-insurance, the owner or operator, and/or guarantor must meet the criteria of subparagraph (b) or (c) of this paragraph besed on year-end finarcial statements for the latert completed fiscal year or financisl reporting year If an owser or operator has in effect more than one financial tert for self-insurance at any one time to assure financial responsibility, the owner or operator must bave 2 tangible net worth and/or a net working capital of at least $(X)$ times the sum of the toial amounts for which this financial ter is used, where $(X)$ equals the Self-Insurance Amount from Table 2 divided by the Annual Assregate Amount from Table 2 based on the number of tanks for which this financial test is used. Table 2 shall be used in both subparagraphs (b) and (c) in determining the tangible net worth and/or net working capital which as owner or operator and/or guarantor must demonstrate in order to self-insure for corrective action and/or third party liability based on the number of tanks for which this financial test is used.

Table 2

\begin{tabular}{|c|c|c|c|c|c|}
\hline $\begin{array}{l}\text { Number } \\
\text { of } \\
\text { Tanks } \\
\text { Owned }\end{array}$ & $\begin{array}{c}\text { Corrective } \\
\text { Action Per } \\
\text { Oceurrence } \\
\text { Amount }\end{array}$ & $\begin{array}{l}\text { Third Party } \\
\text { Compensation } \\
\text { Per } \\
\text { Occurrence } \\
\text { Amount }\end{array}$ & $\begin{array}{l}\text { Total Per } \\
\text { Oecurrence } \\
\text { Amount }\end{array}$ & $\begin{array}{l}\text { Annual } \\
\text { Agsregate } \\
\text { Amount }\end{array}$ & $\begin{array}{c}\text { Self } \\
\text { Insurance }\end{array}$ \\
\hline $\begin{array}{l}1-12= \\
1-12 \\
13-999 \\
1000+\end{array}$ & $\begin{array}{l}\$ 10,000 \\
s 10,000 \\
S 20,000 \\
S 50,000\end{array}$ & $\begin{array}{l}\mathbf{S 1 0 , 0 0 0} \\
\mathbf{S 1 0 , 0 0 0} \\
\mathbf{S 3 7 , 5 0 0} \\
\mathbf{S 2 2 5 , 0 0 0}\end{array}$ & $\begin{array}{l}\$ 20,000 \\
\$ 20,000 \\
\$ 57,500 \\
\$ 275,000\end{array}$ & $\begin{array}{l}\mathbf{S 2 0 , 0 0 0} \\
\mathbf{S 2 0 , 0 0 0} \\
\mathbf{S 7 7 , 5 0 0} \\
\mathbf{S 3 7 5 , 0 0 0}\end{array}$ & $\begin{array}{l}S 20,000 \\
\$ 30,000 \\
\$ 117,500 \\
\$ 525,000\end{array}$ \\
\hline
\end{tabular}

- This applies when either all tanks and assajiated piping ar new, upgraded, a combination of aew and upgraded, or are located at only one faciity. 
(Rule 1200-1-15-.08, continued)

(b) If the owner or operator, and/or guarantor desires ro self-insure and does not choose to mer the requirements of (b)(c), the owner or operator and/or guarentor must meet the requireaconts of this subparagraph.

1. The owner or operator, and/or guarantos, must have a tangible net worth of at least $(X)$ times the sum of (i), (ii) and (iii). $(X)$ equals the Self-Insurance Anount from Table 2 divided by the Arnual. Agsregate Amount from Table 2 based on the number of tanks for which this financial test is used.

(i) The owner or operator may self-insure for all or part of the Annual Asstegate Amoun: specified in rule 1200-1-15-.08(4)(b) based on the nimber of underground storage tantes for which this financial test is used to demonstrate financial responsibility.

(ii) The sum of the corrective action cost estimates, the carrent closure and post-closure care cost estimates, and amount of liability coverage for which a financial test is used to demonstrate financial responsibility to EPA under 40 CFR Parts 264.101, 264.143, 264.145, $265.143,265.145,264.147$, and 265.147 or 10 a state implementing agency under a state program authorized by EPA under 40 CFR Part 2\%'; and

(iii) The sum of cursent plugging and abandonment cost estimates for which a financial test is used to demonstrate financial responsibility to EPA under 40 CFR Part 144.63 or to a state implementing agency under a state program authorized by EPA under 40 CFR Part 145.

2. The orner or operator, and or guarantor, must have a letter signed by the chief financial officer . worded as speciñed in subparagraph (d).

3. The owner or operator, and/or guarantor, must either:

(i) File financial statements annually with the U.S. Stecurities and Exchange Commission, the Energy Information Administration, or the Rural Electrification Administration; or

(ii) Report annually the firm's tangible net worth 20 Dun and Bradstret, and Dun and Bradru must have assigned the firm a financial strength rating of $4 \mathrm{~A}$ or $5 \mathrm{~A}$.

4. The firm's year-end financial statements, if independeinty audited, cannot include an adverse auditor's opinion, a disclaimer of opinion, or a "going concern" qualification.

(c) If the owner or operator, and/or guarantor desires to self-insure and does not choose to meet the requirements of $6(b)$, the owner or operator and/os guarantor must mest the requirements of this subparagraph.

1. The owner or operator, and/or guarantor must meet the financial test requirements of subpars (i) or (ii) of this part.

(i) The owner or operator must have:

(I) Net working capital and tangible net worth each at least $(X)$ times the amount of liability coverage to be demonstrated by this test, where $(X)$ equals the Self-Insurance Amount from Table 2 divided by the Annual Aggregate Amount from Table 2 based on the number of tanks for which this financial test is used; and

(II) Tangible net wort at least $(X)$ times th: amount of liability coverage to be demonstrated by this test, where $(X)$ equals the Self-Inswrance Amount from Table 2 divided by the Annual Aggregate Amoung from Table 2 besed on the number of tanks for which this financial test is used; and 
(Rule 1200-1-15-.08, continued)

A. At least 90 percent of his total assets; or.

B. At least $(X)$ times the amount of liability coverage to be demonstrated by this test, where $(X)$ equals the Self-Insurance Amount from Table 2 divided by the Annual Aseregate Amount from Table 2 based on the number of tanks for which this financial test is used; and

(ii) The owner or operator must have:

(I) A current rating for his most recent bond issuance of AAA, AA, A or BBB as issued by Standard and Poor's or A22, A2, A, or Ban as issued by Moody's; and

(II) Tangible net worth at least $(X)$ times the amount of liability coverage 20 be demonstrated by this test, where $(X)$ equals the Self-Insurance Amount from Table 2 divided by the Annual Aggregate Amount from Tabie 2 based on the number of tanks for which this financial tert is used; and

(III) Assets in the United States amounting to either:

A. At least 90 percent of his total assets; or

B. At least $(X)$ times the amount of liability coverage to be demonstrated by this test, where $(X)$ equals the Self-Insuranes Amount from Tabie 2 divided by the Annual Aggregate Amount from Table 2 based on the number of tanks for which this financial test is used;

2 The fiseal year-end financial statements of the owner or operator, and/or guarantor, must be camined by an independent certified public accountant and be accompanied by the accountant's report of the examination.

3. The firm's year-end financial statements cannot include an adverse auditor's opinion, a disclaimer of opinion, or a "going concern" qualification.

4. The owner or operator, and/or guarantor, must have a letter signed by the chief financial officer, worded as specified in subparagraph (d).

5. If the financial statements of the owner or operator, and/or guarantor, are not submitted annually to the U.S. Securities and Exchange Commission, the Energy Information Administration or the Rural Electrification Administration, the owner or operatos, and/or guarantor, must obtain a special report by an independent cerrified publie accountant stating that:

(i) He has compared the data that the letter from the chief financial officer specifies as having been derived from the latest year-end financial statements of the owner or operator, and/or guarantor, with the amounts in such financial statements; and

(ii) In connection with that comparison, no matters came to his attention which caused him to believe that the specisied data should be adjusted. 
(Ruie 1200-1-15-.08, continued)

(d) To demonstrate that it meets the financial test under subpraragraph (b) or (c), the chief financial officer of the owner or operator, and/or guarantos, must sign, within 120 days of the close of each financial reporting year, as defined by the tweive-month period for which financial statements used to support the financial rest are prepared, a letter worded esactly as.follows, except that the instruetions in brackets are to be replaced by the relevant information and the brackets deleted:

\section{Letter from Chief Financial Officer}

I am the chief financial officer of [insert: name and aidiress of the owner or operator, or guarantor]. This letter is in support of the use of [inser: "the financial test of self-insurance" and/or "guarantee"] to demonstrate financial responsibility for [instert: "taking corrective action" and/or "compensating third paries for bodily injury and property danaage"I caused by accidental releases in the amount of at least [insert: dollar amount] per oceurrence and [inser: dollar amount] annual aggregate arising from operating (an) underground storage tank(s).

Underground storage tanks at the following facilities are assured by this financial test or a financial test under an authorized state program by this [insert: "owner or operator," and/or "guarantor"]) [List for each facility: the name and address of the facility where tanks assured by this financial test are located, the number of tanits at each facility, and the facility identification number(s). If separate mechanisms or combinations of mechanisms are being used to assure any of the tanks at this facility, list each tank assured by this financial test by the tank identificarion number provided in the notifieaion submitted pursuant to rule $1200-1-15-.02(3)$.

A [inser: "Iinancial test", and/or "guarantee"] is also used by this [insert: "owner or operator", or "guarantor"] to demonstrate evidence of financial responsibility in the following amounts under other EPA regulations or state programs authosized by EPA under 40 CFR Parts 271 and 145:

Amount EPA Regulation:

Closure (264.143 and 265.143) ........................

Post-Closure Care (264.145 and 265.145) ..................

Liability Coverage $(264.147$ and 265.147$) \ldots \ldots \ldots \ldots \ldots \ldots \ldots . . .6$

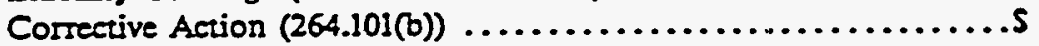

Plugging and Abandonment $(144.63) \ldots \ldots \ldots \ldots \ldots \ldots \ldots . . . . \ldots \ldots$

or

Amount Authorized State Programs:

Closure (Rule 1200-i-11-.05(8)(d) and

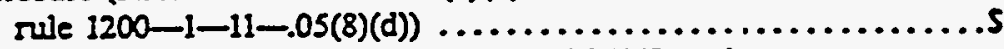

Post-Closure Care (Rule 1200-1-11-.06(8)(f) and

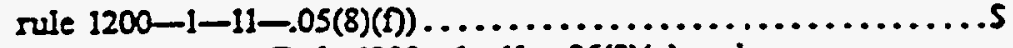

Liability Coverage (Rule 1200-1-11-.06(8)(n) and

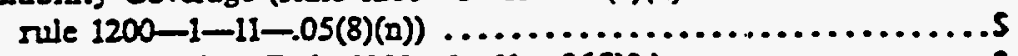

Corrective Action (Ruie $1200-1-11-.06(1) 2$ ) ...............

Plugging and Abandonment (Rule 1200_4-6-.09(6) ..........

This [iosert: "ouner or operator", or "guarantor" has not received an adverse opinion, a disclaime of opinion, or a "going concern" qualification from an independent auditor on his financial statements for the latest completed fiscal year or financial reporing; year. 
(Rule 1200-1-15-.08, continued)

[Ful in the information for Alterdative I if the criteriz of subparagraph (b) of rule $1200-1-15-.08(6)$ are being used to demoartate compliance with the finencial test requirements. Fill in the information for Alternative II if the criteris of subparagraph (c) of rule $1200-1-15-.08(0)$ are being used io demonstrate complianer with the finanoial tert requirements.]

\section{ALTERNATTVE I}

(1) Amount of annual UST aggregate coverage being assured by a financial test, and/or guarantee .......s

(2) Amount of corrective action, closure and post-closure care costs, liability coverage, and plugging and abandonmeat costs covered by a financial test, and or guarantes .5

(3) Sum of lines 1 and 2 .5

(4) Total tangible assets . .5

(5) Total liabiities fif any of the amount reported on line 3 is included in total liabilities, you may deduct that amount from this line and add that amount to line of S

(6) Tongible net worth isubtrat line 5 from line 4 ]

Yes No

(7) Is line 6 at least $(X)$ times line 3 ?

$(X)$ equals the Self-Insurance Amount from Table 2 divided by the Anowal Aggregate Amount from Table 2 based on the number of tanks for which this financial test is used.

(8) Have financial statements for the latest fiscal year been filed witt the Securities and Exchange Commission?

(9) Fave financial statements for the latest fiscal year been filed with the Energy Information Administration?

(10) Fave financial statements for the latest fiscal year been filed with the Rural Electrifieation Administration?

(11) Has financial information been provided to Dus and Bradsreet, and has Dun and Bradstret provided a financial strength rating of 4A or SA? [Answer Yes" only if both criteris have been met. . 
(Rule 1200-1-15-.08, continued)

\section{ALTERNATIVE II}

(1) Amount of annual UST 8ggregate coverage being assured by at financial test, and/os guarantec ....... 

(2) Amount of corrective action, closure and post-closure care costs, liability coverage, and plugsing and abandonment costs covered by a financial tesh and/or guarantee ................

(3) Sum of lines 1 and 2

(4) Total tangible assets .$S$

(5) Total liabilities [if any of the amount reported on line 3 is included in total liabilities, you may deduet that amount from this line and add that amount to line 6

...................................s

(9) Tangible net worth [subtract line 5 from line 4] $\longrightarrow$

(7) Total assets in the U.S. [required only if less than 90 percent of assets are located in the U.S]

.......s

Yes No

(8) Is line 6 at least (X) times line 3 ?

(X) equals the Self-Insurance Amount from Table 2 divided by the Annual Asgregate Amount from Table 2 based on the number of tanks for which this financial test is used.

(9) Are at least 90 percent of assets located in the US? [If "No" complete line 10.]

(10) Is line 7 at least $(X)$ times line 3 ?

$(X)$ equais the Self-Insurance Amount from Tabie 2 divided by the Annual Assregate Amount from Table 2 based on the number of tanks for which this froancial test is used.

[FIl in either lines 11-14 or lines 15-17:]

(11) Curreat assets...........................................s

(12) Curreat liabilities............................................s

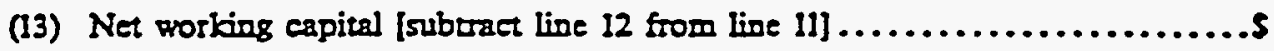


(Rule 1200-1-15-.08, continued)

(14) Is line 13 at least $(X)$ times line 3 ?

$(X)$ equals the Self-Insurance Amount from Table 2 divided by the Annual Asgregate Amount from Table 2 based on the number of tankes for which this financial ters is used.

(15) Current bond rating of most recent bond issue.

(19) Name of rating service.

(17) Date of maturity of bond

(18) Have financial statements for the latest fiscal year been filed with the SEC, the Energy Information Adminirrarion, or the Rural Electrification Administration?

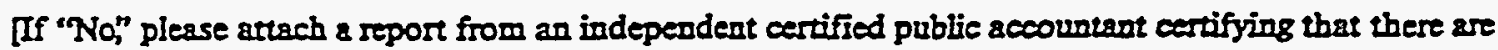
no material differences between the data as reported in lines 4-18 above and the financial statements for the latert fised year]

[For both Alternative I and Alternative II complete the certification with this statement]

I hereby cerrify that the wording of this letter is identical to the pording specified in rule $1200-1-15-.08(6)(d)$ as such regulations were constiruted on the date shown immediately below.

$$
\text { [Signature] [Name] [Title] [Date] }
$$

(e) If an owner or operator using the financial test of self-insurance to provide financial assurance finds that be or she no longer meets the requircoents of the financial test based on the year-end financial statements, the ownes or operator must obtain alternative coverage within 150 days of the end of the year for which financial statements have been prepared.

(f) The Commissioner may require repors of financial condition at any time from the owner or operatos, and/or guarantot. If the Commissioner finds, on the basis of such reports or other information, that the owner or operator, and/or guarantor, no longer meets the financial test requirements of rule $1200-1-15-.08(b)(b)$ or (c) and (d), the owner or operator must obtain aiternate coverage within 30 days after notification of such a finding.

(8) If the oprer or operator fails 20 obtain alterate assurance within 150 days of finding that be or she no longer meets the requirements of the finsacial ter based on the year-end finencial statements, or within 30 dsys of notifieation by the Commissiones that he or she no longer meets the requirements of the financial ters the orner or operator must notify the Commissioser of such fallure within 10 days.

(7) Guarantee

(a) An owner or operator may satisfy the requirecens of rule 1200-1-15-.08(4) by obraining a guarantee that conforms to the requirements of this paragraph. The guarantor must be: 
(Rule 1200-1-15-.08, continued)

1. A firm that:

(i) possesses a controlling interest in the owner or operator,

(ii) possesses a controlling interest in a firm described under (1)(i); or

(iii) is controlled through stock ownership by a common parent firm that possesses a controlling interest in the ouner or operator, or

2. A firm engaged in a substantial business relationship with the owner or operator and issuing the guarantee as an act incident to that business relationship.

(b) Within 120 days of the close of each financial reporing year the guarantor must demonstrate that it meets the financial test eriteria of rule 1200-1-15-.08(G) based on year-end financial statements for the latest completed financial reporting year by completing the letter from the chief financial officer described in rule 1200-1-15-.08(b)(d) and must deliver the letter to the owner or operator. If the guarantor fails to meet the requirements of the financial test at the end of any financial reposting year, within 120 days of the end of that financial reporting year the guarantor shall send by certified mail, before cancellation or nonrenewal of the guarintee, notice to the owner or operator. If the Commissioner notifies the guarantor that he no longer meets the requirements of the financial test of rule 1200-1-15-.08(G)(b) or (c) and (d), the guarantor must notify the owner or operator within 10 days of receiving such notification from the Commissioner. In both cases, the guarantee will terminate no Jess than 120 days after the date the ownt:r or operator receives the notification, as evidenced by the return receipt. The ownes or operator must obtain alternate coverage as specified in rule $1200-1-15-.08(20)$.

(c) The guarantee must be worded as follows, except that instructions in brackets are to be replaced with the relevant information and the brackets deleted:

\section{GUARANTEE}

Guarantee made this [date] by [name of guaranteeing entity], a business entity organized under the laws of the state of [name of state], herein referred to as guarantor, to the State of Tennessee, Deparment of Health and Environment and to any and all third paries, and obligees, on behalf of [oHner or operator] of [business addiress].

Recitals.

(1) Guarantor meets or exceeds the financial test criteria of rule 1200-1-15-.08(b)(b) or (c) and (d) and agrees to comply with the requirements for guarantors as specified in rule $1200-1-15-.08(7)$ (b).

(2) [Owner or operator] owns or operates the following underground storage tank(s) covered by this guarante:: (List the number of tanks at each facility, the name(s) and addiess(es) of the facility(ies) where the tanks are located, and the facility identification number(s). If more that one instrument is used to assure differeat tanks at any one facility, for each rask covered by this instrument, list the tank identification number provided in the notifieation submitted pursuant to rule $1200-1-15-.02(3)$ and the name and address of the facility.] This guarantee satisfies rule 1200-1-15-.08 requirements for assuring funding for [inser: "rak. ing corrective action" and/or "compensating third paries for bodily injury and properry damage" caused by accidental releases; if coverage is different for different tanks or locations, indicate the type of coverage applieable to each rank or location] arising from operating the above-identified underground storage tank(s) in the amount of [insert dollar amount] per oceurrence and [izser dollar amount] annual aggregate 
(Rule 1200-1-15-.08, continued)

(3) [Inser appropriate phrase: "On behalf of our subsidiary" (If guarantor is corporate parent of the owner or operator); "On behalf of our affiliate" (if guarantor is a related firm of the owner or operator); or "Incident to our business relationship with" (if guarantor is providing the guarantee as an incideat to a substan. tial business relationship with owner or operator)] [owner or operator], guarantor guarantees to the Deparment and to any and ail third parties that: In the event that [owner or operator] fails to provide alternate coverage within 60 days after receipt of a notice of cancellarion of this guarantee and the Commissioner has determined or suspects that a release has oceurred at an underground storage tank covered by this guarantee, the guarantor, upon instructions from the Commissioner, shall fund a standby trust fund in ac. cordance with the provisions of rule $1200-1-15-.08(18)$, in an amount not to exceed the coverage limits specified above. In the event that the Commissioner determines that [owner or operator] has failed to perform corrective action for releases arising out of the operation of the above-identified tank(s) in accordance with rule $1200-1-15-.06$, the guarantor upon written instruerions from the Commissioner shall fund a standby trust in accordance with the provisions of rule 1200-1-15-.08(18), in an amount not to exceed the coverage limits specified above If [owner or operator] fails to satisfy a judgment or award based on a determination of liability for bodily injury or property damage to third paries caused by accidental releass arising from the operation of the above-identified tank(s), or fails to pay an amount agreed to in setrlement of a claim arising from or alleged to arise from such injury or damage, the guarantor, upon written instructions from the Commissioner, shall fund a standby trust in accordance with the provisions of rule $1200-1-15-.08(18)$ to satisfy such judgment(s), award(s), or settlement agreement(s) up to the limits of coverage specified above.

(4) Guarantor agrees that if, at the end of any fiscal year or Iinancjal reporting year before cancellation of this guarantee the guarantor fails to meet the financial test criteria of rule $1200-1-15-.08(\mathrm{~b})(\mathrm{b})$ or (c) and (d), guarantor shall send within 120 days of such failure, by certified mail, notice to [owner or operator]. The guarantee will terminate 120 days from the date of receipt of the notice by [owner or operator], as evidene. ed by the return receipt.

(5) Guarator agrees to notify [owner or operator] by cerrified mail of a voluntary or involuniary proceedins under Title 11 (Bankruptcy), U.S. Code, naming guarantor as debtor, within 10 days after commencemeni of the proceeding.

(6) Guarantor agrees to remain bound under this guarantee notwithstanding any modification or alteration of any obligation of [owiner or operator] pursuant to Chapter 1200-1-15.

(7) Guarantor agrees to remain bound under this guarantee for so long as [ownez or operator] must comply: with the epplicable financial responsibility requirements of rule $1200-1-15-.08$ for the above-identified tank(s), except that guarantor may cancel this guarantee by sending notice by cerified mail to louner o: operator], such cancellation to become effecive no earlier than 120 days after receipt of such notice by [owner or operator], as evidenced by the return receipt.

(8) The guarantor's obligation does not apply to any of the following:

(a) Any obligation of [inser ouner or operator] under a workers' compensation, disability benefits, $0:$ unemployment compensation law or other similar law;

(b) Bodily injury to an employee of [insert owner or operator] arising from, and in the course of, employ:ment by [insert owner or operator];

(c) Bodily injury or property damage arising from the ownership, maintenance, use, or entrustment to others of any aireraft, motor vehicle, or watercraft; 
(Rule 1200-1-15-.08, continued)

(d) -Property damage to any property owned, rented, loaned to, in the care, custody, or control of, or oceupied by [insert ofrner or operator] that is not the direct nesult of a release from a petroleum underground storage tank; or

(e) Bodily damage or property damage for which [inser owner or operator] is obligated to pay damages by reason of the assumption of liability in a contract or agreement other than a contract or agreement entered into to meet the requirements of rule 1200-1-15-.018(4).

(9) Guarantor expressly waives notice of acceptance of this guarantee by the Deparment, by any or all third parties, or by [owner or operator].

I bereby cerify that the wording of this guarantee is identical to the wording specified in rule $1200-1-15-.08(7)(c)$ as such regulations were consituted on the effiective date shown immediately below.

Effective date:

[Name of guarantor]

[Authorized signature for guarantor]

[Name of person signing]

[Title of person signing]

Signature of witness or notary:

(d) An owner or operator who uses a gliarantee to satisfy the requirements of rule $1200-1-15-.08(4)$ must establish a standby trust fund when the guarantee is obtainid. Under the terms of the guarantee, all amounts paid by the guarantor under the guarantee will be deposited directly into the standby trust fund in accordance with instruetions from the Commissioner under sule 1200-1-15-.08(18). This standby trust fund must meet the requirements specified in rule 1200-1-15-.08(13).

(8) Insurance and Risk Retention Group Coverage

(a) An owner or operator may satisfy the requirements of rule $1200-1-15-.08$ (4) by obtaining liability insurance that conforms to the requirements of this paragraph from a qualified insurer or risk reiention group. Such insurance may be in the form of a separate insurance policy or an endorsernent to an exising insurance policy.

(b) Each insurance policy must be amended by an endorsement worcied as specified in part 1 or evidenced by a cerificate of insurance worded as specified in par 2, exeept that instruetions in brackets must be replaced with the relevant information and the brackets deleted: 
(Rule 1200-1-15-.08, continued)

\section{1. . ENDORSEMENT}

Name: [name of each covered location]

Address: [address of each covered location]

-..

Policy Number:

Period of Coverage: [current policy period]

Name of [Insurer or Risk Retention Group]:

Address of [Insurer or Risk Retention Group]:

Name of Insured:

Address of Insured:

\section{Endorsement:}

(i) This endorsement certifies that the policy to which the endorsement is attached provides liability insurance covering the following underground storage tanks:

[List the number of taniks at each facility, the name(s) and address(es) of the facility(ies), and the facility identification number(s) where the tanks are located. If more than one instrument is used to assure different tanks at any one facility, for each tank covered by this instrument, list the tank identification number provided in the notification submitted pursuant to rule $1200-1-15-.02(3)$ and the name and address of the facility.]

For [inser: "taking corrective action". and/or "compensating third parties for bodily injury and properiy damage" caused by accidentai release; in accordance with and subject to the limits of liability, exiusions, conditions, and other terms of the poliey, if coverage is different for different tanks or locations, indicate the type of coverage applicable to eacin tank or location] arising from operating the underground storage rank(s) identified above.

The limits of liability are [insert the dollar amount of the "each oecurrence" and "annual essegate" linits of the Insurer's or Group's liability; if the amount of coverage is different for differeat types of coverage or for different underground storage tanks or locations, indieate the amount of coverage for each type of coverage and/or for each underground storage tank or location], exciusive of legal defense costs, which ere subject to a separate limit under the policy. This coverage is provided under [policy number]. The effective date of said policy is [date]. 
(Rule 1200-1-15-.08, continued)

(ii) The insurance afforded with respect to such oceurrences is subject to all of the terms and conditions of the policy, provided, bowever, that any provisions ineonsistent with items (I) through (V) of this subpart (ii) are hereby amended to conform with itews (I) through (V):

(I) Banisuptey or insolvency of the insured shall not relieve the ["Insurer" or "Group"] of its obligations under the policy to which this endorsement is attreched.

(II) The ["Insurer" of "Group"] is liable for the payment of amounts within any deduetible applicable to the policy to the provider of corrective action or a damaged third-party, with a right of reimbursement by the insured far any such payment made by the ["Iosurer" or "Group"]. This provision does not apply with respect to that amount of any deducsiole for which coverage is demonstrated under another mechanism or combination of mectinisms as specified in rale $1200-1-15-.08(6)$ through rule $1200-1-15-.08(12)$.

(III) Whesever requested by the Commissioner, the ["Insuret" or "Group"] agrees to furrish to the Comorissioner a signed duplicate original of the policy and all eodorsements.

(IV) Carcellation or any other termination of the insurance loy the ["Insurer" or "Group"] except for non-payment of premium or misrepresentation by the insured nill be effective onily upon written notice and only after the expiration of 60 days after is copy of such written notice is rectived by the insured. Cancellation for non-payment of premiun or misrepresentation by the insured pill be effective only upon pritien notice and only after expiration of a minimum of ten (10) days after a copy of such written notice is received by the insured.

Insert for claims-made policies:

(v) The insurance covers claims otherrise covered by the policy that are reporied to the ["Insurer" or "Group"] writhin six (6) months of the effeetive date of cancellation or non-renewal of the policy except where the new or renewed policy has the same reiroactive date or a retroactive date eariler than that of the prior policy, and whish arise out of any covered occurrence that collmenced after the policy retroactive date, if applicable, and prior to such poliey renewal or termination date Claims reported during such extended repirting period are subject to the terms, conditions, limits, including limits of liability, and exelusions of the policy.

I bereby cerrify that the wording of this instrument is identical to the wording in rule $1200-1-15-.08(8)(b)$ 1. and that the ["Insurer" or "Group"] is ["Iicensed to transact the business of insurance or eligible to provide insurance as an exeess or surplus lines insurer in the State of Tenoessec'].

[Signature of authorized representztive of Insurer or Risk Retertion Group] [Name of person signing] [Title of person signing]. Autborized Representative of [name of Insurer or Risi: Retention Group] [Address of Represecatative]

\section{CERTIFICATE OF INSURANCE}

Name: [name of each covered location]

Address: [address cf each covered location]

Folicy Number: 
(Rule 1200-1-15-.08, continued) Endorsement (if applicsble):

Period of Coverage: [current policy period]

Name of [Insurer or Risk Retention Group]:

Address of [Insurer or Risk Retention Group]:

Name of Insured:

Address of Insured:

\section{Cerification:}

(1) [Name of Insurer or Risk Retention Group], [the "Insures" or "Group"), as identified above, bereby cerrifies that it has issued liability insurance covering the following underground storage tank(s):

IList the number of tanks at each facility, the facility identification number(s), and the name(s) and address(es) of the facility(ies) where the tanks are located. If more than one instrument is used to assure different tanks at any one facility, for each tank covered by this instrument, list the tank identification number provided in the notification submitted pursuant to rule 1200-1-15-.02(3), and the name and address of the facility.]

For linser: "taking corrective action" and/or "compensating third paries for bodily injury and property damage" caused by accidental releases; in accordance with and subject to the limis of liability, exclusions, conditions, and other terms of the poliey, if coverage is different for different tanks or locations, indicate the type of coverage applieable to each tank or location] arising from operating the underground storage tank(s) identified above.

The limits of liability are linsert the dollar amount of the "each oceurrence" and "annual ageregate" limits of the Insurer's or Group's liability; if the amount of coverage is differeat for different types of eoverage or for different underground storage tanks or locations, indicate the amount of coverage for each type of coverage and/or for each underground storage tank or location], aciusive of legal defense costs which are subject to a separate limit under the policy. This coverage is provided under [policy number]. The effective date of said policy is [date].

(ii) The ["Inswrer" or "Group"] furcher cerifies the following with respect to the insurance described in Pargraph 1:

(I) Banisuptry or insolvency of the instred shall not relieve the ["Insurer" or "Group"] of its obligations under the policy to which this certificate applies. 
(Rule $1200-1-15-.08$, continued)

(II) The ["Inswre" or "Group"] is liable for the payment of amolunts within any deduetible applicable te the policy to the provider of corrective action or a damaged third-party, with a right of reimbursement by the insured for any such payment made by the ["Insurer" or "Group"]. This provision does not apply with respect to that amount of any deduetible for which coverage is demonstrated under another mechanism or combination of mechanisms as specified in sule $1200-1-15-.08(6)$ through rile $1200-1-15-.08(12)$.

(III) Whenever requested by the Commissioner, the ["Insures" ar "Group"] agrees to furnish to the Commissioner a signed duplicate original of the policy and all endorsements.

(IV) Cancellation or any other termination of the insurance by the ["Insurer" or "Group"] except for nonpayment of premium or mirrepresentation by the insured, will be effective onily upon written notice and only after the expiration of 60 days after a foopy of sueh written notice is recived by the insured. Cancellation for nonpayment of premium br misrepresentation by the insured will be effective only upon written notice and only after expiration of a minimum of ten (I0) days after a copy of such written notice is received by the insured.

Inser for clạims-made policies:

(V) The insurance covers claims otherwise covered by the polig' that are reported to the ["Insures" or "Group" " within six (G) months of the effective date of the cancelliation or non-renewal of the poliey except where the new or renewed policy has the sime retroactive date or a retroactive date earlier than that of the prior policy, and which arise out of any covered oceurrence that commenced after the policy retroactive date, if applicable, and prior to such policy renewal or termination date Claims reported during such extended reporing period are subject to the terms, conditions, limits, including limits of tiability, and exclusions of the polity.

I hereby cerrify that the wording of this instrument is identieal to the wording in rule 1200-1-15-.08(8)(b)2 and that the ["Insurer" or "Group"] is ["Zicensed to transact the business of insurance or eligible 20 provide insurance as an excess or surpius lines insurer in the state of Tenosessee"].

[Signature of authorized representative of Insurer]

[Mpe name]

[Title], Authorized Representative of [name of Insurer or Risk Retention Group]

\section{[Addiess of Representrative]}

(c) Each insurance policy must be issued by an insurer or a risk retintion group that, at a minimum, is licensed to transact the business of insurance or eligible to provide insurance as an excess or surplus lines insurer in the state of Tennessec.

(9) Surety Bond

(a) An owner or operator may satisfy the requiremeats of rule 1200-1-15-.08(4) by obtaining a surety bond that conforms to the requirements of this parazraph. The surety company issuing the bond must be among those listed as acceptable sureties on federal bonds in the latest Circular 570 of the U.S. Deparment of the Treasury.

(b) The surety bond must be worded as follows, acept that instructicins in brackets must be replaced rith the relevant information and the brackets deleced: 
(Ruie 1200-1-15-.08, continued)

\section{PERFORMANCE BOND}

Date bond executed:

Period of coverage:

Principal: (legal name and business address of owner or operator)

Type of organization: (insert "individual," "joint venture" "partnership", or "corporation")

State of incorporation (if applicable):

Surety(ies): (name(s) and business address(es))

Scope of Coverage: [List the number of tanks at each facility, the facility identification number(s), and the name(s) and address(es) of the facility(ies) where the tanks are located. If more than one instrument is used to assure different tanks at any one fácility, for each tank covered by this instrument, list the tank identifieation number provided in the notification submitted pursuant to rule 1200-1-15-.02(3), and the name and address of the facility. List the coverage guaranteed by the bond: "taking corrective action" and/or "compensating third parties for bodily injury and property damage" caused by accidental releases arising from operating the underground storage tank"].

Penal surns of bond: Per occurrence $S$

Annual aggregate $S$

Surety's bond number:

Know All Persons by These Presents, that we, the Principal and Surety(ies), hereto are firmily bound to the Deparment of Health and Environment, in the above penal sums for the payment of which we bind ourselves, our heirs, cxecutors, administrators, successors, and assigns jointly and severally; provided that, where the Surety(ies) are corporations acting as co-sureties, whe the Sureties, bind ourselves in such sums jointly and severally only for the purpose of alloring a joint action or actions against any or all of us, and for all other purposes each Surety binds itself, jointly and severally with the Principal, for the payment of such sums only as is set forth opposite the name of such Surety, but if no limit of liability is indicated, the limit of liability shall be the full amount of the penal sums.

Whereas said Principal is required under Tennessee Petroleum Underground Storage Tank Act to provide financial assurance for (insert: "raking corrective action" and/or "compensating third parties for bodily injury and property damage" caused by aceidental releases; if eoverage is different for different tanks or locations, indicate the type of coverage applicable to each tank or location) arising from operating the underground storage tanks identified above and

Whereas said Principal shall establish a standby trust fund as is required when a surety bond is used to provide such financial assurance; 


\section{(Rive 1200-1-15-.08, continued)}

Now, therefore, the conditions of the obligation are such that if the Priscipal shall faithfully ("take corrective action, in accordance with rule 1200-1-15-.06 and the Commissioner's inseructions fors" and/or "compensate injured third paries for bodily injury and properry damage" eaused by accidental releases arising from operating the tank(s) identified above, or if the Principal shall provide alternate financial assurance as specified in rule 1200-1-15-.08, within 120 days after the date the notice of cancellation is received by the Principal from the Surety(ies), then this obligation shall be null and void; otherwise it is to remain in full foree and effect.

Such obligation does not apply to any of the following:

1. Any obligation of (inser ouner or operatos) under a workers' elsmpensation, disability benefits, or unemployraent compensation law or other similar law;

2 Bodily injury to an employee of (insert owner or operator) arising from, and in the course of, employment by (insert owner or operator);

3. Bodily injury or property damage arising from the ownership, raaintenance, use or entrustront to others of any airesaft, motor.vehicie, or patercraft;

4. Property damage to any property orned, reated, loaried to, in the care, curtody, or control of, or occupied by (inser owner or operator) that is not the direct reinit of a release from a petroleum underground storage tank; or

5. Bodily injury or property damage for which (insert owner or ofyerator) is obligated to pay damages by reason of the assumption of liability in a contract or agreement other than a contract or agreement entered into to meet the requirements of rule $1200-1-15-.08(4)$.

The Surety(ies) shall become liable on this bond obligation only when the Principal has failed to fulfill the conditions described above.

Upon notification by the Commissioner that the Principal has failed to ('take corrective action, in accordance with rule 1200-1-15-.06 and the Commissioner's instructions;", and/or "compensate injured third parties") as guaranteed by this bond, the Surety(ies) shall either perform ("comtective action in accordance with ruie 1200-1-15-.06 and the Commissioner's instructions" ancl/or "third-party liability compensation") or place funds in an amount up to the annual aggregate penal. sum into the standby trust fund as directed by the Commissioner under rule $1200-1-15-.08(18)$.

Upon notineation by the Commissioner that the Principal has failed to provide alternate financial assurance witbin 60 days after the date the notice of cancellation is received by the Principal from the Surety(ies) and that the Commissioner has determined or suspects that a release has occurred, the Surety(ies) shall place funds in an amount not exceeding the annual agsregate penal sum into the standby trust fund as direcred by the Commissioner under rule $1200-1-15-.08(18)$.

The Surety(ies) hereby waive(s) notification of amendmeats to applicable laws, statutes, rules, and regulations and agrees that no sueb amendment shall in any way alleviate its (their) obligation on this bond.

The liability of the Surety(ies) shall not be discharged by any payment or succession of payments hereunder, unless and unil such payment or payments shall amount in the annvial aggregate to the penal sum shown on the face of the bond, but in no event shall the obligation of the Surty(ies) bereunder exceed the amount of said annual aggregare penal sum. 
(Rule 1200-1-15-.08, continued)

The Surety(ies) may cancel the bond by sending notice of cancellation by cerified mail to the Principal, provided, however, that cancellation shall not occur during the 120 days beginning on the date of receipt of the notice of canceliation by the Principai, as evidenced by the return receipt.

The Priscipal may terminate this bond by sending written notice to the Surety(ies).

In Witness Thereof, the Principal and Surety(ies) have executed this Bond and have affixed their seals on the date set forth above. The persons whose signatures appear below hereby cerrify that they are autborized to execute this surety bond on behalf of the Principal and Surety(ies) and that the wording of this surety bond is identical to the wording specified in rule 1200-1-15-.08(9)(b) as such regulations were constituted on the date this bond was execuled.

\section{PRINCIPAI}

$\begin{array}{llll}\text { (Signature(s)) (Name(s)) (Title(s)) (Corporate seaj) } & \text { (N) }\end{array}$

\section{CORPORATE SURETY(IES)}

(Name and address)

State of Incorporation:

Liability limit: $S$

(Signature(s))

(Name(s) and titie(s))

(Corporate seal)

(For every co-surety, provide signature(s), corporate seal, and other information in the same manner as for Surety above)

Bond prenium: 5

(c) Under the terms of the bond, the surety will become liable on the bond obligation when the ownes or operator fails to perform as guaranteed by the bond. In ail cases, the surety's liability is limited to the per-oceurrence and ansual agsregare penal sums.

(d) The okrer o: operztor who uses a surety bond to satisfy the requirements of sule $1200-1-15-.08$ (4) must establish a standby : :ust fund when the surety bond is aequired. Under the terms of the bone, all amounts paid by the surety under the bond will be deposited direaly into the standby trust fund in aceordance with instruecions from the Commissioner under sule 1200-1-15-.08(18). This standby trust fund must meet the requirements speciried in rule $1200-1-15-.08(13)$.

(10) Letter of Credit

(a) An owne: or operator may satisfy the requirements of sule 1200-1-15-.08(4) by obtaining an isrevocable standby letter of credit tha: conforms to the requirements of this paragraph. The issuing institusion mus: be an entity that has the authority to issue letsers of credit in the state of Tennesse: and whose letter-of-eredit operations are regulated and examines by a federal ot state agency.

(b) The letter of credit must be worded as follows, except that instructions in brackets are to be replaced with the selevant information and the brackets dejeted: 
(Rule 1200-1-15-.08, continued)

\section{IRREVOCABLE STANDBY LETIER OF CREDIT}

(Name and address of issuing institution) (Name and address of Commissioner of Tennessee Department of Health and Envisonment)

Dear Sir or Madam: We hereby establish our Irrevocable Standby Ietter of Credit No.

in your favor, at the request and for the account of (owner or operator name) of (address) up to the aggregate amount of (in words) U.S. dollars (Sinsert dollar amount), available upon presentation by the Commissioner of

1. your sight draft, bearing reference to this letter of credit, No. and

2. your signed statement reading as follows: "I cerrify that the amount of the draft is payable pursuant 10 regulations issued under authority of Tennessee Petroleum Underground Storage Tank Act."

This letter of credit may be drawn on to cover (inser: "taking corrective aetion" and/or "compen- sating third parties for bodily injury and property damage" causecl by accidental releases) arising from operating the underground storage tank(s) identified below in the amount of (in words) S(insert dollar amount' per occurrence and (in words) S(insert dollar amount) annual aggregate:

(List the number of tanks at each facility, the name(s) and address(1s) of the facility(ies), and the facility identifieation number(s) where the tankes are located. If more than one instrument is used to assure different tanks at any one facility, for ezch tank covered by this instrument, list the tank identification number provided in the notifieation submitted pursuant to rie 1200-1-15-.02(3) and the name and address of the facility.)

The letter of credit may not be drawn on to cover any of the following:

1. Any obligation of (insert owner or operator) under a workers' compensation, disability benefits, or unemployment compensation law or other similar law;

2. Bodily injury to an employee of (insert owner or operator) arising from, and in the course of, employment by (inser owner or operator);

3. Bodily injury or property damage arising from the ownership, maintenance, use, or entrusiment to others of any aireraft, motor vehicie, or watercraft;

4. Property damage to any property owned, rented, loaned to, in the care custody, or control of, or oscupied by (insert owner or operator) that is not the direst result of a release from a petroleum underground storage tank; or

5. Bodily injury or property damage for which (insert owner or operator) is obligated to pay demages by reason of the assumption of liability in a contract or agretment otber than a contract or agreement eatered into to meet the requirements of rale $1200-1-15-.08(4)$. 
(Rule $1200-1-15-.08$, continued)

This ietter of credit is effective as of (date) and shall expire on (date), but such expiration date shall be automatieally extended for a period of (at least the length of the original term) on (expiration date) and on each suceessive expiration date, uniess, at least 120 days before the current expiration date we notify (owner or operator) by certified mail that we have decided not to extend this letter of credit beyond the current expiration date. In the event that (ouner or operator) is so notified, any unused portion of the credit shall be available upon presentation of your sight draft for 120 days after the date of receipt by (owner or operator), as shown on the signed seturn receipt.

Whenever this letter of credit is drawn on under and in compliance with the terms of this credit, we shall duiy honor such draft upon presentation to us, and we shall deposit the amount of the draft directly into the standby trust fund of (owner or operator) in accordanee with your instructions.

We cerify that the wording of this letter of eredit is identieal to the wording specified in rule $1200-1-15-.08(10) b$ as such regulations were eonstituted on the date shown immediately below.

(Signature(s) and title(s) of official(s) of issuing institution)

(Date)

This credit is subject to (insert "the most recent edition of the Uniform Customs and Practice for Documentary Credits, published by the International Chamber of Commerce" or "the Uniform Commercial Code").

(c) An owner or operator who uses a letter of credit to satisfy the requirements of rule $1200-1-15-.08(4)$ must also establish a standby trust fund when the letter of credit is acquired. Under the terms of the letter of credit, all amounts paid pursuant to a draft by the Commissioner will be deposited by the issuing institution direedy into the standby trust fund in accordance with instructions from the Commissioner under sule $1200-1-15-.08$ (18). This standby trist fund must meet the requirements specified in rule $1200-1-15-.08(13)$.

(d) The letter of credit must be irrevocable with a term specified by the issuing institution. The letter of credit must provide that credit be automatically renewed for the same term as the original term, unless, at least 120 days before the current expiration date the issuing institution notifies the owner or operator by cerified mail of its decision not to renew the letter of credit. Under the terms of the letter of credit, the 120 days will begin on the date when the owner or operator receives the notice, as evidenced by the return receipt.

(ii) Petroleum Underground Storage Tank Fund

(a) An owner or operator may use the fund to assist with the financial responsibility requirements of rule $1200-1-15-.08(4)$ for underground storage tanks located in the State of Tennessee after the owner or operator meets fund eligibility requirements described in rule 1200-1-15-.09(4) and (5). The fund will be implemented as described, in rule 1200-1-15-.09. When eligible, monies will be available from the fund to cover costs up to the limits specified in T.C.A. \$68-53-III subject to rule $1200-1-15-.08(20)(d)$.

(b) An owner or operatos ising the fund to meet part of the financial responsibility requirements of Rule $1200-1-15-.08(4)$ must execure a Fund Applicability Statement worded as follows: 
(Rule 1200-1-15-.08, continued)

\section{FUND APPLICABILITY STATEMIENT}

- This statement certifies that the Tennessee Underground Storage Taink Fund will be used to cover costs from the fund entry level amounts io limits specified in rule $1200-1-15-.08(4)$ and T.CA. \$6\$-53-III subject to rule $1200-1-15-.08(20)(d)$.

The fund shall be responsible for cleanup costs above the entry' level to the fund in an amount not to exceed one million dollars $(\$ 1,000,000)$ per site per oceurrense. The fund shall be responsible for court awards involving third party claims above the entry level iuto the fund in an amount not to $\propto x-$ ceed one raillion dollars $(51,000,000)$ per site per oceurrence

[Insert name of owner or operator] guarantees that fund eligibility reguirements described in rule $1200-1-15-.09$ bave been met for the bejow listed tanks.

Thist the number of tanks at each facility, the name(s) and address(es) of the facility(ies), and the facility idertification number(s) where the tanks are located. For each tank covered by this instrument, list the tank identification number provided in the notification submitted pursuant to rule $1200-1-15-.02(3)$, the name and address of the facility, and the type of instrument which assures financial responsibility to the entry level of the fund.]

The fund is being used for financial assurance for [inser "taking corrective action" and/or "sompensating third paries for bodily injury and property damage caused by"l] accidental releases arising from operatiog the underground storage tank(s) identified above Fund dispersement and implementation is deseribed in rule 1200-1-15-.09.

I certify that the wording of this instrument is identical to the wording in rule $1200-1-15-.08(11)(b)$.

[Signature of authorized representative]

[Type Name]

[Titite]

[D2te of Exesution]

(12) Trust Fund

(a) An or:se: or operator may satisfy the requirements of rule 1200-1-15-.08(4) by esiablishisg a trust fund tha: coaforms to the requirements of this paragraph. The trustee must be an entity that has the zuthority to ae: as a trustee and whese trust operations are regulated and examined by a fedeal agency or $2 n$ agency of the staie of Tennessee The trust fund must b: establisined in the state of Tennessee

(b) The wording of the trust agreemen: must be identieal to the wording specified in rule $1200-1-15-.08(13)(b) 1 .$, and mist be accompanied by a formil cerification of acknowled sment as specified in role $1200-1-15-.08(13)(b) 2$ and a satemert of locations as spesinjed is rule $1200-1-15-.08(12)(8)$.

(c) The trust fund, when established, must be funded for the full required zasount of coverage o: funded for par of the required amount of coverage and used in combination with other mechanism(s) that provide the remaining required coverage 
(Rule 1200-1-15-.08, continued)

(d) If the value of the trust fund is greater than the required amount of coverage, the owner or operator may submit a written request to the Commissioner for release of the excess.

(e) If other financial assurance as specified in this rule is substituted for all or part of the trust fund, the owner or operator may submit a written request to the Commissioner for release of the excess.

(f) Within 60 days after receiving a request from the owner or operator for release of funds as specified in subparagraphs (d) or (c) of this rile, the Commissioner will instruer the trustee to release to the owner or operator such funds as the Commissioner speciries in writing.

(g) An owner or operator satisfying the requirements of rule $1200-1-15-.08(4)$ through the use of a trust fund as set forth in this paragraph shall execute the following statement of locations as worded:

\section{STATEMENT OF LOCATIONS}

This statement is in support of the use of the trust fund to demonstrate financial responsibility for [insert: "taking corrective action" and/or "compensating third parties for bodily injury and property damage'] caused by accidental releases in the amount of at least [inser: dollar amount] per occurrence and [inser: dollar amount] annual aggregate arising from operating (an) underground storage tank(s).

Underground storage tanks as the following facilities are assured by the thust fund by this finsert: "ouner or operato,"]: [List for each facility: the name and address of the facility where tanks assured by this financial test are located, the number of tanks at each facility, and the facility identification number. If separate mechanisms or combinations of mechanisms are being used to assure any of the tanks at the facility(ies), list each tank(s) assured by this trust fund by the tank identification number provided in the notifieation submitted pursuant to rule $1200-1-15-.02(3)$ and the name and address of the facility(ies).

[Signature of authorized representative]

[Title]

[Date]

(13) Standby Trust Fund

(a) An owner or operator using any one of the mechanisms authorized by rule 1200-1-15-.08(7), rule $1200-1-15-.08(9)$, or rale 1200-1-15-.08(10) must establish a standby trust fund when the mechanism is acquired. The trustee of the standby trust fund must be an entity that has the authority to act as a trustee and whose trust operations are regulated and examined by a federal agency or an agency of the state of Tennessee. The trust fund must be established in the state of Tennessee

(b) 1. The standby trust agreement must be worded as follows, exeept that instruerions in brackets are to be replaced with the relevant information and the brackets deleted:

\section{TRUST AGREEMENT}

Trust agreement, the "Agrement" entered into as of (date) by and between (name of the owner or operator), a (name of state) (insert "corporation" "partnership", "association", or "proprietorship"), the "Granior" and (name of corporate trastee). (insert "Incorporated in the state of " or "a national bank"), the "Trustee" 
(Rule 1200-1-15-.08, continued)

Whereas, the Tennessee Department of Fealth and Environment, "TDHE": an agency of the state of Tennessee, has established cerain regulations applicable to the Grantor, requiring that an owner or operator of an underground storage tank shall provide assurzace that funds will be avajable when needed for corrective action and third-party compensation for bodily injury and property damage caused by accidental releases arising from the operation of the underground storage tank (This paragraph is only applicable to the standby trust agreement.));

Whereas, the Grantor has elected to establish (insert either "a guarantee" "surety bond" or "letter of credit") to provide all or part of such financial assurance for the underground storage tanks identified herein and is required to establish a standby trust fund abls to accept payments from the instrument (This paragraph is only applieable to the standby trust agreement.)); -

Whereas, the Grantor, acting through its duly authorized officers, has seiected the Trustee to be the trustee under this agreement, and the Trustee is willing to act as trustee;

Now, therefore, the Grantor and the Trustee agree as follows:

\section{Section 1. Definition}

As used in this Agreement:

(a) The term "Commissioner" means the Commissioner of Health and Environment, his authorized representatives, or in the event of his absence or a vacaney in the Commissioner's offies the Deputy Commissioner.

(b) The term "Department" means Tennessee Department of Health and Environment.

(c) The term "Fund" means trust fund.

(d) The term "Grantor" means the owner or operator who enters into this Agreement and any successors or assigns of the Grantor.

(e) The term "Trustee" means the Trustee who enters into this Agreement and any sucsessor Trustee

\section{Section 2. Identification of the Financial Assurance Mechanism}

This Agreement perzains to the (identify the finarcial assurance mechanism, either a guarantee surety bond, or letter of credit, from which the standby trust fund is ertablished to receive payments (This paragraph is only applicable to the standby trust agreement.)).

\section{Section 3. Establishment of Fund}

The Grantor and the Trustee hereby establish a trust fund, the "Fund" for the benefit of the Deparmeat. The Grantor and the Trustee intend that no third party have access to the Fund cxeept as hercin provided. (The Fund is established initially as a standby to receive payments and shall not consist of any property.) Payments made by the provider of financial assurance pursuant to the Commissioner's initruerion are transferred to the Trustee and are referred to as the Fund, together with all earnings and profits thenton, less any payments or distriburions made by the Trustee pursuant to this Agreement. The Fund shall be held by the Trustee, IN TRUST, as hereinafter provided. The Trustee shall not be responsible nor shall it underake any responsibility for the amount or adequacy of, nor any duty $t 0$ collect from the Granror as provider of financial assurance, any payments necessary to discharge any liability of the Grantor established by the Deparanent. 
(Rule 1200-1-15-.08, continued) Section 4. Payment for ("Corrective Action" and/or "Third Party Liability Claims")

The Trustee stall make payments from the Fund as the Commissioner shall direet, in writing, to provide for the payment of the costs of (inser:: "raking corrective action" and/or "compensating third paries for bodily injury and property damage caused by" either "sudden accidental releases" or "nonsudden accidental releases" or "accidental releases") arising from operating the tanks covered by the financial assurance mechanism identiried in this Agreement.

The Fund may not be drawn upon to cover any of the following:

(a) Any obligation of (insert owner or operator) unde: a workers' compensation, disability benefits, or unemployment compensation law or other similar lak;

(b) Bodily injury to an employee of (insert owner or operator) arising from, and in the course of, employment by (insert owner or operator);

(c) Bodily injury or property damage arising from the ownership, maintenance, use, or entrustment to others of any aireraft, motor vehiele, or watereraft;

(d) Property damage to any property owned, rented, loaned to, in the care, custody, or control of, or occupied by (insert orner or operator) that is not the direct result of a release from a petroleum underground storage tank; or

(e) Bodily injury or property damage for which (insert owner or operator) is obligated to pay damages by reason of the assumption of liability in a contract or agreement other than a contrate or agreement entered into to meet the requirements of rule $1200-1-15-.08(4)$.

The Trustee shall reimburse the Grantor, or other persons as specified by the Commissioner, from the Fund for corrective action expenditures and/or third-party liability claims in such amounts as the Commissioner shall direet in writing. In addition, the Irustee shall refund to the Grantor such amounts as the Commissioner specifies in writing. Upon refund, sueh funds shall no longer constitute part of the Fund as defined herein.

\section{Section 5. Poyments Comprising the Fund}

Payments made to the Irustee for the Fund shall consist of eash and securities acceptable to the Trustee

\section{Section 6. Trustee Management}

The Trustee shall invest and reinvest the principal and income of the Fund and keep the Fund invested as a single fund, without distinction between principal and income, in accordance with general investment policies and guidelines which the Grantor may communicate in writing to the Irustee from time to time, subjeer, hovever, to the provisions of this Secion. In inverting, reinvesting, exchanging, selling, and managing the Fund, the Trustee shall discharge his duties with respect to the trust fund solely in the interest of the beneficiaries and with the care, skill, prudence, and diligence under the circumstances then prevailing which persons of prudence, aeting in a like capacity and familiar with such matters, would use in the conduct of an enterprise of a like character and with like aims; except ihat:

(i) Securities or other obligations of the Grantos, or any other owner or operator of the tanks, or any of their affiliates as defined in the Invesment Company Act of 1940, as amended, 15 U.S.C. 80a-2(a), shall not be aequired or held, unless they are securvites or other obligations of the federal or a state government; 
(Rule 1200-1-15-.08, continued)

(ii) The Irustee is authorized to invest the Fund in time or demand deposits of the Trustem to the exrent insured by an ageney of the federal or state government; and

(iii) The Trustee is authorized to hold cash awaiting investment or distribution uninvested for a reasonable time and without liability for the paynlent of inierest thereon.

\section{Section 7. Commingling and Investment.}

The Trustee is expressiy authorized in its discretion:

(a) To transfer from time to time any or all of the assets of the Furd to any common, commingled, or collective trust fund created by the Trustee in which the Fund is eligible to parricipate, subject to all of the provisions thereof, to be commingled with the assets of other trusts participating therein; and

(b) To purchase shares in any investment company registered under the Investment Company Act of 1940, 15 U.S.C. $80 \mathrm{a}-1$ et seq., including one which may be created, man:aged, underwritten, or to which investment advice is rendered or the shares of which are sold by the Trustee The Trustee may vote such shares in its diseretion.

\section{Section 8. Express Powers of Trustee}

Without in any way limiting the powers and discretions conferred upon the Trustee by the other provisions of this Agreement or by law, the Trustee is expressly authorized and empowered:

(a) To sell, exchange convey, transfer, or otherwise dispose of any property held by it, by public or private sale No person dealing with the Trustee shall be bound to see to the application of the purchase money or to inquire into the validity or expediency of any such sale or otber disposition;

(b) To make, execute, acknowiedge, and deliver any and all documents of transfer and conveyance and any and all other instruments that may be necessary or appropriate to carry out the powers herein granied;

.(c) To register any securities held in the Fund in its owr name or in the name of a nominee and to bold any securizy in bearer form or in book entry, or to combine cerificates representing such securities with cerificates of the same issue held by the Trustee in other filiuciary capacities, or to deposit or arrange for the deposit of such securities in a qualified central depository even though, when so deposited, such securities may be merged and beld in bulk in the nanle of the nominee of such depository with other securities deposited therein by another person, or to disposit or arrange for the deposit of any securities issued by the U.S. Government, or any agency or insirumentality thereof, with a Federal Reserve bank, but the books and records of the Irustee shall at all times show that all such securities are part of the Fund;

(d) To deposit any cash in the Fund in interest-bearing aceounts maintained or savings cerifieates issued by the Trustee in its separate corporate capacity, or in any other banking institution affiliated with the Irustee, to the extent insured by an agency of the federal or state government; and

(e) To compromise or otherwise adjust all claims in favor of or against the Fund. 
(Rule 1200-1-15-.08, continued)

Section 9. Texes and Experser

All taxes of any kind that may be assessed or levied against or in respeet of the Fund and all brokerage commissions incurred by the Fund shall be paid from the Fund. All other expenses incurred by the Trustee in connection with the administration of this Trust, including fees for legal services rendered to the Trustee, the compensation of the Irustee to the extent not paid directly by the Grantor, and all other proper charges and disbursements of the Trustee shall be paid from the Fund.

\section{Section 10. Advice of Counsel}

The Trustee may from time to time consult with counsel, who may be counsel to the Grantor, with respett to any questions arising as to the construction of this Agreement or any action to be taken hereunder. The Trustee shall be fully protected, to the extent permitted by law, in aeting upon the advice of counsel.

\section{Section II. Trustee Compensation}

The Trustee shall be entitled to reasonable compensation for its services as agreed upon in writing from time to time with the Grantor.

\section{Section 12. Successor Trustee}

The Irustee may resign or the Grantor may replace the Trustes, but such resignation or replacement shall not be effective until the Grantor has appointed a successor trustee and this successor accepts the appointmeat. The suecessor trustee shall have the same powers and duties as those conferred upon the Trustee hereunder. Upon the successor trustee's acceptance of the appointment, the Irustee shall assign, transfer, and pay over to the successor trustee the funds and properties then constituting the Fund. If for any reason the Grantor cannot or does not aet in the event of the resignation of the Trustee, the Trustee may apply to a court of competent jurisdietion for the appointment of a successor tristee or for instruetions. The successor trustee shall specify the date on which it assumes administration of the trust in writing sent to the Grantor and the present Trustee by cerified mail 10 days before such change becomes effective. Any expenses incurred by the Trustee as a result of any of the acts contemplated by this Section shall be paid as provided in Section 9.

\section{Section 13. Instructions to the Trusteie}

All orders, requests, and instructions by the Grantor to the Trustee shall be in writing, signed by such persons as are designated in the attached Sehedule B or such other designees as the Grantor may designate by amendment to Schedule B. The Trustee shall be fully protected in aeting without inguiry in accordance with the Grantor's orders, requests, and instructions. All orders, requests, and instructions by the Commissioner to the Trustee shall be in writing, signed by the Commissioner, and the Trustee shall act and shall be fully protected in acting in accordance with such orders, requests, and instruecions. The Trustee shall have the right to assume, in the absence of written notice to the contrar; that no event constituting a change or a termination of the authority of any person to att on behalf of the Grantor or the Commissioner hereunder has occurred. The Trustee shall have no duty 10 act in the absence of such orders, requests, and instructions from the Grantor and/or the Commissioner, except as provided for herein.

\section{Section 14. Amendment of Agreement}

This Agreement may be amended by an instrument in writing executed by the Grantor and the Trustea, or by the Irustee and the Commissioner if the Grantor ceases to exist. 
(Rule 1200-1-15-.08, continued)

Section 15. Irrevocability and Termination

Subject to the right of the parties to amend this Agreement as provided in Sertion 14, this Thust shall be irrevocable and shall continue until terminated at the written direction of the Grantor and the Irustec or by the Trustee and the Commissioner, if the Grantor ceases to exist. Upon termination of the Trust, all remaining trust properny, less final trust administration expenses, shall be delivered to the Grantor.

\section{Section 16. Immunity and Indemnification}

The Trustee shall not ineur personal liability of any nature in connection with any act or omission, made in good faith, in the administration of this Irust, or in carrying out any directions by the Grantor or the Commissioner issued in accordance with this Agreement. The Trustee shall be indemnified and saved harmless by the Grantor, from and against ary personal liability to which the Trustee may be subjected by reason of any aet or conduet in its official capacity, including all expenses reasonably incurred in its defiense in the event the Grantor fails to provide such defense.

\section{Section 17. Choice of Low}

This Agreement shall be administered, construed, and enforced according 10 the laws of the state of Tennessee, or the Comptroller of the Currency in the case of National Association tianks.

\section{Section 18. Interpretation}

As used in this Agreement, words in the singular include the plural and words in the plural include the singular. .The descriptive headings for each section of this Agreement shall not affect the interpretation or the legal efficacy of this Agreement.

In Witness whereof the paries have caused this Agreement to be executed by their respective offroers duly authorized and their corporate seals (if applieabie) to be hereunto affixed and attested as of the date first above written. The paries below cerify that the wording of this Agreement is identical to the wording specified in rule $1200-1-15-.08(13)(b) 1$. as such regulations were constituted on the date written above

(Signature of Grantor)

(Name of the Grantor)

(Title)

Artest:

(Signature of Trustee)

(Name of the Irustee)

(Titie)

(Seal)

Artes:

(Signature of Witness)

(Name of Wimess)

(Tivle)

(Seal)

2. The standby trust agreement must be accompanied by a formal certifieation of acknowledgment similar to the following.

State of

County of 
(Rule 1200-1-15-.08, continued)

On this (dste), before me personally came (owner or operator) to me known, who, being by me duly sworn, did depose and say that she/he resides at (address), that sbe/he is (tille) of (corporation), the corporation described in and which executed the above instrument; that she/he knows the seal of said corporation; that the seal affixed to such instrument is such corporate seal; that it was so affixed by order of the Board of Directors of said corporation; and that she/he signed her/his name thereto by like order.
(Signature of Notary Public)
(Name of Notary Public)

(c) The Commissioner will inseruet the trustee to refund the baiance of the standby trust fund to the provider of financial assurance if the Commissioner determines that no additional corrective action costs or third-party liability claims will oceur as a result of a release covered by the firancial assurance mechanism for which the standby trust fund was established.

(d) An owner or operator may establish one trust fund as the depository mechanism for all funds assured in compliance with this rule

(14) Substitution of Finsncial Assurance Mechanisms by Owner or Operator

(a) An owner or operator may substitute any aiternate financial assurance mechanisms as specified in this rule, provided that at all times be maintains an effective financial assurance mechanism or combination of mechanisms that satisfies the requirements of rule 1200-1-15-.08(4).

(b) After obtaining alternste financial assurance as specified in this rule, an owner or operator may cancel a financial assurance mechanism by providing notice to the provider of financial assurance.

(15) Cancellation or Nonrenewal by a Provider of Financial Assurance

(a) Except as otherwise provided, a provider of financial assurance may caned or fail to renew an assurance mechanism by sending a notice of termination by certified mail to the owner or operator.

1. Termination of a guarantes a surety bond, or a letter of credit may not oceur until 120 days after the date on which the ouner or operato: receives the notiee of termination, as evidenced by the return receipt.

2. Terroination of insurance or risk retention group coverage, except for nonpaysent or misrepresentation by the insured, or state-funded assurance may not oceur until 60 days after the date on which the owner or operator receives the notice of termination, as evidenced by the return receipt Termination for nonpaymeat of premium or misrepresentation by the insured may not occur uniil a minimum of ten (10) days after the date on which the owner or operator receives the notice of termination, as evidenced by the return receipt

(b) If a provider of financial responsibility cancels or fails to renew for reasons otber than incapacity of the provider as specified in rule $1200-1-15-.08(10)$, the owner or operator must obtain alternate coverage as specified in this paragraph within 60 days after receipt of the notice of termination. If the owner or operator fails to obtain alternate coverage within 60 days after receipt of the notice of termination, the owres or operator must notify the Commissioner of such faijure and submit:

1. The name and address of the provider of financial assurance;

2 The effecive date of termination; and

3. The eridence of the financiai assurance mechanism subject to the temination maintained in accordance writh rule $1200-1-15-.08(17)$. 
(Rule 1200-1-15-.08, continued)

(10) Reporting by Owner or Operator

(a) An owner or operator must submit the appropriate forms listed in rile $1200-1-15-.08(17)(b)$ documenting eurrent evidence of financial responsibility to the Commissioner:

1. Within 30 days after the owner or operator identifies a release from an underground storage tank required to be reported under rule 1200-1-15-.05(4) or rale 1200-1-15-.05(2);

2. If the owner or operator fails to obtain alternate coverage al; required by this rule, within 30 days after the orner or operator receives notice of:

(i) Commencement of a voluntary or involuntary proceeding under Title 11 (Bankruptcy), U.S. Code, naming a provider of financial assurance as a. debtor,

(ii) Suspension or revocation of the authority of a proviliter of financial assurance to issue a financial assurance mechanism,

(iii) Failure of a guarantor to meet the requirements of the financial test,

(iv) Other incapacity of a provider of financial assurance; or

3. As required by rule $1200-1-15-.08(0)(\mathrm{g})$ and rule $1200-1-15-.08(15)$.

(b) An owner or operator must certify compliance with the financial responsibility requirements of this Chapter as specified in the new tank notifieation form when notifying the Department of the installation of a new underground storage tank under rule $1200-1-15-.02(3)$.

(c) The Commissioner may require an owner or operator to submit evidence of financial assurance as described in rule $1200-1-15-.08(17)(b)$ or other information relevant to compliance with this rule at any time.

(17) Recordkeeping

(a) Owrners or operators must maintain evidence of all financial assurance mechanisms used to demonstrate financial responsibility under this rule for an underground storage tank until released from the requirements of this rule under rule 1200-1-15-.08(19). An owner or operator must maintain such evidence at the underground storage tank site or the owner's or uperator's place of business. Records maintained off-site must be made available upon request of the Department.

(b) An oumer or operator must maintain the following types of evidence of financial responsibility:

1. An owner or operator using an assurance mechanims specified in rule 1200-1-15-.08(6) through rule 1200-1-15-.08(12) must maintain a copy of the instrument(s) worded as specified.

2. An owner or operator using a financial tert or guarantee must. maintain a copy of the chief financial officer's letter based on year-end financial statements for the most recent completed financial reporting year. Such evidesce must be on file no later than 120 days after the close of the finan. cial reporing year.

3. Ar owner or operator using a guarantee, surety bond, or letter of credit must maintain a copy of the signed standby trust fund agreenent and copies of any amendments to the agreernent. 
(Rule 1200-1-15-.08, continued)

4. An owner or operator using an insurance policy or risk retention group coverage must maintain a copy of the signed insurance policy or risk retention group coverage policy, with the endorsement or certiricate of insurance and any amendments to the agreements.

5. An ownet or operator covered by a state fund must maintain on file a copy of evidence of coverage required by the state under rule 1200-1-15-.08(11)(b) and a copy of the current petroleum underground storage tank cerrificaie pursuant to rule $1200-1-15-.10$.

6. An owner or operator using an assurance mechanism specified in rule 1200-1-15-.08(6) through rule 1200-1-15-.08(12) must maintain and submit to the Deparment with the annual tank fee an updated copy of a certification of financial responsibility worded as follows, except that instructions in braekets are to be replaced with the relevant information and the brackets deleted:

\section{CERTIFICATION OF FINANCIAI RESPONSIBILITY}

(Owner or operator) hereby cerrifies that it is in compliance with the requirements of rule $1200-1-15-.08$.

The financial assurance mechanism(s) used to demonstrate financial responsibility under rule $1200-1-15-.08$ is (are) as follows:

(For each mechanism, list the type of mechanism, name of issuer, meehanism number (if applicable), amount of coverage, effective period of coverage and whether the mechanism covers "taking corrective action" and/or "compensating third paries for bodily injury and property damage caused by" ejther "sudder accidental releases" or "nonsudden accidental releases" or "accidental releases:")

(Signature of owner or operator)

(Name of owner or operator)

(Title)

(Date)

(Signature of witness or notary)

(Name of witness or notary)

(Date)

The owner or operator must update this cerification whenever the financial assurance mechanism(s) used to demonstrate financial responsibility change(s). A copy of this updated certification is to be submitted to the Deparment whenever the financial assurance mechanism(s) used to demonstrate financial responsibility change(s).

(18) Drawing on Finansial Assurance Mechanisms

(a) The Commisioner shall require the guarantor, surety, or institution issuing a letter of credit to place the amount of funds stipulated by the Commissioner, up to the limit of funds provided by the financial assurance mechanism, into the standby trust if:

1. (i) The owner or operator fails to establish alternate financial assurance within 60 days after reseiving notice of cancellation of the grarantee, surety bond, letter of credit, or, as applicable other financial assurance mechanism; and

(ii) The Conmissioner determines or zuspects that a release from an uncerground storage tank covered by the mechanism has oceurred and so notifies the owner or operator or the owner or operator has notified the Commissioner pursuant to rule 1200-1-15-.0S or Rule 1200-1-15-.06 of a reiesse from an unde:ground storage tank covered by the mechanism; or 
(Rule 1200-1-15-.08, continued)

. 2 . The conditions of subparagraph (b)1. or (b)2. are satisfiet.

(b) The Commissioner may draw on a standby trust fund when:

1. The Commissioner makes a final determination that a release has occurred and immediate or - Iong-lerm corrective aetion for the release is needed, and the owner or operator, after appropriate notice and opportunity to comply, has not conducted corrective action as required under Rule $1200-1-15-.06$ or

2. The Commissioner has received either:

(i) Certifieation from the opner or operator and the third-party liability claimani(s) and from attorneys representing the owner or operator and the third-party liability claimant(s) that a third-party liability claim should be paid. The certification must be worded as follows, except that instruetions in brackets are to be replaced with the relevant information and the brackets deleted:

\section{CERTIFICATION OF VALID CLAIM}

The undersigned, as principals and as legal representatives of (insert owner or operator) and (insert name and address of third-party claimant), hereby certify that the claim of bodily injury (and/or) property damage caused by an accidental release arising from operating (owner's or operator's) underground storage tank should be paid in the amount of SC ).

(Signatures)
Owner or Operators
Altorney(s) for
Owner or Operator

(Notary) Date

or

(ii) An original or certified copy of a final judgenent (enforceable in Tennessee) establishing a judgment against the owner or operator for bodily injury or property damage caused by an accidental release from an underground storage tank covered by financial assurance under this rule

(c) If the Commissioner determines that the 2mount of corrective action costs and third-party liability claims eligible for payment under subparagraph (b) may ceeed the balanee of the standby trust fund and the obligation of the provider of financial assurance, the first prionity for payment shall be corrective action costs necessary to protect human health and the environment. The Commissioner shall pay third-party liability claims in the order in which the Commissioner receives cerrifications of valid claims under subpar (b)2.(i) and valid final judgments under subpart (b)2.(ii). 
(Rule 1200-1-15-.08, continued)

(19) Release from the Requirements

An owner or operator is no longer required to maintain finsncial responsibility under this rule for an underground storage tank after the tanik has been properly closed or, if correcrive action is required, after corrective action has been completed and the lank has been properly closed as required by sule $1200-1-15-.07$.

(20) Bankruptey or Other Ineapacity of Orner or Operator or Provider of Financial Assurance

(a) Within 10 days after commencement of a voluntary or irvoluetary praceding under Title 11 (Bantruptcy), U.S. Code, naming an okner or operator as debtor, the ormer or operator must notify the Commissioner by certified mail of such commencement and submit the appropriate forms isted in rule 1200-1-15-.08(17) documenting current financial responsibility.

(b) Within 10 days after commencement of a voluntary or involuntary proceding under Title II (BantruptCy), U.S Code, naming a guarantor providing financial assurance as debtor, such guarantor must notify the owner or operator by cerifried mail of such commencement as required under the terms of the guarantee specinied in rale $1200-1-15-.08(7)$.

(c) An owner or operator who obtains financial assurance by a mechanism other than the financial tert of self-insurance will be deemed $w$ be without the required financial assurance in the event of a bankruptcy or incapacity of its provider of financial assurance, or a suspension or revocation of the authority of the provider of financial assurance to issue a guaranter, insurance policy, risk retention group coverage policy, surety bond, letter of credit, or stete-required mechanism. The ouner or operator must obrain alternate financial assurance as specified in this rule within 30 days after receiving notice of such 20 event. If the orner or operator does not obtain alternate coverage within 30 days after such notification, be must notify the Commissioner.

(d) Within 30 days after receipt of notification that the Tennesses Petroleum Underground Storage Tank Fund has become incapable of paying for assured corrective action or third-party compensation costs, the owner or operator must obtain alternate financiel assurance

(21) Replenishneat of Guarantees, Letters of Credit, or Surety Bonds

(a) If at any time after a standby trust is funded upon the instruction of the Commissioner with funds drawn from 2 guarantes, letter of credit, or surety bond, and the amount in the standby trust is reduced bejow the full amount of coverage required, the owner or operator shall by the anniversary date of the financial mechanism from which the funds pere drakn:

1. Repienish the value of financial assurance to equal the full amount of coverage required, or

2. Acquire another financial assurance mechanism for the amount by which funds in the standiby trust have been reduced.

(b) For purposes of this paragraph, the full amount of coverage required is the amount of coverage to be provided by rule 1200-1-15-.08(4). If a combination of meehanisms was used to provide the assurance funds which were drawn upon, replenishment shall occur by the earliest anniversary date among the mechanisms.

Authorty: T.CA $\$ \$ 68-53-101$ er seg, 68-53-107, 68-53-113 and \& 5-201 et seq. Adminitrative Hitror: Original rule filed March 1, 1990; effective April 15, 1990. Amendment filed July 3, 1991; effective August 17, 1991. 


\section{0-1-15-.09 ADMINISTRATIVE GUIDELINES AND PROCEDURES FOR THE TENNESSEE PEIROIEUM UNDERGROUND STORAGE IANK FUND.}

(1) Purpose This chapter is promulgated to establish administrative guidelines and procedures to determine the manner in which disbursements are made from the Teanessee Peiroleum Underground Storage Tank Fund and to implement the purposes and objectives of the Tennessee Petroleum Underground Storage Tani: Act of 1988.

(2) Definitions: The following words and terms, when used in this rule, shall have the following meanings unless the context clearly indieates otherwise

(a) "Board" means the petroleum underground storage tank board established in T.CA. \$68-53-112.

(b) "Commissioner" means the Commissioner of Health and Environment, his authorized representatives, or in the event of his absence or a vacancy in the Commissioner's office, the Deputy Commissioner.

(c) "Connected piping" means all underground piping including valves, elbows, joints, flanges, and flexible connectors attached to a tank system through which petroleum nows. For the purpose of determining how much piping is connected to any individual UST syitem, the piping that joins two UST systems should be allocated equally between them.

(d) "Consumption" with respect to heating oil means consumed on the premises where stored.

(e) "Correetive Action" means any activity, including but not limited to evaluation, planning, design, engineering, construetion, and ancillary service, which is carried out in response to any discharge, release, or threatened release of petroleum.

(f) "Corrective Action Contractor" means a person who is carrying out any corrective action, including a person retained or hired by such person to provide services selating to a corrective action.

(g) "DE Minimis" means very low concentrations of petroleum.

(h) "Deparmen" means the Tennessee Deparment of Health and Environment.

(i) "Director" means the Diresior of the Division.

(j) "Division" means the Division designated by the Commissioner of the Department of Health and Environment as the agency to implement the Underground Storage Tank Program in Tennessee

(k) "Eligible ou'ner" means an owner or operator that is in "Substantial Compliance" as defined in subparagraph (hh) of this paragraph.

(l) "Farm tank" is a tank located on a tract of land devoted to the production of crops or raising animals. inciuding fish, and 2ssociated residences and improvements. A farm tank must be located on the farm propeny. "Farm" ineludes fish hatcheries, rangeland and nurseries wjth growing operations.

(m) "Flow-through process tank" means 2 tank whose principal usie is not for storage but is used in the manufacture of a product or in a treatment process. A flow through process tank forms an integral par of a production process through which. there is a steady; variable, recurring, or iniermittent flow of materiais during the operation of the process. Flow-througla process tanks do not include tanks used for the storage of materials prior to their introducsion into the production process or for the storage of finished produets or by-products from the produetion process. 
(Rule 1200-1-15-.09, continued)

(n) "Free product" refers to a petroleum that is present as a nonaqueous phase liquid (eg., liquid not dissolved in water).

(0) "Fund" means the petroleum underground storage tank fund established under T.CA. \$68-53-110 unless the context ciearly indicates otherwise.

(p) "Gathering lines" means any pipeline, equipment, facility, or building used in the transporation of oị or gas during oil or gas production or gathering operations.

(q) "Grourid water" means water below the land surface in a zone of saturation.

(r) "Heating oil" means petroleum that is No. 1, No. 2, No. 4-light, Na. L-heavy, No. 5-light, No. 5beavy, and Na 6 technicai grades of fue: sili otter tesiciual fuel oils (including Navy Special Fuel Oil and Bunker C); and other fuels when used as substitutes for one of these fuel oils. Heating oil is typically used in the operation of heating equipment, boilers, or furnaces.

(s) "Hydraulic lift tanks" means a tank holding bydraulic fluid for a closed-loop mechanical system that uses compressed air or hydraulic fluid to operate lifts, elevators, and other similar devices.

(t) "Liquid trap" means sumps, well cellars, and other traps used in association with oil and gas production, gathering, and extraetion operations (ineluding gas production plants), for the purpose of collecting oil, water, and other liquids. These liquid traps may temporarily colleet liquids for subsequent disposition or reinjection into a production or pipeline stream, or may collect and separate liquids from a gas stream.

(u) "Noncommercial purposes" with respect to motor fuel means not for resale

(v) "On the premises where stored" with respect to heating oil means UST systems located on the same properry where the stored heating oil is used.

(w) "Operator" means any person in control of, or having responsibility for, the daily operation of the petroleum underground storage tank.

(x) "Owner" means:

1. For petroleum storage tanks in use or brought into use on or after November 8, 1984, any person who owns a petroleum underground storage tank used for the storage, use, or dispensing of peuroleurn products.

2. For petroleum underground storage tanks used priot to November 8, 1984, but no longer in use after that date, the person who last owned the petroleum underground storage tank used for storage use, or dispensing of petroleum immediately before discontinuation of its use

(y) "Person" means any and all persons, including individuais, furms, partnerships, associations, public or private institutions, state and federal agencies, municipalities or political subdivisions, or officers thereof, departments, agencies or instrumentalities, or public or private corporations or officers thereof, organized or existing under the laws of this or any other state or country.

(z) "Petroleum" means crude oil or any fraction thereof that is liquid at standard temperature and pressure ( 60 degrees Fahrenheit and 14.7 pounds per square inch absolute). The term petroleum includes but is not limited to petroleum and petroleum based substances comprised of a complex blend of bydrocarbons derived from enude oil through processes of separation, conversion, upgrading, and finishing. such as motor fuels, jet fuels, distillate fuel oils, residual fuel oils, lubrieants, petsoleurn solvents, and used oils. 
(Rule 1200-1-15-.09, continued)

(2a) ."Pipe" or "Piping" means a hollow cylinder or tubular conduit that is constructed of non-earthen materials.

(bb) "Pipeiine facitities (including gathering lines)" are new and existing pipe rights-of-way and any associated equipment, facilities, or buildings.

(cc) "Reasonable cost" means that monetary amount or range as dietermined by the Deparment, to be commensurate with a corrective aetion. The Deparment's determination is based on an evaluation of typical costs expected for the parricular corrective action under review considering the scope and complexity of the activities involved.

(dd) 'Release" means any spilling, overfilling, leaking, emirting, discharging, escaping, leaching or disposing of a petroleum substance from an UST or its associated piping into groundwater, surface water or subsurface soils.

(ee) "Residential tank" is a tank located on property used primarily for dwelling purposes.

(fi) "Septic tank" is a wate-tight covered receptacie designed to receiv: or process, through liquid separation or biological digestion, the sewage discharged from a building :sewe-. The effluent from such receptacle is distribured for disposal through the soil and settled solids and seum from the tanks are pumped out periodically and hauled to a treatment facility.

(gg) "Storm-water or wastewater collection system" means piping, pumps, conduits, and any other equipment necessary to collect $2 \pi d$ trasspor the flow of surface water run-off resulting from precipitation, or domestic commercial, or inoustrial wastewater to and from retention areas or any areas where treatment is designated to oceur. The collection of storm water and wastexater does not include treatinent except where incidental to conveyance

(hh) "Substanial Compliance" shall mean that an owner or operalior of an underground storage tank has registered that tank with the Division, has timely paid all annual tank fees, and has complied with the requirements of role $1200-1-15-.02(1)$ through rule $1200-1-15-.07(5)$.

(ii) "Surface impoundment" is a natual topographic depression, man-made excavation, or diked area formed primarily of earthen materials (although it may be lined with man-made materials) that is not an injection well.

(ij) "Tank" is a stationary device designed to contain an accumulation of petroleum and conserueted of non-earthen materials (eq., wood, sonerete, steel, fiberglass) that provide structural support.

(kk) "Third Party Claim" means any civil action brought or asserted by any person other than the Deparmen: or EPA against any owner or operator of any underground storage tank for damages to person or property which damages are the direa result of contamination by petroleum released from a petroleum underground rorge tank.

(II) "Underground area" means an unde:ground room, such as a basement, cellar, shaft or vault, providing enough space for physical inspection of the exterior of the tanks situated on or above the surface of the floor.

(ms) "Underground release" means any below ground release 
(Rule 1200-1-15-.09, continued)

(nn) "Underground storage tank" or "UST" means any one or combination of tanks (ineluding underground pipes connected thereto) that is used to contain an accumulation of petroleum, and the volume of which (including the volume of underground pipes connected thereto) is 10 percent or more beneath the surface of the ground. This term does not inciude any:

1. Farm or residential tank of 1,100 gallons or less capacity used for storing motor fuel for noncommercial purposes;

2. Tank used for storing heating oil for consumption on the premises where stored;

3. Septic tank;

4. Pipeline facility (including gathering lines) regulated under.

(i) The Natural Gas Pipeline Safety Act of 1968 (49 U.S.C. App. 1671, et seq.), or

(ii) The Hazardous Liquid Pipeline Safety Aet of 1979 (49 U.S.C. App. 2001, et seq.), or

(iii) State laws comparable to the provisions of law in Subparts (i) or (ii) above if it is an intrastate pipeline;

5. Surface impoundment, pit, pond, or lagoon;

6. Storm-kater or wastewater collection system;

7. Flow-through process tank; ·

8. Liquid trap or associated gathering lines direetly related to oil or gas production and gathering operations; or

9. Storage tanks situated in an underground area (such as a basement, cellar, mine working, drift, shaft, or tunnel) if the storage tank is situated upon or above the surface of the floor, and

10. Piping connected to any of the above exclusions:

(০o) "UST System" or "Tank system" means an underground storage tank, connected underground piping, underground ancillary equipment, and containment system, if any.

(pp) "Wastewater treatment tani" means a tank that is designed to receive and treat an infuent wastewater through physical, chemical, or biological methods.

(9q) "Waters" means any and all water, publis or private, on or beneath the surface of the ground, which are contained within, flow through, or border upon Tennessee or any portion thereof except those bodies of water confined to and retained within the limits of private property in single ournership which do not combine or effect a junerion with natural surface or underground waters. [Aers 1971, ch. 164, \$3; 1977, ch. 366, \$1; T.CA. \$70-326; Acts 1984, ch. 804, \$1.]

(3) Applicability. Requirements of this rule apply to all owners and operators of an underground storage tank system as defined in rule 1200-1-15-.09(2) except as otherwise provided for in rule 1200-1-15-.01(1)(b), rule $1200-1-15-.10(3)(c)$, and rule $1200-1-15-.11(3)(d)$. 
(Rule 1200-1-15-.09, continued)

(4) Fund Eligibility Requirements

(a) Every owner of an UST is required to register that tank with the Division. The owner and/or operator is required to annually pay the required fee for each tank described in rule $1200-1-15-10$ (2) and rule $1200-1-15-.10<6(c)$. Owmers and/or operators satisfying the requirments of this paragraph will have established Fund eligibility. Before the owner and/or uperator will receive Fund benefit, the applieable entry level amount to the Fund must be expended a:s approved costs by the opner and/or operator and/or financial assurance provider. The applicable entury level is the entry level in effect the date the release is reported to the Department.

If the date of release was prior to July 1,1988 , the owner and/or operators are not eligible to receive Fund benefit. If the date of release was between July 1, 1988 and June 30, 1989, the per oceurence entry level for corrective action is seventy-five thousand dollars $(575,000)$ and the per occurrence entry level for third party compensation is one bundred fifty thousand dollars $(5150,000)$. If the date of release was between Juiy 1, 1989 and April 30, 1990 the per oceurrence entry level for corrective action is fifty thousand dollars $(\$ 50,000)$ and the per oceurrence entry level for third party compensation is one hundred fifty thousand dollars $(5150,000)$.

(b) Every orner or operator of an UST is required to maintain Fund eligibility. Requirements to maintain eligibility are as follows:

1. The owner or operator shall remain in substantial compliance for each UST. If a UST does not remain in substantial compliance, the owner or operator is not eligible for Fund benefits for the site containing the non-complying UST.

2. Annual payment of Underground Storage Tank Fees are required for each UST unil such time as permanent closure or change-in-service requirements of sule 1200-1-15-.07(2) through rule $1200-1-15-.07(5)$ are satisfied.

3. The owner or operator shall maintain the records as required in Chapter 1200-1-15 and submit or make them available to the Division upon request or as directed in regulation.

4. All records maintained as required in subparagraph (b)3. above shall be retained by the owner and/or operator until one of the following is accomplisined:

(i) Closure requirements of rule 1200-1-15-.07(2) through 1200-1-15-.07(5) are satisfied;

(ii) Ownership of an UST, and all records pertaining thereto, are transferred to a new owner, or

(iii) Owner or operator is instructed otherwise by the Division.

(5) Loss and Restoration of Fund Eligibility

(a) If at the time of discovery of a release, the Division determines that an owner or operator has failed to establish Fund eligibility in accordance with subparagreph (4)(a), corrective action coss and/or third party damages associated with that release are not eligible for coverage by the Fund.

(b) If at any time the Division determines that an owner or operator has failed to maintain Fund eligibility, the Division will provide notice to the owner or operator of such non-compliance The owner or operafor shall have thirty (30) days from receipt of such notice 10 provide evidence of compliance with all Fund eligibility requirements or such other time period as the Division may allow. If, after this time period, the owner o: operator fails to resolve the non-complianes the Direstor shall issue a Notice of Fund ineligibility and enforement actions which may inciulle penalty assessment may be initiated. The owner or operator shall bave 60 days from receipt of Notiee of Fund Ineiligibility to place in force alternate financial assurance required in rule $1200-1-15-.08(4)$ and rule $1200-1-15-.08(15)$. 
(Rule 1200-1-15-.09, coninued)

(c) An ownes or operator that has been issued a Notice of Fund Ineligibility must resolve the non-compliance to the satisfaction of the Division for Fund eligibility to be restored. Within thirty (30) days of resolution of the non-compliance, the Division will notify the owner or operator of the date that Fund eligability was restored. It is the responsibility of the owner or operator. to provide evidence of compliance to the Division. The Fund will not cover either investigative or consective action coss or third party liability claims associated with a release which occurred during the time of Fund ineligibility.

(๑) Anonual Fee Assessment

(a) As part of the eligibility requirements to parricipate in the liability limitations and reimbursement benefits of the Fund, an UST owner or operator shall pay an annual Tank Fee set by the Board.

(b) Each year UST owners or operators will be notified by the Division of the amoun: of the required Tank Fee

(7) Authorized Disbursements From the Fund

(a) Whenever in the Commissioner's determination, an eligible owner or operator has a release of petroleum from an underground storage tank and the owner or operator has been found to be eligible for Fund coverage, the Department shall, subject to the provisions of this rule, disburse monies available in the Fund to provide for:

1. Emergeney response activities, investigation, and assessment of sites contaminated by a release of $p=:$ roleum in accordance with the requirements of rule .1200-1-15-.05 through $1200-1-15-.06$.

2. The rehabilitation of sites contaminated by a release of petroleum, which may consist of cleanup of affected soil and groundwater, using cost effective alternarives that are technologically feasible and reliable and that provide adequate protection of the public health, safety and welfare and minimize environmental damage, in accordance with corrective action requirements of rule $1200-1-15-.06$.

3. The interim replacemeat and permanent restoration of potable water supplies; -

(b) Monies held in the Fund may be disbursed for making payments to third paries who bring suit rejative to a UST release against the owner or operator of an UST who is eligible for Fund coverage when such third pany obtains a final judgment in that action enforceable in Tennessee

(c) Costs incurred by the Division in the administration of the provisions of this rule or authorized under T.CA. \$68-53-101 et seg. stall be charged to the Fund.

(d) The fund shall be available to the Board and the Commissioner for expenditures for the purposes of providing for the invesigation, identification, and for the reasonable and safe deanup, including monitoring and maintenance of petroleum sites within the state as provided in T.CA. \$68-53-10I et seq.

(e) The commissioner may enter into contracts and use the fund for those purposes direetly associated with identifieation, investigation, containment and cleanup, including moxitoring and maintenance preseribed above including:

1. Hiving consultants and personnel;

2 Purchase lease or rental of necessary equipmens; and

3. Other necessary expenses. 
(Rule 1200-1-15-.09, continued)

(8) Scope of Fund Coverage

(a) The Fund will provide so eligible UST owners or operators coverage for the cost of correzive actions and for compensation of third paries for bodily injury and property damage resulting from accidenial releases arising from the operation of an UST which stores petroleum.

(b) Owner or operators of USTs who are eligible for Fund coverage niust meet the per site per oceurrence financial responsibility requirements specified in pars 1., 2 , or 3 . and illustrated in Table 3.

1. If the date of release was between July 1, 1988 and June 30, 1989, the financial responsibility requirements for eligible UST owners or operators for tabius corrective action will be seventy. five thousand dollars $(\$ 75,000)$ and compensation of third parties will be one bundred fifty thousand dollars $(\$ 150,000)$.

2. If the date of release was between July 1, 1989 and April 30, 1990, the financial responsibility requirenents for eligible UST owners or operators for tabing corrective actions will be fifty thousand dollars $(\$ 50,000)$ and compensation of third parties will ixe one huedred fifty thousand dollars $(5150,000)$.

3. If the date of release was on or after May 1, 1990, the finaulial responsibility requirements for eligible UST owners or operators will be as follows based on the number of tanies owned or operated:

(i) 1 to 12 tanks, ten thousend dollars $(\$ 10,000)$ for taling corrective actions and ten thousand dollars $(510,000)$ for compensation of third parties

(ii) ' 13 to 999 tanks, twenty thousand dollars $(\$ 20,000)$ for inbing corrective actions and thirtyseven thousand five bundred dollars $(537,500)$ for compensation of third paries; or

(iii) 1,000 or more tanks, fifty thousand dollars $(550,000)$ for eaking corrective actions and two hundred twenty-five thousand dollars $(\$ 225,000)$ for compensation of third paries.

In the future the Board may change the owner's or operator's limit of financial responsibility for third party dameges per site per ocesrrence within the limits specified for 13 or more tanks in T.CAA. \$68-53-101 et seq. if deemed necessary.

TABLE 3

OWNERUOPERATOR FINANCLAI RESPONSIBILITY PIER SITE PER OCCURRENCE

\begin{tabular}{|c|c|c|c|}
\hline \multirow{2}{*}{$\begin{array}{c}\text { DATE } \\
\text { OF } \\
\text { REIEASE }\end{array}$} & \multicolumn{3}{|c|}{ NUMBER OF: TANKS } \\
\hline & 1. 12 Tanks & 13 - 999 Tanks & $1000+$ Tanks \\
\hline $\begin{array}{l}\text { Prior to } \\
\text { July 1, } 1988\end{array}$ & $\begin{array}{l}\text { All costs - } \\
\text { Not Fund Eligible }\end{array}$ & $\begin{array}{l}\text { All costs - } \\
\text { Not Fund Elipible }\end{array}$ & $\begin{array}{c}\text { All costs - } \\
\text { Not Fund Eligible }\end{array}$ \\
\hline $\begin{array}{c}\text { Between July 1, } 1988 \\
\text { and } \\
\text { June 30, } 1989\end{array}$ & $\begin{array}{c}575,000 \\
\text { Clesn-up/ } \\
\text { sis0,000 third party }\end{array}$ & $\begin{array}{c}\text { S75,000 } \\
\text { Clean-up/ } \\
\text { S150,000 third parry }\end{array}$ & $\begin{array}{c}\$ 75,000 \\
\text { Clean-up/ } \\
5150,000 \text { third party }\end{array}$ \\
\hline $\begin{array}{c}\text { Between Jujy 1, } 1989 \\
\text { and } \\
\text { Apsil 30, } 1990\end{array}$ & $\begin{array}{c}\$ 50,000 \\
\text { Clean-up/ } \\
\$ 150,000 \text { third party }\end{array}$ & $\begin{array}{c}\$ 50,000 \\
\text { Clezn-up' } \\
\text { siso, } 000 \text { third party }\end{array}$ & $\begin{array}{c}\$ 50,000 \\
\text { Clean-up/ } \\
\$ 150,000 \text { third parts }\end{array}$ \\
\hline $\begin{array}{l}\text { On or Afrer } \\
\text { May 1, } 1990\end{array}$ & $\begin{array}{l}\text { s10,000 Clean-up/ } \\
\text { s10,000 third party }\end{array}$ & 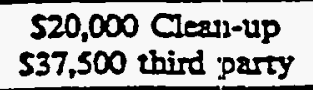 & $\begin{array}{l}\text { 550,000 Clean-up/ } \\
\text { s225,000 third parny }\end{array}$ \\
\hline
\end{tabular}


(Rule $1200-1-15-.09$, continued)

(c) The fund shall be responsible to eligible UST owners or operators for eligible corrective action costs above the entry level to the fund in an amount not to ceed one million dollars $(51,000,000)$ per site per oceurrevice Likewise, the fund shall be responsible to eligible UST owners or operators for court atrards involving third party claims above the entry level inso the fund in an amount not to exceed one million dollars $(\$ 1,000,000)$ per site per oceurrence

(9) Fund Ineligible Costs

(a) Costs of replacement, repair, maintenance, and/or retrofitting of affected tanks and associated piping and any costs not integral to site rebabilitation shall not be eligible for payment or reimbursement by the Fund. Replacement of asphalt or conerete shall not be eligible for Fund payment or reimbursement.

(b) The cost of equipment purchases other than routinely required supplies which are expended as a given site or equipment which must be installed at 2 site to implement a corrective action plan, shall not be charged as a lump sum to the cost of rehabilitating any given site at which Funds are being claimed for containment, investigative, or corrective action costs. Examples of equipment which could not be charged to a specific site would include: drilling rigs, earth moving equipment, groundwater sempling pumps, and photoionization detectors. Examples of equipment which could be charged to a specifie site would include: bailers, sample containers, etc Fourly charges for equipment may be establisbed in the cost proposal submitted for each major phase of work. These hourly rates must be competitive with similar charges by other approved contractors, or they may be rejected by the Division if they are determined to represent unreasonable costs.

(c) The owner or operator finsocial responsibility requirements arounts as specified in rile $1200-1-15-.09(8)(b)$ are not eligible for reimbursement from the Fund. Proof of payment of these initial amounts is required prior to reimbursement of any costs. The ofrater or operator's financiel responsibility requirement for tabing corrective actions can not include ary cost defined as fund ineligible in subparagraph (a) and (b).

(10) Fund Obligations

(a) Contingent upon availability of funds the Commissioner will make obligations from the Fund when:

1. A cost proposal for containment, investigative, or corrective actions, submitted in accordance with rule $1200-1-15-.09$ (11) is approved by the Division.

2. A judgment for a third party claim is submitted for payment in accordance with rule $1200-1-15-.09(7)$ and rule $1200-1-15-.09(12)$.

3. A payment applieation is received for containment, investigative, or corrective action work performed from July 1, 1988 until April 15, 1990, subject to a determination of reasonable costs by the Division. Fund eligibility from July 1, 1988 until April 15, 1990 shall be determined by fee payment as required by the Tennessee Petroleum Underground Storage Thak Aet.

4. A payment application is received for initial release response abatement measures, and initial free product removal under the terms of rale 1200-1-15-.09(11)(c).

5. A payment applicarion is received and approved by the Division for costs associated with providing an alternate water supply to a person whose water supply has been contaminated by a release of petroleum. 
(Rule 1200-1-15-.09, continued)

6. The commissiones or board determines it is necessary to provide for contrinment, investigation, identification, reasonable and safe cleanup and as otherwise jrovided in the Tennesser Peuroleum Underground Storge Thnk Aet.

(b) If the unobligated balance of the Fund is less than the total amourt associated with payment applications, cost proposals and third party judgements which have been. accepted by the Commissioner, to the extent allowed by available funds, funds will be obligated in the chronologieal order in which the claims were submitted, except for the provisions of subparagrph (c)

(c) Obligations of funds required for satisfying fund eligible payment applications for work performed under part (a)3. above or judgements for third party claims which were rendered prior to April 15, 1990 for relesses diseovered from July 1, 1988, watil April 15, 1990, will be given priority over payment applications and cost proposals for releases which oceur after April 15, 1990.

(d) All chaims aquiner the fund arc clearly obligations only of the fund and not of the state, and ary amounts required to be psid under this part are subject to the availabillity of sufficient monies in the fund. The full faith and credit of the state shall not in any way be pleiged or considered to be available

- to guarantec payment from such fund.

(11) Requirements for Fund Coverage of Corrective Aetion Costs. An eligible orner or operator conducting UST corrective actions is entitled to coverage of reasonable corts from the Fund, subject to the following provisions:

(a) Upon confirmation of a release in accordance with rule 1200-1--15-.05(3) or after a release from the UST system is identified in any other manner, owners and operators must perform initial response actions required in rule $1200-1-15-.06(2)$, iritial abatement measures required in rule $1200-1-15-.06(3)(2) L$ through 4. and rule 1200-1-15-.06(3)(b), and initial free product removal according to rale $1200-1-15-.06(5)$ and rule 1200-1-15-.06(3)(a)6. necessary to properly stabilize a site and to prevent significant continuing damage to the environment or risk to human bealth

(b) Upon confirmation and reporting of a release in aceordance with the requirement of rule $1200-1-15-.05(1)$ through rele 1200-1-15-.05(3) the owrer or operator must select a contractor from the Division's list of approved contractors if the owner or ciperator expects to apply for Fund benefits. The Division must be notified in writiag of such a selection within fifteen (15) days or othes time specified by the Division. A contractual agrement must be established between the owner or operator and the contractor. The Division mus be provided a cispy of the contractual agreement. 
(Rule 1200-1-15-.09, continued)

(c) If initial release responses, abatement measures and initial free product removal, conducted in aceordance with rules $1200-1-15-.05$ (2) through rule 1200-1-15-.06(5), are required to properly stzbilize a site and prevent sigmifieant continuing damage to the environmeat or risk to buman health, and the cost of such required measures is expected to exceed ten thousand dollars $(\$ 10,000.00)$, then the owner or the approved corrective action contractor may coneset the Division to obtain verbal or written approval to allow additional expenditures prior to the submittal of a cost proposal. Additional expenditures may be authorized by the Division up to a total of thirty thousand dollars $(530,000)$ which may be reimbursable from the Fund to achieve site stabilization and immediate protection of buman bealth or the environment. Such sparoval may be given following the actual expenditures if immediate actions were necessary to protect human bealth or the environment and Division personnel were unavailable in such a case, the Division must be notified of the actions taken within seveaty-iwo hours.

(d) Following completion of necessary site stabilization acrions as described in (c) of this paragraph, subsequent investigative and corrective actions must be performed by approved contractors and in accordance with the requirements of rule 1200-1-15-.06(2) through rule 1200-1-15-.05(7). Further. prior to initiating any of the corrective actions identified in 1. through S. below, uniess otherwise directed by the Division, the owner or operator must, through the assistance of the selected approved contractor, prepare and submit to the Division a cost proposal for conducting the proposed cortective action. Cost proposais shall be submitred in accordance with a format which shall be esablished by the Division.

1. Preliminary Investigation (Site Check in accordance with rule 1200-1-15-.06(3) through rule $1200-1-15-.05(4))$.

2 Free Produet Removal (in aceordance with rile 1200-i-15-.05(5)).

3. Environmental Assessmeat Plan and Development of Corrective Action Plan (in accordance with rule $1200-1-15-.06(6)$ through rale $1200-1-15-.06(7))$.

4. Implementation of Corrective Action PJan. (This shall include the costs of: finalizing equipment design; purchase of equipment and materials to be dedicated to the site for comretive action; installation and bringing to operational status the contective action system; operation and maintenance costs of corrective action system for the total projected time period in which the corrective action system will be needed to comply with corrective action limits of Chapter 1200-1-15, Appendices 3 and 4).

5. Provision of permanent alternate water supply.

(e) Upon review of a cost proposal for any of the above activities the Division may:

1. Accept the cost proposal and authorize work to be initiated; or

2. Request a modifieation to or clarification of the cost proposal if projected costs are not determined to be reasonable

(I) In addition to the above requirements of (d) and (c) of this paragraph, the owner or operator shall upon submittal of a cost proposal for a site investigation, also submit an estimate of the total cost of remediation for the site which shall be used solely for the purpose of the Board and the Division in projecting future funding requirements for the Fund. The total estimated const of remediation for a site shall be updated by the oumer or operator as recessary and as more complete information regarding a site becomes available. 
(Rule 1200-1-15-.09, continued)

(B) Upon acceptance of a cost proposal by the Division, sufficient monies will be obligated from the Fund for completion of the paricular phase of work for which the cost proposal was submitted and authoriza. tion will be provided for the initiation of the proposed action. Obligation of funds shall be subject to the availability of funds at the time of acceptance of the cost proposal.

(h) Corrective actions performed prior to acceptance of an assuciated cost proposal may not be eligible for reimbursement.

(i) If the cost of completing any of the corrective actions of subparagraph (d) 1. through 5., is expected to exceed the amount of an accepted cost proposal, an amenifed cost proposal must be submitted and accepted to allow additional funds to be obligated.

(i) Any corrective action which is carried out in response to any discharge, release, or threatened release of petroleum from an UST must be conducted in accordance with the requirements of rules 1200-1-15-.06(1) through 1200-1-15-.06(7) and subparagraphs (a) through (d) of this paragraph.

(k) The owner or operator or the selected corrective aetion contractor shall keep and preserve detailed records demonstrating compliance with approved investigative and corrective action plans and all invoices and financial records associated with costs for which reimbursement will be requested. These records shall be kept for at least three years after corrective action has been completed for a site

(1) The selected corsective aetion alternative must be implemented in a manner acceptable to the Division in accordance with an approved plan in order for the owner or operator to be eligible for the reimbursement of costs.

(m) An eligibic owner or operator conducting UST response actions from July 1, 1988 until April 15, 1990, relative to any discharge, release or threatened release of petroleum from an UST, is entived to reimbursement of reasonable costs above entry level from the fund but is exempted from the requirements of subparagraphs (b) through (i) above, provided that corrective actions were carried out in accordance with a plan approved by the Division.

(n) If corrective actions which were initiated during the time period referenced in subparagraph (m) above are still continuing on April 15, 1990, the Division may require submittal of cost proposals for any remaining phases of work and for the total projected cost of the remediation.

(0) If the contractor performing corrective actions as described in subparagraph (n) above is not an approved contszctor, the Division may authorize the continued use of that contractor.

(p) If a contractor is performing corrective action at a site prior tio development of an approved contractor list, the Division may authorize the continued use of that contractor.

(12) Requirements for Fund Coverage of Third Party Claims. An eligible owner or operator is entitled to Fund coverage for third pary ciaims resulting from the release of petroleum from an UST, subjeet to the following provisions:

(a) The Division was notified by the owner or operator upon the receipt of notice of the third parry liability suir;

(b) The ouner or operator was in substantial compliance at the time the release occurred and at the time the third party suit is filed; 
(Rule 1200-1-15-.09, continued)

(c) The third party obtains a final judgment enforceable in Tennessee; and

(d) The final judgment is for an amount greater than the Fund entry level in effeet on the day the release was reported to the Deparment.

(13) Applications for Payment

(a) Applications for reimbursement for costs of corrective actions shall be submitted on a form established by the Division which shall incluce an itemization of all charges according to labor hours and rates, anaiyrieal charges, equipment charges, and other categories which may be identified by the Division, or which the applicant may wish to provide.

(b) The application shall contain the following statement whicin stall be signed by the owner or operator and the project manager of the contracting firm responsible for performance of corrective actions:

I certify to the best of my knowledge and belief: that the costs presented therein represent actual costs incurred in the performance of response actions at ihis site during the period of time indieated on this application; that an accidental release has occurred from a petroleum underground storage tank system at this site; and that no charges are presented 25 part of this application that do not directly relate to the performance of corrective actions related to the release of petroleum at this site

(c) Applications for payments may be submitted following acceptance by the Division of completed corrective actions. Such corrective actions may include but are not limited to the following:

1. Completion of site stabilization activities which were authorized by the Division;

2 Completion and submittal of a report for a Preliminary investigation (site check);

3. Implementation of a Free Product Removal System;

4. Development and submitzal of an Environmental Assessment Plan;

5. Implementation of Environmental Assessment as approved in the Environmental Assessment Plan and Development of Remedial Action Plas;

6. Implemention of Remedial Action Plan; and

7. Provision of an alternate water supply.

(d) Applications for payments for the implementation of corrective action may be subraitted sixty (60) days following initiation of work to implement the corrective action plan and at sixty (60) day intervals thereafter until completion of the authorized activities. Upon request, the Division may approve interim payments at more frequent intervals.

(e) All payment shall be subject to approva: by the Division. Should a site inspecion or other information available to the Division reveal a discrepancy between the work performed and the work addressed by a payment application, the Deparment may deny payment or may require the Fund to be reimbursed. 
(Ruic 1200-1-15-.09, continued)

(I) An application for payment must be received within one year from the date of performanee or acceptance of the work in order to be eligibic for payments from the Fund.

(g) Except for the situations provided for in rules 1200-1-15-.0S'(11)(b) and rule 1200-1-15-.09(11)(1), payment shall not be made for corrective actions performed at a site until the Division has revicwed and accepted a cost proposal for that work and until funds have been obligated from the Fund for completion of that particular stage of work.

(h) For payment of third party claims the UST owner or operator must submit an application to the Division attaching the original or a certified copy of a final judgment (cnforceable in Tennessec) with proof of payment of the applicable financial responsibility requirernent for compensation of third partics as specified in rule $1200-1-15-.09(8)(b)$. This application must be received by the Division no later than thirty (30) days after notification of judgment.

(14) Fund Payment Procedures

(a) Where the owner or operator has submitted an acceptable application for payment for corrective actions or third party claims but has not paid for these activities or claims, payments will be made by a check written to both the eligible owner or operator and the provider of the corrective action scrvices or third party.

(b) Payments from the Fund will be made directly to the eligible: owner or operator in cases where the owner or operator submits documentation verifying the owner or operator has paid in excess of the applicable financial responsibility requirement for taking corrective actions as specificd in rule $1200-1-15-.09(8)(b)$.

(c) The owner or operator is responsible for final payment to the contractor who performed the corrective actions and for payment of judgments to third partics.

(d) Contingent upon availability of funds, the Department shall process all applieations for payment within forty-five (45) days of receipt of application. If all costs are considered to be reasonable and eligible for reimburscment, payment will be issued within the forty-five (45) day period. If certain costs are considered as not being reasonable or cligible for reimbursement, the Department may issuc a check for the amount of the application not in question and provide a fifteen (15) day period in which the owner or operator or contractor may present such information as is necessary to justify the disallowed costs. Following review of such iniormation, the Department may agree to pay the previously disallowed costs, or any portion thereof, or may again disallow the costs for payment.

(15) Approval of Corrective Action Contractors

(a) The Corscctive Action Contractor ("CAC") is the person responsible for conducting and oversccing the corrective action at a petrolcum underground storage tanl: site. There shall be only one CAC fo: each site.

1. The CAC shall be either:

(i) A properly licensed contrator includes general contractors licensed pursunat to T.C.A., Tille 62. Chapler $G$, enginecrs, geologists, and other environmental professionals; or

(ii) An owner or opcrator of the petrolcum underground storage tank(s) which caused the relcase of petroicum to the environment, provided that each contractor'subcontractor working. for the owner or operator must be a properiy licensed contractor pursuant to T.C.A. $\$ 62-6-101$ et seq.

(b) CACs will be approved to perform Fund cligible work upon satisfaction of the following: 
(Rule 1200-1-15-.09, continued)

1. The CAC files a written application to become an Approved Corrective Action Contractor with the Division via certified mail or personal service This application shall be updated annually and include name of CAC, principal(s) of CAC, address(es) of CAC's office, office phone number(s) of CAC, and other information requested by the Division of Underground Storage Tanks.

2. The CAC submits a sworn statement with the written application in part 1., including the following provisions:

(i) The CAC will abide by and comply with the Rules and Regulations of the Department of Finance and Administration, Chapter 0620-3-3, Personal Services and Consultant Services Contracts; $\because$ :

(ii) The CAC will have written contract(s) with all contractors/subcontractors, and contract(s) shall contain provisions that contractors/subcontractors will abide by and comply with the Rules and Regulations of the Department of Finance and Administration, Chapter 06203-3, Personal Services and Consulting Services Contracts. Contract(s) between the CAC and contractors/subcontractors shall also contain provisions that all site workers working under authority of contractors/subcontractors shall have applicable health and safety training when required by the Tennessee Department of Labor,

(iii) Site workers working under authority of the CAC will have the applicable health and safety training when required by the Tennessee Department of Labor;

(iv) The CAC understands that reimbursement from the Fund will be in accordance with the reasonable rate schedule as established by the Department;

(v) If the CAC is not the owner or operator of the tank that caused the release, the CAC will have a written contract with the UST owner and/or operator, and the contract shall contain the following sentence conspicuously located on the first page of the contract:

THE CORRECTIVE ACTION CONTRACTOR WILL/WILL NOT (mark one) USE THE DEPARTMENT'S REASONABLE RATE SCHEDULE WHEN INVOICING THE OWNER OR OPERATOR FOR THE EXPENSES INCURRED IN THE INVESTIGATION AND CLEANUP OF THIS SITE;

(vi) If the CAC is the owner or operator of the tank which caused the release, the CAC will have a written contract with all contractors/subcontractors, and the contract shall contain the following sentence conspicuousiy located on the first page of the contract:

THE CONTRACTOR/SUBCONTRACTOR (mark one) WILL/WILL NOT (mark one) USE THE DEPARTMENT'S REASONABLE RATE SCHEDULE WHEN INVOICING THE OWNER OR OPERATOR FOR THE EXPENSES INCURRED IN THE INVESTIGATION AND CLEANUP OF THIS SITE;

(vii) The CAC's services will be performed in a manner consistent with the level of care and skill ordinarily exercised by members of their profession practicing in the State of Tennessee, under similar conditions, and at the time the services were rendered. The CAC shall not knowingly or willfully cause the spread of contamination nor inhibit corrective action at the site;

(viii) The CAC will gather and maintain documentation and records necessary for filing a claim with the Tennessee Petroleum Underground Storage Tank Fund; 
(Rule 1200-1-15-.09, continued)

(ix) The CAC will, at a minimum, follow Quality Assurance/Quality Control Standard Operating Procedures suppled by the Division, unless altcrnate Quality Assurance/Quality Control is approved in wititing in advance by the Division:

(x) The CAC will assure that the CAC and/or any ptrson the CAC employs or contracts with to engage in the practice of engineering shall be: appropriately licensed/registered under the Tennessee Architects, Engineers, and Landscape Architeets Law (T.C.A. \$62-2-10] et seq.);

(xi) The CAC will assure that any and all work defined as contracting in Tennessee Contrac. tor's License Law (T.CA. \$62-6-101 et seq.) shall be periormed by' a licensed contractor(s) with appropriate ciassification and monetary limitation;

(xii) The CAC will assure that the CAC and/or any person the CAC employs or contracts with to perform professional geologic work shall be appropriately registered under the Tennesse: Geologists Act (T.C.A. \$62-36-101 et seq.); and

(xiii) The CAC will assure that all work done by the CAC had the prior approval of a Registered Professional Engineer or Professional Geologist who is licensed/registered with the Tennessee Department of Commerce and Insurance, and the work was done as specified in chapter $1200-1-15$ and/or according to a plan approved by the Division. The CAC will assure that all plans and repors submitted to the Division were prepared and signed by the Registered Professional Engineer or Professional Geologist who prepared or is responsible for the plan or report. The CAC will further assure that a Registered Professional Engineer or Professional Geologist shall make periodic site visits to verify whether or not the work performed was as specinjed by the Registered Professional Engineer or Professional Geologist, and as specified in chapter 1201)-1-15, and/or according to a plan approved by the Division. The CAC shall require a Registered Professional Engineer or Professional Geologist to submit a signed certification based on their personal observation and review of job site records stating whether or not the work was performed as directed by the Registered Professional Engineer or Professional Geologist, and whether or not the work: has been performed in accordance with chapter $1200-1-15$, and/or a plan approved by the Division. If the work was not performed according to the above specifications, the ceitification shall include a listing of how the work which was performed varies irom chapre: 1200-1-15, the approved pian, and/or the authorization of the Registered Professiona! Engineer or Professional Geologist and the specific reason for each variation. The certification shall be stimitted according to a sehedule and format determined by tine Divisior.

3. The CAC has any applicable license(s) and registration(s) required in the Siate of Tennesses; and

(i) If the CAC is a licensed contractor, the contractor must be properly iicensed with an SUncierground Tank Installers, Removal, and Remediation of Pollutants or other applicabis ciassifieation with a monetary limitation as required under rule $0680-1-.13$ and establishej by the Board for Licensing Contractors of the Tennessee Departmeat of Commerse and Insurance in the amount of at least threc hundred fifty thousand dollars $(\$ 350,000)$. Date of license expiration must be included. The CAC shall submit requirements of this part with the application required in part 1. and must submit documentation of any changes. renewals, renovations. etc. of the CAC's Tennesste license. (There shall be no Fund reimbursement for those expenses which exceed the contractor's monetary limitation.)

(ii) All contractors and their subcontractors and employess shall have other applicable license(s) and registration(s).

4. The C.AC shal! mainiain liability insurance zoveicage of the types and in the amounts desciibet in the Tabie below, o: the equivalent. and shall provide certification io ihe Division of sush coverag: with the appiication described in part 1. and yeasly thereafter. or more freçuently if necessary to kesp the Division updated as to the CAC's evirent insurance coverage. $\rightarrow$

January; 1993 (Revised)

84.2762 
(Rule 1200-1-15-.09, continued) Type of Policy

Worker's Compensation

Employer's Liability

Automobile Liability

General Liability

\author{
Limits of Liability \\ Statutory \\ $\$ 500,000$ \\ $\$ 1,000,000$ combined \\ single limit (bodily \\ injury and properry \\ damages)
}

$\$ 1,000,000$ combined single limit

\section{Description}

All states

All owned, non-owned, and hired vehicles

\author{
Broad Fo:m \\ Comprehensjve General \\ Liability
}

5. The CAC will submit a list of the CAC's employees which will be utilized by the $C A C$ as a par of the assessment and remediation of UST sites in the State of Tennessee This list shall include each employee's job deseription, title, office, location, and telephone number. This information shall be subriitted with the application described in part 1. and annually thereafter.

(c) The Department will provide notice that applieations are to be requested by publication of a legal advertisement which will provide interested firms with the information necessary to request instructions for preparation and submittal of applieations and supporing documentation. Prior to the development of an Approved Corrective Action Contractors list, the Department will contact consuiting firms listed on the unendorsed list titied "Professional Consulting Fims - Engineers and Geologists" to notify consulting firms of the requirements of subparagraph (b) above Applications received within 45 cays of the date of legal adverisement shall be reviewed prior to establishing a list of Approved Corrective Action Contractors. Applications and supporing documentation shall be independently evaluated by members of a review commitree consisting of Division of Underground Storag= Tank staff members according to criteria of subparagraph (b) of this paragraph. Those CAC's satisfactorily meeting the requirements of (b)l. through 5 . above shall be placed on the Department's list of UST Approved Corrective Action Contractors. Once a CAC has been approved they will not be required to requalify except under the provisions of subparagraphs (d). (D), and $(\mathrm{h})$ below.

1. Applications reeeived afte: 45 days from the date of the legal advertisement shall not be reviewed until a list of Approved Corrective Action Contractors is established. These and subsequent applications shall be reviewed by the revisw committee and either added to ine list of Approved CACs or denied Approved CAC status within 90 days of reseipt of the completed application with supporting documentation, or establishment of the Approved CAC lisi, whichever is later.

2. If the reriew committee does not approve a CAC and does not place the CAC on the list of Approved CACs. the decision of the review committee may be appealed to the Board.

3. CAC's who previousiy submitted applications but did not meet requirements of (b)l. through 5. of this paragraph may submit a subsequent applieation for teview at such time they feel that the recuirements of (b)l. through S. may have been met.

(d) A CAC will be removed from the Division's Approved CAC list when it has been determined that the C.AC has failed to satisiactorily maintain the requirements of subparagraph (b) above or has commitred one or more of the violations listed in subparagraph (c) belo:..

1. The removal process shali be initiated when a compliant is refe:red to the Division's review. committee.

2. The seview committee shall inform the CAC via certiried mail of receipt of a compiaint. 
(Rule 1200-1-15-.09, continued)

3. The Division's review committee may request the CAC to appear at a meeting to show cause why the Deparment should not remove the CAC from the list of Approved CACs.

4. The CAC may request a meeting with the review conmittee

5. The review committee shall notify the CAC of its decision via certified mail a minimum of thirty (30) days after dispatch of the certified letter reierenced in part 1. above.

6. If the review committee decides to remove the CAC from the list of Approved CACs, removal shall be effective sixty (60) days after dispatch to the lasi known address on file with the Division unless:

(i) the CAC corrects the non-compliance to the satisiaction of the review committee during the sixty (60) day period; or

(ii) the CAC Illes a written appeal with the Division within the sixty (60) day period requesting a hearing to appeal the decision of the review committee to the Board.

7. The filing of an appeal will postpone actions to remove a CAC from the list of Approved CACs until the appeal is heard by the Board.

8. Once the review committee has dispatched a Nocice of Removal to a CAC via certified mail, the Division will approve no additional plans, scopes of work, or cost proposals if such approval will cause Division personnel to violate T.C.A. \$62-6-120(c)(1).

9. If an appeal is not filed during the sixty (60) day period, the decision of the review commitree will be final.

10. A CAC removed from the Approved CAC list may reapply for approval as provided for in subparts (i) or (ii) below:

(i) A CAC who was removed from the Approved CAC list due to failure to satistactorily maintain the requirements of (b) above may reapply under subparagraphs (b) and (c) above once the requirements of subparagraph (b) have been met.

(ii) A CAC who kas removed from the Approved $C A_{1} C$ list due to one or more of the violations listed in (e) below may reappiy after one (1) yea:. The CAC must submit evijence showing the reasons why the CAC should be reinstated for evaluation by the review committee The CAC must reapply under the provisions of paragraph (15). subparagrapins (b) anc (c) of this rule

(e) A CAC may be removed from the list of approved Corrective Action Contractors if it is de:ermined by a review committee consisting of Division staff memebers that the CAC has done any of the following:

1. The CAC charged the state or swner/operator for work which was not performec:

2. The CAC filed false information with the Department;

3. The CAC nas been found guilty of violating any of the following or a comparable law in another jurisdiction;

(i) T.C.A. $\$ 39-16-503$

(ii) T.C.A. $\$ 39-16-504$

(iii) T.C.A. $\$ 39-14-130$

(iv) T.C.A. $\$ 39-14-114$

(v) T.C.A. \$39-1\$-104

(vi) T.C.A. $\$ 39-14-103$
Tampering with or fabrica:ing evidence;

Destruction of and tampering with governmenial resords; Destruetion of valuable pape:s witi intent to ce?:aud; Forgery;

Thef: of services, or

Thefl of p:operiy. 84.27 .71 


\section{C-96}

UNDERGROUND STORAGE TANK PROGRAN

CHAPTER $1200-1-15$

(Ruie 1200-1-15-.09, continued)

4. The CACs or an employes(s), prineipal(s), or oilicer(s) of the CAC is found to have engaed in the unautorized practice of engineering, contracting, or geology under T.C.A. $\$ \$ 62-2-101$ et seq. 62-6-10l et seq., and 62-36-101 el seg., or a comparable law in another jurisdiction by the appropriate regulatory agencs or cour.

5. Due to the quality of work performed by the CAC, the CAC has sigaificantly delayed or inhibited progress in achieving appropriate corrective action at a site(s). This shall include but shall not be limited to, the following:

(i) The CAC periorms a non-approved action which spreads contamination in the environment;

(ii) The CAC niles a pian (ẹ. Environmental Assessment Plan. Corrective Action Plan, etc) which is rejected by the Division as deñcient, followed by three subsequent revisions, each of which is rejected by the Division as deficiens; or

(iii) The CAC fails to supply recommendations for further assessment, remediation, site speciñic cleanup standards, site closure, or other conclusions supported by the following:

(I) The physical and chemical characteristics of petroleum, including its toxicity, persistence, and porential for migration;

(II) The hydrogeologic characteristies of the petroleum site and the surrounding land;

(III) The proximity, quality, and current and future uses of groundwater;

(IV) An exposure essessment;

(V) The proximity; quality; and eurrent and furure uses of su:face waters;

(VI) Applieable regulations in chapter 1200-1-15; and

(VII) The magnitude and extent of petroleum contamination at the pe:roieum site and the surrounding land.

(iv) The CAC supplies recommendations for further assessmen:, temediatior., site spesific cleanup sianciarcs, site closure or other conclusions noi supposted by items (1) through (VII) listed in subpan (iii) of this part.

6. The C.AC filed pian(s) or report(s) which do not bear the appropriate signature and Tennessee iicense/registration numiser of a Registered Professional Engineer or Proiessional Geologisi.

7. The CAC performed work which did not have the prior approval of a Registered Professional Engineer or Professional Geologist who is licensed/registered with the Tennessee Department of Commerce and lnsurance.

8. The CAC has deviated from an approved plan or scope of work as approved without ihe approva! of the Division. This includes. but is not limited to. the following:

(i) Failure to foliow Quality: Assurance and Quality Control approved in the plan, o:

(ii) Failure to follow tine schedule for implementation approved is the plan.

9. The CAC has fajled to follow Quality Assurance/Quality Conirol (QA/QC) suppiied by ihe Division witiout naving alisinate QA'QC approved in advance in writms by the Divisior.

10. The CAC has failed to iollow LST iegulations promulgated in chapte: i200-1-15. 
(Rule 1200-1-15-.09, con:inued)

11. The CAC failed to have a Registered Professional Engineer or Professional Geologist file a siened certification according to a schedule and format required by the Division. Said certification shall be based on the Registered Professional Engineer's or Professional Geologist's personal observation and review of job size records. The certification shall state whether or not the work was performed as directed by a Registered Professional Enginter or Professional Geologist, and whether or not the work has been performed in accordance with chapter 1200-1-15, and/or a plan approval by the Division. The certification shall include a listing of how the work performed varies from chapter 1200-1-15, the approved plan, and/or the work approved of the Registered Professional Engineer or Proiessional Geologist and the specific teason for each variation.

12. The CAC has failed to annually submit an updated application or a list of the CAC's employees who will be utilized by the CAC as a part of the assessment and remediation of the UST site in the State of Tennessee, ineluaing each employee's name, title job deseription, office, location, and teiephone number.

(f) No CAC shall be placed on the Approved Corrective Action Contractors list if the CAC is on a list of contrectors banned from usage on federally funded projects. If a CAC on the Approved Corrective Action Contractors list is placed on the list of contractors banned from usage on federally funded projects, that CAC will be removed from the Approved Corrective Action Contractors list. When the $C A C$ is removed from the list of contractors banned from usage on federally funded projects, the CAC may apply to be added to the Approved Corrective Action Contractors list according to procedures outlined in subparagraphs (b) and (c) of this paragraph. A CAC on a list of contractors banned from usage on federally funded projects can not work as a subcontractor to an Approved Corrective Action Contractor.

(g) The appearance of a CAC on the Division's list of Approved Correcive Action Contractors shall in no way establish liability or responsibility on the part of the Division, the Fund, or the State of Tennessee in regards to the services provided by the CAC or circumstances which may occur as a result of such services.

(h) An owner or operator may perform corrective actions for reitases of petroleum from USTs he owns or operates provided that he submits an application with docunentation as described in subparag:aphs (b) and (c) and the application is approved by the Division. The owner or operator may use qualiiiseations of subcontractor(s) in addition to qualifications of the owner or operator in applying for Approved Corrective Action Constructor status. If an owner o: operator uses a subsontractor(s) in qualifying for an Approved Correcive Action Coniracior classification and there is a change of a subcontractor whose qualifications were used in the application or documentation, then the owner or opezator must notify the Division; the owner or operator shall be removed from Approved Corrective Action Contractor status. The ouner or operator must submit a new application with documentation anc be approved as aiscussed in subparagiapins (b) and (e) to continue work as an Approved Correstive Action Cont:acto:

(i) A CAC working as a subcontractor unce: contrac: to an Approved $C A C$ is not required to be classiriec as an Approved C.AC. The subeontractor must mantain ali applicable license(s) and/or registration(s) required in the State of Tennessee fo: work performed.

(16) Insufficient Funds

(a) Nothing in these regulations shall establish liability or responsibility on the part of the Commissione: or state of Jennessee to pay any corrective astuon costs or thitc party judgments from any othe: source than the Fund. no: shall the Commissioner or state of Tennessee have any liability or responsibility to make any payments for corrective ac:ion sosts or third party judgments if the Fund is insurficient to cंo so. 
(Rule 1200-1-15-.09. continued)

(b) In the event the Fund is insufficient to make full payments for eligible UST ouners or operators taking iniestigative or coirective actions or for satisfaction of third party judgmen:s, at the time the claim is filed, such claims shall be paid in accordance with the provisions described in rule $1200-1-15-.09(10)(b)$ and (c).

(c) The owner of an LST retains responsibility for any liability that cannot be satisfied by the provisions of this rule.

(d) Within 30 days after receipt of notifieation that the fund has become incapable of paying for assured corrective action or third pany compensation costs. the ourner or operator must obtain alternate innancial assurance.

(17) Recovery of Cosis by State - Apportionment of Liability.

(a) Making use of any and all appropriate existing state legal remedies, the Commissioner may commence court action to recover the amount expended by the state from any and all responsible parties for each site investigated, identified, contained or cleaned up, including up to the limits of innancial responsibility for owners and/or operators of petroleum underground storage tanks covered by the fund and the entire amount from owners and/or operators of petroleum underground storage tanks not covered by the fund.

(b) In any action under this rule no responsible party shall be liable for more than that pary's 2pportioned share of the amount expended by the state for such site. The responsible party has the burden of proving his apporioned share Such apporioned share shall be based soiely on the liable party's portion of the total volume of the petroleum at the petroleum site at the time of action under this chapte:. Any expenditures required by the provisions of this chapter made by a responsible party (before or after suit) shall be credited toward any such apportioned share.

(c) In no event shall the total moneys recovered from the responsible party or parties exceed the total expenciure by the state for eacin site

(d) Any party found liable for any costs or expenditures recoverable under this ciapter who establishes by a preponderance of evicence that only a portion of such costs or expenditures are attributable to his o: her actions shall be reouired to pay only for such portion.

(e) If tise trier of the iact finds evidence insufficient to establish such parry's portion oi costs or expenditures in such a cost recovery, the court shall apportion such costs or expenditures among the deiendants, to the extent practicable, according to equitable principles.

(IS; Failure to Take Proper Action

Any responsible pariy who fails withou: suffisient cause to properly previde for remova! of petroleum o: remedial action upon order of the cormissione: pursuant to this chapter may be liable to the state for a penal!y in an emount eọtal to one hunded fify percent (150\%) of the amount of any costs incurred by the siaie as a result of steh failure to taie proper action. The Commissioner may recoves this peraly: in 2r. 2s::0r: zommenced incer :C.A. $\$ 68-5 j-115$, rule 1200-1-15-.09(i7), or in a scparate civil actios.

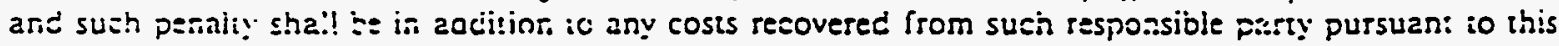
chapis:.

(19) Severability: li any paragraph, subparagraph, part, subpart, item or subitem of this rule is acjudged uncons:ituitiona! or invalic oy a coct: of competent jurisdiction. the remainder of this ruie sinall no: be a:festes ins:eo::

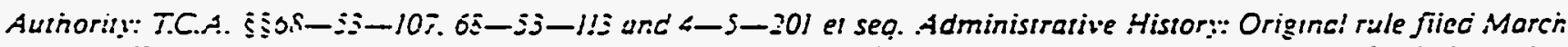

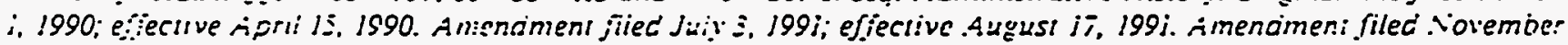
2:. 1992: ejjecture Jonuary 9, 199: 


\section{0-1-15-.10 FEE COLLECIION AND CERTHFICATION ISSUANCE REGULATIONS.}

(1) Purpose - The purpose of this rale is to establish a system and schedule for collection of underground storage tank fees.

(2) Applicability - Requirements of this rule apply to the followinis persons:

(a) All ormers/operators of petroleum underground storage tanks reported under the requirenents of T.CA. 568-53-101 et seq. as follows:

1. All petroleum underground storage tanks that are actively storing petroleum;

2. All petroleum underground storage tanks that are repoited as in service on July 1 of the current year; and

3. All petroleum underground storage tanks taken temporarily out of service after June 30, 1988 and have not been properiy closed.

(b) Rule 1200-1-15-.10 becomes effective July 1, 1990.

\section{(3) Annual Petroleum Underground Storage Tank Fees}

(a) Any person required to pay a fee under this rule sball subrut the fee in the specintied amount, with checks made payable to the Department of Health and Environment/Underground Storage Tank Division for deposit in the State Treasury.

(b) Any person who is an owner of a petroleum underground storage tank subject to annual fees shall pay the required asnual fee uniess a notarized agreement signed by the owner and the operator of petroleum underground storage tanks stipuiates that the operator shall pay the annual fee. A new agreement must be submitted annually if the operator is to pay the annual fee.

(c) The fee sehedule provided in this rule shall be based upon the annual financial requirement to operate the petroleur underground storage tank program established pursuant to T.CA. \$68-53-10I et seq.

(d) The amount of the annual petroleum underground storage tiunk fee shall be one hundred twenty-five dollars (S125) per tank.

(e) The amount of the anoual administrative service fee for agencies and funcions of the U.S. Government having sovereign immunity shall be twenty five dollars (525) per tank. Agencies and functions of the U.S. Government are not eligible for benefit or financial assistance from the Tennesser Petroleum Underground Storage Tank Fund.

(f) Any owner or operator who pays an annual fee on an existing underground storage tank which is subsequently permanently closed in accordance with rule 1200-1-15-.07(2) and replaced by a new underground storge tank installed at the same site in acconiance with rule $1200-1-15-.02(1)$ and $1200-1-15-.02(3)$ will not be required to pay an additional annual fec

(B) Payment of the entire amount of the annual fee is required tor underground storage tanks in service or temporarily out of service during any portion of the currtint billing year. Tanks placed into service after the current billing year begins or tanks which are permanently closed before the current billing year ends are not due a refund of the annual fee or any purcion thereof.

(4) Use of the Fee

(a) The annual petroleum underground storage tank fes shall be cleposited into the Petroleum Underguound Storage Tank Fund and shall be used as specified in the Termessee Petroleum Underground Storage Tank Act. The use of the fund ineludes but is not linited :0:

1. Provide a mechanism to assist with the financial respossibility requirements for ouners and/or operators of petroleum underground storage tanks, including cleanup of contamination and third party claims due to bodily injury and/or property damage caused by leaking petroleum underground storge tanks. 
(Rule 1200-1-15-10, continued)

(i) The fund shall provide for cleanup of contamination caused by leaking petroleum underground storage tanks whose owrers and or operators bave paid the required perroleum underground storage tank fee. The fund shall be responsible for cleanup costs above the entry level to the fund in an amount not to exceed one million dollars $(\$ 1,000,000)$. The initial owner and/or operator financial responsibility requirement for clean-up (eaking corrective aecions) is specified in rule $1200-1-15-.09(8)(b)$.

(ii) The fund shall provide coverage for third-party claims involving bodily injury and/or property damage caused by leaking petroleum underground storage taniks whose orners and/or operators heve paid the required petroleum underground storage tank fee The fund shall be responsible for cour awards involving third party claims above the entry level into the fund in an amount not to exceed one million dollars $(\$ 1,000,000)$. The initial owner and/or operator financial responsibility requirements for third party claims involving bodily injury or property damage is specified in sule 1200-1-15-.09(8)(b).

2. Provide for administrative costs of implementation of the Petroleum Underground Storage Tank Program.

\section{(5) Failure to Pay the Annual Petroleum Underground Storoge Tonk Fee}

(a) Any petroleum underground storage tank owner/operator who fails to pay the lawfully levied petroleurs underground storage tank fee will be assessed a monthly penalty of 5 percent (5\%) of the amoun:. Such pensity shall be assessed monthly until the fee and all associated penalties are paid. The monthiy penalty may be waived by the Commissioner upon receipt of documentation justifyias late fee payment.

(b) The Deparment shall not issue a petroleum underground storage tank cerificate to any facility where the owner/operator has failed to pay the lawfully levied petroleum underground storage tank feer. To refuse or fail to pay the Department the annual fee per tank is an unlawful action as described in T.CA. $868-53-10 .(3)$.

(c) The Deperment shall revoke the perroleum underground storage tank certificate for any facility for which the owroer/operator has failed to pay the lawfully levied petroleuro underground storage tank fee(s). Should an owreer/operator fail to pay the annual fee(s), following 15 days from the receipt of writren notice that the Deparment intends to remove the cerificate a Division representative may remove the certificate from a facility.

(d) Upon failure or refusal of an owner and/or operator of a petroleum underground storage tank, subject to fees by regul=:ion, to pay a fee lewfully levied within a reasonable time allowed by the Commis. siones, the Commissioner may proced in the Chancery Cour of Davidson County to obtain judg. ment and seck exesution of such judgment.

\section{(6) Peiroleum Underground Storge Tank Annual Fee Notices}

(a) Prior to the due date of the ennual underground storage tank fee, the Division shall issue fee notices to the owner/operator oi the petroleim underground storage tanks. Fee notices and due dates shall $b$ staggered using the three grand divisions of the state of Tennessee

1. Tank fees for underground storage tanks in the following East Tennessee counties shall be due on July 31 of each year.

Johnson, Sullivan, Carter, Washington, Unicoi, Haneock, Hawbias, Greene, Claiborme, Grainger, Hamblen, Cocke, Seoth, Campbell, Union, Anderson, Knox, Jefferson, Sevier, Morgan, Roane, Loudon, Blourt, Bledsoe, Rhea, Meias, MeMino, Moaroe, Gnundy, Sequatehie, Fiamillon, Bradles; Polk, Franklin, and Marion. 
(Rule 1200-1-15-.10, continued)

2. Tank fees for underground storage tanks in the folloring Middle Tennessee counties shall be due October 31 of each year:

Stewar, Montgomery, Roberson, Sumner, Macon, Clay;, Piekett, Houston, Hickman, Cheatham, Davidson, Wilson, Trousdale, Smith, Jackson, Overton, Fentress, Putnam, Cumberland, White, DeKalb, Van Buren, Warren, Cannon, Rutherford, Williamson, Dickson, Humphreys, Pern;: Wayne, Lewis, Lawrence, Maury, Giles, Marshall, Lincoln, Moore, Bedford, and Coffee

3. Tank fees for underground storage tanks in the following West Tennessee counties shall be due January 31 of each year:

Lake, Obion, Wealley, Fiesry, Dyer, Croskett, Gibson, Carroll, Benton, Lauderdale, Tipton, Shelby, Haywood, Fayette, Madison, Hardeman, Henderson, Chester, MeNairy, Decatur, and Hardin.

(b) The owner/operator of petroleum underground storage tanks shall pay the annual fee on or before the due date

(c) Any owner who brings an underground storage tank systeml into use after July 1, 1989, must submit the eurrent year's tank fee with the required notice of existince of such tank system required in rule $1200-1-15-.02(3)(\mathrm{a})$.

\section{(7) Ișuance of Annual Petroleum Underground Storage Tank Facility Cerififcotes}

(a) The Division shall issue petroleum underground storage tank facility cerrificates annually. The certificate will contain the facility identification number, addrets, number of underground storage tanks, and the size of said zanks. The color of the certificate will be changed annually in order to assist persons delivering petroleum in determining if the underground storage tank facility has a current certificate

(b) Cerificate issuance shall be staggered using the three grand divisions of the state of Tennessea Certificates shall be issued as follow's:

1. Petroleum underground storage tank facility cerrificates for East Tennessee shall be issued in the month of September to ouner/operators for petroleum underground storage tanks in the following counies:

Johnson, Sullivan, Carter, Washington, Unicoi, Hancock, Hawkins, Greene, Claiborne, Grainger, Hambler, Cocke, Scott, Campbell, Union, Anderson, Knox, Jefíerson, Sevier, Morgan, Roane, Loudon, Blount, Bledsoe, Rhea, Meigs, McMinn, Monroe, Grundy, Sequatchie, Hamilton, Bradle;; Polk, Franklin, and Marion.

The annual cerificate shall be effective for one year, staring October 1 of the year to September 30 of the following y'ear.

2. Petroleum underground storage tank facility certificates for Middle Tennessee shall be issued in the month of December to owner/operators for peuroleurn underground storage tanks in the following counties:

Steurar, Montgomery, Roberson, Sumner, Macon, Clay, Picketh, Houston, Hiciuman, Cheatham, Davidson, Wilson, Trousdale, Smith, Jackson, Overton, Fentress, Putnam, Cumberland, White, DeKalb, Van Buren, Warren, Cannon, Rutheriord, Williamson, Dickson, Humphress, Perry;, Wayne, Lexis, Lak'rence, Maury; Giles, Marshall, Lincoln, Moore, Bedford, and Coffee

The annual cerificate shall be effective for one year, staring January 1 of the year to December 31 of the same year. 
(Rule 1200-1-15-10, continued)

3. Petroleum underground storage tank facility certifieates for Wiest Tennessee shall be issued in the month of March to owner/operators for petroleum underground storage tanks in the following counties:

Lake, Obion, Weakley, Feary, Dyer, Crocket, Gibson, Carrol, Benton, Lauderdale, Tipton, Shelby, Haywood, Fayette, Madison, Fardeman, Fenderson, Chester, McNairy, Decatur, and Hardin.

The annual certificate shall be effective for one year, starting April 1 of the year to March 31 of the following yes.

(8) Uniowful Action

It shall be unlawful to put petroleum into underground storage tanks at a facility without a curreat petroleum underground storage tant facility certificate This is a violation for the person putting petroleum into the underground storage tank as well as for the person having product put into the underground storage tank.

(9) Removal of Certificates

The Division may remove the petroleum underground storage tank facility certificate from a facility if the ornet/operator violates the provisions of T.CA. \$68-53-101 et seq. or any regulations promulgated subsequent to this Act. Such removal must be authorized through issuance of a Commissioner's Order due to violations of the Act or regulations. The Orner/operator may appeal the Commissioner's Order to the Board.

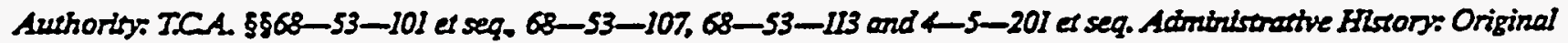
rule filed March 1, 1990; effective April 15, 1990. Amendment filed July 3, 1991; effective August 17, 1991. 


\section{0-1-15-11 UNDERGROUND STORAGE IANI PROGRAM.}

(1) Purpose The purpose of this sule is to establish a system and schedule whereby certain fees shall be levied by the Fetroleum Underground Storage Tank Board and collected by the Commissioner. Expenditures of such fees collected shall be restrieted to operation of the Perrolevm Underground Storage Tratk Program established pursuant to T.C.A. \$68-53-101 et. seq.

(2) Applicability. Requirements of this rule apply to the following pirsons:

(a) All owners/operators of petroleum underground storage tanks iepored under the requirements of T.CAA. \$68-53-101 et. seq. as follows:

1. All petroleum underground storage tanks that are aetively storing petroleum;

2. All petroleum underground storage tanis that are repisrted as in service on July 1, 1989; and

3. All petroleum underground storage tanks taken temporanily out of service after June 30, 1988 and have not been properiy closed.

(b) Rule 1200-1-15-.11 shall be effective December 8, 1989 through June 30, 1990.

(3) Annual Petroleum Underground Storage Tank Fees

(a) Any person required to pay 2 fee under this rule shall subwit the fee in the specified amount, with checks made payable to the Department of Health and Environment Underground Storage Tank Division for deposit in the State Treasury.

(b) Any person who is an owner of a petroleum underground storage tank subject to annual fees shall pay the required annual fee uniess a notarized agreement signed by the owner and the operator of peroleum underground storage tanks stipulates that the operator shall pay the annual fee. A new agreement must be submitted annually if the operator is to pay the annual fee

(c) The amount of the annual petroleum underground storage tarik fee shall be one hundred dollars (S10) per tank for the July 1, 1989 to June 30, 1990 fiscal year.

(d) The amount of the anoual administrative service fee for ageiacies and functions of the United States Goverameat baving sovereigo immunity shall be twenty five dollars $(525.00)$ per tank for the July 1 , 1989 to June 30, 1990 fiscal year. Agencies and functions of the United States Government are Dot eligible for benefit or financial assistance from the Tennessee Petroleum Underground Storage Tank Fund.

(4) Use of the Fee The petroleum underground storage tank fees shall be deposited into the Petroleum Underground Storage Tank Fund and shall be used as specified in the Tennessee Petroleum Underground Storage Tank Act

The use of the fund includes, but is not limited to the following:

(a) The fund shall provide for cleanup of contamination caused by leaking petroleum underground storage tanks whose owners and/or operators bave paid the required petroleum underground storage tank fee The fund shall be responsible for cleanup costs above the entry ievel to the fund in an amount not to ceeed one million dollars $(51,000,000)$. For the period between July 1, 1989 and April 30, 1990, the initial owner and/or operator financial responsibility requirements for cleanup shall be fifty thousand dollars $(\$ 50,000)$. The fund stall be responsible for cheanup of contamination due to leaking petroleum underground storage tanks on a per site per oceurence basis. 
(Rule 1200-1-15-.11, continued)

(b) The fund shall provide coverage for thind-party claims irvolving bodily injury and/or property demage caused by leaking petroleum underground storege tariks whose owners and/or operators have paid the required petroleum underground storage tank fee. The fund shall be responsible for court awards involving third party claims above the entry level into the fund in an amount nos to exeed one million dollars $(\$ 1,000,000)$. For the period between July 1, 1989 and April 30, 1990, the initial owner and or operator financial responsibility requiremeat for thire party claims involving bojily injury or property damage shall be one hundred fifty thousand dollars $(\$ 150,000)$. The fund shall be responsible for th:e party claims involving bodily injury and/or property damage caused by leaking petroleum underground storage tanks on a per site per ocoursence brsis.

(5) Failure to Pay the Annual Petroleum Underground Storage Tank Fee

(a) Any petroleum underground storage tani owner or operator who fails to pay the lawfully leviod petroleum underground storage teak fee on or before the due date shall be essessed a monthly peasity of 5 percent of the amount due, which shall acerue on the first day of delinquency and be added thereta Thereafter, on the last day of each month during which any part of any fec or any prior acerued penalty remains unpaid, an additional 5 percent $(5 \%)$ of the then unpaid balance shall acerue and be added thereto.

(b) The commissioner may proced with action described in the Tensessee Petroleum Underground Storage Tank Act for failure to pay the lawfully levied petroleum underground storage tank fee

(ด) Petroleum Underground Storage Tank Annual Fee Notices

(a) Prior to the due date of the annual petroleum underground storage tank fee the Division shall issue fee rotices to the orners/operators of petroleum underground srorage tanks. Fee notices and due dates shall be staggered using the three grand divisions of the State of Tenoessee

1. Tank fees for underground stoiage tanks located in the following East Tennessee counties shall be due Decermber 31, 1989:

Johnson, Sullivan, Carter, Washington, Unicoi, Hancock, Hawlins, Greene, Claiborne, Grainger, Hamblen, Cocke, Seoth, Campbell, Union, Anderson, Knox, Jefferson, Sevier, Morgen, Roane, Loudon, Blount, Bledsoe, Rber, Meigs, MoMinn, Monroe, Grundy, Sequarchie, Hamilon, Bradley, Polk, Franklin, and Marion.

2. Tank fees for underground storage tanks located in the following Middie Tennessee counties shall be due December 31, 1989:

Stewarh, Montgomery, Roberison, Sumner, Macon, Clay, Picketh, Houston, Hickman, Chearbam, Davidson, Wiison, Trousdale, Smith, Jackson, Overnon. Fentress, Putnam, Cumberland, White, DeKalb, Van Buren, Warren, Cannon, Rutherford, Williamson, Dickson, Humphreys, Perry, Wayne, Lewis, Lawrence, Maury, Giles, Marshall, Liocoln, Moore Bedford, and Coffec

3. Tank fees for underground storage tanks located in the following West Tennessee counties shall be due March 31, 1990:

Lake, Obion, Weakley, Heary, Dyer, Crocker, Gibson, Carroll, Benton, Lauderdaj, Tipton, Shelby, Haywood, Fayette, Madison, Hardeman, Henderson, Chester, MeNairy, Decatur, and Hardin. 
(Rule 1200_l-15-11, continued)

(b) Any owner who brings an underground storage tank system into use after July 1, 1989 shall submit the current year's undergenound storage tank fee with the relguired notice of existence of such tank system(s) required in T.CA. $\$ 68-53-105(4)$.

(7) Unlapful Action. It shall be unlawful to put petroleum into underground storage tanks at a facility vitbout a cursent petroleur underground storage tank facility cerificate This is a violation for the person pu:ting petroleur into the underground storage tank as well as for the person having product put into the underground storage tank.

(8) Removal of Certificates. The Division may remove the petroleum underground storage tank facility certifieate from a facility if the orner/operator violates the provisions of T.C.A. \$68-53-101 et. seq. or any regulations promulgated subsequent to this Aet. Such removal must be aurhorized through issuanes of a Commissioner's Order due to violations of the Aet or regulations. The orrner/operator may appeal the Commissioner's Order to the Board.

Authortty: T.CA. \$\$68-53-101 et seg., 68-53-107, 68-53-113 and 4-5-201 et. seq. Administrative Hilrory: Original rule filed October 24, 1989; effective December 8, 1989. Amendment filud December 19, 1989; effective Februar" 2, 1990. Amendment filed July 3, 1991; effective Augurt 17, 1991.

Tennessee Department of Environment and Conservation. Authorization No. 327437, 2,500 copies. This public document was promulgated at $\bar{c}$ cost of $\$ 1.96$ per copy. March 1993. 


\section{APPENDIX D}

OAK RIDGE Y-12 PLANT

UNDERGROUND STORAGE TANK OPERATIONAL PROCEDURE 


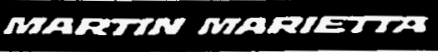

Martin Marietta Energy Systems, Inc. Oak Ridge, Y-12 Plant Command Media
Number: Y10-35-MM-013

Date: $03 / 10 / 94$

Supersedes: New

Fage: 1 of 24

Facilities Management

Materials Management Department

Administrative

Subject:

Fuel Stations, 9754-3 and Transportation Safeguard Division (TSD): Requirements

Approvals:
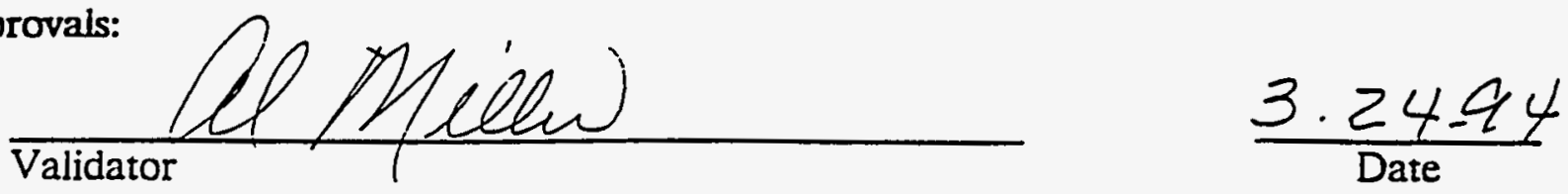

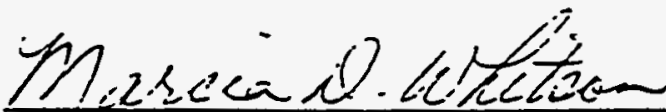

Subject Matter Expert

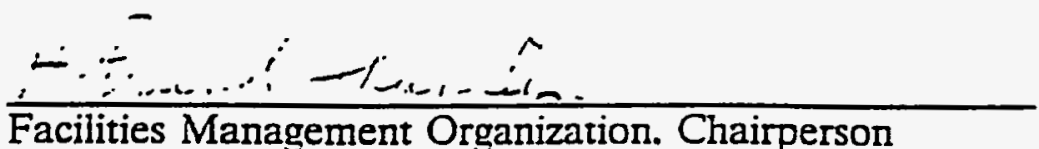

Facilities Management Organization. Chairperson

Procedures Contiguration Control Board

Y.R.Tanhor

Manager. Materiais Management Department

Support Approvals:

S. E. Bohmen

Representative. Environmental Management Department

Health, Safety, Environmental and Accountability Organization

Z272. Can

General Supervisor, Transportation Safeguard Division $\frac{3-21-94}{\text { Date }}$

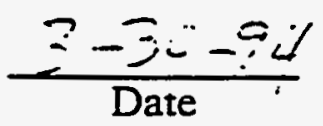

$\frac{3-30-94}{\text { Date }}$

This procedure has been reviewed by an luthorzed Denvatıve Classilier and has been Ietermined to be UNCLASSIFIED. This :e does not constitute clearance for

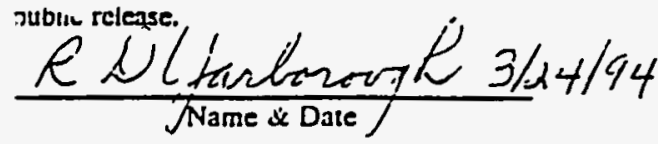

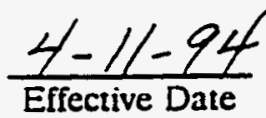


Y10-35-MM-013 Date: 03/10/94 Supersedes: New Page: 2 of 24

Subject: Fuel Stations, 9754-3 and Transportation Safeguard Division (TSD): Requirements

\section{CONTENTS}

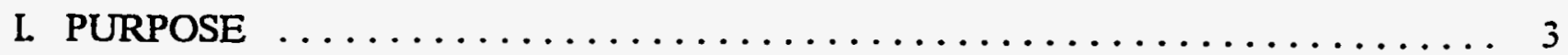

II. REQUIREMENTS REFERENCES $\ldots \ldots \ldots \ldots \ldots \ldots \ldots \ldots \ldots \ldots \ldots \ldots \ldots$

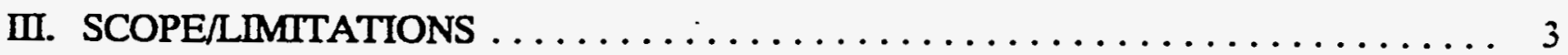

IV. DEFINTTIONS $\ldots \ldots \ldots \ldots \ldots \ldots \ldots \ldots \ldots \ldots \ldots \ldots \ldots \ldots \ldots \ldots \ldots \ldots \ldots$

V. GENERAL INFORMATION $\ldots \ldots \ldots \ldots \ldots \ldots \ldots \ldots \ldots \ldots \ldots \ldots \ldots \ldots \ldots \ldots$

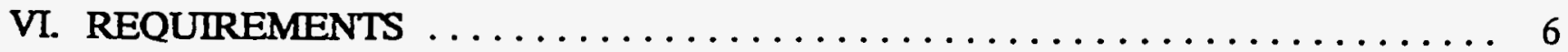

A. General ...................................... 6

B. Documentation .................................. 6

C. Safety ................................. 8

D. Leak Testing (Weekly and Annual Requirements) ................ 9

E. Emergency/Alarms and Notifications ...................... 9

VII. RESPONSIBILITIES . . ............................. 10

A. Materials Management Supervisor . ...................... 10

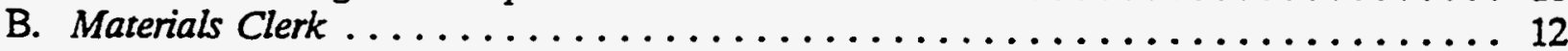

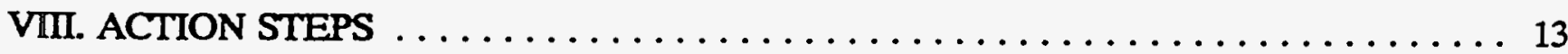

IX REQUIRED RECORDS $\ldots \ldots \ldots \ldots \ldots \ldots \ldots \ldots \ldots \ldots \ldots \ldots \ldots \ldots \ldots \ldots$

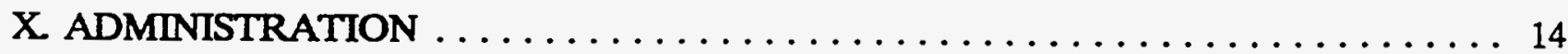

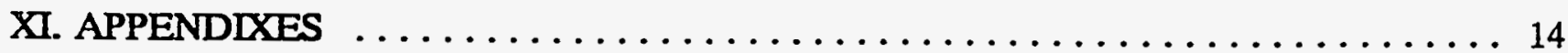

A. Fuel Station Daily Inventory Record for Facility _ . . . . . . . . . . 15

B. Y-12 Plant Fuel Station: Vehicle Fuel Log (Ethanol 11-030-1125) .......... 17

C. Y-12 Plant Fuel Station: Heavy-Equipment Fuel Log (Ethanol 11-030-1125) . . . . 18

D. Y-12 Plant Fuel Station: Vehicle Fuel Log (Diesel 11-025-0900) . . . . . . . . . 19

E. Fuel Station Receipt Form and Steps for Printing Delivery Report ........... 20

F. In-Tank Leak Detection Status and Operating Steps to Perform In-Tank Leak Test . . 21

G. Warmings and Alarms Chart ............................ 23 
D-5

Y10-35-MM-013 Date: 03/10/94 Supersedes: New Page: 3 of 24

Subject: Fuel Stations, 9754-3 and Transportation Safeguard Division (TSD): Requirements

I. PURPOSE

To establish the responsibilities, safety guidelines, and operating instructions for the safe and efficient operation of the Y-12 Plant Fuel Stations located at Building 9754-3 and TSD.

\section{REQUIREMENTS REFERENCES}

A. Flowdown Documents

1. Y-12 Plant Emergency Procedure 40-007: Reporting of and Responding to On-Site Hazardous Material Releases

2. Y-12 Plant Health and Safety Procedure 70-208: Hazard Communication

B. Other Documents Needed

1. Martin Marietta Energy Systems, Inc., Stores Operating Manual

2. State of Tennessee, Tennessee Petroleum Underground Storage Tank Act, T.C.A. 68-215-101, et. seq.

\section{SCOPE/LIMITATIONS}

Applies to all Materials Management Department personnel responsible for the safe and efficient operation and/or supervision of the Y-12 Plant Fuel Stations located at Building 9754-3 and TSD.

\section{DEFINITIONS}

A. Abbreviations: Displayed on reader of Veeder-Root (V-R) TLS-350 and TLS-250 Tank-Monitoring Systems:

C\#: "2 Wire C.L." (Type A) followed by its number

I\#: "External Input" followed by its number

L\#: "Liquid Sensor" followed by its number

P\#: "Pipeline" followed by the specific line number

T\#: "Tank" followed by the specific tank number 
D-6

Y10-35-MM-013 Date: 03/10/94 Supersedes: New Page: 4 of 24

Subject: Fuel Stations, 9754-3 and Transportation Safeguard Division (TSD): Requirements

\section{DEFINITIONS (Cont.)}

B. Alarms: The V-R TLS-350 Tank-Monitoring Systems displaying and sounding four alarms: (1) audible alarm in the monitor, (2) visual alarm on the monitor,(3) audible alarm mounted above the monitor, and (4) a visual alarm located on a pole northeast of Building 9754-3. The V-R TLS-250 Tank-Monitoring System located at TSD displaying and sounding two alarms: (1) audible alarm in the monitor and (2) visual alarm on the monitor.

C. Alphanumeric Buttons: On the V-R TLS-350 system, the twelve right-hand buttons providing alphanumeric functions and allowing input of leak-test start times and test durations while in the operating mode.

D. Calibration: To ensure that the meter on the fuel dispenser is accurate. This calibration is required annually and can be conducted by the operating facility or service contractor. (Note: Retailers are required to have dispensers calibrated and certified by the Department of Agriculture annually).

E. Manual (Dipstick) Tank Gaging: Manual measuring method used for measuring level of fuel in underground storage tanks. The instrument used for actual measurements of the fuel is called a dipstick.

F. Material Safety Data Sheet (MSDS): Descriptive data sheet for fueis, located in the Emergency Manual, Hazardous Materials Section maintained at these facilities.

G. Monitoring Functions: (1) In-tank inventory data, (2) last-shift inventory data, (3) intank test results, (4) liquid status, (5) two-wire (type A) status, (6) start in-tank leak test, (7) stop in-tank leak test, and (8) test output reiays.

H. Operating-Button Functions: On the V-R TLS-350 system, twelve buttons located on the left side providing operational buttons to access and print data and to start and stop leak tests.

I. Pressurized Lines: Used when the sump pump is located at the underground storage tanks to push product to the fuel dispensers.

J. Printer: Printing device attached to front panel of the V-R monitor system which prints reports from the leak-detection monitoring system. The TLS-350 unit uses 2 1/4-inch thermal paper. The TLS-250 unit uses 2 1/2-inch thermal paper.

K. Red Jacket PPM 4000 Line Leak Detector (located at TSD): Detector located on the sump pumps and able to detect leaking at the rate of 3 gallons per hour in the pressurized fuel lines. When a leak is detected, the device constricts fuel flow. 
Y10-35-MM-013 Date: 03/10/94 Supersedes: New Page: 5 of 24

Subject: Fuel Stations, 9754-3 and Transportation Safeguard Division (TSD): Requirements

IV. DEFINITIONS (Cont.)

L. Red Jacket XLD Line Liak Detector (located at Building 9754-3): Detector located on the sump pumps and able to detect leaking at the rate of 3 gallons per hour in the pressurized fuel lines. When a leak is detected, the device constricts fuel flow.

M. TLS-250 Monitoring Device Front Panel (located at TSD)): Monitoring system area housing 6-button keyboards; four-lamp type indicators showing power-on. warning and alarm conditions; and liquid crystal display.

N. TLS-350 Monitoring Device Front Panel (located at Building 9754-3): Monitoring system area housing 24-button keyboards; three-lamp type indicators showing poweron, warning and alarm conditions; and two-line 24-character-per-line liquid crystal display.

O. Tokheim Commercial Refueling Dispenser: Fuel-dispensing device consisting of supply lines from the underground tanks; shear valves; submerged pump.

P. Ullage: The air space inside the underground storage tanks.

Q. Underground Storage Tank (UST) Registration Certificate: Registration certification issued annually by the State of Tennessee. The original certificate must be conspicuously posted at fueling facilities.

R. Veeder-Root TLS-250 UST Monitoring System (located at TSD): An advanced, fully integrated tank monitoring system that can provide (1) complete inventory information on fuel stored in USTs, (2) warning of leaks from these tanks, and (3) detection of product discrepancies to an accuracy of $\mathbf{0 . 2}$.

S. Veeder-Root TLS-350 UST Monitoring System (located at Building 9754-3): An advanced, fully integrated tank monitoring system that can provide (1) complete inventory information on fuel stored in USTs, (2) warning of leaks from these tanks, and (3) detection of product discrepancies to an accuracy of 0.1. 


\section{D-8}

Y10-35-MM-013 Date: 03/10/94 Supersedes: New Page: 6 of 24

Subject: Fuel Stations, 9754-3 and Transportation Safeguard Division (TSD): Requirements

\section{GENERAL INFORMATION}

The Building 9754-3 and TSD fueling stations shall be operated and maintained in compliance with the State of Tennessee regulations and Y-12 Plant policies and procedures.

\section{WARNING}

SMOKING IS PROHIBITED within $50 \mathrm{ft}$ of fueling station islands and underground storage tanks.

\section{REQUIREMENTS}

\section{A. General}

1. At the beginning of each shift the status of the Building 9754-3 and TSD fueling stations shall be determined (i.e., nonalarm status and no detected abnormalities at the tank site or islands).

2. An inventory tape is printed from the V-R monitoring system by pressing the PRINT key. The gallon amounts of fuel indicated on this tape are listed on the Daily Inventory Record (Appendix A), and the tape is attached to the station Narrative Logbook for that day. Other data on the tape is reviewed for unusual or abnormal readings.

3. Fuel pumps shall be turned On at the beginning of the shift and turned Off when personnel leave the facility.

4. While fuel is being dispensed to a vehicle, the vehicle's motor shall be turned off.

B. Documentation

1. Documentation of the status of the fueling facility shall be recorded in the station Narrative Logbook, and the inventory tape from the V-R monitoring system shall be attached to the station Narrative Logbook daily. 
D-9

Y10-35-MM-013 Date: 03/10/94 Supersedes: New Page: 7 of 24

Subject: Fuel Stations, 9754-3 and Transportation Safeguard Division (TSD): Requirements

\section{REQUIREMENTS}

B. Documentation (Cont.)

2. The amount of fuel in the UST when the facility opens, gallons dispensed, gallons off-loaded, and end-of-the-day fuel amount shall be recorded on the Daily Inventory Record (Appendix A).

3. At the Building 9754-3 fueling station ONLY, as fuel is dispensed. the transaction should be documented appropriately as follows:

a. For vehicles, complete Vehicle Fuel Log, a white form (Appendix B).

b. For heavy equipment, complete Heavy Equipment Fuel Log, a yellow form, (Appendix C).

c. For diesel vehicles, complete Vehicle Fuel Log, a blue form (Appendix D).

d. Tenths of miles shall not be recorded from the odometer reading.

NOTE: Each completed form must be submitted DAILY to Material Control.

4. Documentation shall be made of the amount of off-loaded fuel and the readings from V-R monitoring system tape shall be printed after off-loading.

5. The readings taken before and after off-loading are recorded on the Fuel Station Receipt Form (Appendix E) and the Daily Inventory Record (Appendix A).

6. The Fuel Station Receipt Form and any freight bills are submitted to Material Control. 
Y10-35-MM-013 Date: 03/10/94 Supersedes: New Page: 8 of 24

Subject: Fuel Stations, 9754-3 and Transportation Safeguard Division (TSD): Requirements

VI. REQUIREMENTS (CONT.)

C. Safety

1. Before performing maintenance, service, or changing fuel filters/strainers, all power must be shut off at the master electrical panel and impact valve must be closed.

\section{WARNING}

While service is performed, traffic shall be flagged away from the fuel station island.

2. When receiving gasoline/diesel fuel from tanker, all traffic shall be flagged away from the fuel station island and pumps must be tumed off.

3. Should assistance be required to perform the off-loading operation, the following safety equipment is required:

a. Neoprene, nitrile or polyvinyl alcohol gloves

b. Safety glasses with side shields

c. Safety shoes

4. Off-loading operations performed by the vendor shall be monitored:

a. If unsafe conditions are observed, off-loading shall be STOPPED immediately.

b. If the V-R monitoring system fails to track the off-loading of fuel, the dipstick shall be used for measuring.

c. Always ensure that residue from the dipstick drains back into the tank and not onto the ground.

d. After off-loading is complete, a second measurement is taken. Any discrepancies between readings and the freight bill must be resolved.

5. The off-loaded fuel amount shall be recorded on the Fuel Station Receipt Form (Appendix E) and the Daily Inventory Record (Appendix A). 
D-11

Y10-35-MM-013 Date: 03/10/94 Supersedes: New Page: 9 of 24

Subject: Fuel Stations, 9754-3 and Transportation Safeguard Division (TSD): Requirements

\section{REQUIREMENTS (Cont.)}

\section{Leak Testing (Weekly and Annual Requirements)}

1. An in-tank leak detection test by the V-R monitoring systems shall be conducted WEEKIY, when the fuel stations are closed. If the test fails. a manual test shall be conducted, following the steps outlined in Appendix F. The leak-test results shall be printed on a tape from the V-R monitoring system and attached to the Narrative Logbook.

\section{WARNING}

The in-tank leak-detection test shall NOT be conducted while fuel station is in operation or while fuel is being dispensed.

NOTE: The in-tank leak-detection test shall NOT be conducted while fuel station is in operation or while fuel is being dispensed.

2. The Red Jacket line leak detectors shall be checked ANNUALLY to see if the detection device will trip. The results of this annual check shall be recorded in the station Narrative Logbook as a permanent record.

3. Calibration of the fuel-dispenser meters shall be conducted ANNUALLY. Documentation of the step-by-step calibration adjustments during this annual check shall be recorded in the station Narrative Logbook as a permanent record.

4. A validation test of the accuracy of the $V-R$ systemis shall be conducted ANNUALLY. The results of the test shall be reccirded in the station Narrative Logbook as a permanent record.

\section{E. Emergency/Alarms and Notifications}

1. Spills shall be reported to the Plant Shift Superintendent immediately (Building 9754-3 personnel shall call 4-7172 and TSD personnel shall call 4-3282) or 911 or by pulling the Gamewell box.

NOTE: If containment can be SAFELY performed by operating personnel, the spill shail be kept from drains, soil, and water sources until emergency-response personnel arrive. 
D-12

Y10-35-MM-013 Date: 03/10/94 Supersedes: New Page: 10 of 24

Subject: Fuel Stations, 9754-3 and Transportation Safeguard Division (TSD): Requirements

VI. REQUIREMENTS

E. Emergency/Alarms and Notifications (Cont.)

2. The Emergency Stop Button on the west wall inside the 9754-3 fuel station building will disable the dispensers immediately. To reactivate the dispensers the electrical power must be restored at the electrical box and the emergency stop button pulled out.

3. If the audible and visual alarms are activated by the $\mathrm{V}-\mathrm{R}$ monitoring device, follow the steps outlined in Appendix $G$, which includes display messages. type of alarm. cause, response steps. and notification.

4. Alarm devices shall be maintained in good operating order at all times. If failure of any type is identified, the supervisor shall be notified immediately.

5. The V-R monitoring system will automatically send a detailed report should an alarm status be detected. This report shall be maintained in the station Narrative Logbook as a permanent record of the event.

6. If any of the following conditions are detected, the Environmental Management Department is notified who reports to the Tennessee Department of Heaith and Environment:

a. Released fuel is discovered (e.g., in an unusual area or as a visible sheen).

b. Leak detection equipment indicates a release.

c. A spill of more than 25 gallons of product must be reported within $\mathbf{7 2}$ hours or, if less than 25 gallons of product is spilled and cannot be cleaned up within 72 hours.

d. Unusual operating conditions are detected.

e. Monitoring system (V-R) has a failed test result of $>0.2$.

f. Monthly reconciliation of inventory indicates loss of $>1 \%$ flowthrough plus 130 gallons.

\section{RESPONSIBILITIES}

\section{A. Materials Management Supervisor}

1. Ensures that employees are trained to use and operate the fuel dispensing equipment. leak-detection monitoring equipment. and air-compression equipment. 
D-13

Y10-35-MM-013 Date: 03/10/94 Supersedes: New Page: 11 of 24

Subject: Fuel Stations, 9754-3 and Transportation Safeguard Division (TSD): Requirements

VII. RESPONSIBILITIES

Materials Management Supervisor (Cont.)

2. Ensures that employees assigned to operate the Fuel Stations are on-the-job trained.

3. Contacts contract service personnel to make necessary repairs and perform preventive maintenance as needed.

4. Notifies Material Control personnel when fuel should be ordered.

5. Supervises the off-loading of fuel, verifies inventory tape from V-R system against freight bill quantity and signs necessary receipt documents.

6. Ensures that Materials Clerks are maintaining required records and oversees the reconciliation of the Daily Inventory Record MONTHLY.

7. Ensure that spill-response supplies are maintained nearby on the premises.

8. Notifies and/or assists emergency response teams as needed for spills or emergency situations.

9. Reports any occurrences to line and environmental management. Completes occurrence reports as needed.

10. In the event a fuel leak is detected, assisted by Y-12 Plant Environmental Management:

a. Prevents further release if possible.

b. Identifies and mitigate fire, explosion and vapor hazards.

c. Removes as much product from UST as necessary to prevent further leaking.

d. Identifies any aboveground and exposed below' ground released fuel to prevent further release

e. Remedies hazards posed by contaminated soil.

f. Removes any free product detected. 
D-14

Y10-35-MM-013 Date: 03/10/94 Supersedes: New Page: 12 of 24

Subject: Fuel Stations, 9754-3 and Transportation Safeguard Division (TSD): Requirements

\section{RESPONSIBILITIES}

A. Materials Management St;jervisor (Cont.)

11. Should a release occur, assists environmental management in issuing (1) the Initial Abatement Report 20 davs after confirmed release and (2) the Free Product Removal Report 45 davs after confirmed release.

12. Guides the Materials Clerk on correct response to alarms detected by the V-R monitoring equipment.

B. Materials Clerk

1. Conducts a walk-through of the fuel station at the beginning of each shift, to determine the status of the facility and:

a. documents the status in the station Narrative Logbook.

b. prints the inventory listing from the V-R monitoring printer.

c. records the gallons on the Daily Inventory Record.

d. tapes the inventory report into the station Narrative Logbook.

2. Re-energizes the fuel pumps at the beginning of each shift.

3. Dispenses fuel when the status of all equipment is normal and vehicle engines are turned OFF.

4. Documents fuel dispensing on appropriate form Appendix $A$ and for the 9754-3 fuel station, Appendixes B, C, and D.

NOTE: The Appendix A daily inventory record is turned in MONTHL, $Y$ to the supervisor; and Appendixes B, C, and D are turned in DAIIY to Material Control or the supervisor.

5. When fuel is being received, flags all vehicle traffic away from fuel station island.

6. After off-loading of fuel, prints inventory tape from V-R monitoring system, and records on Fuel Station Receipt Form (Appendix E), and on the Daily Inventory Record (Appendix A). If the V-R monitoring system is unable to print inventory tape, takes measurement with the Dipstick.

7. Responds to spills and/or other emergencies by calling the Plant Shift Superintendent, 911, or by pulling the Gamewell box alarm. 
Y10-35-MM-013 Date: 03/10/94 Supersedes: New Page: 13 of 24

Subject: Fuel Stations, 9754-3 and Transportation Safeguard Division (TSD): Requirements

\section{RESPONSIBILITIES}

B. Materials Clerk (Cont.)

8. Notifies supervisor of spills and/or other emergencies.

9. Responds to audible and visual alarms signalled by the V-R monitoring system as described in Appendix G.

10. Maintains supplies as needed for the daily operations of the fuel facility.

11. Notifies supervisor immediately of all maintenance needs and/or equipment failures and documents the condition in the Facility Narrative Logbook.

\section{ACTION STEPS}

None.

\section{REQUIRED RECORDS}

1. Installation and warrantee records of the equipment must be kept for the life of the facility.

2. Record of the results of the initial tank leak test conducted with $95 \%$ product shall be maintained as a permanent record.

3. Record of the location, age of the UST, and the type of equipment shall be maintained as a permanent record.

4. Record of the results of the annual test conducted on the Red Jacket line equipment, the V-R monitoring systems and the calibration test shall be maintained for 10 years.

5. Daily inventory tapes printed from the V-R monitor are maintained in the station Narrative Logbook as a permanent record.

6. All tank leak-test results shall be maintained for 12 months.

7. Daily Inventory Records shall be maintained for 12 months.

8. Any alarm status reports generated by the $V-R$ monitor shall be maintained and attached to the station Narrative Logbook as a permanent record. 
D-16

Y10-35-MM-013 Date: 03/10/94 Supersedes: New Page: 14 of 24

Subject: Fuel Stations, 9754-3 and Transportation Safeguard Division (TSD): Requirements

\section{ADMINISTRATION}

A. The interpretation and the administration of this procedure is the responsibility of the Manager, Materials Management Department.

B. A hard copy of this procedure shall remain in the Y-12 Plant Procedures Representative's office and another copy in the FMO Procedures Representative's work area. The master copy of this procedure is printed in PC WordPerfect 5.1, and the electronic (disk) storage is kept by the FMO Procedures Coordinator.

\section{APPENDIXES}

A. Fuel Station Daily Inventory Record for Facility

B. Y-12 Plant Fuel Station: Vehicle Fuel Log (Ethanol 11-030-1125)

C. Y-12 Plant Fuel Station: Heavy-Equipment Fuel Log (Ethanol 11-030-1125)

D. Y-12 Plant Fuel Station: Vehicle Fuel Log (Diesel 11-025-0900)

E. Fuel Station Receipt Form and Steps for Printing Delivery Report

F. In-Tank Leak Detection Status and Operating Steps to Perform In-Tank Leak Test

G. Wamings and Alarms Chart 


\section{D-17}

Y10-35-MM-013

Date: 03/10/94 Supersedes: New Page: 15 of 24

Subject: Fuel Stations, 9754-3 and Transportation Safeguard Division (TSD): Requirements

Appendix A

\begin{tabular}{|c|c|c|c|c|c|c|}
\hline \multicolumn{7}{|c|}{ FUEL STATION DAILY INVENTORY RECORD FOR FACILTY } \\
\hline \multicolumn{2}{|c|}{ Tank No. } & \multicolumn{3}{|c|}{ Type of fuel in Tank: } & \multicolumn{2}{|c|}{ Month/Year: } \\
\hline DAY & $\begin{array}{c}\text { A } \\
\text { OPENING } \\
\text { GAL } \\
\text { READING }\end{array}$ & $\begin{array}{c}\text { B } \\
\text { GALLONS } \\
\text { DISPENSED }\end{array}$ & $\begin{array}{c}\text { C } \\
\text { GALIONS } \\
\text { ADDED }\end{array}$ & $\begin{array}{c}D \\
\text { INVENTORY } \\
\text { BALANCE } \\
(D=A-B+D)\end{array}$ & $\begin{array}{c}\text { E } \\
\text { CLOSING } \\
\text { GAI } \\
\text { READING }\end{array}$ & $\begin{array}{c}\text { F } \\
\text { DAILY } \\
\text { INVENTORY } \\
(\mathrm{F}=\mathrm{D}-\mathrm{E})\end{array}$ \\
\hline 1 & & & & & & \\
\hline 2 & & & & & & \\
\hline 3 & & & & & & \\
\hline 4 & & & & & & \\
\hline 5 & & & & & & \\
\hline 6 & & & & & & \\
\hline 7 & & & & & & \\
\hline 8 & & & & & & \\
\hline 9 & & & & & & \\
\hline 10 & & & & & & \\
\hline 11 & & & & & & \\
\hline 12 & & & & & & \\
\hline 13 & & & & & & \\
\hline 14 & & & & & & \\
\hline 15 & & & & & & \\
\hline 16 & & & & & & \\
\hline 17 & & & & & & \\
\hline 18 & & & & & & \\
\hline 19 & & & & & & \\
\hline 20 & & & & & & \\
\hline 21 & & & & & & \\
\hline 22 & & & & & & \\
\hline 23 & & & & & & \\
\hline 24 & & & & & & \\
\hline 25 & & & & & & \\
\hline 26 & & & & & & \\
\hline 27 & & & & & & \\
\hline 28 & & & & & & \\
\hline 29 & & & & & & \\
\hline 30 & & & & & & \\
\hline 31 & & & & & & \\
\hline
\end{tabular}




\section{D-18}

Y10-35-MM-013

Date: 03/10/94 Supersedes: New Page: 16 of 24

Subiect: Fuel Stations, 9754-3 and Transportation Safeguard Division (TSD): Requirements

Appendix A (Cont.)

\begin{tabular}{|c|c|c|c|c|c|c|c|c|c|c|}
\hline \multicolumn{2}{|c|}{ MONTHII Y RECONCILIATION } \\
\hline $\begin{array}{c}\text { Total From } \\
\text { Column (B) }\end{array}$ & $\mathrm{X}$ & 0.01 & + & 130 & $=$ & & $\begin{array}{c}\text { Gallons For } \\
\text { Suspected } \\
\text { Reiease }\end{array}$ & $\begin{array}{c}\text { Total From } \\
\text { Column (F) }\end{array}$ & $\begin{array}{c}\text { Monthly } \\
\text { Inventory }\end{array}$ \\
\hline
\end{tabular}




\section{D-19}

Y10-35-MM-013

Date: 03/10/94 Supersedes: New Page: 17 of 24

Subject: Fuel Stations, 9754-3 and Transportation Safeguarci Division (TSD): Requirements

Appendix B

Y-12 PLANT FUEL STATION: VEHICLE FUEI LOG (ETHANOL 11-030-1125)

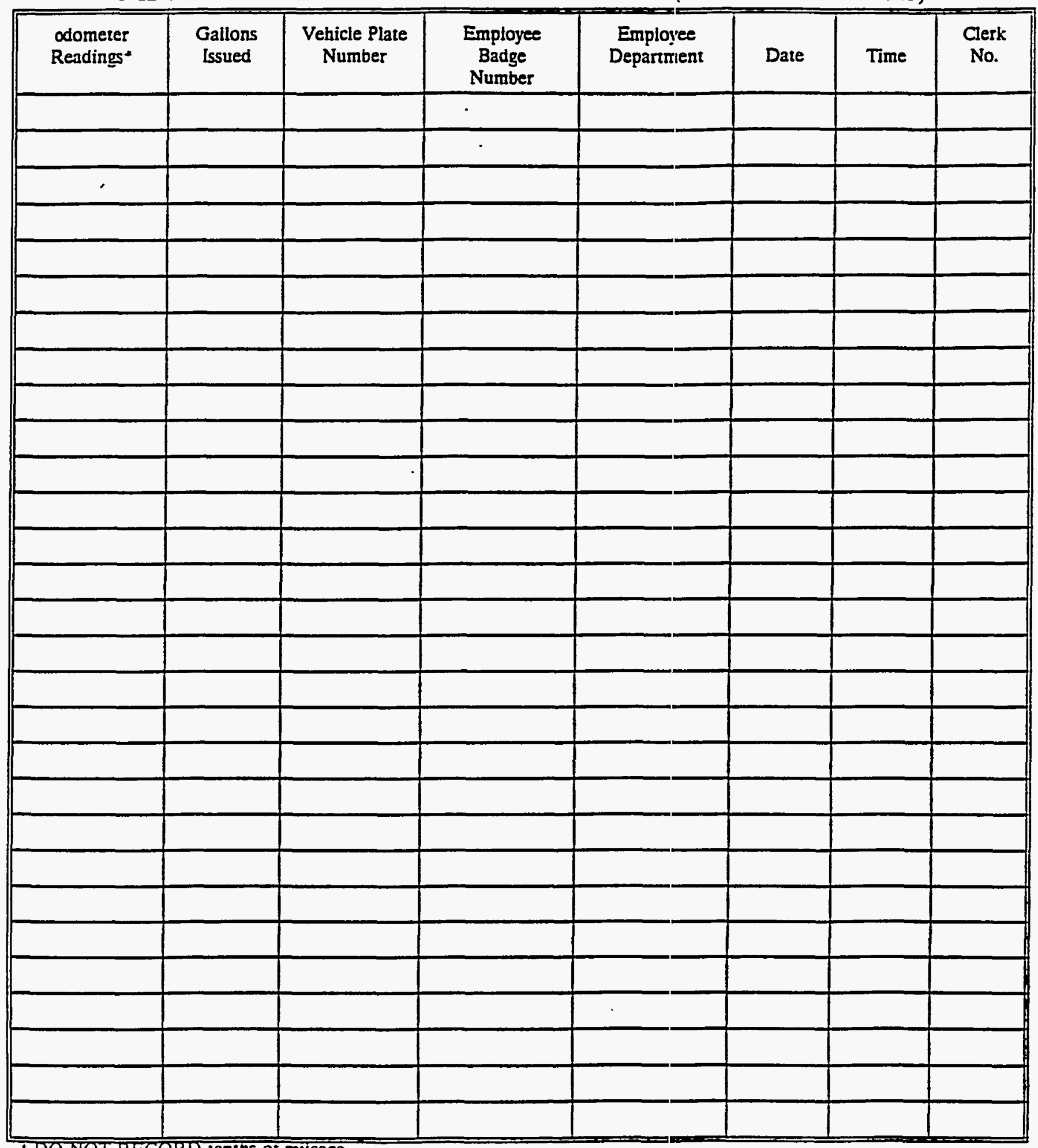

DO NOT RECORD tenths of mileage 
D-20

Y10-35-MM-013 Date: 03/10/94 Supersedes: iNew Page: 18 of 24

Subject: Fuel Stations. 9754-3 and Transportation Safeguard Division (TSD): Requirements

Appendix C

Y-12 PLANT FUEI STATION: HEAVY-EQUIPMENT FUEL LOG (EIHANOL 11-030-1125)

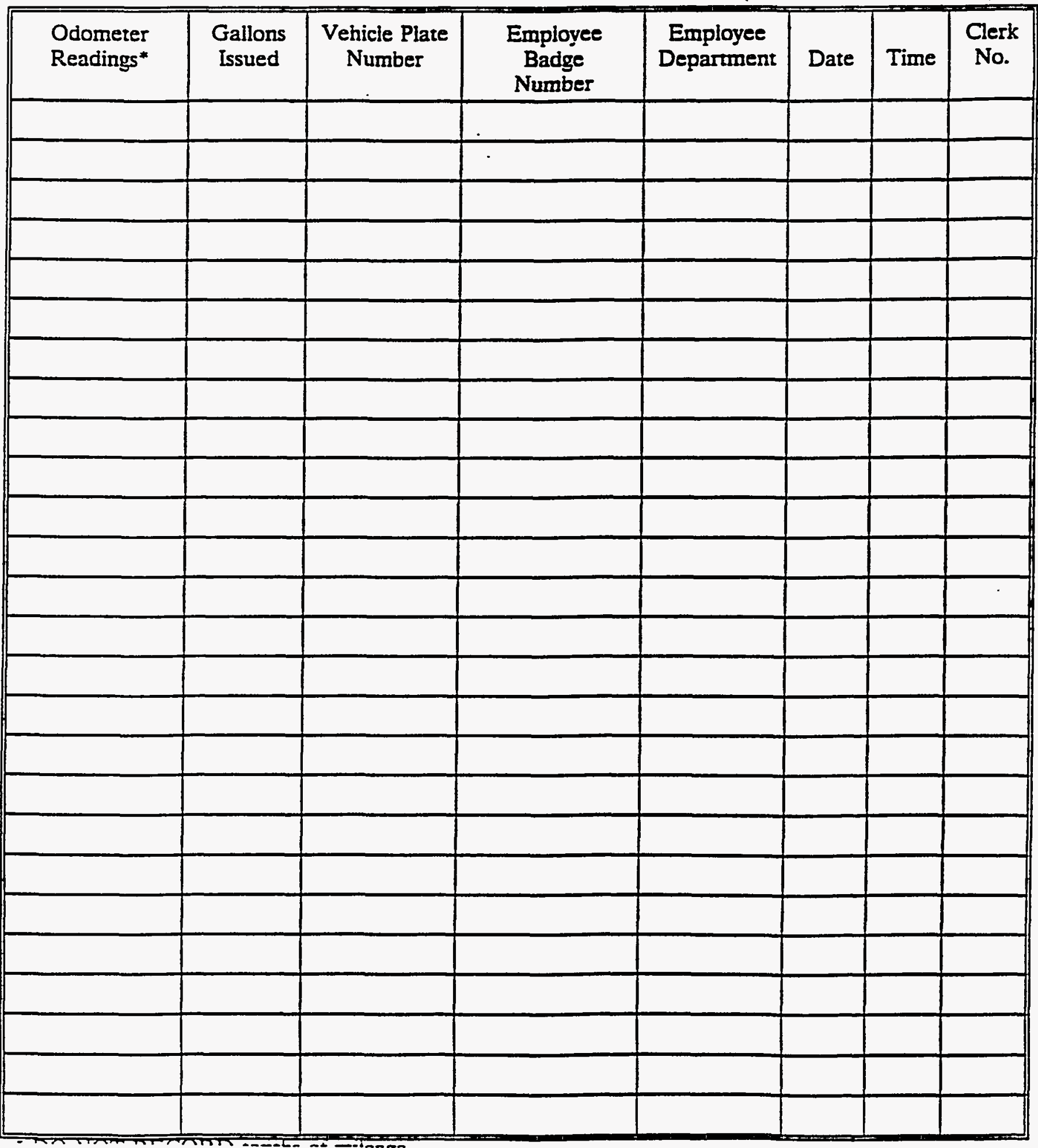


Subject: Fuel Stations, 9754-3 and Transportation Safeguard Division (TSD): Requirements

Appendix D

Y-12 PLANT FUEL STATION: VEHICLE FUEL LOG (DIESEL 11-025-0900)

\begin{tabular}{|c|c|c|c|c|c|c|c|}
\hline $\begin{array}{l}\text { Odometer } \\
\text { Readings* }\end{array}$ & $\begin{array}{l}\text { Gallons } \\
\text { Issued }\end{array}$ & $\begin{array}{c}\text { Vehicle Plate } \\
\text { Number }\end{array}$ & $\begin{array}{l}\text { Employee } \\
\text { Badge } \\
\text { Number }\end{array}$ & $\begin{array}{c}\text { Employee } \\
\text { Department }\end{array}$ & Date & Time & $\begin{array}{c}\text { Clerk } \\
\text { No. }\end{array}$ \\
\hline & & & & & & & \\
\hline & & & & & & & \\
\hline & & & & & & & \\
\hline & & & & & & & \\
\hline & & & & & & & \\
\hline & & & & & & & \\
\hline & & & & & & & \\
\hline & & & & & & & \\
\hline & & & & & & & \\
\hline & & & & & & & \\
\hline & & & & & & & \\
\hline & & & & & & & \\
\hline & & & & & & & \\
\hline & & & & & & & \\
\hline & & & & & & & \\
\hline & & & & & & & \\
\hline & & & & & & & \\
\hline & & & & & & & \\
\hline & & & & & & & \\
\hline & & & & & & & \\
\hline & & & & & & & \\
\hline & & & & & & & \\
\hline & & & & & & & \\
\hline & & & & & & & \\
\hline & & & & & & & \\
\hline & & & & & & & \\
\hline
\end{tabular}


D-22

Y10-35-MM-013

Date: 03/10/94 Supersedes: Law Page: 20 of 24

Subject: Fuel Stations, 9754-3 and Transportation Safeguard Division (TSD): Requirements

Appendix E

FUEI STATION RECEIPT FORM

1. Press, Function Key

2. Press, Step Key until reader displays - DELIVERY

3. Press, Print Key 
Appendix F

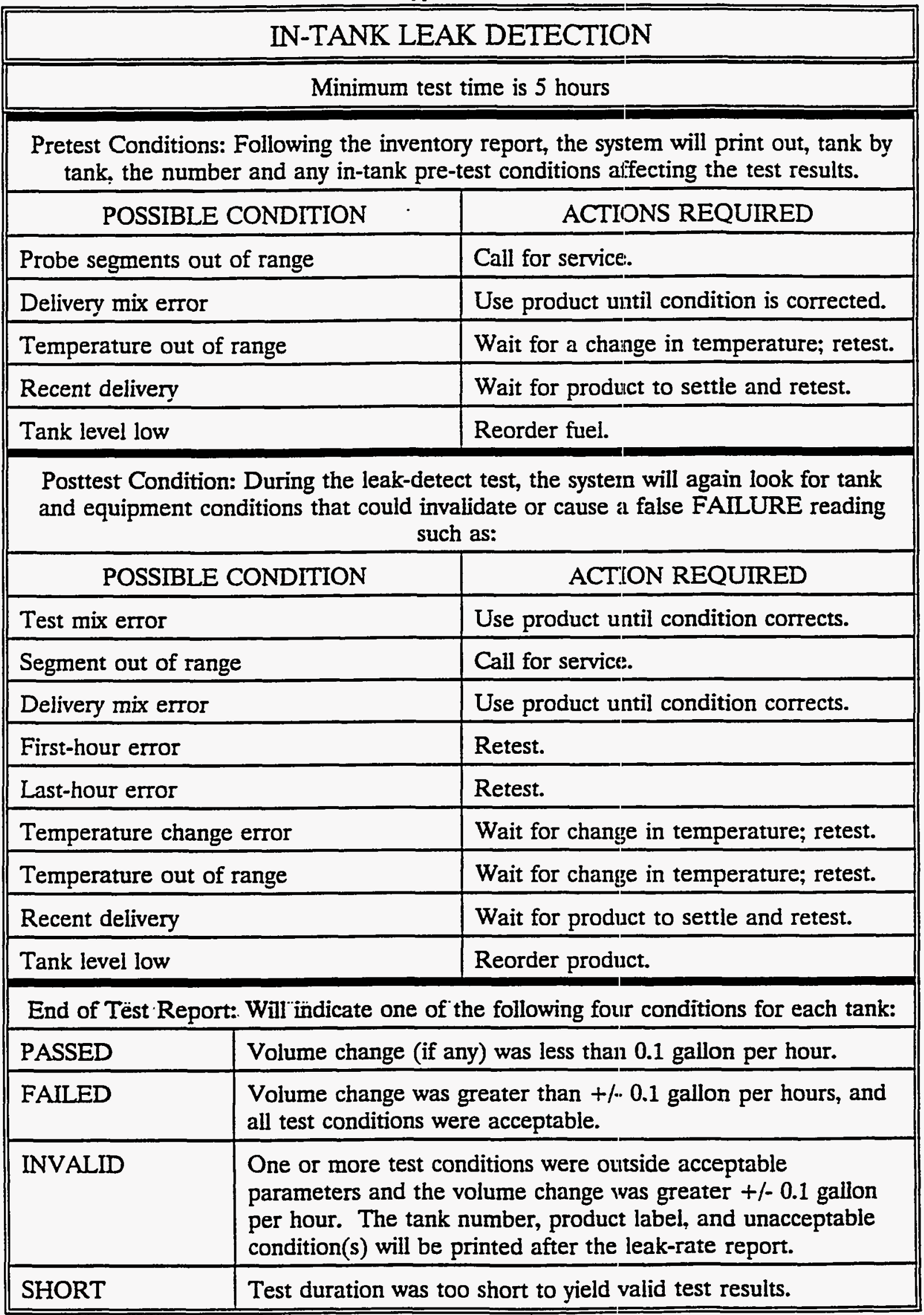


Y10-35-Miv-013 Date: 03/10/94 Supersedes: New Page: 2 i 24

Subject: Fuel Stations, 9754-3 and Transportation Safeguard Division (TSD): Requirements

Appendix F (cont.)

\section{STEPS TO PERFORM IN-TANK LEAK TEST}

\section{TO CONDUCT TEST FOR ALL TANKS}

On Operational Button Functions (left-hand keypad) Press <STEP>

Continuing test for All Tanks

Press $<S T E P>$

All tanks timed duration

Press $\langle$ STEP $>$

All tanks test to $0.1 \mathrm{gal} / \mathrm{hr}$

Press $<S T E P>$

All tanks duration:

Press $<$ CHANGE $>$

Now enter duration: $<5\rangle$

Press <ENTER>

(Test for this system takes a minimum of 5 hours, maximum numbers of hours available to run test should 'e used)

To continue

Press $\langle S T E P>$

Start Leak Test

Press <ENTER >

\section{TO CONDUCT TEST FOR SINGLE TANKS}

On Operational Button Functions

(left hand keypad)

Press $\langle S T E P>$

Continue test for single tanks

Press $<$ CHANGE $>$ Press <ENTER> Press <STEP $>$

To enter tank number

Press $<$ TANK $>$

Enter tank \#: <>

Press <STEP >

All-tanks test to $0.1 \mathrm{gal} / \mathrm{hr}$

Press $<S T E P>$

All-tanks duration:

Press $<$ CHANGE $>$

Now enter duration: $<5>$

Press <ENTER>

To continue

Press <STEP >

Start Leak Test

Press <ENTER> 
Y10-35-MM-013

Date: 03/10/94 Supersedes: New Page: 23 of 24

Subject: Fuel Stations, 9754-3 and Transportation Safeguard Division (TSD): Requirements

\section{Appendix G}

\section{WARNINGS AND ALARMS}

\begin{tabular}{|c|c|c|c|c|}
\hline \multicolumn{5}{|c|}{ SYSTEM-STATUS MESSAGES } \\
\hline $\begin{array}{l}\text { DISPLAY } \\
\text { MESSAGE } \\
\end{array}$ & TYPE OF ALARM & CAUSE & RESPONSE STEPS & NOTIFICATION \\
\hline $\begin{array}{l}\text { Setup } \\
\text { data warning }\end{array}$ & $\begin{array}{l}\text { Audible beep } \\
\text { Yellow flashing } \\
\text { light }\end{array}$ & System-setup problem has been detected. & $\begin{array}{l}\text { Set-up parameters should be input by qualified } \\
\text { persons only. }\end{array}$ & $\begin{array}{l}\text { Supervisor } \\
\text { Service Company }\end{array}$ \\
\hline Paper out & $\begin{array}{l}\text { Audible beep } \\
\text { Yellow flashing } \\
\text { light }\end{array}$ & Paper roll is empty & Replace paper roll in printer, & Nonc \\
\hline Printer error & $\begin{array}{l}\text { Audible beep } \\
\text { Yellow flashing } \\
\text { light }\end{array}$ & $\begin{array}{l}\text { Print free - roller relcase is open, } \\
\text { OR } \\
\text { Printer temperature thermistor has failed. }\end{array}$ & $\begin{array}{l}\text { Push the release lever up to closed position, } \\
\text { OR } \\
\text { No action; notify Supervisor }\end{array}$ & $\begin{array}{l}\text { None } \\
\text { Supervisor }\end{array}$ \\
\hline \multicolumn{5}{|c|}{ 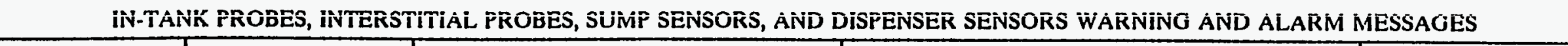 } \\
\hline $\begin{array}{l}\text { Leak alarm or } \\
\text { sudden-loss } \\
\text { alarm }\end{array}$ & $\begin{array}{l}\text { Audible beep } \\
\text { Red flashing light }\end{array}$ & $\begin{array}{l}\text { Fuel loss has exceeded the Leak Alarm } \\
\text { Limit during a leak test; limit is } \\
\text { programmable. }\end{array}$ & $\begin{array}{l}\text { Disengage audible alarms.* Print alarm message. } \\
\text { Notify supervisor immediately. If unable to notify } \\
\text { supervisor immediately, call } 911 \text {, pull the gamewell } \\
\text { box or call } 4-7172 \text { at Y-12 or } 4-3282 \text { at TSD. }\end{array}$ & $\begin{array}{l}\text { Supervisor } \\
\text { PSS } \\
\text { Environmental } \\
\text { Officer }\end{array}$ \\
\hline $\begin{array}{l}\text { High-water alarm } \\
\text { and/or warning }\end{array}$ & $\begin{array}{l}\text { Audible beep } \\
\text { Red flashing light } \\
\text { and/or Yellow } \\
\text { flashing light }\end{array}$ & $\begin{array}{l}\text { Water collecting in bottom of tank } \\
\text { exceeds limit; limit is programmable. If } \\
\text { water level exceeds } 1 " \text {, Environmental } \\
\text { Management should be notified. }\end{array}$ & $\begin{array}{l}\text { Disengage audible alarms.* Print alarm message. } \\
\text { Then notify supervisor. }\end{array}$ & $\begin{array}{l}\text { Supervisor } \\
\text { Environmental } \\
\text { Officer }\end{array}$ \\
\hline
\end{tabular}

*For 9754-3 fuel station the audible alarms are disengaged by switching $\# 5$ in the main electrical box. At the TSD facilities the audible alarms is disengaged by using key to set to Alarm Reset on the V-R front panel. 


\section{Appendix G (Cont.)}

\begin{tabular}{|c|c|c|c|c|}
\hline $\begin{array}{l}\text { DISPLAY } \\
\text { MESSAGE }\end{array}$ & TYPEE OF ALARM & CAUSE & RESPONSE STEPS & NOTIFICATION \\
\hline $\begin{array}{l}\text { Overfill alarm } \\
\text { or high-product } \\
\text { alarm }\end{array}$ & $\begin{array}{l}\text { Audible beep } \\
\text { Red flashing light }\end{array}$ & $\begin{array}{l}\text { Fuel level in the tank exceeds Overfill } \\
\text { Limit during delivery. Limit is } \\
\text { programmable }\end{array}$ & $\begin{array}{l}\text { Disengage audible alarms.* Print alarm message. } \\
\text { Alert driver to stop off-loading operations and } \\
\text { notify supervisor immediately. If a spill has } \\
\text { occurred, follow spill response actions. }\end{array}$ & $\begin{array}{l}\text { Supervisor } \\
\text { Other notifications } \\
\text { as necded }\end{array}$ \\
\hline $\begin{array}{l}\text { Low-product } \\
\text { alarm } \\
\text { and/or delivery } \\
\text { needed }\end{array}$ & $\begin{array}{l}\text { Aubible beep } \\
\text { Red flashing light } \\
\text { and/or } \\
\text { Yellow flashing light }\end{array}$ & $\begin{array}{l}\text { Fuel level has dropped below } \\
\text { programmed Low Level Limit }\end{array}$ & $\begin{array}{l}\text { Disengage audible alarms.* Print alarm message. } \\
\text { Notify Supervisor to reorder fuel. }\end{array}$ & Supervisor \\
\hline $\begin{array}{l}\text { Invalid fuel level } \\
\text { (in systems } \\
\text { equipped with } \\
\text { Magnetostrictive } \\
\text { probes) }\end{array}$ & $\begin{array}{l}\text { Audible beep } \\
\text { Yellow flashing light }\end{array}$ & $\begin{array}{l}\text { The fuel and water measurement floats } \\
\text { on probe are too close because of low } \\
\text { fuel; while this condition exists, fuel } \\
\text { height, volume readings, and delivery } \\
\text { reports are invalid. }\end{array}$ & $\begin{array}{l}\text { Disengage audible alarms.* Print alarm message. } \\
\text { Notify Supervisor to reorder fuet. }\end{array}$ & Supcrvisor \\
\hline Probe oul & Audible beep & $\begin{array}{l}\text { A probe is not currently communicating } \\
\text { with the console. }\end{array}$ & $\begin{array}{l}\text { Disengage audible alarms.* Print alarm message. } \\
\text { Notify Supervisor (1) call for service. }\end{array}$ & $\begin{array}{l}\text { Supervisor } \\
\text { Service Company }\end{array}$ \\
\hline $\begin{array}{l}\text { Periodic test alarm } \\
\text { and/or warning }\end{array}$ & $\begin{array}{l}\text { Audible beep } \\
\text { Red flashing light } \\
\text { and/or } \\
\text { Yellow flashing light }\end{array}$ & $\begin{array}{l}\text { If system is unable to perform a Periodic } \\
\text { test ( } 0.1 \text { gph for } 9754-3 \text { facility or } 0.2 \\
\text { gph for TSD facility) in a programmed } \\
\text { number of days, this warning will show. }\end{array}$ & $\begin{array}{l}\text { Disengage audible alarms.* Print alarm message. } \\
\text { Notify supervisor and programming should be } \\
\text { rechecked. }\end{array}$ & $\begin{array}{l}\text { Supervisor } \\
\text { Service Company }\end{array}$ \\
\hline Test tank active & Yellow flashing light & $\begin{array}{l}\text { This message will be displayed when a } \\
\text { requested tank test is in progress. }\end{array}$ & No action needed. & None \\
\hline
\end{tabular}

*For 9754-3 fucl station the audible alarms are disengaged by swilching \#5 in the main clectrical box. At lile TSD facilities Ihe audible alarmis is disengaged hy using key to set to Alarm Reset on the V-R front panel. 
APPENDIX E

TENNESSEE DEPARTMENT OF ENVIRONMENT AIND CONSERVATION UNDERGROUND STORAGE TANK SYSTEM

REPORT FORMS 


\section{E-3 \\ DEPARTMENT OF ENVIRONMENT AND CONSERVATION DIVISION OF UNDERGROUND STORAGE TANKS INITIAL ABATEMENT REPORT FORM}

The following information shall be provided within tweaty (20) calendar days of 2 ronfirmed release in accordance with Rule 1200-1-15-.06(3)(b). Each item shall be addressed in a typewritten report.

1. Facility ID \#: _-

2. Facility Name:

3. System test failure, laboratory confirmation of petroleum contamination, or discovery of free product was reported to the Division within 72 hours of discovery?

Yes

No

Method of Notification:

(If by telephone, provide the name of the person contacted)

Field Office:

Date:

Reported by:

4. Date release confirmed:

5. Describe how the release was discovered?

6. Describe actions taken to prevent further release to the environment (removal of product from tank, etc.) and prevent further migration of the petroleum (removal of free product, contaminated soil, etc.).

7. Describe the observations from the visual inspection of all aboveground releases and exposed belowground releases.

8. Provide all data resulting from the monitoring of vapors or free product.

9. Describe all actions taken to mitigate fire and safety hazards posed by vapors or free product that have migrated from the UST excavated zone and entered into subsurface structures (such as sewers or basements).

10. Document the amount of contaminated soil removed and the management (storage, treatment, and/or disposal) of contaminated soil. (NOTE: The owner and/or operator shall comply with all applicable State and local requirements.) 


\section{E-4}

11. If applicable, provide the following: date free product was discovered, amount removed, and the way it was managed (storage, treatment, and/or disposal). (Note: Free product removal shall be conducted in accordance with Rule 1200-1-15-.06(5); the Free Product Removal Report shall be submitted within forty-five (45) calendar days of its discovery.)

12. Provide all additional information and data generated during initial abatement.

13. Note: If this is a fund eligible site and reimbursement will be requested from the Tennessee Petroleum Underground Storage Tank Fund an approved Corrective Action Contractor shall perform all work associated with the investigation and remediation of the release from the tank system.

Provide the name(s) of the geologist or professional geologist as defined under Tennessee Code Annotated 62-36-101, the duly licensed professional engineer in the state of Tennessee, and/or an Approved Corrective Action Contractor who conducted the site check, will prepare the Initial Site Characterization Report, and, if necessary, will conduct the soil and ground water investigation and prepare the Corrective Action Plan.

The certification below shall be signed by the tank owner and/or operator (or authorized representative) and the person(s) responsible for preparing the report.

We, the undersigned, certify under penalty of law, including but not limited to penalties for perjury, that the information contained in this report form and on any attachments, is true, accurate and complete to the best of our knowledge, information, and belief. We are aware that there are significant penalties for submitting false information, including the possibility of fine and imprisonment for intentional violations.

Note: Each of the above signatures shall be notarized.

\section{STATE OF}

Sworn to and submitted before me by on this date

My commission expires

Notary Public - Print Name 


\section{DEPARTMENT OF ENVIRONMENT AND CONSERVATION DIVISION OF UNDERGROUND STORAGE TANKS INITIAL SITE CHARACTERIZATION REPORT FORM}

The following information shall be provided within forty-five (45) calendar days of a confirmed release in sccordance with Rule 1200-1-15-.06(4)(b). Each item shall be addressed in a typewritten report.

1. Facility ID \#: _-

2. Facility Name:

3. System test failure, laboratory confirmation of petroleum contamination, or: discovery of free product was reported to the Division within 72 hours of discovery?

Yes No

Method of Notification:

(If by telephone, provide the name of the person contacted.)

Field Office:

Date:

Reported by:

4. Date release confirmed:

5. Describe how the release was discovered?:

6. Type of petroleum released:

7. Estimate of amount released:

8. Provide data concerning the following: surrounding populations, water quality, use and approximate locations of drinking water supplies potentially affected by the release within a 0.5 mile radius of the site, subsurface soil conditions, locations of subsurface sewers, climatological conditions and land use.

9. Identify all off-site impacts resulting from the release.

10. Describe the rationale in selecting the sampling points. (Note: The sampling locations shall be where contamination is most likely to be present and include all potentially impacted drinking water supplies.) 
11. Were all applicable sections of the Environmental Assessment Guidelines followed?

Yes No

If no, address all variations from the Guidelines.

12. Provide information concerning the amount of contaminated soil removed and the management (storage, treatment, and/or disposal) of contaminated soil. (NOTE: The owner and/or operator shall comply with all applicable state and local requirements.)

13. Provide information concerning the amount of ground water removed and the management (storage, treatment, and/or disposal) of contaminated ground water. (NOTE: The owner and/or operator shall comply with all applicable state and local requirements.)

14. If applicable, provide information concerning the date free product was discovered, amount removed, and the way it was managed (storage, treatment, and disposal). (NOTE: Free product removal shall be conducted in accordance with Rule 1200-1-15-.06(5); the Free Product Recovery Report shall be submitted within forty-five(45) calendar days of its discovery.)

15. Appendix A shall include a table of all analytical results, the laboratory analysis sheets, all soil boring logs and monitoring well diagrams.

16. Appendix B shall include the following:

a) A scaled site map (no larger than $11 \times 17$ inches) identifying the location of existing and/or former UST system(s) (indicate former system(s) with dashed lines), the point(s) of release, sampling points, soil borings, monitoring wells, and existing utilities (sewer, water, telephone, etc.).

b) A topographic map identifying the location of the site and all surface water and water wells potentially impacted by the release.

17. Appendix $C$ shall include the results of all tank and piping tightness tests. (NOTE: Rule 1200-1-15-.03(4)(d) requires that repaired tanks and piping be tested in accordance with Rule 1200-1-15-.04(3)(c) and (4)(b) within thirty (30) calendar days following the date of repair, except as provided in parts 1 through 3 of Rule 1200-1-15-.03(4)(d).)

18. Was the presence of contamination in soil or ground water indicated above the most stringent cleanup levels? (NOTE: If TGD-011 was followed to obtain a less stringent soil cleanup level during a site closure then that level shall apply.

Yes No

If yes, the owner and/or operator shall submit the Environmental Assessment Report (EAR) as established in Rule 1200-1-15-.06(6) and other applicable regulations.

If no, the Division will review the actions taken to determine if all work was conducted in accordance with the Guidelines.

19. As required in the Release Response Letter, at a minimum, the initial four (4) soil borings and the initial four (4) monitoring wells were to be installed by the due date of this report. Has this work been performed or an extension granted by the Division?

Yes No

20. The attached Cost Estimate Cover Sheet, the Assessment Activities Cost Estimate Form, and the Report Preparation Cost Estimate Form shall be included in Appendix D of this report. The cost incurred to date for all previous activities and an estimate of the cost to complete the environmental assessment and the Environmental Assessment Report shall be summarized on the Cost Estimate Cover Sheet. 
The certification below shall be signed by the UST system owner and/or operator (or authorized representative) and a geologist or professional geologist, as defined under Tennessee Code Annotated 62-36-101, or a duly licensed professional engineer in the State of Tennessee.

We, the undersigned, certify under penalty of hw, including but not limited to proalties for perjury, that the information contained in this report form and on any attachments, is true, accurate and complete to the best of our knowledge, information, and belief. We are aware that there are significant penalties for submitting false information, including the possibility of fine and imprisonment for intentional violations.

If a P.E. signs this report indicate the area of expertise.

Note: Each of the above signatures shall be notarized.

\section{STATE OF}

Sworn to and submitted before me by on this date

My commission expires

Notary Public - Print Name 


\section{TENNESSEE UST COST ESTIMATE COVER SHEET}

\section{FACILITY INFORMATION}

Facility Name

Address

street
Facility ID\#

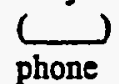

\section{CORRECTIVE ACTION CONTRACTOR}

Name

Address

Contact Person

street
Person

city

state $\underbrace{(}_{\text {phone }}$

zip

COSTS

\begin{tabular}{|l|l|l|l|}
\hline Submit with ISCR & Estimated Costs $: 9$ & $\cdots$ & $\cdots$
\end{tabular} : Actual Costs

Site Check

Initiäl Abatement / Emergency Response

Free Product Recovery

Initial Site Characterization

mental Assessment: $\%$

Environmental.AssessmentReport:

Signature of Person Completing Estimate

Date

Signature of Owner/Operator

Date

\begin{tabular}{|l|l|l|}
\hline Submit with EAR & Estimated Costs & $\ddots$ Actual Costs \\
\hline \hline Environmental Assessment & & \\
\hline Environmental Assessment Report & & \\
\hline Corrective Action Plan & & \\
\hline
\end{tabular}

Signature of Person Completing Estimate

Date

Signature of Owner/Operator

Date

\begin{tabular}{|c|c|c|}
\hline Submit with CAP & Estimated Costs & Actual Costs \\
\hline \multicolumn{3}{|l|}{ Corrective Action Plan } \\
\hline \multicolumn{3}{|l|}{ Corrective Action } \\
\hline \multirow{2}{*}{\multicolumn{2}{|c|}{$\frac{\text { Monitoring }}{\text { Operation \& Maintenance }}$}} & \\
\hline & & \\
\hline Closure & & (2) \\
\hline
\end{tabular}

Signature of Person Completing Estimate

Date

Signature of Owner/Operator

Date 
TN UST Facility ID \#_-_____ _

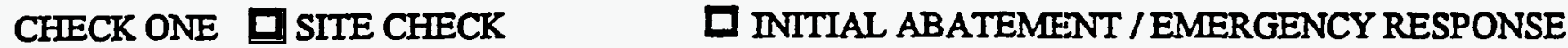 DINITIAL SITE CHARACTERIZATION Q ENVIRONMENTAL ASSESSMENT \\ Provide a brief description of the tasks included in this estimate. Expand this form as necessary)}

1.

2.

3.

4.

5.

6.

7.

8.

\begin{tabular}{|c|r|r|r|}
\hline PROFESSIONAL SERVICES & Cost Per Hour & TOTAL \\
\hline Personnel (List Below) & Hours & & \\
\hline & & & \\
\hline & & & \\
\hline & & & \\
\hline & & & \\
\hline & & & \\
\hline & & & \\
\hline
\end{tabular}

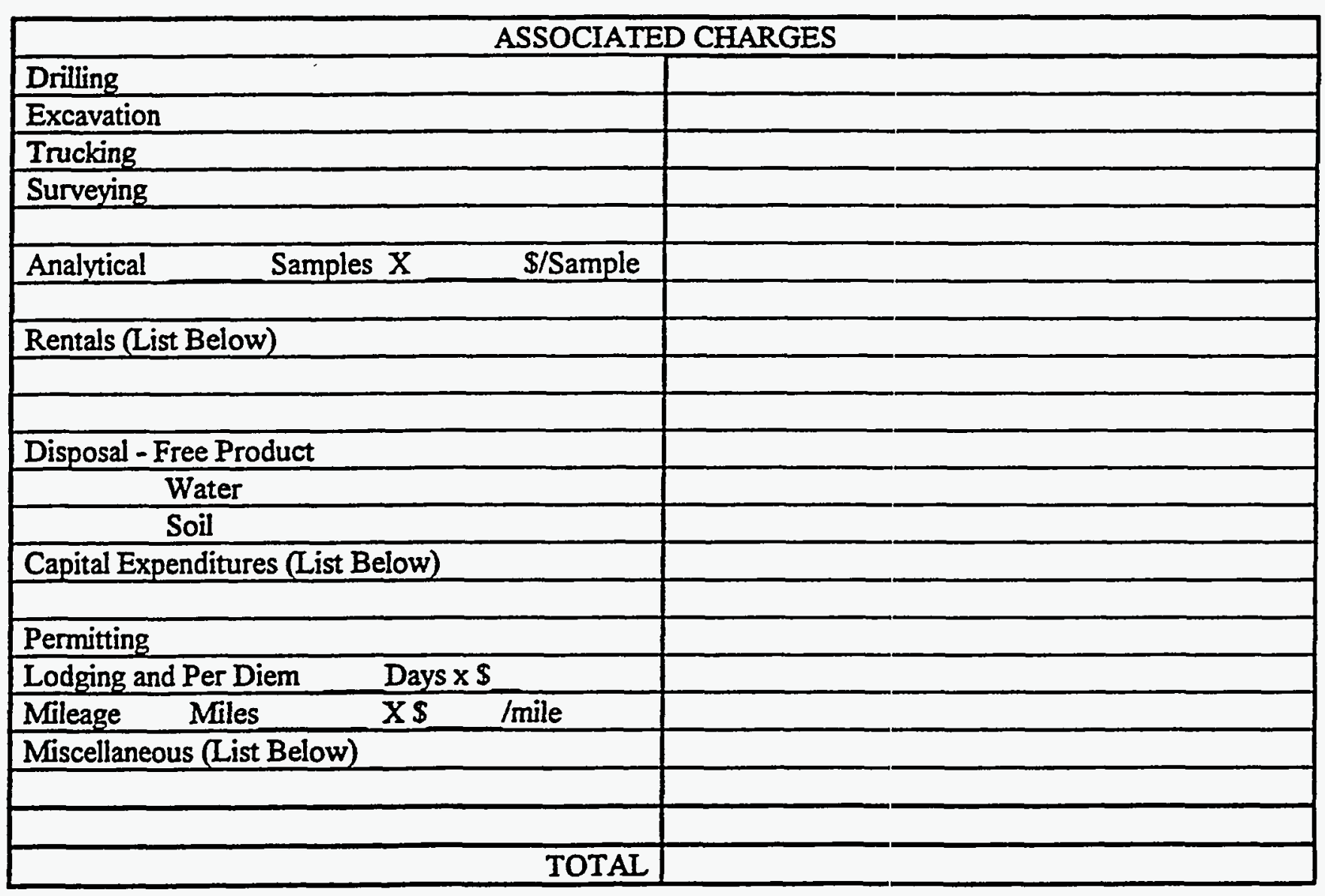


TN UST Facility ID \#_-___

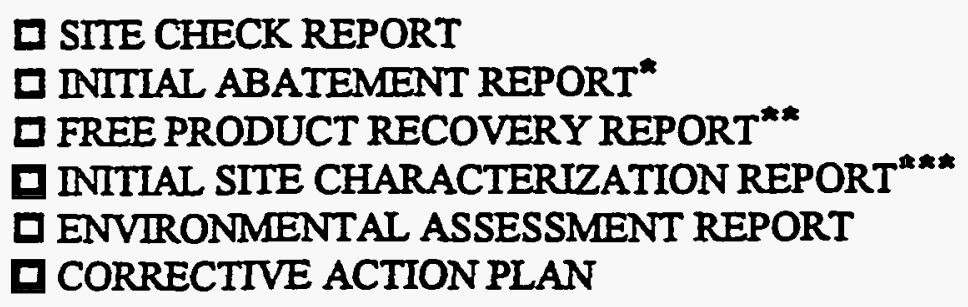

\begin{tabular}{|c|c|c|c|}
\hline \multicolumn{4}{|c|}{ PROFESSIONAI SERVICES } \\
\hline Personnel (List Below) & Hours & Cost Per Hour & TOTAL \\
\hline & & & \\
\hline & & & \\
\hline & & & \\
\hline & & & \\
\hline & & & \\
\hline & & & \\
\hline & & & \\
\hline & & & \\
\hline & & & \\
\hline & & TO] & \\
\hline
\end{tabular}

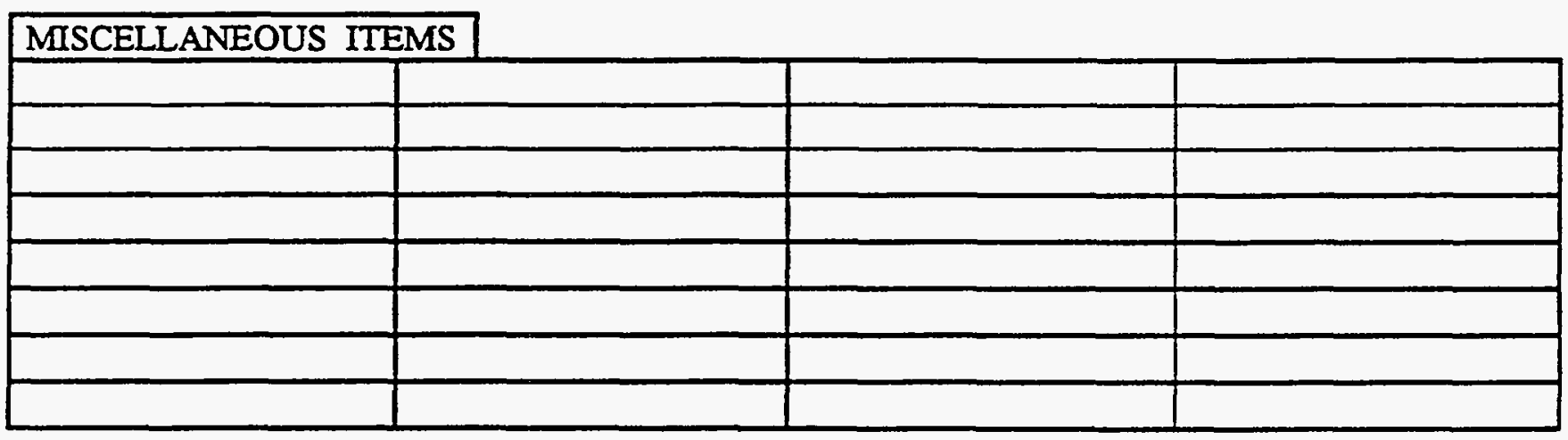

* Initial Abatement Report costs shall not exceed $\$ 250.00$.

** Free Product Recovery Report costs shall not exceed \$125.00.

*** Initial Site Characterization Report costs shall not exceed \$ 1500.00 


\section{DEPARTMENT OF ENVIRONMENT AND CONSERVATION DIVISION OF UNDERGROUND STORAGE TANKS FREE PRODUCT REMOVAL REPORT}

The following information must be provided within forty-five (45) calendar days of the discovery of free product in accordance with Rule 1200-1-15-.06(5)(d). Each item must be addressed in a typewritten report.

When the presence of free product is observed in ground or surface water, an active system capable of continuous free product removal must be installed within forty-ight (48) hours. The minimum objective for the design of the removal system is to stop the migration of free product. When surface water is impacted, petroleum absorbent materials such as booms and pads must be installed and replaced whenever necessary. Flammable products must be handled in a safe and competent manner to prevent fires or explosions.

1. Facility ID \#:

2. Facility Name:

3. Date Free Product Discovered:

4. Date Free Product Removal System Operational:

5. Name, affiliation, and telephone number of the person(s) responsible for implementing the free product removal measures:

6. Describe the estimated quantity, type, and thickness of free product measured in wells, boreholes, and excavations.

7. Describe the type of free product recovery system installed.

8. a. Indicate the location of any discharge taking place on-site or off-site during the recovery operation. (If none, proceed to 9.)

b. Describe the type of treatment applied to, and the effluent quality expected from, any discharge.

c. Describe the steps that have been or are being taken to obtain necessary permits for any discharge.

9. Describe the method for disposal of the recovered free product.

The certification below shall be signed by the UST system owner and/or operator (or authorized representative) and a geologist or professional geologist, as defined under Tennessee Code Annotated 62-36-101, or a properly licensed professional engineer in the State of Tennessee. 
We, the undersigned, certify under penalty of law, including but not limited to penalties for perjury, that the information contained in this report form and on any attachments, is true, accurate and complete to the best of our knowledge, information, and belief. We are aware that there are significant penalties for submitting false information, including the possibility of fine and imprisonment for intentional violations.

Owner/Operator (Print)

Prepared by (Print)

TN Lic./Reg \#

If a P.E. signs this report indicate the area of expertise.

My commission expires

Notary Public - Print Name

Note: Each of the above signatures shall be notarized.

STATE OF

Sworn to and submitted before me by
Signature

Signature

Date
Date on this date 


\section{APPENDIX F}

TENNESSEE DEPARTMENT OF ENVIRONMENT AND CONSERVATION ENVIRONMENTAL ASSESSMENT \& CORRECTIV]E ACTION PLAN GUIDELINES 



\section{Tennessee Department of ENVIRONMENT AND Conservation DIVISION OF UNDERGROUND STORAGE TANKS}

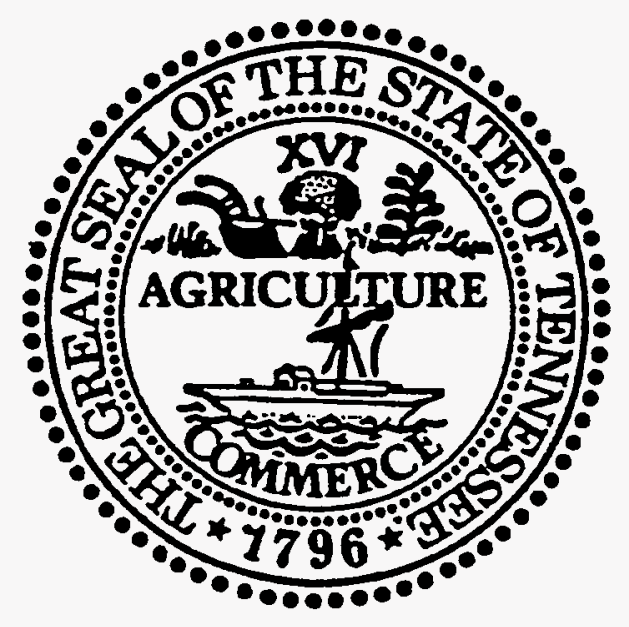

ENVIRONMENTAL Assessment GUIDELINES 
F-4

\section{TABLE OF CONTENTS}

\section{DISCLAIMER}

I. SOIL INVESTIGATION PROCEDURES 1

$\begin{array}{lll}\text { A. Number and Location of Soil Borings } & 1 \\ \text { B. Boring Methods } & 2 \\ \text { C. Procedures for Sample Collection } & 3 \\ & 1 . \quad \text { Equipment and Collection } & 3\end{array}$

2. Procedure for Selection of Soil Samples for

D. Analytical Methods

E. Procedure For Determining Soil Permeability 8

F. Borehole Abandonment

G. Decontamination Procedures

H. Quality Assurance and Quality Control (QA/QC)

I. Data Collection

II. GROUND WATER INVESTIGATION PROCEDURES 12

A. Number, Type and Location of Monitoring Wells 12

B. Drilling Methods

C. Special Procedures for Documenting Results

of Bedrock Sections

1. Camera Logging Procedures 14

2. Rock Coring

D. Single Cased Well Installation Procedures 14

1. Casing and Screen Type 14

2. Screen Length and Placement 15

3. Minimum Borehole Diameter 15

4. Placement and Type of Filter Pack 15

5. Placement and Type of Filter Pack Seal 16

6. Placement and Type of Annular Grout 16

7. Surface Completion 16

E. Double Cased Monitoring Well Installation

Procedures 17

1. Casing and Screen Type 17

2. Outer Casing Placement 17

3. Screen Length and Placement 17

4. Minimum Borehole Diameter 18

5. Placement and Type of the Filter Pack 18

6. Placement and Type of the Filter Pack Seal 18

7. Placement and Type of the Inner Annular Grout 19

8. Surface Completion 19

F. Open-Hole Well Installation Procedures 19

G. Well Development 20

$\mathrm{H}$. Water Level Measurements 21

I. Ground Water Sampling 21

1. Purging 21

2. Sample Containers and Preservation 21

3. Collection Method 22

4. Chain of Custody 23

J. Disposal of Purge and Development Water 23 
K. Analytical Methods 23

L. Ground Water Classification Procedure 25

1. Water Use Survey 25

2. Analytical Sampling 26

3. Pump Test 27

M. Decontamination Procedures . 27

N. Monitoring Well Abandonment Procedure:s 28

O. Quality Assurance and Quality Control (QA/QC) 28

P. Data Collection 29

III. SITE SAFETY PLAN 31

A. Description of Known Hazards and Risks 31

B. Designation of Key Personnel and Alternatives 31

C. Designation of the Levels of Protection 31

D. Delineation of the Work Area 31

E. Description of Control Procedures 32

F. Requirements for an Environmental Surveillance

G. Requirements for Routine of Special Training 32

H. Procedures for Weather-Related Problems 32

I. Determination of Site Specific Medical Requirements 32

J. On-site Emergencies 32

1. Establish site emergency procedure:s 33

2. Address emergency medical care 34 


\section{DISCLAIMER}

This document has been prepared to provide guidance and standardized procedures for conducting Environmental Assessments as required under Rule 1200-1-15-.06(6). These guidelines shall be followed unless prohibited by site specific conditions or other applicable statutes, rules or regulations. If a variance is necessary, the Division shall be contacted for approval. All assessment activities shall be reasonable, proper and justifiable in order to receive reimbursement from the Petroleum Underground Storage Tank Fund.

It is understood that the procedures outlined in this document cannot cover every eventuality; however, these guidelines shall be used in all cases where appropriate. If site specific conditions warrant variations from these procedures, the local field office shall be informed prior to the implementation of these variations and approval shall be obtained. All variations from these procedures shall be noted in the Environmental Assessment Report. 


\section{SOIL INVESTIGATION PROCEDURES}

Prior to installing any soil borings, all above and underground utilities, storage tanks and lines shall be identified and clearly marked to prevent arcidental damage.

\section{A. Number and Location of Soil Borings}

Only the number of soil samples necessary to deline the full extent of soil contamination to the applicable cleanup levels shall be collected and analyzed.

During the investigation, soil samples shall be collected and analyzed from borings placed in the following locations:

1. The first boring (B-1/MW-1) shall be placed in the upgradient direction of the release.

2. The second and third borings (B-2/MW-2, B-3/MW-3) shall be placed in the downgradient direction of the release.

3. The fourth boring (B-4/MW-4) shall be placed as close as possible to the location of the release. If the specific location of the release is unknown, then this boring shall be located where the site specific data suggests the highest levels of contamination exist.

After the installation and sampling of the first four (4) soil borings and monitoring wells the site shall be ranked in accordance with Technical Guidance Document - 014. If the owner/operator decicles to proceed with the investigation or is required to based on the site ranking, additional soil borings may be required. These additional soil borings will be required if the soil contamination has not been defined to the applicable cleanup levels. If additional soil borings are installed they shall not be placed within fifty (50) feet of any other soil boring unless prior approval has been granted by the Division.

Prior to installing additional soil borings, the following innovative soil investigative technologies may be used if site conditions are suitable:

1. A soil vapor survey, either active or passive, to estimate the size and location of the soil contaminant plume and optimize the placement of additional soil borings; or, 
2. A direct push or hydraulic push instrument to retrieve soil samples in lieu of additional soil borings.

The purpose of performing one of these innovative soil investigative technologies is to limit the cost of the additional investigation.

The Environmental Assessment Report (EAR) shall contain written documentation of the order in which these additional boring were installed, the date of installation, and the rationale for the placement of each boring. The rationale shall include, but not be limited to the distance, depth, and direction of the boring from all previous borings, taking into consideration:

1. The estimated and/or known contaminant levels in all previously installed borings;

2. The estimated rate of contaminant migration based on site specific data gathered from all previously installed borings;

3. The estimated or known ground water flow direction and other factors that could influence the direction of the soil contaminant plume migration;

4. The estimated and/or known rate of the decline of contaminant levels between all previously installed borings; and,

5. The results of a soil vapor survey, if performed.

The objective in selecting the additional boring locations is to define the outer limits of the soil contaminant plume without installing a number of intermediate borings. Without proper rationale for the placement of additional borings, the cost for the work may not be reimbursed from the Petroleum Underground Storage Tank Fund.

If the soil plume is adequately identified during the soil sampling procedures, no additional soil sampling shall be required during the installation of subsequent monitoring wells. 
Additional soil samples shall be collected and analyzed from all locations (trenches, ditches, additional borings, etc.) where observations or site conditions indicate that contamination is likely to exist and data is necessary to define the extent of contamination.

\section{B. Boring Methods}

All soil borings shall be advanced utilizing a hollow-stem auger or a direct push instrument. A hand auger or power auger may be utilized if one of the following conditions exist:

1. The area to be investigated is inaccessible to drill rigs;

2. The sampling point is at a shallow depth and therefore appropriate for the technique; or,

3. The sampling point is near utilities, product lines, tanks or buried structures and extreme care must be taken to prevent damage.

\section{Procedures for Sample Collection}

\section{Equipment and Collection}

a. Surface samples shall be collected using a new, disposable scoop or properly decontaminated stainless steel scoop.

b. Samples from hand augers and power augers shall be allowed only if discrete samples can be obtained utilizing a properly decontaminated auger bucket, split spoon, or shelby tube. The sampling of auger cuttings is not acceptable.

c. Samples from borings advanced by a drill rig shall be collected utilizing properly decontaminated split spoon samplers. Soil samples shall be collected continuously for the first twenty (20) feet of a boring and at intervals not to exceed five (5) feet for the remainder of the boring. A two (2) foot or longer split spoon sampler shall be used.

d. When site conditions are suitable, the use of a direct push or hydraulic push sampling method (i.e. Geoprobe, Cone 
penetrometer, etc.) may be utilized. When using the direct push sampling method, all applicable sections of this guidance document shall be followed. Soil samples shall be collected continuously for the first twenty (20) feet of the direct push procedure and at intervals not to exceed five (5) feet for the remainder of the push.

\section{Procedure for Selection of Soil Samples for Laboratory Analyses}

Upon opening the split spoon, the sample shall be split in half lengthwise. One side of the sample shall be immediately placed into a laboratory prepared jar in a manner that eliminates headspace. The jar shall then be properly labeled and stored at $4^{\circ} \mathrm{C}$ or less. All samples shall be maintained at $4^{\circ} \mathrm{C}$ until they are delivered to a Division approved laboratory. Once the potential laboratory sample has been properly stored, the remainder of the soil in the split spoon shall be classified and placed in an air tight container (sealing plastic bag) leaving some air space. The bag shall be properly labeled and the sample allowed to volatilize for a minimum of fifteen (15) minutes at a minimum of $680 \mathrm{~F}$. All samples shall be allowed to volatilize for an equal period of time prior to screening. Once the sample has been allowed to volatilize, the headspace shall be sampled with an Organic Vapor Detector (OVD).

The OVD shall be either a photoionization detector or a flame ionization detector. The use of vapor detection tubes or other methods of screening are not acceptable unless approved in advance by the Division. The following criteria shall be used when selecting soil samples for laboratory analyses:

a. If the OVD readings and other field screening techniques (visual or olfactory) indicate that contamination does not exist in the soil at a boring location, then the deepest sample shall be analyzed by the laboratory. The deepest sample shall be defined as that sample collected immediately above the soil/bedrock interface, the water table, or the bottom of the boring, whichever occurs first. 
b. If the OVD readings indicate that contamination does not exist in the soil at a boring location but visible or olfactory observations indicate that the soil is contaminated (e.g. heavy hydrocaton staining), then a minimum of two (2) samples shall be selected for laboratory analyses. The following two (2) samples shall be selected for laboratory analyses:

i. The sample in which visible or olfactory observations indicated the highest level of contamination; and

ii. The sample collected immediately above the soil/bedrock interface, the water table or the bottom of the boring, whichever occurs first.

If one (1) soil sample meets both of the above listed criteria, then only that sample shall be submitted for laboratory analyses.

c. If the OVD readings indicate that contamination does exist in the soil at a boring location, then three (3) soil samples selected from the following locations shall be submitted for laboratory analyses:

i. The sample in which the OVD screening indicated the highest level of contamination;

ii. The deepest sample which the OVD screening indicated is contaminated; and

iii. The sample collected immediately above the soil/bedrock interface, the water table or the bottom of the boring.

If one (1) soil sample meets more than one of the above listed criteria then the sample with the second highest OVD screening shall also be submitted for laboratory analyses.

\section{Analytical Methods}

For investigations involving petroleum UST's, the two (2) primary types of analyses performed are Benzene, Toluene, and Xylene (BTX) and Total Petroleum Hydrocarbons (TPH). To prevent variances of methods used for 
analyses of this type, specific methods shall be used for the analysis of these contaminants.

When analyzing soil samples for Total BTX, the laboratory shall use Test Methods for Evaluating Solid Waste, commonly known as SW-846. The purge and trap procedures for the soil samples in Method 5030 shall be followed. The actual constituent analysis using gas chromatography with a photoionization detector shall follow Method 8020. The level of Total BTX reported as the sum of Benzene, Toluene, Ortho-Xylene, Meta-Xylene, and Para-Xylene found in the sample as well as the concentration of the individual compounds must be reported. The practical quantization limit for any individual constituent using this method is 0.002 parts per million for low level soil samples. All results shall be reported in parts per million.

Analysis of samples for TPH is more involved. There are three (3) methods that are used depending on the type of hydrocarbon involved.

1. For analysis of hydrocarbon mixtures such as gasoline or other low boiling hydrocarbons (700-1800F), the Gasoline Range Organics Method shall be used.

2. For analysis of high boiling point hydrocarbon mixtures $\left(180^{\circ}-450^{\circ} \mathrm{F}\right.$ ) such as diesel fuel, kerosene, fuel oil $\$ 2$, etc., the Diesel Range Organics Method shall be used.

3. For analysis of heavy hydrocarbon mixtures (boiling point of $>450^{\circ} \mathrm{F}$ ) such as motor oil, used oil, etc., then either Standard Methods of Analysis Method $503 \mathrm{E}$ or Methods of Analysis of Water and Wastes Method 418.1 must be used.

A review of the type of petroleum stored at the site shall be performed to determine which analytical method or methods shall be used for TPH analysis. Refer to the Table 1 below for assistance: 
TABLE 1

\begin{tabular}{|c|c|}
\hline \multicolumn{2}{|c|}{ SOIL ANALYTICAL METHODS } \\
\hline $\begin{array}{l}\text { 1. Boiling points between } 70^{\circ}-180^{\circ} \mathrm{F} \\
\text { (e.g. gasoline) }\end{array}$ & $\begin{array}{l}\text { Gasoline Range Organics Method } \\
\text { (GRO) }\end{array}$ \\
\hline $\begin{array}{l}\text { 2. Boiling points between } 180^{\circ}-450^{\circ} \mathrm{F} \\
\text { (e.g. diesel, kerosene) }\end{array}$ & $\begin{array}{l}\text { Diesel Range Organics Method } \\
\text { (DRD) }\end{array}$ \\
\hline $\begin{array}{l}\text { 3. A mixture of products with one product } \\
\text { having a boiling point between } 70^{\circ}-180^{\circ} \mathrm{F} \\
\text { and one having a boiling point between } \\
180^{\circ}-450^{\circ} \mathrm{F} \\
\text { (e.g. gasoline and diesel) }\end{array}$ & GRC and DRO \\
\hline 4. Hydrocarbon type unknown & GRO and DRO \\
\hline 5. $\begin{array}{l}\text { Boiling points }>450^{\circ} \mathrm{F} \\
\text { (e.g. used oil) }\end{array}$ & Method 503 E or Method 418.1 \\
\hline
\end{tabular}

Most waste oil/motor oil UST's are in a separate area. If the waste oil UST is in the same tank pit as the gasoline and/or diesel UST's at a site, then an appropriate combination of analytical methods shall be required. If samples must be analyzed using both the Gasoline Range Organics Method (GRO) and the Diesel Range Organics Method (DRO), then the results of each analysis shall be summed (GRO + DRO) and reported as Total Petroleum Hydrocarbons TPH.

In those situations where the type of hydrocarbon stored is unknown or both gasoline and diesel products were stored, the samples must be analyzed using both the Gasoline Range Organics Method and the Diesel Range Organic Method with the results summed to determine the TFH level.

The Gasoline Range Organics Method has a practical quantization limit of 5 PPM limit for soil samples. The Diesel Range Organics Methods has a practical quantization limit of 4 PPM for soil samples. These detection limits for analysis either meet or exceed the Division's minimum action levels for soil contamination. Both Methods $503 \mathrm{E}$ and 418.1 have detection limits in soil of less than 100 PPM. 


\section{E. Procedure For Determining Soil Permeability}

Two (2) undisturbed soil samples (using a shelby tube) shall be collected in the unsaturated zone, within or below the zone of suspected soil contamination. These samples shall be collected from a boring located immediately adjacent to the fourth boring (B-4/MW-4) at the following depths:

1. Based upon observed soil characteristics obtained while installing the fourth boring (B-4/MW-4), the first shelby tube shall be collected at the depth that is anticipated to represent the zone of highest permeability.

2. The second shelby tube shall be collected immediately above the soil/bedrock interface or the water table, whichever occurs first.

If one (1) soil sample meets both of these criteria, then a second shelby tube sample shall be collected at the depth where the second highest permeability would be expected.

If the visual observations and the OVD screenings indicate that contamination does not exist at the fourth boring (B-4), then the undisturbed soil samples shall be collected as described in Sections E.1 and E.2 above.

The thin-walled tube sampling method (ASTM Method D1587) shall be utilized to collect the samples. The permeabilities shall be determined utilizing the Triaxial - Cell (Section 2.8) or Pressure-Chamber Permeameter (Section 2.9) Methods as described in Method 9100 of Test Methods for Evaluating Solid Waste, Third Edition (SW-846). Other collection and testing methods may be utilized only if prior approval is received from the Division.

The sample with the highest permeability shall be utilized when determining the applicable cleanup levels in Tables 2 and 3 below.

TABLE 2

\begin{tabular}{|l|c|c|c|}
\hline \multicolumn{4}{|c|}{ BTX SOIL CLEANUP LEVELS (PPM) } \\
\hline \hline Soil Permeability & $>10^{-4} \mathrm{CM} / \mathrm{SEC}$ & $\begin{array}{c}10^{-4} \text { TO } 10^{-6} \\
\text { CM/SEC }\end{array}$ & $<10^{-6} \mathrm{CM} / \mathrm{SEC}$ \\
\hline Drinking Water & 10 & 50 & 100 \\
\hline Non-Drinking Water & 50 & 250 & 500 \\
\hline
\end{tabular}




\section{TABLE 3}

\begin{tabular}{|l|c|c|c|}
\hline \multicolumn{4}{|c|}{ TPH SOL CLEANUP LEVELS (PPM) } \\
\hline Soil Permeability & $>10^{-4} \mathrm{CM} / \mathrm{SEC}$ & $\begin{array}{c}10^{-4} \text { TO } 10^{-6} \\
\text { CM/SEC }\end{array}$ & $<10^{-6} \mathrm{CM} / \mathrm{SEC}$ \\
\hline Drinking Water & 100 & 250 & 500 \\
\hline Non-Drinking Water & 250 & 500 & 1000 \\
\hline
\end{tabular}

If a permeability greater than $1 \times 10-4 \mathrm{~cm} / \mathrm{sec}$ is obtained from the testing of any soil sample within or beneath the contaminant: plume, then no additional permeability testing shall be conducted and the most stringent cleanup levels shall apply.

Regardless of the soil permeability classification of a site based on performing the above procedures, the Division reserves the right to apply a more stringent cleanup level if it is deemed necessary.

\section{F. Borehole Abandonment}

All soil borings that are not converted into ground water monitoring wells shall be filled with grout. The grout shall consist of a mixture of Portland cement and 4\%-6\% powdered bentonite. A grout density of 13.5 to $14.1 \mathrm{lbs} / \mathrm{gal}$ shall be used. The grouting operation shall continue until the grout flowing out of the borehole has a minimum density of $13.5 \mathrm{lbs} / \mathrm{gal}$. If water is present in the boring or the total depth of the borehole is greater than thirty (30) feet, a tremie pipe shall be utilized to place the grout. The upper two (2) feet of the boring does not have to remain filled with grout at completion and may be filled with material that is appropriate for the location.

\section{G. Decontamination Procedures}

Prior to work commencing, the drill rigs and other equipment shall be inspected for lubricant or fluid leaks which could be a potential contaminant to soil or ground water. All over-the-hole portions of the drilling equipment shall be steam cleaned prior to use and as necessary between boring locations. All down hole equipment (augers, drill rods, tools, etc.) shall be steam cleaned prior to use and between all subsequent boring locations. 
All sampling equipment which is not pre-cleaned and disposable (stainless steel scoops, split spoons, etc.) and all monitoring equipment, shall be properly decontaminated before each use by the following procedure:

1. Cleaned with a laboratory grade detergent wash;

2. Triple rinsed with distilled water; and

3. Allowed to air dry.

\section{H. Quality Assurance and Quality Control (QA/QC)}

The following procedures shall be conducted for $Q A / Q C$ :

1. Before each use, all sampling equipment shall be properly decontaminated.

2. Sampling personnel shall wear new, disposable sampling gloves while collecting all samples. Gloves shall be changed between each sampling point.

3. Sampling containers shall be laboratory prepared glass jars.

4. Soil shall be immediately placed in the laboratory jars in a manner to minimize headspace.

5. Soil samples collected for potential laboratory analyses shall be properly labeled and stored at $4^{\circ} \mathrm{C}$ or less.

6. Each jar shall be sealed separately in an airtight container (sealing plastic bag).

7. Chain of Custody forms shall be completed for each sampling event.

8. Sampling shall begin at the location where contamination is least likely to exist (background) and end at the location where the highest levels of contamination are most likely to exist (near the release).

9. All field instruments shall be calibrated daily and the calibration records maintained. 


\section{Data Collection}

At a minimum, the following data shall be collected, recorded, and submitted to the Division in the EAR:

1. The locations of all soil borings and other sampling points on a site map drawn to scale.

2. Boring logs prepared in accordance with Technical Guidance Document 006 "Standard Drilling Log".

3. The calculated and actual amounts of grout used to fill abandoned borings.

4. The date of abandonment.

5. Laboratory analysis sheets identifying the UST facility name, facility ID number, the sample point, analytical method, date sampled, date submitted to the laboratory, date analyzed, and the detection limit.

6. Chain of Custody forms. 


\section{GROUND WATER INVESTIGATION PROCEDURES}

\section{A. Number, Type and Location of Monitoring Wells}

A minimum of four (4) single cased or open hole monitoring wells shall be required to begin the ground water investigation. These wells shall be constructed by converting borings B-1 through B-4 into monitoring wells.

All single cased or open hole monitoring wells shall be installed to monitor the uppermost water bearing zone.

If site specific data or geologic conditions require the monitoring of aquifers other than the uppermost, then double cased monitoring wells shall be required. To prevent the vertical movement of contaminants within a borehole or to prevent the cross contamination of multiple aquifers, double cased monitoring wells shall be installed when monitoring a separate, deeper aquifer for contamination. If conditions exist where double cased monitoring wells are required to seal off contaminant zones, the Division shall be contacted and prior approval received before proceeding.

After the installation and sampling of the first four (4) soil borings and monitoring wells the site shall be ranked in accordance with Technical Guidance Document - 014. If the owner/operator decides to proceed with the investigation or is required to based on the site ranking, additional monitoring wells may be required. These additional monitoring wells will be required if the ground water contamination has not been defined to the applicable cleanup levels. If additional monitoring wells are installed they shall not be placed within fifty (50) feet of any other monitoring wells unless prior approval has been granted by the Division.

Prior to installing additional ground water monitoring wells, the following innovative ground water investigative technologies may be used if site conditions are suitable:

1. A soil vapor survey, either active or passive, to estimate the size and location of the ground water contaminant plume and optimize the placement of additional monitoring wells; or, 
2. A direct push or hydraulic push instrument to retrieve ground water samples. Once the extent of the ground water contamination is defined, additional ground water wells shall be required for future monitoring.

The Environmental Assessment Report (EAJ) shall contain written documentation of the order in which each additional monitoring well was installed, the date of installation, and the rationale for the placement of each monitoring well. The rationale shall include, but not be limited to the distance, depth, and direction of the monitoring wells from all previous monitoring well, taking into consideration:

1. The estimated and/or known contaminant levels in all previously installed monitoring wells;

2. The estimated rate of contaminant migration based on site specific data gathered from all previously installed monitoring wells;

3. The estimated or known ground water flow direction and other factors that could influence the direction of the ground water contaminant plume migration;

4. The estimated and/or known rate of the decline of contaminant levels between all previously installed monitoring wells; and

5. The results of a soil vapor survey, if performed.

The objective in selecting the additional monitoring; well locations is to define the outer limits of the ground water contaminant plume without installing a number of intermediate monitoring wells. Without proper rationale for the placement of additional monitoring wells, the cost of the work may not be reimbursed from the Petroleum Underground Storage Tank Fund.

\section{B. Drilling Methods}

The following drilling methods are acceptable to the Division:

1. Hollow Stem Auger

2. Air Rotary(downhole hammer or tri-cone)

The following drilling methods shall be allowed only upon special approval of the Division:

1. Mud Rotary

2. Cable Tool 


\section{Rock Coring}

4. Wash Rotary (Tri-Cone)

\section{Special Procedures for Documenting Results of Bedrock Sections}

\section{Camera Logging Procedures}

Approval shall be received from the Division prior to camera logging any bedrock wells. Approval shall be granted on a well by well basis. All bedrock wells allowed to be camera logged shall be properly developed prior to logging. The development shall consist of purging the well with a pump to remove particulate matter derived from the drilling process. The pump shall be raised and lowered throughout the water column during purging operations. A minimum of three (3) well volumes shall be purged from the well and the well shall remain undisturbed for a minimum of twenty four (24) hours prior to logging.

All video tapes produced shall be labeled with the following information: facility name, facility ID, monitoring well number, date, time, logging company name and name of professional in charge. All logs shall have a depth indicator visible on the video image. A copy of each log shall be submitted with the EAR.

\section{Rock Coring}

Approval shall be received from the Division prior to rock coring any bedrock wells. Approval shall be granted on a well by well basis. The core shall be logged and photographed.

\section{Single Cased Monitoring Well Installation Procedures}

\section{Casing and Screen Type}

The casing and screen shall be constructed of two (2) inch I.D., pre-cleaned, flush threaded, Schedule 40 PVC. The screen shall have 0.01 inch factory milled slots. The well screen shall be terminated with a threaded end cap and the casing shall be terminated with a locking, watertight cap. If free product is encountered, larger diameter wells may be installed for free product recovery. 


\section{Screen Length and Placement}

The screen length and placement shall be such that the screen intersects the water table at all times. If the screen is placed such so that ground water does not enter the well, the cost for the installation of the monitoring well may not be reimbursed from the Petroleum Underground Storage Tank Fund. Typical placement is such that seven (7) feet of screen is in the water table with three (3) feet of screen above or ten (10) feet of screen in the water table and five (5) feet of screen above. Longer screen lengths may be necessary for areas with large seasonal ground water fluctuations. A centializer shall be used in all single cased monitoring wells with a total depth greater than twenty (20) feet.

If free product is encountered, greater screen lengths (i.e. 20 feet) may be warranted in order to allow for depression of the water table during free product removal operations provided the extra depth does not result in the breaching of a confining unit.

If a confined aquifer is encountered, the water bearing section of the aquifer shall be screened.

\section{Minimum Borehole Diameter}

The borehole diameter shall be a minimum of four (4) inches larger than the outside diameter (O.D.) of the well casing. For example, a 2.5 inch O.D. casing would require a 6.5 inch diameter borehole. A waiver is granted in cases if a 5.5 inch O.D. or larger core barrel will be used to drill the bedrock portion of the hole.

\section{Placement and Type of Filter Pack}

A minimum of six (6) inches of the filter pack material shall be placed under the bottom of the well screen to provide a firm footing. The filter pack shall extend two (2) feet above the top of the screened section. A weighted tape shall be used to help prevent bridging and ensure the proper placement of the filter pack. If the total depth of the borehole exceeds thirty (30) feet, a tremie pipe shall be utilized to properly place 
the filter pack unless the well is being installed through a hollow stem auger. The filter pack shall consist of clean, washed, well sorted silica sand.

\section{Placement and Type of Filter Pack Seal}

The filter pack seal shall be placed atop the filter pack and have a minimum thickness of two (2) feet. The filter pack seal shall consist of a high solids, pure bentonite material. A weighted tape shall be used to help prevent bridging and ensure the proper placement of the filter pack seal. If the total depth to the top of the filter pack exceeds thirty (30) feet, a tremie pipe shall be utilized to place the filter pack seal unless the well is being installed through a hollow stem auger. If the bentonite seal is placed above the water table, two (2) gallons of potable water shall be used to hydrate the pellets. The hydration time for the bentonite pellets shall be a minimum of one (1) hour.

\section{Placement and Type of Annular Grout}

The annular grout shall extend from the top of the filter pack seal to within two feet of the surface. The annular grout shall consist of a mixture of Portland cement and $4 \%-6 \%$ powdered bentonite. A grout density of 13.5 to $14.1 \mathrm{lbs} / \mathrm{gal}$ shall be obtained and verified with a mud balance prior to placement. If water is present in the boring or the depth to the filter pack seal is greater than thirty (30) feet, a tremie pipe shall be used to place the annular grout unless the well is being installed through a hollow stem auger.

\section{Surface Completion}

The final two (2) feet of the annular space shall be filled with concrete terminating with a flush-mounted manhole with a watertight, bolt-down loadbearing cover unless alternate construction is approved by the Division in writing. These manholes shall be concreted in place and sloped so that surface drainage will be diverted. A locking, watertight cap shall be used if surface completion is below grade. A locking cap shall be used on all wells completed above ground level. Above ground protective covers may be used if required by site conditions. All 
monitoring wells shall be clearly marked as monitoring wells and numbered.

\section{E. Double Cased Monitoring Well Installation Procedures}

\section{Casing and Screen Type}

The outer casing shall be decontaminated black steel. If site specific conditions and drilling methods are compatible (i.e. hollow stem auger drilling) schedule 80 PVC may be used in lieu of black steel with prior approval by the Division. The inner casing and screen shall be constructed of pre-cleaned, flush threaded, Schedule 40 PVC. The screen shall have 0.01 inch factory milled slots. The screened section shall be terminated with a threaded end cap and the casing shall be terminated with a locking, watertight cap.

\section{Outer Casing Placement}

The outer casing shall be set at least two (2) feet into competent bedrock, the confining layer or five (5) feet below the last indication of soil contamination, if applicable. The casing shall then be grouted into place using a bentonite/cement grout. The grout shall consist of a mixture of Portland cement and $4 \%-6 \%$ powdered bentonite. A grout density of 13.5 to $14.1 \mathrm{lbs} / \mathrm{gal}$ shall be used. If water is present in the boring or the total depth of the borehole is greater than thirty (30) feet, a tremie pipe shall be used to place the grout unless the well is being installed through a hollow stem auger. The grout shall be allowed to set for a minimum of 24 hours before continuation of drilling activities.

\section{Screen Length and Placement}

The screen length and placement shall be such that the screen intersects the water table at all times. If the screen is placed so such that ground water does not enter the well, the cost for the installation of the monitoring well may not be reimbursed from the Petroleum Underground Storage Tank Fund. Typical placement is such that seven (7) feet of screen is in the water table with thrie (3) feet of screen above or ten (10) feet of screen in the water table and five (5) feet of screen above. Longer screen lengths may be necessary for areas with large seasonal ground water fluctuations. A centralizer shall be used in all 
monitoring wells greater than twenty (20) feet in depth. The centralizer shall be placed below the screened interval at the bottom of the well.

If free product is encountered, greater screen lengths (i.e. 20 feet) may be warranted in order to allow for depression of the water table during free product removal operations provided the extra depth does not result in the breaching of a confining unit.

If a confined aquifer is encountered, the water bearing section of the aquifer shall be screened.

\section{Minimum Borehole Diameter}

The outer borehole diameter shall be a minimum of 4.0 inches larger than the outside diameter (O.D.) of the well casing. For example, a 8.0 inch O.D. casing would require a 12.0 inch diameter borehole. The annular space between the inner casing and the outer casing shall also be 4.0 inches. A waiver is granted in cases where a 5.5 inch O.D. or larger core barrel will be used to drill the bedrock portion of the hole.

\section{Placement and Type of the Filter Pack}

A minimum of 6.0 inches of the filter pack material shall be placed under the bottom of the well screen to provide a firm footing. The filter pack shall extend two (2) feet above the top of the screened section. A weighted tape shall be used to help prevent bridging and ensure the proper placement of the filter pack. If the total depth of the borehole exceeds thirty (30) feet, a tremie pipe shall be utilized to properly place the filter pack unless the well is being installed through a hollow stem auger. The filter pack shall consist of clean, washed, well sorted silica sand.

\section{Placement and Type of the Filter Pack Seal}

The filter pack seal shall be placed atop the filter pack and have a thickness of two (2) feet. The filter pack seal shall consist of a high solids, pure bentonite material. A weighted tape shall be used to help prevent bridging and ensure the proper placement of the filter pack seal. If the total depth to the filter pack exceeds thirty (30) feet, a tremie pipe 
shall be utilized to place the filter pack seal unless the well is being installed through a hollow stem auger. If the bentonite seal is placed above the water table, two (2) gallons of potable water shall be used to hydrate the pellets. The hydration time for the bentonite pellets shall be a minimum of one (1) hour.

\section{Placement and Type of the Inner Annular Grout}

The inner annular grout shall extend from the top of the filter pack seal to within two (2) feet of the surface. The annular grout shall consist of a mixture of Portland cement and 4\%-6\% powdered bentonite. A grout density of 13.5 to $14.1 \mathrm{lbs} / \mathrm{gal}$ shall be used. If water is present in the boring above the filter pack seal or the depth to the filter pack seal is greater than thirty (30) feet, a tremie pipe shall be used to place the annular grout unless the well is being installed through a hollow stem auger.

\section{Surface Completion}

The final two feet of the annular space shall be filled with concrete terminating with a flush-mounted manhole with watertight, bolt-down loadbearing cover unless alternate construction is approved by the Division in writing. These manholes shall be concreted in place and sloped so that surface drainage will be diverted. A locking, watertight cap shall be used if surface completion is below grade. A locking cap shall be used on all wells completed above ground level. Above ground protective covers may be used if required by site conditions. All monitoring wells shall be clearly marked as monitoring wells and numbered.

\section{F. Open-Hole Well Installation Procedures}

Open hole monitoring wells may be used in areas where competent bedrock is encountered and geologic conditions (e.g. karst terrain) dictate their use.

In constructing an open hole monitoring well, the surface casing shall be set at least two (2) feet into competent bedrock. The surface casing shall be black steel in all cases. The casing shall be grouted into place using a bentonite/cement grout. The grout shall consist of a mixture of Portland cement 
and $4 \%-6 \%$ powdered bentonite. A grout density of 13.5 to $14.1 \mathrm{lbs} / \mathrm{gal}$ shall be used. If water is present in the boring or the total depth of the borehole is greater than thirty (30) feet, a tremie pipe shall be used to place the grout. The grout shall be allowed to set for a minimum of 24 hours before continuation of drilling activities.

Upon setting the surface casing, a borehole with a minimum diameter of three and one-half (3.5) inches shall be advanced to the desired depth.

The final two (2) feet of the annular space shall be filled with concrete terminating with a flush-mounted manhole with a watertight, bolt-down loadbearing cover unless alternate construction is approved by the Division in writing. These manholes shall be concreted in place and sloped so that surface drainage will be diverted. A locking, watertight cap shall be used if surface completion is below grade. A locking cap shall be used on all wells completed above ground level. All monitoring wells shall be clearly marked as monitoring wells and numbered.

\section{G. Well Development}

Monitoring well development shall not begin until at least 24 hours following completion of the well and shall continue until such time as the water column is free of visible sediment. Should development procedures not produce a water column that is sediment free, development shall continue until $\mathrm{pH}$, specific conductance, and temperature have stabilized.

The following methods shall be used individually or in combination for well development:

1. Bailing

2. Pumping

3. Surging

All down-hole equipment shall be new and disposable or shall be properly decontaminated. 


\section{H. Water Level Measurements}

All water level measurements, including total well depth measurements, shall be referenced from an established and documented point on the top of the well casing. Measurements shall be correlated with mean sea level datum if available and shall be measured to the nearest 0.01 foot.

Static water levels shall be measured using an electronic water level indicator. Measurements shall be taken no sooner than 24 hours after completion of well development, but prior to purging. Static water level measurements shall be taken prior to each sampling event.

If free product is encountered during water level measurements, the thickness of the free product shall be measured to the nearest 0.01 foot.

\section{Ground Water Sampling}

All ground water monitoring wells shall be sampled unless 0.01 foot or more of free product is encountered. In cases where free product is encountered, the depth of free product shall be documented to the nearest 0.01 foot and ground water sampling shall not be required as long as frie product is present. All monitoring wells containing less than 0.01 foot of free product shall follow the sampling protocol as described in the following sections.

\section{Purging}

After determining the static water level of the well, but prior to collecting a sample, the total volume of water standing in the well shall be calculated. A minimum of three (3) well volumes shall then be purged from the well. If the well is purged to dryness before three (3) well volumes are obtained, no further purging shall be required. The samples shall then be collected as soon as a sufficient volume of ground water recharges into the well.

\section{Sample Containers and Preservation}

Sample containers shall be as follows: 
TABLE 4

\begin{tabular}{|l|l|l|}
\hline \multicolumn{3}{|c|}{ Sample Containers and Preservatives } \\
\hline Parameter & Container & Preservative \\
\hline BTX & $\begin{array}{l}40 \mathrm{ml} \text { amber glass vial } \\
\text { with Teflon lined septa }\end{array}$ & $\begin{array}{l}\text { four (4) drops of 1:1 } \\
\text { hydrochloric acid }\end{array}$ \\
\hline $\begin{array}{l}\text { TPH, Gasoline Range } \\
\text { Organics }\end{array}$ & $\begin{array}{l}40 \mathrm{ml} \text { amber glass vial } \\
\text { with Teflon lined septa }\end{array}$ & $\begin{array}{l}200 \text { uL of 50\% } \\
\text { hydrochloric acid }\end{array}$ \\
\hline $\begin{array}{l}\text { TPH, Diesel Range } \\
\text { Organics }\end{array}$ & $\begin{array}{l}\text { 1 liter amber glass bottle } \\
\text { with Teflon lined lid }\end{array}$ & $\begin{array}{l}\text { five (5) ml of 1:1 } \\
\text { hydrochloric acid }\end{array}$ \\
\hline
\end{tabular}

All sample containers shall be pre-cleaned and sealed by the distributor or laboratory. Each sample bottle shall be preserved with the proper preservative (e.g. HCL) prior to sample collection.

\section{Collection Method}

All samples from ground water monitoring wells shall be collected with a new, disposable bailer. In order to keep agitation of the sample to a minimum, the bailer shall be slowly lowered into the water column. When transferring the sample from the bailer to the sample container, care shall be taken to minimize agitation. When collecting volatile organic samples, the sample container shall be completely filled so that no air bubbles are trapped inside. Care shall also be taken to have minimal overflow so that the preservative is not lost.

Upon collection, samples shall be immediately labeled, placed in a cooler and chilled to approximately $4^{\circ} \mathrm{C}$. The samples shall be maintained at $4^{\circ} \mathrm{C}$ until they are delivered to a state approved laboratory.

No sampling equipment shall be placed directly on the ground or other possibly contaminated surface prior to insertion into a well. A clean plastic sheet or other appropriate material shall be placed by each well for all sampling equipment. 


\section{Chain of Custody}

A chain of custody form shall be completed for each ground water sample point. This form shall be signed by the person collecting the sample, the laboratory receiving the sample, and all intermediary persons with possession of the sample. Sample security shall be maintained during all phases of transport.

\section{J. Disposal of Purge and Development Water}

All purge and development water shall be managed in a manner such that these materials will not cause pollution and disposal is in accordance with all applicable State and Federal Laws.

\section{K. Analytical Methods}

For investigations involving petroleum UST's, the two (2) primary types of analyses performed are Total Benzene, Toluene, and Xylene (BTX) and Total Petroleum Hydrocarbons (TPH). To prevent variances of methods used for analyses of this type, specific methods shall be used for the analysis of these contaminants.

When analyzing water samples for BTX, the laboratory shall use Test Methods for Evaluating Solid Waste, commonly known as SW-846, as follows:

1. The purge and trap procedures for the water: samples in Method 5030 shall be performed; then

2. The actual constituent analysis shall be performed using gas chromatography with a photoionization detector following method 8020 .

The level of BTX shall be reported individually as Benzene, Toluene, and Total Xylene found in the sample. The practical quantization limit for any individual constituent using this method is 0.002 parts per million for ground water samples. All results shall be reported in parts per million.

Analysis of samples for TPH is more involved. There are three (3) methods that are used depending on the type of hydrocarbon inivolved. 
1. For analysis of hydrocarbon mixtures such as gasoline or other low boiling hydrocarbons $\left(70^{\circ}-180^{\circ} \mathrm{F}\right.$ ), the Gasoline Range Organics (GRO) Method shall be used.

2. For analysis of high boiling point hydrocarbon mixtures $\left(180^{\circ}-450^{\circ} \mathrm{F}\right)$, such as diesel fuel, kerosene, fuel oil $\# 2$, etc. the Diesel Range Organics (DRO) Method shall be used.

3. For analysis of heavy hydrocarbon mixtures (boiling point of $>4500 \mathrm{~F}$ ) such as motor oil, used oil, etc. then either Standard Methods of Analysis Method $503 \mathrm{E}$ or Methods of Analysis of Water and Wastes Method 418.1 shall be used.

A review of the type of petroleum stored at the site shall be performed to determine which analytical method or methods shall be used for TPH analysis. Refer to the Table 5 below for assistance:

TABLE 5

\begin{tabular}{|c|c|}
\hline \multicolumn{2}{|c|}{ GROUND WATER ANALYTICAL METHODS } \\
\hline $\begin{array}{l}\text { 1. Boiling points between } 70^{\circ}-180^{\circ} \mathrm{F} \\
\text { (e.g. gasoline) }\end{array}$ & \begin{tabular}{|l} 
Gasoline Range Organics Method \\
(GRO)
\end{tabular} \\
\hline $\begin{array}{l}\text { 2. Boiling points between } 180^{\circ}-450^{\circ} \mathrm{F} \\
\text { (e.g. diesel, kerosene) }\end{array}$ & $\begin{array}{l}\text { Diesel Range Organics Method } \\
\text { (DRO) }\end{array}$ \\
\hline $\begin{array}{l}\text { 3. A mixture of products with one product } \\
\text { having a boiling point between } 70^{\circ}-180^{\circ} \mathrm{F} \\
\text { and one having a boiling point between } \\
180^{\circ}-450^{\circ} \mathrm{F} \\
\text { (e.g. gasoline and diesel) }\end{array}$ & GRO and DRO \\
\hline 4. Hydrocarbon type unknown & GRO and DRO \\
\hline $\begin{array}{l}\text { 5. Boiling points }>450^{\circ} \mathrm{F} \\
\text { (e.g. used oil) }\end{array}$ & Method $503 \mathrm{E}$ or Method 418.1 \\
\hline
\end{tabular}

Most waste oil/motor oil UST's are in a separate area. If the waste oil UST is in the same tank pit as the gasoline and/or diesel UST's at a site, then an appropriate combination of analytical methods shall be required. If samples must be analyzed using both the Gasoline Range Organics Method (GRO) and The Diesel Range Organics Method (DRO), then the results of each analysis 
shall be summed (GRO + DRO) and reported as Total Petroleum Hydrocarbons (TPH).

In those situations where the type of hydrocarbon stored is unknown or both gasoline and diesel products were stored, the samples shall be analyzed using both the Gasoline Range Organics Method and the Diesel Range Organic Method with the results summed to determine the TPH level.

The Gasoline Range Organics Method has a practical quantization limit of 0.1 PPM for water samples. The diesel Range Organics Methods has a practical quantization limit of 0.1 PPM for water samples. These detection limits for analysis meet the Division's minimum action levels for ground water contamination.

Neither Method 503 E nor Method 418.1 used for waste oil analysis will meet the Divisions 0.1 PPM TPH limit for ground water. Both methods have a practical quantization limit of 1.0 PPM for water samples, therefore the Division shall only require that actions be taken involving waste oil in ground water if the TPH level exceeds 1.0 PPM.

\section{Ground Water Classification Procedure}

The following steps shall be performed, IN SEQUENCE, to determine if the ground water at a site should be classified as either a "drinking water supply" or a "non-drinking water supply". If at any point during the classification procedure the aquifer or water supply is classified as a drinking water supply, then no further steps shall be completed. Refer to Table 6 below, to determine the applicable cleanup levels based upon the Ground Water Classification.

\section{Water Use Survey}

Perform a water use survey within a one half (.5) mile radius of the UST site. The following actions shall take place at a minimum:

1. Contact all adjacent property owners to determine the existence of any water use supplies; 
2. Perform a field survey within a one quarter mile radius of the UST site to determine the existence of any water use supplies; and

3. Perform a records search within a one half (.5) mile radius of the UST site to determine the existence of any water use supplies.

If any water supply is found within this one half (.5) mile radius of the UST site, justification may be presented in the EAR as to why the water supply should not be used in classifying the impacted aquifer or water source as a "drinking water supply". The justification shall include but not be limited to the, direction of ground water flow and the geologic characteristics of the impacted area.

If any impacted aquifer or water source is being used by the citizens of the state, then the impacted aquifer or water source shall be classified as a "drinking water supply".

\section{Analytical Sampling}

Determine if the impacted aquifer or water source meets the primary and secondary drinking water standards of rule $1200-5-1$, by analyzing the water from a well which has not been impacted by petroleum contamination, if one exist. If an unaffected well does not exist then the well with the lowest contamination shall be used. The Division reserves the right to require additional analysis from a monitoring well installed at a later date if the initial analysis was performed from an impacted well.

If the impacted aquifer or water source fails to meet any of the primary or secondary standards and is not a drinking water supply as determined in the water use survey, it may be classified as a "non-drinking water supply". However, failure of the aquifer or water source to meet the primary or secondary standards cannot be the result of petroleum contamination, unless naturally occurring. A list of the primary or secondary drinking water standards can be found in Technical Guidance Document - 002. 


\section{Pump Test}

If the ground water meets the criteria of the primary and secondary Drinking Water Standards, then the yield of the aquifer or water supply shall be determined. A suitable pump test method shall be used to determine if the impacted aquifer or water source is capable of providing a yield of at least one-half gallon per minute. The monitoring well considered to have the highest yield shall be the first well pump tested. If this first well does not yield at least one-half gallon per minute, all additional monitoring wells shall be pump tested until either all wells have been tested or one well yields at least one-half gallon per minute. If the impacted aquifer or water source is not able to produce water at the rate of one-half gallon per minute and is not a drinking water supply (as determined in the water use survey), it may be classified as a "non-drinking water supply".

TABLE 6

\begin{tabular}{|l|c|c|}
\hline \multicolumn{3}{|c|}{ GROUND WATER CLEANUP LEVELS (PPB) } \\
\hline & Benzene & TPH \\
\hline Drinking Water & 5 & 100 \\
\hline Non-Drinking Water & 70 & 1000 \\
\hline
\end{tabular}

Regardless of the ground water classification of a site based on performing the above procedures, this Division reserves the right to apply a more stringent cleanup level if it is deemed necessary.

\section{Decontamination Procedures}

Before use, the drill rigs and other equipment shall be inspected for lubricant or fluid leaks which could be potential contaminant sources. All over-the-hole portions of the drilling equipment shall be steam cleaned prior to use and as necessary between boring locations. All down hole equipment (augers, drill rods, tools, etc.) shall be steam cleaned prior to use and between all subsequent boring locations.

All sampling equipment which is not pre-cleaned and disposable and all monitoring equipment shall be properly decontaminated before each use by the following procedure: 
1. Cleaned with a laboratory grade detergent wash;

2. Triple rinsed with distilled water; and

3. Allowed to air dry.

All black steel well casing to be used in well construction shall be decontaminated by steam cleaning prior to use.

\section{N. Monitoring Well Abandonment Procedures}

Upon completion of site investigations and/or corrective actions and as directed by the Division, all monitoring wells shall be properly abandoned. Proper abandonment procedures are as follows:

1. The monitoring well casing shall be filled from bottom to top with a grout mixture consisting of Portland cement and 4\%-6\% powdered bentonite. A grout density of 13.5 to $14.1 \mathrm{lbs} / \mathrm{gal}$ shall be used. The grout shall be placed using a tremie pipe.

2. The casing shall be cut off approximately two (2) feet below ground level and the remainder of the hole shall be filled with an appropriate material (i.e. concrete, native soil, etc.).

\section{O. Quality Assurance and Quality Control (QA/QC)}

The following procedures shall be conducted for QA/QC:

1. All equipment used for purging monitoring wells and collecting ground water samples shall be properly decontaminated.

2. Sampling personnel shall wear new disposable sampling gloves while collecting all samples. Gloves shall be changed between sampling points.

3. Sampling containers shall be laboratory prepared glass bottles or vials.

4. Ground water samples shall be immediately placed in the laboratory bottles or vials in a manner to minimize headspace. 
5. All ground water samples collected for laboratory analyses shall be immediately labeled and stored at $4^{\circ} \mathrm{C}$ or less.

6. Chain of Custody forms shall be completed for each sampling event.

7. Sampling shall begin at the location where contamination is least likely to exist (background) and end at the location where the highest levels of contamination are most likely to exist (near the release).

8. When sampling monitoring wells, one (1) duplicate sample shall be collected during each sampling event.

\section{P. Data Collection}

The following data shall be collected, recorded and submitted to the Division in the EAR:

1. The location of all monitoring wells on a site map drawn to scale;

2. Boring logs prepared in accordance with Technical Guidance Document 006 "Standard Drilling Log";

3. Survey the top of the well casing and establish elevation in relation to mean sea level (MSL);

4. The exact lengths of the casing and slotted section of the screen in each well;

5. The depth from the surface to bottom and top of the filter pack, bentonite seal, and annular grout;

6. The location below ground level of all centralizers;

7. The distance to the top of casing either above or below the ground surface;

8. The depth from the top of casing to the static water level;

9. A table showing the calculated amount of filter pack, bentonite seal, and grout needed to construct each well verses the actual amount used; 
10. The method and length of time of development;

11. Thickness of free product in each well;

12. The water level in each well prior to purging;

13. The calculated and actual amount of water purged from each well;

14. Visible observation of the sample;

15. Laboratory analysis sheets identifying the facility name, facility ID number, the sample point, analytical method, date sampled, date submitted to the laboratory, date analyzed, and the detection limit;

16. Chain of Custody forms; and

17. A comprehensive ground water sampling event shall be conducted utilizing all monitoring wells that have been installed during the investigation. 


\section{SITE SAFETY PLAN}

A Site Safety Plan shall be developed and kept on site at all times work is being performed. It shall be written to avoid misinterpretation. All personnel shall be familiar with all information contained in the Site Safety Plan: At a minimum the plan shall contain the following:

\section{A. Description of Known Hazards and Risks}

This shall include all known or suspected physical and chemical hazards. It is important that all health related data be kept up-to-date. As air, water, soil, or hazardous substance monitoring and sampling data becomes available, it shall be evaluated, significant risk or exposure to workers noted, potential impact on the public assessed, and changes made in the plan. These evaluations need to be repeated frequently since much of the plan is based on this information.

\section{B. Designation of Key Personnel and Alternatives}

The plan shall identify the incident manager, as well as the site safety and health officer (and alternate) and any other personnel responsible for the site safety. It shall also identify key personnel assigned to various site operations.

\section{Designation of the Levels of Protection}

The Levels of Protection to be worn at the locations on-site or by work functions shall be designated. This includes the specific types of respirators and type of chemical protective clothing to be worn for each level. No one shall be permitted in the areas requiring personnel protective equipment unless they have been trained in its use and are wearing it.

\section{Delineation of the Work Area}

Work areas need to be designated on the site map and the map posted. The size of the zone, the zone boundaries, and access control points into the zone shall be marked and made known to all site workers. 


\section{E. Description of Control Procedures}

Control procedures shall be implemented to prevent unauthorized access. Procedures shall be established to control authorized personnel entering work zones where personnel protection is required.

\section{F. Requirements for an Environmental Surveillance Program}

A program to monitor site hazards shall be implemented. This shall include air monitoring and sampling, other types of media sampling at or around the site that shall identify chemicals present, their hazards, possible routes of migration off-site, and associated safety requirements.

\section{G. Requirements for Routine of Special Training}

Personnel shall be trained not only in general safety procedures and use of safety equipment, but in any special work they may be expected to do.

\section{H. Procedures for Weather-Related Problems}

Weather conditions can affect site work. Temperature extremes, high winds, storms, etc. impact personnel safety. Work practices shall be established to protect workers from the effects of weather and shelters provided, when necessary. Temperature extremes, especially heat and its effect on people wearing protective clothing, shall be considered and procedures established to monitor for and minimize heat stress.

\section{Determination of Site Specific Medical Requirements}

Specialized medical requirements due to unusual hazards expected or known to be encountered shall be determined.

\section{J. On-site Emergencies}

The plan shall address site emergencies - occurrences that require immediate actions to prevent additional problems or harm to responders, the public, property, or the environment. Unpredictable events such as fire, chemical exposure, or physical injury may occur and shall be anticipated. The plan shall contain detailed information for managing these contingencies. 
To accomplish this, the contingency plan shall:

\section{Establish site emergency procedures}

a. List the names and emergency functions of on-site personnel responsible for emergency actions along with the special training required.

b. Post the location of the nearest telephone (if none are present on the site).

c. Provide alternative means for emergency communications.

d. Provide a list of emergency services organizations that may be needed. Names, telephone numbers, and locations shall be posted. Arrangements for using emergency organizations may need to be made beforehand. Organizations that might be needed are:

i. Fire and Rescue Agency

ii. Police Department

iii. Local hazardous material response units

iv. Emergency Services Offices

e. Address and define procedures for the rapid evacuation of workers. Clear, audible warning signals shall be established. Well-marked emergency exits shall be located throughout the site. Internal and extemal communications plans shall be developed.

f. A complete list of emergency equipment shall be attached to the safety plan. This list shall include emergency equipment available on-site, as well as all available medical, rescue, transport, fire-fighting, and mitigating equipment: available off-site. 


\section{Address emergency medical care}

a. Determine the location of the nearest hospital or emergency care facility and determine their capability to handle chemical exposure cases.

b. Post the location of medical or emergency care facilities, travel time, directions, and telephone numbers.

c. Determine nearest ambulance service and post the telephone number.

d. Maintain accurate records of any exposure or potential exposure of site workers during an emergency (or routine operations).

e. Advise workers of their duties during an emergency. In particular, it is imperative that the site safety officers practice emergency procedures.

f. Establish procedures, in cooperation with local and state officials if appropriate, for evacuating residents who live or work near the site. 


\section{Tennessee Department of ENVIRONMENT AND CONSERVATION DIVISION OF UNDERGROUND StORAGe TANkS}

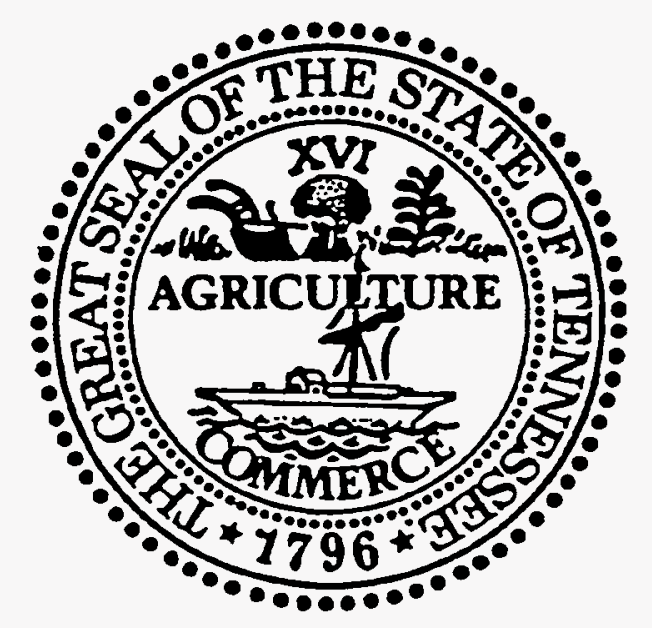

EnVironmental ASSESSMENT
REPORT
GUIDELINES

JANUARY 1994 


\section{TENNESSEE DEPARTMENT OF ENVIRONMENT AND CONSERVATION DIVISION OF UNDERGROUND STORAGE TANKS ENVIRONMENTAL ASSESSMENT REPORT GUIDELINES}

\section{Instructions:}

The Environmental Assessment Report (EAR) is due within one hundred and twenty (120) calendar days after the Responsible Party has been directed by the Division to begin an investigation. The EAR shall contain all data gathered during field activities. The full extent of petroleum contamination shall be identified to the applicable levels unless the site ranking indicated no need for further assessment activities and the owner/operator concurs. The planning of the environmental assessment activities and evaluation of the subsurface investigation shall be conducted by a geologist or professional geologist as defined under Tennessee Code Annotated 62-36-101 or a duly licensed Professional Engineer in Tennessee.

If the activities necessary to complete the EAR have not been performed by the established deadline, a written extension request shall be submitted to the appropriate field office and the central office. The extension is not automatic and enforcement actions may be taken to insure prompt compliance with established deadlines. Failure to meet established deadlines may place the responsible party out of substantial compliance and may result in the loss of fund coverage.

Each section of the EAR shall be assembled in the order presented within these guidelines. Each section shall contain a prepared text that includes the required elements of the section. This text shall provide explanations of the associated tables, maps, and address all variations from the procedure detailed in the Environmental Assessment Guidelines (EAG) provided by the Division. All maps and tables shall be in the section in which they are intended, not in appendices. All maps shall be drawn to scale on $11 \times 17$ inch paper (maximum) and contain at a minimum a north arrow, legend, scale bar, vertical scale if applicable and figure number. These guidelines are intended to provide a structured outline. Any information that is not specifically requested but is relevant to the project shall also be included. The preparer shall assemble the required information in each section so as to provide a comprehensive and cohesive final document. All pages of the report, including the tables and figures, shall be consecutively numbered. Each section and subsection heading must be clearly printed in the report. A table of contents shall be provided listing the location of all sections, maps, tables, and appendices. 
IMPORTANT HOTE: All correspondence, reports, laboratory analysis sheets, etc. shall contain the $T$ IT UST Facility ID Number. A copg of all correspondence and reports shall be submitted to the UST central office and the appropriate field office. Photostatic copies of the laboratory analysis aheets are not acceptable unless the originals have previously been submitted in axlother report. 


\section{Environmental Assessment Report}

\section{Executive Summary}

Provide an Executive Summary describing the findings of the project to date. Include conclusions and interpretation of data derived from implementing the environmental assessment activities.

\section{A. Introduction}

Give a brief site history stressing information that has not been previously stated in prior reports or information that has been revised based upon new findings, include the following, at a minimum:

1. The estimated or known quantity of the release based upon the size of the contaminant plume(s) and the inventory records;

2. A summary of all initial abatement actions taken;

3. A summary of actions taken to identify and eliminate the sources of contamination; and,.

4. The results of the Site Ranking completed in accordance with Technical Guidance Document (TGD)-014. Provide the completed Site Ranking document in an appendix.

\section{B. Site Location}

1. Provide a vicinity map showing the site location including all adjacent streets, nearby buildings, subsurface structures and utilities.

2. Provide a site map including tank and line locations (indicate former tank systems with a dashed line), underground utilities, boring and monitoring well locations, etc. This map shall also include Line A-A' which shall be a line parallel to the direction of ground water flow and Line B-B' which shall be perpendicular to the direction of ground water flow. These lines shall intersect as many soil borings and/or monitoring wells as possible. These lines shall be used for all subsequent cross sectional maps and shall 
therefore represent, as closely as possible, the widest areas of the soil and ground water contaminant plumes.

3. Provide a color topographic map with the site location indicated. Black and white copies shall not be used. This map may be on $8.5 \times 11$ inch paper.

4. Provide a description of the local topography and any effects it may have on contaminant migration at the site.

\section{Soil Investigation}

If more than four (4) soil boring were necessary, provide the order in which each additional boring was installed, the date of installation, and the rationale for the placement of each additional boring. Without proper rationale for the number and placement of additional borings, the cost for the voork may not be reimbursed by the Petroleum Underground Storage Tank Fund.

The rationale shall include, but not be limited to the distance, depth, and direction of the borings from all previously installed borings, taking into consideration:

a. The estimated and/or known contaminant levels in all previously installed borings;

b. The estimated rate of contaminant migration based on site specific data gathered from all previously installed borings;

c. The estimated or known ground water flow direction and other factors that could influence the direction of the soil contaminant plume migration;

d. The estimated and/or known rate of the decline of contaminant levels between all previously installed borings; and

e. The results of a soil vapor survey, if performed. 


\section{Geology}

a. A description of the regional geologic section;

b. A description of the geologic section at the site;

c. A description of the soil and/or bedrock lithologies encountered at the site;

d. A plan view map showing the bedrock contour, if applicable;

e. Cross sectional maps (drawn to scale, along both Line A-A' and B-B') showing the soil and bedrock lithologies; and,

f. The dip and strike of the rock formations encountered.

\section{Soil Boring Results}

a. Describe the methods used to drill and sample all soil borings.

b. Provide detailed boring logs in an appendix. Label and reference all appendices. See TGD-006, for items that shall be included in a boring log.

\section{Analytical Results}

All soil analytical results from every sampling event (i.e., closure, site check, environmental assessment, etc.) shall be included in a table along with the following information:

a. Boring number or location of additional sampling points;

b. Date sample was collected;

c. Sample depth;

d. Parameter (i.e. BTX or TPH);

e. Unit of measurement (Parts Per Million, PPM); and,

f. The applicable cleanup levels. 
Provide all laboratory analysis sheets in an appendix. Label and reference all appendices. Include the TN UST Facility ID Number on all analysis sheets. The chain of custody sheets shall also be included in the appendix.

Photostatic copies of the laboratory analysis sheets are not acceptable unless the originals have previously been submitted in another report.

\section{Soil Cleanup Levels}

Provide the following information to establish the applicable cleanup level:

a. The depths at which the undisturbed soil samples (shelby tube) were collected and the rationale used to select the sampling depths;

b. The procedure used to collect the samples;

c. The laboratory method used to determine the soil permeability and the rationale used to select the test method;

d. The laboratory used to determine the soil permeability;

e. The laboratory permeability results, in centimeters per second (cm/sec); and,

f. The soil cleanup level(s) deemed appropriate for this site based upon the soil permeability and the ground water classification.

All laboratory analysis sheets shall be included in an appendix. Label and reference all appendices.

Regardless of the calculated soil permeability classification, the Division reserves the right to apply more stringent cleanup levels, if deemed necessary.

\section{Soil Contaminant Plume Maps}

Proper rationale shall be provided if extrapolation was used to predict the extent of contamination to the applicable cleanup levels. 
a. Provide two (2) plan view maps (drawn to scale) one showing the horizontal extent of BTX contamination and the other showing the TPH contamination including the following at a minimum:

i. The location of the existing and/or former UST (indicate former UST system with dashed lines) system and existing underground utilities (sewer, water, telephone, etc.); and,

ii. The location of all soil borings and monitoring wells along with the appropriate identification and the contaminant concentrations.

b. Provide two (2) cross sectional maps (drawn to scale) representing Line $A-A^{\prime}$ and Line $B-B^{\prime}$ respectively. Separate maps shall be prepared for BTX and TPH. Each shall include the following, at a minimum:

i. The location and depth of all soil borings and monitoring wells, along the respective line, with the appropriate identification;

ii. The locations at which soil samples were collected for laboratory analysis and their corresponding results;

iii. The organic vapor detector (OVD) readings from all screened soil samples;

iv. The vertical extent of BTX and/or TPH soil contamination to the applicable cleanup level, using labeled isopleths to delineate the extent of contamination;

v. The potentiometric surface;

vi. The bedrock profile, if encountered; and,

vii. The elevation at which ground water was first encountered. 


\section{Estimate of Contaminant Mass}

Based upon the volume of contaminated suil and the concentration gradients as defined through the installation of soil borings, estimate the total mass of TPH in the soil. (Show calculations)

\section{Ground Water Investigation}

If more than four (4) ground water monitoring wells are necessary, list the order in which each additional monitoring well was installed, the date of installation and the rationale for the placement of each additional monitoring well. Without proper rationale for the number and placement of additional monitoring wells, the cost for the work may not be reimbursed by the Petroleum Underground Storage Tank Fund. The rationale shall include, but not be limited to the distance, depth, and direction of the monitoring well from all previous monitoring wells, taking into consideration:

a. The estimated and/or known contaminant levels in all previously installed monitoring wells;

b. The estimated rate of contaminant migration based on site specific data gathered from all previously installed monitoring wells;

c. The estimated or known ground water flow direction and other factors that could influence the direction of the ground water contaminant plume migration;

d. The estimated and/or known rate of the decline of contaminant levels between all previously installed monitoring wells; and

e. The results of a soil vapor survey, if performed.

\section{Hydrogeology}

a. Describe the occurrence and movement of ground water at the site and its relationship to both soil and ground water contamination. Include conclusions concerning the relationship of this site to any areas of off-site contamination, if applicable. 
b. Describe the occurrence and movement of free product at the site. Include estimated quantities, source(s), pathways of migration and estimates of travel time, if applicable.

c. Provide a water level data table for each sampling event containing the following, at a minimum:

i. Monitoring well number;

ii. Date measured ;

iii. Total depth of well;

iv. Top of casing elevation relative to MSL;

v. Depth from top of casing to free product;

vi. Depth from top of casing to water;

vii. Thickness of free product;

viii. Potentiometric surface elevation relative to MSL; and,

ix. Adjusted potentiometric surface elevation relative to MSL.

All ground water measurements previously recorded shall be represented in this table.

d. Provide two (2) potentiometric maps (drawn to scale) derived from data collected at least thirty (30) days apart. If multiple aquifers are investigated due to the presence of contamination in a deeper aquifer and sufficient data is generated, potentiometric maps shall be included for each. These maps shall also include arrow(s) depicting the interpreted direction of ground water flow.

e. Provide the highest calculated hydraulic gradient in $\mathrm{ft} /$ day (Show calculations).

f. Provide the calculated ground water flow rate(s) using the following equation. For all estimated values include a justification and reference (Show calculations).

g. Provide the results of any slug or pump tests.

2. Monitoring Well Construction

a. Describe the monitoring well installation procedures. 
b. Provide a table showing the calculated volumes of the well construction materials such as sand, bentonite and grout versus the actual volumes used. If the actual and the calculated volumes differ by more than $10 \%$, provide an explanation for the difference.

\section{Well Development}

Describe the procedures used to develop all m.onitoring wells. Provide a description of how the development water was managed.

\section{Monitoring Well Sampling}

Describe the procedures used to sample all monitoring wells including purging, sampling, and chain of custody protocols.

\section{Analytical Results}

Provide all ground water analytical results, from. every sampling event (i.e., closure, site check, environmental assessment, etc.) in a table containing the following information, at a minimum:

a. Monitoring Well number or location of additional sampling points;

b. Date sample was collected;

c. Parameter (i.e. Benzene, TPH, etc.);

d. Unit of measurement (Parts Per Million, PIPM); and,

e. The applicable cleanup levels.

Provide all laboratory analysis sheets in an appendix. Label and reference all appendices. Include the TN UST Facility ID Number on all laboratory analysis sheets. A copy of the chain of custody sheets shall also be in the appendix.

Photostatic copies of the laboratory analysis sheets are not acceptable unless the originals have previously been submitted in another report.

\section{Ground Water Classification Procedures}

Provide the following information to establish the: applicable cleanup levels. 


\section{a. Data from the Water Use Survey}

i. Provide a map showing the location of all water supplies within a one half $(.5)$ mile radius of the release site.

ii. Describe the steps that were taken to perform the water use survey.

If any water supply is found within a one half (.5) mile radius of the UST site, justification may be provided describing why the water supply should not be used in classifying the impacted aquifer or water source as a "drinking water supply". The justification shall include but not be limited to the direction of ground water flow and the hydrogeologic characteristics.

\section{b. Data From The Analytical Sampling (If necessary)}

Provide a table summarizing all analytical results used to determine if the impacted aquifer or water supply met the primary or secondary drinking water standards. This table shall contain, at a minimum, the actual concentration, the applicable primary or secondary standard, and the number of the well from which each water sample was taken.

Provide all of the laboratory analysis sheets in an appendix. Label and reference all appendices.

\section{c. Data from the Pump Test (If necessary)}

i. Describe the pump test method which was used to determine the yield of the impacted aquifer or water supply.

ii. Describe the rationale used for selecting the pump test method.

iii. Provide a table summarizing the results of the pump test for each well that was tested. The results shall be reported in gallons per minute (GPM). 


\section{d. Applicable Cleanup Levels}

Based upon the ground water classification, list the ground water cleanup level(s) deemed appropriate for this site.

Regardless of the ground water classificiation, the Division reserves the right to apply more stringent cleanup levels, if deemed necessary.

\section{Ground Water Contaminant Plume Maps}

All contaminant plumes shall be defined to the applicable cleanup levels as determined in Section II of the Environmental Assessment Guidelines. Proper rationale shall be provided if extrapolation was used to predict the full extent of contamination to the applicable cleanup levels.

a. Provide two (2) plan view maps (drawn to scale) one showing the horizontal extent of benzene contamination and the other showing the TPH contamination to the applicable cleanup levels including the following, at a minimum:

i. The location of the existing and/or former UST system (indicate former UST system with dashed lines) and existing underground utilities (sewer, water, telephone, etc.);

ii. The location of all soil borings and monitoring wells, along with the appropriate identification and the contaminant levels;

iii. The horizontal extent of any free phase product.

b. Provide two (2) cross-sectional maps (drawn to scale) representing Line $A-A^{\prime}$ and Line $B-B^{\prime}$ respectively. Separate maps shall be prepared for benzene and TPH. Each shall include the following, at a minimum: 
i. The location and depth of all soil borings and monitoring wells, along the respective line, with the appropriate identification;

ii. The location of the screened portion of the monitoring wells;

iii. The extent of Benzene and/or TPH ground water contamination to the applicable cleanup level, using labeled isopleths to delineate the extent of contamination;

iv. The potentiometric surface;

v. The bedrock profile and any fractures, voids or relevant features in the bedrock, if encountered; and,

vi. The elevation at which ground water was first encountered.

\section{Estimate of Contaminant Mass}

Based upon the volume of contaminated ground water and the concentration gradients as defined through the installation of monitoring wells, estimate the total mass of Benzene and TPH in the ground water. (Show calculations)

\section{Corrective Action Plan Cost Estimate}

The Cost Estimate Cover Sheet and Report Preparation Cost Estimate Form (see attachments) shall be included with the EAR. The costs incurred to date for all previous activities and an estimate of the costs to complete the Corrective Action Plan shall be summarized on the Cost Estimate Cover Sheet. A detailed breakdown of the estimated costs shall be presented in the Corrective Action Cost Estimate Form. 


\section{E. Signature Page}

A signature page, as shown below, shall be attached to the Environmental Assessment Report. The page shall be signed by the owner/operator of the UST system and a geologist or professional geologist as defined under Tennessee Code Annotated $62-36-101$ or a duly licensed professional engineer registered in the State of Tennessee.

We, the undersigned, certify under penalty of law, including but not limited to penalties for perjury, that the information contained in this report and on any attachments is true, accurate and complete to the best of our knowledge, information, and belief. I am aware that there are significant penalties for submitting false information, including the possibility of fine and imprisonment for intentional violations.

Owner/Operator (Print)

P.E. or P.G. (Print)

\section{Signature}

Signature

TN Lic./Reg. \#

If a P.E. signs the report, indicate the area of expertise.

Stamp/Seal

STATE OF

Sworn to and subscribed before me by on this date

My commission expires

Notary Public - Print Name

Signature 


\section{FACILITY INFORMATION}

Facility Name

Address

street

-

\author{
-
}

$+$

$\begin{array}{ll} & \\ \text { city } & \text { zip }\end{array}$

Facility D\#

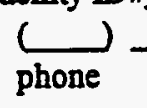

\section{CORRECTIVE ACTION CONTRACTOR}

Name

Address street

Contact Person

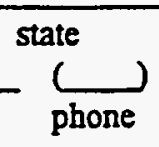

state

$\underset{\text { phone }}{(}$

\section{Costs}

\begin{tabular}{|c|c|c|}
\hline Submit with ISCR & Estimated Costs & Actual Costs \\
\hline \multicolumn{3}{|c|}{ Site.Check ${ }^{\prime}$ - } \\
\hline \multicolumn{3}{|c|}{ Initial Abatement $/$ Emergency Response } \\
\hline \multicolumn{3}{|c|}{ Free Product Recovery } \\
\hline \multicolumn{3}{|l|}{ 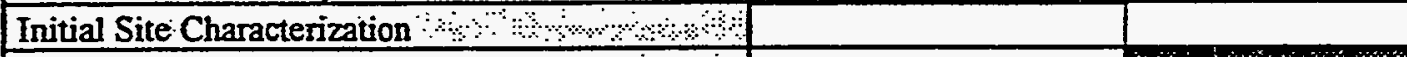 } \\
\hline \multicolumn{2}{|l|}{ Environmental Assessment $\cdots$} & \\
\hline Environmental Assessment Report: & & \\
\hline
\end{tabular}

Signature of Person Completing Estimate

Date

Signature of Owner/Operator

Date

\begin{tabular}{|l|l|l|}
\hline Submit with EAR & Estimated Costs & Actual Costs \\
\hline \hline Environmental Assessment $\cdots \cdots$ & & \\
\hline Environmental Assessment Report & & \\
\hline Corrective Action Plan & & \\
\hline
\end{tabular}

Signature of Person Completing Estimate

Date

Signature of Owner/Operator

Date

\begin{tabular}{|c|c|c|}
\hline Submit with CAP & Estimated Costs & Actual Costs \\
\hline Corrective Action Plan & & \\
\hline Corrective Action & & \\
\hline Monitoring & & \\
\hline Operation \& Maintenance & & \\
\hline Closure & & \\
\hline
\end{tabular}

Signature of Person Completing Estimate Date

Signature of Owner/Operator Date 


\section{REPORT PREPARATION COST ESTIMATE FORM}

TN UST Facility ID \#_-

口 SITE CHECK REPORT

INITLAL ABATEMENT REPORT*

- FREE PRODUCT RECOVERY REPORT ${ }^{\star *}$

INITIAL SITE CHARACTERIZATION REPORT ${ }^{\star \star *}$

口 ENVIRONMENTAL ASSESSMENT REPORT

$\square$ CORRECTIVE ACTION PLAN

\begin{tabular}{|c|c|c|c|}
\hline PROFESSIONAI SERVICES & & & \\
\hline Personnel (List Below) & Hours & Cost Per Hour & TOTAL \\
\hline & & & \\
\hline & & & \\
\hline & & 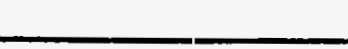 & \\
\hline & & & \\
\hline & & & \\
\hline & & & \\
\hline & & & \\
\hline & & & \\
\hline & & & \\
\hline & & TOTAL & \\
\hline
\end{tabular}

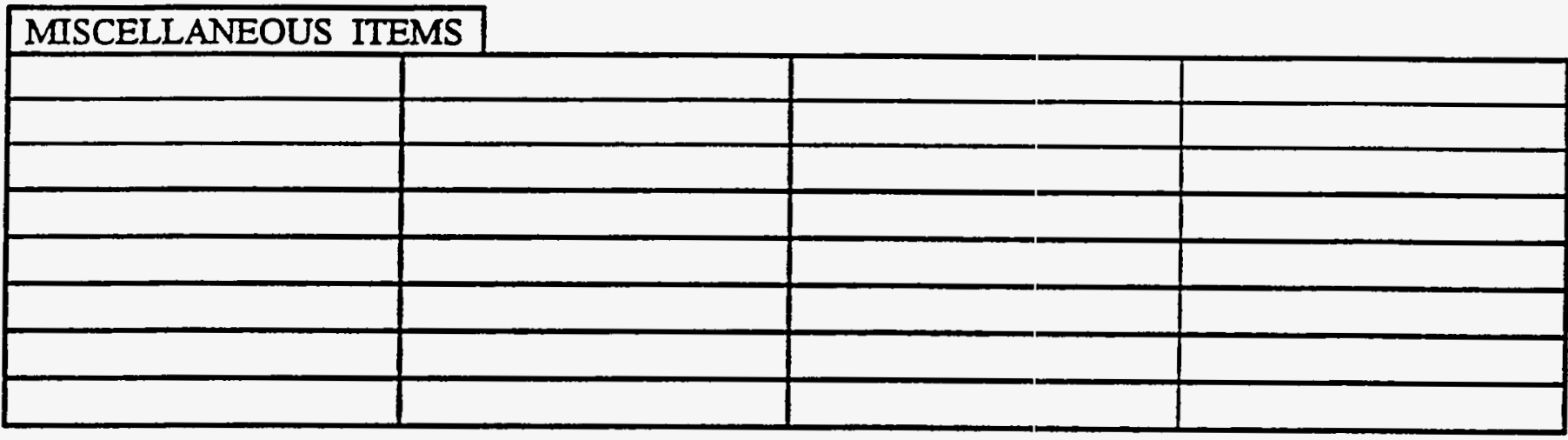

* Initial Abatement Report costs shall not exceed \$250.00.

** Free Product Recovery Report costs shall not exceed $\$ 125.00$.

*** Initial Site Characterization Report costs shall not exceed \$ 1500.00 


\section{Tennessee Department of ENVIRONMENT AND CONSERVATION DIVISION OF UNDERGROUND STORAGE TANKS}

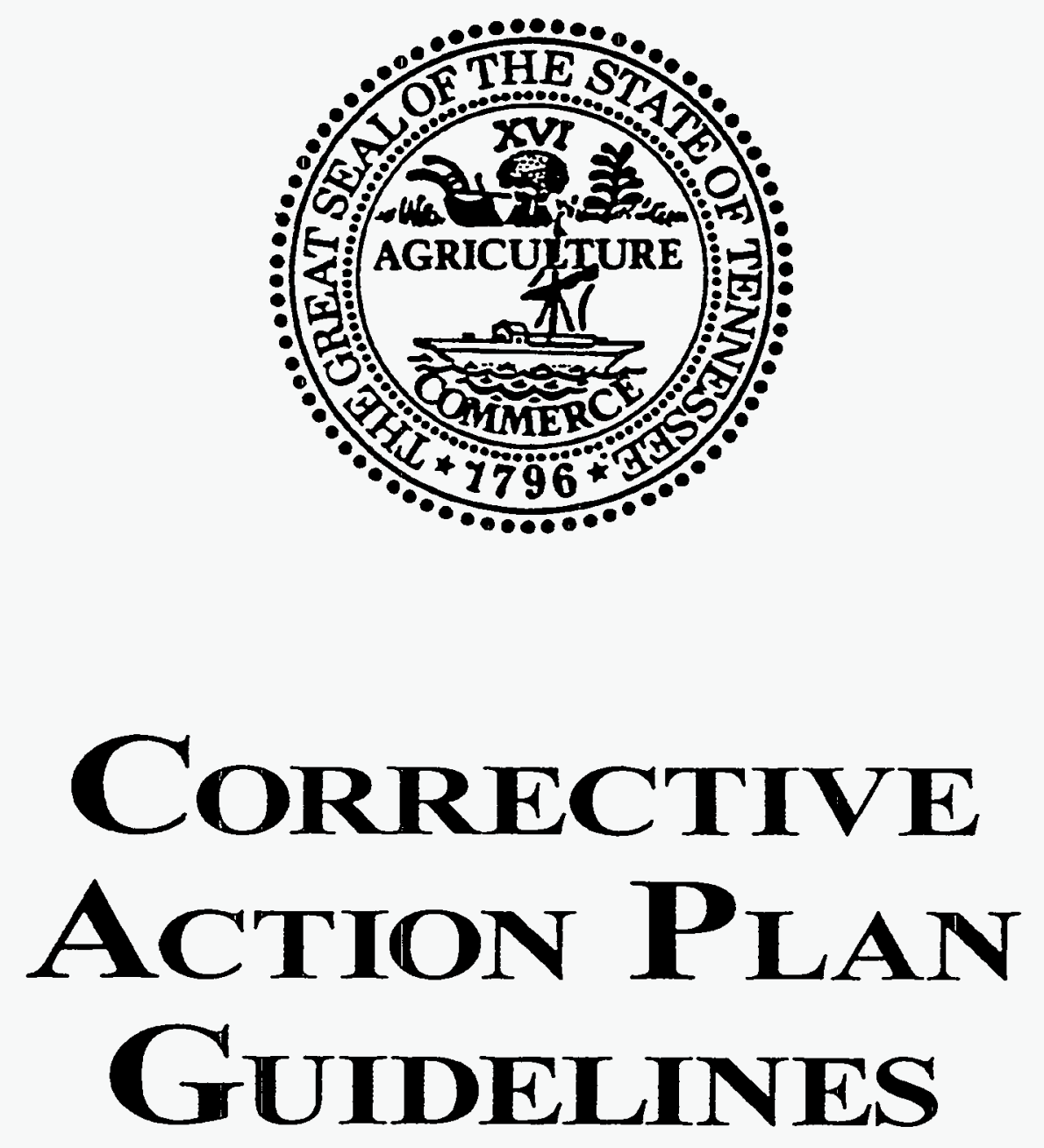

JANUARY 1994 


\title{
TENNESSEE DEPARTMENT OF ENVIRONMENT AND CONSERVATION
}

\section{DIVISION OF UNDERGROUND STORAGE TANKS}

\author{
CORRECTIVE ACTION PILAN
}

\section{GUIDELINES}

\section{INSTRUCTONS:}

A Corrective Action Plan (CAP) shall be prepared and submitted upon completion of the Environmental Assessment Report (EAR) if required. The CAP shall be received within one hundred and fifty (150) calendar days after the Responsible Party has been directed by the Division of Underground Storage Tanks (the Division) to begin an environmental investigation. A Geologist or Professional Geologist, as defined under T.C.A. 62-36-101, or a duly licensed Professional Engineer shall be retained to supervise all geologic work specified in this document. A duly licensed Professional Engineer shall be retained to oversee all corrective action design specifications. This plan shall contain a discussion of the three most technologically feasible and reliable corrective action options which were considered. This plan shall describe in detail the specifications of these corrective actions along with a detailed, itemized cost summary. Keep in mind that the corrective actions chosen shall be the most cost effective options that are technologically feasible and reliable.

If the contaminant plumes are not defined by the established deadline, this plan shall NOT be submitted, but a written, justified extension request shall be submitted to the appropriate field office and the central office. The extension is not automatic and enforcement actions may be taken to insure prompt compliance with established deadlines. Failure to meet established deadlines may place the responsible party out of substantial compliance and may result in the loss of fund coverage.

Each section of the CAP must be assembled in the order presented within these guidelines. Each section shall contain a prepared text that includes the required elements of the section. This text shall provide explanations of the associated tables and maps. All maps and tables shall be in the section in which they are intended, not in appendices. All maps shall be drawn on $11 \times 17$ inch paper (maximum) and contain at a minimum a north arrow, legend, scale bar, vertical scale if applicable and figure number. These guidelines are intended to provicle a structured outline. Any information that is not specifically requested but is relevant to the project shall also be included. The preparer shall assemble the information provided in each section so as to provide a comprehensive and cohesive final document. Each section and subsection heading must be clearly printed in the report. A table of contents shall be provided listing the location of all sections, maps, tables and appendices.

If no soil or ground water contamination above the applicable cleanup levels was found, no further action is necessary and the CAP does not need to be completed. If only soil or only ground water contamination is present above the applicable cleanup levels, only the relevant portions of the CAP need be completed. 
If the responsibie party believes the site should not be subject to the applicable cleanup requirements detailed in Appendices 3 and 4 of the UST Regulations, then the responsible party may petition the Commissioner for a Site Specific Standard as outlined in Rule 1200-1-15-.06(7)(e)5. \& 6. The requirements for requesting a Site Specific Standard are listed in Technical Guidance Document - 008. If the responsible party intends to petition for a Site Specific Standard, the request should be submitted in lieu of the CAP by the established deadline.

IMPORTANT NOTE: All correspondence, reports, laboratory analysis sheets, etc. shall contain the TN UST Facility ID Number. A copy of all correspondence and reports shall be submitted to the UST central office and the appropriate field office.

\section{CORRECTIVE ACTIOH PLAN (CAP)}

This Corrective Action Plan shall provide information concerning the three most technologically feasible and reliable corrective action options that were evaluated and the detailed specifications and costs. The Cost Estimate Cover Sheet and Corrective Action Cost Estimate Form (see attachments to CAP) shall be included with the CAP. The costs incurred to date for all previous activities shall be included on the Cost Estimate Cover Sheet. A detailed breakdown of the estimated costs of the three most technologically feasible and reliable corrective actions for soil and ground water shall be presented in Corrective Action Cost Estimate Form. This section shall be completed only after all contaminant plumes have been fully defined to the applicable cleanup levels.

\section{A. APPLICABLE CLEANUP LEVELS}

State the applicable cleanup levels for soil and/or ground water as determined in the Environmental Assessment Report.

\section{B. CORRECTIVE ACTIONS CONSIDERED}

1. SOIL

Summarize the three most technologically feasible and reliable corrective action options considered to fully remediate petroleum contaminated soil to the applicable cleanup levels. Include for each option considered, the projected time for completion of remediation. Briefly describe the advantages and disadvantages of each option as they relate to this project. In addition to the technological considerations, any capital costs for equipment, operation and maintenance costs, life expectancy of equipment and installation costs shall be discussed.

\section{GROUND WATER}

Summarize the three most technologically feasible and reliable corrective action options considered to fully remediate petroleum contaminated 
ground water to the applicable cleanup levels. Include for each option considered, the projected time for completion of remediation. Briefly describe the advantages and disadvantageis of each option as they relate to this project. In addition to the technological considerations, capital costs for equipment, operation and maintemance costs, life expectancy of equipment and installation costs shall be discussed.

\section{CORRECTIVE ACtIONS ChOSER}

\section{SOIL CORRECTIVE ACTIORS}

Provide a description of the corrective action option(s) chosen for soil remediation. Specify why this system or method is best suited for remediation at this site including the life expectancy of the project and the calculated effective radius of influence (show calculations). If a soil venting system is to be used, a minimum vacuum of 1 inch of water shall be used to define the effective radius of influence. If a soil venting system is not proposed, provide justification as to why this option is not technologically feasible or cost effective. Provide a map showing the calculated effective radius of influence of the remediation system overlaid on maps of the horizontal and vertical contaminant plumes which were supplied in the EAR. Provide an equipment flow diagram including all components of the remediation system. Include a detailed discussion of the following topics at a miniroum, if applicable:

a. Capital costs (Prepackaged systems should not be broken into individual components.)

b. Individual component specifications

c. Installation costs

d. Excavation and disposal costs (if applicable)

e. Operation and maintenance requirements and costs

f. Monitoring and reporting costs

If any soil corrective action is in operation or has been completed, describe how this will affect the proposed option and show the measured effective radius of influence.

If a Soil Venting System is to be operated provide the rationale for the design and placement of the vapor extraction wells and the vacuum pump sizing.

\section{GROUID WATER CORRECTIVE ACTIONS}

Provide a description of the corrective action option chosen for ground water remediation. If a prepackaged, predesigned treatment system is not proposed, provide justification that the costs to design, construct, install operate and maintain the proposed system does not exceed that of a prepackaged system. Specify why this system or method is best suited for remediation at this site including the life expectancy of the 
project and the calculated effective radius of influence (show calculations). A minimum of 0.5 feet drawdown at the edge of the plume is required to be considered an effective radius of influence. Provide a map showing the calculated effective radius of influence of the remediation system overlaid on maps of the horizontal and vertical contaminant plumes which were supplied in the EAR. Include a discussion concerning the number, depth and placement of recovery wells as it relates to the life expectancy of the project. Provide a flow diagram including all components of the remediation system. Disposal options for treated effluent shall be discussed. Specifically why reinjection would not be the most cost effective or technologically feasible. Include a detailed discussion of the following topics at a minimum, if applicable:

a. Capital costs (Prepackaged systems should not be broken into individual components.)

b. Individual component specifications

c. Installation costs

d. Operation and maintenance requirements

e. Pump rates (GPM)

f. Monitoring and reporting costs

g. Effluent discharge options and costs

If any emergency or interim corrective actions are currently in operation (e.g. free product removal, etc.), explain how the implementation of the proposed corrective action will enhance or alter the current system. If the system is currently in operation, show the actual, measured radius of influence.

[NOTE: Proposed corrective actions must actively remediate, entirely encompass, and prevent further migration of the contaminant plume(s).]

\section{PROPOSED IMIPLEMENTATION SCHEDULE}

Provide a detailed schedule of all events necessary to implement the proposed corrective action through system start-up. This schedule shall not exceed 60 days from the time this Division approves a CAP.

\section{E. MONITORING and REPORTING}

Based upon site specific information, propose the monitoring wells to be utilized during the site status monitoring to measure the effectiveness of the corrective action system. Also any springs, water supplies or other areas of concern shall be proposed to be monitored. All monitoring and reporting shall be performed in accordance with Technical Guidance Document - 007. A detailed cost estimate of monitoring and reporting shall be included in the Corrective Action Cost Estimate Form. 


\section{F. Signature PAGE}

A signature page, as shown below, shall be attached to the Corrective Action Plan. A Geologist or Professional Geologist, as defined uniter T.C.A. 62-36-101, or a duly licensed Professional Engineer shall sign this document attesting to all geologic work specified in this document. A duly licensed Frofessional Engineer shall sign this document attesting to all corrective action design specifications. Each signee shall provide a statement of fact attesting to the portions of the report for which they were responsible.

I certify under penalty of law, including but not limited to penalties for perjury, that the information contained in the Corrective Action Plan and on any attachments, is true, accurate and complete to the best of my knowledge, information, and belief. I am aware that there are significant penalties for submitting false information, including the possibility of fine and imprisonment for intentional violations.

Owner/Operator Name (Print)

Date

Signature

Print Name \& Title

Date

$\overline{\text { License \# }}$

(Geologic Sections)

Signature

Print Name \& Title

(Engineering Design Sections)

Date

License \#

Signature

If a P.E. signs the report, please indicate the area of expertise.

Name

Name
Area of expertise

Area of expertise

STATE OF

Sworn to and subscribed before me by on this date

My commission expires

$\overline{\text { Notary Public - Print Name }}$

Signature 


\section{TENNESSEE UST COST ESTMMATE COVER SHEET}

FACILITY INFORMATION

Facility Name

Address

street city

CORRECTIVE ACTION CONTRACTOR

Name

Address

street

Contact Person
Facility ID\#

zip phone

\section{COSTS}

\begin{tabular}{|c|c|c|}
\hline Submit with ISCR & Estimated Costs & Actual Costs \\
\hline Site Check: : & & \\
\hline Initial Abatement / Emergency Response & & \\
\hline Free Product Recovery & & \\
\hline Intial Site Characterization & & \\
\hline Environmental Assessment. & & \\
\hline Environimental Assessment Report & & 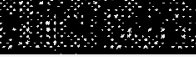 \\
\hline
\end{tabular}

Signature of Person Completing Estimate

Date

Signature of Owner/Operator

Date

\begin{tabular}{|l|c|c|}
\hline Submit with EAR & Estimated Costs & Actual Costs \\
\hline \hline Environmental Assessment & & \\
\hline Environmental Assessment Report & & \\
\hline Corrective Action Plan & & \\
\hline
\end{tabular}

Signature of Person Completing Estimate

Date

Signature of Owner/Operator

Date

\begin{tabular}{||l|c|c|}
\hline Submit with CAP & Estimated Costs & Actual Costs \\
\hline \hline Corrective Action Plan & & \\
\hline Corrective Action & & \\
\hline Monitoring & & \\
\hline Operation \& Maintenance & & \\
\hline Closure & & \\
\hline
\end{tabular}

Signature of Person Completing Estimate Date Date 
TN UST Facility ID \#

CHECK ONE

D Soil Corrective Action

- Ground Water Corrective Action

Define Technologies
A.
B.
C.

\begin{tabular}{|l|l|l|r|}
\hline Corrective Action Implementation & Technology A & Technology B & Technology C \\
\hline Project Life & Year(s) & Year(s) & Year(s) \\
\hline Capital Equipment (List all equipment in & & & \\
\hline excess of \$ 500) & & & \\
\hline & & & \\
\hline & & & \\
\hline & & & \\
\hline Shipping & & & \\
\hline Miscellaneous parts and supplies & & & \\
\hline Drilling & & & \\
\hline Excavation & & & \\
\hline Trucking & & & \\
\hline Surveying & & & \\
\hline Other Services & & & \\
\hline & & & \\
\hline One Comprehensive Monitoring Event & & & \\
\hline & & & \\
\hline Rentals (List Below) & & & \\
\hline & & & \\
\hline Disposal - Free Product & & & \\
\hline Water & & & \\
\hline Soil & & & \\
\hline Utilities & & & \\
\hline Permitting & & & \\
\hline Lodging and Per Diem & & & \\
\hline Mileage & & & \\
\hline Miscellaneous (List Below) & & & \\
\hline Installation of system: (All Labor) & & & \\
\hline /mile & & & \\
\hline Subtotal & & & \\
\hline & & & \\
\hline & & & \\
\hline & & & \\
\hline
\end{tabular}




\begin{tabular}{|l|l|l|l|}
\hline Operations and Maintenance (per month) & Technology A & Technology B & Technology C \\
\hline Professional Services & & & \\
\hline Permitting & & & \\
\hline Utilities (per month) & & & \\
\hline Supplies Miles Imile & & & \\
\hline Disposal X & & & \\
\hline Lodging and Per Diem SUBTOTAL & & & \\
\hline Mileage & & & \\
\hline & & & \\
\hline Miscellaneous & & & \\
\hline & & & \\
\hline $\begin{array}{l}\text { Subtotal of O\&M (Monthly Subtotal X } \\
\text { Project Life In Months) }\end{array}$ & & & \\
\hline
\end{tabular}

\begin{tabular}{|l|l|l|l|}
\hline Site Monitoring (per month) & Technology A & Technology B & Technology C \\
\hline Professional Services & & & \\
\hline Analytical & & & \\
\hline Supplies & & & \\
\hline Disposal X S /mile & & & \\
\hline Lodging and Per Diem MuBTOTAL & & & \\
\hline Mileage Miles & & & \\
\hline Miscellaneous & & & \\
\hline \multicolumn{2}{|c|}{} & & \\
\hline $\begin{array}{l}\text { Subtotal of Site Monitoring (Monthly } \\
\text { Subtotal X Project Life In Months) }\end{array}$ & & & \\
\hline
\end{tabular}

\begin{tabular}{|l|l|l|l|}
\hline Reporting (per month) & Technology A & Technology B & Technology C \\
\hline Professional Services & & & \\
\hline Miscellaneous SUBTOTAL & & & \\
\hline & & & \\
\hline $\begin{array}{l}\text { Subtotal of Reporting } \\
\text { (Monthly Subtotal X Project Life In Months) }\end{array}$ & & & \\
\hline
\end{tabular}

\begin{tabular}{|l|l|l|l|}
\hline Site Closure (per month) & Technology A & Technology B & Technology C \\
\hline Professional Services & & & \\
\hline Supplies & & & \\
\hline Lodging and Per Diem Xiles X /mile & & & \\
\hline Mileage SUBTOTAL & & & \\
\hline Miscellaneous & & & \\
\hline & & & \\
\hline $\begin{array}{l}\text { Subtotal of Site Closure } \\
\text { (Monthy Subtotal X Project Life In Months) }\end{array}$ & & & \\
\hline
\end{tabular}


APPENDIX G

TENNESSEE DEPARTMENT OF ENVIRONMENT ANID CONSERVATION UNDERGROUND STORAGE TANK.

TECHNICAL GUIDANCE DOCUMENTS 

STATE OF TENNESSEE

\section{DEPARTMENT OF ENVIRONMENT AND CONSIERVATION \\ DIVISION OF UNDERGROUND STORAGE TANKS \\ TECHNICAL GUIDANCE DOCUMENT . 002 \\ EFFECTIVE DATE - AUGUST 28, 1991 \\ REVISED DATE - JANUARY 14, 1992 \\ REVISED DATE - JUNE 28, 1993}

RE: PROCEDURE FOR DETERMINING THE GROUND WATER CLASSIFICATION OF A CONTAMINATED AQUIFER OR WATER SOURCE

Division Rule 1200-1-15-.01(3)(p) defines "Drinking water supply" as:

"Any aquifer or water source whose chemical characteristics meet the primary and secondary drinking water standards as defined under rule 1200-5-1 and provides a yield of at least one-half gallon per minute. This shall also include any water supply used for drinking by citizens of the state."

The procedures outlined in Section II L. of the Environmental A.ssessment Guidelines shall be followed when determining if the ground water at a site meets the above referenced definition.

\section{TENNESSEE DIVISION OF WATER SUPPLY \\ MAXIMUM CONTAMINANT LEVEIS \\ RULE 1200-5-1-.06, 12, AND 25}

A. Primary Standards

1) Inorganic Chemicals

LEVEL, PPM

Arsenic

Asbestos (Fibers)

0.05

Barium

7.0

Cadmium

2.0

Chromium

0.005

Fluoride

0.1

Lead

4.0

Mercury

Nitrate (as nitrogen)

0.05

Nitrite (as nitrogen)

0.002

Total Nitrate and Nitrite (as nitrogen)

10.0

Selenium

2) Organic Chemicals

a) Chlorinated Hydrocarbons:

Endrin $(1,2,3,4,10,10$-hexachloro-6,

7-epoxy-1, 4, 4 A, 5, 6, 7, 8, 8 a-octahydro-1,

4-endo, endo-5, 8-dimethano naphthalene)

0.0002 
b) Alachlor

Atrazine

0.002

Carbofuran

0.003

Chlordane

0.04

Dibromadichloropropane

0.002

2,4, Dichlorophenoxyacetric acid

0.0002

Ethylene dibromide

0.07

Heptachlor

0.00005

Heptachlor epoxide

0.0004

Lindane

Methoxychlor

0.0002

Polychlorinated biphenyls

0.0002

Toxaphene

0.04

2,4,5 Trichlorophenoxyproprionic acid

0.0005

Pentachlorophenol

0.003

0.05

0.001

3) Turbidity

The maximum contaminant levels for turbidity in drinking water measured at a representative entry point(s) to the distribution system, are:

a) one (1.0) turbidity unit, as determined by a monthly average pursuant to Regulation 1200-5-1-.08.

b) two (2.0) turbidity units based on an average for two consecutive days pursuant to Regulation 1200-5-1-.08.

4) Microbiological

The maximum contaminant levels for microbiological are applicable to both community water systems and non-community water systems.

a) The maximum contaminant level (MCL) is based on the presence or absence of total coliforms in a sample, rather than coliform density.

The number of total coliform positive samples shall not exceed any of the following:

1. For a system which collects at least $\mathbf{4 0}$ samples per month, if no more than 5.0 percent of the samples collected during a month are total coliform-positive, the system is in compliance with the MCL for total coliforms.

2. For asystem which collects fewer than 40 samples/month, if no more than one sample collected during a month is total coliform-positive, the system is in compliance with the MCL for total coliforms.

3. A public water system which has exceeded the MCL for total coliforms must report the violation to the State no later than the end of the next business day after it learns of the violation and notify the public in accordance with the schedule of $1200-5-1-.19$ (1) using the language specified in 1200-5-.19(1)(i).

4. A public water system which has failed to comply with the coliform monitoring requirements, including a sanitary survey requirement must 
report the monitoring violation to the State within ten (10) days after the system discovers the violation and notify the public in accordance with 1200-5-1-.19(1).

b) Any fecal coliform-positive repeat sample or E. coli-positive repeat sample, or any total coliform-positive repeat sample following a fecal coliform-positive or E. coli-positive routine sample constitutes a violation of the $\mathrm{MCL}$ for total coliforms. For purposes of the public notification requirements in [1200-5-1-.19(1)(a)3.] this is a violation that may pose an acute risk to health, and the language specified by $1200-5-1-.19(5)(j)$ must be used.

c) Fecal coliforms/Escherichia coli (E. coli) testinģ,

1. If any routine or repeat sample is total. coliform-positive, the system must analyze that total coliform-positive culture medium to determine if fecal coliforms are present, except that the system may test for $E$. coli in lieu of fecal coliforms. If fecal coliforms or E. coli are present, the system must notify the State by the end of the day when the system is notified of the test results, unless the system is notified of the result after the Department office is closed, in which case the system must notify the State before the end of the next business day.

2. The State has the discretion to allow a public water system, on a case-by-case basis, to forgo fecal coliform or E. coli testing on a total coliform-positive sample if that system assumes that the total coliform-positive sample is fecal coliform-positive or E. coli-positive. Accordingly, the system must notify the State as specified in paragraph (c)(1) of this section and the provisions of 1200-5-1-.06(4)(b) apply.

d) A public water system must determine compliance with the MCL for total coliforms in (a) and (b) of this section for each month in which it is required to monitor for total coliforms.

e) No variance or exemptions from the maximum contaminant level for total coliforms are permitted.

\section{5) Radionuclides}

a) The following maximum contaminant levels for radium-226, radium-228, and gross alpha particle radioactivity are applicable to all community water systems:

1. Combined radium-226 and radium-228: $-5 \mathrm{pCi} / 1$.

2 Gross alpha particle activity (including radium-226 but excluding radon and uranium): $-15 \mathrm{pCi} / 1$.

b) Maximum contaminant levels for beta particles and photon radioactivity from man-made radionuclides in community water systems shall be as follows:

1. The average annual concentrations of beta particle and photon radioactivity from man-made radionuclides in drinking water shall not produce an annual dose equivalent to the total body or any internal organ greater than four (4) millirem/year.

2. Except for radionuclides listed in Table $\mathbf{A}$, the concentration of man-made radionuclides causing four ( 4 ) mrem total body or organ 


\section{G-6}

dose equivalents shall be calculated on the basis of a two (2) liter per day drinking water intake using the 168 hour data listed in "Maximum Permissible Body Burdens and Maximum Water for Occupational Exposure," NBS Handbook 69 as amended August 1963, U.S. Department of Commerce. If two or more radionuclides are present, the sum of their annual dose equivalent to the total body or to any organ shall not exceed four (4) millirem/year.

TABLE A

Average Annual Concentrations

Assumed to Produce a Total Body or Organ Dose of a $4 \mathrm{mrem} / \mathrm{yr}$.

$\begin{array}{llr}\text { Radionuclide } & \text { Critical } & \text { pCi } \\ \text { Organ } & \text { per } \\ \text { Tritium } & \text { Total Body } & 20,000 \\ \text { Strolntium-90 } & \text { Bone Marrow } & 8\end{array}$

B. Secondary Standards

Level, PPM

Chloride

Color (In Color Units)

Copper

MBAS (Methyl Blue Active Substance)

1

Iron

0.5

Manganese

Odor (In Threshold Odor Number)

0.3

$\mathrm{pH}$

Sulfate

0.05

3

TDS (Total Dissolved Solids)

Zinc

250

Fluoride

500

Aluminum

2.0

Silver

0.2

0.1

C. Volatile Organic Chemicals

Trichloroethylene

Carbon tetrachloride

Vinyl chloride

1,2-Dichloroethane

Benzene

1,1-Dichloroethylene

1,1,1-Trichloroethane

para-Dichlorobenzene

0.005

0.005

0.002

0.005

0.005

cis 1,2-Dichloroethylene

0.007

0.20

1,2-Dichloropropane

Ethyl benzene

0.075

0.07

Monochlorobenzene

0.005

0.7

ortho-Dichlorobenzene

0.1

Styrene

0.6

Tetrachloroethylene

0.1

Toluene

0.005

trans 1,2-Dichloroethylene 1

Xylenes (total) 


\section{STATE OF TENNESSEE \\ DEPARTMENT OF ENVIRONMENT AND CONSERVATION \\ DIVISION OF UNDERGROUND STORAGE TANKS}

TECHNICAL GUIDANCE DOCUMENT - 004

EFFECTIVE DATE - AUGUST 29, 1991

REVISED DATE JULY 8, 1993

\section{RE: REQUIREMENTS FOR FREE PRODUCT REMOVAL}

The purpose of this document is to assist the regulated community in understanding the requirements for free product (nonaqueous phase liquid) removal defined under Rule 1200-1-15-.06(5). Situations which require free product removal are:

1. A measured thickness greater than 0.10 inches of free product in a well;

2. The presence of a sheen on a surface body of water; or

3. The presence of a sheen on the ground or within a subsurface structure.

An eligible owner or operator conducting UST corrective actions is entitled to coverage of reasonable costs from the Tennessee Petroleum Underground Storage Tank Fund, subject to rule 1200-1-15-.09(11)(a), which states:

Upon confirmation of a release in accordance with rule 1200-1-15-.05(3) or after a release from the UST system is identified in any other manner, owners and operators must perform initial response actions required in rule 1200-1-15-.06(2), initial abatement measures required in rule 1200-1-15-.06(3)(a)1. through 4. and rule 1200-1-15-.06(3)(b), and initial free product removal according to rule 1200-1-15-..06(5) and rule 1200-1-15-.06(3)(a)6. necessary to properly stabilize a site and to prevent significant continuing damage to the environment or risk to human health.

Therefore, failure to comply with the requirements of this Technical Guidance Document may result in the loss of Fund coverage.

At sites where free product removal is required, equipment capable of continuous free product removal must be installed within 48 hours, unless otherwise specified by the Division. The minimum objective for the design of the removal system is to stop the migration of free product. Where surface water is impacted, petroleum absorbent materials such as booms and pads must be installed and replaced whenever necessary. Flammable products must be handled in a safe and competent manner to prevent fires or explosion.

Unless directed to do otherwise by the Division, prepare and submit, within 45 days after confirming. a release, a Free Product Removal Report in the format established by the Division. 
STATE OF TENNESSEE

DEPARTMENT OF ENVIRONMENT AND CONSERVATION

\section{Division of Underground Storage Tanks \\ Technical Guidance Document - 007 \\ Effective Date -January 1, 1994}

\section{RE: Monitoring at UST Sites}

The purpose of this Technical Guidance Document (TGD) is to assist the regulated community in determining the requirements for periodic monitoring and reporting at UST sites.

All work associated with this TGD shall be conducted in accordance with the applicable sections of the Environmental Assessment Guidelines.

\section{Monitoring Program Components}

A. Comprehensive

Comprehensive Monitoring shall consist of the following activities in sequence:

1. Water

a. Obtaining water level measurements from all monitoring wells;

b. Sampling all monitoring wells and recovery wells; and,

c. Sampling all springs and water supplies approved by the Division

2. Vapor monitoring of all subsurface structures (i.e. basements, utility vaults, sewers, etc.) within the contaminant plume(s). All structures which have been previously impacted by petroleum vapors, shall also be monitored.

B. Site Status

Site Status Monitoring shall consist of the following activities:

1. Water

a. Obtaining water level measurements from all monitoring wells;

b. Sampling all monitoring wells approved by the Division; 
C. Sampling all springs and water suppiies approved by the
Division; and,

d. Sampling the influent and effluent of the ground water treatment system, if applicable.

2. Vapor Monitoring of all subsurface structures (i.e. basements, utility vaults, sewers, etc.) within the contaminant plume(s). All structures which have been previously impacted by petroleum vapors, shall also be monitored.

3. Emissions Monitoring from the soil vapor extraction system, if applicable. At a minimum, measurements of the total volatiles as measured by an organic vapor detector, $\mathrm{O}_{2}$, and $\mathrm{CO}_{2}$ shall be taken.

C. Soil

Soil Monitoring shall consist of the installation of one boring in the location where the highest level of soil contamination is known to exist through previous site assessment activities.

\section{Monitoring Programs}

A. Corrective Action

Corrective Action Monitoring shall be performed upon approval of the Corrective Action Plan by the Division, and consist of the following:

1. Comprehensive Monitoring shall be conducted prior to the start-up of the ground water corrective action system.

2. Site Status Monitoring shall be conducted semiannually (twice a year) thereafter until the ground water contaminant concentrations decrease below the applicable cleanup levels. Closure Monitoring shall commence 20 to 30 days after the Division approves the termination of the ground water corrective action system in accordance with Item $C$. below.

3. Soil Monitoring shall commence two year's after the soil corrective action system becomes operational. It shall continue every two years until the soil contaminant concentrations decrease below the applicable cleanup levels.

B. Monitoring Only

A monitoring only program shall be implemented up on the Division's approval and consist of the following: 
1. Comprehensive Monitoring shall be conducted 20 to 30 days after the Division approves a monitoring only request.

2. Site Status Monitoring shall be conducted semiannually (twice a year) thereafter until:

a. Contaminant concentrations are below the applicable cleanup levels; or,

b. The Division requires additional activities.

If the analytical results indicate contaminant concentrations have decreased below the applicable cleanup levels, Closure Monitoring shall commence the next quarter in accordance with Item $C$. below and upon approval of the Division.

3. Soil Monitoring shall be performed every two years, until the soil contaminant concentrations are below the applicable cleanup levels or the Division requires additional activities.

C. Closure

Closure Monitoring is to determine that the ground water contaminant concentrations remain below the applicable cleanup levels for one year and consist of four (4) consecutive quarters of sampling using the following procedures:

1. Comprehensive Monitoring shall be conducted 20 to 30 days after the Division approves the start of a Closure Monitoring Program.

2. Site Status Monitoring shall be performed the second and third quarters.

3. Comprehensive Monitoring shall be conducted the fourth quarter.

If contaminant concentrations are detected above the applicable cleanup levels during closure program, additional activities associated with corrective action shall be required.

The Division reserves the right to modify these monitoring requirements at any time.

\section{Report Preparation}

Within thirty (30) days after sample collection, a report shall be prepared and submitted containing the following information:

\section{A. Progress}

If any corrective action has taken place since the last report, briefly describe the progress of the corrective action system(s) to date. 
1. Based upon the readings taken during routine $0 \& M$ visits to the site, what is the average flow rate and the estimated total gallons of water treated for the reporting period. (Report this amount in Table 1)

2. Based upon the last analytical results obtained during the reporting period, estimate the total pounds of Benzene and TPH removed via ground water treatment during the reporting period and the total pounds removed to date. Include all calculations. (Report this amount in 'Table 1)

3. Provide in Table 1 the monthly $O \& M$ costs incurred at the site and the total $O \& M$ costs to date. $O \& M$ costs shall include but not be limited to the following: all personnel time on and off site, report preparation, analytical costs, equipment rental, supplies, capital equipment, repairs, utilities, fees, per diem and mileage. If modifications are made to the system, briefly explain the modifications and why they were necessary.

B. Problems

Briefly describe any problems which have been encountered with the corrective action system(s) since the previous report and the actions taken to resolve the problem. Report the percent of time the treatment system was out of operation during the reporting period due to system failure. (Report this amount in Table 1)

C. Water Monitoring

1. Potentiometric Data

a. Provide a table, prepared in accordance with Section D.1.c. of the Environmental Assessment Report Guidelines (EARG), from the data collected during the last two monitoring periods.

b. Provide two potentiometric maps, prepared in accordance with Section D.1.d of the EARG, from the data collected during the last two monitoring periods.

\section{Analytical Data}

a. Provide a table, prepared in accordance with Section D.5 of the EARG, for the water analytical results from the last four (4) monitoring periods.

Include in an appendix the laboratory analysis sheets from the most recent sampling event.

b. If Comprehensive Monitoring was conducted during the current monitoring period provide a plume map(s) prepared in accordance with Section D.7.a. of the EARG. 
D. Vapor Monitoring Results

Describe the results of the vapor monitoring. Provide a map showing the locations of the sampling points and a table indicating the results of the sampling.

E. Emissions Monitoring Results

Describe the results obtained from the monitoring of any soil vapor extraction systems and provide a table with the results of the last four sampling events.

F. Soil Monitoring Results

Describe the results of any soil sampling if it was conducted during the reporting period. Provide a table with all soil analytical results obtained in accordance with this TGD.

G. Additional Information

Provide any additional information which was included in the approved CAP or required by the Division. If applicable, provide this additional information in tables or maps, in an appropriate format. 


\section{G-13}

\section{Signature Page}

I certify under penalty of law, including but not limited to penalties for perjury, that the information contained in this report and on any attachments, is true, accurate and complete to the best of my knowledge, information, and belief. I am aware that there are significant penalties for submitting false information, including the possibility of fine and imprisonment for intentional violations.

$\overline{\text { Owner/Operator (Print) }}$

P.E. or P.G. (Print)
Signature

Signature TN Lic./Reg. \# $\overline{\text { Date }}$

Date

If a P.E. signs the report, please indicate the area of expertise.

(Print or Type)

Stamp/Seal

All signatures above must be notarized.

STATE OF

Sworn to and subscribed before me by on this date

My commission expires

Notary Public - Print Name

Signature 


\section{MONITORING REPORT \\ Table 1}

\section{TN UST FACILITY ID NUMBER:}

\begin{tabular}{|l|l|l|l|l|}
\hline $\begin{array}{l}\text { Reporting } \\
\text { Period }\end{array}$ & From: & Fo: & From: & From: \\
\hline $\begin{array}{l}\text { Avg. Flow Rate } \\
\text { GPM }\end{array}$ & & & & \\
\hline $\begin{array}{l}\text { Total Gallons } \\
\text { Pumped Per Period }\end{array}$ & & & & \\
\hline $\begin{array}{l}\text { Cumulative Total- } \\
\text { Gallons Pumped }\end{array}$ & & & & \\
\hline $\begin{array}{l}\text { \% Time System } \\
\text { Was Down }\end{array}$ & & & & \\
\hline $\begin{array}{l}\text { Pounds of Benzene } \\
\text { Removed-H2O } \\
\text { Phase }\end{array}$ & & & & \\
\hline $\begin{array}{l}\text { Cumulative Pounds } \\
\text { of Benzene } \\
\text { Removed-H2O }\end{array}$ & & & & \\
\hline $\begin{array}{l}\text { Pounds of TPH } \\
\text { Removed-H2O } \\
\text { Phase }\end{array}$ & & & & \\
\hline $\begin{array}{l}\text { Cumulative Pounds } \\
\text { of TPH Removed- } \\
\text { H2O Phase }\end{array}$ & & & & \\
\hline
\end{tabular}

The Reporting Period described above shall be a six month interval.

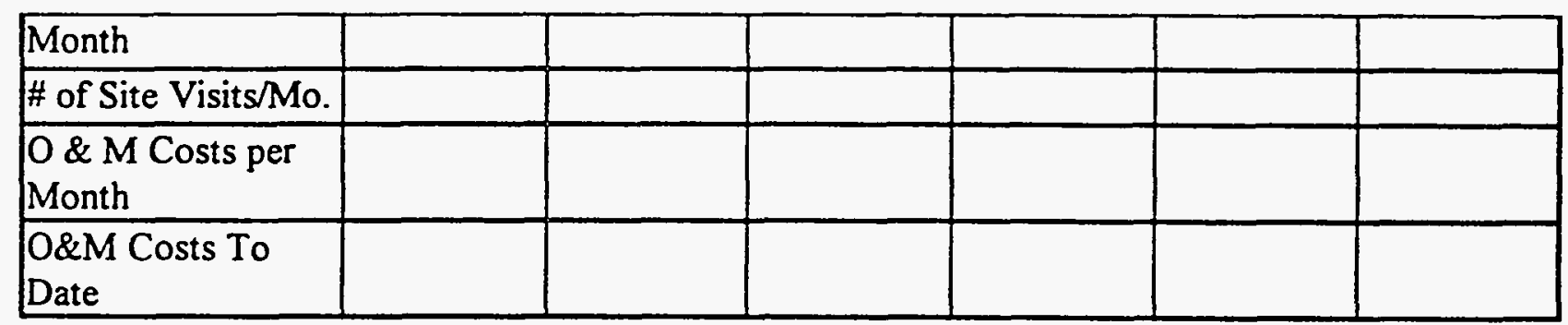

The Reporting Period for O \& $M$ costs is monthly. 


\section{UST Monitoring Program Summary}

Table 1

\begin{tabular}{|c|c|c|}
\hline Monitoring Program Components & Frequency & Description \\
\hline $\begin{array}{l}\text { Comprehensive } \\
\text { (Water and Vapor) }\end{array}$ & $\begin{array}{l}\text { Four (4) Times } \\
\text { 1. Before CA system startup (Baseline) } \\
\text { 2. Upon system shutdown(1st qtr. of } \\
\text { Closure Monitoring) } \\
\text { 3. The 4th quarter of Closure Monitoring } \\
\text { 4. Before beginning a Monitoring Only } \\
\text { Program }\end{array}$ & $\begin{array}{l}\text { Sample all monitoring wells and recovery wells. } \\
\text { Also all springs and water supplies proposed by the CAC } \\
\text { and approved by the Division. } \\
\text { Monitor for vapors in all subsurface structures (i.e. } \\
\text { basement, sewers, utilities) within the contaminant } \\
\text { plume(s). Also any structure previously impacted by } \\
\text { petroleum vapors. }\end{array}$ \\
\hline $\begin{array}{l}\text { Site Status } \\
\text { (Water, Vapor, and Emissions) }\end{array}$ & $\begin{array}{l}\text { 1. Semiannually during the operation of the } \\
\text { corrective action system. } \\
\text { 2. Semiannually during Monitoring Only } \\
\text { 3. During the } 2 \text { nd and } 3 \text { rd quarter of } \\
\text { Closure Monitoring. }\end{array}$ & $\begin{array}{l}\text { Sample all monitoring wells proposed by the CAC and } \\
\text { approved by the Division. } \\
\text { The influent and effluent of the treatment system. } \\
\text { Monitor for vapors in all subsurface structures (i.e. } \\
\text { basement, sewers, utilities) within the contaminant } \\
\text { plume(s). Also any structure previously impacted by } \\
\text { petroteumin vapour } \\
\text { Monitoring of the systems air effluent. }\end{array}$ \\
\hline Soil & $\begin{array}{l}\text { Every two years until achieving soil cleanup } \\
\text { goals. }\end{array}$ & $\begin{array}{l}\text { One boring in the area of highest soil contamination to } \\
\text { monitor contaminant reduction. }\end{array}$ \\
\hline
\end{tabular}




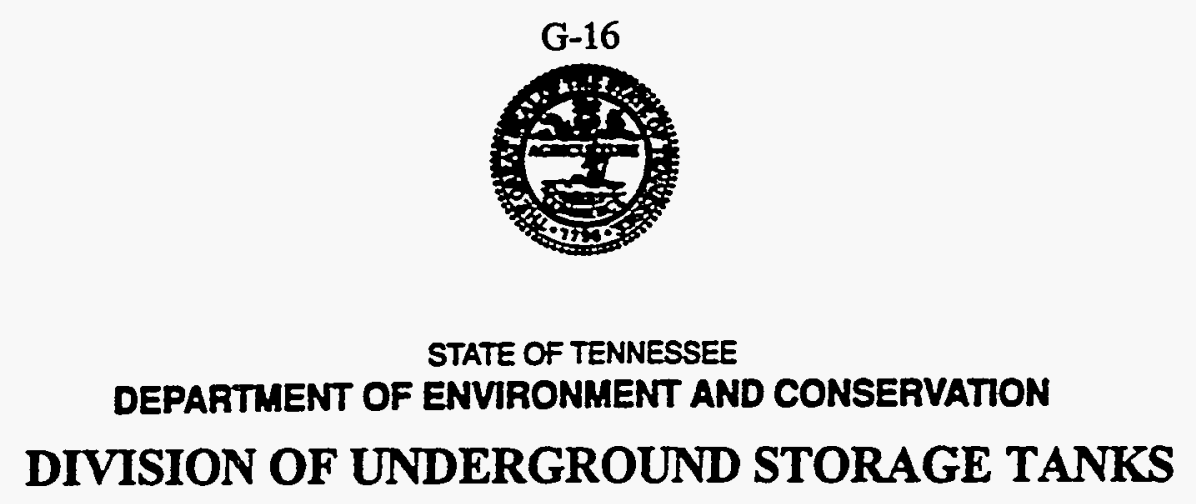

TECHNICAL GUIDANCE DOCUMENT - 008

Effective Date - January 13, 1992

Revised Date - November 19, 1993

\section{RE: Procedure To Obtain a Site-specific Standard For a Petroleum Underground Storage Tank Site}

\section{PURPOSE AND CLARIFICATION}

The purpose of this Technical Guidance Document (TGD) is to provide the owner and/or operator with the minimum requirements necessary to apply for a Site-specific Standard. The development of a Sitespecific Standard Request (Request) may involve significant costs. Submittal does not assure approval of the Request by the Commissioner. The owner and/or operator may petition the Commissioner to grant a Site-specific Standard if:

1. "The owner and/or operator has treated petroleum contamination at a site for an extended period of time and the treatment system for soil and/or ground water has reached asymptotic levels for contaminant removal" as stated in Rule 1200-1-15$.06(7)(e) 4$ (Note: "Asymptotic" is defined as a level of contaminant in the soil and/or ground water which has remained relatively constant for at least four (4) consecutive quarters.).

2. "The owner and/or operator believes that a particular site should not be subject to the cleanup requirements in Appendices 3 and $4^{\prime \prime}$ as stated in Rule 1200-1-15-.06(7)(e)5.

A Site-specific Standard requested in accordance with Rule 1200-1-15-.06(7)(e)5 shall be submitted only after all contaminant plumes have been defined to the applicable cleanup levels and an Environmental Assessment Report (EAR) has been prepared and submitted in accordance with the 1994 revision of the EAR Guidelines. The Request shall be submitted by the Corrective Action Plan (CAP) compliance date. If corrective actions are proposed, the CAP shall be submitted with the Request.

A risk-based assessment (study) may identify sites where conditions warrant a Site-specific Standard. The study must combine information presented in the EAR and a two step evaluation to determine if risks to human health and/or the environment exist. The two step evaluation must include: 
1. Completion of Worksheet 1 comparing the released constituent concentrations and completion of Worksheet 2 comparing the requested constituent concentrations of the contaminant phume(s) to EPA established exposure-limit criteria referenced in:

\section{U.S. EPA. May, 1989. RCRA Facility Investigation (RE) Guidance EPA 530/SW-} 89-031. OSWER Directive No. 9502.00-6D. Office of Solid Waste.

\section{An exposure assessment performed as outlined in Part II of this TGD}

The study may determine that corrective action is necessary. Should it be determined during the study that corrective action is necessary, the owner and/or operator shall:

1. Notify the Division within 72 hours;

2. Incur no further costs to complete a Site-specific Standard Request; and

3. Begin development of a CAP (A compliance date will be established by the Division).

Information gathered during the study shall be submitted as Section $A$ of the CAP. Section A shall contain a detailed, itemized cost summary. Any unnecessary costs incurred to proceed with an unwarranted Request may not be reimbursed by the Petroleun Underground Storage Tank Fund.

Should the Commissioner grant a Site-specific Standard, a monitoring period shall be required. All monitoring and reporting shall be performed in accordance with TGD - 007. The Site-specific Standard may be revoked in accordance with Rule 1200-1-15-.06(7)(e)6 if it is later determined that the information supplied in the request was not accurate or there has bien a change in the information supplied or in actual site conditions.

Should the Commissioner deny the properly completed Request, fail to act within ninety (90) calendar days of receipt or revoke the Site-specific Standard, the owner and/or operator may petition the Petroleum Underground Storage Tank Board for the Site-specific Standard in accordance with Rule $1200-1-15-.06(7)(\mathrm{e}) 5$.

\section{MINIMUM REQUIREMENTS}

Subparts (i) through (v) of Rule 1200-1-15-.06(7)(e)5 require the owner and/or operator to gather specific information regarding the contaminant plume(s) and the surrounding area. The following outline is intended to provide guidance and standard procedures for conducting the risk-based study:

\section{A. Erecutive Summary}

Provide an Executive Summary describing the findings of the project to date. Include conclusions and interpretation of data derived from implementing the environmental 
assessment and/or corrective action activities. The summary shall include the proposed site-specific cleanup levels.

B. Provide the Physical and Chemical Characteristics of Petroleum; Including Its Toxicity, Persistence, and Potential For Migration

1. Physical Characteristics

a. The source(s) of contamination and amount released

b. The background level of each constituent in both the soil and ground water of the area if naturally-occuring petroleum is suspected to exist upgradient of the contaminant plume(s)

c. The media through which the release is spreading or is likely to spread, the direction, and the rate

d. Site maps showing the contaminant plume(s) defined to the applicable cleamup levels as listed in Appendices 3 and 4 of Rule 1200-1-15

e. The results of a Synthetic Precipitation Leach Test (SW-846, Method 1312, July 1992) if BTX soil contamination is present above applicable cleanup levels (Note: The soil sample shall be collected in the area of highest known contamination and analyzed for the ground water constituents in Worksheets 1 and 2)

2. Chemical Characteristics

a. A comparison of the constituents by completing Worksheets 1 and 2 (Note: If the released and requested constituent concentrations are the same, only complete Worksheet 1 . If the released and requested constituent concentrations are different, give the rationale for selecting the requested concentrations.)

b. The mobility of each constituent (i.e., solubility in water, ability to move by vapors, absorption by soil, etc.)

i. Gasoline - Benzene, Ethylbenzene, Toluene, Xylene, Methyl tertiary Butyl Ether, Di-Isopropyl Ether, TPH - Gasoline Range Organics

ii. Diesel, Kerosene, Waste Oil, etc. - TPH - Diesel Range Organics / 418.1 


\section{Provide the Hydrogeologic Characteristics of the Petroleum Site and the Surrounding Land}

1. Petroleum Site
8. The soil permeability as required in Section $E$ of the Environmental Assessment Guidelines (EAG)
b. Ground water recharge area
c. Recharge rate
d. Hydrology (ground water flow gradient, direction, and the occurrence of main aquifers or water bearing zones)

2. Surrounding Land
a. Ground water recharge area
b. Recharge rate
c. Hydrology (ground water flow gradient, direction, and the occurrence of main aquifers or water bearing zones)

\section{Provide the Proximity, Quality, and Current and Future Uses of Ground Water}

1. The ground water classification of the aquifer or water source (i.e. drinking water supply or non-drinking water supply) as required in the EAG

2. Any current and/or future uses of the ground water within a one-half mile radius of the petroleum site (All well and spring locations shall be indicated on an $8.5 \times 11$ or $11 \times 17$ color topographic map.)

3. The depth to each aquifer or water bearing zone encountered during the investigation

\section{E. Perform an Exposure Assessment}

1. Potential exposure routes including any future change in land use (address as appropriate to site)

a. Ground water

i. Oral 


\section{ii. Dermal}

b. Surface water

i. Oral

ii. Dermal

c. Soils

i. Oral
(I) Surficial (12 feet or less)
(II) Deep (greater than 12 feet)

ii. Dermal
(I) Surficial (12 feet or less)
(in) Deep (greater than 12 feet)

d. Air

Volatilization from ground water, surface water and/or soils (i.e. potential vapors in buildings, basements, utilities, etc.)

2. Potential receptors by exposure route
a. Humans
b. Domestic species
c. Aquatic species (plants and wildlife)
d. Terrestrial species (plants and wildlife)

\section{F. Provide the Proximity, Quality, and Current and Future Uses of Surface Waters}

1. Any surface waters within a one-half mile radius and the site location indicated on a color topographic map (This map shall be on $8.5 \times 11$ or $11 \times 17$ inch paper.)

2. Any current and/or future uses of surface waters within a one-half mile radius (i.e. drinking water source, recreation, etc.)

\section{REQUEST FORMAT}

The Site-specific Standard Request must be assembled in the order presented in Part II of this TGD. The Request shall contain a prepared text that includes the required elements of each section, and provide explanations of the associated tables and maps. All maps and tables shall be in the section in which they are referenced, not in appendices. All maps shall be on $8.5 \times 11$ or $11 \times 17$ inch paper and 
contain a north arrow, legend, scale bar, figure number and vertical scale if applicable. Each section and subsection heading must be clearly printed in the Request. A table of contents shall be provided listing the location of all sections, maps, tables and appendices.

The Request shall be concluded with:

1. A summary justifying the proposed site-specific cleanup levels based on all available information. The summary must include a discussion of the calculations in Worksheets 1 and 2, the information compiled in the exposure assessment, and all risk(s) (carcinogenic, systemic toxicant, and other) to human health or the environrnent; and

2. A proposal of the ground water monitoring wells to be sampled during site status monitoring if the Site-specific Standard Request is approved. Closure monitoring and reporting shall be performed in accordance with TGD - 007.

\section{SIGNATURE PAGE}

A signature page, as shown below, must be attached to the Request. This page must be signed by both a Professional Engineer licensed by the State of Tennessee and a Professional Geologist registered by the State of Tennessee or a properly licensed Engineer. Each signee shall provide a notarized statement of fact attesting to the portions of the report which they were responsible.

I certify under penalty of law, including but not limited to penalties for perjury, that the information contained in the Site-specific Standard Request and on any attachments, is true, accurate and complete to the best of my knowledge, information, and belief I am aware that there are significant penalties for submitting false information, including the possibility of fine and imprisonment for intentional violations.

Owner/Operator - Print Name and Title

Date

Signature

STATE OF

Sworn to and subscribed before me by on this date

My commission expires 
Notary Public - Print Name

Signature

Professional Engineer - Print Name

License \#

Signature

Professional Geologist

Date

License\#

or property licensed Engineer - Print Name

Signature

Area of expertise -

properiy licensed Engineer

STATE OF

Sworn to and subscribed before me by on this date

My commission expires

Notary Public - Print Name

Signature 
Worksheet 1 lists EPA-established exposure-limit criteria. Compare the concentrations of each released constituent to the exposure-limit criteria by:

1. Answering yes or no in the "Concentration Exceeds Criteria?" column;

2. Completing the "Ratio of Concentration to Criteria Value" column; and

3. Summing the "Ratio of Concentration to Criteria Value" column to calculate the Carcinogenic Hazard Index (CHI) and the Systemic Hazard Index (SHI). The Hazard Index is a measure of the overall health risk posed by a mixture of constituents.

The "released" concentration is the maximum concentration as indicated in the EAR or by the asymptotic level for each constituent. While some constituents may not be included in the Site-specific Standard Request, they are included in the worksheet for calculation of the Hazard indices.

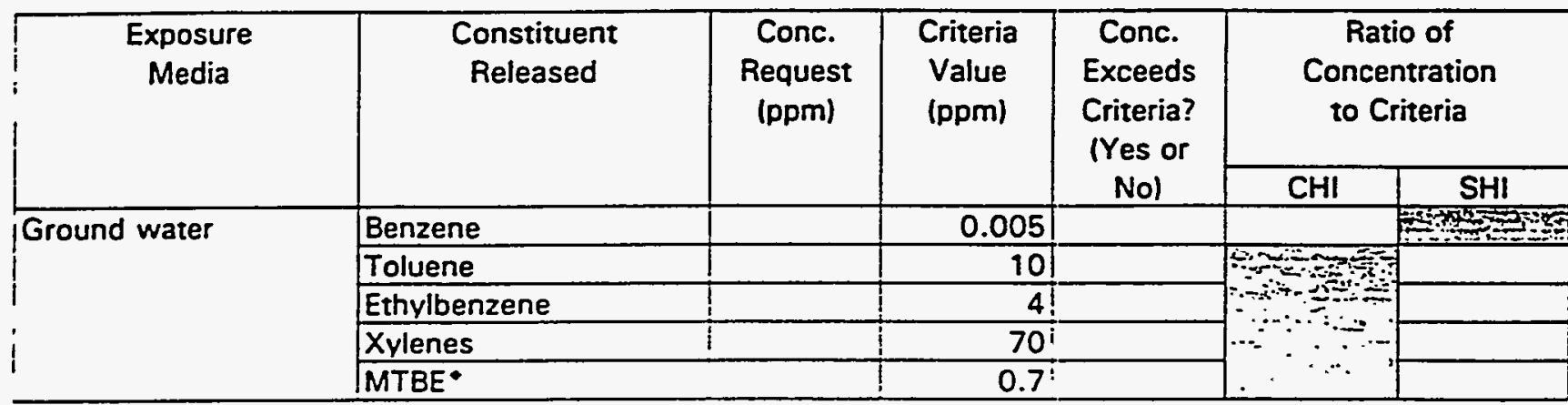

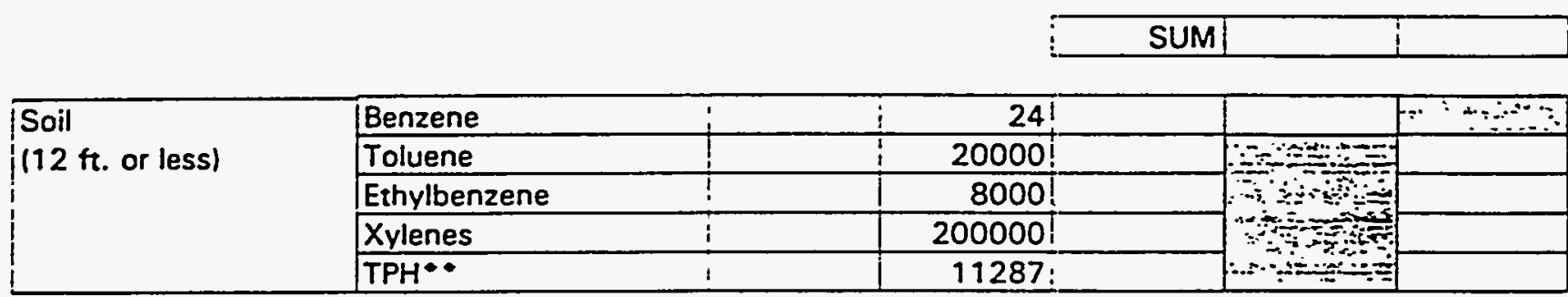


Worksheet 2 lists EPA-established exposure-limit criteria. Compare the concentrations of each released constituent to the exposure-limit criteria by:

1. Answering yes or no in the "Concentration Exceeds Criteria?" column;

2. Completing the "Ratio of Concentration to Criteria Value" column; and

3. Summing the "Ratio of Concentration to Criteria Value" column to calculate the Carcinogenic Hazard Index (CHI) and the Systemic Hazard Index (SHI). The Hazard Index is a measure of the overall health risk posed by a mixture of constituents.

The "requested" concentration is the site-specific concentration being requested. While some constituents may not be included in the Site-specific Standard Request, they are included in the worksheet for calculation of the Hazard Indices.

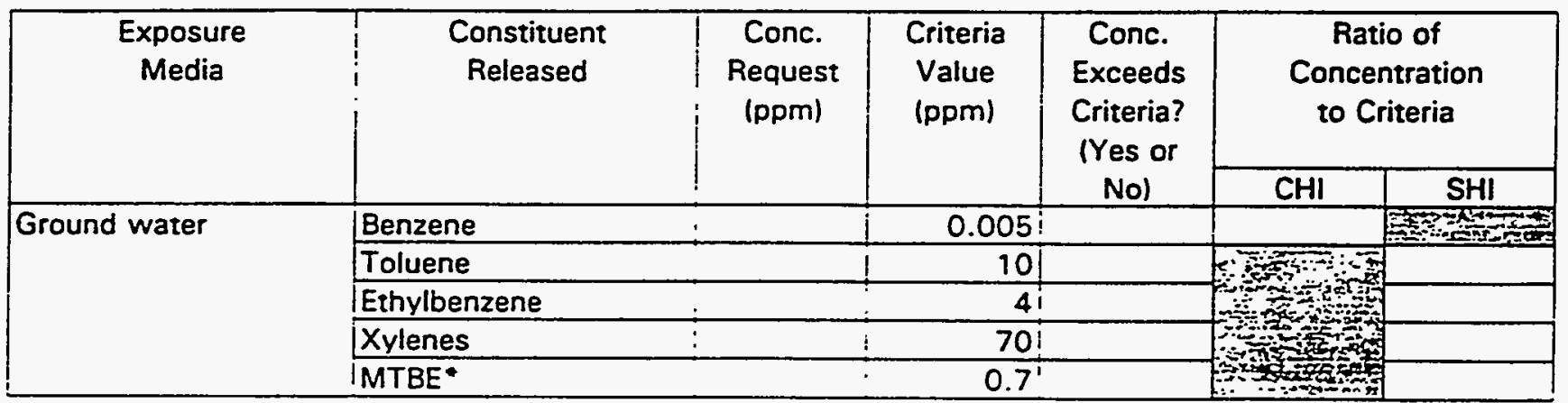

\section{SUM}

\begin{tabular}{|c|c|c|c|}
\hline Soil & Benzene & 24 & \\
\hline \multirow[t]{4}{*}{ (12 ft. or less) } & Toluene & 20000 & . \\
\hline & Ethylbenzene & 8000 & \\
\hline & Xylenes & 200000 & \\
\hline & $\mathrm{TPH}^{\bullet \bullet}$ & 11287 & $\mid$ \\
\hline
\end{tabular}




$$
\begin{aligned}
& \text { STATE OF TENNESSEE } \\
& \text { DEPARTMENT OF ENVIRONMENT AND CONSERVATION } \\
& \text { DIVISION OF UNDERGROUND STORAGE TANKS } \\
& \text { TECHNICAL GUIDANCE DOCUMENT - } 012 \\
& \text { EFFECTIVE DATE: JANUARY 21, } 19194
\end{aligned}
$$

\section{RE: GENERAL FACILITY SITE CHECK}

\section{PURPOSE}

In order to satisfy Rule 1200-1-15-.05(3)(b), this investigation shall be conducted at facilities with evidence of on-site environmental impact (exclusive of analytical data) or off-site environmental impact and at which underground storage tank (UST) system(s) have passed tightness testing.

An environmental impact includes, but is not limited to, the discovery of released petroleum at a UST site or in the surrounding area (such as free product or vapors in soils, basements, sewer and utility lines and nearby surface water). (See Rule 1200-1-15-.05(1)(a)).

\section{GENERAL INFORMATION}

A geologist or professional geologist, as defined under T.C.A. $6.2-36-101$, or a duly licensed professional engineer in the State of Tennessee, shall be retained to supervise all work specified in this document. In addition, all Fund-eligible work shall be conducted and/or overseen by an UST-approved Corrective Action Contractor.

Any of the following conditions shall warrant the installation of one ground water monitoring well at the location indicated in Procedure $\mathrm{C}$ below.

1. Environmental impact which includes surface water and/or groundwater

2. Borings which encounter ground water

3. Tank(s) and/or supply line(s) installed at or below the soil/bedrock interface

If free product is encountered, an acceptable method of free product removal shall be installed.

All site check activities shall be conducted in accordance with the Environmental Assessment Guidelines (Section 3 of the UST Reference Handbook).

The Division reserves the right to modify these guidelines if deemed necessary. 


\section{PROCEDURES}

In order to satisfy Rule 1200-1-15-.05(3)(b), the following procedures shall be completed:

A. Sampling Due to Single Point Environmental Impact

If a single point of environmental impact is observed, then the following procedures will apply:

1. Two (2) imaginary lines (Lines A and B) shall be constructed from the point at which the environmental impact was discovered to the edges of the UST system, as shown in Diagrams 1 and 2. The angle formed by these two lines shall then be bisected by a third imaginary line (Line $C$ ). A fourth line (Line $D$ ) shall be placed perpendicular to Line C, in the area between the UST system and the point of environmental impact, at a distance of 10 to 15 feet from the nearest portion of the UST system. All borings are to be located along Line $D$.

2. All borings shall be placed as follows:

The first boring shall be advanced at the intersection of Line $C$ and Line $D$. Additional borings shall be located on Line $D$ at points fifteen (15) feet to each side of the initial boring. Each additional pair of borings shall be located on Line $D$ at points fifteen (15) feet from the previous pair. Borings may continue outward along Line $D$ in this manner until Lines $A$ and $B$ are encountered. If more than seven $(7)$ borings will be required to meet these guidelines, the Division shall be contacted for prior approval.

3. If, at any point during this subsurface investigation, one of the following conditions is encountered, then the site check may be terminated.

a) Presence of free product

b) Elevated OVD readings at water table

Sample(s) with the highest level of contamination shall be submitted for laboratory analyses.

B. Sampling Due to Multiple Points of Environmental Impact

If multiple points of environmental impact are observed (e.g. sewer and utility lines and/or surface water), then the following procedures will apply:

1. Two (2) imaginary lines (Lines A and B) shall be constructed from the points at which environmental impact was discovered to the edges of the UST system, as shown in Diagram 3. The angle formed by these two lines shall then be bisected by a third imaginary line (Line C). A fourth line (Line $D$ ) shall be 
placed perpendicular to Line C, in the area between the UST system and the points of environmental impact, at a distance of 10 to 15 feet from the nearest portion of the UST system. All borings are to be located along Line $D$.

2. All borings shall be placed as follows:

The first boring shall be advanced at the intersection of Line C and Line D. Additional borings shall be located on Line $D$ at points fifteen (15) feet to each side of the initial boring. Each additional pair of borings shall be located on Line $D$ at points fifteen (15) feet from the previous pair. Borings may continue outward along Line $D$ in this manner until Lines $A$ and $B$ are encountered. If more than seven ( 7 ) borings are required to meet these guidelines, the Division shall be contacted for prior approval.

3. If, at any point during this subsurface investigation, one of the following conditions is encountered, then the site check may be terminated.

a) Presence of free product

b) Elevated OVD readings at water table

Sample(s) with the highest level of contamination shall be submitted for laboratory analyses.

\section{Ground Water Monitoring Well}

1. If warranted, one ground water monitoring well shall be installed on Line $C$ at a point midway between the UST system and the point where an environmental impact was observed. If the midpoint is not located on the site, then the well shall be installed at the intersection of Line $C$ and the property boundary.

2. In the case of multiple impact points, the well shall be installed at the midpoint of an imaginary line from the UST system to the point of the most significant impact. If the midpoint is not located on the site, then the well shall be installed at the intersection of the line and the property boundary. 


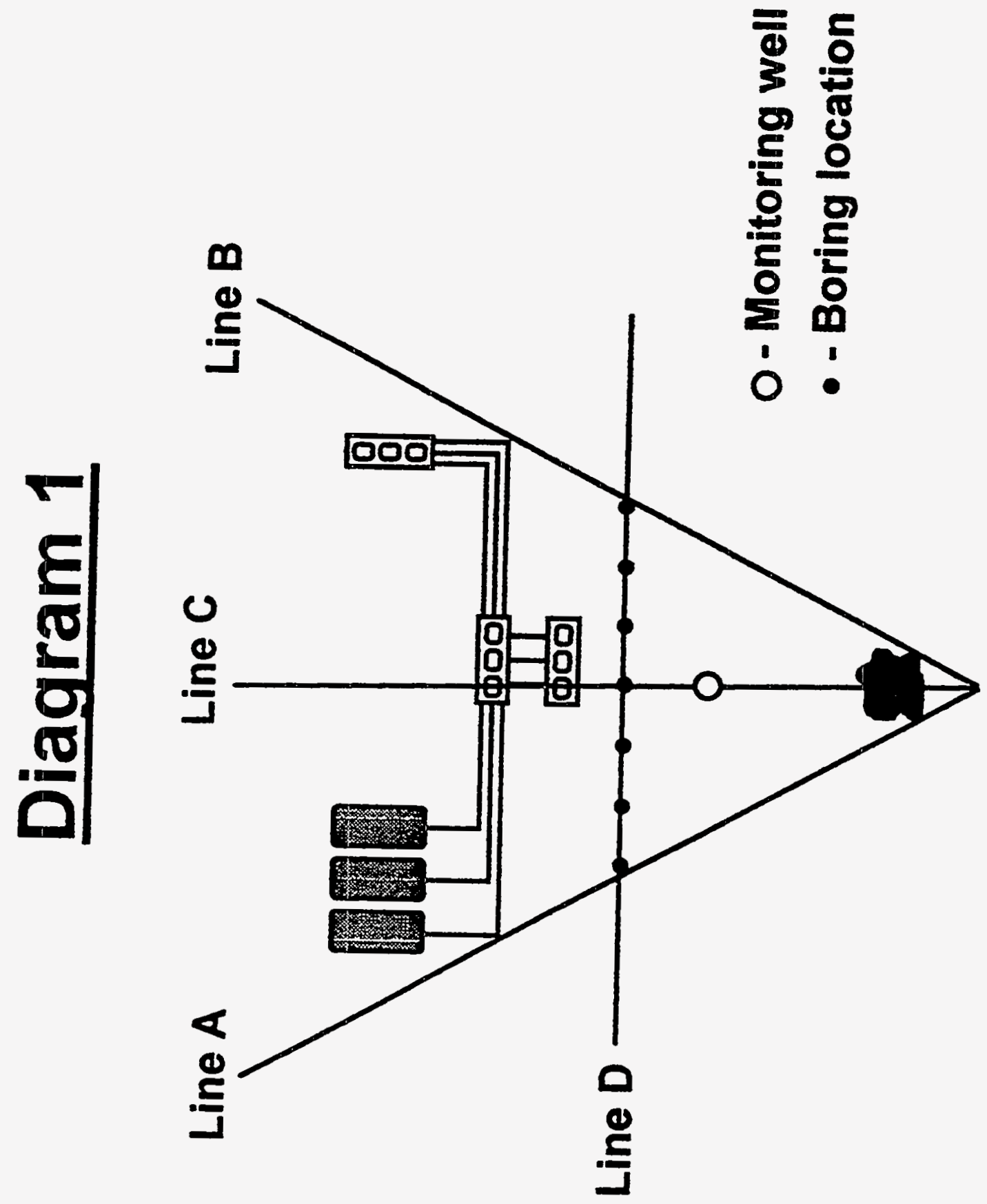




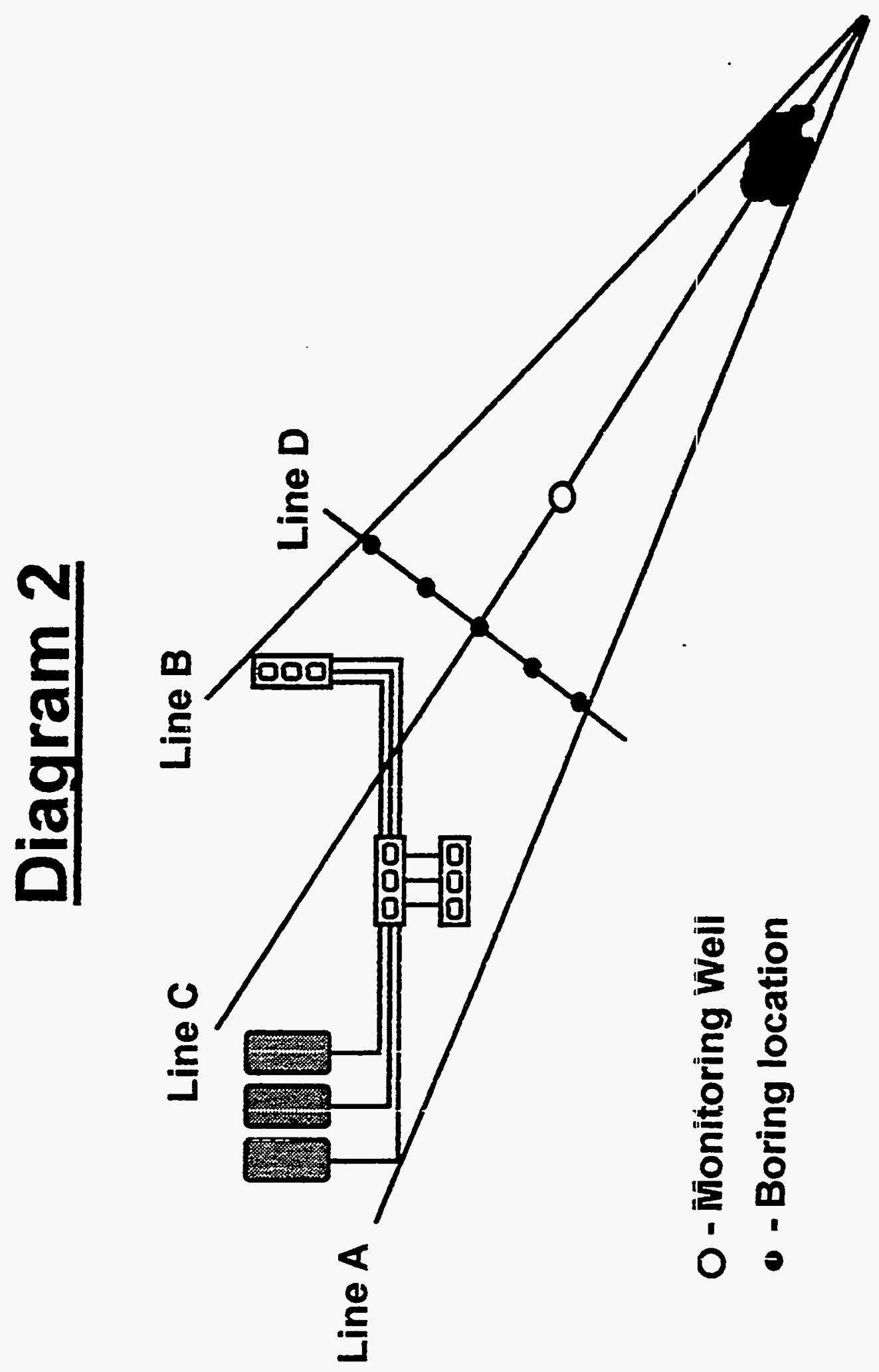



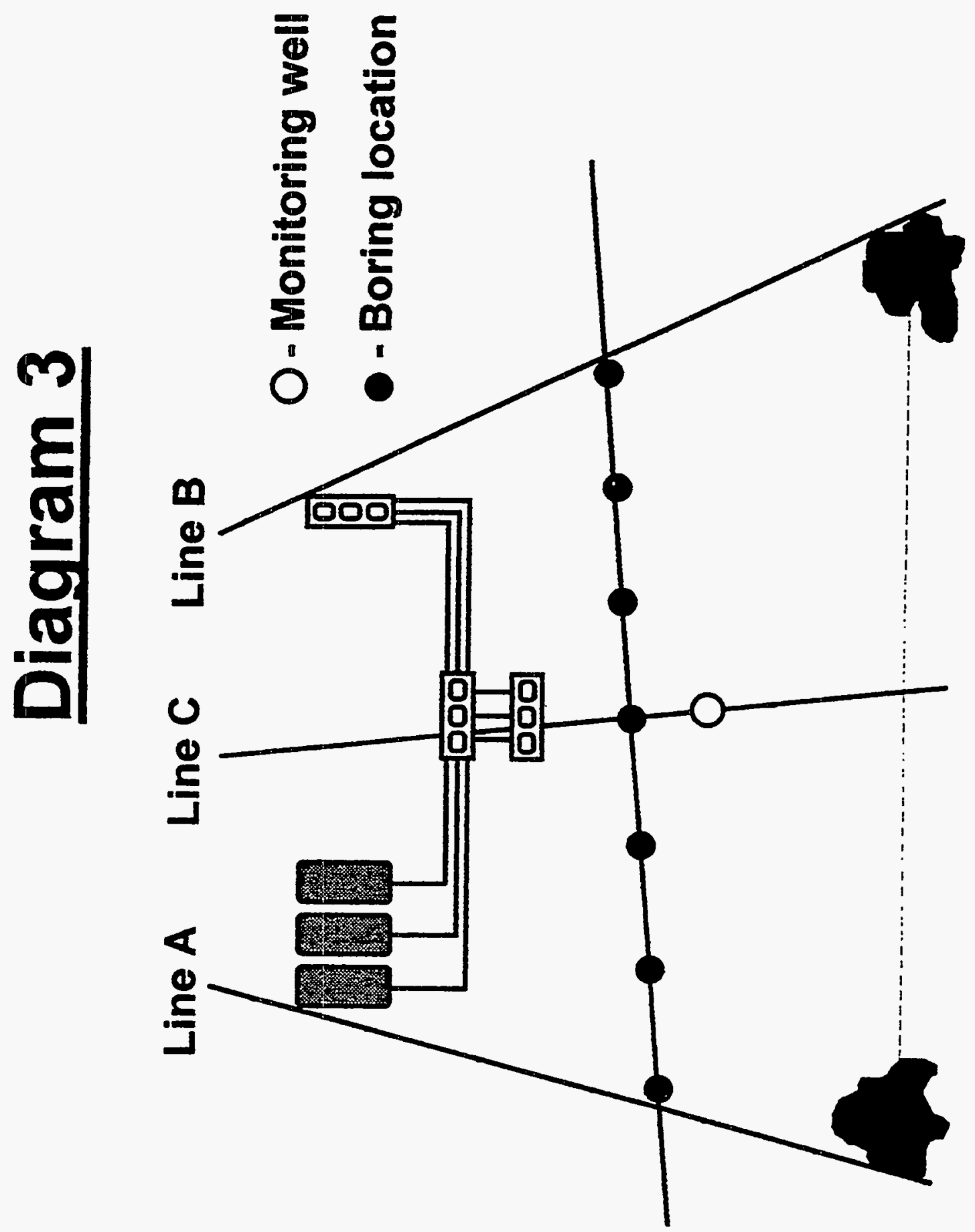
STATE OF TENNESSEE

DEPARTMENT OF ENVIRONMENT AND CONSERVATION

DIVISION OF UNDERGROUND STORAGE TANKS

TECHNICAL GUIDANCE DOCUMENT - 014

EFFECTIVE DATE: JANUARY 19, 1994

\section{RE: UST SITE RANKING SYSTEM}

\section{PURPOSE}

The purpose of this Technical Guidance Document is to determine the numerical ranking for Underground Storage Tank Sites.

If any of the following conditions exist or have existed, then site ranking shall not be applicable and the owner/operator shall proceed with the full environmental assessment and the submittal of the Environmental Assessment Report (EAR) and Corrective Action Plan (CAP) and/or a Site Specific Standard (SSS).

1. Vapor and/or explosion hazards

2. The aquifer or water source is classified as a "drink water supply"

If the numerical ranking is less than the Action Number, the owner/operator has the following options:

1. Submit the findings of the first four (4) soil borings and monitoring wells in an EAR and begin a monitoring only program with no active remediation being performed. This option shall require monitoring until contaminant concentrations are below the applicable cleanup levels. If during the monitoring period, the Action Number is exceeded or one of the two conditions above are discovered, then additional assessment, if necessary, and corrective action will be required.

2. Complete the full environmental assessment and submit the findings in an EAR.

The option selected shall be addressed in the Executive Summary of the Environmental Assessment Report. Regardless of the Action Number for the site, the Division may require the full environmental assessment to be performed and the submittal of the EAR and CAP and/or SSS.

If free product is present, it shall be completely recovered regardless of the site ranking. 
For sites scoring greater than the Action Number, the owner/operator shall complete the full environmental assessment.

\section{Instructions for completing the Site Ranking}

After installing the first four soil borings/monitoring wells and obtaining the analytical results, the attached Site Ranking Form shall be completed from the data generated.

Geologic and Hydrogeologic Factors:

1. Minimum depth to water table

The distance between the surface and the water table shall be determined from the four (4) monitoring wells. The minimum distance shall be used to determine the score in this category.

2. Minimum distance between the water table and contaminated soil

The distance between the soil with concentrations above the applicable cleanup levels and the water table shall be determined. The minimum distance shall be used to determine the score in this category.

3. Soil permeability

The soil permeability shall be determined as described in the Environmental Assessment Guidelines. The maximum permeability shall be used to determine the score in this category.

4. Calculated ground water flow rate

The ground water flow rate shall be calculated and the maximum value shall be used to determine the score for this category. Regardless of the calculated ground water flow rate, if karst conditions exist in the area of the site, 30 points shall apply for this category.

Receptor Factors:

For categories 5 through 8 the following applies:

All sampling locations where analytical results document contamination above any applicable cleanup level shall be identified as known contamination. These sampling locations include soil borings/monitoring wells, soil or water from tank pits, soil or water from line trenches, etc. 
To determine the score for each of these categories, the first step is to determine if any of the receptors (i.e. basement, sanitary sewer, etc.) are within a 50 foot radius of known contamination. If a receptor exists within this area, the highest score shall apply and no additional investigation is warranted to determine the score for each category. If a receptor does not exist withir 50 feet of the known contamination, the investigation shall continue in each sdditional area (50 to 100 foot radius, etc.) until a receptor is identified or it has been determined that a receptor does not exist within 300 feet of known contamination.

For categories 9 through 11 the following applies:

To determine the score for each category, the first step is to determine if a water source is within a 0.1 mile radius of Monitoring Well 4 (MW-4) as defined in the Environmental Assessment Guidelines. If a water source is within this area, the highest score shall apply and no additional investigation is warranted to determine the score for each category. If a water source does not exist within 0.1 miles of MW-4, the investigation shall continue in each additional area (0.1 to 0.25 mile radius, etc.) until a water source is identified or it has been determined that a water source does not exist within 0.5 miles of MW-4.

Special note for Category 11 - If surface water has been visibly impacted by a petroleum product (i.e. sheen, iron flocculate, etc.) 200 points shall be applied to that category.

Contamination Factors:

12. Contaminant Concentration

A. Determine the maximum concentrations from any sampling point of the following:

1. Benzene and TPH in ground water

2. BTX and TPH in soil

B. Determine the applicable cleanup levels in accordance with the Environmental Assessment Guidelines.

C. Divide the maximum concentrations $(A)$ by the applicable cleanup levels (B) to obtain the Contaminant Concentration Ratio (C).

For Categories 13 through 16 the following applies: 
Use the Contaminant Concentration Ratios as computed in Category 12 to determine the score in each category. All numbers shall be rounded up to the next whole number.

\section{Total Site Score}

Sum the scores for Categories 1 through 16 to determine the Total Site Score.

\section{Signature Page}

The following signature page shall be attached to the Site Ranking Form ONLY IF it is not submitted with the Environmental Assessment Report.

I certify under penalty of law, including but not limited to penalties for perjury, that the information contained in this report and on any attachments, is true, accurate and complete to the best of my knowledge, information, and belief. I am aware that there are significant penalties for submitting false information, including the possibility of fine and imprisonment for intentional violations.

Owner/Operator (Print)

P.E. or P.G. (Print)

$$
\text { Signature }
$$

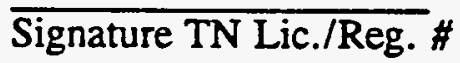

$\overline{\text { Date }}$

$\overline{\text { Date }}$

If a P.E. signs the report, please indicate the area of expertise.

(Print or Type)

Stamp/Seal

All signatures above must be notarized. 


\section{G-35 \\ UST SITE RANKING FORM}

Facility ID Number:

Facility Name:

Facility Address:

\section{Geologic and Hydrogeologic Factors}

\begin{tabular}{|l|r|}
\hline 1 & Minimum depth to the water table \\
\hline$<5.0$ Feet & 50 \\
\hline 5.1 to 10.0 Feet & 45 \\
\hline 10.1 to 15.0 Feet & 40 \\
\hline 15.1 to 30.0 Feet & 35 \\
\hline 30.1 to 50.0 Feet & 25 \\
\hline 50.1 to 75.0 Feet & 15 \\
\hline 75.1 to 100.0 Feet & 10 \\
\hline$>100.0$ Feet & 5 \\
\hline
\end{tabular}

2 Minimum distance between water table and

contaminated soil

$<5.0$ Feet

5.1 to 10.0 Feet

10.1 to 15.0 Feet

15.1 to 30.0 Feet

30.1 to 50.0 Feet

50.1 to 75.0 Feet

75.1 to 100.0 Feet

$>100.0$ Feet

\begin{tabular}{|r|}
\hline 50 \\
\hline 45 \\
\hline 35 \\
\hline 25 \\
\hline 15 \\
\hline 10 \\
\hline 5 \\
\hline
\end{tabular}

3 Soil Permeability

$>10^{\circ}-4 \mathrm{~cm} / \mathrm{sec}$ $10^{\circ} .4$ to $10^{\circ} .6 \mathrm{~cm} / \mathrm{sec}$

$<10^{\circ} .6 \mathrm{~cm} / \mathrm{sec}$

\begin{tabular}{|r|}
\hline 30 \\
\hline 20 \\
\hline Score \\
\hline
\end{tabular}

4 Calculated Ground Water Flow Rate

\begin{tabular}{|l|r|}
\hline$<10$ feet/day & 3 \\
\hline 10 to 40 feet/day & 6 \\
\hline 40 to 90 feet/day & 12 \\
\hline 90 to 130 feet/day & 18 \\
\hline 130 to $260 \mathrm{feet} /$ day & 24 \\
\hline$>260$ feet/day & 30 \\
\hline Karst & 30 \\
\hline
\end{tabular}




\begin{tabular}{|l|r|r|}
\hline 5 & & \\
\hline$<50.0$ feet from known contamination & 150 \\
\hline 50.1 to 100.0 feet from known contamination & 75 \\
\hline 100.1 to 200.0 feet from known contamination & 50 \\
\hline 200.1 to 300.0 feet from known contamination & 25 \\
\hline$>300.1$ feet & 0 \\
\hline
\end{tabular}

\begin{tabular}{|l|l|r|}
\hline 6 & Sanitary sewers & \\
\hline$<50.0$ feet from known contamination & 75 \\
\hline 50.1 to 100.0 feet from known contamination & 40 \\
\hline 100.1 to 200.0 feet from known contamination & 20 \\
\hline 200.1 to 300.0 feet from known contamination & 10 \\
\hline$>300.1$ feet & 0 \\
\hline
\end{tabular}

\begin{tabular}{|l|l|r|}
\hline 7 & Storm water sewers & 50 \\
\hline$<50.0$ feet from known contamination & 30 \\
\hline 50.1 to 100.0 feet from known contamination & 10 \\
\hline 100.1 to 200.0 feet from known contamination & 5 \\
\hline 200.1 to 300.0 feet from known contamination & 0 \\
\hline$>300.1$ feet & Score \\
\hline
\end{tabular}

\begin{tabular}{|l|l|r|}
\hline 8 & Other subsurface utilities & \\
\hline$<50.0$ feet from known contamination & 30 \\
\hline 50.1 to 100.0 feet from known contamination & 20 \\
\hline 100.1 to 200.0 feet from known contamination & 10 \\
\hline 200.1 to 300.0 feet from known contamination & 5 \\
\hline$>300.1$ feet & 0 \\
\hline
\end{tabular}

\begin{tabular}{|l|r|r|}
\hline 9 & Public water supply source & \\
\hline$<.1$ miles & 300 \\
\hline .1 to .25 miles & 200 \\
\hline .25 to .5 miles & 100 \\
\hline$>.51$ miles & 0 \\
\hline
\end{tabular}

\begin{tabular}{|l|l|r|}
\hline 10 & Private water supply source & \\
\hline$<.1$ miles & 200 \\
\hline .1 to .25 miles & 150 \\
\hline .25 to .5 miles & 100 \\
\hline$>.51$ miles & 0 \\
\hline
\end{tabular}


11 Distance to surface water

$<.1$ miles

.1 to .25 miles

.25 to .5 miles

$>.51$ miles

Visibly impacted surface water from a petroleum product

\section{Contaminant Factors}

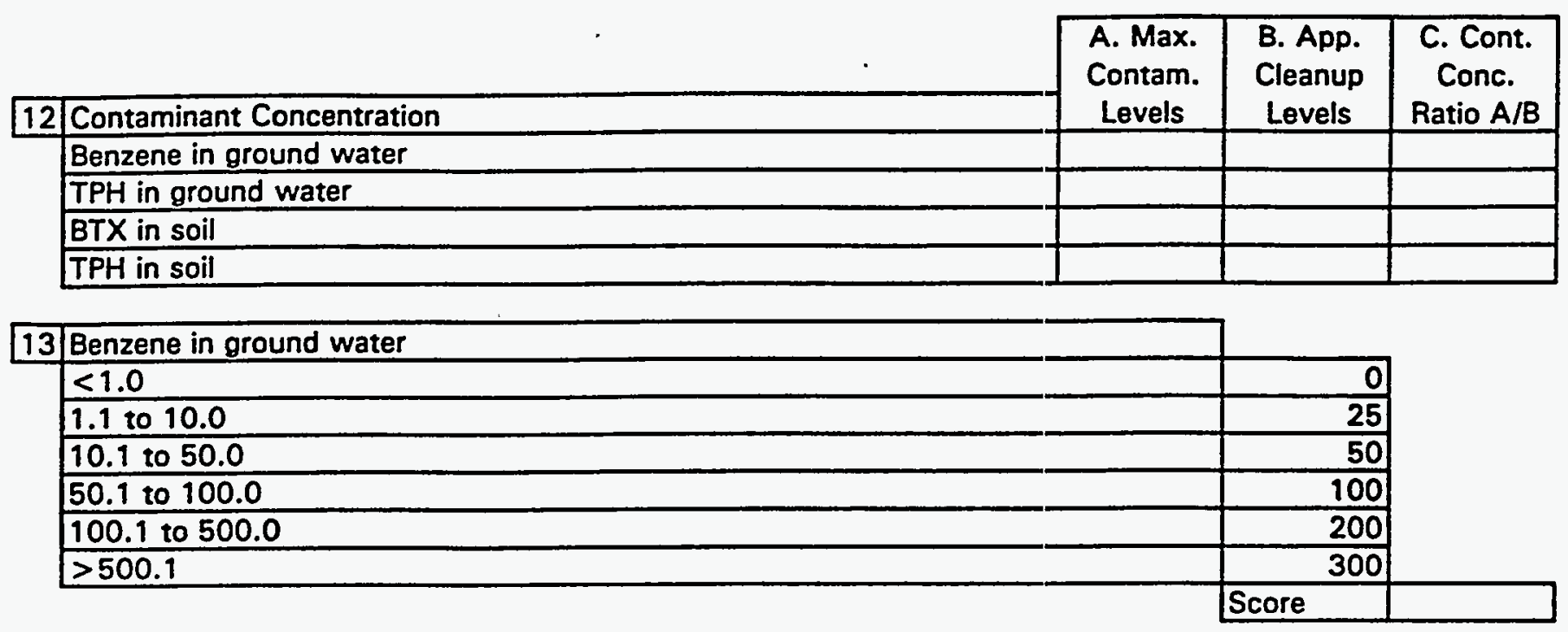

\begin{tabular}{|l|r|r|}
\hline \hline $4 P H$ in ground water & 0 \\
\hline$<1.0$ & 20 \\
\hline 1.1 to 10.0 & 40 \\
\hline 10.1 to 50.0 & 80 \\
\hline 50.1 to 100.0 & 120 \\
\hline 100.1 to 500.0 & 200 \\
\hline$>500.1$ & Score \\
\hline
\end{tabular}

\begin{tabular}{|l|l|r|}
\hline 15 & BTX in soil & \\
\hline$<1.0$ & 25 \\
\hline 1.1 to 5.0 & 50 \\
\hline 5.1 to 10.0 & 100 \\
\hline 10.1 to 50.0 & 200 \\
\hline$>50.1$ & Score & \\
\hline
\end{tabular}

\begin{tabular}{|l|r|r|}
\hline 16 & TPH in soil & 0 \\
\hline$<1.0$ & 20 \\
\hline 1.1 to 5.0 & 40 \\
\hline 5.1 to 10.0 & 80 \\
\hline 10.1 to 50.0 & 100 \\
\hline$>50.1$ & Score \\
\hline
\end{tabular}




\section{APPENDIX H \\ TENNESSEE DEPARTMENT OF ENVIRONMENT AND CONSERVATION UNDERGROUND STORAGE TANK \\ CLOSURE ASSESSMENT GUIDELINES}





\section{Tennessee Departmient of ENVIRONMENT AND CONSERVATION DIVISION OF UNDERGROUND Storage TANkS}

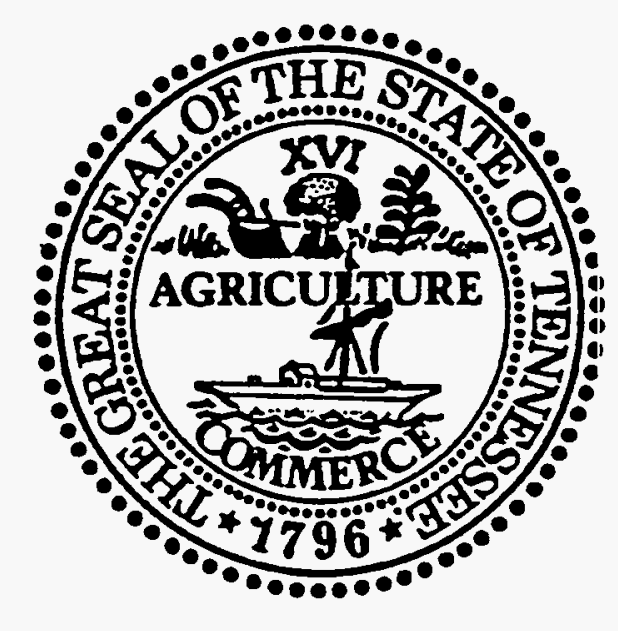

\section{Chosure Assessment GuIDELINES}

JANUARY 1994 


\section{Dear Underground Storage Tank Owner:}

In accordance with rule 1200-1-15-.07(2)(a) of the Tennessee Petroleum Underground Storage Tank Regulations, owners shall notify the Tennessee Division of Underground Storage Tanks of their intent to permanently close an underground storage tank (UST) system. A closure assessment shall be conducted to determine if a release from the UST system has occurred. According to rule 1200-1-15-.01(3)(ccc):

UST system or Tank system means an underground storage tank, connected underground piping, underground ancillary equipment, and containment system, if any.

The enclosed application shall be completed and submitted for approval to the appropriate field office thirty days before initiating any closure activities. Once approved the application is valid for twelve months from the date of approval. The approved application is non-transferable. If ownership of the UST system changes, a new application shall be submitted for approval. The following enclosures are for your use and information during closure of the UST system:

\section{UST System Closure Assessment Guidelines}

Procedure for UST System Closure-in-Place

Application for Permanent Closure of Underground Storage Tank Systems

Approved Laboratory List

Approved Corrective Action Contractor List

Field Office Location Map

Notification Form

When an UST system is removed or closed-in-place, a Notification Form must be submitted to the Division at the Nashville Central Office within thirty days of the closure. The form shall indicate the current status of the UST system at the facility. Be sure to include the Facility I.D. Number and mark "C. CLOSED" to insure accurate processing. If a Notification Form reporting the closure of the tank system is not submitted, you will continue to be billed for the annual tank fee. This form must be submitted to the address located on the notification form.

If there are questions concerning the UST system closure procedures, refer to the enclosed map to contact the appropriate field office.

Enclosures 


\section{DISCLAIMER}

This document has been prepared in an effort to provide guidance and standardized procedures for conducting Underground Storage Tank System Closure Assessments in accordance with Rule 1200-1-15-.07. These guidelines shall be followed unless prohibited by site-specific conditions or other applicable statutes, rules or regulations. If a variance is necessary, approval shall be obtained from Division personnel in the appropriate Division of Underground Storage Tanks field office.

It is understood that the procedures outlined in this document cannot cover every eventuality; however, these guidelines shall be used in all cases where appropriate. If SITE-SPECIFIC CONDITIONS warrant variations from these guidelines, Division personnel in the appropriate field office shall be informed and permission shall be obtained prior to the implementation of these variations. All variations from these guidelines shall be noted in the Permanent Closure Report. 


\title{
DIVISION OF UNDERGROUND STORAGE TANKS
}

\author{
UST SYSTEM CLOSURE ASSESSMENT GUIDELINES
}

The Division of Underground Storage Tanks requires that sample collection follow the protocol described in the UST System Closure Assessment Guidelines. Rule 1200-1-15-.07(3)(a) of the Tennessee Petroleum Underground Storage Tank regulations requires that samples be collected where contamination is most likely to be present at the UST site. According to rule 1200-1-15-.07(3)(a):

The requirements of this paragraph are satisfied if one of the external release detection methods allowed in rule 1200-1$15-.04(3)(e)$ and $(f)$ is operating in accordance with the requirements in rule 1200-1-15-.04(3) at the time of closure, and indicates no release has occurred.

If closure of the UST system in accordance with rule 1200-1-15-.07(3)(a) is applicable, contact the appropriate Division of Underground Storage Tanks field office for further instructions.

In accordance with the Petroleum Contamination Cleanup Levels in Appendix 3 and 4 of the regulations, any material (soil, sand, or rock) with concentrations exceeding 10 parts per million total Benzene, Toluene, and Xylenes (BTX) and/or 100 parts per million Total Petroleum Hydrocarbons (TPH) is considered to be contaminated by a petroleum product. Ground water is contaminated if concentrations exceed 0.005 parts per million Benzene and 0.1 parts per million Total Petroleum Hydrocarbons. A release from the UST system requiring a response in accordance with rule 1200-1-15-.06 has occurred if laboratory results indicate contamination above these cleanup levels.

According to rule 1200-1-15-.01(3)(ccc):

UST system or Tank system means an underground storage tank. connected underground piping, underground ancillary equipment, and containment system, if any.

\section{BEFORE BEGINNING ANY WORK}

Notify the local fire department or State Fire Marshal's office and inform them of the removal time and place. Some local fire departments may have requirements that must also be followed.

Contact a laboratory approved by the Division. A list of approved laboratories is enclosed. Make arrangements to obtain the appropriate sample bottles for the collection and analysis of total BTX and/or TPH. Instructions for collecting and preserving the samples should be provided by the laboratory. The UST system owner is responsible for obtaining the appropriate sample containers and proper handling of all samples.

Total BTX analysis is applicable for soil and/or ground water samples collected where the UST system has stored gasoline. The laboratory shall use SW-846, Test Methods for Evaluating Solid Waste. The levels of BTX shall be reported individually as Benzene, Toluene, and Total Xylenes.

A review of the type of petroleum product stored shall determine the method used for TPH analysis of soil and/or ground water. The Gasoline Range Organics (GRO) method is used if onlv gasoline, or other low boiling point petroleum hydrocarbons, is stored. The Diesel Range Organics (DRO) method is used if onlv diesel fuel, kerosene or other high boiling point petroleum hydrocarbons, is stored. Both GRO and DRO methods shall be used if both gasoline and diesel range fuels are stored in the same tankhold. If samples are analyzed using both GRO and DRO, the results of each analysis shall be summed (GRO + DRO) and reported as Total Petroleum Hydrocarbons (GRO + DRO = TPH). Neither GRO nor DRO method is applicable for analyzing samples collected where only waste oil is stored. These samples shall be analyzed using either Standard Methods of Analysis Method 503E or Methods of Analysis of Water and Wastes Method 418.1. All three methods (GRO, DRO and a waste oil analysis method) shall be used to analyze samples collected where gasoline, diesel range fuels and waste oil are stored in the same tankhold or if the storage history is unknown. 
If the type of product stored is unknown, all samples shall be analyzed using BTX, TPH-GRO, TPH-DRO, and a waste oil method.

Contact the appropriate field office at least one working day prior to inplementing any closure activities and/or sampling events.

Soil samples shall be collected after the UST system has been removed to ensure proper inspection of the excavated area. Composite samples are not acceptable. Areas of obvious contamination shall be overexcavated prior to sampling. If more than 100 cubic yards of material is overexcavated contact Division personnel in the appropriate field office for further instructions. After the overexcavation of 100 cubic yards of material and/or the installation of monitoring wells, the following shall apply:

$$
\text { lexcluder back hill }
$$

An UST approved Corrective Action Contractor shall conduct and oversee all work associated with the investigation and remediation of a release from the UST system if a site is fund eligible and reimbursement will be requested from the Tennessee Petroleum Underground Storage Tank Fund.

For UST system Closure- in-place, refer to Section II below.

\section{UST SYSTEM REMOVAL}

The removal of an UST system shall follow the procedures outlined in Appendix 5 in the regulations.

\section{A. SAMPLING TANK EXCAVATIONS}

1. Soil samples shall be collected after all backfill material is removed from the excavation. Areas of obvious contamination shall be overexcavated prior to sampling. Samples shall be obtained from the pit floor at a depth of one foot into native soil. Refer to Table 1 to determine the sample number and location.

2. All soil samples for laboratory analysis shall be obtained from a depth of one foot into undisturbed native soil. A decontaminated hand auger, scoop, or other sampling device shall be used to collect a fresh unvolatilized soil sample. Clean. disposable, latex gloves shall be worn during the collection of each sample. The sample shall be immediately packed tightly into a sample jar leaving no voids. labeled and stored at $4^{\circ} \mathrm{C}$ until delivered to a Division approved laboratory.

3. Water encountered in tank excavations shall be removed and properly disposed. If the water recharges within 24 hours, a sample shall be collected and submitted to the laboratory. Water samples shall be analyzed for the appropriate petroleum constituents.

\section{TABLE 1}

TOTAL TANK STORAGE

CAPACITY (GAL.) PER PIT

\section{OR LESS}

1121 TO 15,000

15,001 TO 30,000

30,001 TO 45,000

45,001 TO 60,000

GREATER THAN 60,000
MIN. NO. OF SAMIPLES

TO SUBMIT TO LAB

LOCATION

SEE FIGURE 1

SEE FIGURE 1

SEE FIGURE 1

SEE FIGURE 1

SEE FIGURE 1 


\section{B. ENCOUNTERING BEDROCK}

1. If the UST system is installed in bedrock, samples of material up to the size of pea gravel can be collected and submitted for laboratory analysis. Samples shall be obtained from the pit floor. If all the backfill material has been excavated and no material can be sampled, a ground water monitoring well shall be installed. The monitoring well shall be installed immediately adjacent to the area of suspected contamination. If no obvious area of contamination is evident, the monitoring well shall be installed immediately adjacent to the tank pit at the junction of the piping trench. Refer to the Environmental Assessment Guidelines, Section II.D., in the UST Reference Handbook for monitoring well installation.

2. If soil contamination above the most stringent cleanup levels is in contact with bedrock, a ground water monitoring well shall be installed and sampled. The monitoring well shall be installed immediately adjacent to the area of suspected contamination in the apparent downgradient direction.

3. A monitoring well construction diagram, detailed boring log (refer to TGD-006), analitical results and a scaled site map shall be submitted to the appropriate UST field office along with the Permanent Closure Report. The site map shall indicate the location of the monitoring well in relation to the entire UST system.

4. Water encountered shall be removed and properly disposed. If the water recharges within 24 hours, a sample shall be collected and submitted to the laboratory. Water samples shall be analyzed for the appropriate petroleum constituents.

\section{UST SYSTEM CLOSURE-IN-PLACE}

A. Closing an UST system in-place requires utilizing soil boring or direct push tools capable of collecting soil samples. Split-spoon samplers, hand augers, or shelby tubes shall be used to retrieve the samples from the required depth. Sampling of hollow-stem auger cuttings is unacceptable for laboratory analysis.

B. All soil samples for laboratory analysis shall be obtained from a depth of one to four feet below the bottom of the tank. A decontaminated sampling device shall be used to collect a fresh unvolatilized soil sample. Clean, disposable, latex gloves shall be worn during the collection of each sample. The sample shall be immediately packed tightly into a sample jar leaving no voids, labeled and stored at $4^{\circ} \mathrm{C}$ until delivered to a Division approved laboratory. Refer to Table 2 to determine the sample number and location.

C. If bedrock or water is encountered before completing the requirements described above in II.B., a ground water monitoring well shall be installed. The monitoring well shall be installed immediately adjacent to the tank pit at the junction of the piping trench. Refer to the Environmental Assessment Guidelines, Section II.D., in the UST Reference Handbook for monitoring well installation.

D. If soil contamination is above the most stringent cleanup levels, at least one of the following requirements shall be met:

1. Refer to Technical Guidance Document-011 to determine the applicable soil cleanup levels;

2. Remove the UST system and overexcavate areas of obvious soil contamination; or

3. Refer to the Environmental Assessment Guidelines in the UST Reference Handbook.

E. Once the soil and/or ground water has been determined to be within the applicable cleanup levels in accordance with Appendix 3 and 4 in the regulations, refer to the document Procedures For UST System Closure-In-Place. 
1120 OR LESS

1121 TO 15,000

15,001 TO 30,000

30,001 TO 45,000

45,001 TO 60,000

GREATER THAN 60,000
2

4

6

8

10
SEE FIGURE 2

SEE FIGURE 2

SEE FIGURE 2

SEE FIGURE 2

SEE FIGURE 2
APPROVED ON A SITE-SPECIFIC BASIS

\section{GENERAL REQUIREMENTS DURING ALL UST SYSTEM CLOSURES}

A. Immediately after collection all samples shall be placed on ice and maintained at $4^{\circ} \mathrm{C}$ until delivered to a Division approved laboratory.

B. The original or a carbon copy of all analytical results shall be submitted to the appropriate UST field office. Photocopies are not acceptable. The facility name, UST Facility I.D). number, sample location and sample depth from ground surface shall be provided to the laboratory and printed on each laboratory analysis sheet.

C. All excavated material remaining on the site of generation or on a site owned by the generator or subsidiary of the generator shall be placed on and covered with plastic until sampled or managed in accordance with Technical Guidance Document-005. Sampling the excavated material can be done at the time of removal or after proper treatment of the contaminated material.

D. If petroleum contaminated material is managed in accordance with Technical Guidance Document-009, an Application to Treat Petroleum Contaminated Soil shall be completed and submitted to the appropriate field office for approval. If the contaminated material is to be treated on a site owned by a third party, contact the Tennessee Division of Solid Waste Management.

E. Technical Guidance Document-011 shall onlv be used to detennine applicable soil clean-up levels. Technical Guidance Document-011 cannot be used to determine applicable ground water cleanup levels.

F. The Tennessee Petroleum Underground Storage Tank Regulations require the Division be notified within 72 hours of the discovery of free product or petroleum contamination while closing an UST system. Failure to notify the Division could jeopardize fund coverage of corrective action costs associated with this release for fund eligible owners and/or operators.

G. All appropriate closure records shall be maintained for at least 3 years. 


\section{STATE OF TENNESSEE \\ DIVISION OF UNDERGROUND STORAGE TANKS \\ PROCEDURE FOR UST SYSTEM CLOSURE-IN-PLACE}

Some cities in Tennessee may have local ordinances regarding the closure-in-place of underground storage tank (UST) systems. Local ordinances that are more stringent shall always be followed. Otherwise, the outlined closure-in-place procedure shall be followed.

I. A subsurface environmental assessment shall be conducted to determine if a release from the UST system has occurred. The assessment shall follow the Procedures For Closure-In-Place outlined in the UST System Closure Assessment Guidelines. If petroleum contamination is encountered, contact Division personnel in the appropriate field office for further instructions.

II. If petroleum contamination is not encountered, follow the procedure as outlined below.

A. Remove all product from the piping.

B. Remove all product from the tank using a hand pump if necessary. The material removed shall be handled properly.

C. Remove and properly dispose all sludge from the bottom of the tank.

D. Remove the fill (drop) tube. Disconnect all associated piping. Cap or plug all piping not used during purging procedures. The vent line shall remain connected until the tank is filled with an inert solid material.

E. The tank atmosphere shall be purged and regularly tested in accordance with the provisions in Appendix 5 (2) and (3) of the regulations.

F. Fill the tank with an inert solid material as indicated below.

1. Sand: Dry sand can be added to the tank as long as it flows freely. Once the tank is nearly full, a sand/water slurry shall be used to completely fill the tank.

2. Sand/Soil: The tank shall be filled to $80 \%$ of its capacity with sand. A free flowing mixture of sand/soil shall then be added into the tank until the fill pipe is overflowing.

3. Concrete: Concrete can be used to fill a tank if the slurry is free flowing. Add until the fill pipe is overflowing.

4. Concrete/Bentonite: A concrete/bentonite slumy may be used to fill the tank. Add the slurry until the fill pipe is overflowing.

5. Other inert solid material approved by Division personnel in the appropriate field office.

G. Disconnect and cap the vent line.

H. A permanent record of the UST system location, date of closure, and method used to close the UST system in-place shall be maintained.

I. When properties are sold or transferred, the new owners or new lease holders shall be informed of the presence of UST systems that are closed-in-place. 
1,120 gal. or LESS

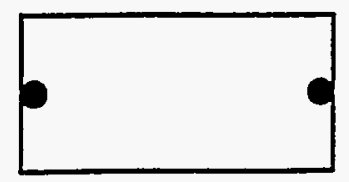

15,001 to 30,000 gal.

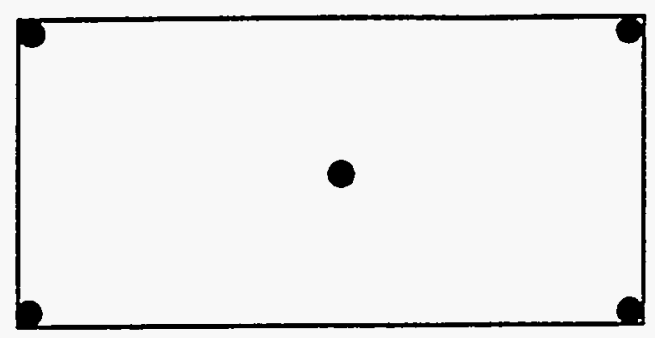

1,121 to 15,000 gal.

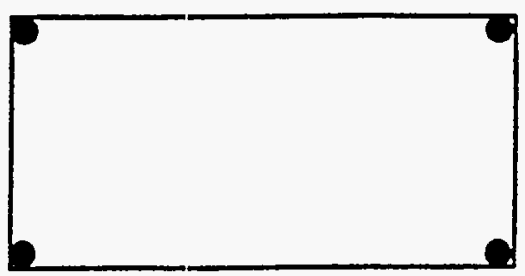

30,001 to 45,000 gal.

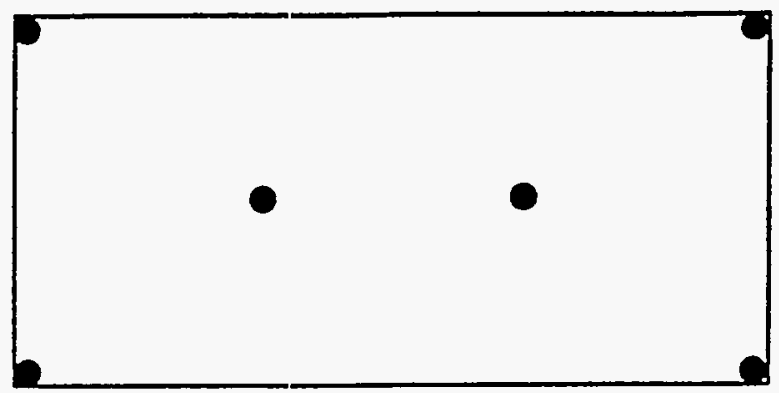

45,001 to 60,000 gal.

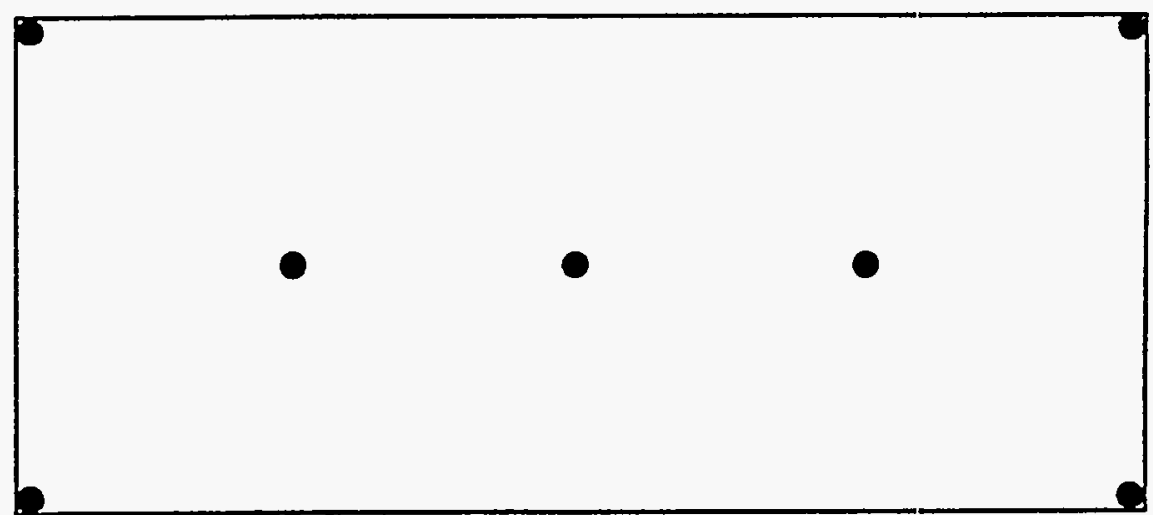

- Sampling point 


\section{FIGURE 2}

\section{SAMPLE LOCATIONS FOR UST CLOSURE - IN - PLACE}

1,120 gal. or LESS

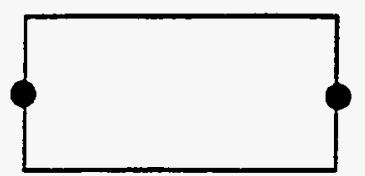

15,001 to 30,000 gal.

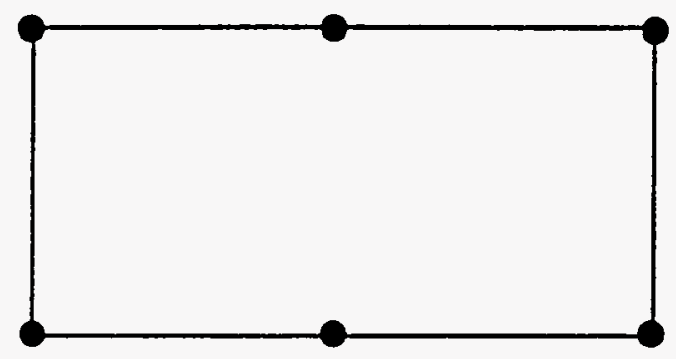

1,121 to 15,000 gal.

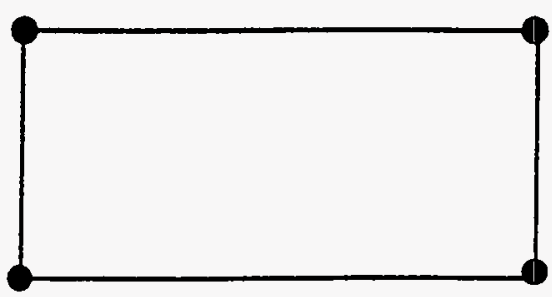

30,001 to 45,000 gal.

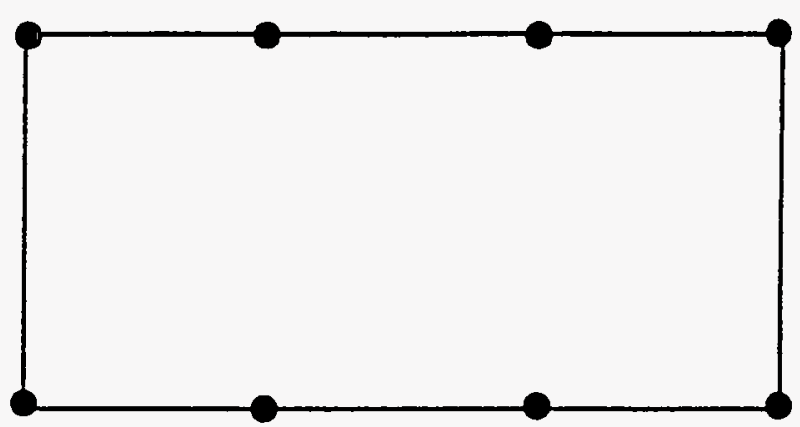

45,001 to 60,000 gal.

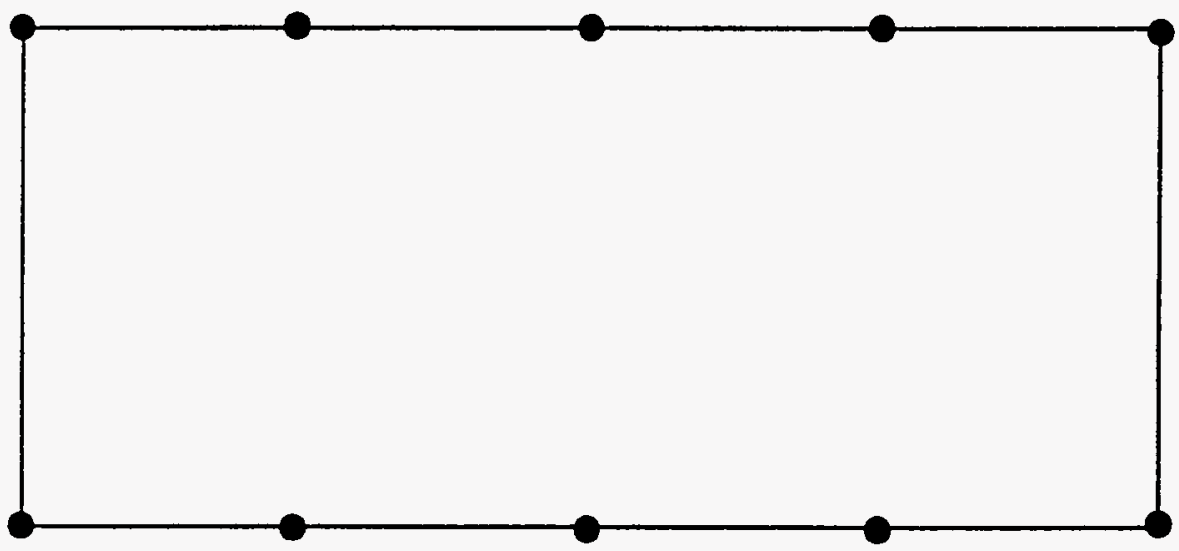

- Sampling point 


\section{H-13 \\ STATE OF TENNISSSEE \\ DIVISION OF UNDERGROUNDI STORAGE TANKS}

\section{APPLICATION FOR PERMANENT CLOSURE OF UNDERGR.OUND STORAGE TANK SYSTEMS}

The UST system owner shall complete and submit the original of this application to the appropriate Division of Underground Storage Tanks field office for approval 30 days in advance of closing an UST system. Refer to the attached map for the address of the appropriate field office. A copy of the approved application shall be on the premises during closure of the UST system. All of the following items shall be addressed.

Once approved this application is valid for twelve months from the date of approval. The approved application is nontransferable. If ownership of the UST system changes, a new application shall be submitted for approval.

1. Facility I.D. Number:

2. Name of Facility:

Address:

Phone Number: ( ) County:

On-site Contact (Operator):

3. Name of Tank Owner:

Address:

Phone Number: ( )

Contact person:

4. Number of tanks registered at this facility:

5. Number of regulated tanks to be closed:

6. List the tank number, size, contents, primary use and date last used for all tanks to be closed.

Tank Number

Size

Contents (past and present)

* Usage (all that apply)

Date Last Used

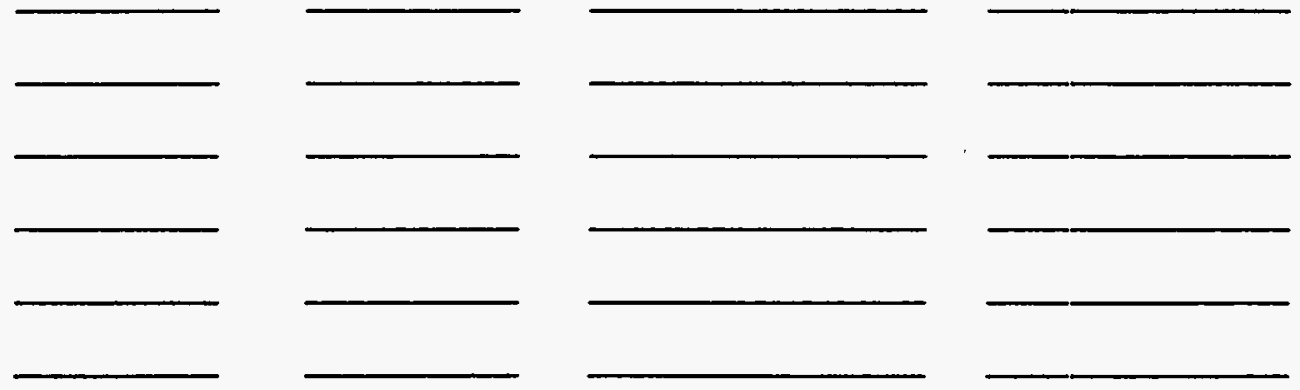

* Heating oil, Emergency generator, Retail, Commercial, Farm, Residential, Other

7. A site map shall be attached showing the location of the underground storage tanks, associated lines, sampling points and any nearby underground utilities. A SITE MAP IS REQUIRED. THE APPLICATION WILL NOT BE PROCESSED WITHOUT ONE.

8. Type of closure: Removal___ * Closure in place

** Inert material selected

** Describe the reason for closing the UST system in-place.

Refer to the document Procedure for Tank Closure-in-Place for selecting the inert solid fill material. 
9. Soil and/or groundwater samples shall be collected. Laboratory analyses are based on the type of product stored. If the type of product stored is unknown, all samples shall be analyzed using BTX, TPH-GRO, IPH-DRO, and a waste oil method. Mark all the following that apply:

\section{GASOLINE TANKS: (Boiling Point Range 70-180 F)}

Benzene, Toluene, Xylene (BTX) AND

Total Petroleum Hydrocarbons-Gasoline Range Organics (TPH-GRO)

DIESEL OR KEROSENE TANKS: (Boiling Point Range $180-450^{\circ} \mathrm{F}$ )

Total Petroleum Hydrocarbons-Diesel Range Organics (TPH-DRO)

WASTE OIL TANKS: (Boiling Point Range greater than $450^{\circ} \mathrm{F}$ )

418.1 OR S03E

\section{CHEMICAL TANKS:}

Contact David Arial with the Environmental Protection Agency in Atlanta at (404) 347-3866.

10. All excavated material remaining on the site of generation or on a site owned by the generator or subsidiary of the generator shall be placed on and covered with plastic until sampled or managed in accordance with Technical Guidance Document-005. Sampling the excavated material can be done at the time of removal or after proper treatment of the contaminated material.

If petroleum contaminated material is managed in accordance with Technical Guidance Document-009, an Application to Treat Petroleum Contaminated Soil shall be completed and submitted to the appropriate field office for approval. If the contaminated material is to be treated on a site owned by a third party, contact the Tennessee Division of Solid Waste Management.

11. Name of Division approved laboratory selected

12. Name of Company/Person performing the UST system closure

13. Name of Company/Person obtaining soil/groundwater samples

14. Proposed date of UST system closure

A copv of the approved application shall be on the premises during closure of the UST sustem.

I. (print) , owner of the petroleum UST system(s) at this facility, agree to submit, within 45 days of collecting the samples. the analyrical results for the UST system closure and will resolve all environmental problems resulung from a release from the UST system(s) at this site.

I cenify under penalty of law, including but not limited to penalties for perjury, that the information contained in this form and on any attachments is true. accurate and complete to the best of my knowledge, information and belief. I am aware that there are significant penalties for submitting false information, including the possibility of fine and imprisonment for intentional violations.

Signature of UST system owner

Date

or owner's authonzed representative

State of

County of

Swom to and subscribed before me by on this date

My commission expires 


\section{STATE OF TENNESSEE DIVISION OF UNDERGROUND STORAGE TANKS}

PERMANENT CLOSURE REPORT

The UST system owner shall complete and submit the original of this report within 45 days of collecting samples during the UST system closure assessment. Attach extra sheets if necessary. Include the following appendices in the report.

Appendix A: Include a table containing the field screening and analytical results. All results shall be reported in parts per million (ppm). The results shall be properly identified and correlated with the sampling locations on the site map.

Appendix B: Include the original or carbon copy of the laboratory analysis sheets. Photocopies are not acceptable. The facility name, UST Facility ID number. sample location and sample depth from ground surface shall be provided to the laboratory and printed on each laboratory analysis sheet.

Appendix $\mathrm{C}$ : Include an updated site map showing buildings, utilities, areas of overexcavation, borings, and sample points. The map shall also include soil stockpiles, their dimensions in feet, and properly labeled screening and sampling points.

Appendix D: Include documentation for treatment and/or disposal of soil, siudge, liquid, tanks and piping. (i.e. Application to Treat Petroleum Contaminated Soil, Solid Waste Permits, Landfill Disposal Manifests, etc.)

1. UST Facility D\#:

2. Facility Name

3. Division personnel with the appropriate field office were notified at least one working day before collecting soil samples for the UST system closure assessment. Yes No

Person contacted

Field office

Date

Reported by

4. The tank atmosphere and work zone were regularly tested with a combustible gas indicator in accordance with UST regulations Appendix 5 (2) and (3). Yes_ No

5. Method of purging tank atmosphere:

Carbon dioxide gas _ Nitrogen_Eductor-type air mover__ Diflused air blower Dry ice $(1.5 \mathrm{lb} / 100 \mathrm{gal})$ Other

6. Product piping was drained into the tank. Yes _ No

7. Product piping was: Capped__ Removed

8. All liquid/sludge was removed from the UST system. Yes_ No_ None encountered

9. Method of liquid/sludge storage:

10. Method of liquid/sludge disposal:

Manifests included in Appendix D. Yes_ No__ Not applicable

11. Tank was labeled in accordance with the UST regulations Appendix 5 (4)(f).

Yes No

Not applicable 
12. Method of UST system storage/disposal:

Cut up for disposal __ Stored on site__ Stored off site _
Other

UST systems stored on-site or off-site are subject to Rules 1200-1-15-.07(2)(e), (i) and (g).

13. Location of UST system storage/disposal:

Certificate of disposal included in Appendix D. Yes _ No

14. Bedrock was encountered during UST system removal/closure-in-place. Yes_ No _

All contaminated material above the applicable cleanup level was excavated. Yes_ No__ Not Applicable

Native soil was sampled from floor of excavation. Yes _ No

15. Water was encountered during excavation of UST system. Yes_ No _

Amount of water removed: gals.

Water recharged within 24 hours. Yes_ No

Recharge water was sampled. Yes_ No _

Analytical results are in Appendix B. Yes_ No

Method of water disposal:

Manifests included in Appendix D. Yes _ No

16. Water was encountered in the soil borings during closure-in-place. Yes No Not applicable

Water was sampled. Yes__ No

Analytical results are in Appendix B. Yes_ No

17. Amount of backfill material initially removed during UST system closure: cubic yards

18. Total amount of contaminated material overexcavated after removal of the UST system: cubic yards

If more than 100 cubic yards of material was overexcavated. Division personnel in the appropriate field office should have been contacted.

Division personnel in the appropriate field office were contacted.

Yes_ No_ Not applicable

Person contacted

Field office

Date

Reported by

All excavated material remaining on the site of generation or on a site owned by the generator or subsidiary of the generator shall be placed on and covered with plastic until sampled or managed in accordance with Technical Guidance Document-005. Sampling the excavated material can be done at the time of removal or after proper treatment of the contaminated material.

If petroleum contaminated material is managed in accordance with Technical Guidance Document-009, an Application to Treat Petroleum Contaminated Soil shall be completed and submitted to the appropriate field office for approval. If the contaminated material is to be treated on a site owned by a third party, contact the Tennessee Division of Solid Waste Management.

All excavations shall be backfilled with material containing levels at or below $10 \mathrm{ppm}$ BTX and/or $100 \mathrm{ppm}$ TPH. 


\section{$\mathrm{H}-17$}

19. Mark all that apply regarding the management of the excavated material:

Stockpiled onsite_ Thermal treatment onsite _ Thermal treatment offsite__ Landfilled__
Other

Documentation is included in Appendix D. Yes_ No _

20. All sample containers were supplied by a Division approved laboratory. Yes_. No _

21. All samples were placed in the appropriate containers. Yes_ No

22. Immediately after collection all samples were placed on ice and maintained at $4^{\circ} \mathrm{C}$ until delivered to a Division approved laboratory. Yes No

23. Laboratory confirmation of petroleum contamination or discovery of free product was reported to the Division within 72 hours. Yes_ No _ Not Applicable

Person contacted

Field office

Date

Reported by

24. A Notification Form reporting the closure of the tank system was submitted to the Nashville Central Office. Yes

No

Failure to submit a Notification Form may result in the assessment of additional tank fees.

I certify under penalty of law, including but not limited to penalties for perjury, that the information contained in this form and on any attachments is true, accurate and complete to the best of my knowledge, information and belief. I am aware that there are significant penalties for submitting false information including the possibility of fine and imprisonment for intentional violations.

Name and Official Title of Owner

or Owner's Authorized Representative

Name (Print)

Oficial Titie

Signature

Date

State of

County of

Sworn to and subscribed before me by on this date

My commission expires 


\section{$\mathrm{H}-18$ \\ STATE OF TENNESSEE \\ DIVISION OF UNDERGROUND STORAGE TANKS}

APPLICATION TO TREAT PETROLEUM CONTAMINATED SOIL

The UST system owner shall complete and submit the original of this application to the appropriate Division of Underground Storage Tanks field office for approval before treating the petroleum contaminated soil. Attach extra sheets if necessary.

\section{REQUIREMENTS:}

1. The UST system owner shall submit the treatment application within 45 days of the date of the laboratory results, or date of the UST system removal. The procedures outlined and approved in this application shall be implemented within 14 days from the date of approval. Technical Guidance Documents 005 and 009 shall be followed.

2. The contaminated soil shall be treated on the site of generation or on a site owned by the generator or a subsidiary: of the generator. A copy of the approved application shall be kept by the UST system owner and shall be made available for review by State personnel. The owner/operator of the UST system shall contact the Division of Solid Waste Management (SWM) to obtain a Solid Waste Processing Facility Permit for soil treated on a site owned by a third party. If the application cannot be approved by this Division, SWM shall be contacted.

3. If the contaminated soil is transported from the site of generation for treatment, a copy of the deed for the treatment site shall be attached.

4. The Division of UST cannot approve the treatment of petroleum contaminated soil in a 100-year flood plain or wetland.

5. The Division of UST cannot approve the treatment of petroleum contaminated soil within 100 feet of any residence, business or other place of human occupancy.

6. The local Zoning Board shall be contacted to determine if the treatment of petroleum contaminated soil is permitted.

7. An impermeable barrier shall be placed between the contaminated soil and native soil. The barrier shall prevent contamination of the surrounding area. A berm shall be placed around the entire perimeter of the soil pile to protect it and the surrounding area from surface runoff. The soil layer shall not exceed 2 feet in depth.

8. The soil pile shall be covered with plastic before precipitation events. The cover shall prevent any moisture (rain, snow, sleet) from coming in contact with the contaminated soil.

9. The treatment process shall not disturb the impermeable barrier.

10. A site map shall be attached showing the treatment site, the location and size of the treatment area, the location of any nearby residence, businesses, or other dwelling, and any nearby water bodies (e.g. streams, creeks, ponds, etc.).

A SITE MAP IS REOUIRED. THE APPLICATION WILL NOT BE PROCESSED WITHOUT ONE.

\section{COMPLETE THE FOLLOWING:}

1. Facility I.D. Number:

2. Name of UST System Owner:

Phone Number:

3. Name of facility generating the contaminated soil:

Address: 
4. Name of property owner of the treatment site:

5. Address of the treatment site:

6. Estimated quantity of contaminated soil: cubic yards

7. Method of soil treatment:

If tilling, indicate frequency:

Describe type of impermeable barrier.

Thickness of soil pile: feet

Describe type of berm:

8. Distance to nearest residence, business, or other place of human occupancy: feet

9. Distance to nearest watér body: feet

10. Property is in a 100-year flood plain or wetland. No

11. Treatment site zoning:

12. Zoning agency contacted:

Person contacted

Office

Date

The zoning agency allows the treatment of petroleum contaminated soil on this property. Yes No

I certify under penalty of law, including but not limited to penalties for perjury, that the information contained in this form and on any attachments is true, accurate and complete to the best of my knowledge, information and belief. I am aware that there are significant penalties for submitting false information, including the possibility of fine and imprisonment for intentional violations.

Name and Official Title of Orner or Owner's Authorized Representative

Name (Print)

\section{Signature}

State of

Sworn to and subscribed before me by

My commission expires

\section{Official Tille}

\section{Date}

County of on this date

\section{Notary Public}

